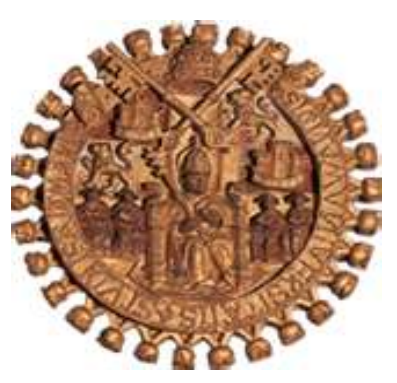

UNIVERSIDAD DE SALAMANCA DEPARTAMENTO DE DIDÁCTICA DE LA EXPRESIÓN MUSICAL, PLÁSTICA Y CORPORAL

TÉSIS DOCTORAL

\title{
LA VIDA MUSICAL EN LOS CONVENTOS FEMENINOS \\ DE ALBA DE TORMES - Salamanca
}

\author{
MATILDE DEL TRÁNSITO CHAVES DE TOBAR \\ Dirigida por: DRA. MATILDE OLARTE MARTÍNEZ
}

№ $\mathrm{B}^{\mathrm{o}}$

De la Directora de Tésis de Doctorado

Drª . Da. Matilde Olarte Martínez

Matilde del Tránsito Chaves de Tobar

Salamanca, 2009 
LA VIDA MUSICAL EN LOS CONVENTOS FEMENINOS DE ALBA DE TORMES - SALAMANCA MATILDE DEL TRÁNSITO CHAVES DE TOBAR 
Dedicado a mi esposo J osé J avier Tobar Gómez Y a mi hija Constanza, por su generosidad de espíritu y por su apoyo incondicional en el desarrollo de mi vida profesional. 
LA VIDA MUSICAL EN LOS CONVENTOS FEMENINOS DE ALBA DE TORMES - SALAMANCA MATILDE DEL TRÁNSITO CHAVES DE TOBAR 


\section{AGRADECIMIENTOS}


LA VIDA MUSICAL EN LOS CONVENTOS FEMENINOS DE ALBA DE TORMES - SALAMANCA MATILDE DEL TRÁNSITO CHAVES DE TOBAR 
Desde mi vida académica en Colombia como profesora universitaria, aparte de algunos otros cargos administrativos, albergué la posibilidad de ver enriquecida aquella vivencia académica, con un Doctorado en Investigación Musical; impulsada por aquella necesidad de saber, de conocer y ahondar en la investigación, tomé la decisión de realizar el Doctorado que en materia musical, ofrecía la Universidad de Salamanca, en el Programa titulado: ASPECTOS ESCENICOS Y COREOGRÁFICOS EN LA HISTORIA DE LA MÚSICA, en el Bienio 1999 - 2001.

Primeramente, agradezco a la Universidad de Salamanca por la formación recibida, a mis profesores de Doctorado y en especial a mis tutores del II año de Investigación, señores Dra. Dña. Matilde Olarte Martínez y Dr. Don José María García Laborda, quienes con gran interés, dirigieron mis trabajos del Curso de investigación.

Para la Dra. Doña Matilde Olarte Martínez, guardo un sentimiento de agradecimiento enorme, primeramente, por haber aceptado la Dirección de la Investigación y por haberme invitado a formar parte de esta Línea investigativa; y en segundo término, por sus continuos y acertados consejos, por su aliento, por su dedicación y disposición en todo momento a las revisiones y corrección del trabajo y por su generosidad. La solvencia académica con que dirigió mi investigación, me proporcionó absoluta confianza en el desarrollo del mismo y conocimiento de los métodos y formas de investigación de gran utilidad para mi futuro desempeño en el campo.

Gracias a mi esposo José Javier Tobar Gómez, quien ha sido mi apoyo en todos los momentos de mi vida personal y profesional; gracias por hacerse cargo de la vida cotidiana de nuestra casa, mientras yo me veía en la obligación de marginarme de ello, por la investigación. Gracias por haber sido lector y crítico objetivo de los apuntes del presente trabajo; A mi hija Constanza, gracias por su aliento, por su comprensión durante estos años de mi dedicación a este compromiso, pero sobre todo, gracias a los dos, por creer en mí y en mi capacidad de trabajo, con tanta entrega y amor. 


\section{LA VIDA MUSICAL EN LOS CONVENTOS FEMENINOS DE ALBA DE TORMES - SALAMANCA}

MATILDE DEL TRÁNSITO CHAVES DE TOBAR

A las Rvdas. Madres Benedictinas del Monasterio de Santa María de las Dueñas de Alba de Tormes - Salamanca. A la Rvda. Madre María Concepción Fanjul, Abadesa del Monasterio, por abrirme las puertas a tan valiosos documentos totalmente inéditos. Mi gratitud de corazón, a la Rvda. Hermana Benedictina Doña Manuela Calle Miñambres, Archivera y monja música del Monasterio, por su amistad, por su dedicación en los momentos que más necesité de su valiosa ayuda en la búsqueda de informaciones, gracias por confiar en mí. Bastantes fueron las horas de trabajo, pasando días enteros, algunos con sus noches en el Monasterio, revisando pergaminos, documentos, libros, carpetas, música..., trascribiendo y corrigiendo. Sus consejos en materia litúrgica, histórica y conventual, fueron inmensamente valiosos.

A las Rvdas. Madres Carmelitas Descalzas del Monasterio de la Anunciación de Alba de Tormes - Salamanca, especialmente a la Rvda. Madre Sonsoles y a la Rvda. Madre Socorro, quienes permitieron la lectura y trascripción de los documentos únicos sobre la Fundación del Monasterio, sobre lo que contiene el Archivo Documental y sobre la vida conventual en general.

Un especial agradecimiento a Instituciones tan importantes y definitivas para el desarrollo de la investigación, como son: el Archivo Histórico Nacional, la Biblioteca Antigua de la Universidad de Salamanca, EL Archivo de la Diputación de Salamanca, el Archivo Municipal de Alba de Tormes, la Biblioteca de la Universidad Pontificia Católica de Salamanca, el Archivo de la Catedral de Salamanca, al Archivo Diocesano del Obispado de Salamanca, el Archivo Diocesano de Zamora, el Archivo Capitular e Histórico de la Ciudad de Tuy, El Archivo Diocesano de la Ciudad de Astorga - León, las Parroquias de varias localidades españolas, la Biblioteca “Casa de las Conchas”; a todos y cada uno, mil gracias pues fueron columna básica para la investigación del tema.

A todas las personas que de una u otra forma contribuyeron al desarrollo del presente trabajo. 


\section{TABLA DE CONTENIDOS}

Abreviaturas

\section{INTRODUCCIÓN}

Objetivos y Metodología 15

- Importancia del tema de investigación 20

- Objetivos 20

- Metodología general 21

- Fuentes primarias 23

- Fuentes secundarias 28

- Estado de la cuestión 29

\section{CONTEXTO HISTÓRICO DESDE EL SIGLO XVII}

\section{LOS CONVENTOS FEMENINOS DESDE EL SIGLO XVII EN ALBA DE TORMES.}

I.1. Contexto social y religioso español en el siglo XVII 39

I.2. Bosquejo histórico de la localidad de Alba de Tormes (Salamanca) 50

I.3. Fuentes para el Estudio de la vida religiosa en los Conventos de Alba de

Tormes (Salamanca)

-I.3.1. Fuentes impresas

-I.3.2. Fuentes manuscritas

- Convento de La Anunciación (Madres Carmelitas Descalzas)

- Archivo Conventual del Monasterio de Sta María de las Dueñas

\section{VIDA CONVENTUAL EN ALBA DE TORMES}

II.1.FUNDACIONES CONVENTUALES EN ALBA DE TORMES 67

II.1.1. Convento de La Anunciación (Madres Carmelitas Descalzas) 75

II.1.2. Monasterio de Santa María de las Dueñas de Alba de Tormes 78

\section{II.2.VIDA COTIDIANA DE LAS ÓRDENES:}

\section{Carmelitas Descalzas y Benedictinas}

II.2.1. La vida de Clausura

II.2.2. Ingreso a la vida de Clausura

II.2.3. Procedencia geográfica y social de las profesas 
II.2.5. Cargos y J erarquías dentro del monasterio 114

II.2.6. Modelo compositivo de la mujer música 131

II.2.7. Economía en relación con la música 139

III. LA ACTIVIDAD MUSICAL EN LOS CONVENTOS FEMENINOS DE ALBA DE TORMES

III.1. EVOLUCIÓN DEL PAPEL DE LA MONJ A MÚSICA

DESDE EL SIGLO XVII HASTA LA ACTUALIDAD

\section{III.2.VIDA CONVENTUAL FEMENINA EN ESPAÑA}

181

- Monasterio de las Madres Carmelitas (Alba de Tormes - Salamanca)

- Monasterio de Santa María de las Dueñas (Alba de Tormes - Salamanca)

- Monasterio de "Santa Clara de Carrión de los Condes" (Palencia)

- Monasterio de la Madre de Dios de Constantinopla (Madrid).

- Monasterio de la Encarnación de Madrid

- Monasterio Cisterciense de Santa Ana (Ávila)

- Monasterios de San J osé - Madres Carmelitas descalzas y Monasterio de

- Santa María de las Dueñas de Salamanca

- Monjas músicas en los Conventos femeninos españoles en el Barroco una aproximación Histórica

- La música en los Conventos femeninos de Granada

III.3.MONJ AS MÚSICAS DESTACADAS EN ALBA DE TORMES

194

III. 1. MONJ AS MÚSICAS DESTACADAS EN EL MONASTERIO DE SANTA MARÍA DE LAS DUEÑAS

- ÁNGELA COLLANTES

- CATALINA GATO

- ISABEL QUINTANA

- ISIDRA SANTOS

- ANTONIA MARTÍNEZ

- ESCOLÁSTICA CAMPOS

- JOSÉFA MARTÍNY MARTÍN

- JULIANA DEL CORAZÓN DE J ESÚS

- DOLORES QUINTANA

IV.LA VIDA CONVENTUAL EN ÉPOCAS VIRREINALES EN LA NUEVA GRANADA, ACTUAL TERRITORIO DE COLOMBIA 291

IV. 1. BOSQUEJ O HISTÓRICO DE SANTA FE DE BOGOTÁ

\section{IV.2. FUNDACIONES CONVENTUALES EN SANTA FE DE BOGOTÁ} EN ÉPOCA VIRREINAL 294

- Convento de Santa Clara de Santa Fe de Bogotá 294

- Monasterio de Santa Inés 


\section{IV.3. DESCRIPCIÓN DE LA VIDA CONVENTUAL}

EN SANTA FE DE BOGOTA ÉPOCA VIRREINAL

- El Convento de Santa Clara de Santa Fe de Bogotá (Colombia) 314

- El Monasterio de Santa Inés de Santa Fe de Bogotá (Colombia)

IV.4. ANÁLISIS COMPARATIVO DE LA VIDA MUSICAL EN

LOS CONVENTOS FEMENINOS DE ALBA DE TORMES

(Salamanca)Y SANTA FE DE BOGOTÁ (Colombia)

IV.5. El maestro de música de las monjas de santa Inés - Dominicas de Santa Fe de Bogotá.

J UAN DE HERRERA 350

IV.5.1. Su producción musical - Obras compuestas para el Monasterio de

Santa Inés

IV.5.2.Análisis de la obra deJuan de Herrera

\section{REPERTORIOS LITÚRGICOS CONSERVADOS EN LAS CAPILLAS} MUSICALES DE ALBA DE TORMES 367

\section{V.1. OBRAS MUSICALES}

V.1.1. introducción Y consideraciones acerca de los Repertorios

Musicales de algunos Monasterios Femeninos de España

V.1.2. Obras musicales conservadas en el Monasterio de Santa María de las Dueñas de Alba de Tormes

- Obras para vozy órgano 379

- $\quad$ Misas

379

- Villancicos

380

- $\quad$ Salves

380

- Un método de Canto Gregoriano

\section{V.2. CATALOGACIÓN DE OBRAS}

V.2.1.Criterios para la catalogación de obras musicales

\section{V.3. FICHA TÉCNICA POR OBRA}

V.3.1. Misas (fichas: 1,2,3)

V.3.2. Villancicos (fichas: $4,5,6,7$ )

V.3.3. Cantos Marianos (fichas: 8,9,10) 
V.4.4. Ficha técnica

V.4.5. Criterios para el análisis musical

446

V.4.6. Procedimiento analítico

447

V. 4.7. Sistematización del análisis

V.5.1. Solo Dios llora - Alfonso Ugarte Leturia 454

V.5.2. Pequeña Misa solemne - Luigi Bordese 457

V.5.2.1. Kyrie

458

V.5.2.2. Sanctus

461

V.5.2.3. Agnus Dei

463

V.5.3. Albricia pastores - Anónimo

465

V.5.4. Salve- Anónimo

CONCLUSIONES

471

BIBLIOGRAFÍA

479

RELACIÓN DE ILUSTRACIONES

ANEXOS

493

Documentos Históricos

495 


\section{ABREVIATURAS}

AHN Archivo Histórico Nacional

ADS Archivo Diocesano de Salamanca

ACS Archivo Catedral de Salamanca

ACHDT Archivo Capitular e Histórico Diocesano de Tuy (Galicia)

ACA Archivo Conventual de la Anunciación

ASMD Archivo del Monasterio de Santa María de las Dueñas

ARCAR Archivo Carmelitano

ADZ Archivo Diocesano de Zamora

ACSC Archivo Convento de Santa Clara - Bogotá (col)

RIMS Catalogación de fuentes musicales históricas

AR.CAR Archivo Carmelitano

ABAUSAL Archivo Biblioteca Antigua - Universidad de Salamanca

BAC Biblioteca de autores cristianos

Acompa. Acompañamiento

Prov. Provincia

p. Página

pp. Páginas

T. Tomo

Sig. Signatura

Fgs Fanegas

Rls Reales

Mrv Maravedíes

$\mathrm{T}^{\mathrm{O}} \quad$ Trigo

Lg. Legajo

v. Reverso

Rvda. Reverenda

* Nacimiento

$+\quad$ Fallecimiento 


\section{INTRODUCCIÓN}

\section{- OBJ ETIVOS Y METODOLOGÍA}

El siglo XVII fue para España un período de grave crisis política, militar, económica y social, que terminó por poner al Imperio Español en un segundo plano ante la Europa de aquel entonces. El Concilio de Trento fue el Concilio de los italianos y de los españoles, en el que se reanimó el arte religioso en todas sus manifestaciones a base de mantener disponibles algunas lecciones formales de lo renacentista. Esta situación favorece el cambio de mentalidades que lleva en torno al 1600, al inicio del período histórico que conocemos como El Barroco, que perdurará hasta el año 1750, aproximadamente. Buena parte de la sociedad europea tenía sus estructuras mentales regidas por la religión; en este campo, el barroco continúa presidido por la ideología de la Contrarreforma, en la que la iglesia entró en un proceso de reafirmación de sus postulados.

En el transcurso del proceso de la búsqueda de las fuentes primarias para la investigación del tema, estas fuentes nos condujeron con propiedad sobre los siglos XVII, XVIII y XIX, puesto que en estas centurias, fue posible recopilar una serie considerable de documentos manuscritos e impresos de gran valor documental, histórico e investigativo.

Ahora, para ubicarnos en el Siglo XVIII y analizando la situación política del momento, se puede decir que este es el siglo de la redención económica y de la explosión demográfica, en el que se desarrollan grandes acontecimientos que marcan una época, especialmente a partir de las segunda mitad de la Centuria. Políticamente, es el siglo del Absolutismo: los reyes son omnipotentes, -excepto la monarquía parlamentaria británica-. Paralelamente, la burguesía va adquiriendo notable importancia, lo que acabará por definir en la revolución francesa. La economía sigue siendo fundamentalmente agrícola. Pero se produce en ella una revolución como resultado de los avances técnicos. El arte barroco da paso al Clasicismo que caracteriza por la racionalidad, la sencillez y el orden. 
El siglo XIX constituye una época de notables transformaciones en todos los ámbitos. Aunque se siguen las ideas reformistas de la Ilustración, la Revolución Francesa provocó una profunda crisis social y política que terminó con el Antiguo Régimen y con el sistema monárquico absolutista. Nace el Romanticismo, aquel movimiento que transformó lo político, lo social, lo artístico y lo ideológico, se generó en las postrimerías del siglo XVIII y se consolidó en la mitad del siglo XIX, perviviendo en la actualidad algunos de sus principios: libertad, democracia y nacionalismo.

En la sociedad moderna, una de las discriminaciones que sufrió la mujer, era la espacial, en las diferentes clases, vale decir, la restricción de su presencia en determinados lugares y el impedimento a ser parte activa de lo político y de lo social; esto unido a las limitaciones impuestas a sus sistemas de relaciones interpersonales. En un mundo en que los hombres son detentadores del poder, de creadores de espacios y de sistemas de relaciones, la mujer quedaba relegada al ambiente privado y muy raramente al espacio público. La casa, el convento, el mercado se convierte en el ámbito propio de una parte de esas mujeres que se sienten protegidas, pero limitadas al mismo tiempo tanto social, como funcionalmente.

Desde mi infancia, el contacto cotidiano con la vida conventual - ya que me eduqué en colegio de religiosas franciscanas en Colombia -, hizo nacer en mí, cierto interés por la vida diaria de aquellas personas que en el monasterio - colegio vivían y compaginaban su vida religiosa, con las labores habituales, con la enseñanza, la música y la liturgia diaria. Al término de mis estudios de la Licenciatura en Educación Musical, visité el convento de las Clarisas en Bogotá, en el año 1987, el cual ofrece al visitante y al investigador, un atractivo pictórico y de vida conventual enorme, por cuanto la Iglesia de Santa Clara fue consagrada en 1645 como oratorio para las monjas Clarisas. La particularidad del templo, concebido de acuerdo a la moda de su tiempo, es la que los muros se cubrían totalmente con adornos de madera y obras pictóricas de los maestros pintores criollos de la época, aspecto que me llamó fuertemente la atención y por el carácter 
crediticio que en épocas virreinales presentó, le convirtió en la primera entidad crediticia del Nuevo Mundo. El interés por conocer la vida conventual en los monasterios de Santa Fe de Bogotá, en el período colonial (siglos XVII y XVIII), radicó en la investigación sobre los aspectos relevantes de la vida colonial, como el manejo de la política, el desenvolvimiento de la vida social, el pensamiento religioso, la conducción de lo económico y lo cultural, lo que permitió hacer puntos de valoración, de analogías y diferencias y saber sobre las relaciones directas que España tuvo con América y lo que se concretizó en sus colonias con las tres importantes culturas que allí confluyeron.

Ya estando en Salamanca y desde el inicio de esta temática, mi interés se centró en el conocimiento de los Archivos musicales religiosos no catedralicios de varios Monasterios de Salamanca y sus comarcas aledañas. Respecto a la posibilidad de investigación en Centros Monacales, parecía fácil en un primer momento acceder a la investigación, pues varias puertas se tocaron, como fueron: Las Dominicas y Agustinas de Salamanca, el Monasterio de Ledesma, el Monasterio de Loreto en Peñaranda de Bracamonte, el Monasterio del Carmen en Piedrahita, pero no se obtuvo ninguna posibilidad de investigación - por distinto motivos -, antes de que tanto las Madres Benedictinas como las Madres Carmelitas de Alba de Tormes, me permitieran entrar en sus archivos. Desde un principio y especialmente en el Monasterio de Santa María de las Dueñas, no solo he tenido las facilidades para revisar sus archivos, sino también la invaluable ayuda de Sor Manuela Calle Miñambres, monja música del Monasterio y archivera. Respecto al Monasterio de las Madres Carmelitas Descalzas, las posibilidades de investigación fueron un tanto limitadas, dado las innumerables actividades que el Monasterio despliega a lo largo del año, con las Festividades de Santa Teresa y las peregrinaciones de devotos al Monasterio, al encontrarse allí, los restos de la Santa, para devoción y complacencia de propios y extraños y al realizarse la escogencia, fueron estos dos Monasterios los que me llamaron la atención, por ser Comunidades de gran trayectoria histórica - Las Hermanas Benedictinas y el Monasterio de "Anunciación" de Santa Teresa de J esús en la localidad de Alba de Tormes, por ser escasa y prácticamente inexistente la investigación en torno a lo conventual y musical en ellos. 
Para el desarrollo del presente trabajo, se ha seguido el modelo investigativo de mi tutora Dña. Matilde Olarte Martínez, buscando informaciones en diversidad de fuentes primarias importantes aportando infinidad de datos inéditos en torno a la figura de la monja música y su entorno sociocultural. Desde muchos frentes (economía, vida conventual, vida musical, vida social, espiritualidad, casuística, médica etc.), se puede enfocar una investigación en este tipo de instituciones. Sabemos que la naturaleza del objeto investigador es la que determina la metodología a seguir.

En el campo de la Liturgia, se sabe que ésta requería la actividad musical en los monasterios, con lo cual este aspecto está representado en la figura de varias monjas músicas, mujeres talentosas e instruidas en el arte musical, que allí ejercieron su profesión; en segundo lugar, está la economía, de donde se desprenden innumerables referencias sobre las inversiones hechas por los monasterios para la música, como compra de instrumentos, pagos por conceptos del arreglo de los mismos, pago a monjas organistas y cantoras de profesión, compra de instrumentos para alguna de las monjas en especial y otros. Desde otro punto de vista, están los epistolarios, la liturgia, los repertorios musicales, la noble ascendencia de las monjas, los cargos y jerarquías dentro del convento; todos son temas que van relacionados y por ende este estudio requiere una metodología interactiva entre los diferentes aspectos investigables (político, economía, espiritualidad, lo social, la música, liturgia y religión etc.)

Periódicamente durante el los cursos académicos, posteriores al II Curso de Investigación del Doctorado, la lectura de la bibliografía y las visitas a los dos Monasterios investigados, permitieron recopilar toda clase de información; durante los períodos vacacionales, momentos en que el tiempo permitía una dedicación casi exclusiva al asunto, tuve la suerte de ser recibida en el Monasterio de Santa María de las Dueñas, durante largas estancias, recluida en dicho monasterio y dedicada sólo a la investigación. Ello me permitió avanzar en la recopilación selección y clasificación de las fuentes documentales tan importantes. 
El trabajo tiene como fin último hacer un análisis tanto en lo documental, como en lo musical, así, como en lo que respecta a la vida cotidiana, que ayude a acercarnos a la vida conventual femenina de Alba de Tormes durante las épocas Barroca, Clásica y Romántica; rescatar y resaltar la actividad musical de las mujeres que allí vivieron; por ello, los objetivos se concretan desde los puntos de interés que ofrecen las fuentes, como son : los documentos que definen el espacio conventual, como espacio femenino para el desempeño musical, para el ejercicio de la mujer como administradora y gestora; y para ejercer el magisterio musical y los documentos que pueden aportar interés desde el punto de vista, música economía.

La recopilación de datos, la organización de los mismos y la elaboración de los contenidos, se realizaron por orden de prioridades e importancia de las fuentes primarias y secundarias y la catalogación y análisis de los repertorios encontrados, según los géneros y número.

Siendo los "monasterios" espacios únicos y propicios para el desenvolvimiento musical de la mujer de la época y siendo considerados como un lugar "menos compresor" que el propio hogar, la mujer en este entorno, logró desenvolverse en la música, en la literatura, en la poesía, en la pintura, en el gobierno y en la gestión, llegando a ocupar cargos de jerarquía al interior de los mismos y a ser respetada por sus capacidades administrativas y por artista.

Varias son las justificaciones que se pueden dar en torno al tema: Sacar a la luz valiosas fuentes que revelan la vida de las mujeres tan marginadas por la sociedad en la Época Moderna, el interés por la historia conventual femenina y su evolución hasta épocas más recientes, la falta de estudios de investigación sobre la figura de la mujer y su rol al interior de los Monasterios.

En lo concerniente al tema, la intención principal está centrada en sacar a la luz la vida de las monjas músicas, conocer su procedencia, las condiciones de su ingreso, su desempeño o magisterio musical y el rol que desempeñaron en particular dentro del Monasterio. Las lagunas encontradas, dieron pie a que los límites 
cronológicos que en principio estaban delimitados entre la mitad del siglo XVII y su finalización, se ampliaran al siglo XVIII y el XIX.

\section{- IMPORTANCIA DEL TEMA DE INVESTIGACIÓN}

La temática planteada en este trabajo, en relación con la investigación musical y su correlación con las mujeres desde el siglo XVII, debe conjugarse desde el punto de vista social, religioso, político y económico de las épocas. Rescatar la memoria de las mujeres que históricamente fueron importantes en su momento, en su ámbito y al servicio de la liturgia, se convierte en la actividad primordial del trabajo. Siendo la música un lenguaje cultural privilegiado, que ensalzaba y ensalza directamente la racionalidad de la persona, permite que esta se distinga del resto de seres vivos.

\section{- OBJ ETIVOS}

Los objetivos primordiales de esta tesis se pueden resumir en cinco puntos. El primero consiste en establecer un marco teórico que pueda servir para ésta y futuras investigaciones sobre la música en el ámbito conventual y sobre la figura de la monja música a través de la historia. Lo anterior permitirá una proximidad a los estudios de género, desde una perspectiva académica que valore los estudios en torno a la figura femenina y su rol dentro de la sociedad y la cultura.

En segundo lugar se podrán conocer las fuertes relaciones, que entre espiritualidad, sociedad, política y economía, funcionaron al interior de los Monasterios femeninos y sus cambios a través de los siglos.

Desde otra perspectiva y la más importante, conocer la vida de las mujeres músicas, que en su momento llegaron a ser Abadesas o alcanzaron otros cargos de responsabilidad y de jerarquía dentro de los Monasterios, mujeres ilustradas, talentosas e instruidas, con gran espíritu de trabajo, de abnegación y ante todo que fueron grandes gestoras, administradoras de capitales y con grandes responsabilidades. 
En cuarto lugar, dando un mirada a lo que fue la traslación de la cultura, desde España a América en el período colonial, se pretende conocer las circunstancias y particularidades de la vida conventual en los Monasterios de Santa Fe de Bogotá, en el antiguo Reino de la Nueva Granada, hoy territorio de la República de Colombia, y hacer un análisis comparativo con los Monasterios investigados en Alba de Tormes.

Como último punto, en este trabajo investigativo, se intenta rescatar, estudiar y catalogar algunos de los repertorios de las Capillas Musicales existentes en los Monasterios Albenses, ligados a la liturgia y a las grandes celebraciones de los mismos.

\section{- METODOLOGÍA GENERAL}

En cuanto a la temática de la vida musical ligada a lo económico en los monasterios femeninos, muchas incógnitas se plantean como hipótesis del trabajo: ¿Fueron los conventos femeninos escenarios de una vida musical, impuesta por las necesidades del culto?, ¿Por las circunstancias socio - económicas del momento?, ¿Por la necesidad de la mujer de consolidarse como persona de valía? La preparación musical, fue para la mujer un proyecto de vida?

Junto a estas cuestiones, resultaba interesante consultar sobre el número de mujeres que, llegando a los conventos con una amplia formación musical adquirida desde la infancia, dado que ingresaban a la edad de quince años incluso menos -, pudieron ejercer su magisterio musical al interior de los mismos, enseñando a otras personas, contribuyendo de esta manera al enriquecimiento de la vida conventual y especialmente de la liturgia y las festividades religiosas substanciales. También interesaban aquellas cuestiones como el hecho de ser merecedoras de un sueldo de por vida, como retribución a su saber y talento musical. Desde el punto de vista de estudio de género, lo más novedoso era conocer la capacidad de dirección, de gestión y la disposición para organizar y promover los proyectos de vida para los monasterios, que tuvieron las mujeres en los cargos de Abadesas, preladas, maestras de novicias o economistas. 
Al reflexionar sobre los planes del trabajo investigativo, el primer quehacer, fue indagar sobre el estado de la cuestión. La búsqueda de la bibliografía (libros, artículos, revistas especializadas, Diccionarios y Enciclopedias, catálogos, reseñas etc..), en bibliotecas de todo orden, como: las bibliotecas públicas del Estado, las universitarias, las conventuales, las personales; y la posterior lectura y selección de las obras relacionadas sobre el tema en sus diferentes aspectos, fue ardua, pero eficaz a la hora de hacer una valoración del interés que este tema - sobre cuestiones de vida conventual, género y música -, despierta en el campo investigativo. De tal manera, que el ocuparse de la diversidad de lecturas disponibles, familiarizarse con ellas, benefició y permitió tener un punto de partida claro. Siendo el tema tan rico en posibilidades, dicha bibliografía se organizó teniendo en cuenta las distintas áreas que componen este trabajo. Lo histórico, lo religioso, la espiritualidad, la música y liturgia, música - economía, lo social - político, estudio de género, lo sociológico y la vida conventual en general, conformaron los aspectos importantes para realizar este entramado investigativo.

Obtenidos los consentimientos de las Abadesas de los Monasterios en cuestión, para hacer la investigación al interior de los mismos, se entró a la búsqueda de las fuentes primarias y una vez ubicadas dichas fuentes, se pasó a su clasificación por orden de importancia y género. Me explico:

Las fuentes primarias, directas que detentan la vida monacal en todos sus aspectos, se organizaron desde varios puntos de vista ya comentados: Lo histórico, lo económico, lo espiritual, lo social, vida conventual, en lo concerniente a la música, en lo referente al estudio de género trabajado en la vida de mujeres músicas, talentosas, dinámicas y gestoras y desde el punto de vista musical propiamente.

1. Privilegios Regios y Cartas de amparo

2. Documentos fundacionales

3. Cédulas Reales

4. Bulas Papales

5. Libros de dotes 
6. Los Libros de cuentas

7. Censos

8. Juros

9. Capellanías

10. Las Constituciones o La Regla

11. Libros de Profesiones

12. Las carpetas de informaciones

13. Los epistolarios

14. Las Actas de exámenes musicales para opositar al los cargos de organistas y cantoras

15. Repertorios musicales

16. Relaciones de documentos Música - economía

\section{FUENTES PRIMARIAS \\ CUADRO SINÓPTICO}

\begin{tabular}{|c|c|c|c|}
\hline \multicolumn{4}{|c|}{ LA VIDA MUSICAL EN LOS CONVENTOS DE ALBA DE TORMES - Salamanca } \\
\hline & & & \\
\hline FUENTES PRIMARIAS & \begin{tabular}{|l} 
Históricas \\
\end{tabular} & \multicolumn{2}{|c|}{ Privilegios regios } \\
\hline & & \multicolumn{2}{|c|}{ Cartas de amparo } \\
\hline & & \multicolumn{2}{|c|}{ documentos fundacionales } \\
\hline & & \multicolumn{2}{|c|}{ Cédulas reales } \\
\hline & & \multicolumn{2}{|c|}{ Bulas Papales } \\
\hline & & & \\
\hline & \begin{tabular}{|l} 
Económicas \\
\end{tabular} & \multicolumn{2}{|c|}{ Libros de cuentas } \\
\hline & & \multicolumn{2}{|c|}{ Documentos fundacionales } \\
\hline & & \multicolumn{2}{|c|}{ Libros de dotes } \\
\hline & & Censos & \\
\hline & & Juros & \\
\hline & & \multicolumn{2}{|l|}{ Capellanías } \\
\hline & & & \\
\hline & & & \\
\hline & Espiritualidad & \multicolumn{2}{|c|}{ Las Constituciones } \\
\hline & y gobierno & o la Regla & \\
\hline & & \multicolumn{2}{|c|}{ Libros de visitas y elecciones } \\
\hline & & & \\
\hline & Vida nersonaly & \multicolumn{2}{|c|}{ Libros de Profesiones } \\
\hline & conventual & \multicolumn{2}{|c|}{ Carpetas de información } \\
\hline & & \multicolumn{2}{|c|}{ Epistolarios } \\
\hline & & & \\
\hline & & & \\
\hline & Vida musical & \multicolumn{2}{|c|}{ Repertorio musicales } \\
\hline & & \multicolumn{2}{|c|}{ Métodos de estudio musical } \\
\hline & & \multicolumn{2}{|c|}{ Documentos música - economía } \\
\hline & & & \\
\hline
\end{tabular}


La clasificación se inició ahondando en los aspectos históricos con los documentos más antiguos, originales e inéditos que se conservan en estos Monasterios, como son los Privilegios Regios y las Cartas de amparo, los cuales son un claro ejemplo de la alta estima en que dichos conventos fueron tenidos por los Monarcas del momento y en segundo lugar, se seleccionaron los documentos que nos dieron a conocer los procesos fundacionales tanto de los Monasterios de Alba de Tormes, como los de los Conventos de Santa Fe de Bogotá en Colombia, los cuales se consideraron de especial interés, puesto que en ellos, esta concretado el espíritu religioso de las órdenes, ligado desde lo histórico a los objetivos que movieron la institucionalización de los conventos en cuestión, a los beneficios económicos y los aspectos sociales que se entremezclan para formar este complejo entramado, como son: Cédulas reales, Bulas Papales, Documentos de fundación.

Ya desde una visión más económica, se revisaron y se incluyeron los Libros de Dotes, las que permitieron confrontar aspectos interesantes que van desde las elevadas sumas de dinero que se consignan para tener el derecho de ingresar a un Monasterio, hasta las formas de pago de las mismas, ya fuese en dinero contante y sonante, como en propiedades (tierras, casas) y más allá por la situación económica, en censos y juros. Los Libros de cuentas, muy importantes, para encontrar las relaciones económico-sociales - culturales, fueron revisados minuciosamente, desde el siglo XVII hasta el siglo XIX, buscando aquellas referencias que nos permitieran advertir el grado de importancia que se le otorgaba a todos los asuntos, pero enfatizándose especialmente en lo relacionado con la música, ligada a la economía de los monasterios. Por último se relacionaron las Capellanías. El Monasterio de Santa María de las Dueñas, conserva valiosos documentos de su protectora Doña María de Rosales, que fueron revisados y que tienen directa relación con lo económico, como su testamento en el que ordena la construcción de la Capilla a su costa y en el que dispone que los restos de sus antepasados, sus herederos y los suyos, reposen en ella.

En referencia a la vida espiritual, unida a lo que es la dirección de las órdenes religiosas, la fuente primaria de importancia, es la llamada Constituciones o La 
Regla, de las que fue posible extraer copiosa información no solo en lo referente a la normativa de la vida en común de los monasterios, sino sobre la forma de pensar de las épocas en materia de conducta, o de gobierno. Las Constituciones imponen ciertos parámetros acerca de la observancia de la pobreza, la obediencia y la castidad, los cuales se han podido constatar en los Libros de Visitas y elecciones, documentos manuscritos tan importantes que por medio de los mandatos, regulan sin contemplaciones el funcionamiento de la vida diaria y los comportamientos espirituales y humanos y plasman los procesos de elecciones y de distribución de cargos jerárquicos para períodos de tres años. Interesantes aspectos resaltan en este aspecto a la hora de hacer las comparaciones entre los Monasterios.

Desde el punto de vista social, la búsqueda sobre la procedencia geográfica, de las monjas en general y en especial de las monjas con dedicación musical, se realizó revisando los Libros de Profesiones y las Carpetas de información, desde el siglo XVII hasta el siglo XIX, fuentes primarias que develaron la procedencia social y la identidad de tantas mujeres que por diversos motivos ingresaron a los monasterios, Los Libros de profesiones y como se estila decir en el Monasterio de Santa María de las Dueñas de Alba de Tormes, las Carpetas de información, arrojaron datos inestimables sobre la procedencia, fechas y condiciones de ingreso (monjas de velo negro, de medio velo, legas, monjas - músicas, huérfanas, viudas en calidad de huéspedes o residentes, etc.), nombre de sus padres y la cuantía de sus dotes. De igual manera, en cada expediente, están relacionados los detalles de los fallecimientos, exaltando las virtudes y en cierta forma, sus hábitos de vida y comportamiento religioso.

Los epistolarios, considerados como una fuente de especial significado, se conciben desde varias perspectivas, así: relaciones socio - económicas, relaciones Obispado - monasterio, Dirección del Monasterio y familia de las pretendientas. Dirección del monasterio y las parroquias sedes del origen de las pretendientas, música - economía, Obispado - organistas de la Catedral. Esta fuente permitió conocer los gastos e inversiones realizadas por los monasterios relacionados con las música, como: compra de instrumentos, arreglo de instrumentos, compra de 
Libros de música, los procesos de ingreso de las monjas - músicas, los procedimientos para convocar a las plazas de monjas - músicas a los monasterios, los requerimientos para acceder a una plaza de cantora u organista, los procesos de la admisión de monjas extranjeras, de huérfanas y de viudas.

Las Actas de exámenes musicales fueron una fuente relevante y reveladora, para la investigación de la temática del desempeño musical de las monjas músicas. Dentro del procedimiento para la escogencia de organista o cantora $1^{\mathrm{a}}$ o $2^{\mathrm{a}}$, dos formas fueron encontradas, así: El modo más usual, era que la pretendienta al cargo enviara una carta o certificación del Maestro de capilla o del profesor que le había formado musicalmente en su lugar de origen y a su vez la Abadesa solicitaba al Obispo la conformación de un tribunal para el examen con el objeto de conocer a fondo sus habilidades de la pretendientea, en lo tocante a la interpretación del canto llano, a la interpretación del órgano y a la gramática musical del canto gregoriano, según fuera el caso ( cantora y/u organista). El Obispo, designaba a dos organistas de la Catedral de Salamanca para llevar a cabo dicho reconocimiento musical o bien, la otra forma, era designar un profesor de música o una persona entendida en la materia que viviera en Alba de Tormes. El Tribunal era constituido por los Maestros de música - organistas, el Arcipreste y la Abadesa. Las fórmulas de procedimiento para la realización de dichos exámenes, eran en sus inicios más rigurosas, simplificándose cada vez a través de los años, hasta llegar a una simple nota por la que se aprobaba a la pretendienta.

Los repertorios musicales, infortunadamente no muy amplios, eran una prioridad dentro el plano musical del presente trabajo; muchos son los motivos que se pueden apuntar, en torno al escaso repertorio conservado en los Monasterios de Alba de Tormes, como pudo ser la falta de previsión para guardar la música manuscrita o impresa, un posible incendio que sufrió el Monasterio de Santa María de las Dueñas extramuros en el siglo XVII - sin fecha determinada -, el estallido de la guerra de independencia española - conflicto armado que entre 1808 y 1814 estremeció a España. Revisando y clasificando las obras que generaron más interés, los repertorios musicales encontrados, se organizaron por formas musicales, así: misas, villancicos, obras para voz y órgano, 
cantos marianos, obras para órgano y/o piano, cuadernos manuscritos de metodología gregoriana. Por género se clasifican en obras vocales (a dos y tres voces), en estilo “canción”, instrumentales (órgano o piano) y el género de obras para voz y piano. Las razones de selección están relacionados primordialmente con la identificación de las obras musicales y el ordenamiento en base a los siguientes parámetros: por orden cronológico, por la Forma, el género, el estilo, la especie, ya fuesen manuscritos o impresos.

Revisando los datos que proyectan las fuentes, se ha elaborado una ficha de catalogación para obras musicales, basada y adaptada a la que hoy, exige la normativa internacional RISM; ello ha permitido, estructurar una ficha propia para el adecuado manejo de la información de cada obra.

En relación con los aspectos musicales, propiamente dichos, la metodología se encamina primeramente hacia la selección de aquellas composiciones que tuvieron vigencia en su momento y que pudieron ser seleccionadas y clasificadas por género y forma. Recabar la mayor cantidad de información a partir de la partitura, fue el primer quehacer en este apartado. Sin embargo algunos datos se indagaron en libros, en enciclopedias, incluso en internet, sobre todo en lo referente a las formas musicales y a los autores y su obra en general. Los datos obtenidos, se fueron anotando en una ficha técnica elaborada para este fin, con lo cual se ha logrado organización, de acuerdo a las prioridades y parámetros de análisis, para llegar a unas conclusiones claras. Todo el material básico de una obra musical, vale decir: células o motivos melódicos, células rítmicas, metro rítmico, tonalidades, escalas, figuran en forma explícita. Los aspectos armónicos, cifrados, polifonía y contrapunto, y las relaciones texto - música, expresión íncipits musicales, se analízan claramente. Así como la forma o estructura de las obras, se presentan en un diagrama con el fin de que sea lo más gráfica y clara posible. En el capítulo V dedicado a los aspectos puramente musicales, se tratará la metodología del análisis musical utilizado para este fin.

De las fuentes secundarias, tan importantes para la complementación de la investigación, merece comentar cómo se seleccionaron, puesto que las hay de carácter general y de carácter específico para el tema. Tanto las fuentes 
secundarias impresas bibliográficas que se conservan en los Monasterios y en las Bibliotecas públicas, así como las fuentes de tipo documental: representadas en grabaciones de música, videos, entrevistas grabadas, fueron de gran ayuda para el conocimiento de la vida de la localidad de Alba de Tormes, como de la vida conventual y musical de los monasterios investigados. La bibliografía de carácter general, como son las obras referentes a la Iglesia, la religión y la espiritualidad, fueron consultadas en las Bibliotecas públicas del Estado o ya en las bibliotecas universitarias; en los Archivos conventuales se encontraron al igual este mismo tipo de fuente bibliográfica pero en menor escala. En mayor grado, se encontró bibliografía referente a obras de los fundadores de las órdenes o de autores que han escrito sobre los aspectos escultóricos de los conventos, al igual que la literatura de la época, fue un valioso y eficaz instrumento para conocer los aspectos femeninos de la época. Las fuentes para la historia de Salamanca, fueron muy valiosas para enmarcar la investigación dentro de la época y conocer las condiciones de vida de las gentes, lo social, lo político y los aspectos económicos y religiosos del momento.

\section{FUENTES SECUNDARIAS}

\section{CUADRO SINÓPTICO}

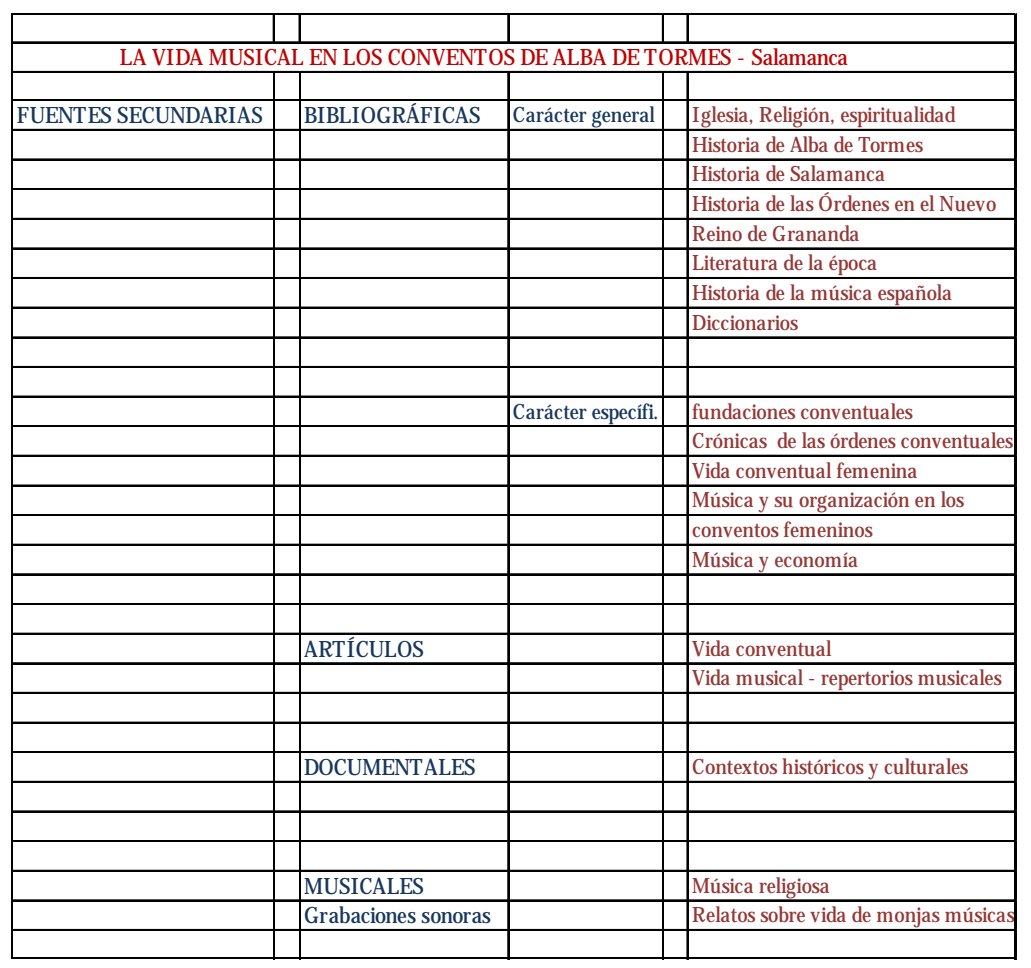


- La amplia variedad de temas que se entrelazan en este tipo de investigación, así como la multiplicidad de fuentes primarias, como material inédito, admitió un cúmulo de probabilidades de investigación y permitió hacer un enfoque metodológico guiando la atención hacia la estructura, planteada en la tabla de contenidos de manera metodológica y coherente, relacionando los aspectos referidos anteriormente. El estilo de redacción se orientó de forma natural, sencilla pero clara.

\section{- ESTADO DE LA CUESTIÓN}

Para dar inicio a un detallado estado de la investigación, como primera medida se ha tratado de establecer las líneas de la bibliografía que ofrecerán un soporte valioso de generalidades y en segundo lugar, se han determinado las fuentes que aportarán la información indispensable para el desarrollo del tema. La lectura y valoración de la bibliografía, de todo género, dentro de marco conceptual establecido, determinan el interés que se tiene sobre el tema y permite al mismo tiempo conocer el contexto social-político y religioso del momento.

Se consideran de importancia, las obras tradicionales de la historia social del siglo XVII, puesto que ofrecen una visión global del contexto socio-cultural y religioso de la época, así como los libros escritos sobre la Historia de la Iglesia su desarrollo a lo largo de estos siglos. Nos han sido muy útiles las obras de Fernández Álvarez, Maravall y Defourneaux, así como las obras de Deleito Piñuela y Caro Baroja.

En la obra Historia de la Música Española dedicada al siglo XVII, del profesor José López Calo, se realiza una exposición interesante, de la evolución de la música, en sus variados aspectos a lo largo de éste período barroco, considerado poco conocido y en gran parte, descuidado para la Historiografía europea. López Calo, hace un amplio y sistemático estudio de esta interesante época, en el que analiza conceptos básicos del barroco, aplicables a la música en España, la armonía y el acompañamiento de las diversas formas musicales sagradas, tanto vocales como instrumentales, de la música profana, tanto la de cámara como la escénica, los instrumentos y su música. 


\section{- BIBLIOGRAFÍA ESPECIALIZADA SOBRE VIDA CONVENTUAL} FEMENINA

Entre la Bibliografía especializada sobre el tema, varias son las obras que sirven de referente y que muestran el interés por este tipo de investigación: De Concha Torres, La clausura femenina en Salamanca en el siglo XVII Dominicas y carmelitas descalzas; de J esús Imirizaldu, Monjas y beatas embaucadoras, una obra fundamental. Otro estudio que merece especial atención es el de Mariló Vigil, La vida de las mujeres en los siglos XVI y XVII; deJ osé L. Sánchez Lora, el clásico Mujeres, conventos y formas de religiosidad barroca. La obra de J esús María Corredera Martín, titulado Alba de Teresa, nos relata los grandes rasgos la vida por tierras Albenses de la Madre Teresa de J esús, los pasos de la fundación de Convento y la vida conventual actual. De Guillermo Furlong, su obra La cultura femenina en la época colonial, muestra la vida social y el papel desempeñado por la mujer en épocas coloniales en América. Distintas historiografías locales se han hecho ya sea desde el punto de vista históricos o artísticos, como por ejemplo, de Nicolás Gonzáles o Jiménez Duque, para las Carmelitas de Ávila, los estudios de Leticia Sánchez para las Agustinas de Madrid; en el caso de Salamanca, los estudios de carácter artístico, de García Boiza y A. Madruga sobre las Madres Agustinas, de J osé María Martínez Frías sobre las Isabeles [Espacios visibles Espacios invisibles] y de Gloria García y Mari Luz de Prado Mujer y memoria en la Salamanca del siglo XVI, , publicado dentro del proyecto internacional "La mujer y los lugares de la memoria", concebido por la Fundación Pascual Valerio, para impedir que la secular experiencia femenina quede en el olvido; pretende focalizar la atención a partir de la visibilidad de los lugares que han acogido las mujeres y que ellas mismas han hecho vivos. Del musicólogo Paulino Capdepón hemos utilizado sus estudios tan completos sobre la vida musical en los conventos madrileños de gran importancia como son Descalzas Reales y la Encarnación, y de la investigadora J ulieta Vega su magnífica tesis sobre la música en los conventos femeninos de Granada.

Con motivo del IV Centenario de la muerte de Santa Teresa, en 1982, salieron a la luz, varias publicaciones sobre su figura y sobre la Orden, que son de gran valor 
para este trabajo, entre ellas, las Actas del IV Congreso Internacional Teresiano, contenidas en dos volúmenes. Así mismo, el libro Salamanca, Conventos y Monasterios. Tres Diócesis y una Provincia de Ana Fortes García y Jacobo Sánchez Hermida, nos brinda una visión global de los Conventos y Monasterios que pertenecen a tres diócesis: Salamanca, Plasencia y Ciudad Rodrigo, mostrando la vida Conventual, vestigios artísticos, arquitectura, imaginería y diferentes oficios que aún se desarrollan al interior de los mismos.

\section{DICCIONARIOS:}

Otro género Bibliográfico que aporta datos puntuales sobre la música religiosa en Colombia es el de los Diccionarios enciclopédicos y entre estos vale citar al Diccionario de la Música Española e Hispanoamericana de la SGAE e ICCMU, obra dirigida por Emilio Casares Rodicio, en el tomo III , pps. 815-822, brinda una reseña y las generalidades sobre la historia colonial de Colombia, el desarrollo de la cultura y el papel predominante de la Iglesia en lo referente a la vida familiar, social, a la evangelización y aculturación indígena, así como la supremacía y control que ejerció sobre la vida intelectual, vigilancia de la imprenta, la producción literaria y musical, el contenido y la divulgación y circulación de las obras. De igual manera ofrece una reseña de los músicos españoles, Maestros de Capilla que viajaron al Nuevo Mundo y de las Colecciones importantes de la Música Sacra de los siglos XVI, XVII Y XVIII que fueron enviadas a América y de los músicos naturales formados ya en el territorio que más adelante tomo el nombre de Colombia.

De la misma forma, el Diccionario de la Historia de la Iglesia [cuatro tomos] permite obtener datos concretos de muchos aspectos de los temas eclesiásticos y seculares, que atañen al presente trabajo.

\section{- DESARROLLO DE LA MÚSICA Y SU ORGANIZACIÓN EN LOS CONVENTOS FEMENINOS:}

Para empezar, citamos el artículo "Aportaciones de la correspondencia epistolar de Miguel de Irízar sobre música y músicos españoles durante el siglo XVII", de Matilde Olarte, donde se nos ofrecen datos referentes a la importante 
correspondencia mantenida por dicho músico con maestros de Capilla y compositores de su época (un total de 362 cartas recibidas durante los años 1663 y 1684); muchas de sus composiciones fueron llevadas a América por los maestros músicos. Otros aspectos a los cuales hace referencia el artículo, son los relacionados con las múltiples recomendaciones que para la composición de las obras, hacen los músicos a sus discípulos, o por ellos mismos, de acuerdo a las característica y habilidades del candidato, los instrumentos que tocan o su destreza en la composición y ejecución. El intercambio musical de Miguel de Irízar es continuo a lo largo y ancho de la geografía de España. Las Ordenes Conventuales solicitaban al compositor, música para las diferentes festividades y que estuvieran acordes con el tipo de personas disponibles para el canto y la interpretación de instrumentos.

En segundo lugar, el artículo de Soterraña Aguirre "El manuscrito polifónico de Santa Clara de Carrión de los" (Libro de música dedicado a Sor Luisa), Condes más que un repertorio musical, brinda en primera instancia, una reflexión del tema, considerándolo como el fruto de una cultura muy particular, susceptible de ser examinado y rescatado y en segundo término, muestra la tarea realizada por las personas creadoras, emisoras del códice y las receptoras, fomentándose de ésta manera, una formas de comunicación entre las mismas. Otra consideración que se aprecia la ponencia, es la relacionada con los aspectos religiosos -culturales del convento, como por ejemplo, el ceñimiento de sus actividades musicales a un calendario litúrgico y el compromiso religioso asumido por las monjas en estas actividades.

Así mismo, de María Leticia Sánchez Hernández, en "El Monasterio de la Encarnación de Madrid", nos invita a conocer sobre la Fundación del Monasterio, sobre vida material y religiosa, sobre su hacienda y en una palabra todo lo relacionado con extensa e interesante vida conventual.

De Collen R. Baade, "La música sutil del monasterio de la madre de Dios de Constantinopla: aportaciones para la historia de la música en los monasterios femeninos de Madrid a mediados del siglo XVI y del siglo XVII", nos brinda 
detallada descripción de la fundación del Monasterio de Nuestra Señora de la Salutación, conocido más comúnmente como Madre de Dios de Constantinopla, así como detalles de los libros de fábrica del convento, con los que fácilmente se puede hacer un seguimiento de la actividad musical y la puesta al día en cuanto a las prácticas musicales y se puede tener una visión llamativa de lo que era la música en los coros y capillas de las monjas músicas españolas, así como las memorias de toma de hábito y profesiones y en los que destaca la presencia en el monasterio, de monjas destacadas en el canto.

De la Bibliografía colombiana, es preciso mencionar la investigación realizada por Constanza Toquica, Directora del Museo de Santa Clara de Bogotá, titulada A falta de oro: linaje, crédito y salvación, en el cual ilustra la vida conventual y la riqueza pictórica del Monasterio durante los siglos XVII y XVIII.

De J osé Ignacio Perdomo Escobar, la obra Historia de la Música en Colombia, nos da una visión muy completa sobre la música desde sus orígenes y el desenvolvimiento de la misma hasta el siglo XX. En su obra, el autor describe la vida musical de la Catedral de Santa Fe de Bogotá y la vida conventual de algunas órdenes religiosas, destacando sobre los compositores musicales, las formas y géneros musicales, así como la vida musical en lo tradicional, en lo popular y en el nacimiento de la música seria en Colombia.

De Edgardo Bermúdez, su obra Historia de la Música en Santa Fe de Bogotá, rescata cuatrocientos años de música, desde épocas coloniales hasta 1938, sin dejar de lado el momento en que apareció la música grabada y los diferente géneros y estilos, difundidos por la radio, que cambiaron paulatinamente las costumbres de la naciente sociedad bogotana. Una publicación de la Fundación de Música, que con el apoyo de la Alcaldía, en 220 páginas ofrece una documentación gráfica, fotografías de músicos, recintos e instrumentos; este estudio recopila: Música colonial, Música de la época Republicana, la que se disfrutó en los primeros conciertos y espectáculos musicales que se vivieron en Santa Fe de Bogotá. Se autor, se valió del Archivo Capitular de la Catedral Primada de Bogotá y de algunos investigadores, que sobre compositores santafereños se llevaron a cabo en el siglo XIX, así como publicaciones periódicas e importantes hallazgos 
como el Archivo de Música colonial, del Convento de Santa Clara, que data de los albores del siglo XVIII, y que se convierte junto al de la Catedral, en los únicos archivos que sobre el género, existen en Colombia. Este estudio, está complementado con una parte sonora compuesta de 2 discos compactos con 46 piezas, que recrean lo mejor de la música de Bogotá en los últimos cuatro siglos realizados con criterio de interpretación histórica, utilizando réplicas e instrumentos originales de la época. El repertorio está conformado por villancicos, contradanzas, valses, bambucos y pasillos.

La Historia de la música en Bogotá se empezó a escribir en las iglesia en la colonia, estructurándose los mejores coros, con clérigos destacados, Maestros de canto, que con sus voces y partituras construyeron un invaluable archivo musical, que se ha conservado intacto desde el siglo XVI, en la catedral de Bogotá.

Por último, gracias a los préstamos Inter bibliotecarios, he podido acceder a excelentes artículos y libros de Italia e Inglaterra, que siguen modelos metodológicos diferentes, los que permiten hacer puntos de comparación y valoración, como por ejemplo, el estudio de Anne Yardley, Bagnall sobre la actividad musical en los conventos ingleses durante la Edad Media (Performing Piety: Musical Culture in Medieval English Nunneries), y los de Colleen Reardon y Elissa B. Weaver sobre la vida musical en los conventos italianos (Holy Concord Within Sacred Walls: Nuns and Music in Siena, 1575-1700, y Convent Theatre in Early Modern Italy: Spiritual Fun and Learning Women, respectivamente.

En conclusión, se puede observar que paulatinamente el interés en torno al tema, va en aumento, por cuanto la figura femenina, concebida en un primer momento como inexperta, aporta innumerables testimonios de capacidad y es vivo ejemplo de ser profesional en la labor escogida y encomendada. Tanto la vida conventual, como musical e intelectual de las monjas, incluso los detalles más personales de sus vidas son motivo de estudio, por parte de los investigadores. 


\section{CAPÍTULO I}




\section{CAPÍTULO I}

\section{CONTEXTO HISTÓRICO DESDE EL SIGLO XVII \\ LOS CONVENTOS FEMENINOS DESDE EL SIGLO \\ XVII EN ALBA DE TORMES}




\section{I.1. CONTEXTO SOCIAL Y RELIGIOSO ESPAÑOL DESDE EL SIGLO XVII}

\section{LOS CONVENTOS FEMENINOS DESDE EL SIGLO XVII, EN ALBA DE TORMES.}

Para la historia general de España y para la de su cultura, el Barroco es un momento crucial e importante. Políticamente, es el período en que se inicia la decadencia, gradualmente en un comienzo y vertiginosamente al final, ya que la muerte de Felipe II coincide con el final del Renacimiento y la desaparición del gran músico español Tomás Luís de Victoria, se produce ya iniciado el Barroco. Al imponerse la Dinastía francesa después de la muerte de Carlos II, la expansión colonial en América y los recursos que de ella llegaban, ayudaron a sostener económicamente a un reino que habiendo perdido aquel brillo Renacentista, aún daba frutos interesantes. Culturalmente, la época tiene gran interés puesto que el llamado Siglo de Oro de la cultura española llega hasta más allá de la mitad del Barroco. La culminación de la pintura española iniciada con energía en el Renacimiento, tendrá su culminación en el Reinado de Felipe IV con el más grande de los pintores barrocos de Europa: Diego Velásquez. También la literatura tiene su apogeo y nos ofrece ejemplos magníficos con un Góngora y un Quevedo que, pese a una clarividente imagen pesimista de la situación que se vivía en el momento y del futuro, logran obras espléndidas. En la novela, El Quijote de Cervantes, surgida en el Renacimiento, tiene su proyección en el Barroco. En el Teatro, la literatura española dará sus mejores obras con Lope de Vega que marca la transición entre ambas épocas, y un Calderón de la Barca que es la culminación del Teatro Barroco, además de una serie de autores que contribuyeron eficazmente en la tarea literaria.

Para la música, o al menos para algunos de sus aspectos, la decadencia es aún más rápida que para las otras artes, después de haberse vivido el esplendor de la polifonía en un momento tan inmediatamente anterior; la razón, habría que encontrarla, para algunos autores, en la perpetuación de las formas ya anticuadas y en la difícil y lenta penetración de las corrientes nuevas de la monodia 
acompañada, que hace por ejemplo que el Oratorio sea algo más tardío y reducido casi siempre a la forma menor de la Cantata. Otro tanto experimentó la música instrumental, que después de haber conocido un inicio puramente español en la época renacentista de Cabezón u Ortiz, se mueve muy lentamente en el Barroco; en cambio, el espectáculo teatral entró con rapidez y se compusieron óperas con la misma rapidez que se hacía en otros lugares. Este gran episodio musical de la época barroca en España proporcionó la implantación de géneros como la ópera y la zarzuela, géneros que no llegaron a cristalizarse en una ópera nacional española, por la invasión italiana que se opera a la llegada de los Borbones.

El Barroco es sin lugar a dudas, uno de los períodos más interesantes y ricos de la Historia de la Música. Ubicándonos cronológicamente en los finales del siglo XVI y hasta mediados del XVIII, podemos conocer que durante él, se producen gran cantidad de cambios en lo literario y en la plástica y surgen tantas nuevas formas de religiosidad, nuevas formas en el pensamiento, nuevas formas musicales apoyadas claro está en el Renacimiento, entre las que se destacan la Fuga, la sonata, la Opera, la Cantata, la Pasión, el Oratorio, la Suite y el Concerto como compositores tan importantes como Bach, Corelli, Lully, Couperin, Vivaldi, Purcell, Monteverdi y Haendel, los cuales dieron identidad propia a este período, considerado una de las cumbre de la Historia musical, por lo que la aceptación del término Barroco, se impone y es clara su procedencia de las necesidades internas del período. Aquella variedad de formas técnicas e idiomas musicales nacidas en este período, que han sobrevivido con diversas variantes hasta hoy en día, nos permite apreciar su valor definitivo, sin desconocer aquella realidad fundamental existente entonces como fue la importante función que desempeñó la música ante el poder religioso, ante la monarquía absoluta o ante pueblo llano. El Barroco a la vez que cerraba paulatinamente las puertas al Renacimiento, se convertía en un período caracterizado por una profunda crisis en todos los sentidos; no solo en lo económico, sino también en lo social y en lo religioso; la crisis en valores era evidente, ya que el hombre se voló en la magia, las supersticiones, lo sobrenatural o las falsas devociones. El protagonismo religioso alcanzado por el XVII, tuvo su origen en el proceso de necesaria renovación en todos los 
aspectos, social, político y por ende, religioso. Analizando la herencia recibida de siglos anteriores, se puede decir que la Iglesia convertida ya, en el siglo XIII en una fuerte y poderosa institución, no estuvo exenta de la necesidad de cambios radicales. "Los hombres comienzan a ponerla en entredicho pues no responde plenamente a sus necesidades espirituales, limitándose a aplicar de forma automática los mismos ritos de siempre."1

Dos grandes eventos en materia religiosa marcaron el panorama de la Edad moderna: La Reforma protestante y la Contrarreforma Católica. La primera fue "un movimiento renovador de la iglesia comenzado en 1517 por el monje Martín Lutero, fuera de la iglesia de Roma y en contra de ella"2. "Por Contrarreforma entenderíamos: "el conjunto de manifestaciones resueltamente anti-protestantes del Catolicismo en vías de renovación de los siglos XVI y XVII, que tiene como máxima expresión el Concilio de Trento”3.

Ahora, analizando cuáles fueron las causas de esta revolución religiosa, se puede decir que la espiritualidad alcanzó un punto en el que no brindaba satisfacción alguna; a su vez, las teorías luteranas enfatizaban sobre la justificación por la fe, creando el caos en Europa. Por su parte la Iglesia Católica emprendía la Contrarreforma, en la que la intervención de los monarcas y los teólogos especialmente de la Compañía de Jesús, fue decisiva. El Concilio de Trento, celebrado entre los años 1543 y 1563, se constituyó en la eterna lucha de la Iglesia Católica contra el Protestantismo. "El Concilio tenía dos grandes objetivos: uno era determinar definitivamente los dogmas fundamentales de la fe católica; el otro era llevar acabo una reforma eclesiástica"4. Respecto a las instituciones, como el clero, y las órdenes conventuales, se hablará más concretamente más adelante.

En la obra de Concha Torres sobre el tema, encuentro de interés lo siguiente: “Un papel muy importante en la obra divulgativa y propagandística de la Contrarreforma, la desempeña la hagiografía. El culto a los santos fue un punto

1 TORRES SÁNCHEZ, Concha. La clausura femenina en la Salamanca del siglo XVII. Salamanca: Publicaciones de la Universidad de Salamanca, 1990, p. 26.

2 Op.cit, .p. 20

3 Ibídem, p. 20.

4 Ibídem, p. 21. 
importantísimo en el Concilio de Trento, era uno de los dogmas que más fuertemente tenían que ser reafirmados frente a los protestantes (que lo negaban). No solo se emplearon en favorecer el culto a la imagen sino también a través de la palabra”5. La confusión mantenida a través de largos años, se fue aclarando paulatinamente, pero la Reforma propiamente se consolidó en los últimos decenios del siglo XVI y los primeros del XVII. Los J esuitas desempeñan un papel importante en la época. Con todo este proceso, se reanimaron los antiguos ritos religiosos. El incremento del nacimiento de Hermandades de todo tipo, el esplendor de las fiestas eclesiásticas, el esmerado cuidado de las Iglesias y su decoración, y la fastuosidad de las procesiones, fortalecen la religiosidad en el pueblo. Los reformadores desterraron el abuso del culto a los santos y a sus reliquias, dándole una nueva dimensión de purificación, desechando la idea reconocida que existía de abuso arraigado de esta práctica. Desde Roma se introduce en todos los países católicos la reforma católica de la Iglesia. En el arte, Miguel Ángel condujo la armonía del Renacimiento hacia la nueva concepción del arte, con una idea conductora clara que reafirmó la religiosidad en torno a la figura de San Pedro, piedra angular de la Iglesia. Se construyeron las grandes catedrales con un gran altar Mayor, espaciosas naves laterales, un púlpito central para el predicador y las capillas laterales, constituyeron la nueva Iglesia del barroco. Se crean en Roma nuevas Órdenes religiosas e Iglesias como la de los Teatinos, la de San Andrea in Valle, San Ignacio continúa con su ideal con el máximo entusiasmo. Respecto de la decoración de los altares mayores, en la obra de Wilhem Nauss, encuentro la siguiente explicación: “Grandes altares mayores con abundantes imágenes, no pocas veces sustituibles en cada época del año eclesiástico, y sumamente plásticos dominan todo el espacio del templo. Los altares laterales con imágenes y relicarios de sus santos patronos se ordenan más abajo. Si se consideran más atentamente, pronto se confirma que ha desaparecido una buena parte de las representaciones medievales. El riquísimo altar lateral de la Edad Media con sus grabados de leyendas y sus tablas ha cedido el puesto a un altar dominado totalmente por una gran imagen o un gran cuadro o de la imagen tiene siempre algo de la elevada fe en el triunfo de Cristo y de su Iglesia. Por eso en lugar de pintar las leyendas de la vida de los santos, pinta su glorificación celestial:

5 Ibídem, p. 30. 
ímpetu extático que es precisamente el paralelo artístico del empuje de la mística”6.

No se puede ofrecer con ligereza, una idea exacta de la vida de piedad de la Iglesia, especialmente de la del pueblo. Algunos autores señalan que la Reforma vino de la mano del temor que los gobernantes católicos tenían a ver disminuidos sus derechos sobre la Iglesia; se emprendió la Reforma con ciertas vacilaciones y los Capítulos protestaron contra cualquier disminución de sus heredados privilegios. Pero preguntémonos, que trajo el Barroco y qué carga verdadera soportaba el hombre del siglo XVII? La superstición, la magia, la fe, el fenómeno de los milagros, exorcismos, cada una de ellas estrechamente relacionadas con el entorno familiar, político y en gran medida en las prácticas de la medicina, hacían que la vida social de la época, girase en torno a una arraigada religiosidad que, de por sí, regía en todos los ámbitos sociales.

Por aquel entonces, la historia se pensaba, se vivía y se concebía en torno a los valores religiosos; basta escudriñar en la bibliografía escrita sobre el tema, para enterarse de lo mucho que se ha escrito sobre los orígenes de iglesias y conventos, sus tesoros, las reliquias que en ellos, aún hoy en día se veneran y las festividades que en la actualidad se conservan como patrimonio del pueblo. La vida de las personas era vigilada celosamente por la iglesia. La administración de los Sacramentos como: el bautismo, la confesión y la comunión Pascual eran actos obligados para todo individuo; el niño al nacer debía ser bautizado de inmediato, dada la incidencia de defunción infantil. La asistencia a la Santa Misa se consideraba con carácter obligatorio. La ceremonia de vigilia por la muerte de algún individuo, también estaba impregnada de sentido religioso; basta ver los mausoleos de las grandes familias, en los que se puede apreciar tallas o esculturas con motivos religiosos, además de los sufragios y el número de misas que debían aplicarse por su alma, tratándose de personas acaudaladas, especialmente. "si la Casa Real mantenía comunidades enteras para que le dedicaran sufragios, un Grande de España debía dejar encargados muchos miles de misas; el noveno Duque de Medinaceli se excusó de no mandar decir más que $10.000<$ por lo

6 NEUSS, Wilhem. La Iglesia en la edad moderna y en la actualidad. Historia de la Iglesia, v. IV. Madrid: Rialp, 1962, p.283. 
crecido de sus deudas > $>$ 7. El concepto de salvación, como se puede observar en esta crónica, se valoraba de acuerdo al número de misas que la persona pudiera hacer aplicar por su alma, después de la muerte. Las ciudades y los pueblos sufrieron en la época grandes epidemias, que les obligó a enterrar a centenas de personas en lo denominado carneros o cementerios improvisados fuera de las áreas urbanas. Llegando la Ilustración y por motivos de higiene esta medida fue la que encontró más reticencia en aplicarse. La devoción a las ánimas benditas del purgatorio fue otro de los aspectos de la religiosidad que se vivió por esta época, las que se encontraban en retablos, en paredes y en todo tipo de manifestaciones artísticas. Se incrementó en el calendario oficial, el número de fiestas religiosas en virtud de un largísimo proceso de cristianización.

La familia en sí asumió un compromiso con la Iglesia, en el sentido de mantener una estrecha vinculación con ésta, representada en fundaciones conventuales, donaciones, patronatos, oratorios privados o el derecho de presentación a un beneficio. España con su interrumpida tradición religiosa continuó en este siglo, su camino de piedad habitual. Los grandes místicos de la época inflamaron las almas, especialmente en los conventos existentes y dieron pie a la fundación de nuevos claustros, dando de esta manera nuevos y poderosos impulsos a la piedad. La mística española alcanzó su máxima plenitud, ratificada en dos formas: La mística cristológica activa de San Ignacio y la sosegada mística de Dios, representada en Santa Teresa de Jesús; ambas tuvieron conexiones directas.

Diversidad se ejemplos pueden ilustrar este fenómeno místico en el que familias enteras se vieron involucradas directamente en la fundación de Ordenes conventuales. María de Agreda (1602-1665) hija de una familia piadosa, vio su casa convertida en Convento, en el que ingresaron como monjas, ella, su madre y su hermana. La misma María de Agreda fue superiora. En la fundación del Convento de la Anunciación de Alba de Tormes en la provincia de Salamanca, nobles cónyuges como Don Francisco de Velásquez y Doña Teresa Laiz, se comprometieron con sus bienes y sus personas, en la fundación del Convento de la Anunciación de Alba de Tormes en la provincia de Salamanca. Ana de la Cruz, de

7 DOMINGUEZ ORTÍZ, Antonio. “Historia de la Iglesia”. Las clases privilegiadas en la España del antiguo régimen, p. 6. 
noble familia, hija de los Duques de Alba, Don Antonio de Toledo y Doña. Mencía de Mendoza, que estuvo casada con el Marqués de Villanueva, al enviudar ingresó en el mencionado convento, ayudando a la vez, con su considerable dote, al ingreso de tres religiosas más; llegando a ser prelada. Beatriz, sobrina de Santa Teresa de J esús, ingresó en el Convento de la Anunciación influenciada por su tía; pocos meses después de la muerte de la Santa, Beatriz tuvo un sueño, que acrecentó su vocación y le hizo tomar la decisión de tomar los hábitos, llegando a ser fundadora en Madrid; permaneció 64 años como religiosa de los 84 que vivió; su muerte ocurrió en la capital de España, en el año de 1647; su santidad fue tal, que aún se conserva su cuerpo incorrupto en el presente siglo. Como estos ejemplos se pueden mencionar muchos más, que brindan una clara visión de la tradición religiosa que se vivió en la época.

Otro aspecto social para destacar en la vida escolástica, es el referente a la educación y a la beneficencia. Como el Estado se desentendió de ello, los municipios constituidos en piezas fundamentales del Antiguo Régimen, en colaboración con la iglesia, proveyeron las necesidades más inmediatas en este sentido. Se crearon las Fundaciones Benéficas tan apreciadas por las gentes, puesto que con sus recursos se dotaban doncellas, se contribuía a socorrer a los ancianos, se fundaban centros de enseñanza, etc. Los hospitales crecieron en número y con determinada especialidad, como: Hospitales para dementes, para sifilíticos y para leprosos, dolencias que aquejaban con más frecuencia a las gentes en la época.

El sistema carcelario y la asistencia a los presos, fue otro de los aspectos y ocupaciones que interesaron a los eclesiásticos, respectivamente. Algunos personajes jesuitas como Pedro de León, se consagraron a realizar su ministerio en las cárceles y a lograr para los reos una sepultura decente después de su muerte. Como se puede observar la Iglesia mantuvo su presencia en la vida social en forma activa. Otra de las actividades en las cuales se la vio muy involucrada, fue en la atención a los expósitos. Antonio Domínguez Ortiz, nos dice lo siguiente al respecto: "Hasta finales del siglo XVIII, el Estado apenas se ocupó de esta cuestión, y los municipios muy poco, a pesar de que era del mayor interés reforzar 
una demografía depauperada por emigraciones, guerras y epidemias"8. En una apreciación muy personal, considero que fue una labor encomiable, asumida con voluntad pero carente de una adecuada planificación, pues según lo investigado al respecto, en ocasiones, algunas diócesis no encontraban soluciones a los problemas de solvencia económica para las casa-cunas, mientras las rentas se utilizaban en lujos, pleitos eclesiásticos o a pensiones a personas adineradas e influyentes que no lo necesitaban; sirva de ejemplo la situación angustiosa que vivió la casa-cuna de Sevilla en alguna oportunidad por aquellos tiempos, también relatada en la obra de Domínguez Ortizg.

Y continuando con los aspectos relevantes de este contexto social y religioso, cabe destacar la educación. En gran parte la Iglesia asumió esta responsabilidad. La enseñanza primaria careció de atención por parte del gobierno. En las áreas rurales no era raro encontrar al párroco o al sacristán enseñando a leer o a escribir a un grupo de niños. En los conventos se impartía la enseñanza elemental. Las universidades en gran parte tuvieron carácter religioso, sin embargo presentaban a su vez rasgos seglares. Las universidades de Salamanca y Granada por excelencia fueron de carácter eclesiástico representado en profesores y alumnos de las cátedras de Teología y Cánones. El nacimiento de los Colegios Mayores frecuentemente originaron pugnas en su relación con las Universidades y en algunas ocasiones dichos colegios llegaron a absorber a las universidades como es el caso de Alcalá de Henares en el que el Colegio de san Ildefonso llegó a absorber a la institución universitaria o viceversa; o el caso del colegio dominico de santo Tomás, que en su momento llegó al fracaso en su intento de erigirse como universidad autónoma. Los colegios jesuíticos impartieron la enseñanza media como una actividad regular y permanente dentro de su concepción social. Pronto tomaron auge y su pedagogía fue aceptada y asimilada por la sociedad, llegando a extenderse por toda España y por Hispanoamérica. Su filosofía amplió el panorama o la visión del hombre como tal, en el sentido de formar no solo al sacerdote, si no al hombre culto, al caballero, un individuo con roce social, mediante el cultivo de disciplinas como el teatro, la

8 DOMINGUEZ ORTÍZ, Antonio. "Historia de la Iglesia”. Las clases privilegiadas en la España del antiguo régimen, p. 9.

9 Op.cit., p. 10. 
declamación, la danza, la esgrima y la equitación; en una palabra ser un hombre de mundo y de una basta cultura. A todo esto, las críticas llovieron y las acusaciones apuntaron a que los jesuitas impartían la educación para las una juventud noble, que en buena parte le hacía falta, tratándose de jóvenes ociosos, mal acostumbrados a los que les venía bien una formación humanística y religiosa.

La actividad misional muy propia de España, tomó fuerza durante el siglo XVII y primera mitad del XVIII y su principal protagonista fue el clero regular y en menor presencia o escala, el clero secular. Sus procedimientos dieron fruto gracias al conocimiento de la psicología popular; con una oratoria sencilla llegaron fácilmente a los corazones, todo esto acompañado de un estilo culto de predicación. Los misioneros generalmente fueron bien recibidos y lograron la cooperación del pueblo. Para impresionar, se valían de variados recursos, como por ejemplo, mostrar calaveras o pinturas de almas sumidas en los infiernos. Gracias a la acción misionera, se lograban buenos resultados, pasajeros, pero provechosos desde el punto de vista social, pues reconciliaban enemigos, se arreglaban uniones deshechas, se combatía la usura; pero una vez pasada la euforia, toda la vida volvía a ser como antes, con todos sus abusos, corrupciones y degeneraciones.

Con toda esta popularidad alcanzada por el clero, era lógico que las autoridades civiles se sintieran indispuestas. Se sabe por la historia que innumerables personajes pertenecientes al clero encabezaron rebeliones y motines. Por otro lado, el clima de terror creado por las epidemias en esta época fue explotado, y con la idea divulgada de que estos acontecimientos eran producto de la ira divina, lograron conseguir en ocasiones el arrepentimiento colectivo y el recrudecimiento de la piedad y de esta forma el clero alcanzaba más protagonismo, tanto por sus funciones y acciones como por el heroísmo de misioneros que arriesgaron su vida atendiendo a los enfermos; pero así como alcanzaron cierto grado de protagonismo en la historia, también en el siglo en cuestión, grandes fallos acompañaron a esta empresa. Enuncio algunos ejemplos citados por Domínguez Ortiz: “En 1598, los cabildos de Vigo y Tuy abandonaron estas ciudades. En Bilbao, los párrocos rehusaron asistir a los atacados, por lo que muchos murieron sin sacramentos. Pero estos casos fueron excepcionales; por lo común, ambos cleros permanecieron en su puesto cumpliendo su peligroso deber, 
y en no pocos casos se excedieron, pagando su celo con mortalidades altísimas. Durante la gran peste de 1649 murieron 1025 de sus moradores en los 37 conventos de Sevilla, o sea más de la mitad"10. Acusaciones de diversa índole, recibieron por motivos económicos especialmente como las exenciones fiscales, acaparamiento de rentas y en contadas ocasiones de competencia profesional.

Pero lo más usual, fueron las acusaciones recibidas por la sociedad a causa de reunir gran cantidad de bienes raíces exentos de impuestos recayendo esta carga monetaria en los seglares. Otro aspecto negativo que en su momento fue severamente criticado apuntaba hacia el ordenamiento sacerdotal apresurado y por ende, la baja moral de estos. Ya en otro sentido más delicado que lo anterior, en los Archivos inquisitoriales reposan infinidad de procesos contra sacerdotes depravados, que llegaron a prostituir incluso el uso de los sacramentos. Pese a toda la protesta colectiva por las acciones deshonrosas cometidas, por los abusos y la falta de ética, el clero continuó siendo respetado, sin que se afectara su integridad social.

Ahora analizando la clase de personas o grupos sociales que abrazaron la vida religiosa y que a su vez engrosaron las filas del clero o de las Ordenes conventuales, encuentro que influyó en ello y en gran medida, el factor económico y las motivaciones fueron de toda índole: por ejemplo, el hijo de un modesto labrador que deseaba llegar a ser el párroco de su pueblo, respetado y/ o aceptado en alguna poderosa comunidad. Situaciones de orden social que llevaban a personas a hacerse religiosas fueron muy variables; por ejemplo, hijas de buenas familias pero sin dote, viudas respetables, mujeres que habían pasado por situaciones sentimentales difíciles, entre ellas amigas íntimas de reyes o nobles que habían perdido sus favores, que al final llegaban recluirse en los conventos; también se dio el caso de hombres que buscaban ya en sus últimos años, una vida tranquila.

Dejando aparte todos estos aspectos mundanos, en esta época de tan arraigada religiosidad, la gran mayoría abrazó la fe, por pura convicción; recordemos aquí, que este fue un período en que la religiosidad y el ambiente de

10 Op.cit., p. 16. 
piedad reinaban de forma intensa. Se sucedieron casos de conversiones súbitas que se hicieron populares, como las de San Ignacio o la de San Francisco de Borja.

Por los albores de 1660, ya el fenómeno místico fue descendiendo y a partir de esta fecha se registran menos fundaciones conventuales. Sin embargo cabe analizar aquí, lo siguiente: el crecimiento del clero regular obedeció a razones más individualizadas, no tenía límite y sus miembros tuvieron motivaciones muy personales como lo anoté anteriormente. Por su parte el clero secular, de organización más rígida, caracterizado por poseer unos escalafones y rentas fijas, se constituyó en lo que algunos denominaron la "Iglesia oficial", bastante burocratizada. Costumbre de las nobles familias de la época, fue dedicar a la iglesia a los hijos segundones que no podían suceder el mayorazgo; de ahí la lucha por colocarlos en cargos de competencia y dignidad acorde con su rango y fue así como llegaron a ocupar las mitras episcopales, hijos segundos en la línea sucesoria de las familias o los hijos bastardos ilustres como: San Juan de Ribera, hijo del Duque de Alcalá, D. Enrique Pimentel, hijo del conde de Benavente, obispo de Cuenca y presidente del Consejo de Aragón, Fr. Alonso de Santo Tomás, presunto hijo de Felipe IV y que llegó a ser Arzobispo de Málaga y muchos otros de importante rango social. Respecto al reclutamiento del clero, según se puede leer en la historia de las ordenes monacales, muchas exigieron el rango de nobleza de sus miembros, como por ejemplo, el caso de los monasterios Benedictinos, que integraban la comunidad claustral de Tarragona, por citar un ejemplo.

Muchos monasterios acogieron a nobles de alta alcurnia que ya dentro del claustro, no muchos olvidaban los privilegios de su nobleza y quisieron reclamar ante Roma sin resultado positivo. Otros por su parte vistieron su sayal con gran estoicismo y verdadera vocación religiosa. Vale destacar en este momento, un aspecto relevante que en la época se tuvo muy en cuenta: la limpieza de sangre, que hoy en día se considera discriminatorio de raza y profesión y que cayó en desuso a través del tiempo. Previo al ingreso en las Ordenes monacales se les preguntaba si el postulante o las postulantes -o pretendientas como se encuentra en los documento - era cristiano(a) viejo y practicante y se investigaba por lo menos cuatro generaciones anteriores, que no tuvieran sangre judía, mora o gitana, o si había sido penitenciado por el Santo oficio o a tribunal alguno, o si había tenido acciones bajas y ruines que afectaran a la causa religiosa. 
Ahora un tema muy importante que no se puede dejar en el tintero, es el relacionado con la fundación de los Seminarios Conciliares y la formación que ahí se impartía, sobre su misión social, su visión y su filosofía. La preocupación de que la formación que los futuros sacerdotes estaban recibiendo, no estaba bien orientada en el ámbito de las universidades, por el carácter disoluto y libertino, vino de Trento. En España, las reticencias para su establecimiento, llegaron de la mano de la poca voluntad de los Cabildos y de los Prelados para desprenderse de las elevadas sumas de dinero que significaba su sostenimiento. En el siglo XVI, más concretamente en la segunda mitad, se crearon diecisiete Seminarios, mientras que en el siglo XVII, solo nueve y al entrar el siglo XVIII, la gran mayoría de las Diócesis, no contaban con estas instituciones de formación religiosa.

En conclusión, dentro de este ambiente marcado fuertemente por el misticismo, por la espiritualidad, el simbolismo y la exacerbación de todas las manifestaciones religiosas, el clero es cada día más fuerte y nacen innumerables órdenes conventuales masculinas y femeninas, congregaciones y Seminarios conciliares; la Iglesia en general representada en sus ministros en sus frailes y monjas, desempeñó un rol decisivo en la concepción y desarrollo de la ámbito social, religioso y político de la época, sin olvidar que este rol tuvo su continuación en las tierras colonizadas de Hispanoamérica.

\section{I.2. BOSQUEJ O HISTÓRICO DE LA LOCALIDAD DE ALBA DE}

\section{TORMES}

ALBA DE TORMES (España): Lugar de silencio. De Salamanca la separan unas pocas leguas de tierra plana; bañada por el Tormes se encuentra esta villa en la colina de fácil acceso, a 90 metros sobre el nivel del río. En relación con su más remota historia, se sabe que fue fundada por los expulsos de Tito y Vespaciano. En el 1197, perteneció al Rey Don Alonso VIII y ya por el año 1304, fue concedida por los reyes de Aragón y Portugal, a Don Alonso de la Cerda y de esta manera y sucesivamente la villa en el transcurso de su existencia, ha pasado a manos de personajes importantes y ha quedado demostrada su popularidad y su categoría. Desde 1581, la villa ha sido célebre, tras la muerte de santa Teresa de J esús, Doctora de la Iglesia. Esta hermosa villa, colinda al N. y O. con límites de la 
capital, al E. con los de Peñaranda de Bracamonte y al S. con los de Piedrahita (prov. de Ávila) y Béjar. Sus tierras por excelencia, son aptas para la ganadería y para la agricultura y por espacio de muchos siglos, han pertenecido al Gran Ducado de Alba.

Se ignora cuándo pisó las tierras de Alba de Tormes el primer evangelizador; sin embargo, cuando se promulga el fuero en el año 1140, ya para entonces, la comunidad cristiana es conciente de estar agrupada en parroquias, con un Alcázar y un Monasterio. La vida espiritual y religiosa tuvo su arraigo en esta villa. Parroquias como las de San Salvador, San Esteban y Santa Cruz, se ubicaron a espaldas del Monasterio Benedictino. En la de Santo Domingo donde asentaron su convento, los franciscanos y la de San Andrés, contigua a la de Santa María de los Serranos, se encontraban en el barrio del Castillo Ducal; en la Parroquia de Santa María, se bautizaron los descendientes de la Casa de Alba, nacidos en la villa. Como es conocido, éstas desaparecieron, perdurando otras de interés arquitectónico y artístico; lo románico, lo mudéjar, lo gótico se conservan en iglesias como las de Santiago, la de San Juan, la de San Pedro, el Monasterio de San Leonardo, el de Santa María de las Dueñas, el convento de Santa Isabel y el de los padres Carmelitas, considerándose a esta villa como un foco de expansión de este Arte ${ }^{11}$.

En lo referente a la directa vinculación del clero con la vida cortesana de entonces, se puede afirmar que los obispos acostumbraban a enfundarse en sus armaduras y salir lanza en ristre a las batallas, a la par, participaban en las intrigas palaciegas y en el reparto de las tierras. El Ducado de Alba, acampa en el obispo Don Gutierre Gómez de Toledo, ocasionalmente prelado de Palencia, quien le recibió en el año 1429, gracias al reparto de tierras que se hizo al expropiar de la villa a J uan II, rey de Navarra y distribuyendo sus heredades entre los cortesanos. La villa salió ganando, puesto que el Obispo Don Gutierre, reside casi que frecuentemente en ella, paga los tributos al Rey y funda el Monasterio de Los J erónimos, estabilizando la región y tomando el dominio completo de la Villa y sus alrededores. El momento cumbre y determinante del ducado, se produce con Don Fernando de Toledo, llamado el Gran Duque, nieto del primer duque Don García.

11. SÁNCHEZ Y SÁNCHEZ, Daniel. Alba de Tormes Historia, Arte, Tradiciones. Salamanca: Artes Gráficas Europa, 1984. p. 12. 
La época del siglo XVII, se caracterizó en Alba de Tormes por innumerables acontecimientos en torno a Santa Teresa de J esús, como su beatificación acaecida el 24 de abril de 1614, por el Papa Paulo V. En 1649, Calderón de la Barca reside en Alba tras su destierro y escribe en esta villa varias de sus obras. Hacia el año 1686, la iglesia de San Pedro es consagrada por el Obispo de Salamanca D. Fray Pedro de Salazar y hacia el 1695, se funda en Alba de Tormes, el Convento de los Carmelitas Descalzos. La historia de los pueblos, queda adherida ineludiblemente a los grandes acontecimientos de su vida y de los egregios personajes que la habitaron o visitaron. Alba concretamente tiene y ha tenido siempre como norte dos figuras señeras de la historia de España: Teresa de Ahumada y Fernando Álvarez de Toledo, el gran Duque. ${ }^{12}$

Para contextualizar la vida religiosa en Alba de Tormes, es importante referirnos a Salamanca, la capital de la provincia donde pertenece. Ciudad universitaria por excelencia, cuya universidad, con una trayectoria insuperable de proyección en el Nuevo Mundo durante el siglo XVII, se erigió como la madre de las más antiguas universidades de Hispanoamérica, a las que transmitió el pensamiento, la cultura y el saber de la época y de cuyos claustros salieron los personajes más interesantes que hicieron historia. El peso urbano de Salamanca tiene su origen en su sede episcopal, la universidad y en la representación en Cortes, extendiendo su influencia hasta las zonas situadas al sur del Sistema Central y de Piedrahita. A partir del 1102, la ciudad surge propiamente con la llegada y fusión de personas de variado origen; serranos, mozárabes, castellanos, portugueses. Las expediciones contra los musulmanes, permitieron a los pobladores, conocer más a fondo el territorio que ocupaban y controlar la inmensa superficie comprendida entre el Tormes y el Tajo. A comienzos del siglo XVII, Salamanca contó con un grupo social pujante y poderoso. El clero, precedido por el Obispo, cuya dignidad y competencia sacramental, se complementaba con una altísima capacidad administrativa: "Está marcada por el privilegio que la divide en dos grandes grupos (privilegiados y no privilegiados)", nos dice Concha Torres13. La ciudad no se escapa a la crisis extendida del siglo XVII: baja de la población,

12 GARCÍA GARCÍA, Jesús María. Alba de Tormes. Páginas sueltas de su historia. Salamanca: Diputación de Salamanca, 1991. p. 11.

13 TORRES SÁNCHEZ, Concha. La clausura femenina en la Salamanca del siglo XVII.

Salamanca: Publicaciones de la Universidad de Salamanca, 1990, p.34. 
descenso de la producción agrícola, inundaciones y hambre generalizada. En siglo XVII, gran número de prelados se sentaron en la silla Salmantina (19 en total); sin embargo se adoleció de cambios continuos, ya por muerte, ya por promociones o por mutaciones. Acontecimientos importantes marcaron éste siglo: En 1618 bajo el Obispado de Don Francisco Mendoza, la ciudad, en el Colegio de la Vega, la Universidad y el Consejo hicieron votos solemnes para defender la Concepción de María. La Canonización de San Juan de Sahagún, fue otro de los hechos sobresalientes de esta época, así como la fundación de órdenes religiosas tanto femeninas como masculinas. Maestros de Capilla y organistas importantes como: Bernardo de Clavijo, Sebastián Vivanco, Diego Verdugo, fueron a su vez Catedráticos de Música en la Universidad.

Respecto al establecimiento de las órdenes religiosas en Salamanca, fueron numerosas las instituciones conventuales; como se sabe, hubo alrededor de 20 Conventos de diferentes órdenes y en especial al tema que nos atañe, los conventos de monjas, fueron muchos, tales como: el de la Madre de Dios, el de San Pedro, el de las Dueñas, el de Santa Clara, el de Franciscanas, el de Santa Isabel, el del Corpus Christi, el de Carmelitas, el de Santa Ursula, el de Agustinas recoletas, de Monterrey, todos encerrando una gran historia en el campo musical, arquitectura y pinacoteca. Entre estas fundaciones de considerable importancia, se puede citar la de la Clerecía, impulsada por la Reina Margarita, esposa de Felipe III.

El clero secular, disfrutaba de altos ingresos regularizados a través del Cabildo Catedralicio. Es menester, hacer una referencia a la Universidad, Institución que desde hace siglos ha patentado el sello de la ciudad. El Alma Mater, experimentó un esplendor artístico y cultural durante el siglo XVI; muchos de sus teólogos, participaron en el Concilio de Trento y en las gestas de América. Relucía en la ciudad y en la Universidad el arte plateresco; El siglo XVII, es estimado como una etapa de transición, y baja el número de Fundaciones conventuales, pero es la época de las grandes fiestas por la beatificación de San J uan de Sahagún y de Santa Teresa de J esús, personajes muy unidos a la ciudad. Un grupo de relevancia fue el conformado por los estudiantes de la Universidad, que pertenecían a diferentes estamentos de la ciudad. 


\section{3. FUENTES PARA EL ESTUDIO DE LA VIDA RELIGIOSA EN LOS CONVENTOS DE ALBA DE TORMES (SALAMANCA)}

Primeramente, vale hacer mención sobre la situación que sufrieron tantos monasterios de España por el sistema de desamortización; pese a ello, esta localidad salmantina ha brindado una diversidad de fuentes tanto primarias como secundarias de gran valor; fuentes representadas en manuscritos, las cuales brindan una visión clara, en primer lugar, del pensamiento de la época, de la forma de sociedad y de la inmensa religiosidad del momento; $\mathrm{y}$, en segundo término, de las fundaciones conventuales y su organización al interior de los conventos tanto en lo jerárquico, como social y en lo administrativo, de la vida contemplativa, de la economía, de la vida cotidiana y del desarrollo de la arquitectura, la música y de las artes.

\section{I.3.1. FUENTES IMPRESAS}

Entre las fuentes impresas, destacamos las de carácter general y las de carácter específico para el tema.

En primer lugar, las obras de carácter general aunque no enfrentan directamente el tema, si brindan una información del todo aprovechable para ubicar el contexto social, político y religioso de la época. Entre ellas, destacan las obras tradicionales de la historia social y conventual del siglo XVII, como son: las de Fernández Álvarez - España y los españoles en los tiempos modernos y Defourneaux - La vida cotidiana de la España del Siglo de oro. La serie de libros referentes a la Historia de la Iglesia y las que hablan del contexto religioso, como Las Clases privilegiadas del antiguo régimen de Antonio Domínguez Ortiz, proporciona una imagen completa de la vida social y religiosa del siglo XVII, realizada en su mayor parte con fuentes de investigación directa; da a conocer lo que fue la sociedad estamental, grupos privilegiados y los que no lo son; analiza los rasgos peculiares de la clase dominante, sus formas de vida, sus estatutos jurídicos, su poder económico y de su palabra, su función política. La iglesia en la edad moderna y en la actualidad de Wilhem Neuss, La historia de la Iglesia en España de Ricardo García Villoslada, Católica y latina: La cristiandad occidental 
entre los siglos IV y XVII de Miguel Ángel Laredo Quezada, así como la obra de J osé Luís Sánchez Lora, Mujeres, conventos y formas de la religiosidad barroca.

En todas las obras sobre la historia de la vida conventual en Salamanca y Alba de Tormes, son de reseñar especialmente para nuestro estudio La historia de Salamanca de Miguel Villar y Macías; Compendio histórico de la ciudad de Salamanca de Bernardo Dorado; Historia de la antigüedad de la ciudad de Salamanca de Gil González Dávila; Salamanca, geografía, historia y arte, de Ángel Cabo Alonso; Arte conventual en Alba de Tormes: Convento Santa Isabel y Benedictinas de Luís Javier Cuesta Hernández; La clausura femenina en Salamanca en el siglo XVII de Concha Torres Sánchez; Alba de Tormes, páginas sueltas de la historia de Jesús María García García; Religiosidad femenina, expectativas y realidades de Ángela Muñoz y María Luz de Prado, Salamanca, Conventos y Monasterios. Tres Diócesis y una provincia de Ana Fortes García y Jacobo Sanz Hermida; y Alba de Tormes: Historia, arte y tradiciones de Daniel Sánchez y Sánchez; Alba de Teresa de J esús María Corredera Martín

\section{I.3.2. FUENTES MANUSCRITAS}

Las fuentes inéditas se constituyen en la base del trabajo. Para empezar, inclinarse por los archivos conventuales es lo más adecuado para llegar a las fuentes inéditas.

\section{- Monasterio de “La Anunciación”. Madres Carmelitas Descalzas.}

El Archivo Conventual da a conocer la trayectoria histórica de la casa, testigo fidedigno de la vida y obra de Santa Teresa de J esús. La historiografía del Archivo conventual nos remonta a la mitad del siglo XVII cuando el historiador Manuel de Santa María organizó todo el material histórico, siendo su trabajo decisivo para la posterior ordenación del mismo. Los libros de Hacienda y economía, aparecen al día. En agosto de 1910, el archivo tuvo otra revisión realizada por el Padre Miguel de la Sagrada familia y de hecho famosos estudiosos del tema han pasado por el Monasterio, como son: Gerardo de San Juan de la Cruz, Lemano, Beneite, Silverio de Santa Teresa. La última revisión del archivo, vino de manos de la archivera actual del convento, la Hermana María Luz, quien lo organizó siglo a siglo y gracias a ello se refleja la trayectoria histórica de la casa. 
De ésta reorganización existe el Catálogo que se maneja en la actualidad redactado a maquina de escribir y se conserva custodiado en armarios metálicos y bajo llave. La catalogación actual, ha permitido un ordenamiento y valoración más completa y el ingreso de documentación que estaba fuera del mismo. Según los parámetros principales que conforman éste catálogo, el historiador hace énfasis en que la parte más completa e importante de éste archivo es la relacionada con la hacienda y la casa de los fundadores Francisco Velásquez y Teresa Laíz, como también lo relacionado con la hacienda de Don Pedro de Aponte. Ya en el campo histórico y como valor documental, merecen ser mencionada la conservación de las escrituras fundacionales, firmadas por Santa Teresa y el Cuaderno de meditaciones sobre los cantares Según su autor, hace falta la inmensa mayoría de información de los Libros de cuentas de los siglos XVI y XVII y falta valiosa documentación sobre los Centenarios Teresianos, puesto que de un sitio como éste, se pudiera esperar mucha más documentación. La metodología utilizada para la ordenación del archivo, consistió en sellar y numerar cada documento, lo que facilita su búsqueda e identificación como también la cita para los investigadores. Se abrieron Libros oficiales para organizar el historial de la casa y el orden del archivo. La ordenación, clasificación y catalogación de los documentos, se ha realizado con base en el esquema aplicado en otros Monasterios de Castilla, adaptando el proceso a las exigencias internas de la casa; lo anterior ha permitido salvaguardar la documentación existente y al mismo tiempo, deja abierta la posibilidad de incrementarlo con la incorporación de Documentación que posiblemente surgirá con el paso del tiempo. Tres copias existen del referido catálogo que está inédito y que se conserva en impresión muy casera o familiar. De las copias mencionadas, dos permanecen en el Convento y una en el Archivo Provincial de Castilla. Existe documentación sobre la historiografía de la casa, en otros archivos institucionales como en el de los P.P. Carmelitas de Alba de Tormes y en el Archivo general en Roma.

Secciones Del Archivo Conventual14.

A - Sección Teresiana

14 Como es natural, la documentación del Archivo Carmelitano, es más extensa que la encontrada en el archivo del monasterio de Santa María de las Dueñas 
I . Libros de visitantes del Sepulcro (firmas)

II . Familia Ovalle Ahumada

III . General

IV . Sepulcro y reliquias

$\mathrm{V}$. Basílica

VI . Hermandad de Santa Teresa (Amigos de Santa Teresa)

VII . Centenario Teresiano - 1882

VIII. Centenario Teresiano - 1914

IX .Centenario Teresiano - 1922

X .Centenario Teresiano - 1962

XI .Centenario Teresiano - 1970

XII .Centenario Teresiano - 1982

B - Sección San Juanista

C - Libros Oficiales de la Comunidad

D - Documentación relativa a la Casa

I . Fundación e historia posterior

II . Fundadores (F. Velásquez y Teresa Láiz)

III . Memoria Pedro de Aponte

IV . Cuentas, memorias y economía posterior

$\mathrm{V}$.J uros y censos

VI . Fabrica del convento e iglesia

VII . Hacienda

E - Documentos de la Santa Sede y Congregaciones Romanas

F - Documentos Episcopales

G - Documentos de los Superiores de la Orden

$\mathrm{H}$ - Documentos de la Autoridad Civil

I - Casa Ducal de Alba de Tormes

$\mathrm{J}$ - Personal

$\mathrm{K}$ - Monasterios O.C.D.

L - Carmelitas Descalzos de Alba de Tormes

M - Manuscritos

$\mathrm{N}$ - Libros Impresos Raros O De Valor

O - Miscelánea 
P - Planos

Q - Grabados, Estampas, Fotografías Y Casettes

Catálogo actual del Archivo: C-100

Catálogo anterior (1975): C - 75

Catálogo antiguo (s. XVIII): C - 69

Libro de visitantes e investigadores: C - 109

Libros Oficiales De La Comunidad : Libros de profesiones y de defunciones (1600 al 1699), Libros de cuentas, Libros de dotes, y Libros de actas

\section{- El Archivo Conventual de Santa María de las Dueñas}

Al no estar catalogada la información, la hemos clasificado teniendo en cuenta un orden de importancia de las carpetas, los libros y documentos.

En el legajo de Índices y propiedades, en una carpeta con el título de “Censos perpetuos. Índice de los documentos del archivo. Año 1783”, se encuentra la nómina de instrumentos de mayor entidad que tiene el convento y religiosas de Santa María de las Dueñas en su archivo, sacada en el año 1783 siendo Abadesa Doña Manuela Álvarez Reyero, los cuales se relacionan a continuación :

\section{Carpetas:}

"Privilegio del Papa Inocencio IV, concedido al Monasterio de las Benedictinas, por medio del cual, se les exime de pagar diezmo alguno". Esta información reposa en esta carpeta, pero el documento en si, está desaparecido.

“Privilegio del Arzobispo de Toledo Don Gutiérrez Álvarez de Toledo, primer Señor de Alba, para eximir de pagar diezmos al Monasterio; año de 1444. Relacionado en el libro de Crónicas y en la Carpeta de Ventas (1598 - 1866), censos (1616- 1829) y el Privilegio de don Gutiérrez Álvarez de Toledo de 1444”.

“Privilegios de los Reyes y de los infantes que dieron a este convento y tienen muchas mercedes, de que no se utiliza, a falta de confirmación de los Señores sucesores en la corona, estando todos juntos y atados en un legajo”.

“Privilegio de su Majestad de no pagar subsidio, está trasladado por Tomás Rodríguez escribano de esta villa su fecha 28 de J unio de 1558”

Cartas de Amparo (pergaminos sueltos) 
"Carta o cédula de amparo del infante que luego reinó con el nombre de D. Sancho IV El Bravo y que a la letra dice: "Sepan cuantos esta carta vieren, como yo, infante Don Sancho, hijo mayor e heredero del rey noble Don Alfonso rey de Castilla, por facer bien e merced al Monasterio de las Dueñas de Santa María de Alba, recibo en mi guarda y en mi encomienda a la priora de este Monasterio ya dicho y a Las Dueñas y a todas sus cosas. Onde mando e defiendo firmemente que ninguno non sea osado de las fazer fuerza nin tuerto mal alguno a ellas nin a ninguna de sus cosas ea cualquier que lo feziere pensarie en coto al rey mio padre, mil maravedis e a ellas o a cuantos qui su voz toviere todo el daño doblado e adamas el cuerpo e a quanto que obiese me tornaria por ello: dado en Alba de Tormes veite e siete dias de Mayo era de CCC e diez y siete años"

\section{Legajo De Informaciones}

En él, se relacionan las informaciones más personales de cada religiosa, sus actas de Bautismo, informaciones de limpieza de sangre de ella misma y de sus antepasados (padres, abuelos y bisabuelos), permisos del Obispado para la entrada al Monasterio, toma de hábito y profesión, interrogatorios antes de la profesión y en casos, el certificado de defunción.

\section{Escrituras}

"De la Capellanía de Antonio de Escobar"

"Del Cabildo de esta villa de la fiesta de San Benito de Marzo en este convento ante Andrés J iménez, escribano, fecha en 2 de Enero de 1579 años"

"En que el Convento se obliga a decir cinco misas por Doña María de León, monja que fue de este Convento, ante Marcos González, su fecha, el 5 de septiembre de 1595.

"Escritura de la fundación de la fiesta que el Cabildo hace el viernes después del Corpus, por Doña María de Ovalle, monja que fue de este convento, ante Francisco de Gante, su fecha, 2 de agosto de 1578".

"Escritura en que el Cabildo obliga se obliga a hacer el sábado de la octava del Corpus, la fiesta para estas Señoras religiosas de este Convento, con misa y completorio, ante Andrés J iménez - escribano. Su fecha de Mayo de 1604". 


\section{Capellanías15}

"La fundada por Mencía Fernández con las anual carga de tres misas en cada semana de agosto del año 1464".

“Fundada por Doña María de Rosales vda. de Cristóbal del Águila en el 10 de noviembre del año de 1519".

"Fundada por Diego de Salazar; su renta consiste en 16 fanegas de trigo que producen yugada y media en el lugar de García Hernández".

“Fundada por Don Diego de Salazar; su renta consiste en 9 fanegas de trigo y 3 de cebada, 16 reales vellón por una yugada en el lugar de Gajotes con una carga de 36 misas".

"Fundada por Don Antonio de la Fuente y su mujer Elvira de la Peña. Tiene de carga 52 misas. Sus rentas consisten el 12 fanegas de trigo, 8 de centeno que producen cuarenta y tres huertas de tierra en el lugar de Exeme (Ejeme)".

“Fundada por Don Gonzalo de Limiñón, con cargo a 156 misas, reducida a 60 misas al año, por el Canónigo Magistral de Salamanca Don Gabriel Vázquez, por solo tener de renta 19 fanegas de trigo, en una heredad en el lugar de encinas".

"Fundada por Doña Sancha de Limiñón que dejó 9 misas que se digan en este convento, y tiene obligación de decirlas Don Cristóbal de Oviedo, pero de ésta se desconocen sus rentas".

\section{$\underline{\text { Libros }}$}

Libros de profesiones y tomas de hábito. Estas informaciones se encuentran relacionadas en dos libros: Asientos de Religiosas. Dotes y traslación de las religiosas y convento año 1776-1863, y Dotes del año 1831 al 196116. Las cartas de profesión se hallan sueltas en carpetas catalogadas por años.

Libro de Crónicas, manuscrito, escrito por la hermana Carmen Rojo en el año 1906

Libros de cuentas. Dos legajos, “Granerías 1737- 1834” y “Granerias 1793$1836^{\prime \prime}$

15 Las Capellanías que se hallan fundadas en la Iglesia de éste Convento, se encuentran escritas en el Libro de visitas (Legajo del Libro de Visitas), pp. 10v-11v.

16 Ambos libros recogen las informaciones sobre defunciones del convento. No existe, por tanto, un único Libro de defunciones como en otros conventos femeninos 
Cuentas generales. Dos legajos, sacadas de las cintas del Archivo Histórico Nacional: Primer Legajo [Cuentas desde 1671- 1690, Libro de pagos 1725- 1739, Libro de Cuentas 1750-1773, Libro de cuentas 1774-1794]. Segundo Legajo [Libro de Cuentas y pagos 1782- 1799, Libro de Cuentas de 1794- 1834, Reparos de Azeñas 1790-1907, Libro de gastos 1807-1830].

\section{Testamentos a favor del Monasterio}

"Escritura de Dote y testamento de Doña María de Oviedo. Novicia del Monasterio de Santa María de las Dueñas 1610” [Legajo de libro de Dotes, testamento y defunciones y en carpetas individuales].

“Testamento de doña María de Rosales 1519" [Legajo de libro de Dotes, testamento y defunciones y en carpetas individuales].

“Testamento del Arcipreste de Alba Juan Martines por el que concede al Monasterio de Santa María de las Dueñas el derecho de llevar a pacer sus bueyes y a coger leña en los términos de Derrengada. Noviembre de 1393" [Legajo de libro de Dotes, testamento y defunciones y en carpetas individuales].

“De Doña Inés González, consta de donaciones a esta Comunidad con carga de misas ante Simón Santos de Prado en 26 de septiembre de 1703" [Libro de Índice general de documentos].

“Testamento de Doña Inés Romero en que consta los legados que dejó a sus hijas Doña Barbola y Doña Lucía Romero para fundar una memoria en su convento de Santa María de las Dueñas, ante Antonio Santos de Prado al 9 de Abril de 1612, digo ante Diego López, escribano de Salamanca” [Legajo de libro de Dotes, testamento y defunciones y en carpetas individuales].

\section{Libros Oficiales de la Comunidad}

En el Libro de Visitas están recogidos los Mandatos, que eran las disposiciones que el Obispo hacía después de cada visita, y Las elecciones de Abadesa y la distribución de cargos

Es menester comentar que algunos de los libros de economía y demás informaciones sobre hacienda y censos del Monasterio de Santa María de las Dueñas, reposan en el Archivo Histórico Nacional, encontrándose en el Monasterio, a disposición para la investigación, una copia microfilmada; La 
documentación del Archivo Histórico Nacional sobre este Monasterio está relacionado así :

1. Pergaminos [carpeta 1875 Números 1y 2]: Dos, de los años 1395y 1401.

2. Libros [signaturas 10.408 y 10.407]. Se refiere a cuantas y gastos de los siglos XVII y XIX

3. Legajos de Papeles [signaturas 5556 a 5562]. La documentación que contiene trata de la hacienda del Monasterio y su administración. Hay títulos de propiedad, censos, apeos y arrendamientos; también sobre obras pías reales provisiones y cédulas y algún documento eclesiástico. Siglos XV y XIX.

La última escala de búsqueda, se realizó en los Archivos, Diocesano de Salamanca, de la Universidad y en el de la Catedral; en ellos existen documentos relacionados con la Fundación hecha por Santa Teresa en Alba de Tormes, pleitos de los monasterios con la Universidad, con la Catedral, peticiones de derogación de pago de diezmos y las actas de exámenes de música para las plazas de organistas y cantoras, para el Monasterio de Santa María de las Dueñas de Alba de Tormes, desde el año 1853 - 1942, y de los que luego hablaremos al nombrar a las monjas músicas a los que hacen referencia.

En conclusión, la búsqueda de las fuentes manuscritas e impresas, y la revisión primera de las mismas, relacionadas específicamente con la música, nos dan a entender la relevancia que la música tenía al interior de los conventos; sin embargo, es difícil encontrarlas en épocas remotas, por los innumerables factores desafortunados que rodearon a los Monasterios en sus momentos: Incendios, traslados, desamortización, incluso falta de previsión para guardar la información sobre las monjas músicas y la música en sí. 


\section{CAPÍTULO II}

VIDA CONVENTUAL EN ALBA DE TORMES

II.1. FUNDACIONES CONVENTUALES

EN ALBA DE TORMES

II.2. VIDA COTIDIANA DE LAS ÓRDENES:

CARMELITAS DESCALZAS Y BENEDICTINAS 


\section{CAPÍTULO II}

\section{VIDA CONVENTUAL EN ALBA DE TORMES}

\section{II.1. FUNDACIONES CONVENTUALES EN ALBA DE TORMES}

Literalmente la palabra monacato significa el estado o la profesión del monje, cuya forma latín monachus viene del griego, que quiere decir solitario o anacoreta; con ello el individuo trata de llevar una vida de mayor perfección, es decir, de cultivo intenso de las virtudes cristianas. En los inicios, el esplendor monacal está corroborado por los importantes monasterios que las ciudades tenían entre sus muros o en sus alrededores. En el siglo VII, Zaragoza, Toledo, Gerona, Córdoba, Mérida, la región de Cataluña, la de Galicia, entre otras, fueron las ciudades y regiones respectivamente, que mantuvieron monasterios de los cuales salieron figuras tan destacadas como: Santa Engracia, San Eladio y San Ildefonso, J uan Blicarense (obispo de Gerona), por citar algunos personajes de importancia. El proyecto de vida apostólica de sus fundadores, es transmitido a sus seguidores. La invasión musulmana fue fatal para la vida monástica; con la invasión, este florecimiento quedó roto súbitamente; los monasterios fueron destruidos y con ello gran parte de la cultura antigua. Los monasterios más sólidos resistieron a los embates del invasor y por lo general sus monjes decidieron entregarse pacíficamente y algunos otros emigraron con sus tesoros (libros, reliquias, etc). En cuanto a los Monasterios de Córdoba y los Pirenaicos, muchos lograron sobrevivir en el siglo IX, como es el caso de Tábanos y Peñamelaria, y alcanzaron una reorganización, gracias a la relativa tolerancia de los emires de Córdoba. Los monasterios fueron centros de trabajo, de cultura, oasis de vida intelectual, de caridad y de vida religiosa. Los monjes cultivaban sus campos y construían sus edificaciones, todas bellas exponentes de la arquitectura de aquellos tiempos. Las actividades eclesiásticas estaban en sus manos, pues muchos monasterios eran escuelas y parroquias, incluso los más importantes llegaban a regentar varias parroquias; generalmente todos estaban dotados de bibliotecas grandes o pequeñas; por ejemplo, los monjes de Cister, ya en tiempos modernos, apartados de las labores manuales y de los cultivos del campo, presentan una verdadera legión de escritores, hombres cultos y sabios, que desarrollaron su 
actividad en los campos del saber. Gracias al esfuerzo de monjes copistas e iluminadores de siglos pasados, obras como: biblias, comentarios de la vida de los Beatos, Códices Conciliares, enriquecieron las bibliotecas y son conservados en los archivos actuales como joyas de aquellos monasterios y como testimonios del alto grado de intelectualidad que se cultivaba entonces. Sin otro preámbulo, pasemos a analizar el hecho de que en toda la Península, numerosos conventos, iglesias y hospitales, fueron erigidos durante los reinados de Felipe III y Felipe IV, sin olvidar que en la expansión y colonización de las Indias occidentales se fundaron gran número de conventos en el Nuevo Mundo. La "colonización" conllevó entre otras empresas, al proceso de "evangelización", en el cual las órdenes religiosas tuvieron un papel preponderante.

\section{- Órdenes religiosas femeninas}

Respecto a la vida religiosa en las órdenes femeninas, España presenta un rasgo muy característico en la Edad Moderna. Los conventos existentes entonces, que por lo general fueron de clausura, se encontraban en desventaja numérica en relación con las órdenes masculinas, y esto obedeció a un aspecto puramente económico. Los hombres encontraron más apoyo para la fundación de sus conventos, por variadas razones: Eran garantía de una vida más larga y más posibilidades de supervivencia, su proyección social tenía más alcance, se dedicaban al estudio, a la enseñanza, a las misiones y otras actividades que les permitía llegar a las gentes necesitadas. Por su parte las monjas no se proyectaban a la comunidad con entera dedicación, su vida era más contemplativa y sus ingresos eran escasos, a lo que hicieron frente con donativos del rey si pertenecían al patronato regio, o con los de los obispos y personas caritativas. Desarrollaron en un mínimo porcentaje, actividades benéficas y de enseñanza. Las labores de bordar, coser, hacer confituras, les proporcionaban una mínima ayuda económica. De ahí la importancia de las dotes al ingreso de las aspirantes. Ahora, se puede pensar que estos conventos nacieron de una actitud interior y se multiplicaron con la misma rapidez que los monasterios de hombres; sin embargo, fueron variadas las motivaciones que carentes de intención religiosa, llevaron a muchas mujeres a 
recluirse en un claustro; Sánchez Lora ${ }^{17}$ dice al respecto, lo siguiente: "Es cierto que estamos ante un fenómeno no cuantificable; no existe documentación monástica que permita apreciar más razón para ingresar en un convento que la vocación religiosa. Con todo, no son pocos los indicios que dan pie a afirmar algunos problemas puestos de relieve por la legislación canónica: “La primera diligencia que han de hacer las religiosas cuando alguna viniere a pedir el Hábito Santo, es atender al principio de su vocación, y examinar bien si viene de afecto propio o si viene violentada de sus parientes, porque en esto suele haber mucho peligro"18.

Tal y como se estilaba en la época, una de las causas que con mucha frecuencia llevaron a muchas mujeres a seguir la vida religiosa y más concretamente, el enclaustramiento, fue la práctica social, de enlaces matrimoniales de conveniencia por honor y estatus, vale decir, que en caso de existir varias hijas, solo la mayor tenía el privilegio de contraer matrimonio, apoyada económicamente por una dote que no desmerezca al futuro esposo. Las demás hijas, tomarían los hábitos religiosos, asegurando de esta manera una vida futura honorable y las dotes asignadas para el ingreso en el convento, eran de menor cuantía.

Ahora, ciñéndome expresamente a los conventos escogidos para esta investigación, como son: el Convento de la Anunciación de Nuestra Señora del Carmen (Madres Carmelitas) cuya fundación data del 25 de enero de 1571, y el Monasterio de Santa María de las Dueñas (Madres Benedictinas) cuya Fundación tiene orígenes inciertos - ya veremos el porqué, de Alba de Tormes, se puede decir que cada uno desde su composición misma ofrece un cúmulo de fuentes para su investigación.

\section{- ORDEN DEL CARMELO}

Los orígenes de la Orden del Carmelo -a la que pertenece el Convento de la Anunciación de Nuestra Señora del Carmen de Alba de Tormes-, se remontan al Antiguo Testamento. Para conocer sus inicios es necesario remitirse al libro II de

17 SÁNCHEZ LORA, J osé Luis. Mujeres, conventos y formas de religiosidad barroca. Madrid: Fundación Universitaria Española, 1988, pp. 139-40.

18 ARBIOL, Fray Antonio. La religiosa instruida... para todas las operaciones de su vida regular, desde que recibe el hábito santo, hasta la hora de su muerte. Madrid, s.e., 1791, p. 32. Cfr. SÁNCHEZ LORA. Op. cit., p. 84. 
los Reyes, que en su capítulo II, versículos 1 al 18, habla de que San Elías tiene unos profetas seguidores, que continúan su misión en el Monte Carmelo, cuando él es arrebatado al cielo en el carro de fuego19. Se dice que Elías que vivió a mediados del siglo IX a.C. durante el reinado de Ajab y su sucesor Ocozías, luchó contra los sacerdotes de Baal para mantener la integridad del judaísmo monoteísta. Vivió Elías en dos cuevas durante su estadía en el Monte Carmelo, una de las cuales, está en la parte más alta de la colina; la cueva inferior está justo debajo de la primera, en la base de la montaña. Estas dos cuevas han sido utilizadas para fines religiosos desde los primeros tiempos. Durante el período árabe, la capilla superior se convirtió en una Mezquita o maqám (santuario pequeño) y fue agregado un nicho dirigido hacia la Meca. En el año 1226 d.C. los cruzados recibieron la autorización de Roma para formar lo que actualmente es la Orden Carmelita. La primera institución de Monjas Carmelitas fue fundada en 1452 y en 1826, fue construido el monasterio en este antiguo lugar en el Monte Carmelo, donde se halla actualmente.

La Rvda. Madre Priora María Guadalupe del Sagrado Corazón20, del Convento de las Carmelitas de Badajoz, en su artículo "La orden del Carmelo" nos dice: "Tenemos que situarnos 900 años antes de J esucristo para ver los orígenes remotos de los acontecimientos sucedidos en el Monte Carmelo y por lo tanto el nacimiento de la Orden de María”. Relata la religiosa, dos episodios más del libro de los Reyes, relacionados directamente con la fuerza de la fe y la oración, que describo a continuación: En el análisis del segundo episodio de la Biblia, en el cual el profeta Elías se postra en la cima del Monte Carmelo y ora a Dios por la lluvia, (I Reyes,18,41-46), se le da una interpretación relacionada con la venida del Mesías, representada en la lluvia y la Virgen María simbolizada en la nubecilla portadora de la lluvia. Un tercer episodio narrado en el libro I de los Reyes (I Reyes, 18,3040), muestra el duelo de los profetas de Baal, la degollación y muerte de los mismos por mandato de San Elías. En este episodio está representada la fuerza de la oración y de la fe, dos cualidades esenciales de la vida contemplativa. El

19 El Monte Carmelo se sitúa en Galilea, al norte de Israel y Sur del Líbano; monte fértil y fecundo que ofrece toda clase de frutos. Está situado junto al mar Mediterráneo y se considera el sitio por donde discurrió la vida del profeta Elías Tesbita. Según la bibliografía consultada respecto a la historia de la Orden, existe una relación directa entre Elías, El Carmelo y María 20 Cfr. <http:// www.cristiandad.org/aportes/orden_carmelo.htm> (consultada el 16 de junio de 2006). 
Carmelo de distingue por su espiritualidad y por la oración. Desde sus inicios, la Orden tiene una configuración misional, sin embargo, ya en el siglo XVI, las Carmelitas se habían alejado bastante de los principios y propósitos originales; con el paso de los años, aquel espíritu de oración, penitencia, mortificación y ocultamiento, se llegó a perder en casi todas las Órdenes religiosas, incluso en la Orden del Carmelo, lo que ocasionó un estado de relajamientos. Ante el estado que presentaba la Orden para ese entonces, la Madre Teresa de J esús (1515-1582)21 se propuso devolverla a sus orígenes y emprendió una reforma interna, le infundió esa orientación y esa vocación que caracteriza a la Orden hoy en día; esta determinante filosofía misional en la orientación y desarrollo de la vida al interior de la Orden, ha permanecido como línea constante en el Carmelo Teresiano. Poco después ayudada por el místico y Doctor de la Iglesia San Juan de la Cruz, se

21 Religiosa, Doctora de la Iglesia, mística y escritora española, fundadora de las carmelitas descalzas, rama de la Orden de Nuestra Señora del Monte Carmelo (o carmelitas).Teresa de Cepeda y Ahumada, como era su verdadero nombre, nació el 28 de marzo de 1515 en Ávila. Nieta de judío judaizante, sambenitado en Toledo en 1485, su padre, Alonso Sánchez de Cepeda, hizo todo lo posible para borrar la vergüenza de aquellas procesiones inquisitoriales. Su migración a Ávila, el matrimonio con su segunda esposa, Beatriz de Ahumada, madre de la santa, y la educación de sus hijos en el severo catolicismo que había adoptado, serían solo parte de ese proceso. La santa, estudió en el convento de las agustinas y en 1535 ingresó en el convento carmelita de la Encarnación. En 1555, después de muchos años de sufrir grave enfermedad y someterse a ejercicios religiosos cada vez más rigurosos, experimentó un profundo despertar en el que vio a J esús, el infierno, los ángeles y los demonios. En ocasiones sintió agudos dolores que, según sus palabras, estaban provocados por la punta de la lanza que un ángel le clavaba en el corazón. Disgustada a causa de la indisciplina de las carmelitas, decidió emprender la reforma de la orden y se convirtió, con el apoyo del Papa, en una dura oponente para sus inmediatos superiores religiosos. En 1562 consiguió fundar en Ávila el convento de San J osé, la primera comunidad de monjas carmelitas descalzas, en el que reforzó el cumplimiento estricto de las primitivas y severas reglas de la orden. Sus reformas fueron aprobadas por el director de la orden y en 1567 se le permitió fundar otros conventos similares para religiosos. Con la ayuda de san J uan de la Cruz, santa Teresa organizó una nueva rama del Carmelo. Contó también con el apoyo del padre Antonio de Heredia. Aunque siempre acosada por poderosos y hostiles funcionarios eclesiásticos, logró fundar 16 casas religiosas para mujeres y 14 para hombres. Dos años antes de morir, las carmelitas descalzas recibieron el reconocimiento del Papa como orden monástica independiente. Murió el 4 de octubre de 1582 en Alba de Tormes y fue enterrada en el convento de la Anunciación de este municipio salmantino. Además de una mística de extraordinaria profundidad espiritual, Santa Teresa fue una organizadora muy capaz, dotada de sentido común, tacto, inteligencia, coraje y humor. Purificó la vida religiosa española de principios del siglo XVI y contribuyó a fortalecer las reformas de la Iglesia católica desde dentro, en un periodo en que el protestantismo se extendía por toda Europa. Sus escritos, publicados después de su muerte, están considerados como una contribución única a la literatura mística y devocional y constituyen una obra maestra de la prosa española. Destacan: su autobiografía espiritual, Camino de perfección (1583), libro de consejos para las monjas de su orden; Castillo interior (1577), volumen más conocido por el título Las Moradas, que contiene una descripción elocuente de su vida contemplativa, y El libro de las fundaciones (1573-1582), un documento sobre los orígenes de las carmelitas descalzas. Canonizada en 1622, en 1970 se convirtió (junto con santa Catalina de Siena) en la primera mujer elevada por la Iglesia católica a la condición de Doctora de la Iglesia. Su festividad se celebra el 15 de octubre. 
propuso llevar a cabo una Reforma iniciada desde el convento de San J osé de Ávila, que después se extendería a todas las Ordenes, dando sus frutos de santidad; Fray Juan de la Cruz, decidió realizar lo mismo con la rama masculina. Estos hechos marcaron el nacimiento de las llamadas "descalzas". En el año 1593 los Carmelitas llamados "calzados o mitigados", se independizaron de los "Carmelitas "descalzos o reformados" por no aceptar la Reforma, organizándose en otra Orden.

Santa Teresa cuenta este episodio así en el libro de su vida No 33,14-15:

"Vínome un arrobamiento tan grande que casi me sacó de mi....Parecióme ....que me venía vestir una ropa de mucha blancura y claridad...Vi a Nuestra Señora, hacia el lado derecho, y a mi padre San J osé al izquierdo, que me vestían aquella ropa. Dióseme a entender que estaba ya limpia de mis pecados. Acababa de vestir, y yo con grandísimo deleite y gloria, luego me pareció asirme de la mano de Nuestra Señora. Díjome que la daba mucho contento en servir al glorioso San J osé, que creyese que lo que pretendía del Monasterio se haría y en el se serviría mucho el Señor y ello dos, que no temiese habría quiebra en ello jamás...porque ellos nos guardarían; y que ya su hijo nos había prometido andar con nosotros, que para señal que sería esto verdad me daba aquella joya. Parecíame haberme echado al cuello un collar de oro muy hermoso, asida un cruz a él de mucho valor...Era grandísima la hermosura que vi en Nuestra Señora... vestida de blanco con grandísimo resplandor; no que deslumbra, sino suave, apréciame muy niña. Estando así conmigo un poco y yo con grandísima gloria y contento... Parecióme que los vi subir al cielo con mucha multitud de ángeles. Yo quede con mucha soledad, aunque tan consolada y elevada y recogida en oración y enternecida, que estuve algún espacio...casi fuera de mi... Dejóme consoladísima y con mucha paz"

Por el año 1562 y ya en el monasterio de San J osé, la Madre Teresa había iniciado su Reforma. Se había quitado el calzado - usaba solo alpargatas de esparto y tela- , usaba un habito de tosca tela y ahora se llamaba Teresa de J esús, dejando atrás su apellido Ahumada. Ella se sentía diferente, trabajando solo por el amor y para el amor de Dios. Ella y sus compañeras del Convento fueron criticadas duramente por las mismas hermanas de la Encarnación, por la gente de Ávila, que la consideraban loca y que por su actitud, podía ella y sus compañeras, acabar en la Inquisición. Hubo de convencer al arzobispo Álvaro de Mendoza, para que 
tomara bajo su jurisdicción el nuevo monasterio, ya que el provincial de los Carmelitas, se negaba. A todas estas dificultades se sumaba el rechazo de gran parte del pueblo de Ávila, cuando se supo que el convento estaba constituido bajo el régimen de pobreza y por ende, las monjas deberían vivir de las limosnas que buenamente les brindaran y de su propio trabajo. El convento estuvo bajo amenazas justamente en agosto de 1562 y la madre Teresa había sido llamada por la priora del convento de La Encarnación, para disculparse públicamente delante del Capítulo de las monjas y del provincial. Un pleno del Consejo Municipal convocó a una reunión para tratar el caso de estas mujeres que separándose del convento inicial, han tomado casa aparte y han iniciado una vida diferente. "Pero todas esas resistencias y dificultades habían puesto a prueba al grupito de mujeres decididas a seguir a Teresa en su proyecto de vida solitaria y pobre, y habían contribuido a consolidar la tranquilidad de la que ahora gozaban - ahora cuando los inconvenientes habían sido superados- en el pequeño monasterio, que había una hermosa vista sobre el campo castellano"22. En este momento había llegado para Teresa y sus compañeras, la oportunidad de demostrar al mundo que se podía vivir y experimentar otra vida, con menos temor a la muerte y al infierno. Poco a poco se fueron sumando otras religiosas al convento hasta llegar el número de trece, cantidad que ella había concebido para alcanzar la convivencia tranquila en este régimen de pobreza. En diciembre de 1562, logró el permiso definitivo para establecerse oficialmente en el convento de San J osé y con ella se encontraban: Isabel de la Peña, prima suya, María Dávila, pariente también y rica heredera, quien llegó al convento acompañada por muchas personas de la ciudad, su sobrina Leonor de Cepeda y más adelante se sumaron Isabel Ortega, hija espiritual de Pedro de Alcántara y María de Ocampo, hija de un primo suyo, que tomó el nombre de María Bautista; todas tenían en común el haber vivido el drama de los certificados de hidalguía que comprados aseguraban la honra, tenían un linaje de conversos y lo más importante, deseaban dejar atrás todos aquellos acontecimientos y comenzar una nueva vida en libertad con su esposo y con Dios. “En San J osé no se pedían certificados de limpieza de sangre, y nunca Teresa hubiese aceptado que se pidiese "pruebas" que negaban la igualdad ante Dios

22 ROSSI, Rosa. Teresa de Ávila. Biografía de una escritora. Barcelona: Icaria, 1997, p. 81. 
adquirida con el bautismo"23. Teresa de J esús se empeñó siempre en lograr y conservar la igualdad por lo menos al interior de su convento; libre de legas, criadas y esclavas. "Era menester alcanzar dos objetivos a la vez: mediante el retorno a la tradición del Carmelo, era necesario llegar a construir una nueva forma de vida, y era también necesario conjugar la forma interior - que cada una viviría con ritmos diferentes, así como son diversas en cada persona las relaciones de amor y de amistad- con las reglas y los problemas de la vida comunitaria, de la convivencia. Todo este proyecto no podía confiarse solo al diálogo interior, ni tampoco al intercambio de palabras que interrumpían, a veces los largos silencios de San J osé; hacía falta consolidarlo y retenerlo por escrito"24. Estas palabras de Rosa Rossi se pueden considerar como propósitos de vida, unidos al tesón y dedicación que llevó a Teresa de Jesús a lograr la Reforma del Carmelo y a continuar con más ahínco a escribir sobre la oración, sobre cómo llegar a aquellos estados tan excepcionales como los que ella misma estaba experimentando en su relación con Dios - el éxtasis con Dios- y sobre los acontecimiento vinculados al recién fundado convento de San J osé.

Teresa de J esús, tenía claridad en la importancia de escribir las Constituciones del novísimo convento, el cual poseía un permiso y una orden de fundación tal como rezaba el Breve Papal y en ese trabajo se enfrascó ella, no concebía volver a la regla Carmelitana primitiva, puesto que consideraba menester reelaborarla y adaptarla tanto a las necesidades de la convivencia femenina así como imprimirle su impronta fundacional, su sentido propio. En él, reglamentó importantes aspectos acerca de las "cosas espirituales", la regulación de las actividades diarias y los días festivos y de penitencia, la calidad del trabajo diario, la igualdad entre las monjas, las normas de comportamiento en las comidas, sobre las vestimentas que se debían llevar y sobre el aspecto externo e interno de los conventos. Dejó muy expresa, la libertad para que cada religiosa escogiera su confesor y habló del amor entre las hermanas de San J osé. 'Y finalmente, en este libro, Teresa habló abierta y polémicamente - y sobre este tema no había modificado ni el contenido, ni el tono- sobre una de sus más profundas convicciones, es decir, que no se llega a Dios 
a través del rigor y el encerrarse en si mismo sino a través del desarrollo de los afectos". .25

\section{II.1.1. Convento de la "Anunciación", Hermanas Carmelitas Descalzas}

Santa Teresa, en el libro de Las Fundaciones narra el complicado proceso que llevó a la fundación de Alba, debida como es sabido al mecenazgo de Francisco Velázquez y su mujer Teresa de Laiz, y a la intervención como mediadores de J uana de Ahumada, hermana de la Santa y su marido J uan de Ovalle. Tras no pocas negociaciones, el 25 de enero de 1571, se traslada el Santísimo Sacramento con lo que se considera iniciada definitivamente la vida conventual. Atrás quedaban varios intentos y negociaciones encaminados a lograr rentas suficientes para el convento y adecuar para la comunidad las que fueron casas principales de los fundadores y otras que compraron para tal fin. Ante esta reja del locutorio del monasterio de las MM Isabeles de la Villa, quienes la cedieron más tarde a este Carmelo, firmaron las escrituras del convento Santa Teresa y los fundadores: $\mathrm{D}^{\mathbf{a}}$ Teresa de Laíz y D. Francisco. Cuando los Contadores de los Duques, que residían en Salamanca, vinieron a establecerse en Alba de Tormes, vio asombrada Teresa de Laiz en su propia casa, un patio con un pozo exactamente iguales a los que ella había visto en un sueño que tuvo en Salamanca, donde además, junto al pozo, se le había aparecido San Andrés, Santo de su devoción. Ante este suceso, de acuerdo con su marido, cedieron su casa de Alba para monasterio de las Descalzas, con otras fincas colindantes, pues ya tenían acordado con Santa Teresa donarle la fundación. En el patio de la portería interior del convento, un pozo y un corredor, recuerdan el episodio del sueño de Teresa de Laíz. La reja del muro pertenecía al locutorio del convento de las MM. Isabeles de la Villa. Ante ella firmaron las escrituras del monasterio, el matrimonio Velázquez y Teresa de J esús.

De su tiempo y utilizados por ella se conservan el locutorio, el refectorio, las escaleras, el coro primitivo, las celdas de la enfermedad y de la muerte y la huerta.

Del Libro de Fundaciones son los siguientes apuntes referentes a la constitución del Convento: 
“No había dos meses que se había tomado la posesión, el día de Todos Santos, en la casa de Salamanca, cuando de parte del contador del duque de Alba y de su mujer fui importunada que en aquella villa hiciese una fundación y monasterio. Yo no lo había mucha gana a causa que, por ser lugar pequeño, era menester que tuviese renta, que mi inclinación era a que ninguna tuviese. El padre maestro fray Domingo Bañes, que era mi confesor, de quien traté al principio de las fundaciones, que acertó a estar en Salamanca, me riñó y dijo que, pues el Concilio daba licencia para tener renta, que no sería bien dejase de hacer un monasterio por eso; que yo no lo entendía, que ninguna cosa hacía para ser las monjas pobres y muy perfectas."

“En este tiempo acertó a ir este fraile a cierto lugar, adonde le dieron noticia de estos monasterios de nuestra Señora del Carmen que ahora se fundaban. El, informado muy bien, tornó a ella y díjole que ya había hallado que podía hacer el monasterio como quería; díjole lo que pasaba, y que procurase tratarlo conmigo. Así se hizo. Harto trabajo se pasó en concertarnos, porque yo siempre he pretendido que los monasterios que fundaba con renta la tuviesen tan bastante, que no hayan menester las monjas a sus deudos ni a ninguno, sino que de comer y vestir les den todo lo necesario en la casa, y las enfermas muy bien curadas; porque de faltarles lo necesario vienen muchos inconvenientes. Y para hacer muchos monasterios de pobreza sin renta, nunca me falta corazón y confianza, con certidumbre que no les ha Dios de faltar. Y para hacerlos de renta y con poca, todo me falta. Por mejor tengo que no se funden."

“En fin, vinieron a ponerse en razón y dar bastante renta para el número; y lo que les tuve en mucho, que dejaron su propia casa para darnos y se fueron a otra harto ruin. Púsose el Santísimo Sacramento e hízose la fundación día de la Conversión de San Pablo, año de 1571, para gloria y honra de Dios, adonde, a mi parecer, es Su Majestad muy servido. Plega a El lo lleve siempre adelante."26

\section{- ORDEN DE SAN BENITO DE NURSIA}

Los orígenes de la Orden Benedictina se remontan a la Italia del siglo VI, cuando San Benito de Nursia, funda la Orden Benedictina, basada en su Regla: "Ora et labora" lema que distingue a los Benedictinos, tanto a hombres como a mujeres, para los que cada día transcurre entre la oración y el trabajo. San Benito 
nació en Nursia en el año 480; se le considera el Abad y patrón de Europa y de Monastisismo occidental.

En el libro II de sus Diálogos, el Papa San Gregorio Magno (540-610) relata cómo un joven que estudiaba en Roma a finales del siglo $\mathrm{V}$ d.c. oyó la voz del Señor y dejándolo todo siguió a Cristo a semejanza de los antiguos monjes, recluyéndose en la Cueva de Subiaco. Su hermana gemela llamada Escolástica había sido consagrada a Dios desde la infancia. San Benito, basado en los Evangelios, en la Sabiduría de los antiguos monjes y en su propia experiencia, funda varios Monasterios en Subiaco y en el año 529, en Montecasinos, funda el Monasterio donde escribe la Regla para los monjes y en él, reside hasta su muerte. Allí ejerce gran influencia en sus discípulos y sobre toda la región vecina. Es allí también donde escribe una Regla para monjes que con el tiempo llegaría a ser la Santa Regla, maestra del monacato cristiano occidental. Esta Regla, escrita para monjes que viven en comunidad, ordena toda la vida orientándola hacia la oración, encuentro personal e íntimo con Dios. En el último capítulo de la misma, San Benito la llama "mínima regla de iniciación", la cual ha sido, sin embargo, a lo largo de los siglos cristianos, un instrumento poderoso para transformar los corazones, imitando a Cristo y agradando a Dios. San Benito y su Regla están de tal modo unidos que "si alguien quiere conocer más profundamente su vida y sus costumbres, podrá encontrar en la enseñanza de su Regla todas las acciones de su magisterio, porque el santo varón en modo alguno pudo enseñar otra cosa que lo que él mismo vivió". 27

27 S. Gregorio Magno, Diálogos II, 36. Cfr. <www.arcangelsangabriel.com> (consultado el 24 de junio de 2006). 


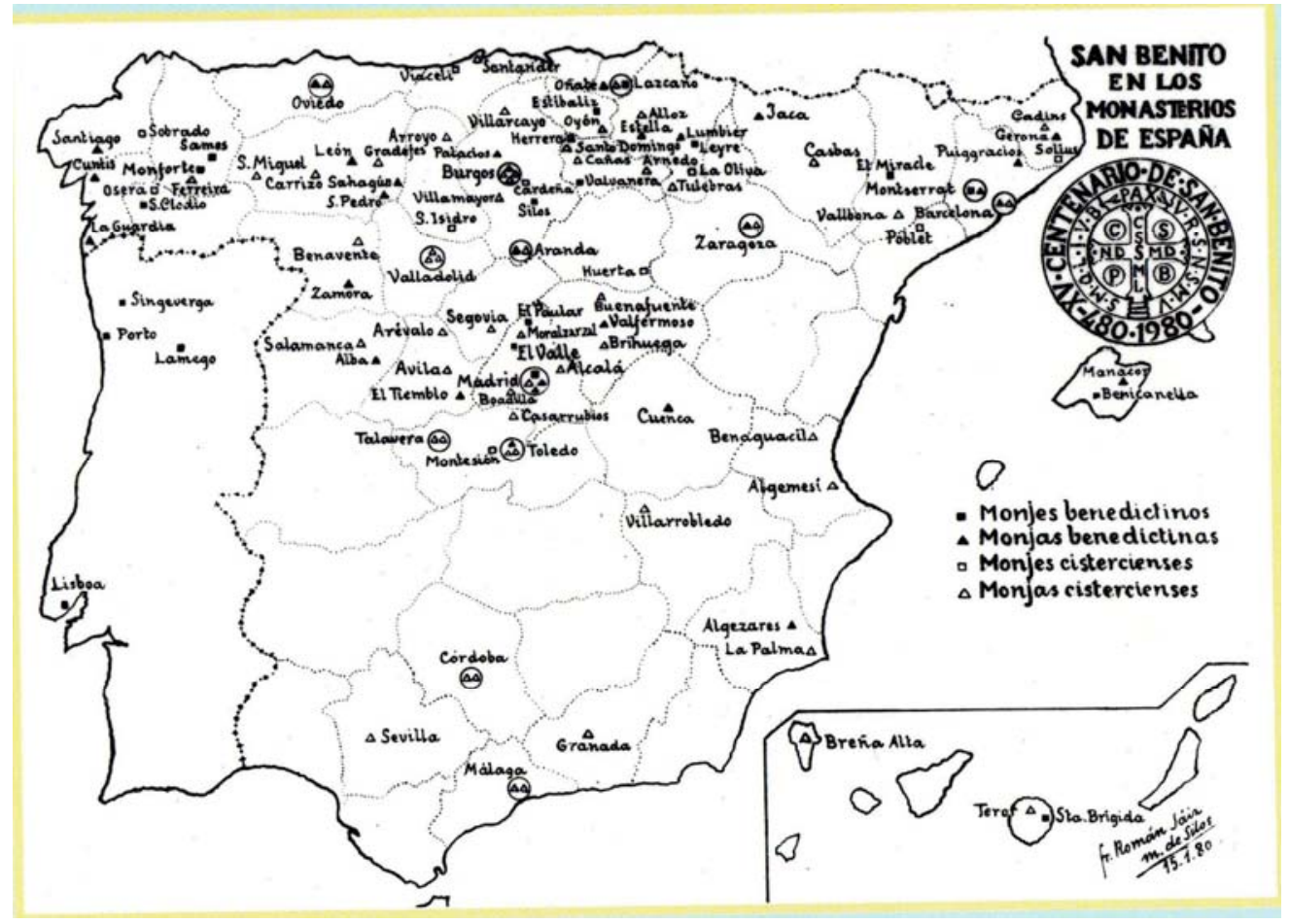

1. Mapa de los Monasterios Benedictinos en España28

\section{II.1.2. MONASTERIO DE SANTA MARÍA DE LAS DUEÑAS. Alba de Tormes}

El Libro de Crónicas del Monasterio, nos relata de cómo el Monasterio de las Benedictinas, cuyo nombre titular es el de Santa María de las Dueñas, en Alba de Tormes, comienza su andadura histórica desde el siglo XIII y su historia ha perdurado en el tiempo gracias a una continua presencia de religiosas, que han mantenido la Casa en tiempos de guerra y paz. Según el libro de las Crónicas que reposa en el Convento, los orígenes de la fundación de este Monasterio son inciertos, puesto que el archivo de esta casa desapareció durante un incendio, según cuenta la tradición; durante los conflictos de guerra con los franceses, gran parte de los valiosos documentos que podrían aclarar muchos aspectos de su fundación y de su vida conventual desaparecieron. El origen del nombre "Santa María de las Dueñas", es considerado en las Crónicas, como un Monasterio fundado para damas de noble cuna y con títulos de nobleza, siendo esta una mera suposición, derivado del nombre "Señoras", pensándose que sus fundadores pudieron ser personas de nobleza: “En las afueras de esta Villa Ducal de Alba de

28 Tomado de la Revista Monjas Benedictinas. 
Tormes, en un sitio silencioso, ameno y pintoresco, estuvo enclavado en sus principios de existencia, este Monasterio; parece que sus Fundadores tuvieron en cuenta que Ntro. Glorioso P. San Benito en los días de su preciosa Vida, buscaba para sus hijos e hijas los sitios más retirados del bullicio del mundo como más a propósito para la comunicación y trato Intimo con Dios"29. De la traslación del Monasterio que hasta entonces se ubicaba extramuros de la villa, el libro de las Crónicas del Convento, dice: "De la fecha de la traslación y de otras cosas no menos importantes y curiosas ocurridas en ella, nos da noticia un documento conservado hasta el día de hoy en esta Comunidad con especial estima y cariño por ser tan importante no menos que interesante y que al pié de la letra vamos a copiar; dice así: “En 12 de Mayo de 1769 entre cuatro y cinco de la tarde salió esta Comunidad de Religiosas Benitas del Convento de afuera para este intra-muros de la Villa de Alba, en compañía de nuestro prelado Don Felipe Beltrán, Ilmo. Señor Obispo de Salamanca, con asistencia de los Srs. del Cabildo, Religiosos Franciscanos, Jerónimos, Carmelitas y una comunidad de Capellanes; tocaron todas las campanas y reloj"30. Ignorados sus orígenes, si es posible conocer por estas crónicas, los nombres de Reyes que tomaron bajo su protección a esta casa y la favorecieron con privilegios: Fernando IV, Alfonso XI, Enrique II, J uan I, enrique II, Sancho IV llamado "El Bravo". Del Papa Inocencio IV, por los años 1244, el Monasterio gozaba del privilegio que lo eximía de pagar el diezmo. En el libro de las Crónicas del Convento, se lee, lo siguiente:"Sea de ello lo que fuese es lo cierto que el Monasterio de Benedictinas de Santa María de las Dueñas, ya existía por el año 1279, es casi más que probable que ya su fundación era un hecho en 1244 (siglo XIII,) más lanzarnos por el terreno de las conjeturas a señalar el siglo en que erigió este Monasterio la piedad cristiana, lo creemos muy aventurado ya a las fechas que arriba anotamos pudiera lo mismo, pudiera repetimos, llevar un siglo de existencia uno o llevar cuatro"31.

29 Crónicas, ms, Archivo conventual de Santamaría de las Dueñas de Alba de Tormes, p. 3r.

30 Libro de las Crónicas de dicho Convento, p. 33v.

31 Libro de Crónicas - Archivo Conventual de Santa María de las Dueñas de Alba de Tormes. p. $25 r$. 


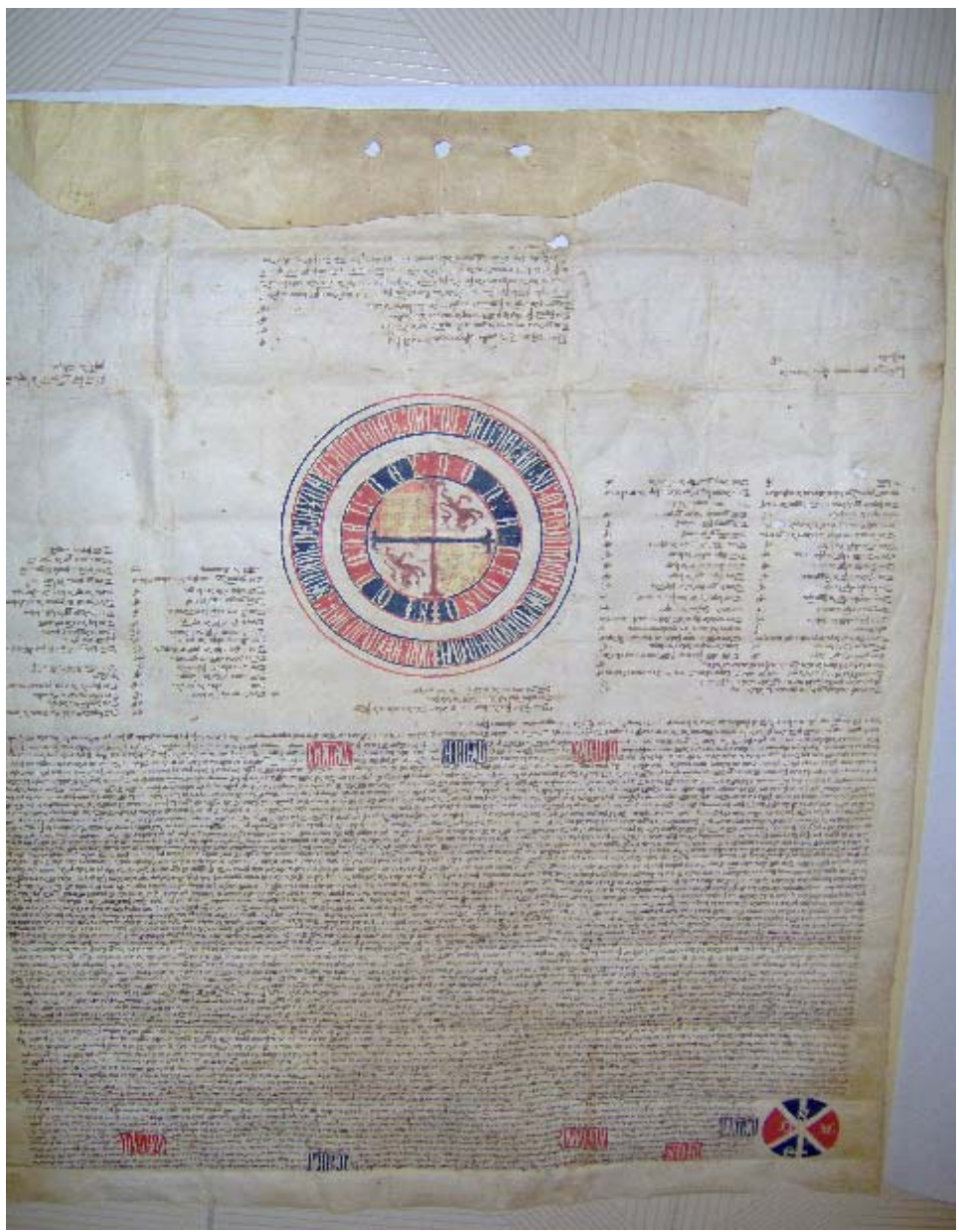

2. Privilegio del Rey Alfonso XI - “El Emplazado32

Esta Casa no estuvo bajo la dependencia de patronos seglares como muchas casa lo estuvieron sobre todo durante los siglo XIV y XV, pero si durante los mencionados siglos, el Convento recibió innumerables y generosos legados de personalidades como: El Archipestre de Alba de Tormes como J uan Martínez, el Arzobispo Don Gutierre Álvarez de Toledo, el monje Jerónimo reverendo Padre Alonso Álvarez de Toledo, hijo del Duque de Alba Don García, la Casa de los Toledo, doña María de Rosales, Don Gonzalo Vivero, Obispo de Salamanca, Doña María de Oviedo y Frías y Doña J uana de Valdenebro, entre otros, que le hicieron objeto de su distinción a este Monasterio.

32 Documento que reposa en el Archivo del Monasterio de Santa María de las Dueñas, Alba de Tormes 


\section{2. VIDA COTIDIANA DE LAS ÓRDENES FEMENINAS CARMELITAS DESCALZAS Y BENEDICTINAS DE ALBA DE TORMES \\ (Salamanca)}

\section{II.2.1. La vida de Clausura}

\section{II.2.2. Ingreso a la vida de clausura}

II.2.3. Procedencia geográfica y social de las profesas

II.2.4. La noble ascendencia de las monjas

II.2.5. Cargos y J erarquías dentro del monasterio

II.2.6. Modelo compositivo de la mujer música

II.2.7. Economía - Relacionada con la música

II.2.8.Convento de Santa Clara de Santa Fe de Bogotá (Col)

II.2.9.Monasterio de Santa Inés de Santa Fe de Bogotá (Col)

\section{II.2.1. La vida de Clausura.}

Investigar, conocer y analizar los componentes más necesarios de un grupo humano como son las religiosas de clausura, especialmente aquellos que se consideran esenciales para las simple organización de su forma de vida (hábitat, vestido, comida, espiritualidad, liturgia, ocio, trabajo, etc.) ayudan a comprender de forma clara su estilo de vida. Primeramente, y conociendo de antemano cómo fueron los inicios de los dos Monasterios investigados, la primera aproximación que podemos hacer a la vida cotidiana es: Estudiar el entorno en el que se desarrolla.

En esta época de tan arraigada religiosidad, pero de tantos conflictos sociales y políticos, la gran mayoría de profesas abrazó la fe, por distintos motivos familiares y económicos pero una buena parte de ellas, por pura convicción; recordemos aquí, que este fue un período en que la religiosidad y el ambiente de piedad reinaban de forma intensa. Se sucedieron casos de conversiones súbitas muy importantes como las de San Ignacio y la de San Francisco de Borja.

Por los albores de 1660, ya el fenómeno místico fue descendiendo y a partir de esta fecha se registran menos fundaciones conventuales. Sin embargo cabe 
analizar aquí, lo siguiente: el crecimiento del clero regular obedeció a razones más individualizadas, no tenía límite y sus miembros tuvieron motivaciones muy personales; por su parte el clero secular, de organización más rígida, caracterizado por poseer unos escalafones y rentas fijas se constituyó en lo que se denominó la "Iglesia oficial", bastante burocratizada. Costumbre de las nobles familias de la época, fue dedicar a la iglesia a los hijos segundones que no podían suceder el mayorazgo; de ahí la lucha por colocarlos en cargos de competencia y dignidad acorde con su rango y fue así como llegaron a ocupar las mitras episcopales, hijos segundos en la línea sucesoria de las familias o los hijos bastardos ilustres; podemos citar entre tantos nombres a San Juan de Ribera, hijo del Duque de Alcalá, Dn. Enrique Pimentel hijo del conde de Benavente, obispo de Cuenca y presidente del Consejo de Aragón, Fr. Alonso de Santo Tomás, presunto hijo de Felipe IV y que llegó a ser Arzobispo de Málaga y muchos otros de importante rango social. Respecto al reclutamiento del clero, según se puede leer en la historia de las ordenes monacales, muchas exigieron el rango de nobleza de sus miembros, como por ejemplo, el caso de los monasterios Benedictinos, que integraban la comunidad claustral de Tarragona, por citar un ejemplo. Muchos monasterios acogieron a nobles de alta alcurnia que ya dentro del claustro, no muchos olvidaban los privilegios de su nobleza y quisieron reclamar ante Roma sin resultado positivo. Otros por su parte vistieron su sayal con gran estoicismo y verdadera vocación religiosa. Vale destacar en este momento, un aspecto relevante que en la época se tuvo muy en cuenta: La limpieza de sangre, que hoy en día se considera discriminatorio de raza y profesión y que cayó en desuso a través del tiempo.

Previo al ingreso en las Ordenes monacales se les preguntaba si el postulante era cristiano viejo y practicante y se investigaba por lo menos cuatro generaciones anteriores, que no tuvieran sangre judía, mora o gitana o si había sido penitenciado por el Santo oficio o a tribunal alguno o haber tenido acciones bajas y ruines que afectaran a la causa religiosa.

Respecto a la vida religiosa en las órdenes femeninas, España presenta un rasgo muy característico en la Edad Moderna. Los conventos existentes entonces, que por lo general fueron de clausura, se encontraban en desventaja numérica en 
relación con las Órdenes masculinas y esto obedeció a un aspecto puramente económico. Los hombres encontraron más apoyo para la fundación de sus conventos, por variadas razones: Eran garantía de una vida más larga y más posibilidades de supervivencia, su proyección social tenía más alcance, se dedicaban al estudio, a la enseñanza, a las misiones y otras actividades que les permitía llegar a las gentes necesitadas. Por su parte las monjas, no se proyectaban a la comunidad con entera dedicación, su vida fue más contemplativa y sus ingresos fueron escasos, a lo que hicieron frente con donativos o privilegios de los Reyes o si pertenecían al patronato regio o con los de los obispos y personas caritativas Desarrollaron en un mínimo porcentaje, actividades benéficas y de enseñanza. La labores de bordar, coser, hacer confituras, les proporcionaba una mínima ayuda económica. De ahí la importancia de las dotes al ingreso de las aspirantes. Según la historia, las dotes de matrimonio eran muy elevadas y esto se constituyó en una preocupación para los nobles, pues si casaban a la primogénita, las segundas y terceras hijas se enviaban al convento, por la cantidad de la dote, que podía ser de mucha menos cuantía.

La vida conventual está regida por las llamadas "Constituciones" o la "Regla", que son las normas de vida, que a su vez se constituyen en la guía espiritual de los monásticos (hombres o mujeres). En otro lado y como parte esencial están los Santos fundadores y completando el triángulo, encontramos a las figuras más relevantes dentro de cada una de las corrientes espirituales de cada Orden Religiosa. La espiritualidad Benedictina se puede considerar de trayectoria hacia el interior del Monasterio, "Ora et labora" es el lema de la Orden de San Benito; así, las reglas hacen referencia a los Santos que las pusieron en práctica y les dan su nombre. En el Caso de Carmelitas, la Regla adquiere especial protagonismo por cuanto fue la fuente de discordia en el momento de la Reforma. La Santa quería volver a la Regla primitiva, sin las "mitigaciones" que habían sido introducidas en el siglo XV. Esta resolución de Santa Teresa, significaba volver a los fundamentos básicos de la Orden Carmelita, que lógicamente se mantenían en la Regla primitiva. La carta de renuncia de la Santa, fechada del 8 de Julio de 1571, se encuentra en todos los Conventos Carmelitanos. Estas Constituciones no solo reglamentaban la práctica espiritual de la vida religiosa, sino cada uno de los actos de la vida cotidiana; en ellas, habían instaurados códigos de comportamiento, 
códigos de honor, códigos de conciencia; cómo cantar, cómo vestir, cómo actuar, cómo ser. Pero también había en ellas, un apartado para las culpas y su forma de castigarlas. Cuando en la vida de clausura se registraban ciertas deficiencias, en cuanto a la observancia de la Regla, en cuanto a las relaciones personales, en cuanto al cumplimiento de las obligaciones contraídas, justamente y para ejercer un control sobre ello, se instituyeron las bien sabidas "visitas", en las que el Prelado ordinario - generalmente el Obispo pasaba por los Monasterios con una periodicidad de tres a seis años; a manera de control espiritual y material, pasaban estas visitas en las que se encontraba todo tipo de casos y en las que se ponía coto a las malas acciones, con los "mandatos" y/o con castigos que iban desde mortificaciones impuestas, privación de voz y voto, comer en el suelo, hasta la excomunión y la pérdida del hábito, según fuera el grado de la culpa.

Veamos cómo se expresan éstos castigos, en la Visita del 21 de febrero de 1530:

“Otro si que hallamos que las religiosas, o muchas de ellas entran en el coro al oficio divino sin cogullas y algunas veces en cuerpo, no tan honestamente como sería razón, mandamos en virtud de la santa obediencia que desde aquí adelante ninguna entre en el coro, sin cogulla, a teniéndola, y a las que no la tienen se proveerá luego como se las den y todas conforme desde aquí adelante"33 “Otro si somos informados por nuestra visitación que las religiosas novicias que toman el hábito, ni son enseñadas en el amor divino, ni doctrinadas en las cosas eclesiásticas y de la santa religión, ni acostumbradas a la disciplina y recogimiento que a buenas costumbres conviene, antes se crían sueltas y sin freno de disciplina, y reciben y dan mensajes en la villa, prohibimos y mandamos, que desde aquí adelante, a las religiosas que se recibieren se den maestras que las tengan recogidas y las enseñen a servir a nuestro Señor y las cosas de la religión y no las consientan andar por las cocinas y porterías, más antes sea sujeción en el coro y en la celda con su maestra."

"mandamos a la Señora Prelada como a todas las otras religiosas en virtud de santa obediencia, que desde aquí en adelante guarden ésta nuestra visitación y porque más lo traigan a la memoria se lea en el convento de cuatro a cuatro meses, y la Prelada la tenga guardada en sus arcas porque no la pierdan o rasquen. Así mismo por bien de la paz y por quitar ocasiones de discordia y rencillas,

33 ASMD. Cinta microfilmada N o 5 del AHN, que reposa en el Monasterio de Santa María de las Dueñas. 
mandamos en virtud de santa obediencia y so pena de excomunión "trina armonitione", premisa que ninguna religiosa sea osada decir a otra voz dijiste esto a los visitadores, y si alguna lo contrario hiciere sea puesta en el cepo por seis días sin remisión y cuando de allí saliere coma en el refectorio en tierra un día."34

Para los Monasterios era de vital importancia observar la disciplina interior y creo que como debe ser la vida normal de las personas y las instituciones. La disciplina es fundamental para su buen funcionamiento, llámese la familia, el gobierno, el Monasterio, la Iglesia.

Otro aspecto para mencionar es el tema de las mortificaciones; En los libros de Difuntas o Fallecimientos, incluso el Libro de Crónicas se puede percibir que la "mortificación" está presente en la vida espiritual, física y en forma cotidiana de las monjas como una forma de "auto - castigo", con el objeto de limpiar culpas y como elemento de un sacrificio que les brindaba después en cierta forma la paz interior. Los Libros de Difuntas brindan información al respecto, ya que en ellos, se hace exaltación de la vida de cada religiosa y especialmente a las cualidades y entre estas cualidades, se describen las "mortificaciones". Todo tipo de mortificaciones se encuentran en estos relatos, que iban desde someterse al ayuno, a diversas privaciones, aplicarse silicios hasta vivir con austeridad; En el Libro de Visitas y Elecciones del Monasterio de Santa María de las Dueñas, en el apartado correspondiente a los "Mandatos", se encuentran recomendaciones como la siguiente:

\footnotetext{
“5o Que así la Abadesa como las demás religiosas mías amadas súbditas guarden los ayunos, disciplinas que prescribe la Regla de su Gran Padre, o disponen sus Constituciones; procurando cumplir exactamente en este particular con ellas, pues la mortificación ayuda a el espíritu a que dejando lo terreno y caduco se eleve a gozar de los consuelos que vinculó Dios a la mortificación y penitencia para curar las heridas que en el alma dejan las culpas y pecados." 35
} 
La "oración" diaria, era otro de los aspectos muy importantes de la vida conventual. Hay que tener en cuenta que la distribución de las jornadas de trabajo en un Monasterio, se hace en función de las pausas establecidas para las horas comunes a la oración, Prima, Tercia, Sexta, Nona, Vísperas, Completas, Maitines y Laudes. A la par con estas prácticas diarias, hay que tener en cuenta las Ceremonias como: misas, elecciones de Priores, profesiones, solemnidades de Navidad y Semana Santa, funerales. Las oraciones comunes en el Coro, de igual manera tienen carácter de Ceremonia. La devoción a los santos patronos, santas, a J esús, la Santísima Trinidad o la Virgen María, ha llevado a los monjes y monjas a tomar nombres nuevos en su vida religiosa. En los primeros tiempos la tendencia generalizada era la de cambiar completamente el nombre de la Profesa, como significado de renuncia a la vida anterior para consagrarse al servicio de Dios y del prójimo enteramente. Esto cambió sustancialmente con el tiempo, conservando el nombre de pila o nacimiento. Analizando dichos nombres es menester hacer una relación entre ellos y ver la preferencia correspondiente a cada Monasterio.

\begin{tabular}{|l|l|}
\hline \multicolumn{1}{|c|}{ NOMBRES DE LAS MONJ AS } & \\
\hline & \\
\hline \multicolumn{1}{|c|}{ MONATERIO DE SANTA MARÍA } & \\
\hline DE LAS DUEÑAS - Madres Benedictinas & CONVENTO DE " LA ANUNCIACIÓN" \\
\hline & Madres Carmelitas \\
\hline Ana María dela Encarnación & Teresa de J esús \\
\hline Escolástica & Eufracia de J esús \\
\hline Benita de Oviedo & Inés de Cristo \\
\hline Baltasara & Juana del Espíritu Santo \\
\hline Josefa dela Anunciación & Francisca dela Madre de Dios \\
\hline María Antonia delaVisitación & Eugenia del Santísimo Sacramento \\
\hline Teresa de Benito & Mariana dela Encarnación \\
\hline Teresa Francisca & Ana dela Cruz \\
\hline Bonifacia & Antonia de Santa Teresa \\
\hline María Francisca de la Presentación & Magdalena de San J osé \\
\hline Benita Dolores de la Asunción & Catalina de San Francisco \\
\hline & $\begin{array}{l}\text { Luisa Gerónima de la Santísima } \\
\text { Trinidad }\end{array}$ \\
\hline
\end{tabular}


En el Monasterio de Santa María de las Dueñas, hay gran variedad de nombres, predominando los que hacen alusión a San Benito, al igual que el nombre de María combinado con algunos nombres de Santas, los que tiene estrecha relación con la Asunción de la Virgen y nombres combinados que honran a Santa Teresa. En el Monasterio de La Anunciación, encontramos nombres relacionados con las fiestas de la vida de J esucristo, como "de Sacramento", "de la Cruz", "de J esús", "de Cristo", "de la Santísima Trinidad" y los relacionados con la Orden y con Santa Teresa. Con lo anterior es posible conocer cuáles eran las devociones más frecuentes.

En conclusión, la vida de la mujer en estos tiempos estuvo regida por los principios del "honor" y en virtud de ello, estuvo marcada por el estigma de ser inferior al hombre; sin embargo y pese a ello, existieron al interior de los conventos, mujeres que destacaron por su inteligencia, por su talento y por su energía al frente de la Dirección de los Monasterios.

\section{II.2.2.INGRESO A LA VIDA DE CLAUSURA}

¿Qué significó la vida de clausura para una mujer en estas épocas?

Analizando en forma general, la clase de mujeres que abrazaron la vida religiosa, encuentro que influyó en ello y en gran medida, el factor económico y las motivaciones fueron de toda índole, como por ejemplo: en situaciones de orden social, pueden calificarse las hijas de buenas familias pero sin dote, las viudas respetables, las mujeres que habían pasado por situaciones sentimentales difíciles, entre ellas, amigas íntimas de reyes o nobles que habían perdido sus favores, que al final llegaban recluirse en los conventos, o mujeres solteras que querían pasar sus últimos días tranquilas. Durante los siglos XVII - XVIII - XIX, ha de entenderse, que llegaron a los conventos femeninos, grupos de mujeres de distinta idiosincrasia y procedencia y que confluyeron ahí por distintos motivos.

Las había con verdadera convicción de fe, con verdaderas inquietudes espirituales, que deseaban sinceramente estar ahí, y ser verdaderas monjas; otras, se encontraron en los cenobios por beneplácito de su familia; las había que por designios de sus padres, estaban destinadas a otros fines, y debían vencer ese obstáculo familiar y otras que por motivos de diversa índole, como por ejemplo: el 
abandono de sus familias, haber quedado huérfanas, por haber sido ultrajadas o simplemente porque nunca encontraron con quien contraer nupcias, llegaron a ellos.

De este modo, convivieron durante siglos, mujeres, que voluntariamente escogieron ingresar, junto con las que fueron obligadas a profesar, y con las que aceptaron este estado como un mínimo mal, en su vida personal. Mariló Vigil, nos dice:

"El ingreso en un convento fue la solución para las hijas de familias de la alta, mediana y pequeña aristocracia, a las que sus padres no podían dotar convenientemente para casarlas dentro de sus linajes."36

Qué se puede pensar de las mujeres que no ingresaron por una decisión personal sino como una imposición familiar? Se puede pensar que al llegar en estas condiciones, estas mujeres presentaron al interior de los conventos, una actitud de abierta rebeldía o de disimulado resentimiento. Al contrario de este caso, el internamiento de muchas mujeres, no fue siempre la consecuencia de las presiones de padres autoritarios o de penurias económicas; las biografías de monjas que vivieron en estas épocas, escritas por ellas mismas, abundan en ejemplos que la futura religiosa tiene que oponerse a la voluntad de sus progenitores para profesar o verse en situaciones de Orfandad absoluta, como le aconteció a Sor Ángela Collantes del Monasterio de las Benedictinas de Santa María de las Dueñas de Alba de Tormes, quien en su momento, se sintió en una situación de desamparo;

“que yo, la dicha Da Ángela por más agradar y servir a Dios Nuestro Señor, huir y evitar los peligros del siglo de muchos años a esta parte me dedique al estado de religión y para poderlo mejor conseguir, hallándome falta de medios y sin humano socorro me apliqué a aprender solfa y Canto llano y a tañido de los instrumentos de órgano y arpa, lo que llegué a entender y entiendo suficientemente."37

36 VIGIL, Mariló. La vida de las mujeres en los siglos XVI y XVII. Madrid: Siglo XXI de España, 1986, p. 208.

37 ASMD.Tomado de las cintas microfilmadas del AHN sobre informaciones de monjas. Cinta № 7. Escritura de Dote. Ángela Collantes.p.2. 
Merece ilustrar que estas sabias palabras salidas de boca de Sor Ángela Collantes, Maestra de Música como fue llamada al interior del monasterio, durante su larga y activa vida musical,- pues había ingresado a la edad de 25 años -, nos ilustran claramente lo comentado anteriormente. En sus primeros términos, sugiere la necesidad de evitar los peligros a los que se puede enfrentar en el mundo exterior, una mujer sola, huérfana y desamparada en estas épocas, de esta manera el ingresar a un Monasterio le brindaba seguridad, confianza en sí misma y con el saber y talento musical que poseía, no veía otro camino a seguir, por ello solicitó el ingreso y especialmente la plaza de "Monja Cantora" para reemplazar a Dña Catalina Rivera, quien hallándose en precarias condiciones de salud, deseaba dejar el cargo.

Tal y como se estilaba en la época, una de las causas que con mucha frecuencia llevaron a muchas mujeres a seguir la vida religiosa y más concretamente, el enclaustramiento, fue la práctica social, de enlaces matrimoniales de conveniencia por honor y estatus, vale decir, que en caso de existir varias hijas, solo la mayor tenía el privilegio de contraer matrimonio, apoyada económicamente por una dote que no desmerezca al futuro esposo. Las demás hijas, tomarían los hábitos religiosos, asegurando de esta manera una vida futura honorable y las dotes asignadas para el ingreso en el convento, eran de menor cuantía. Ahora, ciñéndome expresamente a los conventos escogidos para esta investigación, como son: el convento de la Anunciación de Nuestra Señora del Carmen y el convento de las madres Benedictinas Monasterio de Santa María de las Dueñas de Alba de Tormes y analizando sus crónicas de fundación y vida conventual, encuentro que éstos siguieron las directrices de sus fundadores y el ejemplo dado, en una vida de perfección y entrega a la causa.

En la medida que el ambiente económico de las familias de la época, iba en quebranto y que el importe de las dotes iba cada día en aumento, la colocación de las hijas se convertía en un complicación para los padres, especialmente en la clase media y de la pequeña aristocracia. Toda esta problemática, dio pie a las preferencias o favoritismos en el proceso de otorgamiento de los cupos en los conventos; abundaban las concesiones para hijas de Ministros, generales y otros 
altos cargos y rangos. En interior de la vida de clausura, existieron en la época multiplicidad de compromisos de diversa índole a los que las postulantes estaban ligadas y uno de ellos y el primero, era acatar la norma de sus fundadores; en el Caso del Monasterio de santa María de las Dueñas, tiene la siguiente explicación: San Benito institucionalizó el año del noviciado; con el pasar de los tiempos, la Orden ha fijado los plazos y se han instituido las leyes especiales que rigen la solemne y pública profesión de la vida religiosa; períodos de tiempo - en la actualidad, tres años-, en los que el postulante o postulanta, se prepara espiritualmente para asumir sus obligaciones, su compromiso y finalmente poder profesar para siempre, la vida religiosa.

"El Derecho Canónico vigente, contemplando las muchas y variadas formas de vida religiosa existentes hoy y queriendo abarcarlas todas, dice que son religiosas "aquellos fieles que profesan, los consejos evangélicos de castidad, pobreza y obediencia , y por la caridad a la que éstos conducen, se une de modo especial a la Iglesia y a su ministerio" (Canon 573, 2) (Derecho Canónigo.)

Las monjas Benedictinas que ciertamente se ven definidas por lo que el Derecho Canónico actual presenta como elementos esenciales que definen la vida religiosa bajo todas sus formas; deben acatar lo esencial: La estabilidad, la conversión de costumbres y la obediencia. Todo en la Orden desde sus orígenes y siguiendo la Regla de San Benito, hace convergencia hacia la oración y el trabajo. En el Libro II de Gobierno de los Monasterios Benedictinos, en su Capítulo IV, de ¿Cómo se han de admitir los postulantes o novicios al Santo hábito, - regla válida igualmente para los Monasterios femeninos -, existen una serie de condiciones para acceder al ingreso y toma de hábito.

En el Monasterio de la Madres Benedictinas de Alba de Tormes, cada jornada tiene asignados largos momentos dedicados a la oración, a la litúrgica y a lo personal, iniciando labores a las seis de la mañana y terminando a las diez de la noche. Todo ello, entrelazando la oración, el trabajo y los momentos o espacios personales de cada religiosa. 
El Libro de Profesiones, válido para cualquier Monasterio, es fundamental; ya que brinda una relación rigurosa de la vida y obra de todas y cada una de las religiosas que han profesado, describe la organización jerárquica y permite conocer la naturaleza de la vida conventual. En el caso del Monasterio de Santa María de las Dueñas de Alba de Tormes - Salamanca los datos relacionados con el ingreso de religiosas inicialmente al noviciado y posteriormente con la toma de habito y demás condiciones para entrar en toda regla, en la vida religiosa, se encuentran relacionados en las llamadas "Cartas de Profesión"; este acto queda plasmado en aquellos documentos que legitiman todo aquel proceso de averiguación sobre la vida y costumbres de la doncella, permisos y licencias para su ingreso en el Monasterio y su definitiva toma de hábitos; por lo tanto estas "Cartas de profesión" nos indican el ingreso oficial de las profesas a la vida monacal mediante un hecho que queda plasmado en una fórmula determinada, que se analizará más adelante

Retomando el tema sobre las formulas de "Profesión" concretas encontradas en este Monasterio las cuales contienen una serie de datos determinados comunes a todas las profesiones, como: procedencia, nombres completos y apellidos de los padres y en algunos casos de sus abuelos paternos y maternos, con sus respectivos títulos - si los tuvieren-, el sitio, día, mes y año donde se realiza el acto y los nombres de los testigos que pudiesen estar presentes y las condiciones del ingreso, así como el talento y los conocimientos musicales que la religiosa aportaba o la dote en especie o dinero, se detecta una evolución formulística que se dio en este aspecto a través de los años. Sin embargo y previa a la admisión en el Monasterio, la aspirante era investigada y de ella, "explorada su voluntad" - según reza en los documentos originales-. Esta serie de preguntas y las respuestas obtenidas, eran expuestas y corroboradas respectivamente, por el Señor Notario que daba Fe de lo ocurrido en el interrogatorio hecho a la aspirante. 


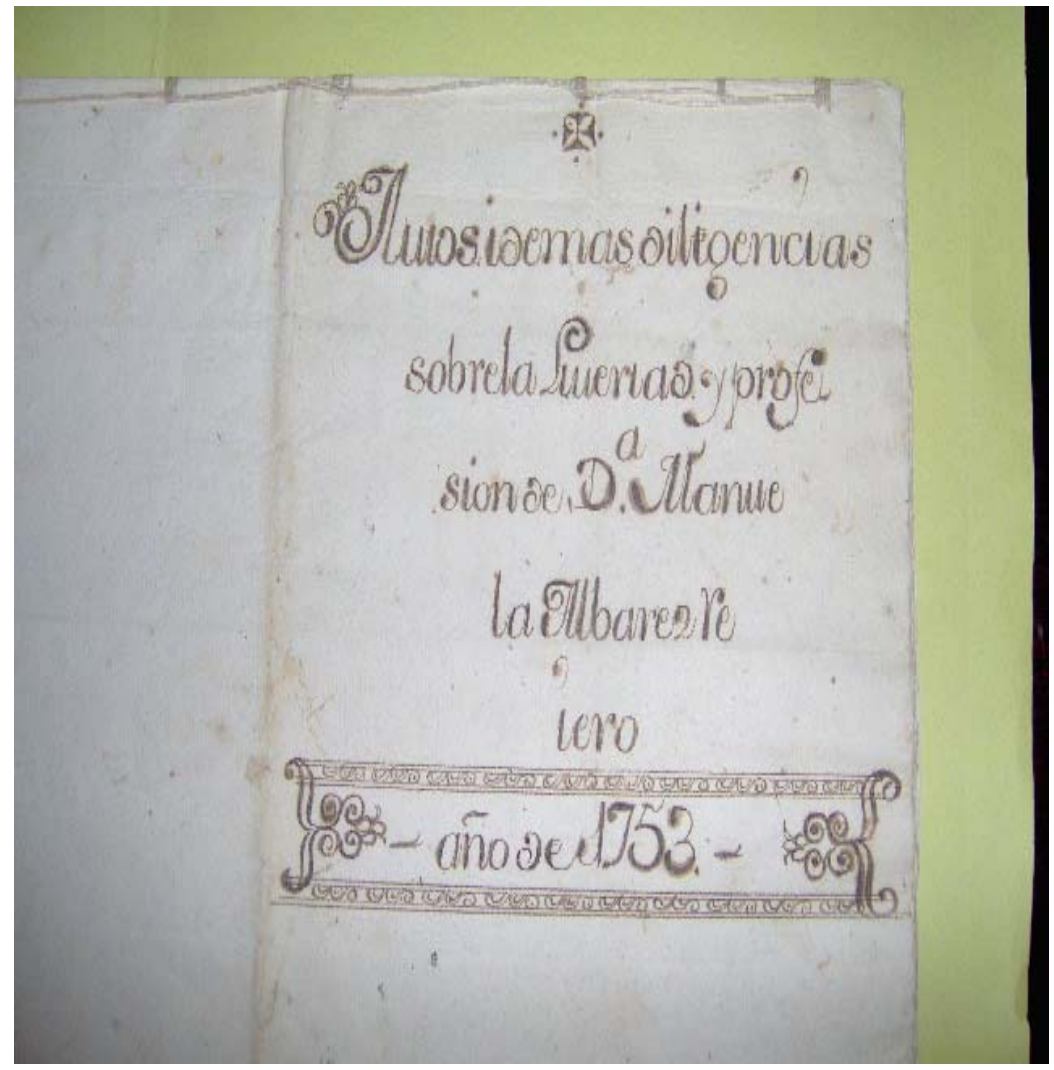

3. ASMD. Informaciones: “Autos y demás diligencias sobre la libertad y profesión de Dña Manuela Álvarez de Reiero - Año de 1753” - Monja música

Vamos a detenernos un poco en la naturaleza de las preguntas de estos cuestionarios; a través de ellas podemos ver muchos de los convencionalismos de la época. Se fija un claro deseo de conocer el mayor número de datos personales posibles a cerca de la aspirante y se advierte el interés porque sean aportados por las personas más relevantes del pueblo, vale decir, personas de total confianza y honradez posible.

El primer dato y el más importante era saber si la aspirante era hija legítima del matrimonio de sus padres. Si se negaba o no, el ingreso en caso de ser hija ilegítima, no hemos encontrado ningún caso que nos corrobore esta situación, pero se sabe que así estaba dispuesto por la Iglesia de aquellas épocas. Se investiga sobre el origen de sus abuelos paternos y maternos y si los unos o los otros ejercieron profesiones $\mathrm{u}$ oficios viles como: carniceros, verdugos, pregoneros $\mathrm{u}$ otros semejantes. En segundo lugar, se averigua, si la aspirante es de vida honesta, si presenta sanas y cristianas costumbres, si pretende el hábito por verdadera 
vocación o si lo hace por violencia de sus padres o parientes y si padece enfermedad alguna que le impida la vida en comunidad. En tercer lugar, las investigaciones se centran en conocer el estado civil de la aspirante; si es soltera y sin compromiso o vínculo matrimonial o si ha tenido matrimonio ya consumado. Y por último, y considerándose de suma relevancia, averiguan si sus padres, abuelos paternos y maternos se hallan comprometidos en ser descendientes de judíos, moros, herejes, recién convertidos o si alguno de ellos ha sido castigado por el Inquisición. La Iglesia española, era una fiel seguidora del cumplimiento de los Estatutos de la "limpieza de sangre".

Talvez la polémica más candente de las averiguaciones, rondaba en torno a si la futura novicia, tenía un antepasado de origen judío, converso o condenado por la Inquisición. Una vez analizado el expediente de la aspirante, se le daba ingreso al período de noviciado y completando los meses exigidos por la comunidad en este status, la Abadesa, se dirigía al Ilmo. Prelado (Obispo de Salamanca), para que diera su consentimiento para poner en votos últimos a la joven aspirante y ratificarla en su profesión. Un ejemplo de ello, es la $4^{\underline{a}}$ pregunta, se puede trascribir con exactitud:

"Si sobre que dicha pretendienta sus padres, abuelos Paternos y Maternos se hallen comprometidos en notoria infancia en el descender de judíos, moros, herejes recién convertidos o si alguno de ellos ha sido castigado por el Santo Oficio de la Inquisición o algún otro tribunal con votos, infamia castigado."

Dichos interrogatorios pretendían especialmente averiguar la vida y ascendencia de cada profesa, considerándose motivo de impedimento para el ingreso en la vida religiosa, variados aspectos de la vida común de las personas, como la legitimidad, la salud, el estado civil, entre otros. Con esto se pretendía tener bajo su dominio la posibilidad de abrazar la vida religiosa, a toda aspirante.

En cuanto a la Profesión de las religiosas, se trascribe a continuación un acta de Profesión, útil para ilustrar los términos de dicho ingreso y la naturaleza del mismo, después de haber estado un año en posición de novicias. 
“J oseph Zorrilla de San Martín por la gracia de Dios y de la Santa Sede Apostólica Obispo de la ciudad y Obispado de Salamanca del Convento de Santa Magdalena vicario y prelado ordinario del Convento de religiosas de Santa María de las Dueñas, Orden de San Benito extramuros de esta Villa de Alba de Tormes afirma

Por cuanto se nos ha hecho constar por certificación de la reverenda Madre Doña Teresa de Arapiles Abadesa del dicho convento que Doña Manuela Álvarez de Reyero hija legítima de Don Vicente Álvarez Reyero y de Doña Teresa Gonzales vecina de la ciudad de Salamanca habiendo tomado el hábito de novicia en el expresado convento y estando para cumplirse el año de su aprobación con nuestro permiso y licencia ha sido admitida por votos secretos de todas las monjas capitularmente congregadas para hacer su profesión en el; $y$ mediante que a este fin ha sido explorada su voluntad por comisión de nuestro provisor y vicario y permanece en la de abrazar libre y espontáneamente el Estado de aquella religión para mejor servir a Dios nuestro Señor en ella; y atendiendo que es Doncella de honestas costumbres y que concurren en ella las demás calidades y circunstancias que previene el Monasterio= Por tanto por las presentes damos nuestro permiso y licencia a la referida Madre Abadesa para que sin incurrir en pena alguna pueda admitir a la Profesión de velo y choro a la sobre dicha Doña Manuela Álvarez Reyero con la solemnidad y ceremonias que prescribe la Cartilla y Ceremonial del referido Monasterio y conforme lo han ejecutado todas las demás religiosas de el: previniendo que por dicha profesión solemne queda obligada a guardar clausura perpetuamente sin hacer voto expreso de ella, por anexa a los otros tres substanciales de pobreza, obediencia y castidad según la disposición del Santo Concilio de Trento Bula Circa Pastoralis de Su Santidad Pio V y sentencia definitiva dada en juicio contradictorio por el Nuncio de su Santidad en estos Reinos y para que en nuestro nombre se autorice la referida profesión damos comisión en forma y cometemos nuestras veces a Manuel Hernández Mayno vicario de esta dicha villa o a la persona en quien delegare y queremos que uno y otro se ejecute por ante notario que de fe y ponga testimonio en nuestra secretaría de Cámara dada en esta referida villa de Alba de Tormes a doce de Noviembre de mil setecientos cincuenta y tres Años.

José Zorrilla de San Martín, Obispo de Salamanca. Alonso Hernández del Corral - Notario"38

38 ASMD.Legajo de Informaciones - Autos y demás diligencias sobre la libertad y profesión de las religiosas (Religiosa Doña Manuela Álvarez Reyero. Año 1753). 
En la siguiente cita, se puede conocer que esta carta de Profesión sigue las notas comunes de la fórmula usada en aquel entonces: la obediencia que prometen las monjas a la Orden y en este caso, en presencia de la Abadesa, del Obispo de Salamanca y ante el capellán mayor del convento. Ofrecemos a continuación la profesión de Benedictina hecha por Ana María de la Encarnación el 17 de mayo de 1770, documento original escrito en latín trascrito a continuación:

\begin{abstract}
“Yo,hermana Ana María de la Encarnación prometo perpetuamente permanencia en clausura y la conversión de mis costumbres, y obediencia ante Dios y sus santos según la regla de nuestro santo padre Benito en este monasterio de santa María de las Dueñas de la orden del mismo santo, en la presencia del Señor, del señor J osé de Herrám y bajo la obediencia de las superioras, la Abadesa Catalina Sánchez de este mismo Monasterio y también bajo (la obediencia) del Ilustrísimo y reverendísimo Obispo de Salamanca Felipe Beltrán.
\end{abstract}

+ Ana de la Encarnación Buendía.

Año 1770 - día 17 de Mayo”39

En referencia al Monasterio de La Anunciación - Madres Carmelitas-, la fundación de éste Monasterio, así como el de otros fundados por la Santa, está fuertemente marcada por el espíritu de la Orden del Carmelo, y por el temple y empuje de su fundadora. El proceso de fundación de éste Monasterio, está suficientemente documentado.

Merece destacar la importancia de la norma que rige los conventos; la cual está establecida por la Regla y las Constituciones de la Orden y por una serie de disposiciones agregadas que dan los patronos, fundadores, Padres generales o Vicarios. Las reglas hacen reseña a los Santos que las pusieron en práctica y les dan su nombre; Así, en el tema Carmelitano y remontándonos al año 1562, ya en el monasterio de San J osé, la Madre Teresa había iniciado su "Reforma". Se había quitado el calzado - usaba solo alpargatas de esparto y tela - , usaba un habito de tosca tela y ahora se llamaba simplemente Teresa de J esús, dejando

39 Carta de Profesión hecha por Ana María de la Encarnación, que data del 17 de mayo del año 1770. Archivo del Monasterio de Santa María de las Dueñas, Alba de Tormes (Salamanca). 
atrás su apellido Ahumada. Ella se sentía diferente, trabajando solo por el amor y para el amor de Dios. Ella y sus compañeras del convento fueron criticadas duramente por las mismas hermanas de la Encarnación, por la gente de Ávila, que la consideraban loca y que por su actitud, podía ella y sus compañeras, acabar en la Inquisición.

En Alba de Tormes, la Santa Teresa de J esús tuvo por compañeras de fundación a las religiosas Madres Inés de Jesús, natural de Ávila y María del Sacramento (monja música) y Tomasina Baptista natural de Medina. El matrimonio Velázquez - Láiz, sin descendencia, eran de ocupación hacendados, con una excelente fortuna muy bien administrada por Don Francisco, quien había sido contador del Duque de Alba, administrador de la Universidad de Salamanca y prestamista. Su apellido significó la pujanza social de esta obra pía y el mecenazgo.

La dote de los fundadores, para la iniciación de esta obra, fue de considerable importancia. Del convento que nos ocupa, por su significación, transcribo literalmente las palabras de sus benefactores:

'Nos, los dichos Francisco Velásquez y Teresa de Lays, su mujer, decimos que nos obligamos por nuestras personas é bienes, muebles é raíces, habidos é por haber (...) de dar é pagar é que daremos é pagarémos para la dote é fundación del dicho Monasterio cien maravedises de juros, e dineros de contado en cada un año, a razón de catorce mil maravedises el millar, p0or los días é años de nuestra vida. E después de nuestros días é fallecimiento hemos de dar é paga $\mathbf{r}(. .$.$) .otros cincuentamil maravedises de juros en cada$ año, a la dicha razón, demás é aliende de los dichos cien mill maravedises que habemos de dar por nuestros días. Por manera que , después de nuestros días é fallecimiento, os hemos de dar é pagar ciento é cincuenta mil maravedises....en cada un año, perpetuamente, para siempre jamás"

“E ansimesmo nos obliasdos de dar, é que daremos é de presente damos é donamos para el dicho Convento é Monjas del é para su sustentación é menesteres, ciento é cincuenta fanegas de trigo, de renta perpetuas, en casa un año, firmes é seguras, para que siempre jamás, para que el dicho Convento las haya é tenga é goce".

“Otrosí, con que en el dicho Monasterio no haya más número de doce relixiosas é con la priora del dicho Monasterio trece é.teniendo para cada 
una monja hasta quince mill maravedises é no más; é que si de ste número pasaren pierdan la renta que nosotros le dejamos".

"Otrosí: nos los dichos Francisco Velásquez é Teresa de Layz, su mujer decimos que nos obligamos dexar fundada una capellanía, en la dicha Iglesias é Monasterio, para que se diga cada día Misa en el dicho Monasterio, con congrua sustentación del capellán que fuere de dicha capellanía". 40

Constituida ésta fundación, se da como fecha fundacional, el día de la Conversión de San Pablo, año de 1571.

Algunas condiciones especiales exigieron los fundadores y protectores del convento, a cambio de esta gran dote, en su tiempo, entre ellas:

- El Convento debería llevar y conservar el nombre de "La Anunciación de Nuestra Señora del Carmen".

- De las misas que se oficiaren, se aplicarían una por ellos y otras por sus parientes.

- En día domingos y festivos, las misas serían cantadas y oficiadas en Coro y se debería hacer el respectivo responso sobre sus sepulturas.

- La monjas estarían obligadas a celebrar el aniversario el día de la Anunciación, el de San Pedro y el de San Andrés.

- La celebración de vigilias y oficios acostumbrados cada año y hacer cantos por las almas de los fundadores y difuntos bienhechores, así como encomendar a Dios en toda misa y oblaciones, a los fundadores.

Las anteriores disposiciones formaban parte importantes del desenvolvimiento de la vida conventual; tanto los aspectos materiales como en los religiosos, están regidos por las constituciones Teresianas y en ellas se suelen seguir los asuntos temporales como: la forma de vestir, los oficios, los cargos desempeñados por las monjas, el ceremonial de comportamiento, las horas litúrgicas y la distribución del trabajo diario; todo lo anterior bajo la estricta ideología de pobreza y mortificación.

40 ACA. Dote de los Fundadores. Fechada en 24 de enero de 1571. 


\section{II.2.3. PROCEDENCIA GEOGRÁFICA Y SOCIAL DE LAS PROFESAS}

Qué importante es saber de dónde llegaron tantas profesas a estos Monasterios; tantas mujeres que por diferentes motivos y como ya se ha dicho, entre ellos, los sociales y los económicos, llegaron dejando su entorno familiar, para recluirse en estos pequeños Centros que representaban otra clase de sociedad y conocer las razones que motivaron éstas profesiones. Ya Sánchez Lora nos ilustra acerca de las motivaciones que influyeron en éstas decisiones:

“El ingreso en un convento fue la solución para las hijas de familia de la alta, mediana y pequeña aristocracia, a las que sus padres no podía dotar convenientemente para casarlas dentro de sus linajes." 41

Para analizar el ingreso de profesiones, el Libro de profesiones se convierte en una fuente primaria de gran valor. De él, se pueden extractar datos tan importantes como el número de profesas que ingresaron en determinado espacio cronológico, así como fechas de nacimiento, procedencia, fecha de toma de hábito, edad, oficio desempeñado al interior del Monasterio.

En este Monasterio de La Anunciación, la cifra general de profesión es de 55 religiosas que ingresaron en el siglo XVII. Con el objeto de observar la evolución, se ha dividido por períodos de cada diez (10) años, con la siguiente deducción:

- $1600-1620=9$

- $1624-1630=9$

- $1632-1640=5$

- $1643-1654=9$

- $1660-1666=7$

- $1672-1679=6$

- $1681-1686=3$

- $1693-1699=7$

$$
\text { Total }=55
$$

41 Concha Torres Sánchez cita a Vigil, Mariló en La Clausura femenina en la Salamanca del siglo XVII - Dominicas y Carmelitas Descalzas. Salamanca, 1991, p. 64. 
Haciendo referencia a la Orden Carmelitana, las disposiciones para llevar a cabo las averiguaciones para investigar a las postulantes, fueron menos rigurosas, por cuanto Santa Teresa repudiaba en cierta forma, la dureza de los Estatutos pensemos que ella misma vivía temerosa de que se descubriera y se declarara su origen converso-. Leyendo los interrogatorios practicados en la época, se puede observar que estos no son tan exhaustivos como los que se pueden trascribir de los documentos encontrados en el Monasterio de Santa María de las Dueñas. Teniendo en cuenta que éste Monasterio fue fundación de Santa Teresa, junto con el Matrimonio Velázquez - Láiz, la vida de observancia, de austeridad y recogimiento espiritual fueron las características relevantes en ésta obra conventual.

Monasterio de la Anunciación -Madres carmelitas (1600 - 1699)

Profesiones

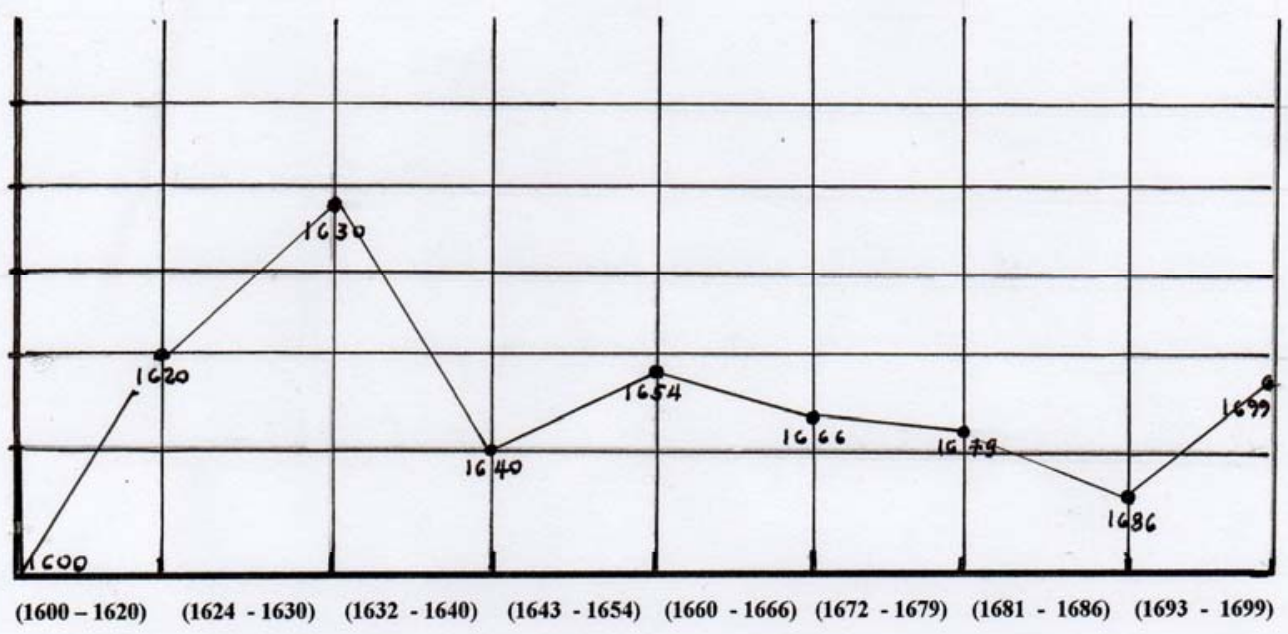

Profesiones (55)

Sobre la vida práctica del diario vivir al interior del convento, el Libro de difuntas que aunque no se cumplimentan tan rigurosamente como los Libros de Profesiones, si nos permite recopilar una serie de relevantes datos acerca de las cualidades, jerarquías, cargos y actividades que las religiosas desarrollaban y el 
Libro de Crónicas del Monasterio nos a conocer apreciables referencias sobre los acontecimientos importantes que ha vivido el Monasterio.

Los datos sobre la procedencia geográfica de las profesas del Monasterio de Santa María de las Dueñas, se han podido encontrar en diferentes documentos como la Carpeta de Informaciones, muy importante por cuanto recopila todas la informaciones sobre la vida y actuaciones de las religiosas y las Actas de Defunción, incluso el Libro de Crónicas señalan la procedencia de algunas religiosas. Una correcta relación de ingresos de novicias, nos las brinda el Libro de Crónicas del Monasterio, al precisar el día y año de Elecciones. Exclusivamente se encuentran datos a partir del año 1750 y con una periodicidad de cuatro años, así:

1. Elección del 19 de Febrero de 1751: 14 religiosas

2. Elecciones del 26 de J unio de 1754: 3 religiosas

3. Elecciones del 17 de Octubre de 1757: 1 religiosa

4. Elecciones del 20 de Octubre de 1760: 1 religiosa

5. Elecciones del 20 de Agosto de 1763 : No hubo ingresos

6. Elecciones del 27 deJ ulio de 1766 : 4 religiosas

7. Elecciones del 20 de Agosto de 1769 : 9 religiosas

8. Elecciones de Septiembre de 1772 : No hay ingresos

9. Elecciones del 11 de Octubre de 1775: 2 religiosas

10. Elecciones del 5 de Noviembre de1778 : 1 religiosa

11. Elecciones del 21 de Diciembre de 1781: No hubo ingresos

12. Elecciones del 1 de Diciembre de 1784 : No hubo ingresos

13. Elecciones del 8 de Octubre de 1787 : 3 religiosas

14. Elecciones del 17 de Noviembre de 1790: No hubo ingresos

15. Elecciones del 21 de Noviembre de 1793: 4 religiosas

16. Elecciones del 20 de Noviembre de 1796 : No hubo ingresos

17. Elecciones del 15 de Diciembre de 1799: 2 Religiosas

(De nacionalidad francesa) 
Monasterio de Santa María de las Dueñas de Alba de Tormes

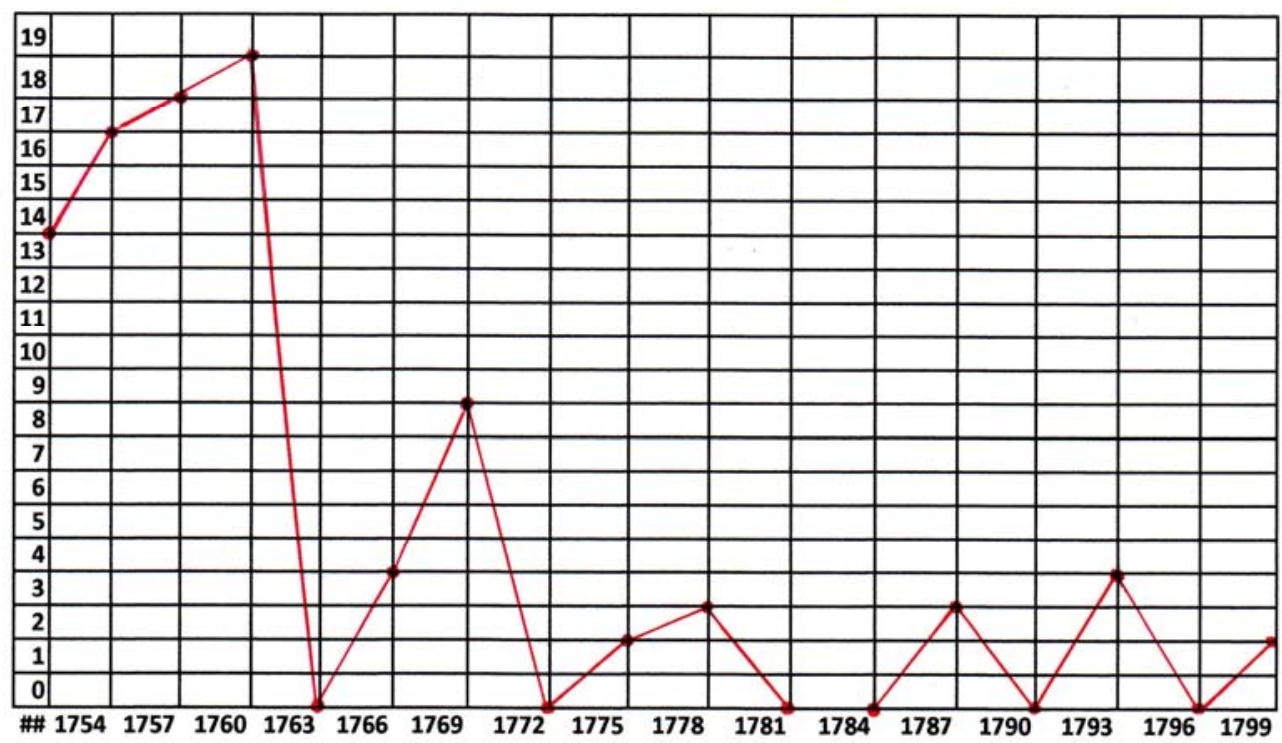

En el caso de estas monjas originarias de Francia, ¿se puede pensar en las motivaciones que tuvieron estas profesas para ingresar en un Monasterio tan apartado de su tierra natal?

Dos religiosas de nacionalidad francesa se encuentran relacionadas en los Libros de la Comunidad. Vicenta Sanson (1799) y J osefa Delpy (1880). De la primera, poco se sabe, solo que en la Elección del 15 de Diciembre del año 1799, como lo relaciona el Libro de Crónicas en su pág. 87, dicha monja desempeñaba el cargo de Refitolera y, ni antes de este dato ni más adelante, existe documentación alguna que ofrezca más información sobre su vida y su desempeño en el Monasterio.

El ejemplo más claro lo tenemos en la figura de María Rosalía Delpy: Hija de J osé Delpy y Juana Courvet naturales de Montalban - Toulouse (Francia); tomó el hábito en este Monasterio de Santa María de las Dueñas en 25 de julio de 1880 y profesó “de velo negro y de rosario” el 28 de agosto de 1881. Dio una dote de 29.000 reales [equivalente a 5.000 cinco mil pesetas] y tenía 51 años cuando ingresó, tomando el nombre de J osefa Delpy. Murió el 21 de diciembre de 1909. Sus datos se encuentran relacionados tanto en el Libro de Dotes, como en el Libro de Crónicas y en la Carpeta de Informaciones.42

42 ASMD. Libro de Dotes, p. 55. Libro de Crónicas, pp. 150- 151. Carpeta de Informaciones № 2, Religiosas. 
El epistolario conservado, cruzado entre su confesor, el Obispo de Urgel (Lérida), la Abadesa del Monasterio de Alba y el Señor Obispo de Salamanca, da buena cuenta de su desafortunada situación familiar, de su trayectoria desde Francia a España, los motivos de su desplazamiento y sus esfuerzos y sufrimientos para llegar a este Monasterio de Santa María de las Dueñas.

En su expediente, encontramos entre muchos, los siguientes documentos:

1. Carta de la referida, solicitando la admisión al Noviciado de este Monasterio de Santa María de las Dueñas de Alba de Tormes

2. Carta de la Abadesa de este Monasterio como respuesta al Señor Obispo de Salamanca, en la que afirma o expresa que el Monasterio no se opone al ingreso de personas extranjeras.

3. Cartas del Párroco y confesor de las "Monjas del Refugio" de la localidad de Montalban (Francia) a la Abadesa de este Monasterio.

4. Carta de la Abadesa al Señor Obispo solicitando consejo para tomar una decisión al respecto.

5. Cartas de J osé María Garay, su confesor, recomendando su ingreso en el Monasterio.

6. Carta del Obispo de Urgel, dirigida a la Abadesa del Monasterio, ofreciendo informaciones sobre su vida y conducta.

7. Carta del Obispado de Salamanca otorgando permiso y licencia para su ingreso y la imposición del Santo hábito.

8. Acta de exploración de Dña. Rosalía Delpy

9. Acta de entrega de dote.

De su nacimiento y de su infancia se sabe por la carta de Obispo de Urgel, que la referida María Rosalía Delpy, llegó donde las “Monjas del Refugio” de la ciudad de Montalban (Francia) siendo muy niña y que él la conoció cuando ella tenía 15 o 17 años.

"sin padre y con una madre indolente estaba muy expuesta, y una hermana suya, si mal no recuerdo le procuró la entrada a la clase."43

43 Carta del Obispo de Urgel (Roma, 10 de julio de 1878) a la Madre superiora del Convento. Carpeta de informaciones № 2 . 
Sin Bautismo, ni confirmación, fue bautizada "sub condicione"; tenía el nombre de María y le fue agregado el de Rosalía.

J osé María de Garay- capellán-, dice:

"Allá permaneció hasta los 30 o 32 años en que se vio precisada a variar de clima causa de su salud y que por entonces era muy delicada; después ha vivido en Bilbao y sus pueblos inmediatos por causa de la guerra dedicada únicamente a enseñar en practicar y trabajar al bordado con cuya ocupación ha podido reunir de sus ganancias 29.000 r. de que dispone y los tiene en el banco." 44

Esta persona fervientemente deseaba tomar la vida religiosa y su llegada a España, como lo podemos ratificar, fue motivada expresamente por causas de salud. Es de admirar su tesón y su perseverancia para alcanzar su único deseo, el de hacerse religiosa, y siendo bordadora ingresó en éste Monasterio, ocupándose por varios años sobre el cuidado de la ropa y los paños de vestir mesas y ornamentos para la Liturgia.

A partir de la Elección del 2 de J unio de 1881 hasta la del 14 de marzo de 1903, Josefa Delpy, como es su nombre de Comunidad, aparece relacionada con diferentes cargos o competencias, así:

- 1881 = Ropera

- $1884=$ Ropera

- $1887=$ Enfermera

- $1890=$ Sacristana

- $1893=$ Hortelana

- 1896 = Laborera

- 1899 = Laborera

- $1903=$ Auxiliar

Por carta que la Sra. Abadesa J osefa Martín dirige a Don Severino Fernández Vega, el 3 de enero de 1895, dice: "también que hace dos meses que viene a dar paso de francés con Sor María Josefa, tres señoritas, dos hijas de Don Miguel

44 Carta del Capellán José María de Garay a la Abadesa de las Benedictinas. Caja № 2. Informaciones. 
Perlines y la otra es la institutriz del hijo de Don Luís Zúñiga y cada una la da treinta reales que son cuatro duros y medio" 45 Por lo anterior, se puede ver el talante de esta mujer, que siendo bordadora de profesión también ejercía su magisterio enseñando a otros el idioma francés.46

Haciendo hincapié en las monjas - músicas, se encuentran datos de relevancia en los límites cronológicos del año 1700, incluidas en las 44 profesiones anotadas anteriormente, de lo que se hace la siguiente relación de su procedencia:

\section{Siglo XVIII}

- Astorga (León)

1 prof. (solfa, organista, cantora y arpista)

- Toro (Zamora) 2 prof. (una violinista y cantora y otra cantora)

- Alba de Tormes (Salamanca) 2 prof. (cantoras)

- Tuy (Galicia) 1 prof. (organista y cantora)

- Monte Mayor(Extremadura) 1 prof. (cantora)

- Candelario(Salamanca) 1 prof. (cantora)

- Salamanca 1 prof. (organista y cantora)

- Salamanca 1 prof. (organista)

\section{SIGLO XIX}

- Burgos

- Terradillos (Salamanca)

- Palencia

- Burgos

- Villalonquejar (Burgos)

- J aén
2 prof. (organista)

1 prof. (cantora)

1 prof. (cantora)

1 prof. (cantora)

1 prof. (organista)

1 prof. (organista)

45 ASMD. Epistolario - cartas., Caja № 1

46 Como dato curioso, en Alba de Tormes aún existen los descendiente de Don Miguel de Perlines y Don Luís Zúñiga siendo personas muy conocidas y apreciadas en la comarca, según relato de la monja Dña. Manuela Calle Miñambres, archivera del Monasterio de Santa María de las Dueñas, comentado al encontrar esta documentación ( 2 mayo del 2006). 
Los anteriores datos han sido tomados de la Carpeta de informaciones № 1 y 2 , Actas de Difuntas y Libro de Crónicas; de ellos se desprende apreciable información que nos lleva a observar notoriamente la preeminencia de otras regiones fuera de Salamanca, aunque muchas de las doncellas que formaron parte de este monasterio Benedictino, llegaron de Salamanca y su provincia. El conocimiento de la existencia de los monasterios estuvo activado por las redes de comunicación; y si los conventos requerían de las monjas músicas, esto se hacía por intermedio de las convocatorias públicas difundidas desde Obispados y Catedrales. Desde otra perspectiva, la devoción por determinado Patrono o fundador de las órdenes monacales, acrecentaba el interés en la escogencia de uno u otro monasterio, para el ingreso de las jóvenes aspirantes. Los monasterios de una misma orden, ya fuese masculina o femenina, trasladaban a sus religiosas/ os, por diferentes motivos, como por ejemplo: saturación de personas, o por salud, buscando un mejor clima que aminorara las dolencias. También se dio el caso de la unificación de dos monasterios y por ende el traslado de religiosas.

\section{II.2.4.LA NOBLE ASCENDENCIA DE LAS PROFESAS \\ MONASTERIO DE SANTA MARÍA DE LAS DUEÑAS}

La nobleza tuvo un vigoroso y decisivo papel en las fundaciones conventuales. En el caso de el Monasterio de Santa María de las Dueñas, acerca del origen y fundación de éste convento, nada se puede asegurar - ya dicho anteriormente-, dada la carencia de documentos que existe en el actual archivo de la comunidad, lo que hace pensar que dicho archivo, fue destruido por algún incendio como lo afirma el canónigo escritor D. J osé Lamano. Lo importante, es la existencia de los documentos pontificios y reales que revelan la existencia del Monasterio desde tiempos remotos y que a lo largo del tiempo lo han favorecido, como: la Bula del Papa Inocencio IV, la cual acredita la existencia del mismo ya desde la primera mitad del siglo XIII, la Carta de amparo, concedida por el infante D. Sancho, que después reinaría con el Nombre de Sancho IV "El Bravo" - fechada en Alba de Tormes en el año 1279- y los Privilegios por D. Fernando IV "llamado "El Emplazado", dan protección al Monasterio por muchos siglos. Alfonso IX, 
confirmó por cuatro veces los citados Privilegios; Otros tres diplomas fueron expedidos durante el siglo XIV, por Enrique II, por J uan II y Enrique III.

“CARTA DE AMPARO DEL INFANTE DON SANCHO - 1279

Sepan cuantos esta carta vieren como yo Infante Don Sancho hijo, mayor y heredero del muy noble Don Alfonso por la gracia de Dios Rey de Castilla, de León, de Toledo, de Galicia, de Sevilla, de Córdoba, de Murcia, de J aen e del Albarbe. Por facer buen e mercet al monasterio de las Dueñas de Santa María de Alva, recibo en mi guarda e en mi encomienda a la Priora de este monasterio ia dicho e a las Dueñas e a todas las sus cosas. Donde mando e defiendo firmemente que ninguno han sea osada delles fazer fuerça nin tuerto, ni mal ninguno a ella nin a nengunas de sus cosas. A quienquier que lo feciese pecharie en coto al Rey mi padre mille maravedies e a ellas o a quien su bez tuviere todo el danno doblado e de mas al cuerpo e a cuanto que omase me tornaría por ello. Dada en Alva de Tormes a veite e siete días de Mayo era de mille e CCC e diez e siete annos.

Yo Diego Perez la fiz escribir por mandato del Infante. Carta para vista" 47.

De igual manera esa protección ha sido continuada en diferentes formas o aspectos, como el del Arcipreste de Alba de Tormes D. J uan Martínez el cual por testamento fechado en 1393, dejó al Monasterio, toda la leña para el gasto de la Comunidad, en los montes de las localidades de Derrangada y Velayos; además, concedía permiso para que los bueyes de la Comunidad, pudiesen pastar en determinados tiempos en todas sus posesiones y por último, después de fundar una capellanía, de la Iglesia de San Pedro, nombra por heredera de todos sus bienes, a la Priora del Convento Dña. Margarita García.

Adjudicada Alba de Tormes en 1429, por J uan II de Castilla a D. Gutiérrez Álvarez de Toledo, con título de Señor, el Monasterio de Santa María de las Dueñas no tardó en sentir la benéfica influencia de tan ilustre Prelado. El Monje jerónimo Fray Alonso Álvarez de Toledo, hijo del Duque de Alba D.García y profeso del Monasterio de San Leonardo de ésta villa, que dejó en testamento a la comunidad, una manda considerable. Poco después, el Monasterio recibiría otra nueva prueba de distinción y afecto, de la gran Casa de Los Toledo, por parte de Dña. Isabel de

47 ASMD. Pergamino. 
Zúñiga y Pimentel esposa del Duque de Alba D. Fadrique, la cual dio a las Benedictinas, la limosna anual de cinco mil maravedíes de renta. Otra bienhechora, -ya mencionada -, es la noble y distinguida Dña. María de Rosales, quien fundó una Capellanía y dejó entre sus patronos de la misma a la Abadesa de las Benedictinas.

EL Libro de Crónicas, las "Carpeta de Informaciones" - el Libro de Dotes y Defunciones, nos permiten conocer el ingreso de varias mujeres que desde el punto de vista social, tuvieron gran relevancia en su momento y para la posteridad, como son las hermanas e hija de Don Juan de Ovalle, cuñado de Santa Teresa. Durante los años 1565 y 1566, ingresaron Doña Mayor y Doña María de Ovalle (hermanas) y por ésta misma época, fue educanda de éste Monasterio Doña Beatriz de Ovalle, la hija del citado D. Juan de Ovalle. El libro de Crónicas nos lo relata de la siguiente manera:

"las Benedictinas de Santa María de las Dueñas recibían en su Monasterio algunas niñas de corta edad y de familias bien acomodadas, para fundamentarles el corazón en la más sólida piedad e instruirlas en las labores propias de su sexo: una de éstas fue la niña Beatriz de Ahumada que por los años 1565, apenas cumplidos los cinco años de edad, sus padres la llevaron a nuestro Monasterio, para que al lado de sus tías Doña Mayor y Doña María de Ovalle, aprendiera virtud y educación y le formasen un corazón sólidamente piadoso; la niña Beatriz recibió una educación litúrgica y basada en sanas tradiciones Benedictinas".48

Como consta en las crónicas y los archivos del Monasterio de la Anunciación, Beatriz de Ahumada vistió a imitación de su Tía Santa Teresa, el hábito Carmelitano y fue modelo de perfección. Las Benedictinas se sienten orgullosas de su labor en la educación de la niña, que más adelante por el año 1585 profesó con el nombre de Beatriz de J esús; fue fundadora en Ocaña, en Toledo y en Madrid; murió en Madrid. Don José de Lamano en su obra Santa Teresa en Alba de Tormes, nos relata las heroicas virtudes de la insigne Religiosa "y ejemplos de la más alta y sublime santidad con la fragante incorrupción de su cuerpo, que se conserva en Madrid" 49 


\section{MONASTERIO DE LA ANUNCIACIÓN - Carmelitas Descalzas}

Haciendo específica referencia a la noble ascendencia de las monjas, se encuentran relacionadas en el Libro de Difuntas №1, monjas que pertenecieron a diferentes estratos sociales; de destacada posición social, encontramos a varias sobrinas de los fundadores, las sobrinas de Santa Teresa,- una de ellas fundadora más adelante en otros sitios de la geografía española-, las hijas de los Duques de Alba, otras, viudas de grandes Señores, etc. Los siguientes datos correspondientes al Siglo XVII, nos ilustran claramente éste punto:

* Sobrinas de la Santa:

- Beatriz de J esús - procedía de Ávila, profesó en 1585; hija de Don J uan de Ovalle y Doña Betriz de Ahumada.

- J uana de San Pedro - tomó los hábitos a los 11 años, monja con grande dotes musicales, servía en el Coro, hablaba el latín y tocaba el salterio murió en 1601.

* Sobrinas de los fundadores:

- Mariana de la Encarnación, fue una de las que primero tomaron los hábitos, después de la fundación; profesó el 17 de mayo de 1572 y murió en 1614.

- Mariana de la Concepción, encargada de la enfermería y provisora de la misma. "Excelente lectora en el Coro y con muy buena voz" (Libro de Difuntas № 1, p. 2)

- Isabel de San J osé

* Hijas y parientes de los Duques de Alba:

- Ana de la Cruz, hija de los Duques de Alba, Don Antonio de Toledo y Doña Mencia de Mendoza. Profesó en el 1624 y murió el 21 de octubre de 1643. Estuvo casada dos años con el Marqués de Villanueva del Río y otros dos, viuda antes de ingresar al Convento. Con su generosidad, ayudó con la dote de tres religiosas más y aunque llegó a tener varios cargos dentro del Convento, no tenía reparos para lavar, limpiar y hacer todo oficio de casa.

- Beatriz de Toledo, hermana del Duque de Alba Don Antonio de Toledo ciega de nacimiento-, llegando a ser Priora por rango social y económico. Murió en el 1643.

* De igual rango social, se encuentra la profesa, Francisca de la Madre de Dios, (fallecida el 17 de septiembre de 1603), hermana de la Duquesa del 
Infantado, que aunque había tenido una vida cultivada y regalada en el saber y había vivido en la abundancia, en su vida conventual fue muy humilde.

Vinieron con la Santa, algunas monjas que merecen ser mencionadas, como: Santa María de San Francisco, nativa de Toledo, murió en 1614 y desempeñó varios cargos, entre ellos Cantar en el Coro, fue Maestra de Novicias y Prelada, igualmente, María de J esús, Catalina de la Concepción, María de Sacramento y J uana del Espíritu Santo.

\section{MONASTERIO DE SANTA MARÍA DE LAS DUEÑAS}

María de Oviedo Camargo, ostentaba su noble ascendencia, por cuanto era hija legítima de Don Pedro de Oviedo Camargo - de la Cámara de su Majestad Felipe III -, y Dña. Isabel de Frías su legítima mujer, difuntos vecinos de la Villa de Madrid. Su Dote fue de 1.000 Ducados fuera de las propinas y otras cosas ordinarias que se suelen dar a la paga- según consta en su escritura de dote y testamento a treinta y un días del mes de mayo del año 1610.50

Otro tipo de mujeres, que se encuentran relacionadas en los Libros de Profesiones y Defunciones de los dos Monasterios investigados, pertenecen a familias sin noble ascendencia de las diferentes comarcas de Salamanca y de diversa procedencia geográfica; muchas de las cuales eran parientas de las monjas, que a muy temprana edad ingresaron al convento para ser preparadas para la vida religiosa y que después profesaron. El caso ya mencionado de Beatriz de Ahumada, sobrina de la Santa, que fue educada en el Monasterio de Santa María de las Dueñas de Alba de Tormes y más adelante fundadora y que había ingresado a la edad de cinco años.

* Doña ISABEL GARCÍA QUINTANA VERDUGO cuyo nombre de pila fue el de Isabel María de San Juan García Quintana Verdugo, natural de Tuy (Galicia) hija de Juan García Quintana y Felipa Verdugo; fue considerada de noble ascendencia por cuanto su padre fue el Ministro de las Rentas Reales de la ciudad de Tuy y en los documentos acreditativos de su vida, aparece como considerada con rasgos de nobleza. En su ciudad natal eran

50 ASMD. Libro de Dotes, Testamentos y Defunciones. 
tenidos por nobles. Isabel García Quintana tuvo dos hermanos, que tomaron los hábitos de San Francisco e ingresaron como también como cantores.

Algunas otras que se encontraron en situación de desamparo u orfandad, pero que dominaban el arte musical, llegaron al los Monasterios buscando protección y amparo, como el caso de la profesa Ángela Collantes, natural de Astorga (León), que solicitó el ingreso - (1724)- al Monasterio de Santa María de las Dueñas, al verse huérfana de padre y madre y con una destacada formación musical; durante varios años antes de solicitar al Monasterio su ingreso como Monja de Coro, se había instruido en el arte del solfeo y del Canto llano, en el tañido de instrumentos musicales como el órgano y el arpa; para lograr el cargo, debió esta postulante a cantora y organista, trabajar arduamente en su aprendizaje musical antes de su ingreso.51 Dada su importancia se hablará de esta monja música, más adelante.

También buscaron refugio en los Conventos, viudas o mujeres que tenían a sus maridos ausentes y que por motivos de reputación preferían ingresar a los Conventos.

Varios casos se pueden relacionar al respecto:

Primero el de la monja Dominica Zarduí, su madre quedó viuda y desamparada y solicitó su ingreso al Monasterio, como seglar y fue admitida para vivir al lado de su hija, en el Monasterio de Santa María de las Dueñas en el año 1801.

El caso de Dña. Teresa de Arapiles viuda del Cirujano Bartolomé Nieto, vecinos de Alba de Tormes, quien expresó su deseo de ingresar al Monasterio, en calidad de seglar en el año 1792 con su sobrina Dña. María de Arapiles Cornejo religiosa profesa de velo y coro. A la vista de documentos como: El Libro de Visitas y el Libro de Crónicas, se intuye que las dos, llegaron a tener cargos de jerarquía dentro del Monasterio, como Abadesas, Priora y Maestra de Novicias. Por una

51 ASMD. Según lo relaciona la copia microfilmada del AHN. - cinta № 7 p. 2 
nota que se lee en el Libro de Visitas, nos aclara como ésta Señora Teresa de Arapiles, muere siendo Abadesa en el año 1763.

“Setenta y ocho maravedíes

\section{SELLO SEGUNDO, SESENTA Y OCHO MARAVEDIES}

\section{AÑO DE MIL SEISIENTOS NOVENTA Y DOS}

Sepase por esta carta como yo, Teresa de Arapiles viuda que quedé de Bartolomé Nieto cirujano difunto, vecina de esta villa de Alba de Tormes, digo que por cuanto mi deseo para acabara los días de mi vida es retirarme del mundo y entrarme en el Monasterio de Santa María de las Dueñas Orden de San Benito extramuros de la dicha villa, de seglar en compañía de mi sobrina Doña María de Arapiles Cornejo religiosa profesa de velo y coro en el, para lo cual se ha conseguido licencia del Ilustrísimo Señor Obispo de la ciudad de Salamanca como Prelado ordinario de él, mediante yo tenía una casa en esta dicha villa por mia propia junto a la de Marcos López Barbero y hoy en este día la he vendido a Antonio de la Peña y Vega Procurador de causas del número de la dicha villa y vecino de ella en precio de doscientos ducados de ha once reales de vellón los seiscientos del principal de un censo que sobre ella está impuesto a favor de la iglesia del lugar de Pedrosillo y los mil seiscientos reales restantes que el dicho Antonio de la Peña cargo a censo sobre dicha casa y otro bienes que se obligó a pagarme y quien mi dueño represente, ochenta reales de vellón de réditos anuales por el día seis del mes de Abril, en el interin que se redima su principal como más por menos constará de la escritura que cerca de ello se otorgó hoy día de la fecha de esta ante el presente escribano y ahora mi voluntad es el que yo en mis días y después de ellos dicha Dña. María de Arapiles Cornejo mi sobrina en los suyos si me superviviere gocemos los dichos ochenta reales de renta en cada un año Para nuestras necesidades y acabadas que sean nuestras vidas, recaiga y venga dicha renta a la Sra. Abadesa y religiosas y Convento de Santa María de las Dueñas, orden de San Benito extramuros de dicha villa para que la goce perpetuamente con carga y obligación que han de tener $y$ decir por mi ánima en intención en la Iglesia de dicho convento un oficio de la comunidad cantando y vigilando con misa y responso poniendo la cera y ofrenda para ello en la misma conformidad que lo hace con otras dotaciones , que tiene por dichas Sras. Abadesas, religiosas y convento ,se me pidió que para que lo dicho tenga perpetuidad y en todo y en todo tiempo conste se 
otorgue por una y otra parte la escritura que en tal caso se requiere y poniéndolo en efecto yo por la mía en la forma que puedo y ha lugar en derecho y cierta y sabedora de que en este caso me compete de mi libre y espontánea voluntad sin ni inducimiento alguno, otorgo por esta carta que hago gracia y donación, cesion y traspasación irrevocable que el derecho llama inter vivos desde el día que finalicen las vidas de mi sobrina y mía para siempre jamás a las dichas señoras abadesa, religiosas y convento de Santa María de las Dueñas orden de San Benito extramuros de la dicha villa de Alba ara dicho convento y aumento de sus rentas." 52

Como un comentario a lo anterior, y siguiendo la trayectoria de sus vidas gracias a los documentos existentes en el Monasterio, la presencia de estas dos religiosas parientas con un grado de consanguinidad tan directo, se puede apreciar y decir, que la dicha sobrina llamada María de Arapiles Cornejo ya era monja de velo y coro, incluso Abadesa por el año 1761, cuando a su tía viuda se le asigna el cargo de Portera.53

Otro caso muy representativo del tema tratado y que se encuentra relacionado en la Carpeta de Informaciones del Monasterio de Santa María de las Dueñas, es el de la niña Rosa Infanzón natural de Pola de Lena - Oviedo, hija legítima de Don Antonio Infanzón y Doña María Torres, quien había ingresado al Monasterio con la edad de 11 años - nacida el 2 de noviembre de 1843, como educanda donde eran monjas sus dos tías Dña. Benita Infanzón y Dña. J osefa de Haza, últimas Benedictinas de Santa Ana de Salamanca, ya que el Convento quedó tan reducido, que éstas pasaron a engrosar el Monasterio De Santa María de las Dueñas de Alba.

\section{* LAS BENEDICTINAS DE SANTA ANA DE SALAMANCA}

“Otro acontecimiento notable para nuestro Monasterio, es la anexión del Monasterio de Benedictinas de Santa Ana de Salamanca a nuestra Comunidad. Este Monasterio fue fundación de Sta. María de Carvajal de León; primeramente fue Priorato dependiente de dicho Monasterio, más tarde se emancipó de la Casa

52 ASMD. Informaciones de Ingresos A.H.N. Cinta 7 - 11 Carta de donación de Teresa de Arapiles. Año 1692.

53 ASMD.Datos tomados del Libro de Crónicas del Monasterio, pp. 26 - 29.

Libro de Visitas, pp. 2-23. 
Madre, como consta en diversos documentos de nuestro archivo. Últimamente viéndose la Comunidad tan reducida a solas seis monjas, los Superiores optaron por unirlas a nuestra Comunidad; lo que se llevó a efecto el año, 1835.”54 De ésta Comunidad, las Benedictinas heredaron la industria de las almendras.

Por el Oficio fechado a 9 de septiembre de 1866, que la Abadesa envía al Señor Obispo de Salamanca vemos solicitada su admisión como monja de velo negro dando una dote de "treinta mil reales en nominales de $3 \%$ consolidados y gastos de noviciado y de más por parte" -. La imposición del hábito se lleva a cabo el 17 de septiembre de 1866 cuando cumplía los 22 años y profesó el 24 de septiembre del año siguiente; desde este momento toma su nuevo nombre el de Florentina Reguera Infanzón.55

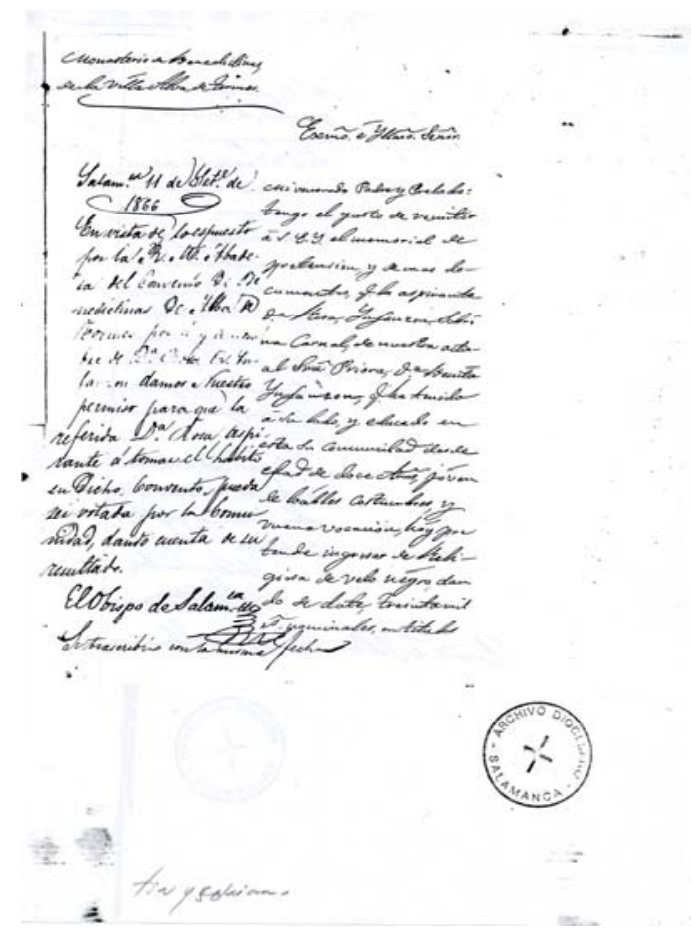

4. Solicitud de la Monja Florentina Infanzón para la toma de Hábito de su sobrina Rosa Infanzón. 56

54 "Nuestros Monasterios. Monasterio de Santa María de las Dueñas". Norma Vitae [Revista de las Benedictinas de España], XVIII (1958), p. 119.

55 ASMD. Libro de Dotes, p. 46. Carpeta de Informaciones № 1. Años 1724 - 1868 - Religiosas. Florentina Infanzón 9 de sep. de 1866 y la respuesta del Obispo 11 de septiembre del mismo año, en la p. 1 de la solicitud.

56 ASMD. Libro de Dotes, p. 46. Carpeta de Informaciones № 1. Años 1724 - 1868 - Religiosas. Florentina Infanzón 9 de sep. de 1866 y la respuesta del Obispo a 11 de septiembre del mismo año. 
Los Libros de Dotes del Monasterio de La Anunciación y expresamente la Carpeta de Informaciones del Monasterio de Santa María de las Dueñas, indican la variada procedencia de las profesas, bien fuesen de las nobleza, clase alta, poderosas económicamente y en otra categoría, de clase media, desamparadas y huérfanas.

\section{II.2.5. CARGOS Y J ERARQUÍAS DENTRO DE LOS MONASTERIOS}

El siglo XVII con su característica espiritualidad, fomentó el nacimiento de los Conventos femeninos, con unas normas instauradas, lo que los reafirmaban como un instrumento de poder. Cada Monasterio tiene un orden interno minucioso determinado a las normas de cada Orden (Las Constituciones) normativa salvaguardada por quienes se encargaban de esta tarea. Para un efectivo y sensato ejercicio de su misión de gobierno y para que toda la Comunidad participe, la Abadesa cuenta con el Consejo de Decanas y el Capítulo conventual. Dicho Consejo de Decanas, está formado a partes iguales: por monjas elegidas por el Capítulo conventual y por otras tantas nombradas por la Abadesa. El número de Decanas no será inferior a cuatro (4). En el Monasterio de Santa María de las Dueñas de Alba de Tormes, en el Órgano regidor de Convento - el Consejo-, tomaban parte: la Abadesa, la Priora, la Arquera, (en la actualidad Mayordoma) y dos monjas más de diferente jerarquía, en total cinco (5) monjas, éstas dos últimas, elegidas por la Comunidad - proporcional al número de religiosas existentes -. Haciendo referencia especial al Monasterio de Santa María de Las Dueñas, este Consejo tiene entre sus competencias:

1. Decidir sobre la admisión de las Postulantes al noviciado.

2. Para admitir de nuevo en el Monasterio a aquellas que lo hubieren abandonado.

3. Para privar a una monja de su derecho al voto, por faltas graves cometidas.

4. Para declarar a una monja incapacitada para ejercer sus derechos Capitulares por razones de salud.

5. Para hacer gastos extraordinarios o para contraer deudas u obligaciones o enajenar bienes por un valor que no supere la décima parte de la suma fijada por la Santa Sede. 
6. La Abadesa consultará al Consejo el despido de una Novicia.

7. Para presentar a la votación de la Comunidad a una novicia para la Profesión temporal y a una Profesa para la Profesión solemne.

8. Para el nombramiento de los principales oficios del Monasterio.

9. Para establecer los horarios de la Comunidad.

10. En general para todos los casos que se requiere un voto deliberativo del Capítulo, antes de pasarlo al voto del mismo.

EL CAPITULO CONVENTUAL está constituido por todas las profesas solemnes del Monasterio y sus competencias son específicas, son entre otras:

1. Admisión de una candidata afectada por un defecto físico.

2. Fundación de una nueva casa.

3. Traslado del Monasterio

4. Cambios en puntos importantes de la Observancia regular.

5. Dar una nueva orientación económica a la Comunidad.

6. Para hacer gastos extraordinarios y contraer deudas, hacer préstamos y enajenar bienes por un valor que supere la décima parte de la suma fijada por la Santa Sede.

En la Regla de San Benito, el Capítulo tercero, está dedicado al Consejo. (p. 44 de la Regla de los Monjes - Edición Abadía de Silos - 1994.) En él, se ofrece una visión reflexiva y de humildad al momento de tomar las decisiones, recomendando a los consejeros, no defender obstinadamente su punto de vista y respetando la decisión que tome el Abad frente a los casos de importancia. En referencia a los Monasterios Femeninos, vemos que mediante Decreto de la Santa Sede fechado a 19 de julio de 1986, en las "Declaraciones a la Regla de San Benito para los Monasterios de la Federación Galaico - Leones de España”, en su Edición de Montecasino - 1986. Benedictinas de Zamora, se encuentran relacionadas las competencias del Consejo referidas anteriormente.

El Libro de Crónicas del Monasterio de Santa María de las Dueñas nos permite hacer una valoración de las distintas actividades o tareas que las religiosas 
desarrollaban, dependiendo en cierta manera de los cargos jerárquicos que se tenían al interior del mismo, como por ejemplo:

Abadesa

Priora

Maestra de Novicias

Maestra de Ceremonias,

Vicaria de coro - $1^{\mathrm{a}}, 2^{\mathrm{a}}, 3^{\mathrm{a}}$ y $4^{\mathrm{a}}$

Portera $1^{\underline{a}}$ y $2^{\text {a }}$

Arquera $1^{\underline{a}}$ y $2^{\mathrm{a}}$

Provisora $1^{\mathrm{a}}$ y $2^{\mathrm{a}}$

Granera $1^{\mathrm{a}}$ y $2^{\mathrm{a}}$

Sacristana $1^{\underline{a}}$ y $2^{\text {a }}$

Enfermera $1^{\underline{a}}$ y $2^{\underline{a}}$

Acompañadora $1^{\underline{a}}$ y $2^{\underline{a}}$

Maestra correctora de Coro

Corista $1^{\underline{a}}$ y $2^{\underline{a}}$

Refitolera

“Estos variados cargos se pueden clasificar por jerarquías, por actividades y por la preparación intelectual de las religiosas. Como es tradición en estos Conventos, para las competencias de los cargos jerárquicos, se sigue la Regla de San Benito, válida para los Monasterios masculinos y femeninos."57

Cargos de Dirección (La Abadesa, la Priora)

- Cargos de Conducción de las novicias (Maestra de novicias)58

- Cargos de atención a la Liturgia (Maestra de Ceremonias)

- Cargos de dedicación a la Música (Organistas, Vicarias de Coro, Coristas, Maestras de Coro)

57 Testimonio oral de Sor Manuela Calle Miñambres. Monja música y Archivera del Monasterio de Santa María de las Dueñas.(julio 25 de 2005.)

58 Regla de los Monjes - San Benito. Abadía de Silos. 1994, p. 133. 
En este Convento se da la particularidad, de que estos dos cargos y en variadas ocasiones recaían en una misma persona.

- Los anteriores cargos estaban estrechamente unidos para el desempeño de la Liturgia.

- Cargos de atención a la Economía (Arqueras, Provisoras, Graneras). En la actualidad: Mayordoma

- Cargos de atención a la salud (Enfermeras)

- Cargos de legas, con diversas tareas, como: la comida, la ropa, la limpieza y las cosas domésticas.

\section{* LA ABADESA}

"Abba" significa Padre; En la Regla de San Benito, el capítulo II está dedicado a la figura del Abad,59 válida tanto para los Monasterios masculinos, como para los femeninos; J erárquicamente, la Abadesa es la figura principal de la Comunidad, y su papel es el más preponderante. En dos direcciones tiene encomendada su labor: En lo espiritual y en lo material.

En lo espiritual: “Responsable ante Dios”. La Regla de San Benito, lo enseña de la siguiente forma:

"Y sepa el Abad, que el pastor será el responsable de cuanto el Padre pueda encontrar de menos provechoso en sus ovejas" 60

"Se le encarga guiar almas.

Recuerde siempre el Abad lo que es y cómo le llaman, sin olvidar que a quien más se le confía, más se le exige. Sepa que difícil y arduo encargo ha recibido de guiar almas y servir a temperamentos tan variados, halagando a unos, reprendiendo a otros, persuadiendo al resto." 61

Ha de enseñar, establecer y mandar e instruir a las profesas, de dos maneras: con su ejemplo, enseñando lo bueno y lo malo, sin hacer distinción de personas y siendo recta en sus actuaciones, mezclando "rigor con dulzura" vale decir, exigente pero con afabilidad. El encargo que se le haya encomendado, "de guiar almas y servir a temperamentos tan variados, halagando a unos, reprendiendo a otros", es

59 Regla de los monjes - San Benito. Burgos: Edición Abadía de Silos, Año 1994, p. 37

60 Ibídem, Cap. II, p. 40

61 Ibídem. Cap. II, p. 40. 
muy encomiable. Ella, se debe adaptar a todo y mantener el entusiasmo y la vocación de sus encomendadas.

“(...) el Abad, no ha de enseñar, establecer o mandar nada que se aparte de lo mandado por el Señor sino que sus mandatos y doctrina deben derramarse en el corazón de sus discípulos como levadura de la justicia divina."62 Otra manda referida a lo espiritual, y que se encuentra relacionada en el Libro de Visitas (Año 1790, p. 67), es la siguiente:

“ 4o La oración es el alimento de la vida espiritual, sin la cual no se pueden hacer muchos progresos en el camino de la perfección; y siendo este el que deben andar las religiosas en este mundo si no quieren engañarse a sí mismas, y carecer voluntariamente del premio que el Señor ha de dar a sus escogidos; en el otro, encarga Su Señoría a la Señora Abadesa que sin gravísimas causas, no dispensen el tiempo que debe durar la oración mental; como también que cuide mucho de que se guarde silencio en el Convento a las horas correspondientes por ser muy conveniente a la tranquilidad espiritual y corporal de las religiosas"

En lo material: El Libro de Visitas nos permiten ver relacionados “Los mandatos" sobre lo material:

“Encarga Su Señoría mucho a la Señora Abadesa que no permita que se abra con frecuencia la puerta reglar fuera de los casos de necesidad por los gravísimos inconvenientes que de ellos se siguen; como tampoco el que haya griterías en ella, ni que se introduzcan niños dentro de la clausura aunque sean de corta edad. Todo lo cual se halla repetidas veces mandado en anteriores visitas."63

"Sepa el Abad que su misión es más servir que presidir. Es necesario que sea conocedor de la Ley divina para que sepa y tenga de dónde sacar cosas nuevas y viejas."64

Con lo anteriormente expuesto, queda claro la categoría o jerarquía de este honroso cargo, elegida teniendo en cuenta el mérito de su vida y la sabiduría de su doctrina por su responsabilidad tanto en lo espiritual - conduciendo al igual que la Maestra de Novicias a sus postulantes - , la vocación de sus profesas, como en lo material, decidiendo sobre la organización del Monasterio.

Algunas consideraciones en torno a la figura de la Abadesa:

* Será elegida por sufragio secreto por el Capítulo conventual, bajo la Presidencia del Ordinario del lugar o de un delegado suyo.

62 Ibídem. Cap, II, p. 37.

63 ASM. Libro de Visitas y Elecciones. Visita y Elección del Año 1790, p. 66.

64 Regla de San Benito Cap. II, p. 148. 
* La elegida, debe cumplir con las cualidades que le exige la Regla

* En la actualidad se elige por seis años. En los documentos de la época (1790) se la elegía por tres años.

La abadesa tiene absoluto control sobre las diversas tareas y oficios dentro del Monasterio, asume gran parte de las funciones: económicas, de gobierno y espirituales. Esta figura siempre ha tenido una relevante influencia sobre las demás integrantes de la comunidad. La escogencia de la Abadesa que regía y que rige en la actualidad el destino de las Comunidad se hacía con minuciosidad y aún se lleva a cabo con rigurosidad. En sus manos está encomendada la tarea de ayudar a cada una de sus profesas a realizar su propia vocación; conservar, fortalecer y acrecentar en su Comunidad el espíritu monástico; de promover y afianzar en ella la armonía y la caridad fraterna y orientar y aprovechar todos los valores y posibilidades de las monjas de tal manera que el Monasterio procure a la Iglesia y al mundo todo el servicio que les debe, según los requerimientos de su propia vocación.

Pero veamos cómo era el proceso para la elección de la Abadesa, la Priora y demás cargos y cuáles eran los mandatos o competencias.

Tomo del Libro de Visitas del Monasterio de Santa María de Las Dueñas, como ejemplo ilustrativo, la VISITA Y ELECCIÓN DEL AÑO 1790, que a la letra dice:

"En la Villa de Alba de Tormes a diez y siete de Noviembre de mil setecientos y noventa: el Señor Don Francisco Antonio de Asas, Canónigo de la Santa Iglesia Catedral de Salamanca, Provisor y Vicario General de este Obispado por el Ilustrísimo Señor Don Andres J osef de Barco, Obispo de este Diócesis del Consejo S. M. y Prelado Ordinario del Convento de Religiosas Benitas de esta otra Villa: En virtud de comisión especial de su Ilustrísima, pasó a hacer la Visita y elección de Abadesa del citado Convento, acompañado de mi el Secretario de Cámara y constituido en su iglesia hizo la Visita del Santísimo Sacramento que halló colocado en el Tabernáculo del Altar mayor con la correspondiente decencia, como también los Altares, Aras, vasos sagrados, ornamentos y demás que visitar se debía; y concluido esto, paso a la reja del Coro bajo en donde estaba congregada a la Comunidad y procedió al escrutinio; seguro oyendo separadamente a cada religiosa por el orden de su antigüedad haciéndoles las preguntas que tuvo por convenientes; $y$ después procedió a la nueva elección de Abadesa, reuniendo los votos de las 
religiosas por cedulas de papel que fueron colocando en una arquita destinada para este fin; y regulados se hallo que correspondían al número de catorce religiosas vocales, pero que no había elección canónica; lo que hizo presente a la Comunidad, mandándola procediese al segundo escrutinio votando solamente por Dña. María de Frías, y Dña. Rosa Amores, que son las dos religiosas que habían tenido mayor número de votos, lo que así se ejecuto en la misma conformidad que en el anterior escrutinio y concluido y regulado los votos se hallaron ser los doce que debía haber por no deber votar en esta ocasión las dos religiosas referidas y que por la mayor parte de ellos estaba canónicamente electa por Abadesa, Dña. Rosa Amores, cuya elección hizo Su Señoria, presente a la Comunidad, quien en señal de su aceptación y acción de gracias canto el "Te Deum Laudamus" y en interin se cantaba, prestaron obediencia a la nueva Prelada todas las religiosas por su orden y antigüedad, diciendo su Señoría los versículos y oraciones que prescribe el Ceremonial.", Seguidamente y como nos lo describe la fuente: “y sucesivamente se paso a disponer la elección de los oficios con la asistencia de la nueva Prelada, y Discretas; el que se ejecutó y su tenor es el siguiente:

\section{OFICIOS}

Priora...........................................Dña. María Francisca Frias

Maestra de Novicias......................Dña. Manuela Álvarez Reyero

Porteras de la Puerta Reglar.........Dña. Theresa Francisca Dominguez, Doña J uana De Frias

Dña. Ana María Buendía

Arqueras.....................................Dña. María Antoni Barrientos y Dña Juana de Frías

Graneras.....................................Dña. Balthasara de Acosta y Doña Dominica Zardui.

Provisoras.................................. Dña. Josefha Gómez y Doña Bonifacia de Frias

Sacristana...................................Dña. Fernanda Tamaris y Dña. J osefa Somoza

Acompañadoras...........................Dña. Isabel Luengo y Doña Bonifacia de Frias

Acomodadora de carros.............. Dña. Isabel Luengo

Enfermeras..................................Dña. J osefa Somoza y Dña. Dominica Zardui

Refectolera..................................Dña. Manuela Gato

Corista........................................La Hermana María Antonia de la Visitación

Maestras de Coro.........................Doña J uana de Frias y Dña. Manuela Gato. 
Cuya elección, y nombramiento fue publicado a la Comunidad, exhortando Su Señoría a las religiosas cumplan cada una su respectivo ministerio con la exactitud correspondiente."65

Observando el proceso referido, las elecciones de cargos jerárquicos y sus competencias estaban presididas por el Canónigo de la Santa Iglesia Catedral de Salamanca, Provisor y Vicario General del Obispado, Obispo de la Diócesis del Consejo S. M. y Prelado Ordinario del Convento de Religiosas Benitas de esta Villa de Alba de Tormes. Una vez terminada la elección, el Obispo hacía una visita a la Clausura, pasando por las celdas, locutorios, puertas, mirador, con asistencia de la misma Abadesa, haciendo énfasis en el aseo y la seguridad. Al término de esta visita, se disponía a la elección de oficios. En este caso la designación de la Priora ha recaído sobre la persona que ha quedado en segundo lugar en el segundo escrutinio. Según testimonio de la Monja Archivera del Monasterio de Santa María de las Dueñas, no siempre ni necesariamente se daba de esta forma, puesto que la Abadesa de siempre ha tenido libertad para elegir a su Priora y demás cargos. De tal forma y revisado el Libro de Visitas se puede confirmar que no siempre había dos monjas en pos del primer y segundo lugar.66

\section{* LA PRIORA}

Sucede con frecuencia que al elegir estos cargos jerárquicos, se hayan podido originar discrepancias entre la Abadesa y la Priora, ya que ambos cargos han sido elegidos por la misma Comunidad. Pero al ser la Priora la segunda en elección, ésta debe estar bajo las órdenes de la Abadesa.

"Dicho Prior realizará respetuosamente lo que le haya mandado el Abad, no haciendo nada contra su voluntad o mandato."67 “Incumbe a la Abadesa el derecho de elegir y nombrar las diversas oficiales del monasterio con quienes pueda compartir confiadamente sus cargas. La duración de sus respectivos oficios depende de la voluntad de la Abadesa, pero terminarán cuando una nueva superiora asumiere el gobierno de la comunidad".68

65 Libro de Visitas. Visitas y Elecciones del año 1790, p. 63.

66Testimonio de Sor Manuela Calle Miñambres, monja música y archivera del Monasterio de Santa María de las Dueñas de Alba de Tormes (4 de Septiembre de 2005).

67 Regla de los monjes. San Benito. Burgos: Abadía de Silos, 1994, p. 152.

68 Declaraciones a la Regla de San Benito para los Monasterios de la Federación Galaico Leones de España. Zamora: Benedictinas de Zamora, 1986, pp. 44- 45. 
"La priora es la primera auxiliar de la Abadesa y tendrá las atribuciones que ésta le otorgare. Suple a la Abadesa durante sus ausencias. Cuando el cargo Abacial quedare vacante, compete a la Priora la administración del Monasterio hasta que una nueva superiora se haga cargo del régimen del mismo. Durante este período obrará con prudencia y se abstendrá de toda innovación”69

A mi parecer, este cargo no tenía mayor relevancia por cuanto sus funciones estaban delimitadas a cumplir órdenes de su superiora inmediata, salvo la posibilidad de reemplazarla en el Gobierno del Monasterio en determinadas ocasiones pero sin poder decisorio.

Del año 1790 al 1834, los cargos de Abadesa, Priora y Maestra de Novicias del Monasterio de Santa María de las Dueñas, se alternaron entre las monjas Rosa Amores, María Francisca de Frías y Manuela Reyero. Datos ratificados en el Libro de Visitas y en el Libro de Crónicas.

\section{- LA MAESTRA DE NOVICIAS}

Este cargo si que era relevante. Tenía tanta importancia pues la Maestra de Novicias formaba parte del Órgano Rector del Monasterio y su principal tarea era la de guiar, formar y cultivar a las futuras religiosas. Se miraba con especial cuidado a quien debía hacer esta labor, sobre la que recaía toda la responsabilidad y que a su vez tenía la autoridad moral de las novicias.

La educación de las novicias era un punto muy significativo para la estabilidad de la Comunidad; en ella se invertía mucho tiempo y se cuidaba hasta los más mínimos detalles, empezando por quien debía realizar esta labor.

En el Siglo XVII, incluso en el XVIII, las mujeres en España, eran poco instruidas y esto daba pié a la vulnerabilidad de su carácter; se les podía moldear e instruir con facilidad. Es de recordar que el analfabetismo era lo más usual y solo las de las clases nobles o las que pertenecían a las clases altas, las más pudientes económicamente hablando, sabían algo más que tan solo leer y escribir.

La Regla de San Benito remarca la importancia de quien guía a los hermanos que entran por primera vez.

69 Ibídem., p. 45. 
(...) "Se les asignará un anciano que sea capaz de ganar almas y que se dedique a ellos con la mayor atención."70

San Benito exige de esta figura, una cualidad nada común: “(...) que sea apto para ganar almas.”71 Las Constituciones Carmelitanas, recalcan la importancia de la tarea de la Maestra de Novicias respecto de la importancia de la formación y aprendizaje de la lectura en las Novicias:

“La Maestra de Novicias (...) tenga mucho cuidado en leer las Constituciones a las Novicias, y enseñarles todo lo que han de hacer (.,.) Manda la Priora que la ayuden en enseñarlas a leer"72

Santa Teresa que fue una gran lectora y llamada la "Doctora de la Iglesia, recomendaba especialmente el aprendizaje de la lectura, por considerar esta práctica vital en la formación de las futuras religiosas. Nos ilustra este privilegio, la siguiente nota:

“(...) procuren tratar todas y comunicar sus almas con personas que tengan letras, en especial si los confesores no las tienen, por buenos que sean. Son gran cosa las letras, pues de todo dan luz"73

Algunas obras fueron recomendadas por la Santa para la mejor instrucción de sus religiosas; veamos cuáles fueron esos autores: Fray Luís de Granada, Tomás de Kempis y la lectura de la vida de los Santos, Las obras de la Santa, fueron recomendadas para la lectura en sus Monasterios ya a finales del siglo XVII; la lectura de libros profanos de comedias y fábulas amatorias, o novelas y poesías de amores, estaba vetada dentro de la formación intelectual de las profesas en España.

En el Monasterio de Santa María de las Dueñas reposan Libros tan importantes y que eran para la lectura diaria de las monjas, como:

- La paz interior, Tratado escrito por Fray Ambrosio de Lombez, Zaragoza. Imprenta de Francisco Moreno. 1771. Tratado de la paz interior del espíritu.

- Obras de Ludovico Blosio. Abad de San Benito. Traducidas por Gregorio de Alfaro. Tomo II

70 Regla de San Benito, p. 134.

71 San Benito - Su vida y su Regla. Madrid: BAC, 1954, p. 91.

72 ARCAR. Constituciones. 1581. Cap. 40. Libro impreso № 19.

73 TERESA DE JESÚS. “De los confesores”. Camino de Perfección (1583). En: Obras completas. Burgos: El Monte Carmelo, 1982, 123-31. 
Imprenta de Don Manuel Martín. Madrid. 1770.

1. Manual de los Humildes

\section{Recreación del alma}

La religiosa instruida - Dirigida en todos los estados de la vida, con diálogos familiares. Escrita por una religiosa Carmelita descalza. Traducida al Castellano por el Padre Fray J oseph Quilles del Orden de los Predicadores. A expensas de Francisco Benedito impresor de libros. Murcia. 1774. "Destinado a instruir y perfeccionar a las hijas cristianas y religiosas que lo han dejado todo pos seguir a J esucristo, vuestro amado hijo"

- Libros de Santa Teresa de J esús, que datan del 1611

- La religiosa en la soledad por Juan Pedro Pinamonti. 1733

- Vida de santos y mujeres ilustres del Orden de San Benito Patriarca de los monjes. Pedro de Gina R. - I. Inojosa. 1684.

- La regla de San Benito. 1780

- Ceremonial Monástico. 1774.

\section{* LA MAESTRA DE CEREMONIAS}

Del oficio divino y la oración.

La alabanza diaria a Dios por medio de la solemnidad del Oficio Divino constituye la labor esencial de la monja y nada debe anteponerse en la ordenación de la vida en Comunidad. El rito de la Santa Misa es el Centro del día en un Monasterio; en torno a este ceremonial se cimientan las horas del Oficio, que se distribuyen en las horas de la vida en comunidad y de acuerdo a los tiempos. Todas las monjas están obligadas a asistir a este oficio divino; solamente la Abadesa tiene facultad para dispensar por razones justas.

Ya en la educación de las novicias, se va inculcando el sentido de piedad y se les brinda una sólida formación litúrgica para que en la celebración del Oficio Divino, el espíritu concuerde con la voz y la vida espiritual de las monjas y se centre en el Misterio Pascual de Cristo. 
Las competencias de este cargo son: específicamente organizar el Culto Divino, en las horas, en el oficio del Coro y en la Misa y demás cosas que conciernen a la puntualidad que en tales actos se debe tener. Para ejercer este oficio la persona encargada de ello, debe tener conocimiento en los Oficios divinos y cuidar de ellos, enterando al celebrante de lo que le toque hacer. Debe estudiar o tener claridad en todos los actos que se prevén. Debe tener conocimiento de las partes musicales que se interpretarán y en los momentos que corresponda. Téngase en cuenta que a él, pertenece todo lo que es acompañar al celebrante, así como a los demás indicar genuflexiones, inclinaciones y en todo lo que cada uno deba hacer y cuando se lea el evangelio, las lecturas y oraciones, ayudar con los cantores a su lado.

Al tener tanta relevancia para los ceremoniales esta figura, se puede apreciar según, las fuentes del Monasterio de Santa María de las Dueñas, como monjas que fueron Maestras - músicas o Correctoras de Coro, y Organistas, en variadas ocasiones, fueron a su vez, Maestras de Ceremonias. Varios casos nos pueden ilustrar lo expuesto; es el ejemplo de Sor Ángela Collantes - monja música-, relacionado en el Libro de Crónicas, en la que simultáneamente ejerce de Vicaria de Coro y Maestra de Ceremonias.74 O el caso de Isabel Quintana - monja música -, que ejercía como Vicaria de Coro y Maestra de Ceremonias.75

\section{* LA MAESTRA DE MÚSICA - CANTORA}

El Ceremonial Monástico, nos enseña las competencias de este importante cargo; el CANTOR MAYOR que es el que posee el gobierno del Coro, dispone el orden de cantar y rezar el Oficio Divino y de su cuidado depende la puntualidad de los actos Litúrgicos. Debe entonar los cantos. Nadie tiene Licencia para corregirle, únicamente quien preside. Debe cuidar de los Libros de Música, debe ordenar la tabla de los oficios de la semana, organizar o igualar los coros, acompañar al Abad a la hora de la lectura del Evangelio en compañía del Maestro de Ceremonias. Él ha de tener el Libro, ha de encargar al Abad, las Antífonas y los Himnos, y a su Coro en oficio doble a Vísperas, Maitines, Laudes y en Completas. Coordinar a los cantores. El Cantor segundo, reemplaza al Cantor principal en su ausencia y de 
igual manera debe estar muy diestro en el oficio y canta con el Cantor Mayor, en medio del Coro.

Adaptando estas competencias, - que a grandes rasgos se han descrito -, a la vida musical de las Monjas en el Monasterio de Santa María de las Dueñas, podemos decir:

Había dos cargos establecidos que se pueden corroborar, en el Libro de Visitas y en el Libro de Crónicas. El cargo denominado Maestra de Coro aparece relacionado como Vicaria de Coro y es lo que correspondería del Ceremonial, al Cantor Primero. La segunda cantora, corresponde al segundo cantor.

Sobre la Vicaria de Coro recaía toda la responsabilidad de la música en el sentido de entonar las antífonas, los salmos, hacer los solos, enseñar los cantos, y dirigir el Coro en general. Ya hemos visto lo significativo y vital que siempre ha sido este cargo de cantora, para la vida conventual, para la liturgia y para la vida espiritual de la comunidad.

Reflexionando sobre las competencias del cargo y las conocidas condiciones de ingreso de las mujeres - músicas a los conventos, podemos pensar en que esta situación podría haber procurado que la mujer fuera adquiriendo la condición de privilegiada y de persona vital en la prestación de un servicio para producir un bien de uso común. El ser música, en cierta formas le representaba un medio de asegurarse la vida y por otro lado, a diferencia de los maestros de capilla no estaban sometidas a una dedicación exclusiva de ser compositoras a lo largo de su vida conventual y de su trayectoria musical.

Considero menester en este punto, hablar lo referente a las disposiciones "Del Canto".

\section{DEL CANTO}

El Ceremonial Monástico de la Orden de San Benito, nos ilustra sobre la importancia del Canto y ya hemos visto el valor que éste adquiere dentro de todas las solemnidades religiosas de los Monasterios en general; a continuación expongo algunas de las disposiciones: 


\section{“Capítulo XI \\ -Del Canto-}

Las religiosas harán del canto sagrado una de sus principales preocupaciones. Se acordarán constantemente de esta sentencia de la Santa Regla: "nostre concorded voce nostree (...)" y procurarán por su canto completar y dar el sentido a las palabras de la Liturgia. Se acordarán que el Canto Gregoriano es el servidor y el adorno de la Literatura sagrada y que debe reflejar los diferentes sentimientos que las palabras expresen con toda la fidelidad de una humilde y sumisa ayuda. Procurarán cantar con voz clara, con pronunciación distinta y enérgica que haga rresaltar bien la hermosura de las palabras aún en su forma exterior.”, “(...) no se hará durante el oficio divino más que el Canto Gregoriano. La Misa conventual será cantada todos los días; lo mismo en Prima, el el Martirológio, el J ube Domne, la bendición y el fragmento de la Santa Regla. En la Vigilia de Navidad se cantará Prima íntegramente hasta el "Bendeicamus Domino", inclusive, lo que sigue se hace como en los días de primera Orden. Lo mismo de hace el día de la Santísima Trinidad, añadiendo el "Quicumque". También cantado.”, "Las Vísperas serán siempre cantadas, excepto los tres días de la Semana Santa. Las Completas también exceptuando los tres días de la Semana Santa, se canta siempre las Antífona a la Santísima Virgen pero en tono menor o simple y no lo mismo cuando las horas menores se cantan enteramente.", "Si es una Misa de 1a , 2" o 3ª Orden a Completas se cantará el "Yube Domine". Los Domingos y dobles Mayores, cantarán también en Maitines el "Deus in adjutorium", las tres "Deus labia mea aperies"- el Salmo Tercero. De cada Nocturno, las Antífonas- las Absoluciones y Bendiciones - las Lecciones - el Evangelio, el "Te decet laus" y la oración. La hora Tercia se cantará íntegramente los domingos y y días de 3 $3^{\underline{a}}$ Orden. En las fiestas de 3a Orden se cantará además a Laudes, el “Deus in adjutorium", el Salmo 55 inclusive. A sexta y Nona se cantará el "Deus in adjutorium", el Himno y desde la Capítula hasta el "Benedicamus" inclusive.", "El día de Navidad se cantará los (...) del 1o Nocturno. - Los cantos de los Maitines se cantarán en las fiestas de 1a clase y 10 Orden. Los jueves, viernes y sábado de la Semana Santa cantarán las Antífonas y Salmos del Primer Nocturno. Se cantarán íntegramente las Laudes.", "Se cantará siempre a dos coros, los "Salmos", los "Cánticos", los "Himnos", el "Kyrie" de las Misas, el "Gloria in excelsis", los "Tracus", las "Secuencias" y el "Símbolo de la Misa”.76

76 ASMD. Ceremonial Monástico. Capítulo XI “Del Canto”, pp. 47-50. 
Al respecto, en La Visita del 21 de febrero de año 1530 - 31, hecha por el Revdo. Padre Fray Blas de Pedrosa, Prior de San Vicente de Salamanca, Visitador y Reformador de este Monasterio de Santa María de las Dueñas, a la letra dice:

“(...) como a la Señora Cantora y a todas las otras religiosas que rezan según la orden de los breviarios de nuestra Congregación de San Benito de Valladolid, y por ellos se rijan y sigan en los tiempos que se ha de decir $y$ celebrar el oficio: sigan y tengan esta forma que los Maitines a las dos, y a la Prima tañan según la variedad de los tiempos ya de día, y digan sola la Prima y la después a las nueve tañan a Tercia la cual dicha se digan luego Seta y Nona y después oigan o canten misa. Las vísperas se digan a las dos en invierno y a las tres en verano y cuando fueren a las completas antes de las de decir tengan su lección de la Regla de nuestro Glorioso Padre San Benito como es costumbre, y siempre se cante la Salve después de las Completas."77

A continuación se hace una relación de las Horas Litúrgicas en los servicios de la semana o feria y domingos o solemnidades:

\begin{tabular}{|lcc|}
\hline & SEMANA O FERIA & DOMINGO O SOLEMNIDADES \\
\hline MAITINES & $6: 30$ & $7: 30$ \\
\hline LAUDES & $7: 15$ & $8: 45$ \\
\hline EUCARISTÍA & 8.00 & $11: 00$ \\
\hline SEXTA & $13: 00$ & $13: 00$ \\
\hline NONA & $3: 45$ & $2: 30$ \\
\hline VÍSPERAS & $7: 30$ & 7.30 \\
\hline COMPLETAS & $10: 00$ & $10: 00$ \\
\hline
\end{tabular}

\section{* LA ORGANISTA}

El cargo de ORGANISTA fue y sigue siendo muy importante. Se suele tañer el Órgano en Domingos y Fiestas de guardar, según el Ceremonial. En el Kyrie eleison, Sanctus y Agnus Dei, se alternan los Coros con el órgano78. La organista tenía la función de acompañar el canto en los distintos oficios. Las competencias

77 ASMD. Documento de la Visita 1531 (a 5682) Leg. 5560. AHN. CLERO. Cinta microfilmada № 7. 78 Ver el Ceremonial Monástico [Impreso por orden del Capítulo General, celebrado en 1773]. Madrid: Imprenta de Pedro Marín, 1774, p. 57 (de los cantores), p. 84 (del órgano y organista). 
de este cargo están relacionadas en el Ceremonial monástico (Palacio de Benaver Burgos publicación del año 1928) en el Capítulo XXIX - Del cargo de organista - , veamos algunas:

"Si sucede que en el Monasterio hay varias monjas capaces de tocar el órgano, la organista entrará en su oficio una semana entera. Su cargo comprende dos partes: el acompañamiento del canto gregoriano y las piezas de órgano solo. La primera es la más importante de las dos y la organista pondrá en ello un cuidado particular. Trabajará con esmero por darse cuenta de cada pieza del canto, así como del sentido de las palabras. No empleará sino acordes severos y conformes a las reglas del canto sagrado. Su acompañamiento estará siempre bien sostenido, se identificará al canto lo más posible y observará esta regla invariable del gusto. Que un acompañamiento no debe nunca sobresalir sino solamente sostener el canto. Se guardará bien de toda innovación y no pretenderá imponer a otra organista su manera de interpretar el acompañamiento y ejecutarlo, lejos de querer obligar a las cantoras a someterse a ella, la organista se acordará que al contrario debe seguirlas en todo."

"Entrando a la segunda parte de su cargo, la organista será muy suave en la elección de trozos de órgano solo. Mo pretendiese nunca en la improvisaciones ninguna reminiscencia profana, centrándose siempre que la invención de las modulaciones mundanas en la música de la Iglesia es a la vez una falta contra el buen gusto y contra la "conveniencia" lo que no puede aprovechar de ninguna manera la belleza del arte.

Sin embargo en tiempo de Navidad la organista puede hacer uso de cantos sencillos y fáciles llamados "villancicos" pues no pueden asemejarse de ninguna manera a lo que debe ser permitido"

“En las fiestas de 10 y $2^{\circ}$ orden se tocará para la entrada antes de tercia y 1 y $2^{\text {a }}$ vísperas. En estas fiestas se tocará igualmente a la salida después de sexta y vísperas. El día de Navidad se tocará además a la entrada antes de Maitines y a la salida después de Laudes.", "El sábado Santo a la entrada y salida de las Completas. Solamente el sábado Santo se cantan y se acompañan las Completas. 79

En la actualidad se tañe el órgano no solo en las Solemnidades y Domingos, sino diariamente.

79 Ibídem. Capítulo XIX - Del cargo de Organista. pp. 135 - 137. 


\section{OTROS CARGOS}

\section{CARGOS DE ECONOMÍA}

Son los cargos relacionados con la administración de los intereses temporales, como: la arquera, la provisora y la granera, las cuales en conjunto llevaban la economía del Monasterio. La $1^{\mathrm{a}}$ y $2^{\mathrm{a}}$ arqueras, responsables del dinero que había depositado en las arcas; Las provisoras $1^{\mathrm{a}}$ y $2^{\mathrm{a}}$, encomendadas para surtir de lo necesario diariamente, como alimento, carbón, leña, vestido y demá; las graneras $1^{\mathrm{a}}$ y $2^{\mathrm{a}}$, encargadas de recoger las rentas por granos, como cebada, trigo y centeno.

\section{SACRISTANA}

Cuida lo referente al Culto de la Iglesia, las vestiduras sacerdotales, las velas, la limpieza de la Iglesia.

\section{PORTERA}

Elegida por la Abadesa; su misión era la de recibir a quien se acercaba al Monasterio y en la actualidad esto se conserva.

En la Regla se San Benito, cuando habla del Capítulo de Los Porteros, dice: "Póngase a la puerta del Monasterio, un anciano prudente, que sepa recibir y dar un recado (...) Dicho portero deberá tener la celda junto a la puerta para que los que llegan siempre encuentren alguien que les responda." 80

J erarquías de Ingreso:

- Monjas de velo negro (y rosario): Monja que ingresaba con obligaciones al Oficio Divino

- Monjas músicas: Organistas y Cantoras.

- Monjas de velo blanco: Hermanas Legas

- Monjas de medio hábito: mujeres que ingresaban como Señoras de Piso, como seglares o acompañadoras de sobrinas. 


\section{II.2.6. MODELO COMPOSITIVO DE LA MUJ ER MÚSICA}

El mundo conventual tuvo una especial notabilidad en el siglo XVII. Fue la época, en que se cultivó la lectura de la vida de los Santos, tuvo auge la Fábula como género literario y la poesía y se dio la proliferación de la publicación de las Hagiografías. Las mujeres de la nobleza, las de clase alta, o las económicamente bien posesionadas, por lo general tuvieron la oportunidad de cultivarse más y en todo sentido; los documentos nos permiten saber de varias monjas que desde muy pequeñas ingresaron a la vida conventual llevando consigo el arte musical. Remitiéndonos a esas épocas y aún en el siglo XVIII, singularmente por el hecho de que una mujer pudiese leer y escribir, ya era considerada instruida, aunque el hecho de que llegara a "saber tanto" no era aceptado fácilmente, lo que dio pie a pensar que la que tuviera la capacidad de "saber" podía ser considerada dotada de poderes extraordinarios, lo que le acarreó a la mujer innumerables problemas, persecuciones, acusaciones y por último hasta la misma muerte.

Un aspecto meritorio de reseñar es el de la posibilidad que la mujer tenía, de entrar sin dote en un Monasterio, o dicho de otra manera, ingresar aportando como única dote, el saber y el talento musical. Según las fuentes, a los Monasterios llegaron mujeres que traían consigo diferentes artes aprendidas desde su infancia, como: el arte de bordar, de pintar, y en música, el arte de solfear el canto llano, de tañer algún instrumento, y tocar especialmente el órgano, mujeres que poseían una excelente voz y que entendían los asuntos musicales con suficiente solvencia; éstas, tuvieron un trato especial dentro de los Monasterios, puesto que por su formación, eran consideradas fundamentales para el desarrollo de la actividad musical - ligada íntimamente a la Liturgia - y aptas para desempeñar el Cargo de Coristas, de Maestra de Coro llamadas también Maestras Correctoras o Vicarias de Coro y de Organistas, arpistas, incluso violinistas ya bien entrado el siglo XVIII.

¿Cómo debió ser inicialmente la formación musical de una monja en estas épocas? Esta inquietud se analizará en dos direcciones: Las monjas que siendo muy jóvenes se educaron musicalmente en el seno familiar y las que llegaron a los Monasterios desde temprana edad - 5 o 10 años- para ser instruidas y educadas en la fe y que aprendieron el arte musical ahí. 
Partiendo de que la educación - en la extensión de su palabra -, para la mujer en aquellas épocas se la tomaba con poca importancia y que la música se concebía como un arte que requería tiempo y talento, los hombres eran considerados con más capacidad para hacer música, para escribir, para pintar o para realizar innumerables tareas de responsabilidad. Pero en referencia con la primera dirección de nuestro análisis, nos encontramos con reseñas tan claras como la encontrada en el Convento de la Anunciación, Madres Carmelitas; se sabe por sus documentos fundacionales, que el 25 de enero de 1571, cuando se traslada el Santísimo Sacramento al claustro, se considera iniciada definitivamente la vida conventual. La primera noticia encontrada sobre la actividad musical en el Convento, data de 1585, con J uana de San Pedro, sobrina de la fundadora y quien tomo los hábitos a la edad de 11 años, empezando a servir en el Coro a su ingreso, "dotada de una gracia particular, hablaba el latín y tocaba el salterio."81 Si a la edad de 11 años tomó los hábitos y llegó con el saber musical, es de suponer que había iniciado desde el hogar su instrucción; cómo y con quién?; en el caso de esta religiosa, muchas lagunas se tienen respecto a los datos exactos de su aprendizaje musical, pero en algunos otros casos puntuales, que se relatarán en el siguiente capítulo, será posible saber tan importante información.

Estas profesionales de la música necesitaron como es lógico, una adecuada instrucción musical. Es posible también que muchas familias y en especial las menos favorecidas por la fortuna, decidieran invertir en la educación musical de sus hijas con miras a una futura entrada a la vida conventual; un ejemplo referido anteriormente y que nos ilustra lo que significaba para una mujer el ingreso a un Monasterio y con el saber musical que a sus 24 años poseía, es el la monja Ángela Collantes del Monasterio de Santa María de las Dueñas, la cual al verse huérfana de padre y madre, ella misma se aplicó durante varios años, en las nociones de órgano, arpa y solfa con el objetivo de ingresar como monja de velo y coro. Su proyecto de vida, su única opción, al saberse sola, sin dinero para pagar una dote, fue el de ingresar por el único medio que podía hacerlo: ser música. La actividad 
musical dentro de los Monasterios femeninos, se consideró como el único espacio en que la mujer podía ejercer su magisterio musical.

En relación con los maestros de música instructores de las más jóvenes, podemos pensar que pudieran ser los clérigos amigos de las familias quienes las iniciaban en los rudimentos musicales. El caso de Doña escolástica Campo Martín, otrora Dorothea Campo Martín, nacida en Burgos, quien había recibido la instrucción musical, de un maestro organista y a la edad de quince años, solicitó en el 1857 al Obispo de Salamanca, su ingreso al Monasterio de Santa María de las Dueñas, siendo aceptada "con la instrucción al parecer, de su maestro" y previo examen practicado,82 por los dos Maestros organistas asignados por el Obispo de la Catedral de Salamanca: Don Juan J osé de Siles , organista ํo y Don Manuel Hernández Organista $2^{\circ}$. Los mencionados organistas habían ganado las plazas de Organistas 1 - y $2^{\circ}$ respectivamente de la Catedral de Salamanca por oposiciones y eran personas idóneas en la materia musical.83 Los Monasterios femeninos, en general y por diferentes motivos quisieron que su actividad musical resaltara, ya por alcanzar un determinado nivel artístico, ya porque las mujeres destacaran en su único espacio de representación o por el enaltecimiento de las actividades litúrgicas. De ahí, sea cuales fueren sus objetivos, los Monasterios se esmeraron en tener las mejores organistas y cantoras; buena cuenta de ello dan las actas de exámenes practicados a las aspirantes a determinados cargos organistas y/o cantoras -, exámenes que eran practicados en algunos casos por Profesores de Música que vecinos de la Villa de Alba de Tormes, o por Maestros Organistas asignados por el Obispado de la Catedral de Salamanca. El caso arriba referido.

82 ASMD. Actas de Examen y Epistolario. Caja de Informaciones.

83 ACS - Archivo de la Catedral de Salamanca. Oposiciones a Organistas - Cajón 69. Leg. 2, № 32 y № 33 . 


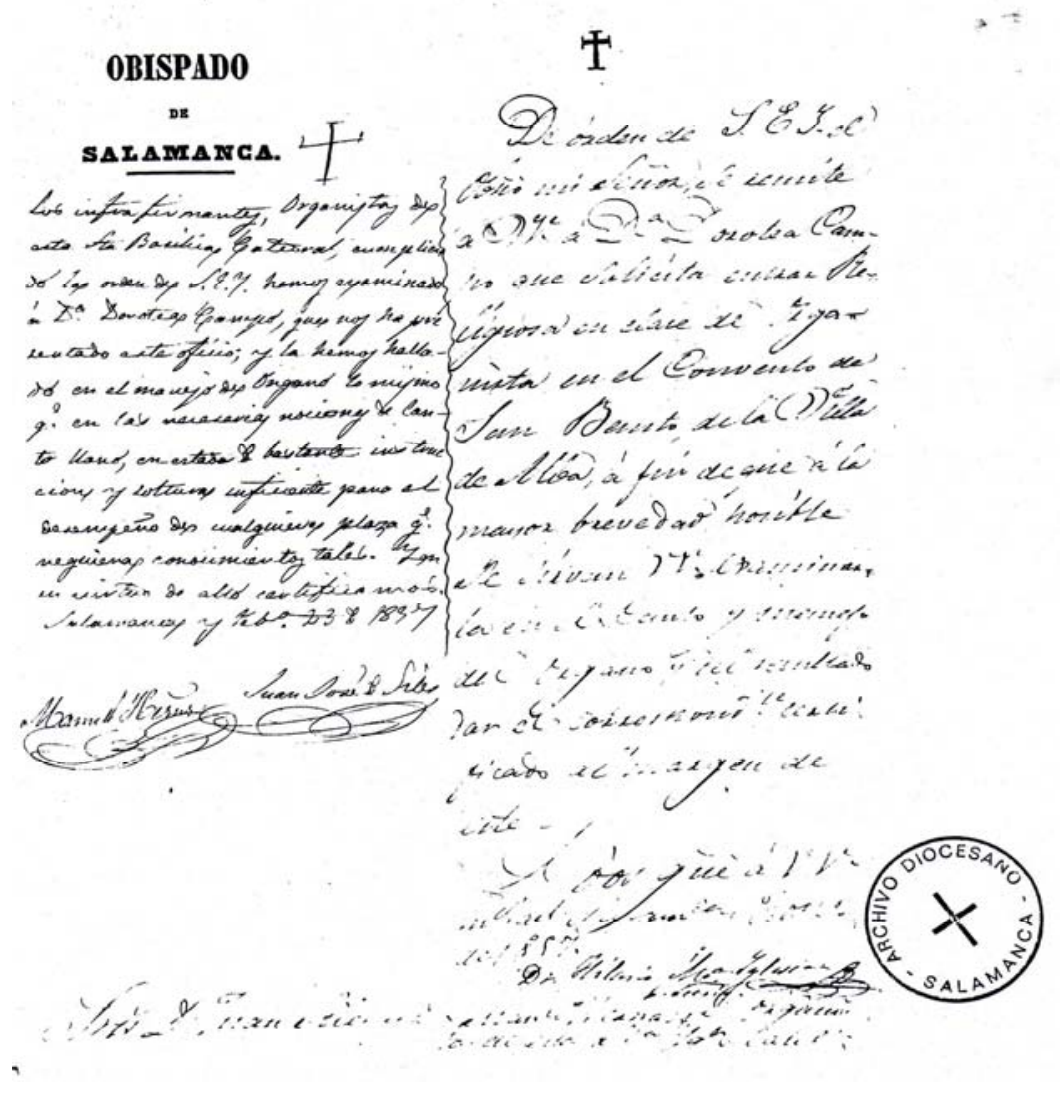

5. Acta del examen de órgano y canto llano aplicado a la monja - música Dña. Escolástica Campo Martín, del Monasterio de Santa María de las Dueñas de Alba de Tormes - Salamanca.

¿Cómo debía estar capacitada una monja para su desempeño musical?

La música es un arte en el que convergen varias cualidades y algunas condiciones que permiten a una persona hacer música: buen oído, la voz, el talento, la habilidad o destreza para interpretar un instrumento musical, la lectura musical o solfeo, el pensamiento musical y el ámbito social y familiar en que se desenvuelve cada individuo. Si desde la infancia estas monjas tuvieron una vivencia musical, si tuvieron la oportunidad de aprender este arte perfecto de la música, es de suponer que a tan temprana edad cuando se instruían y posteriormente ingresaban a los conventos, poseían y llevaban ya consigo una forma de vida.

Materia de examen fue la lectura del canto llano, el canto o lectura de órgano, el interpretar el órgano o tañer otro instrumento musical como el arpa, el salterio o el violín, a que eran sometidas las aspirantes a ingresar como monjas de Velo y 
Coro u organistas, - en algunos casos encontrados-, como el de Dña. Catalina Gato, para quien el Monasterio compró un violín y un clave para su ejercicio musical. 84 No se encuentra referencia alguna en la que alguna aspirante haya sido reprobada en sus exámenes, y tampoco se localizan en los Monasterios investigados, referencias sobre la existencia de monjas compositoras, que debieron existir, por el talento musical que poseían y por la calidad de su formación, pero ya tenemos claridad en el nivel de supresión en que se encontraba la mujer en aquellos tiempos, para determinadas actuaciones o competencias. Con el cambio de los tiempos, con las reivindicaciones de la mujer como individuo que vale y que es capaz de ejercer y asumir retos importantes en todas las disciplinas profesionales, ya hoy día, se tienen referencias importantes sobre monjas compositoras, como: Carmen Cañada monja Teresiana cuya música es conocida por las obras editadas como, Cancioneros y Grabaciones fonográficas - C.D.- Todo vuelve a ser posible - Amigos de orar. De la monja clarisa Rosa María Riera, de Vitoria, Diversos cantos en el C.D. Iglesia Soy en el XVIII Centenario del nacimiento de Santa Clara y de la monja compositora Benedictina Ángeles Álvarez Prendes, de Oviedo, la grabación sonora "Escucha". Sor Cecilia Díaz monja cantora solista del Monasterio ha grabado junto a un grupo de músicos y por intermedio del Instituto Pontificio de San Pio X, de Salamanca, dos trabajos discográficos (en soporte de acetato) - Producido por Discos BELTER, S.A. en el año 1964-Titulados: “Propio de la misa” y “Vía crucis de la Pascua del Señor”.

Los Libros de Crónicas y los Libros de Visitas, del Monasterio de Santa María de las Dueñas, nos describen determinados Actos Litúrgicos y la relevancia de ellos en los que la música adquiere considerable importancia, destacando el desempeño de sus monjas músicas. Cada visita Canónica, era un acontecimiento relevante para el Monasterio, en el que la nueva Abadesa y el Coro tenía su desempeño a la hora del canto del "Te Deum Laudamus" y en el intermedio, antes de la presentación de obediencia por parte de las monjas a la nueva Prelada. 85 
Otro ejemplo merecedor de resaltarse es la Bendición de la nueva Iglesia del monasterio de Benedictinas. El día 26 de julio de 1775, día memorable para la Comunidad en el que se llevaron a cabo varios actos litúrgicos y en referencia a la música, fue el día en que se colocó y se inauguró el órgano en la Nueva Iglesia.86

Ahora, analizando la cuestión desde el segundo punto de vista: las monjas que ingresaron a tan tierna edad a los Conventos - de 5 y/o 10 años - , Cómo se formaron, musicalmente hablando? Inicialmente el objetivo del ingreso de cualquier niña a tan corta edad, era el de instruirla en la fe y prepararla para su vida futura dentro del Monasterio. Como el caso ya referido de Beatriz de Ahumada - sobrina de Santa Teresa, quien fue ingresada en el Monasterio de Benedictinas a la edad de cinco años, para que al lado de sus tías paternas Dña. Mayor y Dña. María de Ovalle, iniciara su formación espiritual, pero a la par de aquella formación y su posterior consagración ya hablando en términos generales, la preparación para la actividad musical - de las pequeñas que ingresaban - debió tenerse en cuenta al interior de los Monasterios. Alfonso de Vicente nos lo muestra de la siguiente manera: "Sin embargo para otros centros si se ha documentado la presencia de maestras mujeres o la obligación de las propias monjas músicas a enseñar a otras; es también el caso del convento de Las Gordillas de Ávila: en el contrato con las monjas músicas Gertrudis Aznar y Antonia de la Dehesa 24/2/ 1756, se les obliga a enseñar a otras monjas canto llano, canto de órgano y a tañer el órgano."87 En el Monasterio de Santa María de las Dueñas, según su testimonio, la Hermana Sor Manuela Calle M. monjas archivera, narra que esta práctica de enseñar a otras monjas era muy común, por cuanto las que ingresaban con conocimientos musicales y tenían a su cargo la responsabilidad del Coro, debía instruir a las monjas puesto que dentro de sus deberes contraídos y que la regla de San Benito así lo solicita, debían orar, trabajar y cantar en el Coro en todas las Solemnidades litúrgicas, incluso en el rito de la Santa Misa diaria, como lo ordenan los Mandatos en las Visitas. En esta materia es posible hacer una correspondencia con las competencias de un Maestro de Capilla de una Catedral; veamos: Las obligaciones del Maestro de capilla eran entre otras las de custodiar la capilla física (lugar de los ensayos y las clases), impartir lecciones del Canto llano, no sólo a los cantorcicos, sino también a otras personas ligadas a la iglesia que las quisieran aprender; incorporar nuevos cantores y músicos para responder por la buena marcha de la capilla musical; frecuentemente alojar en su casa a los niños

86 ASMD. Libro de Crónicas, pp. 51- 54.

87 DE VICENTE, Alfonso. "La actividad musical de las monjas en los Monasterios de Ávila". Revista de Musicología XXIII (2000), p. 527. 
cantores y ocuparse de su educación general y manutención; componer, las obras destinadas especialmente para las festividades exclusivas, como Navidad, Semana Santa o Corpus Christi. El incumplimiento de las normas se castigaba con sanciones económicas, e incluso con la exclusión del cargo.

Estas funciones y obligaciones fueron cambiando hasta el siglo XVIII, siendo las descritas las que conocemos para los siglos XVI y XVII en España. Con el pasar de los tiempos fueron aumentando las oportunidades para los "Maestros de Capilla" de hacer carrera como músicos sin una vinculación tan directa a las capillas musicales de las iglesias o de las Catedrales.

Si los Monasterios contaban con monjas músicas cualificadas, lo más natural sería, que quisieran cultivar este hecho para incrementar la actividad musical, y de esta manera impulsar el desenvolvimiento de su Capilla musical. De hecho, la música está presente en todos los actos Litúrgicos de la vida conventual. Cada celebración sea cual fuere estaba y aún está enaltecida por la música. Las fiestas solemnes, las tomas de hábito, los fallecimientos, la celebración de Bodas de Oro, las misas diarias, en todo momento la música tiene un papel preponderante.

Se sabe que en determinados límites cronológicos de la vida conventual, convivieron a su vez generaciones de monjas músicas, entre organistas y cantoras y/ o instrumentistas con las monjas que conformaban la Comunidad en sí y que dentro de su labor estaban las acciones de orar, cantar y trabajar. En épocas del magisterio musical de Dña. Ángela Collantes, quien fuera organista, arpista y Maestra correctora de Coro, le acompañaron Doña Catalina Gato cantora, violinista y también organista y Dña. Ana Pérez, cantora.

Y así, de igual manera se podrían enumerar otros cuantos casos en diferentes épocas de la vida conventual y musical del Monasterio de Santa María de las Dueñas.

En conclusión, podemos afirmar: ¡Que importantes fueron y aún son las monjas instruidas en la música para el desenvolvimiento de la vida litúrgica y artística de los Monasterios!

Dentro de los límites cronológicos investigados - a partir de los siglos XVII, XVIII y parte del siglo XIX, fueron ellas las que dieron realce a las Solemnidades de la 
liturgia y contribuyeron a la conservación del canto gregoriano y al impulso de las formas de la música religiosa a través de estos tiempos y aún lo siguen manteniendo.

\section{- MAESTROS DE MÚSICA INSTRUCTORES DE LAS MONJAS}

Que importante es éste tema por cuanto el perfeccionamiento musical de las jóvenes profesas debió estar en las manos de excelentes profesionales del momento, que las instruyeron en el aprendizaje y adelantamiento de la interpretación del órgano, instrumento musical que requiere cierto grado de destreza y maestría y en el aprendizaje del Canto llano.

En referencia al tema, en carta encontrada del 3 de enero de 1895 de la Abadesa J osefa Martín dirigida a Don Severino Fernández Vega dice:

“(...) que también han escrito dando noticia de una cantora gallega de 19 años con buena voz que la está instruyendo el Maestro de Capilla de una Catedral, y la dirige el Dr. (...) no le digo porque hoy estas noticias son algo golosas; este es un favor de San J osé si es que se llegase a arreglar porque le estamos importunando con los siete domingos, cuatro veces consecutivas toda la Comunidad para que nos busque organista y cantora".88

Del año 1906, encontramos una referencia sobre la presencia del monje del Monasterio de Silos Carlos Azcara en el Monasterio de las Benedictinas, quien fue invitado en dos ocasiones por la Abadesa Doña Escolástica Campos, para instruir al grupo de cantoras - que más poseían conocimientos musicales-, en el Canto Gregoriano, quedado implantado desde esa época hasta la fecha que está escrita la Crónica (1933) la costumbre de cantar la Misa en Gregoriano.89

En la actualidad el Canto Gregoriano se canta mucho menos, sin embargo, aun se conserva la costumbre de cantar en Gregoriano en Laudes y Vísperas, en algunas solemnidades y fiestas como son: Adviento y Navidad, Asunción de la Virgen, para el Día de San Benito, en latín.90

88 ASMD. Cartas - Caja 1.

89 ASMD. Libro de Crónicas, pp. 174-75.

90Testimonio directo de Sor Manuel Calle Miñambres, actual monja archivera del Monasterio de Santa María de las Dueñas. (abril de 2006) 


\section{II.2.7. ECONOMÍA EN RELACIÓN CON LA MÚSICA}

No es el aspecto económico en general de estos dos Monasterios, el que viene a ser uno de los objetivos o contenidos planteados en el presente trabajo, sin embargo es preciso concederle especial atención a la economía con relación a la Música.

Numerosas fuentes nos dan bases para hacer un estudio detallado del interés que existía en torno a los asuntos dinerarios y la música.

Las economías conventuales seguían un patrón de quehacer financiero sujeto a muchas normas que dictaba cada orden religiosa, pero en muchos casos al no ser entidades públicas como Universidades, Cabildos o Consejos o Fundaciones Reales, que tuvieran que rendir cuentas periódicamente, funcionaban con entera libertad, cuidando eso sí, que lo que poseían y administraban, les garantizara una existencia segura sin penurias ni carencias. El uso de los Libros de cuentas se puede decir que es doméstico y servían para llevar las cuentas y ser presentadas en determinado momento al ordinario del lugar - el Obispo y en forma normal cada año.

Veamos cuáles eran esas fuentes de ingresos de que los Monasterios se nutrían y se mantenía a lo largo de su vida: Hay que diferenciar los pecuniarios de los materiales. Entre los primeros, se pueden describir las dotes que entregaban las monjas, (si eran forma dineraria), las limosnas, las rentas por censos y juros y las rentas por alquileres de casas, los privilegios. Las fuentes materiales están representadas en propiedades como: casas, las tierras y sus rentas, el mobiliario, los objetos del culto (cálices, custodias, ornamentos de oro y/o plata), de gran valor monetario, mobiliario y los obsequios de alimentos y las reliquias de gran valor espiritual.

Otros gastos que se relacionan en sus Libros de Cuentas, son los que podemos describir o catalogar como de primera mano, como vestido, calzado, alimento, leña, carbón, medicinas o botica, vino, sal, garbanzos, incienso, aceite, azúcar, velas y gastos de sacristía, los de mediana cuantía relacionados directamente con la música como la compra de un órgano nuevo, el arreglo del órgano, la compra de instrumentos musicales, compra de libros corales, "Que se compre un libro 
Coral"91, y otros de mayor cuantía como compra de una casa o parcelas, arreglos del Coro alto y del Coro bajo, arreglo o ampliaciones de una ala del Convento, cambio o mejora de los techos, etc...entre otros.

Previamente conviene hacer una pequeña referencia al contexto económico desde el siglo XVII al XIX.

La crisis económica caracterizó al siglo XVII y fue el resultado de la agudización de las tensiones creadas en el antiguo régimen. Ello resulta evidente, en primer lugar en el terreno de la riqueza. Los desequilibrios existentes en su momento, entre la población y los recursos, se agravaron como efecto de las malas cosechas y de las periódicas crisis de hambre. Por lo demás, el desarrollo de Europa sufrió una ralentización al descender los envíos de metal precioso importado de América, que habían alimentado la expansión del XVI. La disminución de las importaciones de plata condicionó, a su vez, una bajada de los precios. Si la inflación del siglo anterior había estimulado la acumulación de capitales y el desarrollo económico general, las tendencias deflacionistas del XVII, encubiertas a menudo tras violentas oscilaciones de los precios, habrían conducido irremediablemente a una caída de los beneficios, agravada por la compresión de la demanda que, junto a la mala situación económica general reinante, produciría la menor circulación monetaria.

La disminución de los beneficios desincentivó a su vez las inversiones en actividades productivas y, a la postre, hundió la vida económica de las gentes y atrasó el desarrollo de las regiones. La aparente caída del volumen de intercambios de mercancías y el consecuente estancamiento comercial contribuyeron a una innegable situación de "crisis". La causa de la "crisis" no radicó en las guerras, sino en la permanencia de ciertos factores que entorpecieron el desarrollo capitalista en Europa, tales como la estructura feudal-agraria de la sociedad, las dificultades en la conquista y aprovechamiento de los mercados coloniales de ultramar y lo estrecho del mercado interior. Entre otras causas de ésta conocida "crisis", se pueden enumerar: el descenso general de la población, el hambre y las epidemias, la precariedad y el endeudamiento de la hacienda pública, la agitación social y el declive económico y como consecuencia a todo esto, el 
derrumbe de la Monarquía Católica, la acentuación de las divisiones internas de la sociedad en España, el empobrecimiento para las gentes en lo material, pero a la par una exaltación de lo religioso al interior de los Monasterios.

En el siglo XVIII, Carlos III (1759-1788), hijo de Felipe V y hermanastro de Fernando VI, antes de ser rey de España desempeñó el cargo de Rey de Nápoles de 1735 y 1759.

Su reinado se caracterizó por la aplicación de las reformas del despotismo ilustrado:

El siglo XVIII fue un período de recuperación económica. Esta fue desigual, mayor en la periferia que en el centro peninsular. En ese contexto de crecimiento económico, con el Conde de Aranda (1769) y Floridablanca (1787) se llevaron a cabo los primeros censos con la finalidad de conocer las potencialidades económicas y fiscales.

Entre los ilustrados se extendió la conciencia de la necesidad de emprender reformas en la agricultura, actividad que ocupaba a la mayoría de la población y que estaba muy atrasada. Para ello se crearon asociaciones como las Reales Sociedades Económicas de Amigos del País y los ministros de Carlos III prepararon diversos planes de reforma como el Memorial Ajustado de Campomanes y el Informe sobre la Ley Agraria de J ovellanos.

Todos estos proyectos y documentos del período denunciaban las enormes propiedades amortizadas (mayorazgos de la nobleza o manos muertas de la Iglesia) y afirmaban que el acceso del campesinado a la propiedad de la tierra era una condición necesaria para el progreso del país. Por primera vez, se empezaba a hablar de la desamortización. Sin embargo, la negativa rotunda del Clero y la Nobleza, incluso hubo procesos de la Inquisición a ministros ilustrados como el Conde de Aranda, que llevaron a la paralización de las reformas.

Las únicas medidas que se llevaron a cabo fueron el reparto de tierras comunales en Extremadura, la repoblación (fallida) de Sierra Morena bajo el gobierno de 
Olavide, la reducción de los derechos de la Mesta y algunas obras de regadío (Canal Imperial de Aragón, Canal de Castilla)

Los ministros ilustrados aprobaron medidas para fomentar el desarrollo de la Industria. Se rompió el monopolio de los gremios en 1772; se establecieron, con escaso éxito económico, las Reales Fábricas, con apoyo del estado (armas, astilleros, vidrio, tapices) Las industrias textiles privadas catalanas ("indianas") fueron más competitivas que las empresas estatales.

Con respecto al comercio se adoptaron medidas conducentes a integrar el comercio nacional, como la mejora de las vías comunicación o la supresión de las aduanas interiores. Un decreto de 1778 estableció la liberalización del comercio con América, acabándose con el secular monopolio de la Casa de Contratación. Sin embargo, se mantuvo la política comercial proteccionista con respecto a los demás países vigorizados. En el terreno financiero, se estableció el Banco de San Carlos, antecedente del futuro Banco de España. En este período, aparece la peseta, aunque no será la moneda oficial del país hasta 1868.

Echemos un vistazo breve a las características de las principales medidas monetarias que se emplearon en estas épocas, por cuanto ello nos podrá proporcionar las bases para entender las equivalencias y tomar una idea de los valores correspondientes a las fuentes de ingresos que manejaban los Monasterios.

El DUCADO, fue la moneda de oro creada en Sicilia en siglo XII y difundida más tarde por toda Italia y a la postre por toda Europa. Su peso es de 3,5 g. de oro de 0.986 de pureza. En el siglo XIV llegó a convertirse en un patrón monetario internacional a cuyo peso y ley se ajustaron la mayor parte de las unidades áureas de los países de occidente.

El DUCADO de oro español tiene un peso de 3,6 g. (ley 23. 75 de quilate) moneda unitaria de oro y corresponde a medio doblón y fue la unidad de cuenta durante los siglos XVI y XVII; (Según la Real Pragmática de Medina del Campo del 13 de J unio de 1497) equivale a 11 reales y a 375 maravedíes. En 1537 se introdujo una moneda de oro de menos peso y ley que el ducado pasando a tener una ley de 22 quilates con el objeto de igualar esta moneda española a la de otros países. Dicha 
moneda fue el Escudo o Corona que equivalía a 350 maravedíes. Los Reyes Católicos fijaron un límite máximo a la cantidad de vellón circulante que se mantendrá durante todo el siglo XVI. En 1548, Carlos I autoriza una mayor cantidad de vellón y en el año 1552 reduce su contenido de 7 a 5 1⁄2 . En el siglo XVII, en España y en sus colonias se utilizó el denominado ducado de plata, equivalente a 375 maravedíes de plata.

El MARAVEDÍ fue una de las moneda españolas, que allá por los años 1172 y 1221 fue acuñada con el nombre de "morabetin" como una copia exacta del Dinar Almorabide de $3.88 \mathrm{~g}$. El maravedí llegó a tener difenentes valores y calificativos, como por ejemplo: El maravedí de plata, moneda cuyo valor era la tercera parte de un real de plata antigua. El Burgalés, fue un Maravedí de Plata, la moneda de vellón con tres partes de cobre y una de plata que mandó labrar en Burgos el Rey Alfonso "El sabio" y valía la sexta parte del Maravedí de plata. El cobreño, moneda antigua que valía dos blancas. El Maravedí de oro, moneda con ley de 16 quilates de oro, que Alfonso "El sabio" tasó en seis maravedíes de plata. El maravedí nuevo, Moneda de vellón que equivalía a la séptima parte de un real de plata. Entre los siglos IV y XV, Enrique II, creó el Cruzado con el valor de 1 maravedí, lo hizo en vellón. El Blanco de Juan II y las Doblas Blancas de Enrique III también tuvieron el mismo valor y calidad.

Los REALES, al igual que los anteriores tuvieron su evolución a través de los tiempos; el Real de plata equivalía a 43 maravedíes en tiempos de los Reyes Católicos. Ya por el 1566, Felipe II, modificó la estampa, ley y talla del vellón que pasó a acuñarse con una nominalidad 8,4 y 2 maravedíes. En la penúltima década del siglo XVII, Carlos II dio el valor de 34 maravedíes a un nuevo real de vellón, en tanto que el antiguo se alzó a 510 maravedíes. Bajo los Borbones continuó perteneciendo al sistema de la "Calderilla" siendo Carlos III que en 1770 introdujo la última tipología: en una cara el busto real y en la otra la del Infante. Por un Decreto de Abril de 1848, se instauró un sistema monetario de base Decimal que tenía en el Real, su unidad de cuenta. En 1856 la nueva unidad se sustituyó en la contabilidad de las instituciones públicas, aplicándose una equivalencia de 3 céntimos de real por cada maravedí. 
Siglo XIV El valor del Real se estableció en tres (3) maravedíes

(3.48 g. (66 piezas de marco) y una ley de 930 milésimas) por lo que 12 Reales constituían Una Dobla

A principios del siglo $\mathrm{XV}=$ El Real pasó a valer ocho (8) maravedíes y más adelante tomó un valor de 15 maravedíes.

En el siglo XVII, Felipe IV, redujo el peso de los Reales a 2.85 g. (83,4 por marco). Aumentó en un $25 \%$ la equivalencia del antiguo Real de 8 para valer 10 de los Nuevos Reales. Así que, el Real Plata nueva subió a dos Reales de Vellón en tanto que el peso fuerte o real de a 8 antiguos, quedaba en 20 Vellón base.

Con los Bonaparte se modificó la nomenclatura de las piezas: la de Real de a dos, pasó a llamarse: "de a cuatro Reales de Vellón” y el Real de Plata, fue rebautizado como "Dos Reales".

En el Siglo XIX - más concretamente en 1848, por el Real Decreto del 15 de Abril se adoptó el "Real vellón" como unidad fundamental del sistema monetario con una unidad de Plata de 1,31 g.; un año después el Real se dividió en cien (100) céntimos, sustituyó al Maravedí como unidad de cuenta, hasta que en 1868 fue ocupando el puesto "La peseta”.

Las primeras PESETAS - peça, que significa pieza - , se labraron en Barcelona durante la época de la Independencia.

Unidad base Real de Plata:

Peseta $=$ cuatro (4) Reales

Peso $=5.25 \mathrm{~g}$

Ley $=900$ milésimas.

Con lo anterior es posible observar lo cambiante de las unidades monetarias. Conocido es de todos, que estos cambios constantes o inestabilidades de la moneda estaban sujetos a las cantidades de materia prima, riqueza interna bruta, 
que los reinos tenían tanto en sus propios territorios, como en sus colonias, ya fuesen en oro, plata, minerales, piedras preciosas y por otros conceptos, como el comercio de infinidad de productos intercambiables, que pudieran existir y por la recaudación de los impuestos.

\section{FUENTES DE INGRESO}

\section{Las Dotes}

En cuanto a las fuentes de ingreso pecuniarias de las que se nutrían los Monasterios, están principalmente las "dotes". Gracias a estas aportaciones los conventos no solo se sostienen y obtienen gran parte de su patrimonio sino que este aspecto marca la marcha económica de la institución. Las "dotes" se las puede considerar desde dos puntos de vista: los económico y lo moral. En lo económico, se consideraban el sostén financiero del Monasterio y en lo moral, al considerarse la "dote" como una herencia, que fue utilizada por los padres para manipular la vida de sus hijas y como un elemento justificador para señalar las pautas sobre el honor.

Concha Torres nos lo ilustra de la siguiente manera:

“Moralmente es el instrumento final del que se valían los padres, bien para que se admitiese a profesar a su hija (si existía alguna opción por parte del convento) o para obligar a esa hija que era reacia a la profesión: frecuentemente la dote era una herencia que de no ingresar en el claustro, no se disfrutaría en el siglo. Este cometido puede enfocarse también como una función social: es un elemento justificador del Orden, como el honor.”92

El posicionamiento del poder en todos los estamentos, no favorece a la mujer en estas épocas. Sin embargo, las dotes, se las considera un premio a lo que una mujer en este caso está obligada a ser, según lo establecido en el orden social, ser la "depositaria del honor masculino".

92 TORRES SÁNCHEZ, Concha. La clausura femenina en la Salamanca del siglo XVII Dominicas y Carmelitas descalzas. Salamanca: Ediciones de la Universidad de Salamanca, 1991. p. 70 . 
En el Monasterio de Santa María de las Dueñas, las “dotes” están recogidas en los dos Libros de Dotes en el que a su vez, aparecen las profesiones y las defunciones a partir del siglo XVIII, ya que existen muchas lagunas al respecto, por las circunstancias referidas anteriormente. Las informaciones de dotes y profesiones del siglo XVII están llenas de lagunas y prácticamente perdidas. Las dotes generalmente se entregaban en dinero y en propiedades representadas en casas, tierras o censos. Veamos a través de los tiempos, la calidad de las dotes y sus relaciones dinerarias, de acuerdo a los cambios de la moneda:

El caso ya relacionado en la noble ascendencia de las monjas: María de Oviedo, monja de velo negro, - llegó a ser Abadesa-, hija legítima de Don Pedro de Oviedo Camargo - de la Cámara de su Majestad Felipe III -, y Dña. Isabel de Frías, había dado una dote de 1.000 ducados que a la letra dice su acta de dote: "1.000 ducados, fuera de las propinas y demás cosas que suelen dar a las religiosas de dicho convento como todo ello consta y aparece de las dichas escrituras y licencias y libertades."93

Se da el caso de algunas monjas músicas que al final de su desempeño musical, después de 20 años o más años como organistas o cantoras, pagan su dote, para continuar su vida sin cargas ni obligaciones musicales.94 Leyendo a Francisco Javier Lorenzo Pinar, en su artículo: Profesiones religiosas femeninas zamoranas en el siglo XVIII, en la Actas del I Congreso Internacional del Monacato femenino en España, Portugal y América 1492 - 1992, se puede conocer un aspecto interesante sobre los montos de las dotes que determinaban la jerarquía del tipo de ingreso, ya fuese de Velo negro o de Velo blanco. Lorenzo Pinar, dice:

“La posesión o carencia de medios monetarios determinaba que la futura monja tuviese que optar por un monjío de velo negro exonerado de ciertas labores domésticas, o por uno de velo blanco, subordinado a ciertas tareas y trabajos arduos."95

93 ASMD. Carpeta de informaciones. María de Oviedo.

94 ASMD. Tomado del Libro de Dotes - pp. 33 y 37.

95 LORENZO PINAR, Francisco J avier. Profesiones religiosas femeninas zamoranas en el siglo XVIII. Actas del I Congreso Internacional del Monacato femenino en España, Portugal y América 1492 - 1992, t. II. León: Servicio de publicaciones de la Universidad de León, 1993, p. 380. 
En el Monasterio de Santa María de las Dueñas, se manejan loe términos “De Velo negro" y de "medio velo" lo que puede estar en correspondencia con los términos que se estilan en los Monasterios de Zamora mencionados por Lorenzo Pinar.

Variados ejemplos del registro de "dotes", nos ayudarán a hacer una valoración de la moneda de acuerdo a los diferentes siglos (XVII, XVIII, XIX y XX), sacados de los Libros de Dotes (1610 - 1766 - 1863) - (1831 - 1961) del Monasterio de Santa María de las Dueñas:

* Sigo XVII - 31 de mayo de 1610

\section{Dote de DOÑA MARÍA DE OBIEDO}

"Sepan cuantos esta carta y cuya escritura y lo demás que en ella será contenido como yo Doña María de Obiedo monja novicia en el Monasterio en el Monasterio de Santa María de las dueñas de esta Villa de Alba que llaman de afuera con licencia que primero y ante todas las cosas piso y demando por Diego González clérigo vecino de la dicha villa mi curador y hara y hacer yo tesar y por mi sola jurar esta escritura y lo que en ella sea contenido por el dicho Diego González que estoy presente que doy y concedo a la dicha licencia a la dicha Doña María de Obiedo mi menor según y para el efecto que por ello que por ella me es referida y demandada yo la dicha Doña María de Obiedo la acepto y recibo y de ella usando decimos que por cuanto yo la Dicha María de Obiedo estado y estoy en ese dicho Monasterio habrá año y medio y poco más o menos y conmigo se anego las diligencias que con las tales monjas novicias el tanto Concilio manda y es sabida mi voluntad de vivir y permanecer en profesión en el dicho Monasterio Orden de San Benito donde al presente estoy para lo cual se han sacado licencias de Luis Fernández de Córdoba y de Obispo de Salamanca Pastor y Prelado y su provisor y últimamente su Señoría mando que yo me dotase de mis propios bienes en mil ducados fuera de las propinas y demás cosas que suelen dar a las religiosas del dicho Convento como todo aquello consta y que aparece de las dichas escrituras y licencias y libertades que su tenor de todo ello a la letra es del tenor siguiente."96

96 ASMD. Carpetas de informaciones. s/n de p. 
* Siglo XVIII

Veamos algunas formulas de entrega de "dote" y los valores dinerarios que se manejaron durante el siglo XVIII. Son variadas las formulas encontradas:

* Fórmula № 1

Doña ROSA BERNARDINA AMORES - 1 de mayo de 1767

“Dote de Doña Rosa Bernardina Amores

“En veinte y uno del mes de mayo de 1767 se entraron en este Archivo 7.000 reales de vellon al capital por la dote de Doña Rosa Bernardina Amores con la asistencia del Señor Don J oseph de Herrán y Strada asistente de Vicario. las Señoras Abadesa, Priora, Dis crettas y clavarias a quienes se entregaron dicha cantidad y la firmaron de que yo el Notario doy fe y firme. = Joseph Herrán Strada, Doña Benita de Oviedo Abadesa, Antonia Barrientos, Doña Catalina Sánchez Priora, Ángela Collantes,

Ramón Amores - Notario."97

Ahora, miremos una fórmula en la que las aportaciones para gastos de Sacristía y demás, estás separadas de la dote principal:

\section{* Fórmula № 2}

Doña BONIFACIA SIDONA DE FRIAS - 12 de septiembre de 1772

"Deposito de la dote de Doña Bonifacia Sidona de Frias

En doce de Septiembre de mil setecientos setenta y dos mi señora Doña Francisca Xaviera Urtes entregó a este Archivo por via de deposito, Nueve mil quinientos de la dote de Doña Bonifacia Sidona de Frias su hija, que está para entrar de religiosa en este de Santa María de las Dueñas orden de San Benito y a demás entregó quinientos reales para gastos de Sacristía; como igualmente entregó setecientos noventa y nueve, los quinientos veinte $y$ nueve de los alimentos y los doscientos y setenta reales, de cuya cantidad la Señora Abadesa y clavarias se dieron por entregadas en presencia del Señor Don Joseph Carvajal Vicario y Don Joseph de Herran representante de vicario y capellán de este Monasterio y que yo el Notario doy fe y la firmamos y firme $=$

Y además de toda esta entrega Dos mil reales a los gastos de profesión y lo firmaron y doy fe.

97ASMD.Libro de asiento de religiosas, dotes y traslado de las religiosas y convento. p. 17. 
J oseph Antonio Carvajal, J oseph Herran, Doña J osefa Margarita Enríquez, Abadesa, Doña Ángela Collantes, Doña Ana Pérez, Benita de Oviedo, priora, antemi Ramón Amores (Not)”98

* Fórmula № 3

Esta tercera fórmula nos muestra una entrega en monedas de oro y plata.

\section{Dote de Dña. J OSEFA VÁSQUEZ DE SOMOZA - 10 de julio de 1777}

* "En 10 de Julio de mil setecientos setenta y siete por el Señor Don Franco Vásquez de Somoza, como padre de Dña. Josefa Vásquez de Somoza se entregaron a éste archivo diez mil reales Vellón, de la dote de la dicha su hija, como así mismo quinientos reales vellón de sacristía y trescientos de gala en que está ajustada dicha dote, $y$ de todo se dieron por entregados en monedas de oro y plata, la Señora Abadesa y demás señoras clavarias a presencia del Señor Don Domingo Martín de Huerta, vicario de que yo el notario doy fe y firmaron $=$

Domingo Martín de Huerta - J osefa Margareta Enríquez - Abadesa

Teresa Domínguez - Priora Benita de Obiedo

Ramón Amores - Notario”99

* Formula № 4

Esta cuarta fórmula está relacionada con los zensos (censo). Conocemos por zenso al Contrato por el cual se sujeta un censo al pago de una pensión anual. Con esta definición literal, veamos en un ejemplo la dote entregada por la religiosa Dominica Zardui:

* "En 11 de mayo de 1787 quedaron en el Archivo, en la bolsa de la dote de Doña Dominica; 823 reales y 18 ms Principal de un zenso que redimieron; Francisco; Leonardo; Maria, Juan, J oseph; y Theresa Muñoz; hijos de Domingo Muñóz, ; vecinos todos del lugar de Alaraz; lo impuso J uan Ramos; vecino de dicho lugar. Los reditos y mora quedaron en el arca de mrs; de las que darán cuenta las señoras arqueras; la escritura de imposición se le entregó a Blaz Caravias, 
vecino de Alva; siendo Abadesa Doña Theresa Domínguez y arqueras Maria Francisca de Frias y Doña Rosa Amores."100

Entre el período cronológico comprendido entre 1767 y 1797 el monto de las dotes principales creció paulatinamente de 7.000 a 10.500 reales, y hacia 1825 los montos subieron hasta 12.000 reales sin contar lo recabado por alimentos, hábitos y profesión de las aspirantes. La última fórmula para la entrega de una dote, encontrada en este período cronológico, reza así:

* Fórmula № 5

Doña MARÍA TERESA SALGADO Y OLIVA - 1 de enero de 1797

“En la villa de Alva de Tormes a primero de Enero del año de mil setecientos noventa y siete el señor Don Juan Martínez Oliva presbítero provincial visitador y vicario general de la ciudad y Obispado de Salamanca por el Exmmo señor Don Felipe Fernández de Vallejo gobernador del reino y supremo consejo, consejero de estado Obispo de Salamanca y habiéndose constituido en uno de los locutorios del Monasterio de Santa María de las Dueñas de esta villa, orden de San Benito para ante mi y en presencia de las señoras Doña Rosa Amores, Doña María Antonia Barrientos, Doña Maria Teresa de Frias, Doña Manuela Reyero, Doña Baltazara de Acosta Abadesa, priora, prudentes y claveras, recibió diez mil y quinientos Reales vellon por mano de Don Francisco Martínez Oliva del dote de María Teresa Salgado y Oliva su sobrina novicia en dicho convento en cuya cantidad se incluyen lo que por estilo se acostumbra dar por razon de sacristía y demás de gastos hechas cargo dichas señoras $y$ contado a su voluntad se dieron por entregadas y lo firmaron con su señoría de que yo el notario doy fe=

Señor Don Juan Martínez Oliva, Rosa Amores, Abadesa, Maria Antonia Barrientos, Manuela Reiero, María Francisca de Frias, Baltazara de Acosta, arquera y J osefa Vasquez de Somoza, arquera.

Antemi = Don Isidoro Gómez Notario"101 


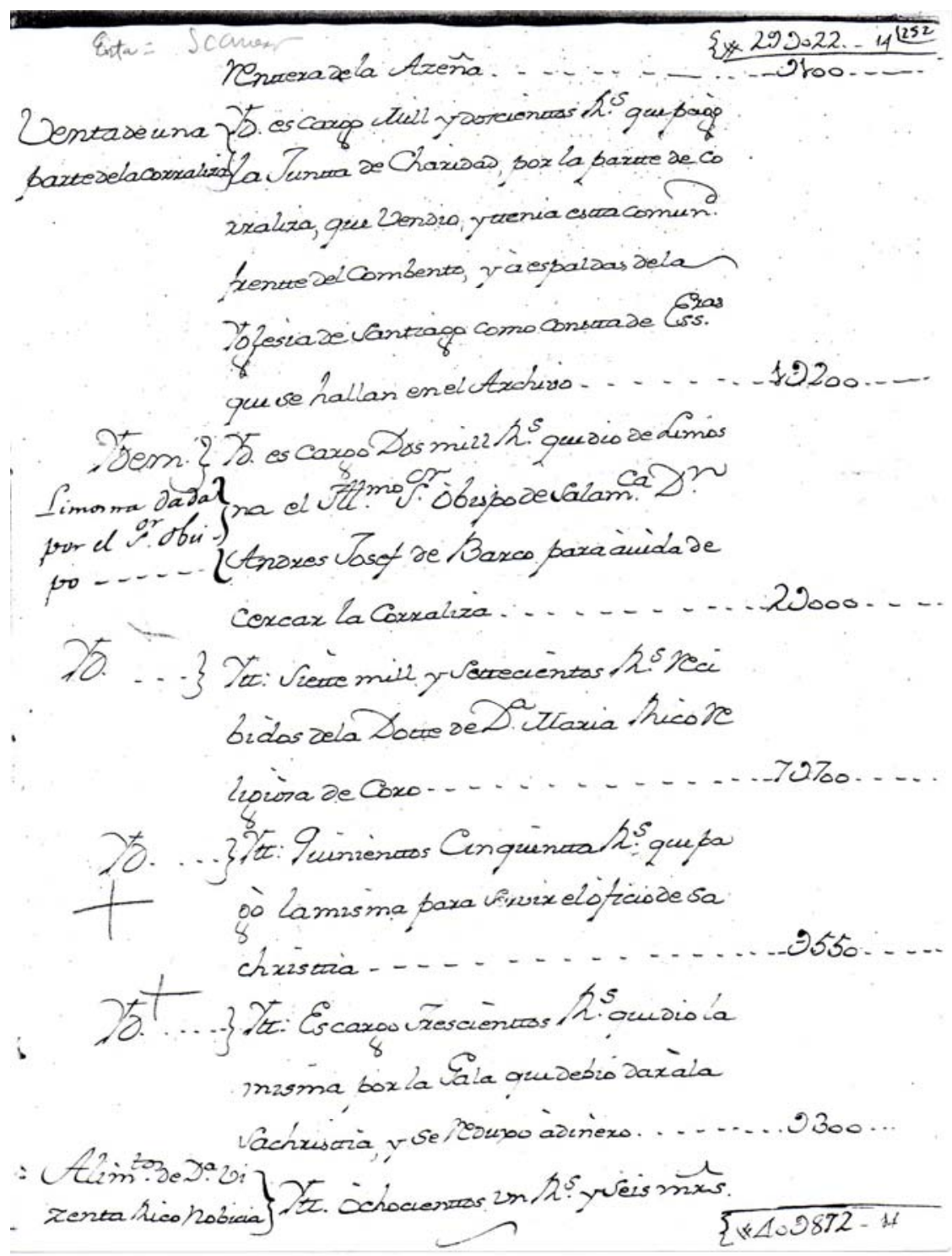

6. Distribución de los Dineros de una dote. ASMD.

\section{Siglo XIX}

Alrededor del 1858, los valores de las dotes ya se entregaban en pesetas.

\section{Dña. PRESENTACIÓN GARCÍA FRUTOS}

“Doña Presentación García Frutos natural de Salamanca tomó el hábito en este Monasterios de Benedictinas de Santa María de las Dueñas a los 18 años de edad el día 24 de Octubre de 1858 y profesó el 29 del mismo mes del año siguiente en 1859: Dio de tres mil pesetas." 102

102 ASMD. Libro II de Dotes. Caja: Libro de Dotes, Testamentos y Defunciones. p. 38. 


\section{Siglo XX}

Dote de Dña. PILAR GÓMEZ BARRADO de noviembre de 1886.

“Dña. Pilar Gómez Barrado, en el siglo (María de la Presentación) hija legítima de Don J osé Gómez y de Dña. Serafína Barrado, naturales de Alba de Tormes; nació en la citada villa de Alba en 21 de noviembre de 1886: Tomó el hábito en este Monasterio de Benedictinas de Santa María de las Dueñas, el 7 de marzo de 1909 y profesó el 28 del mismo mes al año siguiente 1910, a los 23 años de edad. Dio de dote 5.000 pesetas." 103

Analizando las fórmulas de entrega de las dotes, podemos decir al respecto: En un principio el alto valor de estas; la dote más alta que se encuentra registrada en los documentos del Archivo conventual es la de 1.000 ducados. Parece ser que los valores establecidos fluctuaban entre los 800 a 1.000 ducados. También podemos observar que con el cambio de las monedas y con los problemas de la situación económica, paulatinamente las aportaciones por dotes van cambiando; Otro aspecto que se observa es que los valores monetarios se alternan encontrándose ducados con maravedíes, más adelante, reales con reales vellón y finalmente las pesetas. En el siglo XVIII según se observa, los valores predominantes por dote principal fluctuaban entre los 7.000 y los 10.000 reales; en algunos casos, el valor de la dote se distribuye en gastos de Sacristía, para alimentos, para hábito y gala o estos valores para gastos se pagaban fuera de la dote principal. En las últimas fórmulas presentadas se observa que éstas, cada vez se reducen a unas breves palabras prácticamente sin discriminar o fragmentar los valores y su destinación. En el Monasterio de Santa María de las Dueñas, no se encuentran datos sobre pagos diferidos o a plazos.

\section{- FUNDACIÓN DE “DOTES PERPETUAS”}

La fundación de las “dotes perpetuas”, por parte de personas ajenas al Monasterio pero que tenían el espíritu de ayuda a los más necesitados, era muy común en estas épocas. Se hacía esta fundación con carácter de perpetuidad, con el objeto de procurar y garantizar la estancia en el Monasterio a varias monjas que pasaran por situaciones económicas difíciles; La “dote perpetua” de 10.000 pesetas fundada por Dña. María Dolores Cantero vecina de Salamanca, el 7 de agosto de 1900, para el Monasterio de Santa María de las Dueñas, expresaba a la letra lo siguiente:

103 ASMD. Libro II de Dotes. Caja: Libro de Dotes, Testamentos y Defunciones. p. 80. 
"En la villa de Alba de Tormes a siete de Agosto de 1900 y hallándonos en el Locutorio de Religiosas Benedictinas Doña María de los Dolores Cantero de estado viuda may or de edad y vecina de la ciudad de Salamanca

Y Sor Escolástica Campo Abadesa de dicho Convento, por si y en nombre de toda la Comunidad, decimos

Que la Doña María de los Dolores Fernández desea para mayor gloria de Dios Nuestro Señor y de su siervo el Gran Padre San Benito, fundar como desde este momento funda un dote perpetuo en dicho Convento de Benedictinas de ésta Villa de Alba de Tormes para que siempre haya en el dicho convento una religiosa que ruegue por ella de suerte que cuando falta la primera religiosa agraciada con este dote entrará a sustituirla otra y así sucesivamente.

Las favorecidas con este dote llevarán el nombre de Benita Dolores, en la religión y les recomienda muy especialmente ola devoción al Santísimo sacramento, rezando por su bienhechora el jueves de cada semana la Visita y Estación al Santísimo; además desea y quiere la Dña. María de los Dolores Fernández que el día en que ocurra su fallecimiento o en el siguiente, la Comunidad ofrezca la Comunión en sufragio de su alma y también que la dicha Comunidad tenga una misa cantada con vigilia; y lo mismo todos los años en el aniversario de su defunción.

Para constituir este dote entrega la Dña. María de los Dolores Fernández Cantero en este acto y recibe la citada Madre Abadesa de citado Convento de Benitas de Alba de Tormes, y en su nombre y en el de la Comunidad la suma de diecisiete mil quinientas pesetas nominales en Títulos de la Renta perpetua interior al cuatro por ciento cuya numeración es como sigue: Un Título serie D; capital doce mil quinientos pesetas, número treinta y un mil doscientos. Otro Título tipo B; capital de Dos mil quinientas pesetas, número treinta, número treinta y siete mil ochocientos veintiséis y otro Título también serie $B$, capital dos mil quinientas pesetas, número cuarenta y un mil cuatrocientos; por consiguiente los tres mencionados títulos suman el capital de las referidas Diez y siete mil quinientas pesetas nominales.

La Madre Abadesa por sí y en representación de la Comunidad dando las gracias a la Señora Donante acepta la fundación consignada en este documento comprometiéndose en lo que de la Comunidad dependa, a tener 
siempre provista ésta plaza de religiosa y a cumplir con los sufragios que la Sra. Donante desea.

Dado conocimiento de la constitución de ésta fundación de dote perpetuo al muy Ilustre Señor Doctor Don Ramón Barbería y Boada, Dignidad de Arcipreste de la Santa Basílica Catedral de esta ciudad, Provisor Vicario General y Gobernador Eclesiástico del Obispo S.P. , la aprobó e interpuso su superior Autoridad para la firmeza y validez de la misma fundación habiendo designado al Señor Cura Ecónomo de la Villa de Alba de Tormes, o en su defecto al Coadjutor de la misma Don J osé Sánchez Bustos para que en su nombre presencie la entrega de los Títulos de la Deuda que ha de recibir la Comunidad y mandó que se extendiera éste Documento por triplicado entregando un ejemplar a la Señora Fundadora, otro se archivaría en el Convento de Religiosas Benedictinas de Alba con el fin de preservarlo."104

La primera religiosa que fue favorecida por esta dote perpetua, fue la llamada Claudia Puerto Puerto, natural de La Alberca - provincia de Salamanca; profesó el 12 de octubre de 1900 a los 30 años de edad y tomó el nombre de "Benita" Dolores, como lo encomendaban los Documentos de esta dote. Esta monja vivió tan solo un año y medio de Religión y murió soportando una penosa enfermedad. La siguiente favorecida con esta dote, fue María Luisa Grego Hernández en su vida de religión, de igual manera pasó a llamarse "Benita" Dolores Grego Hernández.

104 ASMD. Documento de Fundación de Dote Perpetuo. Caja de Dotes y Testamentos. 


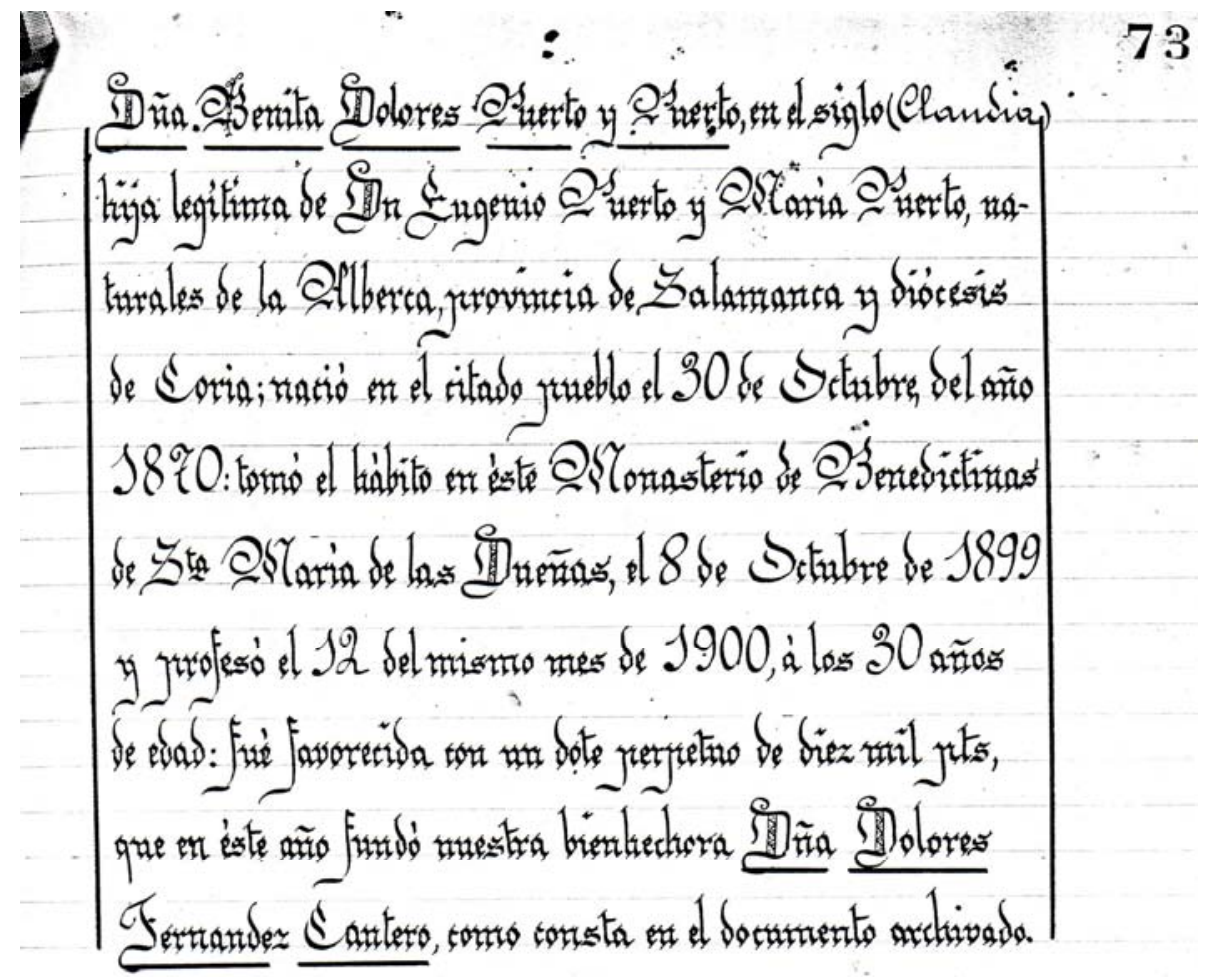

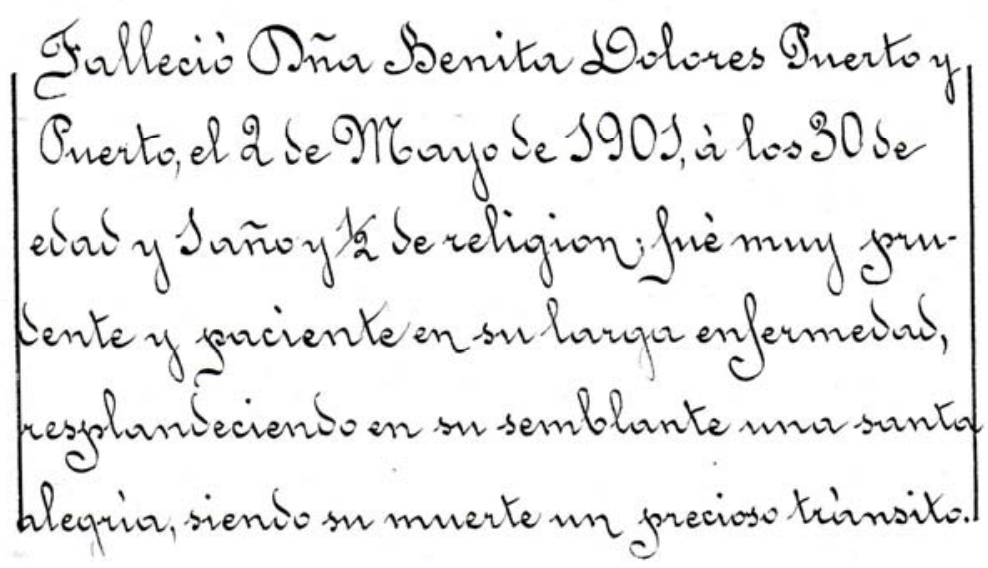

7. “Dote perpetua” fundado por Dña. María de los Dolores Fernández Cantero ASMD. Libro de Dotes, Testamentos y Defunciones 1900

\section{* “AÑOS DE PROSPERIDAD”}

\section{CAPELLANÍAS QUE PERTENECIERON A ESTA COMUNIDAD}

Entendiéndose por Capellanía como una Fundación en la cual ciertos bienes quedan sujetos al cumplimiento de misas y otras cargas pías o también "eran 
cantidades fijas en efectivo que ofrecían los particulares a cambio de una Capilla en el convento, o la posibilidad de que alguien de la familia ejerciera de capellán. También se podían decir una serie de Misas durante un tiempo determinado, que generalmente solía ser muy largo."105 la primera Capellanía de la que se tiene conocimiento que existió en el Monasterio de Santa María de las Dueñas, fue la instaurada por Doña Mencia Fernández el 10 de agosto de 1464, con una carga anual de tres (3) misas cada semana, de la que fue Patrona la Abadesa de aquel entonces; dicha Capellanía estaba dotada sobre dos yugadas (espacio de tierra que puede arar una yunta en un día) y un pajar en el término de Encinas, su renta anual, son 27 fanegas de pan mediado trigo y centeno; quedó reducida a 52 misas por año y su capellán fue Don Francisco Sánchez, clérigo de primera.

La segunda y la de más renombre fue la fundada por Doña María Rosales viuda de Don Cristóbal del Águila, que ante el escribano de Alaba de Tormes Diego Becerrillo, se instituyó el día 10 de noviembre de 1519, fueron sus Patronos, el Abad de la villa y la Abadesa de este Monasterio. "una yugada de tierra que produce 13 fanegas de trigo 46 reales y 20 maravedíes sobre la Dehesa de Melardos término de Santiago de la Puebla; la yugada está en el término del lugar de Ejeme; gózala Don J uan Antonio de Oviedo Presbítero."106

Doña María de Rosales fue una noble y distinguida dama, protectora de este Monasterio, de quien se conserva en el Archivo, su testamento original hecho en el año de 1543. En él se asignan rentas para la fundación de la Capellanía - dejando como patrona de dichas rentas a la Abadesa del Monasterio -, rentas para la construcción de la Capilla mayor de la Iglesia (Capilla del Coro y bóveda) y para ella y sus familiares, unos aristocráticos sepulcros acordes con su rango.

105 TORRES SÁNCHEZ, Concha. La clausura femenina en la Salamanca del siglo XVII. Dominicas y Carmelitas descalzas. : Ediciones de la Universidad de Salamanca, Salamanca, 1991, p. 133.

106 Libro de Crónicas. Primera Parte, p. 13. 


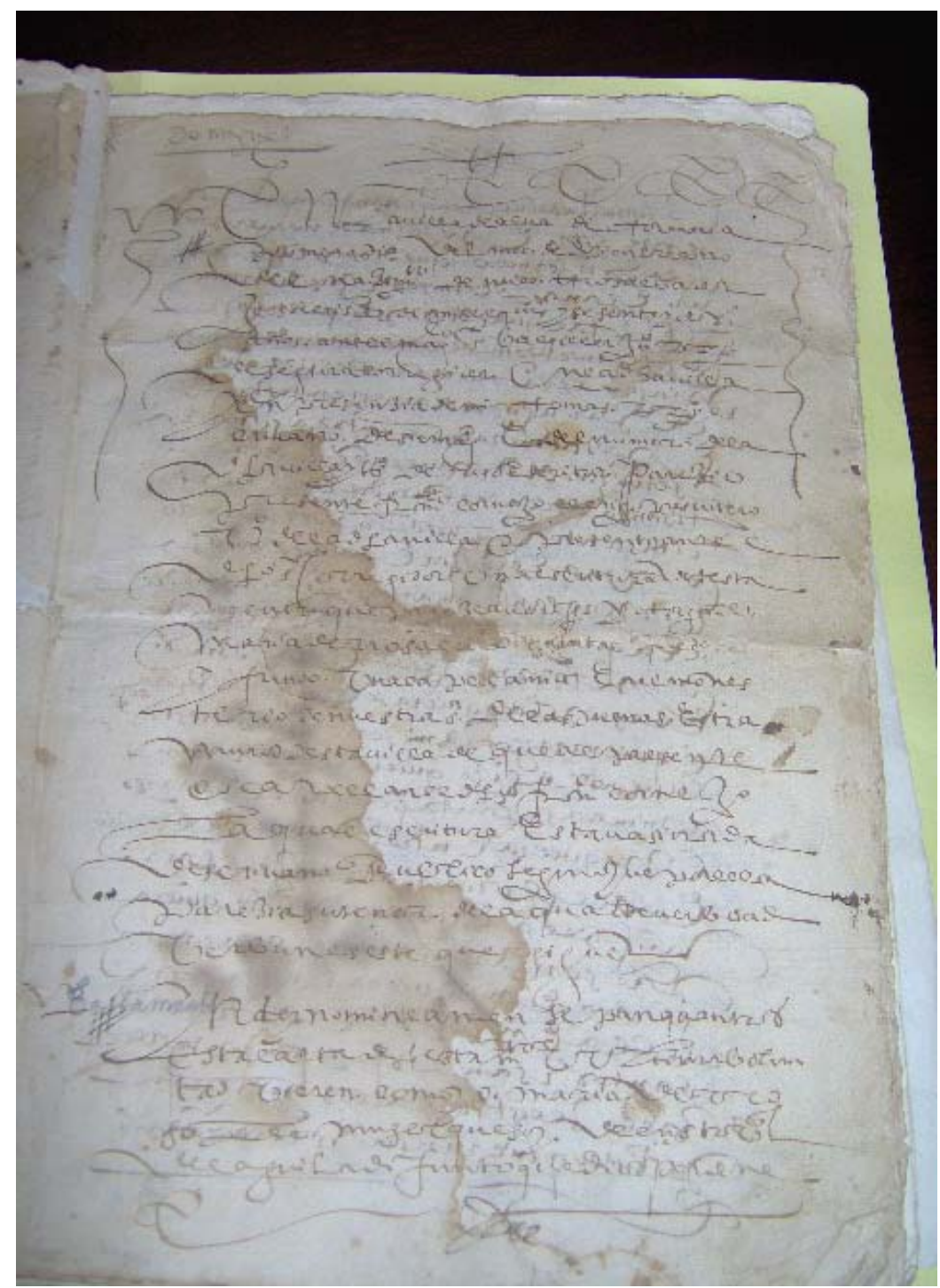

8. Testamento de Doña María de Rosales, benefactora del Monasterio. ASMD.

ASMD. Caja de Dotes y testamentos

De aquellos sepulcros, el Monasterio actual conserva cuatro, pues en tiempos de crisis fue vendida una de las piedras talladas.

Respecto a la construcción de la Capilla, la protectora dejo claro en su testamento, los dineros asignados para dicho gasto y las indicaciones de cómo debía hacerse. En su testamento se lee lo siguiente al respecto:

“Testamento de Doña María de Rosales por el cual manda del Monasterio de Santa María de las Dueñas la Capilla del Coro y vobeda y demas que aquí se contiene. 
(...) Y mando que se haga la Capilla del dicho Monasterio que es el Coro de Santa María de las Dueñas extramuros del ancho e alto, que a la priora, monjas e convento bien visto fuere juntar con mis testamentarios; que sean las paredes y estribos por de fuera de Piedra, e de pizarra e cal e de vobeda é la áz por de dentro de toda la Capilla évobeda sea de piedra blanca labrada de canteria de silleria labrada , elímpia, á boca de escoda éque entrada un lado de la Capilla se hagan escudos con sus molduras, y que en la clabe y cuerda de la vobeda se pongan los escudos de mis armas, en la misma piedra éque en el primero arco de la mano del Evangelio hacia el altar se ponga el bulto de Gonzalo Iañes, miSeñor Padre y de mi Señora aguela, según agora est, y que enel hagan mi bulto de persona con los escudos de mis armas, para de tal manera con sus ollajes ésus sillones por bajo con su letrero de Piedra de Villamayo , si pudiesen ser habidas, esino de la mejor que se pueda haber, élo pongan en primero Arco de la hacia la epístola, hacia el Altar; étecho pongan en el dicho Arco mi cuerpo, epuesto, le den un lustre de alabastro éyeso encolado, por manera que quede blanco, épinten en espaldar un crucifijo con Nuestra Señora é san Juan, éque los dos Arcos mas bajos sean de mi heredero, ésusPadres, parientes mas propinquos, ése haga la mejor émas provechosa que ser pueda de mis vienes, según yo desuso declarare.”107

En relación con su petición de misas después de su fallecimiento, Dña. María de Rosales dice:

"mando que me digan en el dicho Monasterio durante el año, por Dios y por mi ánima las misas de la Consolación (...) cinco (...) me digan las misas de la novena en el dicho Monasterio” , “Y mando que la Priora de este Monasterio sea obligada de hacer apuntar las misas y tomar cuenta de ellas al capellán que fuere para que dentro de treinta días después y que así tomada la dicha cuenta, el capellán cumpla las misas que debiere y en efecto de las no cumplir la dicha Priora, las haga decir por su propia autoridad y tomar de la renta de la dicha capellanía y las pague a medior real cada una y se acaben de decir en cada un año, todas las misas que así le caben. 108

107 ASMD.Testamento de Doña María de Rosales - Protectora del Monasterio. Caja de Dotes y testamentos.

108 Ibídem. Caja de Dotes y Testamentos. 
La tercera la fundó Don Diego de Salazar de la que era patrono Don Alfonso de Oviedo y su Capellán nominado Don J uan Antonio de Oviedo. Su renta consiste en 16 fanegas de trigo que producen yugada y media en el lugar de Garcihernández.

La cuarta también fue fundada por Don Diego de Salazar teniendo como Capellán al Presbítero Don Alonso Condado; tenía de renta 9 fanegas de trigo, 3 de cebada y 19 reales vellón por una Yugada en el lugar de Gajates y tiene de carga 36 misas al año.

La quinta la fundó Antonio de la Puente y su mujer Elvira de la Peña. Sus rentas consisten en 12 fanegas de trigo y 8 de centeno que producen 43 huebras de tierra en el lugar de Ejeme. Tenía una carga de 52 misas por año.

La sexta la fundó Gonzalo de Liminón con carga a 156 misas por año, la cual fue reducida a 60 misas anuales, por Don Gabriel Vázquez Saavedra y Rojas Canónigo Magistral de Salamanca, por tener de renta solo 19 fanegas de trigo en una heredad del lugar de Encinas.

Hubo una séptima Capellanía que fundó Doña Sancha, pero de la cual se desconocen sus rentas.

Las descritas Capellanías ya no existen, pues desaparecieron cuando el gobierno se incautó de los bienes de las comunidades, por lo que viéndose privadas de percibir las rentas que las sostenían, los prelados Diocesanos dejaron libres de tales cargas y obligaciones contraídas, al Monasterio.109

\section{RENTAS POR CENSOS Y J UROS}

Los Censos y J uros, se constituían para los Monasterios, en una fuente de ingresos y era un patrimonio económico; De los siglos XVII y XVIII, un simple sumario, nos puede informar acerca de las tierras propiedad del Monasterio por las que se cobraba algún tipo de renta y que estaban en:

109 ASMD. Libro de Crónica, pp. 12-14. 
Peñaranda, Ejeme, Vadillo, Terradillos, Navales, Anaya, Casasola, Encinas, Alaray, Doñinos, Valdecarros, La Rodrigo, Fresnillo, Galiduste, Palacios, Coca, Pedraza, Pelayo, Pedrosillo, Macotera, Turra, Amatos y Siete Iglesias. Una de las grandes propiedades que el Monasterio apreciaba en grado sumo, fue la Hacienda Santa Inés, donada por los padres J erónimos en el año 1472 de la que el Monasterio fue propietario hasta el 1835, cuando la infausta desamortización se las desposeyó. Fue esta una propiedad que dejó buenos réditos a la comunidad. El Libro de las Crónicas nos describe una nómina de Instrumentos públicos (fincas y censos) propiedad del Monasterio.

\section{PROPIEDADES DEL MONASTERIO DE SANTA MARÍA DE LAS DUEÑAS SIGLOS XVII y XVIII}

Censos: de Macotera, de Alba, de Nava del Rey, de Alavar y muchos otros, de los cuales, varios fueron dotes de religiosas que ingresaron, como María De Oviedo y Frías, - ya mencionada -, hija de Pedro de Oviedo y Camargo - gentil hombre de Cámara del Rey Felipe IV, cuyo censo en total era de 1.500 ducados.

Los Juros o privilegios concedidos al Monasterio, se pueden relacionar de la siguiente manera:

1. Privilegio de Fernando IV “EL Emplazado”, a causa de los desperfectos sufridos por el Monasterio con motivo de cerco puesto a la Villa por las tropas de dicho Rey por valor de 12 Escusados, en el año de 1312.

2. Alfonso XI otorga un nuevo privilegio fechado el 3 de septiembre de 1319 en Ávila en el que además de ratificar lo otorgado por Fernando IV, la aumenta con 4 escusados más, a cambio de que monjas y capellanes rueguen por el alma de su padre y por su salud también.

3. Los reyes Enrique II, Juan I y Enrique III, de igual manera beneficiaron al Monasterio; en el Archivo Conventual, reposan tres diplomas que corroboran lo anterior.

En cuanto a las propiedades pertenecientes al Monasterio y que están representadas en casas, podemos decir lo siguiente: La primera casa que el 
Monasterio adquirió dentro de los muros de Alba de Tormes, fue la comprada a Bartolomé Martínez Malo. La adquisición de este inmueble consta en el Libro de Cuentas de 1769 y dice así:

\section{“diez mil reales pagados a D. Bartolomé Martínez Malo con los cuales se hizo paga de los 34.000 que costó la casa para fundar el nuevo convento"110}

En el folio 68 de este Libro de cuentas, del mencionado año, surge la primera mención de gastos relacionados con la construcción del Monasterio "se llevan gastados en la obra del nuevo Convento la cantidad de 37.625 reales"111 Para continuar la reedificación compran cuatro casas más. De este hecho da fe la escritura de compra.112

Como un ejemplo de los gastos de mediana cuantía, están los siguientes egresos:

- Fundición de la campana ...................................158 reales

- Arreglo del órgano .......................................... 2.165 reales

(Varias referencias al respecto se encuentran a través de los años)

- Gastos de sillería nueva y ornamentos

para la Sacristía como: Palio casullas y otros............ 3.906 reales

- Arreglo de puertas y ventanas y otros ..................... 1.142 reales

- Hacer escaleras nuevas, ballado nuevo, poner árboles, pagar jornales, materiales y carros..... 2.450 reales

- Arreglos para el nuevo convento: tejas, ladrillo,

Cal, piedra, madera, rejas. 3.618 reales

La vida cotidiana requería de numerosos gastos considerados ordinarios, tales como:

110 Libro de cuentas. Año 1769.

111 Ibídem.

112 ASMD. Documento de compra. Fechado del 22 de marzo de 1722. 
Comida, vestido, calzado, velas, carbón, botica, etc. Veamos un ejemplo de los valores que ocasionaban los gastos más importantes en Santa María de las Dueñas durante el siglo XVIII, año 1823:

- Jabón............................ 15 reales y 32 mrv.

- Velas de cebo.............. 107 reales v

- Cera......................... 686 reales vy 14 mrv. a 13 reales y medio la libra

- Carbón...................... 2800 reales v y 32 mrv. Por 1.308 arrobas y $1 / 2$ de carbón

- Chocolate................. 483 reales v incluyendo azúcar y canela traídos de Salamanca

- Aceite..................... 1836 reales v valor de 27 cántaros de aceite

- Sal........................... 297 reales v pagados por 3 fanegas y 10 zelemines de sal. A 78 la fanega

- Pescado........................ 88 reales v- arroba y media para Adviento y

\section{Cuaresma}

- Miel.......................... 47 reales v

- Garbanzos................... 200 reales por por 5 fanegas y media de garbanzos

- Alubias....................... 75 reales y 20 mrv pagados por una fanega y ocho zelemines de alubias.

- Arrozy las castañas....... 83 reales pagados por arroba y media de arroz y dos arrobas de castañas

- Trigo.......................... 180 reales v y 4 mrv. en portes de trigo

- Botica ........................ (Sin contabilizar)

- Agua ......................... 400 reales v por 9 meses del agua de la comunidad Junio de 1824

- Vestuarios................... 96 reales $v$ por los vestuarios para las festividades de la Iglesia

- Gastos de Iglesia.......... 31 reales v y 20 mrv. Gastos en arreglos de algunas cosas de la sacristía y una propina para el sacristán

- Herraje. 26 reales pagados 
- Dado a las religiosas..... 1438 reales v

- Limosnas.

82 reales $v$ a las tropas de Alba distribuidas así:

30 reales a unas pobres mujeres

20 reales a la casa santa

20 reales a los Padres Franciscos

8 reales a una que quería ser religiosa

- Extraordinarios.......... 1550 reales v a 100 reales a 11 monjas de coro y 50 reales a otra hermana

- Gastos menores ........... 90 reales v para gastos menores

- Obras del Convento....... 257 reales v. gastados así:

- Paredes y tejado de las Carboneras

- Blanqueado y enladrillado el Coro

- Al Carpintero por arreglar balcones y puertas

- Escritorio.................. 13 reales v y 18 mrv en papel y cosas de caligrafía.

Otro tipo de gastos son los que ocasionaba la profesión y/ o el enterramiento de alguna religiosa. Si la fallecida era la Abadesa, los gastos se incrementaban. Observemos un ejemplo de este aspecto:

Ubicándonos en el año de 1837, con el fallecimiento de la Abadesa del Monasterio de Santa María de las Dueñas, lo cual ocasionó el siguiente cargo y data:

\section{CARGO}

- Depósito: Docientos reales vellón (240 rles v)

- Pensión: Ciento veinte reales vellón del mes de Abril (120 rles v) cobrada en el mes de Mayo.

- Prorata: Cuarenta y cuatro reales vellón por los 11 días del mes de Mayo que la Abadesa alcanzó a estar con vida. (44 rles v)

- Expolio: Quinientos treinta y dos reales vellón de la venta de los efectos del expolio de la Sra. Abadesa, (532rles v) para un total de Novecientos treinta y nueve reales vellón (936 rles v) 
DATA

- Entierro del cadáver de la Abadesa: Cuarenta reales vellón (40 rles v) (caja)

- Abrir y cerrar la sepultura: Diez y seis reales vellón (16 rles v)

- Cera para el funeral : 28 reales vellón (28 rles v)

- Clerecía: Noventa reales vellón (90 res v) pagados al Abad, por la asistencia de su comunidad al entierro de la Abadesa

- Sacristán: diez y seis reales vellón (16 rles v) pagados a los sacristanes por tañer las campanas y asistir con las cruces parroquiales a este entierro.

- Misas de Novenario: Cuarenta y cinco Reales vellón (45 rles v) pagados por las nueve misas aplicadas por el alma la Sra.Abadesa

- Alumbrado: Cuatro reales vellón (4 rles v) por el alumbrado del Santísimo Sacramento

- Cofradía: Dos reales vellón (2 rles v) pagados a la Cofradía de Santa Lucía por la asistencia a este entierro

- Lavandera: Cinco reales vellón (5 rles v) por el resto de su cuenta

- Misas rezadas (40): Ciento sesenta reales vellón (160 rles v)

- Misas rezadas (19): Setenta y seis reales vellón (76 rles v)

- Misas rezadas (15):Sesenta reales vellón (60 rles v)

Total: 542 reales vellón

Estos gastos correspondían a la cuenta del caudal propio de la Sra. Abadesa en la que se aúnan el depósito, la pensión y el expolio.

Ahora, es menester hablar sobre los sueldos pagados a las distintas personas que trabajaban para el Monasterio, en diferentes épocas:

Hacia 1671- siglo XVII, eran así: 


\section{En el año de 1675113}

"Mayordomo" 15 fanegas de trigo por su salario.

“Capellán” 10 fanegas de trigo por el año de esta cuenta.

"Sacristán" 4 fanegas de trigo pagadas por el año de esta cuenta.

"Cirujano" 6 fanegas de trigo por su salario.

"Criada de la cocina" 4 fanegas de cebada.

"Mozo del carro" treinta y siete fanegas y media de trigo.

"Guarda de Bueyes" una fanega de trigo.

"Demandadera" 9 fanegas de trigo.

\section{En 1774, un siglo después: 114}

“Capellán Mayor" 600 reales.

"Capellanes menores" (2) 60 reales a cada uno.

"Sacristán" 176 reales.

"Médico" 300 reales.

“Criada de la cocina" $671 \frac{1}{2}$ reales.

“Lavandera” 73 reales.

"Señora cantora” 168 reales.

\section{De 1 de Agosto de 1873 hasta julio de 1874 un siglo después:}

“Lavandera" .......................... 1.020 rls. Por 12 meses, a 85 rls. Cada un mes

"Panadero"..........................26 fanegas de trigo a 24 rls y $1 / 2$

"Sacristán" .......................... 132 rls. a razón de 11 rls. cada mes

"Médico" ......................... 300 rls pagado de iguala al médico, cirujano y

Boticario.

"Criada"............................. 300 rls. a razón de 20 rls quedan pagados 15 meses

“Demandadera" .................. 132 rls por todo el año a razón de 11 rls. cada mes 
"Aguador".......................... 280 rls. por todo el año115

¿Porqué se pagaba en especie, vale decir: trigo, cebada, centeno, incluso algunos pagos a las monjas - músicas se hacían con huevos?

Para evitar la devaluación de la moneda, se procedía a pagar en especie. Esta forma de pago - a la figura del Maestro de Capilla -, también se puede encontrar en las cuentas relacionadas en los Libros de Cuentas de la Catedral de Salamanca.

\section{GASTOS RELACIONADOS CON LA MÚSICA}

Anteriormente reflexionamos sobre la importancia que la música tiene al interior de los Monasterios, ya que la Regla o Constituciones así lo disponen y porque la música ha estado siempre presente y al servicio de la Liturgia. Llegando a este importante apartado, iniciamos por los límites cronológicos del trabajo, siglo XVII. Dando un paseo por los Libros de cuentas de los siglos correspondientes, vemos que existen en los Monasterios, infinidad de referencias dinerarias relacionadas con la música, como la compra de instrumentos musicales, pagos a las Organistas y cantoras, compra de cuerdas y materiales para los instrumentos de cuerdas, como arpas y violines, compra y arreglo de órganos, lo que demuestra que la actividad musical era muy significativa. En el Monasterio de Santa María de las Dueñas, la trascripción de los libros de cuentas de la comunidad correspondientes entre los años 1671 y 1690 realizada por Rosa Sánchez Arroyo y cuyos originales reposan en el Archivo Histórico Nacional, se encontraron las siguientes reseñas sobre dineros asignados para a la música, referentes al año 1671.

\section{- Pago a dos organistas:}

“Descargo en Dalta

Raciones - mas quince dogo cinco fanegas y quince libras y media de la racion de las dos organistas desde quince de enero hasta primero de agosto importan

115 ASMD. Libro de cuentas: Años 1865- 1876. 
docientas y noventa y cinco libras y medias y estas las dichas fanegas 005 fs 15 lib"116

\section{- Pago a monjas cantoras:}

"Extraordinarios

Más se le reciben en cuanta nueve fs. y tres zs de to que en todo el año desta cuenta se han gastado en extraordinarios con los carpinteros, sacristía, sacristanas, profesión de la cantora, limosnas y ofrendas."117

\section{- Compra de un órgano:}

"Item. Dos mil ciento y sesenta y cinco mvs. Que se pagaron al Sr. Juan Antonio (...) por la mitad del valor del órgano que vendió a esta comunidad los que van cargados y se sacaron del archivo porque la otra mitad la dio de limosna dicho Dn J uan Antonio de esta comunidad 20165 (...)"118

\section{- Arreglo del órgano del Coro bajo:}

"Idem. Y un trecientos cuarenta Mvs. que tuvo a costar el componer el órgano viejo pequeño para el coro bajo 340"119

\section{- Arreglo del órgano:}

"Se pagaron 2.000 reales a los organeros que hicieron los fuelles del órgano, teclas que faltaban y afinarlo"120

\section{- Pago para el organista:}

“Pago de dos fanegas y media de cebada para el Organista." (002 fs.6 zel)121

Del siglo XVIII, infinidad de datos sobre el mismo tema de interés, se encontraron en el Archivo de este Monasterio y es así como encontramos las siguientes referencias:

\section{- Arreglo del órgano:}

"Son datta doscientos veinte nueve reales y veinte y ocho maravedíes que en el año de esta cuenta se han gastado en esta forma 157 reales pagados a Don Roque Lara organero por veinte dias que gasto en componer el organo incluidos veinte y

116 Libro de Cuentas de las Benitas de esta Villa de Alba de Tormes. № 10408, año 1671, p. 7.

117 Ibídem. Año de 1671, p. 13.

118 Libro de Cuentas. Año de 1766, p. 184.

119 Libro de Cuentas. Año 1750- 1753, p. 184.

120 Libro de Cuentas. Año 1774- 1797, p. 95 v.

121 Ibídem. Año de 1671, p. 9 de la trascripción. 
cinco reales de valdeses, cola y yerros el dicho, y veite reales de guantes - 66 reales y 229 (...)"122

Se encuentra en sus libros de Cuentas la relación de documentos que dan crédito por la compra de un órgano: Mediante un oficio fechado el 26 de abril de 1766, el Obispado de Salamanca autorizó a la Comunidad de las Benedictinas de Alba de Tormes, la compra de un nuevo órgano para los oficios religiosos. El manuscrito, a la letra dice:

\begin{abstract}
"Sra. Abadesa:
Muy Señora mía: Al Ilustrísimo mi Señor le ha parecido bien y aprueba el convenio últimamente hecho por esta Comunidad con Don J uan Antonio de Oviedo, de que se retenga los dos mil ciento sesenta y cinco reales vellon mitad del coste del órgano que la ofreció de limosna sin carga alguna y le entregue la otra mitad en dinero, respeto a no querer hacer ya fundación alguna; como Ud. me significa en la suya del 25 del corriente. Y deseando SS.J. se lleve cuanto antes a su debido efecto con las formalidades correspondientes, da y concede a Uds y esta su Comunidad, la facultad y Licencia para ello necesaria y tambien para poder sacar del Archivo los dos mil ciento sesenta y cinco reales que han de entregarse al dicho Don Juan Antonio, con la condición que si proceden de dinero que debe emplearse y darse a renta en beneficio de la Comunidad, se vaya remplazando de esta cuantía del sobrante de las rentas anuales de ella en dicho Archivo, y de modo que le sea menos gravoso hasta su total reintegro. Póngalo en noticia de Ud. de orden de este Señor, para su inteligencia y cumplimiento y me ofrezco a la disposición de Ud. estimando las afectuosas expresiones que se sirve dispensarme en su favorecida del 25 del corriente y dando a Ud. gracias por la remesa de los 30 maravedíes de las dos licencias. Nuestro Señor que de a vuestra merced salud como deseo y le suplico. Salamanca. 26 de Abril de 1766. B.G.M. de Ud. J uan Crisóstomo Simancas. Secretario.”123
\end{abstract}

$\mathrm{Al}$ reverso de este documento se encuentra el resguardo de la compra del órgano, firmado por Don Juan Antonio de Oviedo, a mayo de 1766. En relación con la existencia de un instrumento musical tan importante y esencial como el órgano, en

122 ASMD. Libro de cuentas. Años 1774 - 1797, p. 255v.

123 ASMD. Oficio del Obispado a las Benedictinas de Santa María de las Dueñas, autorizando para que se pague a J uan Antonio de Oviedo el coste del órgano. 26 de abril de 1766, leg. № 9. 
esta clase de instituciones monacales, en el manuscrito ilustrativo que se ofrece a continuación, se puede corroborar la gestión realizada para la obtención del instrumento y por ende la concesión de la facultad y licencia para ello otorgada a la Abadesa del Monasterio, Doña Beníta de Oviedo por el Obispado de Salamanca. De tal manera, este es el único manuscrito, que de una época ya más allá del barroco - siglo XVIII-, se encuentra en los Archivos de este monasterio. Sin embargo y como se dijo anteriormente, los libros de cuentas nos ilustran sobre los pagos realizados a un organista y a monjas organistas que en plena época barroca, considero, desplegaron una importante actividad musical, sin existir documento alguno manuscrito que permitan conocer más a fondo esta actividad.

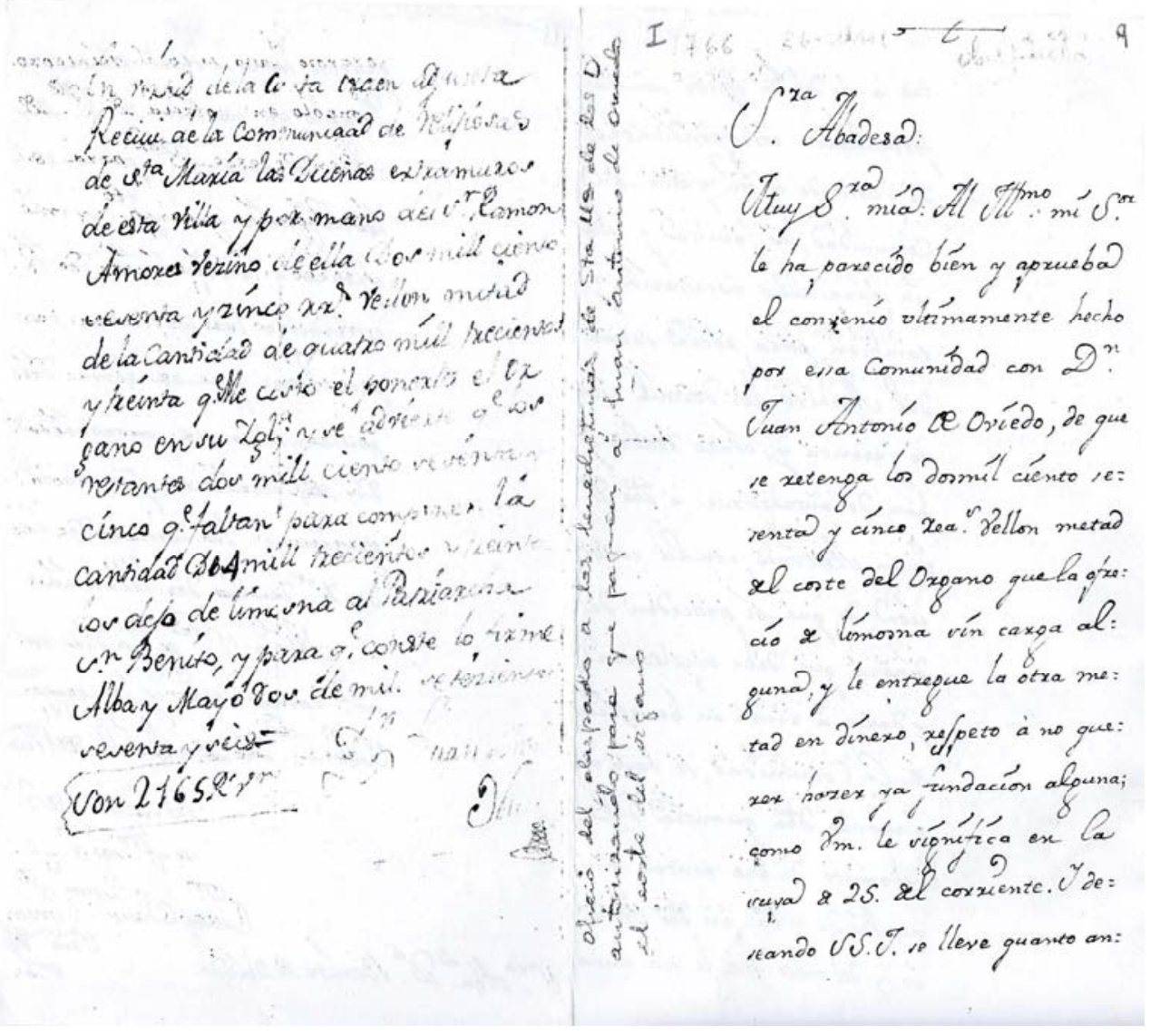

9. Manuscrito de la compra de un órgano para el Monasterio de Santa María de las Dueñas de Alba de Tormes - Salamanca. En el año de 1766. ASMD. 


\section{Pago a monjas cantoras:}

“Pago a monjas cantoras: 188 reales pagados a Doña Ángela Collantes y a Doña Catalina Gato"124

10. Pago a monjas cantoras:

"Pagado a la cantora 187 reales por concepto de su salario"125

"Pagado a la cantora 184 reales por concepto de su salario" 126 


\section{CAPÍTULO III}




\section{CAPÍTULO III}

III. LA ACTIVIDAD MUSICAL EN LOS CONVENTOS FEMENINOS DE ALBA DE TORMES

III.1. EVOLUCIÓN DEL PAPEL DE LA MONJA MÚSICA DESDE EL SIGLO XVII HASTA LA ACTUALIDAD

\section{III.2. VIDA CONVENTUAL FEMENINA EN ESPAÑA}

- Monasterio de las Madres Carmelitas (Alba de Tormes - Salamanca)

- Monasterio de Santa María de las Dueñas (Alba de Tormes - Salamanca)

- Monasterio de “Santa Clara de Carrión de los Condes” (Palencia)

- Monasterio de la Madre de Dios de Constantinopla (Madrid)

- Monasterio Cisterciense de Santa Ana (Ávila)

- Monasterios de Dominicas y Carmelitas descalzas (Salamanca)

\section{III.3. MONJAS MÚSICAS DESTACADAS}

MONASTERIO DE SANTA MARÍA DE LAS DUEÑAS

- ÁNGELA COLLANTES

- CATALINA GATO

- ISABEL GARCÍA QUINTANA VERDUGO

- ISIDRA SANTOS

- ANTONIA MARTÍNEZ

- ESCOLÁSTICA CAMPOS

- JOSEFA MARTÍN Y MARTÍN

- JULIANA DEL CORZÓN DE JESÚS

- DOLORES QUINTANA Y SÁNCHEZ 


\section{CAPÍTULO III}

\section{LA ACTIVIDAD MUSICAL EN LOS CONVENTOS FEMENINOS DE ALBA DE TORMES}

\section{III.1. EVOLUCIÓN DEL PAPEL DE LA MONJ A - MUSICA DESDE EL SIGLO XVII HASTA LA ACTUALIDAD.}

A manera de introducción, se puede señalar que la música como una de las Bellas Artes, ha ido progresando junto con la vida misma; el papel femenino en todo este proceso ha sido fundamental $\mathrm{y}$, al igual que la música, la mujer también evolucionó y ha desplegado dentro de este arte con grandes dificultades, rompiendo importantes fisuras marcadas por las diferencias de género prevalecientes en la antigüedad y que paulatinamente se han podido fraccionar; si bien no en su totalidad, pero sí de forma tal que le han permitido desarrollarse en este ámbito, tanto como ejecutante de todo tipo de instrumentos y compositora y, en general, como una artista de la música. Los Monasterios desde remotos tiempos, albergaron en sus espacios, a mujeres que solo ahí, alejadas del mundo profano, pudieron desenvolverse con propiedad y solvencia, en el arte de la música, el cual traían adquirido desde su infancia.

Hablar de este tema es muy significativo; en la actualidad existen muchas instituciones, y personas que se han dado a la tarea de investigar sobre el papel que juega y ha jugado la mujer a lo largo de la historia, dentro de diferentes campos del conocimiento, pero merece ahondar la investigación en el rol desarrollado por esta, en el arte de la música al interior de los Monasterios, ya que la figura femenina unida a la vida monacal, aporta considerablemente datos sobre vivencias inéditas en torno a su desempeño musical. Concebir el Monasterio como un espacio de quietud, de contemplación y oración no es lo propio; sí, muchas llegaron empujadas por diversas causas, - aunque lo conocido es que la gran mayoría llegó por vocación -, pero que importante fue para ellas, este espacio. 
Importantes figuras femeninas en los Monasterios iniciaron su camino en diferentes artes como la Literatura, la Poesía, la Música, la Pintura, pero al mismo tiempo fueron frenadas por sus propios superiores; varios casos conocemos, pero recordemos el de Sor Juana Inés de la Cruz, llamada en su vida real, Juana de Asbaje y Ramírez de Santillana. Nacida en 1651 en México, (+1695), de padre vasco y madre mexicana, que ingresó en la Orden de San J erónimo a los 17 años y de ahí hasta sus últimos días. Escritora y poetiza. La historia nos dice que su saber iba tan lejos, que fue obligada por sus superiores, a dejar sus escritos y entregar por completo su biblioteca, que constaba de 4.000 volúmenes, para ser vendida y destinar este dinero a obras benéficas. Tenía amplios conocimientos musicales, creando un Tratado de Teoría Musical, al que llamó "Caracol", el cual versaba sobre asuntos puramente teóricos. Lo anteriormente expuesto, nos ilustra sobre la concepción o criterio, que en aquellas épocas, se manejaba respecto a la figura femenina y sobre el malestar existente acerca de sus talentos. Fuera de los Monasterios, la mujer desde la época antigua hasta bien entrado el siglo XX, se limitaba a formar parte del adorno familiar; si se le proporcionó el aprendizaje de para la interpretación del órgano, se le permitió tomar clases de canto llano y Teoría musical con un profesor o Maestro de Capilla, pero el objetivo en cierta forma y en muchos casos, fue formarlas para su ingreso a un Monasterio, solucionando de esta manera una situación familiar y proporcionando un proyecto de vida para la mujer. En el caso de aquellas que destacaban por su talento o sobresalían por sus capacidades intelectuales, no les era permitido mostrar en público su calidad interpretativa o compositiva, quedando confinadas finalmente entre cuatro paredes. Por otro lado, las hubo, que contando con un enorme talento y que a pesar de verse limitadas para desarrollarlo, se valieron de diferentes recursos para poder continuar con su labor en la composición y ejecución. Ya este empuje y el destacar, se vio entrado el siglo XVIII y el XIX.

Volviendo la mirada hacia el Renacimiento, - sin adentrarnos tan rigurosamente en lo estrictamente histórico -, por ser cuestiones ya conocidas, sabemos que es una etapa históricamente importante en lo cultural; en este momento, hay una tendencia hacia lo mundano, que depone el sentir ascético que dominaba hasta entonces. Será a partir de este momento cuando ya cobrará fuerza el redescubrimiento del hombre como individuo, el redescubrimiento del mundo 
como armonía y realidad que rodea al hombre liberado de todas las preocupaciones religiosas. El Renacimiento es ante todo, un espíritu que transforma no sólo las artes, sino también las ciencias, las letras y las formas de pensamiento. En su conjunto se ha visto una clara rebeldía al espíritu teológico de la Edad Media, sin embargo la ruptura no se produce de manera violenta porque no pocas de las concepciones que se van a desarrollar tuvieron su origen durante el medievo, y esto es claramente apreciable en el terreno artístico. Se inició en Italia, pero además, el Renacimiento del siglo XV se da solo en este país. Se puede decir que en Francia, España y Alemania solo hacia 1450/1500 se conoce este movimiento, pero no se despliega plenamente sino hasta el siglo XVI. Ahora, la figura del hombre es el centro de del universo. El humanismo es el dominador en este momento.

Hablando en términos generales, analicemos cómo evolucionó la mujer dentro del ámbito primeramente social y luego en lo conventual, tanto en lo personal, como en lo artístico. Esta evolución se puede ver desde dos puntos de vista, así: En primer lugar, lo social: las creencias religiosas, las supersticiones, la mística, la literatura, el arte, figuran como un conjunto de creencias y que reinaban dentro de la sociedad de los siglos XVI y XVII. Muchas mujeres monjas ya fuese en España o Hispanoamérica fueron músicas, pintoras, escritoras, poetas y destacaron a contramarea. Concha Torres en su obra: La clausura femenina en Salamanca en el siglo XVII, citando a Bennassar, nos dice al respecto:

“Hay autores que afirman que la extravagancia femenina en materia religiosa fue mayor que la masculina: quizás fuese así, para que ellas se hiciesen valer en un mundo dominado por los hombres (...)"127

Ya es conocido lo conflictivo de la época en cuestiones religiosas que invadían la vida espiritual y social de las gentes. Ya vimos en el capítulo de la vida personal de las monjas músicas, como para que una mujer pudiera acceder a un puesto de organista o cantora, era primeramente examinada por un tribunal conformado por hombres, entre ellos, los maestros de capilla de las Catedrales, los organistas y

127 TORRES SÁNCHEZ, Concha. La clausura femenina en la Salamanca del siglo XVII Dominicas y Carmelitas descalzas. Salamanca: Ediciones de la Universidad de Salamanca, 1991, p. 31. 
hasta un Arcediano o delegado del Obispo, quienes daban su última palabra y firmaban un acta de examen. La inferioridad de la mujer se quería demostrar el todos los campos; su incapacidad moral, jurídica y política. En lo moral porque en estas épocas, solo se mostraba a la mujer como símbolo de perversión en la sociedad, el lo jurídico, porque el reglamento sobre la figura femenina está fijado por las leyes matrimoniales y basado en función de algo tan restringido como es "la dote" y en lo político se la consideró incapaz de pensar con inteligencia sobre los asuntos que atañen a la organización y sostenimiento político de un país. En la historia varias mujeres se impusieron y entre ellas podemos nombrar a dos grandes protagonistas: Isabel "La Católica" en España e Isabel I en Inglaterra. Desde su Monasterio, destaca Sor María de Agreda con su influencia sobre el Monarca Felipe IV. Santa Teresa de J esús, mujer talentosa, decidida, de firmes convicciones y de una entereza extraordinaria.

Ya en el Capítulo sobre la Vida Conventual, vimos y desglosamos los cargos que desempeñó la mujer al interior de los monasterios y pudimos apreciar lo importante de cada uno de ellos, sobre sus funciones y competencias. El espacio para la mujer y en especial para la mujer -música de convento, se fue abriendo gradualmente, en los Monasterios y con más razón al encomendárseles la educación; la monja pudo tener contacto más directo con las gentes y al tener este contacto directo con la infancia y la juventud, pudo llegar a ellos por medio de la música; se abrieron para ella aún más las posibilidades para desarrollar su talento y expresar con la música de forma más abierta, sus creaciones y sus interpretaciones. En segundo término, los cambios realizados en referencia al idioma utilizado en la liturgia, proporcionó, el acercarse aún más al pueblo; el latín en cierta forma, limitó en su momento el acercamiento, por cuanto el pueblo llano, no lo sabía, ni lo comprendía fácilmente. Varias religiosa consideradas destacadas o de vida ejemplar, nos las muestra el Libro de Crónicas y las notas relacionadas en las indicaciones de sus fallecimientos, que reposan en los Archivos conventuales. Cada virtud o cualidad es relacionada resaltando por lo general las buenas acciones humanas y su espiritualidad, sus talentos y su desempeño en el Monasterio a través de su vida. La disposición de los Archivos conventuales ha ayudado mucho a determinar quiénes eran aquellas mujeres destacadas y en especial las monjas músicas enfatizadas. 
Ahora, analizando el tema desde el punto de vista del desempeño artístico de la mujer, desde la interpretación instrumental y/ o vocal y la composición, se puede decir que siendo en un principio la música concebida para ser interpretada dentro de los Monasterios expresamente para la liturgia y el culto divino en general, esta quedó inicialmente inscrita dentro de estos recintos, sin embargo, paulatinamente fueron saliendo de los claustros para llegar a divulgarse en otros ámbitos, inicial y principalmente en los ámbitos religiosos. Pero los repertorios musicales ya fueran estos compuestos por las monjas mismas o por compositores o maestros de capilla, muchos investigadores se han interesado por el tema y han sacado a la luz aquellos que en su momento conformaron la vida musical de los Monasterios, una vida rica en expresiones artísticas. A la mujer como compositora, se la conoce desde los tiempos de la Abadesa Hildegard von Bingen, Benedictina: Una Visionaria en el Medioevo. Aunque el mundo de la composición musical ha estado reservado a los hombres, desde la mencionada Abadesa en el Medioevo, hasta nuestros días ha habido una serie de mujeres que han roto con las normas y han dedicado su vida a la música. Reinas, nobles, burguesas, monjas y toda clase de mujeres han desafiado al hombre en este sentido, sin que su talento, dedicación y su esfuerzo hayan sido reconocidos. Veamos lo que se dice de la Abadesa alemana 128:

128 “En pleno siglo XII, la abadesa Hildegard von Bingen dedicó los ochenta años de su vida a contrariar con astucia y sutileza los mandatos opresivos de su época. Entregada a los diez años como diezmo a la Iglesia, Hildegard fue una visionaria, escribió sobre teología, pregonó el herbalismo, se carteó y polemizó con Papas, compuso música de avanzada y fundó en Rupertsberg su propia abadía, una suerte de comunidad femenina donde las monjas daban rienda suelta a sus talentos artísticos, aprendían a cantar, copiaban e ilustraban manuscritos, hacían gimnasia y bebían cerveza. (Hildegard adoraba las mejillas ruborizadas.) Su credo era dinamita: promovía la igualdad de géneros, negaba que el placer sexual fuera fruto del pecado y sostenía que la sangre que verdaderamente manchaba no era la de la menstruación sino la que derramaban las guerras. Hildegard nació en Bemersheim (Alemania) en el valle del Rin, el año 1098, y en el seno de una familia noble alemana. Fue la menor de diez hijos, estando así, destinada a la Iglesia. Desde muy niña, Hildegard sufrió visiones que más tarde la propia Iglesia confirmaría como inspiradas por Dios. Estos episodios, descritos como una gran luz que la rodeaba, la dejaban muy mal e incluso la cegaban temporalmente. Sus padres preocupados decidieron entregarla totalmente al convento benedictino Disibodenberg, que se encontraba bajo la órdenes de Jutta, quien se encargó personalmente de la educación de Hildegard. Así, tuvo un profundo aprendizaje en latín, griego, liturgia, música, oración y ciencias naturales, y además una disciplina asceta. A los dieciocho años, Hildegard toma los habitos bendictinos. En 1136, Jutta murió y Hildegard -a pesar de ser muy joven- asumió el mando del convento. A la edad de cuarenta y dos años, le sobrevino el despertar religioso, el episodio de visiones más fuerte que tuvo, y durante el cual recibió la misión de predicar sus visiones y la comprensión religiosa que le había sido otorgada. A partir de ahí, Hildegard escribe sus experiencias. De los nueve libros que escribió, se destacan Scivias - de corte místico -, Liber Vitae Meritorum -sobre ética- y Operatione Dei -sobre teología-. Otro de sus libro, el Liber Simplicis 
El Monasterio de Santa María de las Dueñas de Alba de Tormes, guarda entre sus repertorios una copia manuscrita de una Misa en Latín de Hildegarda de Bingen, la cual incorporo en los anexos del trabajo.

En varias referencias al tema, algunos autores relacionan que hubo alguna otra monja música que como Sor Hildegarda, compuso motetes religiosos:

“Conocemos el nombre de la Madre Gracia Bautista (siglo XVI) que aparece citada junto a grandes personalidades de la música sacra española del Renacimiento, pero de ella solamente se conserva una pieza."129

Esto ha dado pie a algunas para pensar que fueron más las que compusieron en los conventos, pero aún falta una investigación detallada. Conocer historias concretas ayuda a resplandecer a las anónimas... Pero todo esto ocurre también con los cuadros y otras creaciones artísticas. Haciendo un fugaz repaso al tema, veamos

Medicinae es importantísimo para la medicina, pues en el se hace un acercamiento a la ciencia de curar desde la perspectiva olística, incluyendo conocimientos de botánica y de biología. De la misma forma, el Liber Compositae Medicinae trata sobre las enfermedades, pero desde el punto de vista teórico y explica sus causas y síntomas. Pero, Hildegard no sólo se dedicó a escribir, si no que además compuso música y escribió setenta y siete canciones aproximadamente, y una ópera Ordo Virtutum, por la cual se ha dicho que la compositora fue más allá de las normas de la música medieval y le otorgó un nuevo lenguaje. Es por esta época, que un comité de teólogos del Vaticano legitimó sus visiones y sus mensajes, que para muchos eran predicciones del futuro, aunque ella lo negara y dijera que más bien era una proyección del presente. Tal fue su reconocimiento, que llegó a ser conocida como la "Sibila del Rin". En este momento, la gente la buscaba para escuchar sus palabras de sabiduría, para curarse o para que los guiara. En cuanto a su relación con la Iglesia, no siempre fue amorosa, pues Hildegard atacó seriamente las costumbres de ésta y la denunció por corrupta y por no seguir los preceptos de compasión realmente. Además, la desafiaba constantemente y en una época en que no había duda de la culpabilidad de Eva, ella se limitó a decir que Eva no había cometido falta, sino que era una víctima engañada por Satán, quien le envidiaba a la mujer su capacidad de dar vida. Por si fuera poco, se atrevió a visualizar el acto sexual como una unión espiritual que iba más allá de la procreación.

La relación con la Iglesia alcanzó su crisis, cuando Hildegard y las monjas del convento Rupertsburgo que ella había fundado (se llama así por un santo del que ella escribió la biografía) le dieron sepultura en el cementerio de su convento a un joven revolucionario, que había sido excomulgado por el arzobispo. Así, según la Iglesia el joven no merecía santa sepultura, pero Hildegard insistía en que él se había arrepentido. Se negó a desenterrarlo e incluso hizo desaparecer cualquier rastro de entierro, para que nadie se atreviera a buscarlo. Este problema le acarreó a Hildegard y a todas las mojas a su cargo una prohibición de hacer música. Ella muy molesta, le escribió al Arzobispo una carta bastante dura en las que se lamentaba de la "perdida" que esto significaba para todo el Rin y además amonestaba a la autoridad eclesiástica. La Iglesia decidió perdonarla y pocos años después, esta polifacética y mística mujer murió. Hubo varias tentativas de canonizarla, y aunque esto nunca se llegó a dar, popularmente se reconoce como santa e incluso el Papa J uan Pablo II la reconoció como "una mujer santa

129 ". Leer en Internet: http// : www.mundo historia. Citado por María J osé Arana."Mujeres en la Historia" <http:// www.nodo50.org/mujeresred/historia - mj_arana.htpl> (consultada el 14 de marzo del 2006). 
desde tiempos remotos: en la Edad media, Hildegarda de Bingen, en el Renacimiento: Tarquinia Molza, Madre Gracia Bautista, Francesca Caccini, Isabella Leonarda, en el Barroco: Élisabeth J acquet de la Guerre, Bárbara Strozzi, Nannerl Mozart, Fanny Mendelssohn y desde el Romanticismo a la época

Contemporánea, mujeres tan importantes como: Clara Schumann, Carlotta Ferrari, Andrea Elfrida, Ángela Peralta, Teresa Carreño, Alma Mahler, Lily Boulanger, Nadia Boulanger, Germaine Tailleterre, Claude Arrieu, Alma Rosé, Mely Duver, Rosario Marciano, todas y cada una talentosas en la interpretación y en la composición, muchas de ellas debieron someterse a que los hombres de su entorno artístico o familiar firmaran por ellas, apropiándose tristemente de sus composiciones u obras de arte y quedando ella relegadas a un segundo plano.

En nuestros actuales tiempos, con la apertura de los monasterios a la vida que puede llamarse más "pública" en que el contacto con las gentes es más directo gracias a ello - se han abierto una serie de posibilidades a la producción y divulgación de la música y de las mujeres músicas. De varias monjas que hacen poesía y/o componen, sus obras han sido grabadas y divulgadas por sellos discográficos. Su música llena de mensajes que invitan a la convivencia pacífica, a la paz interior, dirigidos a la infancia y a las juventudes, entre otros temas, llegan a las gentes con gran facilidad, mientras su talento poco a poco va siendo reconocido. Del Monasterio de Santa María de las Dueñas de Alba de Tormes, varios ejemplares de producción discográfica relacionamos anteriormente.

\section{III.2. VIDA CONVENTUAL FEMENINA EN ESPAÑA}

$\mathrm{Si}$ las aproximaciones a la vida conventual femenina, realizadas por diferentes entendidos en la materia - por citar algunos como: Francisco J avier Lorenzo Pinar, J esús Paniagua Pérez, Matilde Olarte Martínez, Concha Torres Sánchez, Isabel Viforcos, Mariló Vigil, J osé L. Sánchez Lora, María J ulieta Vega García - Ferrer, Alfonso de Vicente, Collen R, Baade, Soterraña Aguirree Rincón -, por razones conocidas ya presentan ciertas lagunas de las fuentes documentales, qué se puede decir de las dificultades que se tienen al investigar respecto a la vida musical de los 
Monasterios femeninos en general y en especial los de Alba de Tormes. Pese a ello, se han realizado valiosas investigaciones y en el presente trabajo, las fuentes halladas en los Monasterios de Alba de Tormes - Salamanca, han sido objeto de motivación y han brindado gran material documental para desarrollar un interesante labor investigativa y de análisis comparativo tanto de la vida monacal como la vida musical de los Monasterios femeninos españoles y de Hispanoamérica. Habiéndose dado durante épocas coloniales - especialmente durante los siglos XVII, XVIII y los albores del XIX -, la traslación de la cultura, costumbres e ideologías desde España y Europa en general, hacia tierras americanas, aquellas aportaciones tuvieron eco y se arraigaron en el seno de la naciente sociedad mestiza.

Iniciaremos estos razonamientos, teniendo en cuenta los siguientes parámetros: la vida monacal y la vida musical.

Para comenzar este análisis comparativo, en primer lugar es preciso recordar la demarcación de los límites cronológicos en que se encuadra la presente investigación; partiendo del siglo XVII, se han obtenido con suerte, valiosos conocimiento sobre la Fundaciones y sobre la vida conventual de la gran mayoría de los Monasterios ya citados. Para la investigación, los siglos XVIII y XIX, se presentan con mayores posibilidades investigativas, - apuntando a aquellas lagunas cronológicas en cuanto a documentación se refiere -, que han permitido conocer más a fondo la vida conventual y la influencia del pensamiento de cada época al interior de los mismos.

Incluso, es preciso apuntar hacia aquella curiosidad innata que se tiene por lo más remoto; el interés por escudriñar en lo profundo del tiempo y de la historia, llama la atención; saber cómo fue la vida cotidiana de las gentes y especialmente la vida de las mujeres que conformaron en su momento un grupo heterogéneo en el que convergían, doncellas, niñas de corta edad, viudas, casada, separadas, etc.. Mariló Vigil nos presenta los Monasterios como “(...) aparcamientos de mujeres”.130 
En los estudios realizados por los investigadores ya citados, se puede observar que estos están centrados en la vida monacal del siglo XVII; las pesquisas revelan el interés por la vida cotidiana de las mujeres en una época considerada concretamente difícil para ellas y en la que por medio de la investigación se ha llegado a conocer los mecanismos utilizados por las mismas, para oponer resistencia férrea a las formas de dominación masculina y de oposición familiar. Sin embargo, en las Actas del I Congreso Internacional del Monacato femenino en España, Portugal e América, los límites cronológicos de este amplio espectro investigativo, abarcan desde el año 1492 hasta el 1992; así que, de varios ponentes encontramos interesantes aportaciones en torno a la vida monacal en diferentes conventos.131

Entre las mujeres llamadas al servicio divino, las hubo dotadas de inteligencia, de saberes, y curiosidad intelectual, que prefirieron el aislamiento conventual por muchas razones y con variados objetivos, entre ellos: las mujeres nobles por citar un ejemplo, tenían, además, el convento como lugar placentero en la viudedad, en la orfandad o en el desamor, de ahí que en Madrid, se puede presumir de Fundaciones conventuales reales, magníficas. El claustro, para la mayoría de los frailes y las monjas, era una carrera, una profesión, un proyecto de vida, una salida. Naturalmente que no eran infrecuentes las vocaciones auténticas porque la idiosincrasia, el aire del siglo, era religioso como el de nuestros tiempos es científico y/ o técnico. Muy bien lo dice Octavio Paz en su extraordinario ensayo, publicado en 1982, - el cual tiene un triple carácter: histórico - sociológico, literario y biográfico - sobre la asombrosa Sor J uana Inés de la Cruz, cuando advierte que la vocación religiosa proporcionaba ocupación y destino a miles de mujeres (y de hombres) que de otra manera se habrían encontrado sin acomodo, siendo, además una manera de respuesta social a través de la beneficencia, la caridad, y la enseñanza que las distintas Ordenes ejercían.

La vida conventual de clausura, aunaba innumerables cuestiones, relacionadas con la vida cotidiana, con la liturgia, la espiritualidad, la Regla, la música, la economía; sus miembros celebraban con música los grandes días de solemnidad 
religiosa, también había festejos del siglo como comidas, cantos, bailes, y hasta representaciones teatrales, y no faltaban las visitas. Las monjas no perdían las costumbres o habilidades sino que aumentaban lo que era característico de sus "hermanas en el mundo" como hacer dulces, potajes, licores, bordaban, si bien en estas labores caseras eran ayudadas por el gran número de monjas legas, discretas o depositarias que servían a las profesas, para no distraerlas de su vida contemplativa, entre sus oficios. Dedicaban tiempo a la lectura de obras espirituales, sacando temas para sus meditaciones y sus propios escritos.

Al comienzo del trabajo, deseando realizar una investigación concreta limitada a unos órdenes cronológicos, pensados, preestablecidos y enmarcados en el siglo XVII en el trascurso de la labor, la lectura de las fuentes, nos llevaron a ampliar paulatinamente aquellos límites por cuanto en estos Monasterios Albences, la vida musical, y los datos que producían más interés en torno al tema -, se encontraron en mayor volumen, relacionados, correspondientes a siglos posteriores. Ya se comentó anteriormente y en primer lugar, sobre el desconocimiento total de las fechas y personajes fundadores del Monasterio de Santa María de las Dueñas (Alba de Tormes), no así lo que se conoce sobre el proceso de la Fundación del Monasterio de la Anunciación de Alba de Tormes, Fundación directa de Santa Teresa de Jesús y de Don Francisco Velázquez y su mujer Teresa de Laíz.

Siendo este trabajo pensado con un enfoque hacia la vida conventual y musical de los Monasterios Albences, la organización de las temáticas sobre la vida monacal, incluidos los procesos fundacionales y referencias recogidas sobre la vida personal de las monjas músicas, lo recogido sobre las cuestiones de hacienda relacionadas con la música, la vida diaria, Liturgia y Festividades, tuvieron un punto de apoyo importante en las obras bibliográficas relacionadas y consultadas como referente investigativo.

- Monasterio de "La Anunciación" de las Madres Carmelitas Descalzas de Alba de Tormes 
Lo descrito anteriormente, conformaba la vida diaria conventual, pero cada Fundación, cada Monasterio tiene su impronta, su espiritualidad marcada por sus fundadores o Santos Patronos como se dijo anteriormente; en este Monasterio de "La Anunciación" marcada por la fuerte personalidad de Santa Teresa de Jesús, quien fija las normas de vida conventual, siguiendo su ideal de pobreza y austeridad, la vida conventual se desarrolló, cuidando especialmente aquellos recintos que servían de encuentro común como eran el Coro y el refectorio y se dictaron medidas especiales para locutorios, puertas y puntos de contacto con el exterior. Sobre su fundación y el carisma carmelitano, este Monasterio estuvo marcado en su día a día por los condicionamientos sociales, políticos y económicos del momento, que en cierta forma configuraron el estilo de religiosidad, evolucionando con las épocas hacia la modernidad. La actividad musical, debió ser intensa, puesto que en él, se encontraron misas, himnos, villancicos, cantos Marianos, Cantos a la Santa, antífonas, maitines y nocturnos, salves, motetes, canto gregoriano, entre otros géneros, conforman el repertorio de este Monasterio. Comparando con lo investigado por Concha Torres Sánchez, en su obra: La Clausura femenina en Salamanca - Dominicas y Carmelitas Descalzas, se puede conocer la importancia que revestía a las fiestas religiosas; Pentecostés, Corpus, Epifanía, Difuntos, Presentación de la Virgen, San José, la Virgen del Carmen. Según la autora, los datos de la actividad musical, del Monasterio de Carmelitas de Salamanca, se pueden obtener - como en todos los monasterios - , de los Libros de Cuentas, en los que aparecen importantes referencias sobre pago a músicos; sin mencionar pago a monjas músicas. Pero, veamos cómo Santa Teresa describe la Fundación del Monasterio de San J osé en su Libro de Fundaciones - Capítulo 18 y la del Monasterio de “La Anunciación” de Alba de Tormes, en su capítulo 20:

\section{“CAPÍTULO 18}

Trata de la fundación del monasterio de San J osé de Salamanca, que fue año de 1570. Trata de algunos avisos para las prioras, importantes (1).

1. Acabadas estas dos fundaciones, torné a la ciudad de Toledo, adonde estuve algunos meses, hasta comprar la casa que queda dicha y dejarlo todo en orden. Estando entendiendo en esto, me escribió un rector de la Compañía de J esús de Salamanca, diciéndome que estaría allí muy bien un monasterio de éstos, dándome de ello razones; aunque por ser muy pobre el lugar, me había detenido a hacer allí fundación de pobreza (2). Mas considerando que lo es tanto Avila y nunca le falta, ni creo faltará Dios a quien le sirviere, puestas las cosas tan en razón como se pone, siendo tan pocas y ayudándose del trabajo de sus manos, me determiné a hacerlo. Y yéndome desde Toledo a Avila (3), procuré desde allí la licencia del Obispo que era 
entonces..., el cual lo hizo tan bien que como el padre rector le informó de esta Orden y que sería servicio de Dios, la dio luego.

2. Parecíame a mí que en teniendo la licencia del Ordinario tenía hecho el monasterio, según se me hacía fácil. Y así luego procuré alquilar una casa que me hizo haber una señora que yo conocía (4), y era dificultoso por no ser tiempo en que se alquilan y tenerla unos estudiantes, con los cuales acabaron de darla cuando estuviese allí quien había de entrar en ella. Ellos no sabían para lo que era, que de esto traía yo grandísimo cuidado, que hasta tomar la posesión no se entendiese nada; porque ya tengo experiencia lo que el demonio pone por estorbar uno de estos monasterios. Y aunque en éste no le dio Dios licencia para ponerlo a los principios, porque quiso que se fundase, después han sido tantos los trabajos y contradicciones que se han pasado que aún no está acabado del todo de allanar, con haber algunos años que está fundado cuando esto escribo (5), y así creo se sirve Dios en él mucho, pues el demonio no le puede sufrir.

3. Pues habida la licencia y teniendo cierta la casa, confiada de la misericordia de Dios, porque allí ninguna persona había que me pudiese ayudar con nada para lo mucho que era menester para acomodar la casa, me partí para allá, llevando sola una compañera (6), por ir más secreta, que hallaba por mejor esto y no llevar las monjas hasta tomar la posesión; que estaba escarmentada de lo que me había acaecido en Medina del Campo, que me vi allí en mucho trabajo; porque, si hubiese estorbo, le pasase yo sola el trabajo, con no más de la que no podía excusar. Llegamos víspera de Todos Santos, habiendo andado harto del camino la noche antes con harto frío, y dormido en un lugar, estando yo bien mala (7)."

\section{CAPÍTULO 20}

\section{En que se trata la fundación del monasterio de Nuestra Señora de la Anunciación, que está en Alba de Tormes. Fue año de 1571.}

1. No había dos meses que se había tomado la posesión, el día de Todos Santos, en la casa de Salamanca, cuando de parte del contador del duque de Alba y de su mujer fui importunada que en aquella villa hiciese una fundación y monasterio. Yo no lo había mucha gana a causa que, por ser lugar pequeño, era menester que tuviese renta, que mi inclinación era a que ninguna tuviese. El padre maestro fray Domingo Bañes, que era mi confesor, de quien traté al principio de las fundaciones, que acertó a estar en Salamanca, me riñó y dijo que, pues el Concilio daba licencia para tener renta, que no sería bien dejase de hacer un monasterio por eso; que yo no lo entendía, que ninguna cosa hacía para ser las monjas pobres y muy perfectas (1).

Antes que más diga, diré quién era la fundadora y cómo el Señor la hizo fundarle.

2. Fue hija Teresa de Layz, la fundadora del monasterio de la Anunciación de nuestra Señora de Alba de Tormes, de padres nobles, y muy hijosdealgo y de limpia sangre (2). Tenían su asiento, por no ser tan ricos como pedía la nobleza de sus padres, en un lugar llamado Tordillos, que es dos leguas de la dicha villa de Alba. Es harta lástima que, por estar las cosas del mundo puestas en tanta vanidad, quieren más pasar la soledad que hay en estos lugares pequeños de doctrina y otras muchas cosas que son medios para dar luz a las almas, que caer un punto de los puntos que esto que ellos llaman honra traen consigo. Pues habiendo ya tenido cuatro hijas, cuando vino a nacer Teresa de Layz, dio mucha pena a sus padres de ver que también era hija."

14. En fin, vinieron a ponerse en razón y dar bastante renta para el número; y lo que les tuve en mucho, que dejaron su propia casa para darnos y se fueron a otra harto ruin. Púsose el Santísimo Sacramento e hízose la fundación día de la Conversión de San Pablo, año de 1571 
(9), para gloria y honra de Dios, adonde, a mi parecer, es Su Majestad muy servido. Plega a El lo lleve siempre adelante"132.

Considerando la Madre Teresa de J esús, lo pobre de estos lugares, los veía con aprehensión y a su modo de ver, serían fundaciones complicadas, por la escases de renta y preveía las dificultades que tendrían las monjas para sobrevivir. Ella era consciente de la necesidad de los elementales recursos económicos para la realización de su obra. Respecto al Monasterio de San J osé, varios traslados sufrió la Comunidad desde el año 1570 hasta 1970. Concha Torres Sánchez lo describe así:

“Todos estos traslados iban acompañados de múltiples problemas de la pobreza con la que se había establecido la fundación: falta de dinero, para los alquileres, las condiciones de vida no eran buenas, etc.

La propia Santa Teresa murió sin ver establecida esta comunidad de forma permanente $y$ su preocupación queda recogida en la documentación conventual:

“Nuestra Madre Santa Teresa (...) dos años antes que muriese sentía harto ver lo mucho que padeçían las religiosas, y así decía que todas las fundaçiones que havia hecho no le habían costado tanto como esta, por ver padecer tanto a las religiosas, así como la descomodidad de las casas y en especial con la mucha persecución que tuvieron (...) y así deçia que la casa de Salamanca le quitava la vana gloria que le podían dar las demás."133 “También se advierte que el convento "no tuvo fundador ni persona que pusiera para ella ninguna renta ni limosna."134

Pese a las preocupaciones económicas naturales de la Madre Teresa de J esús, las Fundaciones se llevaron a cabo, pero las dos presentan caracteres distintos. Del primero, como ella misma lo expresa, sin persona alguna que lo cobijara económicamente, saliendo adelante con muchas dificultades, lo que hace de este un modelo diferente de vida conventual, se incrementaron las vocaciones y de este Monasterio salieron a fundar en Flandes y en Francia; del segundo, el de Alba de

132 < http:// www.clerus.org para la Biblioteca Católica Digital>(consultada el 14 de marzo del 2006).

133 TORRES SÁNCHEZ, Concha. Ibídem, p. 48.

134 Ibídem. 
Tormes, como vemos, tuvo la suerte de contar con el beneficio económico otorgado por la familia Velázquez Laiz.

- Monasterio de Santa María de las Dueñas (Alba de Tormes Salamanca)

Siguiendo las enseñanzas de su Santo Patrono y Maestro San Benito, las Benedictinas enmarcan las actividades de su vida cotidiana; lo más importante, la celebración de la Liturgia diaria. La música es muy importante, por cuanto desde el amanecer, su quehacer diario inicia con los salmos hasta la entonación de las Completas antes de su retiro nocturno. En su Monasterio la monja Ora y trabaja. Los sitios de encuentro colectivo como son la Sala Capitular, en la que se estudian y se toman decisiones sobre asuntos de interés comunitario y en la que la Abadesa ilumina y anima con su palabra la vida espiritual de sus religiosas y el Refectorio o comedor, donde se toma el alimento mientras se escucha una lectura edificante, se cuidan con especial esmero. En otro sentido se encuentran los sitios en donde las religiosas trabajan las diferentes labores manuales, artísticas o hacen apostolado. Lo descrito, viene manteniéndose desde tiempos remotos y los documentos en torno a la vida diaria, marcada por las constituciones o la Regla y los Mandatos referidos en los Libros de Visitas, dan una visión de lo estricto de la vida de clausura.

En lo referente a la música, la vida de las monjas músicas, nos permite conocer la actividad musical que desplegaba el Monasterio tanto en la Liturgia diaria como en las solemnidades importantes. La economía del Monasterio, de igual manera arrojó importantes referencias sobre lo relevante de la actividad y el Libro de las Crónicas del Monasterio de igual manera, permiten conocer valiosas referencias relacionadas con la música. Los repertorios musicales que datan de los siglos XVIII y XIX, aportan la vivencia musical desarrollada al interior del Monasterio; de estos repertorios se conoce que con el ir y venir, con la constante comunicación que ya en estos siglos se tenía entre Monasterios y Monasterios, algunos ejemplares de dichos repertorios han sido encontrados en otros Monasterios. 


\section{- Monasterio de Santa Clara de Carrión de los Condes (Palencia)}

La historia de esta comunidad nos remonta al año 1231, en el ya existente beaterío de Santa María del Páramo. En el 1255, las mujeres que había en Santa María del Páramo, se trasladaron hasta sus nuevas instalaciones extramuros de la villa de Carrión. Este traslado se realizó por la intervención de su santidad el Papa Alejandro IV quién impulsó a doña Mencía López de Haro, viuda del rey Sancho II de Portugal, a invertir los dineros que tenía reservados para la fundación de un monasterio, en el traslado del ya existente, desde el Páramo a Carrión.

El documento de Soterraña Aguirre Rincón, que versa sobre el estudio del Manuscrito polifónico - Libro de Música dedicado a Sor Luisa -, como dice su autora, "es un instrumento, fruto de una cultura concreta que nos habla de ella y por ende de la vida musical donde se gestó y donde iba destinado."135 La filiación franciscana del Monasterio, asiente lo determinante de su calendario de festividades. El manuscrito según se lee en el documento, aporta Música para la Liturgia, así como Música para las grandes solemnidades (llámese piezas musicales escritas especialmente para enaltecer a los Santos patronos, como San Francisco, Santa Clara y San Antonio), y hace énfasis especial en la Misa de la Concepción, que a mi juicio, serán los grandes referentes de que se compone el manuscrito.

Si paso ahora a examinar cuál ha sido la aportación de este documento al desarrollo de la investigación en los Conventos de Alba de Tormes, puedo decir, que al ser este un documento específicamente conducente al estudio de un códice o un corpus de repertorio musical, se ha tomado como punto de referencia la organización por orden de importancia de los repertorios, por género y por calendario, aplicándose este diseño a los escasos repertorios encontrados en el Monasterio de Santa María de las Dueñas.

\section{- Monasterio de la Madre de Dios de Constantinopla (Madrid)}


Otro de los Estudios realizados sobre la vida Monacal en España y más concretamente sobre la vida musical, es el realizado por Colleen Baade, pero su interés se amplía a los Límites cronológicos de finales del siglo XVI y concretamente el siglo XVII. Con suerte se han conservado en él, innumerables documentos de épocas tan remotas que han permitido conocer como se fundó un Monasterio para monjas músicas, que alababan a Dios, pero que cantaban e interpretaban para la diversión del pueblo y según palabras del autor:

"Fundar o patrocinar un convento de monjas músicas parece haber sido tanto una forma de ostentar la prosperidad del patrón como una demostración de su fe cristiana." 136

\section{- Monasterio de “La Encarnación” de Madrid}

La investigación realizada María Leticia Sánchez, en torno a los aspectos fundacionales, monacales y de hacienda del Monasterio de la Encarnación de Madrid, enmarcada de igual manera en los límites cronológicos de principios del siglo XVII, es otra muestra del interés por la época, por cuanto nos lo presenta como modelo de vida religiosa que inicia su andadura en momentos que se da una coyuntura histórica importante como es la ordenanza hecha por el rey Felipe III, de la expulsión de los moriscos que aun quedaban en Madrid.

"por entrar en contacto con unas determinadas formas de existencia que posibilitan la reconstrucción de modelos de vida, gracias a la mentalidad, las costumbres y la religiosidad existentes"137

La gran impulsora de la creación del monasterio fue la reina Margarita, razón por la cual el monasterio era conocido entre la gente de la ciudad como las Margaritas. Haciendo una comparación sobre los orígenes de este Monasterio madrileño, con el de Santa María de las Dueñas de Alba de Tormes, las diferencias están claramente marcas, por cuanto si muchos de los Conventos españoles fueron

136 BAADE Colleen R. “La música sutil del Monasterio de la Madre de Dios de Constantinopla: Aportaciones para la Historia de la música en los Monasterios femeninos de Madrid a finales del siglo XVI y XVII". Revista de Musicología XX (1997), p. 222.

137 SANCHEZ HERNÁNDEZ, Maa Leticia. "Prólogo". El Monasterio de la Encarnación de Madrid: Un modelo de vidareligiosa en el siglo XVII. Madrid; Ediciones Escurialenses, 1997. 
importantes fundaciones de Reyes y/o de grandes Señores, otros simplemente existen, desconociéndose sus verdaderos orígenes, como es el caso del Monasterio aquí investigado (Benedictinas). Los privilegios o donaciones recibidas de sus fundadores se reflejan en gran parte en sus Capillas musicales. Aborda este documento varios e importantes aspectos tanto en lo referente a las fuentes documentales, como a los aspectos de la vida cotidiana, material, cargos y jerarquías, hacienda y fundación del Monasterio, sirviendo como parámetro de organización temática por orden de importancia, para el presente trabajo.

\section{- Monasterio de "Santa Ana” (Ávila)}

Este monasterio nace a comienzos del siglo XVI de la unión de los tres conventos femeninos que existían en la ciudad (Santa Escolástica, San Millán y Santa Ana) y desde sus inicios estuvo formado por mujeres pertenecientes a las familias más poderosas de la ciudad, hecho que explica la gran riqueza de que estuvo dotado, debido principalmente a las donaciones que realizaban los familiares de las mencionadas religiosas.

En referencia al tema de las dotes de este Monasterio, hay que destacar que su obispo fundador, Carrillo de Albornoz, estableció que cualquier persona de su familia - los Dávila- que quisiera ingresar en el monasterio que él había fundado aunque no tuviera dote, podría hacerlo, con lo que encontramos la primera de las exenciones de pago acostumbrados en estas épocas.

La segunda forma de evitar la dote consistía en dedicarse a la música ya que, como señala De Vicente el monasterio de Santa Ana admitía sin dote a jóvenes que se dedicasen a la música debido a la necesidad de que hubiera personas encargadas del canto en el convento. De esta forma, aquellas mujeres que tuvieran "aptitudes musicales" y quisieran dedicarse a la vida religiosa sabían que no estarían condicionadas por la falta de recursos porque al tiempo que se evitaban la dote, recibirían un salario por su trabajo.138

138 Leer a DE VICENTE, Alfonso. "La actividad musical en los Monasterios de monjas en Ávila durante la edad moderna - Reflexiones sobre la investigación musical en torno al Monasterio de Santa Ana”. Revista de Musicología XXIII (2000), pp. 513 y 523. 
En opinión de Alfonso de Vicente, se explica que dada la formación musical de las monjas, el Monasterio tuvo una gran actividad musical, de tal manera que es lógico que en él se conserven tratados y métodos de canto llano, órgano, arpa, solfeo, piano, etc. Paulatinamente capilla musical del monasterio fue decayendo y según lo encontrado por De Vicente, los repertorios musicales conservados hasta la fecha de su investigación en los archivos conventuales, la gran mayoría proceden de músicos compositores que formaban parte de la Capilla Abulense y más aún las compuestas explícitamente para el Monasterio.

Anotar que en general los conventos femeninos de clausura fueron focos de cultura, en que la mujer tuvo su espacio académico, un espacio artístico y una posibilidad de formación musical, es justiciero y es reivindicador de la figura femenina. El hecho de contar con una capilla estable en la que se interpretaban repertorios novedosos y frente a la cual había una monja cualificada que cobraba un sueldo por su trabajo -lo que se suma a la exención del pago de la dote al ingresar en el convento- y que se traducía en independencia económica con respecto a la familia, es verdaderamente relevante para la forma de pensamiento de épocas pasadas. De Vicente aporta con su investigación la actualización de los datos en torno a los repertorios musicales y sobre la historia musical del Monasterio, aparte que repasa la importancia de los temas relacionados con la "inserción de los conventos femeninos en el entramado musical de la ciudad y las peculiaridades del fenómeno de las monjas músicas en el antiguo régimen".139

En cuanto a las aportaciones que este artículo de De Vicente brindó al desarrollo del presente trabajo, se puede decir, que afianzó la idea de valorar la figura de la mujer como parte importante de la estructura musical de las ciudades y en especial de los Monasterios que deseaban mostrar un nivel artístico alto en las solemnidades de la liturgia, las cuales por diferentes motivaciones se vieron obligadas a ingresar, ya fuese por verdadera vocación, por motivos económicos y / o sociales o familiares. Lo cierto es que muchas mujeres fueron formadas en la música como un proyecto de vida.

139 Ibídem, p. 509. 
- Monasterio de "San José" - Madres Carmelitas Descalzas y Monasterio de Santa María de la Dueñas de Salamanca

De Concha Torres Sánchez en su obra La clausura femenina en la Salamanca del siglo XVII - Dominicas y Carmelitas descalzas, sin ser esta una investigación dedicada a las cuestiones musicales, si es un gran referente de la historia social y local de Salamanca y del mundo femenino y monacal, que de alguna manera sirvió de modelo en aspectos tan importantes como las generalidades de la vida conventual, aplicadas a la metodología de trabajo.

- Las Monjas músicas en los conventos españoles del Barroco. Una aproximación etnohistórica.

Matilde Olarte Martínez, nos presenta en su artículo una motivante reflexión en torno a las actividades profesionales de la mujer, tan desconocidas y tan poco reconocidas. Vale analizar en profundidad las fuentes primarias directas como son los Libros de Profesiones, Libros de fábrica, Actas capitulares, Libros de Defunciones y de muy especial importancia los espistolarios, que revelan todos los procesos de la actividad musical desde el interior de los Monasterios con sus puntos de contacto con el mundo exterior, dice la autora. En este artículo también Olarte Martínez aborda la Educación musical femenina, las cuestiones sobre su desempeño musical tanto en lo vocal como en lo instrumental, los aspectos de remuneración, las convocatorias a las vacantes a los cargos de organistas o cantoras, salarios y cuantías de dotes, relaciones de los conventos con otros centros musicales de importancia, epistolarios y en un apéndice documental, anota ejemplos representativos de las profesiones y tomas de hábito.

En palabras de la autora: "Todo lo expuesto intenta mostrar el papel activo que desempeñaba la "monja música" en la vida musical y cultural de su época, totalmente equiparable al de los músicos profesionales. Este hecho es símbolo de la importancia histórica de la enseñanza musical en los conventos femeninos de clausura; e invita por otra parte, a reflexionar sobre la excesivas generalizaciones 
que a veces se producen a la hora de juzgar el papel social de la mujer en el período barroco." 140

Al ser Matilde Olarte Martínez la directora del presente trabajo, con su concepción sobre el mundo femenino y su interés en la reivindicación de la figura de la mujer como sujeto valioso - especialmente la monja música - , ha contribuido de manera decisiva e integral al desarrollo del mismo.

\section{La Música en los Conventos femeninos de clausura de Granada 141}

Su autora, María Julieta Vega García - Ferrer, embarcada en la tarea de investigar nueve conventos granadainos, saca a la luz la investigación soportada con documentos inéditos de gran valor gráfico. Haciendo un parangón con los trabajos investigativos mencionados y analizados anteriormente, a diferencia de éstos - los cuales nos brindan informaciones más concretas sobre un determinado tema - , la autora hace una amplia investigación sobre lo musical primordialmente, tratando los recursos humanos, instrumentos y los materiales musicales encontrados, vale decir las partituras de música. Los aspectos históricos, sociales y políticos los trabaja cronológicamente y con rigor, permiten conocer sobre la vida monacal.

\section{III.3. MONJ AS MÚSICAS DESTACADAS EN ALBA DE TORMES}

\section{III.1.Monjas músicas destacadas}

MONASTERIO DE SANTA MARÍA DE LAS DUEÑAS

- ÁNGELA COLLANTES

- CATALINA GATO

- ISABEL GARCÍA QUINTANA VERDUGO

- ISIDRA SANTOS

- ANTONIA MARTÍNEZ

- ESCOLÁSTICA CAMPOS

- JOSEFA MARTÍN Y MARTÍN

- J ILIANA DEL CORZÓN DE JESÚS

- DOLORES QUINTANA Y SÁNCHEZ

140 OLARTE MARTÍNEZ, Matilde. Las monjas músicas en los conventos españoles del Barroco. Una aproximación etnohistórica. Revista de Folklore № 13. Caja España. p. 59.

141 VEGA GARCÍA FERRER, María Julieta. La música en los conventos femeninos de clausura en Granada. Granada: Universidad de Granada. 2005. 
El Barroco, incluso el siglo XVIII y la vida conventual tuvieron fuertes lazos de unión; Aquella tendencia a dejar en todas las actuaciones de la vida cotidiana una enseñanza ejemplificadora de lo vivido o de las experiencias surgidas de una convivencia diaria tanto fuera o al interior de los Monasterios, fue un estilo de vida, una forma de pensar para estas épocas. Las lecturas recomendadas en los monasterios femeninos a cerca de la vida de los santos y en especial si los personajes eran mujeres o monjas destacadas por su vida ennoblecida y realzada por sus cualidades, por su espíritu de sacrificio, o por haber sido objeto de algo milagroso, se solían hacer en las distintas horas del día.

El llegar ser monja, tiene una especial significancia y ser monja - música, mayor significancia; más, si llegaba a destacar durante su vida conventual ya fuese por revelaciones, estigmas o milagros; por ser "monja" a la mujer se la consideraba ejemplar y modelo de perfección, y desde otro punto de vista, se la veía como algo excepcional por el entendimiento de la música, o por ser escritora o poetisa. La que ingresaba a la vida religiosa de esta forma, era muy valorada y respetada y la instruida en la música especialmente, adquiría ciertos privilegios, entre ellos el de librarse de "determinadas tareas para no estropear su voz con el trabajo"142

Es menester en este punto, explicar el procedimiento que en éste Monasterio de Santa María de las Dueñas, se llevaba a cabo para la aceptación definitiva del ingreso de una aspirante al Monasterio, como monja - música, cantora y especialmente si era organista. En primer lugar se debía dar la posibilidad de una vacante o para reemplazar a la monja que estuviera para retirarse, ya por los años o por ya por enfermedad. En los documentos analizados, no se encuentran referencias de que una aspirante haya sido rechazada, pues siempre la mujer que entendiera de música era bien recibida. Dos posibilidades o situaciones se daban; veamos: La primera, que la aspirante buscara la plaza para entrar como monja -

música y la segunda, que el Monasterio buscara una organista o una cantora por las necesidades del culto y la Liturgia - caso que se daba en el año 1792, cuando la Sra. Abadesa Dña. Rosa amores, escribía a Ilustrísimo Prelado Don Joseph 
Amores Del Barco, comentándole la necesidad urgente de una organista y cantora para el Monasterio 1895.143 Aparte de las consabidas averiguaciones y sus correspondientes interrogatorios para ingresar, la Abadesa solicitaba al Sr. Obispo la licencia para aceptar a la aspirante y justificaba las necesidades del cargo; la aspirante por lo general mostraba los documentos acreditativos de su preparación musical, vale decir alguna carta o certificación del Maestro de Música que la había instruido y seguidamente el Obispo autorizaba a los Organistas de la Catedral, para que se le practicara un riguroso examen sobre el arte de tocar el órgano, de solfear y de interpretar el canto llano. Con el acta del examen, la Sra. Abadesa y las Señoras que conformaban el Consejo se reunían y analizaban la situación de la aspirante y daban su decisión final, expresando y dejando sentadas las condiciones del ingreso y sus competencias, que ya las hemos analizado en el apartado de los cargos y jerarquías. La disposición de los Archivos Conventuales ha sido esencial para establecer quiénes eran las monjas - músicas que hicieron la historia musical de los Monasterios y que permanecieron en ellos gran parte de su vida.

Del siglo XVII, en el Monasterio de Santa María de las Dueñas, no se encuentra ninguna información específica sobre la vida de las monjas - músicas, desafortunadamente; solamente valiosas reseñas de la economía relacionada con la música y los documentos sobre el ingreso de monjas con dedicación musical, solo a partir del siglo XVIII - cuando el Monasterio aún se ubicaba extramuros -, y hasta el siglo XIX, incluso las actuales; para destacar en el Monasterio de Santa María de las Dueñas y de las que gracias a la documentación hallada se podrá hacer una crónica sobre sus vidas, vale destacar a las siguientes monjas: Ángela Collantes, Catalina Gato, Manuela Gato y Catalina - hermanas -, Isabel García Quintana, Ana Pérez, Isidra Santos, Antonia Martínez, Escolástica Campos, J osefa Martín y Martín, Manuela Huerte, Trinidad Iglesias, Dolores Quintana, Del Monasterio de "La Anunciación" Madres Carmelitas, del siglo XVII, podemos destacar a María de San Francisco, María de Sacramento, J uana de San Pedro, Teresa de San Andrés.

143 ASMD. Carta que la Sra. Abadesa Dña. Rosa Amores dirige al Prelado de Salamanca Don J oseph Amores del Barco en el 25 de Octubre de 1792. Informaciones de Isabel García Quintana. Caja 1. 
Recordemos muy rápidamente lo que englobaba el Siglo XVIII llamado el siglo de las luces. El ambiente de libertad política, diversidad religiosa y prosperidad económica especialmente de la burguesía imperante en Inglaterra y Holanda, pero fue en Francia donde se produjo el verdadero movimiento de la Ilustración. En esta centuria se vivió el progreso de las ciencias y la evolución artística de vital trascendencia y básico para entender la situación del progreso actual.

\section{* ÁNGELA COLLANTES ABARCA}

Es la primera monja - música que nos ofrece el Archivo Conventual de Santa María de las Dueñas de Alba de Tormes; vivió en el Monasterio de afuera "extramuros" y luego en el "de adentro" expresiones que se estilaban por aquellas épocas. Sus inicios dentro del Monasterio los ubicamos en el primer cuarto del siglo XVIII, concretamente en el año 1724. Un acontecimiento importante nos ubica en el tiempo; se daba inicio en la historia de España a la famosa Guerra de Sucesión, concluida con la firma del Tratado de Ultrech, el 13 de julio de 1713.

Nació en la ciudad de Astorga, provincia de León, y con esto, trasportémonos a esta hermosa ciudad con su historia, sus calles, su Catedral y tantos vestigios romanos que la hacen tan importante, desde tiempos inmemoriales.

J unto a Teleno, la montaña sagrada de los astures, se levantó la Asturica Augusta romana, capital del ámbito de los Astures, a la que Plinio historiador romano (El viejo) la señaló como "urbs magnifica". Situada junto a los ríos Tuerto y J erga, era surcada por múltiples vías romanas, que la unían con Lugo, Zamora, Salamanca, Zaragoza y Mérida. Astorga era un punto capital dentro de la Vía de la Plata, así como un centro estratégico para la poderosa explotación de las vecinas Médulas (minas de oro) y punto obligado del Camino de Santiago.

Astorga favoreció la plena romanización del territorio y, más adelante, su pronta evangelización. De ello nos da cuenta la carta sinodal escrita por san Cipriano de Cartago y otros treinta y seis obispos africanos hacia 254, en respuesta a las comunidades de Mérida, Astorga y León. Harnack denomina a esa carta «primer documento», y es el primer testimonio explícito conocido sobre comunidades hispánicas organizadas con diáconos, presbíteros y obispos. Alfonso I de Asturias 
(739-757) reconquistó Astorga a los musulmanes en fecha temprana, aunque la conquista definitiva no tuvo lugar hasta el reinado de Alfonso III. Más tarde, la ciudad sufrió la destrucción total con la expedición de Almanzor, en 964. Sin embargo, su importancia en la antigua red de comunicaciones y su situación próxima a Santiago de Compostela propiciaron que Astorga se convirtiera en un hito indispensable en la ruta jacobea desde los inicios de las peregrinaciones.

Dentro de este importante cuadro o panorama, ubicamos a nuestra monja música, Ángela Collantes Abarca, cantora, organista y arpista nacida - según los documentos que reposan en el Archivo conventual -, aproximadamente en el 1699, quien fuera hija legítima de Don Manuel Collantes y Dña. Ángela de Abarca; con abuelos paternos Don Simón de Collantes y Dña. Catalina Crespo naturales de la localidad de Valderas (León) y con abuelos maternos, Don Juan de Abarca y Dña. Catalina Mayoli, naturales de la Corte de Madrid. Investigadas las Parroquias de Santa Marta, De Santa Colomba y Santa Ana, San Bartolomé y San Andrés, de la ciudad de Astorga, la búsqueda de su partida de Bautismo ha sido infructuosa. De su vida sabemos que había quedado huérfana primero de su padre y seguidamente de su madre, sin embargo por los documentos de las "averiguaciones", muchos buenos vecinos les conocían personalmente, a ella y a su familia y sabían de sus buenas costumbres y su limpia ascendencia. Siendo interrogada e investigada hasta varias generaciones atrás, dichas exploraciones, nos hacen conocer que se encontraba libre de los impedimentos que podrían obstaculizar su ingreso en la vida conventual. Tres testigos presentó Dña. Ángela Collantes Abarca, ante el Escribano Tomás Gómez, para cumplir con los requisitos exigidos para su ingreso a la vida religiosa; entre ellos, estaban. Don Ambrosio Rubio, Don Miguel Alonso y Don Amaro Rodríguez, todos naturales de Astorga.

Respecto a la declaración de los testigos encontramos lo siguiente:

"Testigo el dicho Miguel Alonso que así dijo llamarse vecino de esta dicha ciudad de la misma presentación y para el mismo efecto que el antecedente el que después de haber jurado en la forma del derecho y siendo examinado al tenor al tenor del pedimento antecedente dijo que conoce muy bien a Manuel Collantes a Ángela Abarca Mayoli su legítima mujer vecinos que fue y la sobre dicha es de esta dicha ciudad padres de dicha Ángela Collantes que lo presenta 
y unos y otrosde habla y trato y comunicación y y los vio tratar de padres a hijos y de hijos a padres y tuvo noticias de los abuelos paternos y maternos mencionados en dicho pedimento $y$ unos $y$ otros por buenos cristianos $y$ limpios de toda mala raza de judíos penitenciarios moros ni de los nuevos convertidos ahora santa fe y por tales han sido tenidos sin jamás persona alguna haya oído cosa en contrario porque de serlo no dejarán de haber llegado a noticia mía esto es lo que sabe y puede declarar de vista como de oídas por ser como es todo ello la verdad para el juramento que lleva fecha en que se firme ratifico y lo firmo declaro ser de edad de setenta y dos años poco más o menos y en fe de ello lo firmo. Miguel Alonso. Toma esta declaración Don Tomás Gómez por escribano del número de esta ciudad a 9 de Mayo de 1724."144

De la declaración tomada a su segundo testigo Don Ambrosio Rubio se sabe lo siguiente:

"Testigo el dicho Ambrosio Rubio que así dijo llamarse vecino de esta dicha ciudad el que después de haber declarado (...) en forma de (...) siendo examinado por el tenor del pedimento antecedente que por mí el escribano le fue leído y dado a entender dijo que conoce de entero conocimiento habla, trato y comunicación a la parte que le presenta y así mismo conoció a Manuel Collantes su padre y Ángela Abarca su legítima mujer vecino que fue y sobre y sobre dicho es de esta ciudad y también conoció a Simón Collantes y a Catalina Crespo abuelos paternos de la dicha Ángela Collantes vecinos que fueron de la villa de Valderas y tuvo entera noticia de Don J uan de Abarca y de Da Paula Mayoli vecinos que fueron de la villa de Madrid abuelos maternos de la dicha ÁNGELA Collantes y unos y otros por buenos cristianos y no descendientes de judíos ni moros ni penitenciados por elSanto Tribuna ni descendientes de los nuevos convertidos ahora santa fe y por tales habidos y tenidos y recíprocamente llamados los unos y los otros de padres e hijos nietos y abuelos y esto así de vista como de oída y de público y notorio y la verdad el juramento que lleva hecho sea firme y ratifico y lo firmo declaro ser de edad de setenta y dos años poco más o menos y en fe de ello lo firmo. = Ambrosio Rubio"145

144 ASMD. Cinta № 7 - 36 Microfilmada del AHN. Informaciones. Escritura de Dote sobre Dña. Ángela Collantes. p. 8.

145 ASMD. Cinta № 7 - 36 Microfilmada del AHN. Informaciones. Escritura de Dote sobre Dña. Ángela Collantes. pp. 7 - 8. 
De su tercer testigo Don Amaro Rodríguez se sabe por el escribano Don Tomás Gómez, que dijo lo siguiente el 1 de mayo de 1724:

“Testigo el dicho Amaro Rodríguez que así dijo llamarse que soy vecino del Arrabal de Santa Coloma extramuros de esta ciudad de la misma presentación y para el mismo efecto que los antecedentes el cual después de haber jurado en forma de derecho y siendo examinado al tenor del pedimento antecedente dijo que conocía muy bien a Manuel de Collantes y a Ángela de Abarca su legítima mujer vecino que fue y la sobre dicha es de esta dicha ciudad padres legítimos de legítimo matrimonio de la dicha Ángela Collantes teniendo entera noticia de los abuelos paternos y maternos de la parte que la presenta mencionados en dicho pedimento y que unos y otros eran cristianos viejos limpios de toda mala raza de moros judíos penitenciados ni de los nuevamente convertidos a nuestra santa fe, ni haber ejercido de oficios viles sin que jamás haya oído cosa en contrario = Esto es lo que sabe y puede decir. J uramento hecho en que se afirmó ratificó y no lo firmó por no saber escribir, declaró ser de edad de setenta y cuatro años poco más o menos y en fe de ello lo firmé. Tomás Gómez por Escribano”146

¿Con ello que se pretendía? En lo posible conocer la mayor cantidad de información personal de la aspirante; lo primero y creo que lo más importante era saber si sus padres estaban legítimamente unidos en santo Matrimonio y si varias generaciones atrás tenían o no orígenes judíos, moros, condenados por la Inquisición o conversos a lo que se llamó limpieza de sangre y que la Iglesia estaba comprometida en el cumplimiento de la ley tanto para los altos cargos como para los monasterios.

De tal manera la aspirante Dña. Ángel Collantes superaba con estas testificaciones de los amigos y conocidos de sus padres y abuelos, uno de los primeros pasos para su ingreso a la vida religiosa.

Según sus mismas palabras, estamos al tanto de que al quedar en situación de desamparo, la única opción para su vida futura, era ingresar en un Monasterio, pero al verse sin recursos económicos decidió capacitarse para entrar como monja cantora. Desconocemos con quien pudo capacitarse en la música durante

146 ASMD. Cinta № 7 - 36 Microfilmada del AHN. Informaciones. Escritura de Dote sobre Dña. Ángela Collantes. p. 8. 
varios años, como ella misma lo expresa en el documento del año 1724 que guardan las cintas microfilmadas del AHN. (Cinta № 7 - 36 Información), A la letra dice:

“Que yo la dicha Dña. Ángela por más agradar y servir a Dios Nuestro Señor, huir y evitar los peligros del siglo de muchos años a esta parte me dediqué al estado de religión y para poderlo mejor conseguir, hallándome falta de medios y sin humano socorro, me apliqué a aprender solfa y canto llano y al tañido de los instrumentos de de órgano y arpa, lo que llegué a entender y entiendo suficientemente, $y$ habiendo tenido noticia de que en este dicho Monasterio se necesitaba una monja cantora por hallarse enferma e impedida la Sra. Dña. Catalina de Rivera que actualmente sustiene este cargo, le solicité por intermedio del Dr. Don Manuel de Robles Ruíz médico conocido mío y residente en esta villa, y con efecto merecí con la Divina Dignación y piedad de dichas Señoras religiosas el que me votasen según me votaron en dicha plaza de tal monja Cantora y en ella advirtieron en virtud de patente y licencia que ha este fin obtuvieron del Ilmo. y reverendísimo Señor Obispo de la ciudad de Salamanca que aquí se insiere justamente con los tratados en dicha razón hechos cuyo tenor sucesivo es como sigue." 147

Ya vemos como por intermedio del Dr. Manuel de Robles Ruíz, médico de Alba de Tormes, nuestra monja tuvo conocimiento de la villa y que el Monasterio de Benedictinas necesitaba una "cantora" y enseguida, solicitó su ingreso a los 25 años de edad, allá por el año 1724 cuando aún existía el antiguo Monasterio "Extramuros" y el 12 de Mayo de 1769 participó en el traslado de la Comunidad de religiosas Benitas, al nuevo Claustro "intramuros" de la Villa de Alba, siendo Abadesa Dña. Benita de Oviedo. A esta fecha, Dña. Ángela Collantes llevaba ejerciendo su magisterio al interior del Monasterio hacía 58 años, llegando a vivir en este nuevo recinto por 13 años más. Las Carpetas de Informaciones y el Libro de Crónicas nos la describen como una religiosa muy virtuosa y hacen referencia a su carácter pacífico y su entrega en las obligaciones contraídas con su desempeño musical y al goce mismo de la música, que para ella, aparte de ser su trabajo, era una verdadera complacencia; haciendo el análisis de los 83 años vividos por esta religiosa, podemos deducir que fue muy longeva y esto puede considerarse

147 ASMD. AHN. Leg. 5562 (a.5684) Clero. Cinta № 7 - 36 microfilmada Informaciones. Escritura de Dote sobre Dña. Ángela Collantes. 
excepcional para la época. ¿A qué se puede atribuir tanta longevidad?, ¿A la paz interior?, ¿a la vivencia musical diaria?, ¿al estado de vida monacal? ¿A su constitución física?, Bueno, son muchos los interrogantes, que trataremos de aclararlos más adelante comparando su vida con la vida de otras monjas músicas.

La licencia de su Ilma. para el ingreso de la Sra. Collantes, nos muestra el procedimiento que se acostumbraba en estos casos.

“Licencia de su Ilmo:

Nos D. Silvestre García Escalona por la gracia de Dios y de la Santa Sede Apostólica, Obispo de ésta ciudad y Obispado de Salamanca del Consejo de Su Majestad Prelado ordinario del Convento de religiosas de Santa María de las Dueñas Orden de San Benito de la Villa de Alba = Por cuanto Dá Ángela Collantes hija legítima de Manuel Collantes y de Isabel Abarca vecinos de la ciudad de Astorga desea ser religiosa de velo y coro en dicho nuestro convento como las demás que en él hay, por tanto atendiendo que en su persona concurren los requisitos y circunstancias necesarias, damos licencia a la Sra. Abadesa de el, para que tome los votos de la comunidad y estando conforme la mayor parte de ellas admitan a la sobre dicha por Religiosa Novicia de dicho nuestro Convento, habiéndose antes asegurado por su parte con escrituras y fianzas abonadas la dote y propinas que están convenidas para que llegando el caso de su profesión un mes antes se ponga dicha cantidad en especie de dinero y efectivamente y no en otra en el arca de las tres llaves del dicho convento con los demás capitales de donde no se sacará sin nuestra licencia, y para que exista el auto damos nuestra comisión en forma al Vicario o en su lugar teniente de dicha villa quien advertirá a la sobre dicha que llegando el caso de su profesión la ha de hacer conforme a los ritos, ceremonias y solemnidades que previene el Ritual Romano y Cartilla de dicho nuestro Convento, y que se ha de obligar a guardar clausura sin votarla como (...) a los tres votos esenciales de Pobreza, Castidad y Obediencia con que todas profesan con que así está ordenado por el santo Concilio de Trento y por la Constitución Pastoralis de nuestro Santi Padre Pio Quinto mandados por los señores Obispos nuestros predecesores y confirmado en juicio, contradictorio por el Ilmo. Señor Nuncio de su Santidad en estos reinos de España, todo lo cual será por ante notario que de ello de fe, y ponga testimonio en nuestras manos o nuestro secretario de cámara: Dado en el Palacio Episcopal de Salamanca a 
12 de mayo de mil setecientos veinte y cuatro años, $y$ respecto a no dar dote ni pagar propina por entrar por el ministerio de cantora se le admitirá en esta conformidad $=$ Sivestre Obispo de Salamanca $=$ por mandao de su Ilma. El Obispo mi señor = Don J oaquín García y Salinas Secretario.”148

Con este procedimiento, en primer lugar la aspirante, ingresaba en calidad de novicia y el Obispado por medio del requerimiento de las "escrituras y fianzas" se aseguraba de que el Monasterio tuviera en su haber, la "dote y propinas" para que llegada la hora, la aspirante pudiera hacer su profesión definitiva y conforme a lo establecido.

Ahora veamos cuál fue el siguiente paso que debió salvar Doña Ángela Collantes; en el TRATADO PRIMERO se conocerán las peticiones de la aspirante a "cantora" para su vida conventual y su desempeño musical y que la Sra Prelada enteró a la comunidad. Ya habíamos hablado en el capítulo anterior, para qué servía el Consejo y cuáles eran sus competencias y una de ellas era: “Decidir sobre la admisión de las postulantes al noviciado." De tal manera, ahora encontramos al Consejo de religiosas reunido en pleno para deliberar sobre la suerte de la nuestra candidata y acompañadas de varios testigos como son: El Licenciado Juan de Caravias Muñóz, el Dr. Don Manuel de Robles Ruíz - ya habíamos comentado que por intermedio de este buen Dr., Doña Ángela Collantes tuvo conocimiento del Monasterio -, y Don Manuel Antonio Vásquez de Lozada vecinos y residentes en Alba de Tormes. Las religiosas que formaban este Consejo, fueron: Doña María de Oballe - Abadesa -, Doña María Delgado - Priora -, Dña. Catalina Álvarez, Dña. Catalina Rivera - monja que tenía el cargo de cantora y que solicitaba la baja -, y todos ellos ante el escribano Ignacio Vásquez de Somoza.

\section{Tratado primero:}

Estando a la puerta regular del muy Religioso Monasterio de Santa María de las Dueñas Orden de Nuestro Padre San Benito extramuros de la villa de Alba hoy catorce de Mayo de mil setecientos veinte y cuatro años por sonde 
campanas tañidas según costumbre a presencia de mi el escribano y testigos infrascritos se congregó su comunidad en dicho sitio en la forma que lo tienen de estilo cuando se ofrece que conferir y resolver sobre los negocios y dependencias de su utilidad, y mejor régimen nominadamente las Señoras Dª María de Oballe Abadesa, Dª María Delgado, Priora, D ${ }^{\underline{a}}$ Catalina Albarez , Da Catalina Rivera Claveras, Da Francisca Jiménez, D ${ }^{\mathbf{a}}$ Manuela Jirón, Da María Arapiles, $D^{a}$ Mariana Montero, $D^{a}$ Petronila de Oballe, $D^{a}$ Josefa Molina, Dạ Manuel Montero, Da Ángela Sánchez, Da ${ }^{a}$ María Teresa de Arapiles, $D^{a}$ María Teresa pillante, $D^{\mathbf{a}}$ Teresa Benito, $D^{a}$ Teresa Arapiles, todas monjas profesas en dicho Monasterio y únicas vocales que dijeron ser de que al presente se componen dicha esta Santa comunidad a quienes hallándose así juntas, por dicha Sra. Abadesa se representó , como se hallaba por Licencia y patente de Ilmo. Y Rmo. Señor Obispo de la ciudad de Salamanca, Prelado ordinario de este Monasterio para poder recibir en el por monja de velo y coro en la plaza y ejecución de cantora a $D^{a}$ Ángela Collantes y Abarca, doncella hija legítima de Manuel Collantes difunto y de Ángela de Abarca su mujer en quien estaba informada concurrían las prendas de honestidad para el estado que pretende de religión y así mismo conveniente voz e inteligencia de Música y de tañer Órgano y Arpa que son los instrumentos que se necesitan para la asistencia de su cobro, pero que pretendía dicha plaza, no solo sin pagar dote ni propina sino que también por este Monasterio, a causa de ser sumamente pobre se la había de dar celda alhajada, una cama estera de ropa, y un hábito, esto solo por una vez y doscientos reales para la ayuda de su viaje, con entera voz y voto en todos los actos de comunidad y los alimentos subsidiarios que fuese costumbre darse a la cantora después de los días de la Sra. Da Catalina Rivera que lo es actualmente y mientras viviere solo cien reales para cuerdas de los instrumentos y socorro de sus necesidades, todo lo cual las proponía y propuso para que teniéndolo entendido dichas Señoras diesen su voto y pareceres libremente declarasen si tenían o no por conveniente admitir dicha religiosa con las condiciones $u$ circunstancias expresadas $y$ habiéndolo oído y entendido y entre sí sobre ello consultado dijeron: que antes de ahora han tenido noticia de dicha pretensión, y están informadas de personas de su entera satisfacción de la virtud, habilidad y calidad de la pretendiente y halar ser útil, y conveniente a esta Santa comunidad el recibirla por monja de velo y coro, con las circunstancias y calidades que les han sido expresadas por dicha Abadesa por la gran falta que hace la cantora al séquito del coro, $y$ hallarse de ello imposibilitada por su mucha edad y achaques dicha Señora $D^{a}$ Catalina Rivera, y que por ahora este era su voto y sentir, sin embargo de los cual se informarían de nuevo conferirían 
siempre la materia y a su debido tiempo deliberación lo que hubiesen por más acertado y conveniente y para que conste aquí se pone por fe y lo firmaron en nombre de la comunidad las cuatro señoras de su diputación a las cuales como a las demás doy fe y conozco siendo testigos el Licenciado Don Juan de Caravias Muñóz: el Dr. Don Manuel de Robles Ruíz y Don Manuel Antonio Vásquez de Lozada vecinos y residentes en dicha villa doy fe $=D^{\mathbf{a}}$ María de Oballe Abadesa $=D^{\mathbf{a}}$ María Delgado , Priora $=D^{\mathbf{a}}$ Catalina Albarez, Dạ Catalina de Rivera, ante mi Ignacio Vásquez de Somoza.”149

Del catorce de mayo al veinticinco del mismo mes del año de 1724, el Consejo efectuó tres sesiones de deliberaciones para conocer bien las cualidades personales y musicales de la aspirante y las condiciones del ingreso y para tomar la última decisión. Ahora veamos en el Tratado segundo cómo se vuelve sobre el tema y aunque no hay oposición por parte de las religiosas, deciden volver a mirar el asunto y dar "a su debido tiempo" una respuesta final.

“Tratado segundo:

Hoy veinte de Mayo de mil setecientos veinte y cuatro años nuevamente por son de campana se junto la comunidad de este Monasterio de Santa María de las Dueñas, y todas las Señoras religiosas de que se compone, nombradas en el primer tratado (a que me refiero) por son de campana tañida según costumbre a dicha su puerta regular a donde por ante mi el escribano y la Sra. Da María de Oballe Abadesa nuevamente propuso lo mismo que en el Tratado antecedente se expresa y en los propios términos que la dicha comunidad se pudo muy bien actuar de ello y con efecto habiendo oído y entendido uniformemente respondieron de los buenos informes con que se hallan de persona de virtud y de su confianza de las buenas partes y prendas que concurren en la de $D^{a}$ Ángela Collantes pretendiente a la plaza de cantora de este Monasterio, son de sentir y parecérsela admitir y recibirse con las calidades propuestas por dicha Sra. Prelada, lo que tenían por útil y conveniente, y aunque era el sentir y parecer de todas dichas Sras. religiosas todavía se volverían a mirar sobre ello, harían su última resolución a su debido tiempo , y para que constelo firmaron en nombre de dicha santa comunidad las cuatro Señoras Diputadas según su estilo siendo

149 ASMD. Cinta № 7 Microfilmada del AHN. - Clero. Leg. 5562.(a5684), p. 3 
testigos Don Cristóbal de Villoria, Don Francisco Vallesa y Don Ignacio Gabriel Vásquez de Somoza que doy fe $=D^{\underline{a}}$ María de Oballe Abadesa $=D^{\underline{a}}$

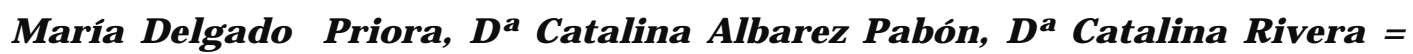
ante mi, Ignacio Vásquez de Somoza."150

La tercera sesión de deliberaciones nos da a entender que fue la última y la definitiva y a letra dice:

\section{“Tratado tercero:}

Estando a la puerta regular de dicho Monasterio de Santa María de las Dueñas hoy veinte y cinco de Mayo de mil setecientos veinte y cuatro años se congregó por ante mí el escribano su comunidad por son de campana tañida según su estilo a donde comparecieron todas las señoras religiosas vocales contenidas y declaradas en el tratado primero, a quien por la Sra. Abadesa de este dicho Monasterio tercera vez se propuso la pretensión de $D^{a}$ Ángela Collantes a la plaza de monjas cantora de él, y todas las circunstancias y condiciones con que la intentaba, según y como en dicho primer tratado (a que me remito) se declara $=y$ recapacitadas dichas señoras de todo ello dijeron : que por último voto y deliberación eran todas nula discrepante de sentir y parecer se la admitiese y recibiese por tal monja cantora con las calidades y circunstancias propuestas, mediante estaban informadas $y$ certificadas de su virtud, destreza $y$ habilidad $y$ concurría en dicha pretendiente todas las calidades que se requieren así para el estado de religión como para su ejercicio, y que esta era su última determinación, sobre el asunto y para que conste lo firmaron las cuatro señoras de su Diputación, siendo testigos el Licenciado Don Juan de Caravias Muñoz, Don J oseph Pozo y Don Francisco Sánchez vecinos de esta dicha villa de que doy fe $\mathrm{D}^{\mathbf{a}}$ María de Oballe Abadesa, $\mathrm{D}^{\mathbf{a}}$ María Delgado Priora, Da ${ }^{\mathbf{a}}$ Catalina Albarez Pabón y $D^{\mathbf{a}}$ Catalina de Rivera = Ante mí: Ignacio Vásquez de Somoza.”151

Visto lo anterior, la aspirante a monjas cantora, llegó a la villa de Alba de Tormes, a expensas del Monasterio, doscientos reales le fueron enviados para sus gastos de viaje como estaba convenido. Como no traía dote ni propina alguna, el Consejo de religiosas dispuso que dichos tratados se escriturasen, además que era lo usual en 
estos casos y fue admitida como monja de velo y coro en la plaza de cantora, con todas las obligaciones y el entero peso de su cargo; Le dieron su celda con su comodidad, hábito entero y cama con todas sus ropas.

El subsidio de sus alimentos fue asignado en cien reales anuales y para siempre, de los cuales la monja debía mantener sus instrumentos en buen estado, siempre con cuerdas y para sus necesidades más inmediatas hasta que la actual Maestra de Música Sra. Da Catalina Rivera viviere y después de la muerte de la dicha Sra. Rivera, la compensaban con 80 reales más reservados para su ancianidad, sus achaques y como reconocimiento a sus años de trabajo. Par un total de 180 reales anuales, "situados por ley y estilo de este Monasterio a su Cantora para cuerdas y huevos"152 Inicia así nuestra monja - música, su período de Noviciado, un año, al cabo del cual sería puesta en entera libertad para decidir, para declarar su vocación o para renunciar. Desde este momento, su compromiso fue para siempre con la música en el Monasterio. Sus palabras así lo confirman:

\begin{abstract}
“Yo la dicha Dña. Ángela Collantes reconociendo y agradeciendo el beneficio recibido prometo el asistir y servir hasta el último esfuerzo de mi posibilidad dicho oficio y el servicio de Cantora asintiendo de noche y de día a todas las horas regulares así cantadas como rezadas manteniendo el entero séquito del Coro, como de cualesquier fiestas públicas o particulares que se ofrecieren en dicho Monasterio, así de lo cantado para la observancia de la Regla, como Villancicos y recitados, y lo tañido de órgano y arpa las cuales he de mantener siempre enceadada de mi cuenta, sin poder pretender más gajes, ni asistencias que las aquí señaladas con la diferencia y declaración antecedentes prevenidas y observando en todas las ordenes y preceptos de las Señoras Preladas que son o fueron de este dicho Monasterio sin repugnancia alguna como humilde y obediente religiosa y a la observancia y cumplimiento de lo así pactado."153
\end{abstract}

Lo anterior se producía el veintisiete de Mayo de 1724, con la presencia de la pretendiente al cargo, ante la Señora Abadesa y demás profesas del Monasterio y

152 ASMD. De los tratados de ingreso de la monja Dña. Ángela Collantes Abarca. Cinta microfilmada № 7 del AHN, p. 5

153 De los tratados de ingreso de la monja Dña. Ángela Collantes Abarca. ASMD. Cinta microfilmada № 7 del AHN, pp. 5- 6 . 
los testigos Don Diego Antonio de Camarra, Dr. Don Manuel de Robles y el Licenciado J uan de Caravias Muñóz y el escribano Ignacio Vásquez de Somoza.

Haciendo referencia al apartado de los pagos, veamos un ejemplo del manuscrito tomado del Libro de Cuentas, sobre lo que se pagaba a la Sra. Collantes por su desempeño musical en el año 1752:

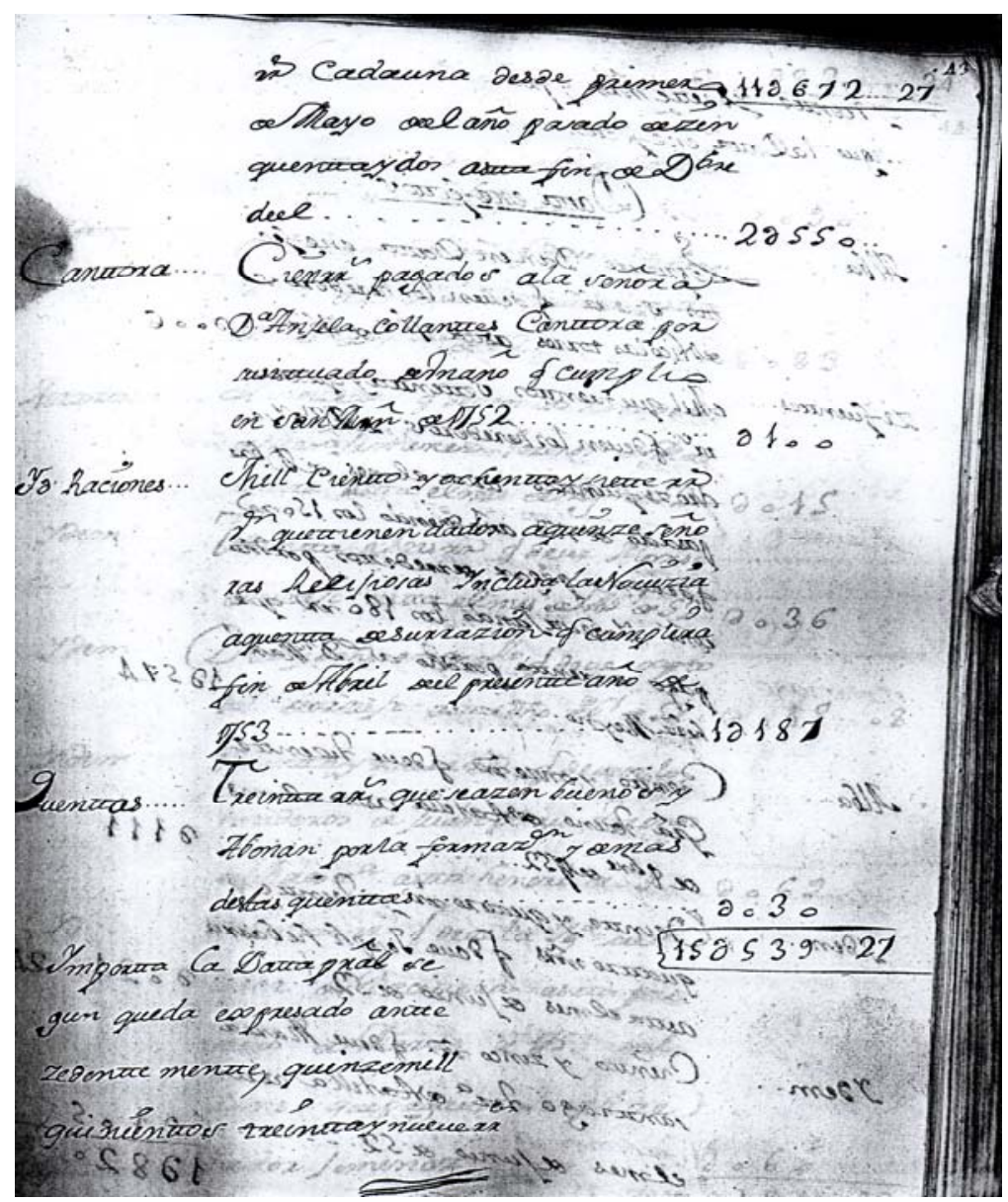

10. ASMD - Manuscrito del Libro de cuentas de los años 1750 - 1773. p. 43 Pago a la monja música Dña. Ángela Collantes Abarca.

Leyendo y analizando las fuentes sobre los asuntos económicos relacionados con su quehacer musical, se han tomado los límites cronológicos del 1750 al 1760, para la elaboración de una relación de pagos, ya que recordando "Los tratados", para su ingreso quedó estipulado claramente que su asignación anual sería de 100 reales y 80 más, cuando acaeciera el fallecimiento de Dña. Catalina Rivera - en su momento, la Cantora Primera - aún con vida al ingreso de Dña. Ángela Collantes; de tal manera que los pagos se relacionan así: 


\section{RELACIÓN DE PAGOS A Doña ÁNGELA COLLANTES ABARCA}

(Del año 1750 al 1760)

\begin{tabular}{|c|c|}
\hline AÑO & PAGOS ANUALES \\
\hline 1752 & 88 rls. \\
\hline 1752 & 100 rls. \\
\hline 1754 & 200 rls. (pagos de 1753 y 1754) \\
\hline 1755 & 100 rls. \\
\hline 1756 & 88 rls. \\
\hline 1757 & 100 rls. \\
\hline 1758 & 80 rls. \\
\hline 1759 & 88 rls. \\
\hline & 100 rls. \\
\hline 1760 & 100 rls. \\
\hline
\end{tabular}

\section{SU PERSONALIDAD Y SU VIDA MUSICAL}

Ya estamos al tanto de que nuestra monja - música quedó huérfana de padre y madre desde muy joven y creemos que como es natural, este período de su vida debió trascurrir entre pesares y la angustia de perder a seres tan queridos. En cierta forma todas estas vivencias preparan el espíritu de cualquier persona, moldean su personalidad y la hacen fuerte ante las situaciones más complicadas de la vida. El Libro de Crónicas nos la describe como una mujer virtuosa, de carácter afable y especialmente pacífica. Su oficio musical lo desempeñó con el entusiasmo que caracteriza a cualquier persona que ama la música y que disfruta de su saber, pero también nos la revelan como una mujer muy fervorosa en los momentos de recogimiento y devota de San Miguel Arcángel, al punto que antes de su muerte había dejado ordenados de su dinero, doscientos reales para contribuir a la compra de una imagen del Santo, imagen que costó 450 reales y que la Comunidad sufragó la otra parte del valor. Esta imagen no se conserva en la Comunidad, pues años más tarde fue vendida por motivos económicos. La siguiente referencia la encontramos en el Libro de Crónicas del Monasterio. p. 62. 


\section{“EL AÑO DE 1782 SE COMPRA LA IMAGEN DE SAN MIGUEL}

Esta devota y bonitísima imagen que con tanto cariño y estima se conserva aún en la Comunidad, fue traída de Salamanca en el año 1782; costó 450 reales; 250 pagó la Comunidad y los 200 restantes los dejó mandados para este fin Doña Ángela Collantes que acababa de fallecer. Este rasgo nos dice una vez más cuan virtuosa era esta Benedictina, Cantora primera en la Comunidad, como más arriba queda dicho."154

Su situación de desamparo, la llevó a buscar la seguridad para su vida futura; nace en ella aquel instinto de la necesidad de tener una estabilidad en todo sentido o de - por lo menos - asegurarse un futuro y por ello piensa en la mejor opción que en su momento existía para una mujer que vivía en las circunstancias descritas: ingresar en un Monasterio, sin entregar dote alguna, pero preparándose en la música. Las fuentes sobre su vida al interior de Monasterio son pocas pero las encontradas nos permiten llegar a conocer su personalidad y su quehacer musical, ya que fue llamada la Maestra y siempre desde su profesión se desempeñó en diferentes cargos relacionados directa y únicamente con la música: CANTORA MAYOR y ORGANISTA, MAESTRA CORRECTORA DE CORO Y VICARIA DE CORO. Ya el Libro de Crónicas describe lo "honroso" del cargo de Primera cantora y Correctora de Coro.155 Atrás en sus declaraciones leíamos, cómo ella se comprometía devotamente a cumplir con sus obligaciones y las notas del Libro de Crónicas nos corroboran sobre aquel compromiso, con los votos profesados, con su comunidad y con la música, recordémoslo: “Desempeñó el oficio de cantora siendo muy virtuosa."

154 ASMD. Libro de Crónicas. p. 62.

155 Ibídem. 


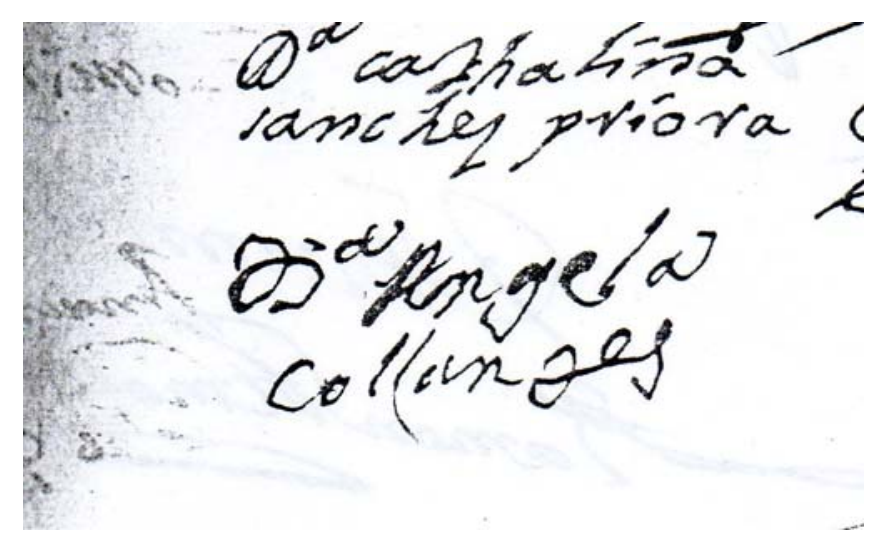

11. Rúbrica de Dña. Ángela Collantes Abarca - Monja música del Monasterio de Santa María de las Dueñas

ASMD. Tomado del Libro de Dotes 1766 - 1863. p.17

Desde el punto de vista humano, se percibe que ya desde muy joven fue una mujer interesada en su superación personal y los años vividos en el Monasterio, le proporcionaron su estabilidad económica, según nos lo narra del Libro de Crónicas -, y la posibilidad de ejercer su magisterio musical.

A su lado ejercieron la música otras cantoras y organistas que hicieron la vida musical del Monasterio, como: Ana Pérez; cantora segunda, Catalina Gato; cantora, organista y violinista, Isabel Luengo y Baltasara Acosta; coristas. Es preciso recordar aquí, que en estas épocas existían los cargos para dos cantoras de oficio y por las crónicas sabemos que estos cargos perduraron por muchos años más, con los nombres de Maestras correctoras de Coro y Vicarias de Coro, así como el de Maestra de Ceremonias, cargos que ella desempeñó en varias ocasiones y por muchos años.

Una de las ocasiones en que la Comunidad tuvo motivo de tristeza y regocijo a la vez, fue el hecho de abandonar el Monasterio "extramuros" en el 12 de mayo de 1769 y asentarse definitivamente en su nueva morada dentro de los muros de Alba de Tormes, que es en la que hasta la fecha residen. Pasados seis años, el 26 de julio de 1775, acaeció la inauguración del Iglesia, del Coro alto y Bajo, la Sacristía y los enterramientos; fue un día grande, un acontecimiento especial en que la Música debió tener un papel preponderante ya que las Fiestas del Corpus Christi se 
trasladaron para estas fechas y durante cuatro días el Monasterio vivió con gran celebración el acontecimiento, con Misas, Sermones con destacados personajes de filiación Carmelita, Benedictina y Franciscana como Fray Antonio Martínez franciscano -, Francisco de la Asunción - Prior de las Carmelitas -, y el Ilm. Pedro de San Francisco, religioso J erónimo y demás agasajos con la asistencia del Cabildo en pleno durante las festividades. El Libro de Crónicas nos describe estas fechas como días de gran acontecimiento; y ahí encontramos a nuestras monjas músicas en su papel principal, Ángela Collantes, Ana Pérez, Catalina Gato, Isabel Luengo, Baltasara Acosta, dando realce a las festividades relatadas, de las que se habla de su talento y sus virtudes.

\section{* SU FALLECIMIENTO}

Su fallecimiento con ochenta y tres años de edad y cincuenta y ocho de magisterio musical nos dejan percibir la responsabilidad asumida tanto con la Comunidad, como con la música, sirviendo con dedicación hasta muy avanzada edad; Las últimas referencias de su magisterio musical datan del 20 de agosto 1769, cuando aún aparece en el Libro de elecciones relacionada con el cargo de Correctora de Coro; de ésta última fecha a la de su muerte se puede suponer que se retiró de su trabajo musical aproximadamente 10 años antes de su fallecimiento, ya que los cargos asumidos mediante "Las elecciones", en este Monasterio, tenían una duración de tres años. En las notas redactadas sobre su fallecimiento es revelador leer como destacan en ellas, lo anteriormente dicho sobre su carácter y sus virtudes, a la que describen como una mujer ejemplar en todo sentido.

El Libro de Crónicas nos lo narra así:

“El día 3 de febrero del año 1782 falleció en este Monasterio de Benedictinas Dña. Ángela Collantes; esta virtuosa hija de Nuestro Padre San Benito ejerció por muchos años en el Monasterio el cargo de Cantora." "Doña Ángela Collantes tomó el Santo Hábito en este Monasterio de Santa María de las Dueñas extramuros el año 1724; profesó el siguiente de 1725 y falleció el día 3 de febrero de 1782, cumplió medio siglo y ocho años más en el 
Monasterio; 45 en el de extramuros y 13 en el que actualmente habitamos; desempeñó el oficio de cantora siendo muy virtuosa y pacífica."156

En el documento a la vista se puede observar los últimos pagos hechos a Dña. Ángela Collantes; sabemos que murió el día tres de febrero del 1782 y en éste último pago le fueron incluidos los 9 días del novenario rezado por su alma. A la letra dice:

\section{“Señoras cantoras}

Ciento noventa y nueve rls v. y diez y seis maravedíes pagados a las Señoras cantoras Ángela Collantes y Catalina Gato los ciento once rls v y diez y seis maravedíes que por rateo le tocaron hasta el doce de febrero a Dña. Ángela los ciento en reales últimos de noviembre del 81 y los once maravedíes hasta doce de febrero incluido el novenario" 157

Ahora, en este mismo Libro de cuentas se encuentra una relación de gastos ocasionados por el motivo de su fallecimiento. Ya tenemos claridad que de lo percibido por su trabajo, las monjas músicas pudieron tener algunas reservas; incluso algunas de ellas ayudaron con aquellas reservas, a las dotes de otras aspirantes. Ya conocimos anteriormente, los gastos que ocasionaba para el Monasterio, el fallecimiento de una religiosa y en una mayor cuantía si la religiosa era Abadesa o alguien que hubiera destacado durante su vida conventual. Una relación clara de los gastos ocasionados por su fallecimiento podemos relacionar aquí, teniendo en cuenta que estos gastos salían de su propio dinero, el que le correspondía por los pagos anuales percibidos.

“Entierro de Dña. Ángela Collantes. Trecientos cincuenta y nueve rls v y veite y un maravedíes que van gastados en el entierro de Dña. Ángela Collantes en esta forma $=$ Noventa y cuatro rls $v$ y cuatro maravedíes del Cabildo _ _ por su salida = cuatro rls por la misa de este día y esta primera del Novenario $=$ cuatro rls $\mathbf{v}$ del Sacristán del Cabildo = cuatro rls al de la comunidad $=$ cuatro al que abrió la sepultura $=$ ciento treinta y dos rls y medio en ocho lb. De (...) = Alquiler de seis libras de velas y (...), doce rls menos cuartillo libra = treinta mrv., los veinte y dos rls. $y$ medio y diez por la ofrenda que se ponía y doce a cuerpo presente, y los 
ocho restantes al novenario a tres rls y demás gastos que se ofrecieron_ 359. 21 mrv"158

El cabo de año de su fallecimiento originó un gasto de tres reales v. por la misa dada en su recuerdo.

Hemos presentado nuestra primera monja música con las características de una auténtica religiosa de clausura con dedicación exclusiva al oficio musical, hemos intentado mostrar de dónde provenía, cómo fue su difícil situación personal, cómo logró su ingreso al Monasterio y cómo fue su desempeño musical hasta los últimos días de su vida.

A ella le siguieron importantes mujeres músicas, las cuales es preciso destacar, pues fueron continuadoras de su trabajo y que junto a ella aprendieron, vivieron los momentos tristes, difíciles y momentos de prosperidad y de grandes festividades y regocijo.

\section{* CATALINA gATO ROSETE}

Continuadora de la obra de Dña. Ángela Collantes Abarca, encontramos a Dña. CATALINA GATO ROSETE, la que ingresa al Monasterio de Santa María de las Dueñas en el año de 1764; con ella vivió también en estado de religión y como monja música - cantora, su hermana Manuela Gato Rosete, ingresó en el 1775; ya en el capítulo anterior habíamos visto cómo era costumbre en la época, que ingresaran o convivieran en los Monasterios, hermanas, primas, tías y sobrinas, incluso madres e hijas.

Catalina Gato Rosete era Natural de Toro en provincia de Zamora - hija de J oseph Gato y J osefa Rosete -, había nacido el 5 de febrero de 1747 y fue bautizada el 14 del mismo mes y año, en la Parroquia de San J ulián. Sus abuelos paternos fueron Don Domingo Gato y Dña. Manuela Espindola y maternos, Hemeregildo Rosete y Catalina Lauredo, todos oriundos de la localidad de Toro.

Consultando sobre la vida de esta monja música, en el Archivo Diocesano de Zamora, tuve la suerte, de encontrar, en el primer Libro de Bautizmos consultado,

158 ASMD. Libro de Cuentas. Años 1774 - 1794, p. 109. 
toda la trayectoria de su vida, incluso de sus hermanos: los certificados de Fe de Bautizmos y Confirmaciones y en los Libros de Actas Matrimoniales, se encontró inscrita el Acta del Matrimonio de sus padres.

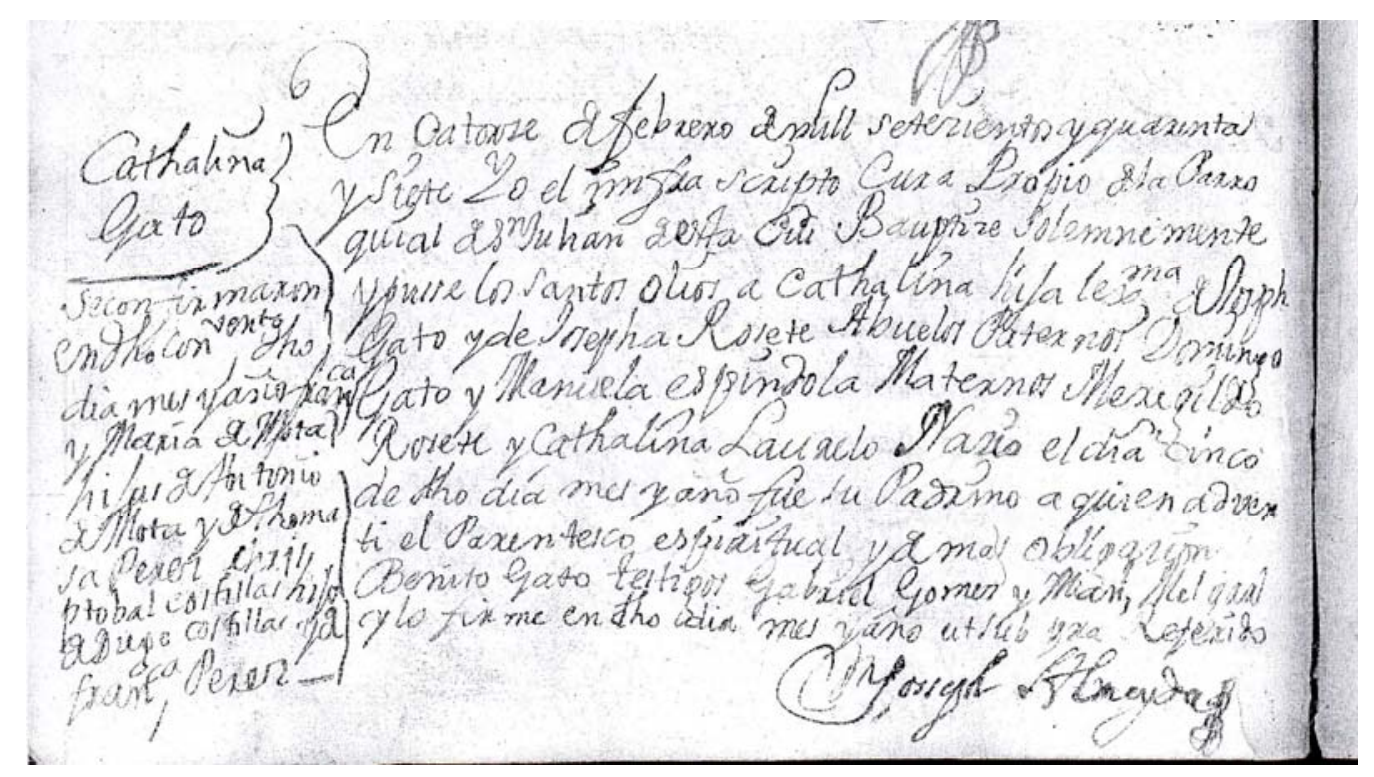

12. ADZ. Partida de Bautismo de Dña. Catalina Gato Rosete

Libro de Bautismos 227-1 Libro 3. Parroquia de San J ulián - Toro (I -1-3) p. 109 v.

Para ubicarnos en el entorno de nuestra monja música, recordemos cuál es la historia de Toro en la Provincia de Zamora: Tiene orígenes muy antiguos pues los vestigios arqueológicos encontrados nos llevan a la etapa celtibérica. Históricamente, la región guarda su identidad con episodios importantes conocidos; fue repoblada por el infante Don García, hijo de Alfonso III el Magno, a finales del siglo IX, con gentes venidas del norte, concretamente de Asturias, Vasconia y Navarra. Fue cuna de reyes, casa de nobles y asentamiento de judíos y moriscos, de órdenes militares y religiosas, tuvo voz y voto en las Cortes al reunirse éstas en el año 1397 en época de Enrique III; como también en 1426 y en 1442 durante el reinando Juan II, jugó un papel importante durante el enfrentamiento de Isabel la Católica y Juana la Beltraneja por la corona de Castilla, aquí tuvo lugar la famosa Batalla de Toro el 1 de marzo del año 1476.

En el año 1505 se reúnen las Cortes convocadas por Fernando el Católico, se lee el testamento de Isabel la Católica y se proclama reina a Juana la Loca, 
promulgándose las célebres Leyes de Toro. Estas importantes Cortes de Toro se reunieron en el Palacio de las Leyes. En el año 1923 se produjo un gran incendio que destruyó totalmente el citado Palacio quedando solamente la bella Portada. Durante el reinado de Carlos I tomó parte activa en la lucha de las comunidades, desde ese momento empieza su declive político y social.

En el siglo XVII es nombrada capital de la provincia, formada por tres partidos: el de Toro, Carrión y Reinosa. En el año 1833 deja de ser provincia por una nueva demarcación del mapa geográfico de España. Tiene una gran importancia la actividad agrícola, sobre todo en el sector vitivinícola. El Ayuntamiento se encuentra en la antigua Ciudad de Toro (10.000 habitantes). Situada junto al río Duero que riega una fértil vega donde se cultivan cereales, hortalizas, frutales y su producto estrella el muy apreciado vino de Toro. Como se puede comprobar el sector vitivinícola tuvo y tiene una gran importancia. Últimamente grandes bodegas de otras zonas de España se han aposentado en estas tierras atraídas por las buenas vides de estos pagos. La actividad principal es como decimos el cultivo de viñedos y también existen algunas industrias de transformación. Tiene una gran importancia la fabricación de galletas y dulces.

Continuando con nuestro relato sobre la vida de Dña. Catalina Gato Rosete, hemos conocido por los Libros de Bautismos de la Parroquia de San Julián (Toro) que reposan en el archivo Diocesano de Zamora, que fue la mayor de tres hermanas; tuvo dos hermanas: Isabel nacida en 1749 y Manuela - ya referida anteriormente -, nacida en el 1757 y también monja música - cantora de este Monasterio de Santa María de las Dueñas de la Villa de Alba de Tormes.

El Archivo Diocesano de la ciudad de Zamora conserva su Fe de Bautismo que a la letra dice:

\section{"Cathalina Gato}

En catorce de febrero de mil setecientos y cuarenta y siete yo el mfra. Scripto cura propio de la parroquia de San Julián de esta ciudad bauticé solemnemente y puse los santos oleos a Cathalina hija legítima de Joseph Gato y de Josepha Rosete abuelos paternos Domingo Gato y Manuela Espindola maternos Hemeregildo Rosete y Cathalina Lauredo nació el dia cinco del dicho día mes y año fue su Padrino a quien advertí el parentesco 
espiritual y a más obligación Benito Gato testigos Gabriel Gómez y Manuel

Delgado y lo firme en dicho día mes y año ad sub pra referido Joseph Almeyda"159

\section{- INGRESO AL MONASTERIO}

El año de 1764, a la edad de diez y siete años tomó el hábito como monja de velo y coro; cantora que ingresó inicialmente en el Monasterio extramuros y participó al igual que Doña Ángela Collantes del traslado de la Comunidad al nuevo recinto dentro de la Villa de Alba de Tormes. Desafortunadamente las investigaciones realizadas sobre el procedimiento de su ingreso, las averiguaciones, testigos y exámenes de música practicados, no produjeron ningún dato positivo, ni en el Archivo Conventual, ni en el Archivo Diocesano de Salamanca.

\section{- SU PERSONALIDAD Y DESEMPEÑO MUSICAL}

Los pocos documentos encontrados nos la describen como una mujer alegre, entusiasta a la hora de cantar las "alabanzas divinas". Es de suponer que ingresando a la edad de diez y siete años, lo realmente interesante es que siendo tan joven tuviera los conocimientos necesarios para desempeñarse con solvencia en el arte de tocar el clave y el violín.

\section{- ASUNTOS ECONÓMICOS EN TORNO A SU MAGISTERIO MUSICAL}

Por los Libros de cuentas, se puede conocer que al ingresar como monja música, la Comunidad se esmeró con ella, al comprar como regalo de bienvenida y para su desempeño musical, un clave y un violín, aparte de cubrir los asuntos de vestuario, viaje y refrescos a su llegada al Monasterio, todo por un valor de mil setecientos reales v. y 1/2. El hecho de ingreso de una nueva monja música, era causa de gran regocijo en el Monasterio, pues aquello representaba que la liturgia, se iba a ver embellecida, enriquecida y los asuntos concernientes a la música se fortificarían. 
Veamos el documento que corrobora este detalle tan importante para la vida musical de nuestra monja - música.

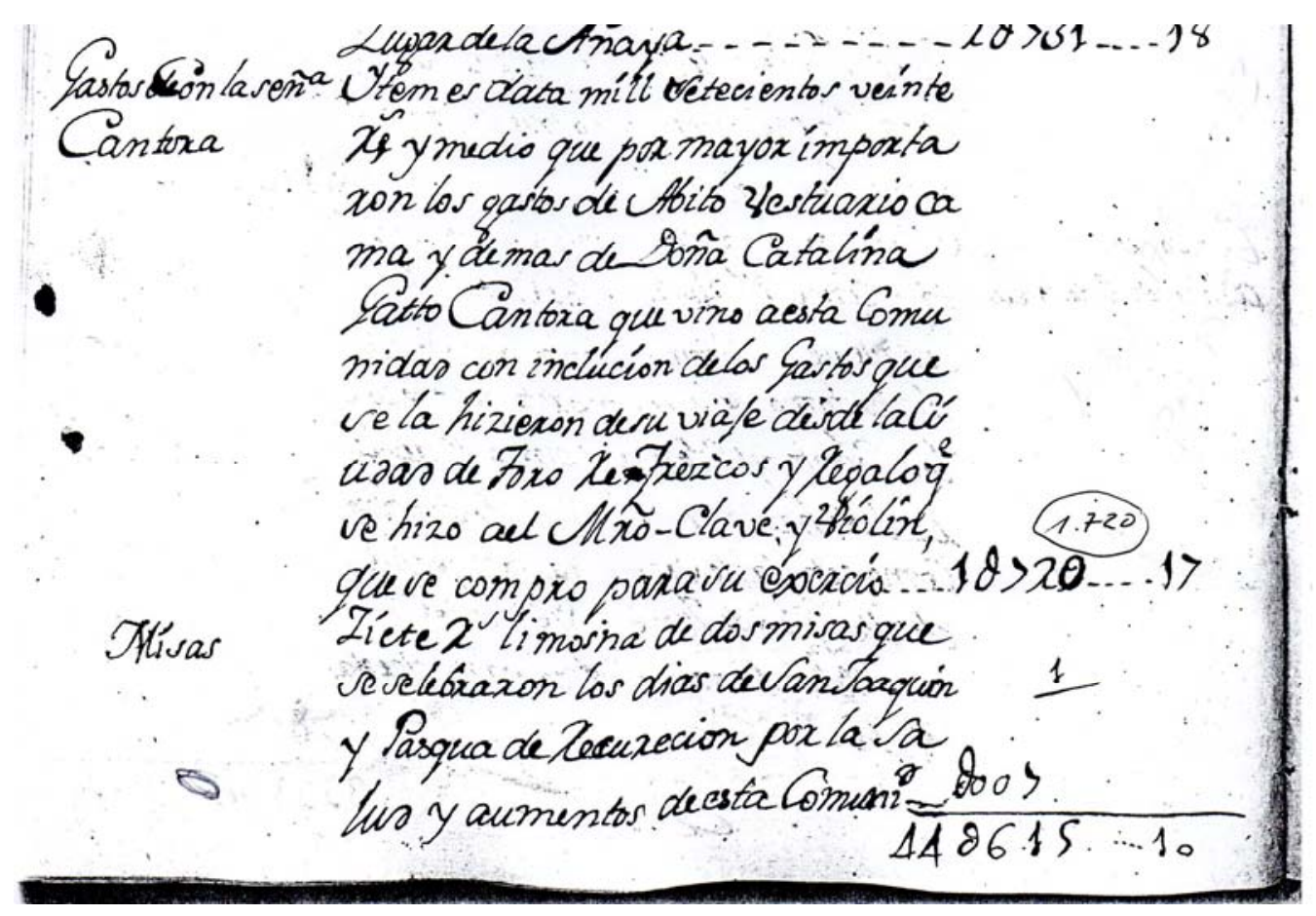

13. ASMD. Gastos con la Señora Cantora Dña. Catalina Gato.

Libro de cuentas 1750 - 1773. p. 175 v.

Siendo aún novicia cantora, el Monasterio pagó a su llegada doscientos y ochenta y dos rls. v. y doce mrs., supliendo la Comunidad de esta manera, su ración y demás gastos ya que llegaba sin dote ni alimentos; a la letra el documento nos dice: "pagados por su ración a diez cuartos del día", "desde el tres de diciembre de 64 hasta el último de julio de 65”160

Otros gastos importantes a su ingreso fueron los ocasionados por la compra del hábito, la cogulla, pagos de las Licencias de Profesión, propina para el Vicario, los refrescos ofrecidos y algunas otras cosas que fueron precisas para la ceremonia de Profesión. 161 
Como un ejercicio y para ubicarnos en el contexto económico actual, analicemos las posibles conversiones que se pueden hacer de los valores monetarios de aquellas épocas a nuestros días:

Sabemos que una peseta era equivalente a 4 reales; aquello nos permite llegar a determinar que 1.720,5 reales v. - valor de los gastos del ingreso de nuestra monja música al Monasterio -, son equivalentes a 430,125 pesetas y desde éste punto podemos deducir que ese valor en la actual moneda común, serían $4.05 €$. Para aquellos tiempos debió ser una cantidad bastante considerable, pero pensemos que este Monasterio al igual que muchos, tuvo también sus épocas de prosperidad. Con qué asignación ingresó como monja música Catalina Gato? Los Libros de cuentas nos lo enseñan y tomando como base cien reales. Veamos lo devengado por el estado de profesión musical y sobre los límites cronológicos de 1780 y 1789. Murió Dña. Catalina Gato el 13 de diciembre de 1788. Se ha tomado los últimos nueve años de su vida por ser los que devengó en los dos años últimos de su antecesora Ángela Collantes Abarca y después de la muerte de ésta.

\begin{tabular}{|c|c|c|}
\hline 1 & RELACIÓN DE PAGOS & \\
\hline & Dña. CATALINA GATO ROSETE & \\
\hline \multicolumn{3}{|l|}{$\overline{3}$} \\
\hline & AÑOS 1780 - 1789 & \\
\hline \\
\hline AÑO & & PAGOS \\
\hline 1780 & & 188 rls. \\
\hline 1781 & & 188 rls. \\
\hline \multicolumn{3}{|l|}{ 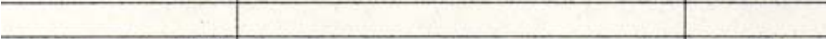 } \\
\hline 1782 & & 82 rls. \\
\hline 1783 & & 188 rls. \\
\hline $\begin{array}{r}1784 \\
\end{array}$ & & 184 rls. \\
\hline \multirow{2}{*}{$\begin{array}{r}1785 \\
\end{array}$} & & 188 rls. \\
\hline & . & \\
\hline 1786 & $t$ & 188 rls. \\
\hline 1787 & & 188 rls. \\
\hline \multicolumn{3}{|l|}{$\begin{array}{ll}+2 \\
\end{array}$} \\
\hline 1788 & & $188 \mathrm{rls}$. \\
\hline 1789 & 3 & 188 rls. \\
\hline & 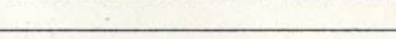 & \\
\hline \multirow[t]{2}{*}{ Gastos de entierro } & & 411 rls. \\
\hline & Total: & 2.181 rls. \\
\hline
\end{tabular}

14. Relación de pagos a Dña. Catalina Gato Rosete

ASMD. Datos tomados del Libro de Cuentas 1774 - 1794 


\section{- SU FALLECIMIENTO}

El día 13 de diciembre de 1788, muere Catalina Gato Rosete, después de haber desempeñado durante veinticuatro años el cargo de cantora. Una nota encontrada en el Libro de Crónicas nos da a conocer lo siguiente:

Su fallecimiento - como es natural, ocasionó una serie de gastos, que relacionamos a continuación:

- Asistencia del Cabildo........................... 98,04 rls. v. mrs.

- $\quad$ Al sacristán...................................... 8 rls.v.

- Dela caja............................................. 38 rls.v.

- Diez libras de Bujias.............................. 141 rls.v.

- Treinta misas.......................................... 124 rls.v.

- Vestuario (incluido en las misas)

- Otros................................................. 2 rls.v.

Total: 411 rls.v.

Ahora veamos una nota interesante relacionada en los Libros de cuentas, en la que se describe lo que quedó de sus bienes a la Comunidad después su fallecimiento:

“Descargo noventa y nueve reales v. y veiteidos maravedíes en una de tres partes que thoco a la comunidad de los vienes de Doña Cathalina Gato lo restante quedo en muebles como consta en el Libro de Gastos de las dos partes de sus vienes se la aplicaron ciento zinquenta y nueve misas a tres rls.v.como consta en los recibos que se hallan en el Arca (y murió en 13 de diciembre de 1788) 99 rls.v. 22 mrs."162

La situación comentada, se encuentra en muchas notas de los Libros de cuentas, lo que nos hace ver que de lo percibido económicamente por el ejercicio musical, a la hora del fallecimiento de una religiosa, una de tres partes se invertía en su enterramiento, novenarios, incluso en la conmemoración del Primer Aniversario de su deceso y el Monasterio se beneficiaba de las otras dos partes y de los muebles u objetos personales de la religiosa música.

162 ASMD. Parte que le tocó a la Comunidad de Catalina Gato. Libro de cuentas de 1774 - 1794, p. $209 \mathrm{v}$. 
Catalina Gato Rosete según la describen los documentos, al igual que su antecesora, fue una de las monjas músicas con mayor formación musical; tocaba el órgano y el violín y fue Vicaria de coro y primera cantora.

\section{- ISABEL GARCÍA QUINTANA VERDUGO}

Ubicando al lector en el final del siglo XVIII, cuando caía el Antiguo régimen y se iniciaban las ideas de independencia en América, los epistolarios cruzados entre las Sra. Abadesa del Monasterio de Santa María de las Dueñas Dña. Rosa Amores y el Prelado Don J oseph Andrés del Barco, permiten conocer las necesidades imperiosas que el Monasterio tenía en la consecución de una monja música por estas fechas, ya que por el fallecimiento de las tres religiosas que asumían las responsabilidades propias de la música en general y del culto y por el impedimento de otra religiosa por razones de salud, se habían quedado sin una persona cualificada para desempeñar este cargo. Con fecha de octubre 29 de 1792, la Sra. Abadesa escribe a su Ilustrísima, J oseph Amores del Vasco, para que a nuestra tercera monja música de éste Monasterio de Santa María de las Dueñas -, se le diera Licencia para su ingreso.

“1792

Atte Benitas de Alba

Excelentísimo Señor y mi venerado Prelado como hace cuatro años esta Comunidad se halla con necesidad de una religiosa organista y cantora porque de cuanto que había fallecieron las tres, y la que ha quedado no puede con el trabajo; y aunque sea con justa causa de esto, se la ha ido dando esperanzas y entreteniendo este tiempo atendiendo a lo atrasada que esta la Comunidad pero habiéndomelo pedido todas las religiosas que hiciera diligencias para este efecto; yo la falta que hace lo puse por la (...) y en efecto la hall ; con todas las circunstancias que podía más apetecer ; Diestra en la música y órgano y de poca edad y robusta y de claro nacimiento, ayer 24 del corriente se presentó aquí con su padre que será el dador de esta; lo cierto es que no la esperábamos tan pronto pero se temieron el tiempo y se pusieron en camino sin avisar a la Comunidad; por lo que suplico a su Señoría digne de dar su Licencia para pasar a recibirla y así mismo si puede ser estimaré que envíe su Ilustrísima la Licencia para dar el hábito, juntamente porque de estar aquí detenidos se le siguen más gastos a la Comunidad que sabe Ilustrísima lo atrasadas que estamos; la pretendienta se llama Isabel 
María hija legítima de Don Juan García Quintana , y de Felipa María Verdugo del Obispado de Tuy Reino de Galicia como verá su Ilustrísima por la Fe de Bautismo que incluyo en esta es cuanto se me ofrece por pedir a Dios que sea larga la vida de su Ilustrísima Dilatados años que le suplico en este Monasterio de Benitas de Alba.

Octubre 26 de 1792

B.L.M. de su Ilustrísima Su afecta y humilde su dicha Rosa Amores Abadesa"163

Doña Isabel García Quintana Verdugo cuyo nombre de pila fue el de Isabel María de San Juan García Quintana Verdugo, natural de Tuy (Galicia) y quien fuera bautizada en la iglesia Catedral de Tuy, Nació el día 15 de diciembre de 1777, y bautizada al día siguiente, hija de Juan García Quintana y Felipa Verdugo; aquel, natural de la feligresía de Beiça Obispado de Lugo y jurisdicción de la Villa de Sarria y su madre de la Villa de Padrón Arzobispado de Santiago, con abuelos paternos Francisco García y Juana Quintana y maternos Luis de Verdugo Ministro de las Rentas Reales de la ciudad de Tuy - y Benita de Arredondo o Redondo - como aparece en otros documentos -. Isabel García Quintana tuvo dos hermanos, que tomaron los hábitos de San Francisco e ingresaron como también como cantores.

Para ubicarnos en un contexto geográfico y social, conozcamos ligeramente sobre la localidad de Tuy y veamos cuál ha sido su historia:

La romanización que inicia con la llegada en el año 137 de Décimo J ulio Bruto, que trae consigo una época de paz, que permite a los habitantes de la zona abandonar los castros y poblar las tierras bajas, aledañas al río Miño.

Las fuentes clásicas (Plinio, Ptolomeo, Silo Itálico y otros) documentan la existencia de Castellum Tude y de la fundación mítica de la ciudad por el héroe griego Diomedes, hijo del héroe Tideo (de ahí el nombre Tuy). Son muy abundantes los hallazgos de época romana en el territorio tudense, destacando sobre todo los de la zona Santa Eufemia-San Bartolomé, con varias necrópolis 
excavadas, así como la propia ciudad de Tuy, que era una de las mansiones de la vía XIX, del itinerario de Antonino, como testimonian los miliarios y otros restos hallados.

No han quedado muchas restos visibles de esta época, aunque sí se han documentado en distintas excavaciones. Por Tuy pasaba la vía romana que iba desde Braga (Portugal) a Astorga cruzando por Lugo. De esta vía se conserva un miliario, que se encuentra ahora en Pontevedra, y un pequeño tramo de calzada en la contigua Valença.

En el Bajo Imperio y en los primeros tiempos medievales Tuy continúa siendo un importante centro militar, administrativo y religioso, cuya sede episcopal se documenta desde el siglo V. Con la llegada de los suevos - siglo IV- Tuy figura como capital del reino con Rekiamundo (458-463) y varias monedas de la época fueron acuñadas en la ceca tudense, que continuará funcionando aún después de la integración de los suevos en el reino visigodo (585). El rey godo Witiza tuvo en Tuy su corte y palacio, en el lugar de Monterreal - Pazos de Reis.

Con la caída del imperio romano se emprende la etapa de mayor importancia histórica de Tuy. Sus obispos aparecen en los concilios de Braga y dejan sentir su dominio en una zona muy amplia tanto del sur de Pontevedra como del norte de Portugal. En la última etapa del reino visigodo, la corte de Toledo era un lugar muy peligroso para los jóvenes príncipes, y éstos eran enviados a Tuy; para mantenerlos alejados de las intrigas palaciegas; al lugar que, todavía hoy se conoce como "Pazos de Reis".

En el 711, con la invasión árabe ya en puertas de Toledo, el último de esos príncipes, Witiza, asume el gobierno de la Hispania visigoda desde Tuy, convirtiéndola en capital provisional del reino, de allí el nombre de reino de la Tudesia.

A comienzos del siglo VIII Tuy sufre la invasión de los árabes que asolaron la ciudad que fue liberada en el año 739 por Alfonso I, en el 860 Alfonso Betote y Hermenegildo Gutiérrez, condes de Ordoño I, la repoblaron y en el 915 Ordoño II restauró la sede episcopal. 
En estos tiempos los ataques normandos nuevamente saquean Tuy. Se produce entonces una vacante en la sede episcopal que llega hasta el año 1071 en que el rey de Galicia D. García y Doña Urraca restauran y dotan nuevamente la sede que se instala en el monasterio de S. Bartolomé de Rebordans - iglesia que data del siglo IX aunque con vestigios anteriores-.

Recuperará su esplendor al convertirse en capital de la provincia (que lleva su nombre) del antiguo Reino de Galicia ya que se convierte en un puesto estratégico en los márgenes del río Miño tanto para la guerra como para el comercio, este esplendor se verá aumentado en el siglo XII, época en la que se revitaliza toda la franja norte de España, hasta el Duero

En la primera mitad del siglo XII se produce un hecho significativo, el nacimiento de Portugal como reino independiente de Galicia y Castilla. En esta época el río Miño adquiere su carácter de frontera natural que todavía hoy perdura.

Con la independencia del reino portugués Tuy será escenario, a lo largo de los siglos, de múltiples acontecimientos bélicos relacionados con las luchas fronterizas. En el año 1170 Fernando II mandó trasladar la población tudense desde la zona de San Bartolomeu a la actual ubicación dotándola de un sistema amurallado - del que aún conservamos diversos tramos- y concediéndole un fuero y privilegios a los pobladores de San Buenaventura, nombre con el que pretendía designar a la nueva ciudad pero que no prosperó.

Los monarcas, tanto castellanos como portugueses, apoyarán a la Sede tudense con importantes donaciones. El obispo es el señor de ciudad y su coto y Tuy experimenta un importante desarrollo socio-económico y cultural. En los siglos medievales Tuy era un importante centro comercial, con un dinámico puerto fluvial, contaba con diversos gremios y una comunidad judía con sinagoga y era lugar de paso del camino de peregrinación jacobea, disponiendo de un hospital para los peregrinos. En el actual casco histórico, que ocupa una superficie en torno a 10 ha se conservan numerosas edificaciones de época medieval (especialmente del siglo XV con sus característicos arcos conopiales) y moderna (muchas de ellas blasonadas). 
La Catedral de Santa María de Tuy es el máximo exponente de la riqueza artística de esta ciudad. Se eleva sobre la parte más alta de la ciudad, conservando la apariencia de Fortaleza con torres almenadas, caminos de paso y pasadizos.

Iniciada su construcción en 1120 (siglo XII), en pleno románico, corresponden a este estilo su planta, portada norte y la magnífica iconografía de los capiteles. La fachada principal, correspondiente al gótico es la primera obra de este estilo realizada en la Península Ibérica. La consagración y conclusión de la construcción fueron en 1225.

El claustro, único original conservado en las catedrales gallegas, es una soberbia obra del gótico. Un paseo por este cuidado claustro es toda una tranquilidad para los sentidos. Por él accedemos a la primitiva Sala Capitular románica del siglo XII y al torreón de los Soutomaior, divisando una estupenda panorámica de la ciudad con el Río Miño, y el vecino Portugal. En conclusión, podemos decir que Tuy es una ciudad con una interesante historia, protagonista de importantes acontecimientos y en la actualidad, Tuy y la comarca del Bajo Miño están realizando un proceso de modernización en la industria y la agricultura, a la que se le une el turismo de una gente que busca conocer su historia y disfrutar de la tranquilidad de esta hermosa zona de Galicia.

Continuando con nuestro relato sobre el tema principal que nos atañe, hemos podido conocer que en el Convento de San Antonio de la ciudad de Tuy, el 8 de Octubre de 1792, se llevaron a cabo los interrogatorios y averiguaciones sobre la ascendencia y la vida personal de nuestra monja música Isabel García Quintana. Así que reunidos Don Francisco Rodríguez Vergara, predicador general y guardián del Convento, Don Gaspar López, lector jubilado Padre y Ministro provincial de la Provincia de Santiago y Don Gregorio de Ocampo por la facultad que tienen de la Abadesa Doña Rosa Amores del Monasterio de Santa María de las Dueñas de la Villa de Alba de Tormes, para recibir las informaciones de limpieza de sangre, legitimidad de vida y costumbres de Isabel García Quintana, llevaron a cabo los interrogatorios a los testigos, conocidos y allegados a la familia de la pretendienta. 


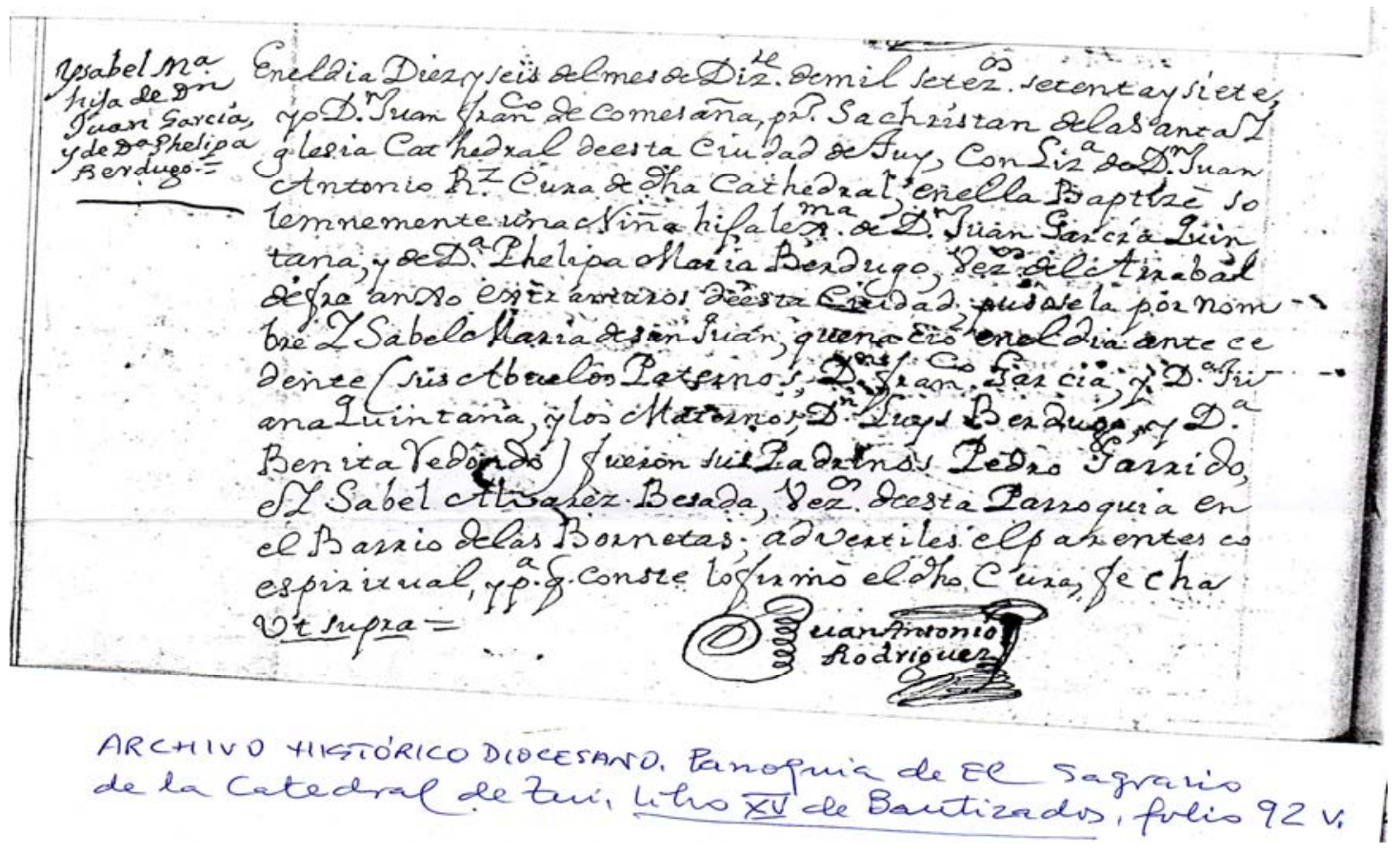

15. ACHDT. Fe de Bautismo de Dña. Isabel García Quintana Verdugo Parroquia del Sagrario - Catedral de Tuy. Libro XV. Bautizados. Folio 92 v.

Ya conocemos el procedimiento utilizado para saber la verdad acerca de la vida personal de las profesas y por los documentos, podemos estar al tanto de la naturaleza de las cuatro preguntas formuladas a los testigos de la dicha Isabel García Quintana y Verdugo en el sentido de conocer lo que se consideraba primordial:

1 o Si se conoce a la pretendienta, a sus padres y Abuelos paternos y maternos si unos u otros han ejercido oficios viles como ser carniceros, verdugos o pregoneros. $2^{\text {o }}$ Si la dicha aspirante a monja, es de vida sana, honesta, recogida y de cristianas costumbres y si saben que su inclinación por la vocación es natural o es violentada para hacerlo.

3o $\mathrm{Si}$ saben que la pretendienta está en estado libre, sin vínculo matrimonio alguno contraído ni consumado.

4 ${ }^{\mathrm{o}} \mathrm{Si}$ saben si sus padres y sus abuelos paternos y maternos se hallan comprometidos en notoria infamia como el de descender de judíos, moros, herejes recién convertidos, o si alguno de ellos ha sido castigado por el Santo Oficio de la Inquisición. 
Varios testigos se presentaron para dar informaciones sobre la vida personal de Dña. Isabel García Quintana Verdugo; el primer interrogado fue el Presbítero Thomás González, el segundo fue Don Ventura Árias de Prega, el tercer testigo fue Don Domingo Barreiro Costal, el cuarto testigo fue Don Lorenzo Domínguez.

"En el convento de San Antonio de la ciudad de Tuy a ocho días del mes de octubre año de mil setecientos noventa y dos yo, Fray Francisco Rodríguez Vergara predicador general y guardián de este referido convento de San Antonio de la ciudad de Tuy de orden que tengo de M. R. Gaspar López lector jubilado Padre y misionero provincial de esta Santa y Apostólica provincia de Santiago por la facultad que su paternidad M. r. tiene de la $\mathbf{R}$ Madre Rosa Amores Abadesa del convento de religiosas Benedictinas de la Villa de Alba de Tormes era recibir información de limpieza de sangre, legitimidad, vida y costumbres de Dña. Isabel García Quintana hija que dice ser de Don J uan García Quintana y Dña. Felipa Verdugo, vecinos que fueron de esta dicha ciudad de Tuy para tomar el Santo hábito en el sobre dicho convento de Religiosas Benedictinas de la mencionada villa de Alba de Tormes, digo que obedezco y acepto la tal comisión; para cuyo fin nombro y elijo por secretario notario que de fe de la dicha información al Padre Presbítero Fray Gregorio de Ocampo, visitador de terceros de nuestro seráfico Padre San Francisco, el que acepto dicho nombramiento y ofreció bajo juramento que hizo in verdad sacerdotis de guardar secreto y guardar dicho oficio fiel y legalmente y lo firmó conmigo dicho día, mes y año ut supra.

Fray Francisco Rodríguez Vergara Fray Gregorio de Ocampo"

Ya estando al tanto la naturaleza de las preguntas, conozcamos lo que contestó el primer testigo Don Thomás González, a las preguntas que le formularon los señores de la Comisión:

“1̄ Pregunta.

A la Primera pregunta dijo este testigo que conocía y conoce bien a Doña Isabel García Quintana , hija legítima de Don J uan García Quintana y de Dña. Felipa Verdugo, su legítima mujer, aquel natural de la feligresía de San J ulián de Beiça, Obispado de Lugo y jurisdicción de la Villa de Sarria y esta de la Villa de Padrón Arzobispado de Santiago, vecinos que fueron 
muchos años de esta mencionada Ciudad de Tuy; que conoció igualmente a Don Luys Verdugo natural de la villa de Yai en Alicante y vecino y Ministro por mucho tiempo de las rentas reales de esta dicha ciudad de Tuy: pero que no conoció a los demás abuelos pero si tuvo noticias de Don Francisco García y Dña. J uana Quintana, abuelos paternos, naturales y vecinos que fueron de la arriba dicha San J ulián de Beyça y Dña. Benita de Arredondo natural de la villa de Padron mujer del nombrado Don Luys Verdugo, abuelos maternos de la dicha pretendienta. Y dice el testigo que no sabe ni oyó jamás decir, que ni sus padres, ni unos ni otros abuelos hayan ejercido ni por si ni por forzosos algunos de los oficios viles contenidos en la pregunta, antes que tanto unos como otros han sido y son tenidos en esta y en sus respectivos pueblos por gente de honor, crédito y reputación y que aún por la parte materna son tenidos y reputados por nobles y el padre de la pretendienta es oficial interventor de la Real Aduana del Puente de Barjas. Que no es pariente en grado alguno de consanguinidad ni de afinidad, amigo especial, ni enemigo de la pretendienta y sus padres y que no se haya con impedimento alguno por el cual no pueda declarar en esta información y que es de edad de cincuenta años poco más o menos." 164

Como percibimos, en esta primera pregunta la intención más importante, es saber en forma integral los orígenes de la aspirante y sobre todo la "limpieza de sangre" de sus ascendientes, lo cual es considerado en la época, de vital importancia. Los cuatro testigos coinciden en resaltar el rango de nobleza de los abuelos maternos, al decir que eran “tratados y reputados por nobles".

El apellido VERDUGO es originario de Arévalo - Provincia de Ávila; según consta en los Archivos de la Real Cancillería de Valladolid, los Verdugo, acreditaron su hidalguía en esta institución. Se sabe que los Verdugo tuvieron radicaciones importantes en otros sitios, tanto de España como en las tierras de América, especialmente en las Islas Canarias y en Extremadura y en La Nueva Granada y Chile, respectivamente.

Los siguientes datos nos muestran aquellos orígenes de alcurnia:

“I.- Francisco Verdugo o Berdugo, admitido en el noble linaje y gremio de los Verdugo de Arévalo, fue inscrito y empadronado en el libro de la familia, y presto

164 ASMD. Carpeta de informaciones. 
servicios de importancia al emperador D. Carlos I (V de Alemania) y su hijo D. Felipe

II. Caso este caballero con Teresa de Sepúlveda y tuvo de ella por hijo a: II.- Nicolás Verdugo de Sepúlveda, llamado comúnmente Nicolás de Sepúlveda, que nació en Arévalo, en las casas de sus antepasados, y pasó a las Indias en servicios de los Reyes D. Felipe II y D. Felipe III. Sirvió por espacio de trece años en la villa de María, de la provincia de Cartagena, y en las de Ibagüe y Neyba. Fue por elección, Regidor de la ciudad de Santa Fe en 1569, Procurador General de la misma en 1564 y 1570 y Alcalde Real ordinario en 1597. Caso en Santa Fe, en el Sagrario de la Catedral el 20-2-1588 con Francisca Ruiz de Tapia, Señora de las Encomiendas de Gachencipa y Tentiva (hija de Antonio Ruiz, Procurador General y Alcalde ordinario de Santa Fe en 1555 y Encomendero de Tentiva y Gachencipa)."165

Continuando con nuestro análisis de averiguaciones, vemos que a la segunda pregunta, formulada por los comisionados, Don Thomás González respondió que:

“la dicha Dña. Isabel García Quintana es hija legítima de legítimo Matrimonio de Don Juan García Quintana y Doña Felipa Verdugo y Arredondo y que por tal es tenida y está comúnmente reputada sin saber ni haber oído jamás cosa alguna contra este su dicho : que es de vida honesta y recogida muy frecuente en confesarse y recibir el Santo Sacramente de la Sagrada comunión; de virtuosas y honestas costumbres: que no sabe pretenda el Santo hábito movida de violencia alguna antes entiende y sabe lo hace de su buena voluntad por su inclinación al estado religioso, huir los peligros del mundo y servir mejor a Dios en el retiro del Claustro; que no tiene enfermedad algun , que la impida entrar y profesar en la Religión."166

En esta pregunta van encerrados tres cuestionamientos: Primeramente, saber la legitimidad de la aspirante, seguidamente, si la pretendienta desea tomar los hábitos por voluntad propia vale decir, no violentada en sus decisiones y en tercer lugar se quiere saber a cerca de su salud o si está libre de enfermedades que le impidan su desempeño al interior del Monasterio. En tres palabras, saber sobre: legitimidad, voluntad y salud.

165 Genealogía desde Arévalo del apellido VERDUGO. En: $<w w w . T e l e f o ́ n i c a . n e t /$ web2/ garciaverdugo/ p31.htm> (consultado el 5 de diciembre de 2007). 166 ASMD. Carpeta de informaciones. 
En la tercera pregunta, podremos conocer lo dicho acerca de si la pretendienta tiene algún vínculo Matrimonial o no tiene compromiso alguno.

A la tercera pregunta dice el comisario: "sabe que la dicha Dña. Isabel García Quintana es soltera, libre de todo Matrimonio y que por tal es tenida y comúnmente reputada sin saber la más leve sospecha."

Y por la cuarta y última pregunta, podremos conocer la historia sobre si antepasados han sido penitenciados por el Santo Oficio, al lo que el testigo contestó:

“que ni la pretendienta, ni sus padres, abuelos Paternos y ni Maternos jamás fueron comprendidos en infamia alguna pues son descendientes de católico, límpio y de buen linaje, cuya verdad - añade- está ya comprobada por una información jurídica , que hizo su padre de su honrada ascendencia y buen linaje, que yo el presente Notario he visto y leído y para en el Ayuntamiento de esta ciudad y por otras dos informaciones que se hicieron a dos hermanos de la referida pretendienta Dña. Isabel García Quintana para tomar el Santo hábito de la Religión de Nuestro Padre San Francisco , sin que sepa ni haya oído decir cosa alguna contra su limpieza , ni catolicismo , ni que ninguno de sus causantes ha sido por el Santo Oficio penitenciado ni por otro tribunal castigado con nota suya ni de sus descendientes.”

“Así lo dijo y declaró: Leyosele su dicho y se afirmó y ratificó en el y lo firmó de su propia mano su dicho día, mes y año en supra de que yo notario Doy fe = entre renglones $=$ de la villa de Ivy Alicante $=$ valga $=$ lo tildado no valga $=$

Fray Francisco González Vergara - Comisario Don Thomás Antonio González Ante mi Don Gregorio De Ocampo - Notario." 167

Continuando con este proceso de ingreso de Doña Isabel García Quintana, con fecha veintiocho de diciembre de mil setecientos noventa y tres, reunidos Don Francisco Martín Lagunal, vecino de la Villa de Alba de Tormes, Procurador de Causas, en calidad de Notario Apostólico habilitado y único de la Vicaría y Don J osé Sánchez Velazco su secretario hicieron entrega a la Abadesa del Monasterio de Santa María de las Dueñas de Alba de Tormes Doña María Francisca de Frías, el permiso y licencia para admitir en la profesión de monja de velo y coro, a Doña

167 Ibídem. 
Isabel María de San Juan García Quintana Verdugo, con toda la solemnidad y ceremonia que exige el Ceremonial de la Orden.

Como dato curioso, una nota que fue encontrada en el ADS. en el Acta de defunción de los Libros de Fallecimientos de la Parroquia de San Pedro de Alba de Tormes, de los años 1685 - 1850, nos dice que Don Martín Lagunal falleció "pobre de solemnidad", después de haber tenido el Cargo de Notario, Procurador de Causas y ser una persona muy apreciada en la Villa de Alba de Tormes. Su acta de Defunción dice a la letra:

“Fco. Martín Lagunal conjunto con Nicolasa de Siennas. (pobre)

A treinta días del mes de Enero de este año de mil ochocientos y seis, de tercianas dobles y accidente de perlecia, Fco. Martín Lagunal, de oficio Procurador de Causas, conjunto de Nicolasa de Siennas naturales de la Villa de Olmedo, Diócesis de Ávila y vecinos de esta Villa. En el día siguiente treinta y uno se dio sepultura eclesiástica a su cadáver en la Iglesia de San Pedro de la cual era feligrés y no pagó costo por hallarse sumamente pobre, por lo cual pagó su entierro la Cofradía de Ánimas de esta Villa. Recibió los Santos Sacramentos de Penitencia, Sagrado Viático y Extremaunción y de ser verdad lo firmo (ut supra), como cura párroco de la expresada Iglesia de San Pedro Apostol de esta Villa de Alba de Tormes. Jerónimo Domínguez."168

Continuando con nuestro relato: Llegado el dos de enero de mil setecientos noventa y cuatro, fecha elegida por la Comunidad para hacer la profesión de la novicia música, a las nueve de la mañana de aquel día, se dio inició a la ceremonia, con una Misa solemne al Espíritu Santo, celebrada por el Vicario de la Comisión Don Felipe Hernández Prieta y el los señores Don Manuel J iménez y Don Vicente Gómez capellanes menores del Convento, Diácono y subdiácono respectivamente -

En el momento del Ofertorio, el Vicario impartió la bendición de la Cogulla, el anillo y el velo y la novicia que estaba preparada en la puerta del Coro bajo, hizo su profesión e hizo los votos según lo establecido en los Estatutos de Religión, 
tomando como único nombre el de ISABEL y por la ventana del comulgatorio, fue recibiendo las vestiduras, el anillo y las bendiciones impartidas. Finalizado este ceremonial, se continuó con el sacrificio de la Misa hasta su conclusión con la ostentación debida.

De esta manera, inicia la nueva profesa su vida conventual y su magisterio musical al lado de otras religiosas músicas, entre las que podemos nombrar a Dña. J uana de Frías, Abadesa, Dña. Manuela Gato, Doña Rosa Amores - Abadesa en aquel entonces cuando nuestra monja - música hizo la petición inicial de ingreso en el Convento de San Antonio de la ciudad de Tuy -, Doña Baltasara Acosta, Doña Bonifacia de Frías, Doña Inés Salgado, Dña. Catalina Barrientos, Dña. Fernanda Tamariz y Dña. J osefa Somoza, María Francisca Cebian, Dña. Gregoria Panamás, Dña. Vicenta Rico, todas monjas con profesión musical, algunas Vicarias de Coro, otras coristas u organistas.

\section{* GASTOS OCASIONADOS POR SU INGRESO y PROFESIÓN}

- INGRESO

Fecha: 26 de Octubre de 1792

1. Hábito entero con sus hechuras. 254 rls. $14 \mathrm{mrv}$.

2. Refrescos para la Comunidad el día que tomó el hábito Por traer la licencia de Hábito,estampa y escapularios que

3. se regaló al padre de la monja y a sus dos criados. .187 rls. $16 \mathrm{mrv}$.

4. Pagados a Don J uan Quintana por dos mulas que alquiló para venir e irse 1.000 rls.

5. Un bote de tabaco para Don J oseph Amores, por alojar en su casa A Don J uan, su hija y sus dos criados, por cuatro días........ 82 rls.

6. Una arroba de trigo y Un cuarto de arroba de azúcar.......... 33 rls.

7. Pago de la cama de la novicia........................................ 44 rls.

8. Importe de la Cogulla y por traerla de Madrid................204 rls $17 \mathrm{mrs}$.

$$
\text { Total }=1.804,13 \mathrm{rls} \text {. }
$$


* PROFESIÓN:

- Jubón hecho a su medida 140 rls.

- Zapatos 14 rls.

- Licencia de Libertad 90 rls.

- Al Notario 15 rls.

- Al Ministro de la Corona 4 rls.

- Por las Escrituras que hizo a la Comunidad. 20 rls.

- La Misa de Profesión. 8 rls.

- Pago al Señor Lagunal por el testimonio que envió 8 rls.

- Refrescos y agasajo...................................... 108 rls.

Total: 407 rls. 169

\section{SU PERSONALIDAD Y SU VIDA MUSICAL}

El Libro de Crónicas nos la describe como una mujer a la que se consideró como el "alma del oficio divino"; ingresó a la edad de quince años e inicialmente como cantora segunda, pero paulatinamente fue ascendiendo en conocimientos y en responsabilidades y por lo tanto asumió el trabajo del canto tanto salmodiado como cantado, además de ser organista; ya sabemos que era común que en estas épocas convivieran varias monjas músicas, ya fuesen cantoras u organistas, pero remitiéndonos a las fechas de ingreso de Dña. Isabel García Quintana y a la vida de Sor Catalina Gato - cantora primera, organista y violinista-podemos ver o recordar que esta había fallecido en el año de 1788. En el año de mil setecientos noventa y tres le sobrevivía su hermana Dña. Manuela Gato, también monja música pero de la cual poca información se encuentra en los Archivos.

¿Cómo se formó musicalmente? Es uno de los interrogantes que se quedan en el tintero ya que infortunadamente se desconoce por completo información alguna; no existe ningún documento en los Archivos consultados que brinden datos acerca del tema y que puedan acreditar su formación musical. Únicamente se conserva el 
testimonio de la Sra. Abadesa del momento Doña Rosa Amores, que dice saber y así lo comunica al Prelado: que era "diestra en la música y órgano, de poca edad y robusta"170

\section{- PAgOS REALIZADOS POR SU TRABAJ O MUSICAL}

Revisando los Libros de cuentas, una anotación del año 1835, nos permite saber lo pagado en la fecha referida a Dña. Isabel García Quintana: 100 rls.

A la letra dice: "cuatrocientos doce reales de agasajo para las arqueras mas cien rls. a Doña Isabel García Quintana por cantora”

Haciendo una comparación con sus antecesoras, el pago de cien (100) rls., no varió desde los primeros años del siglo XVIII, cuando se puede leer que a Dña. Ángela Collantes Abarca, los pagos por su oficio de cantora y organista ascendían al mismo valor.

\section{- SU FALLECIMIENTO}

Es una verdadera lástima que en el lapso de tiempo comprendido entre los años 1836 y 1850, se pierda el rastro de muchos detalles de la vida de varias monjas músicas que son de entero interés para el presente trabajo y de otros asuntos relacionadas con la vida conventual, como pagos a monjas músicas, dotes, defunciones, economía en general, música, etc. Ya conocemos ampliamente todo aquel largo proceso histórico-económico - que vivió España -, de la desamortización de Mendizabal, en el que desaparecieron para la posteridad valiosos e innumerables documentos de los Monasterios, entre otras cosas. Hablando expresamente de Dña. Isabel García Quintana, se han investigado los Documentos del Archivo Conventual como son las Carpetas de informaciones, los Libros de Dotes (en el se relacionan conjuntamente los fallecimientos), los Documentos del Archivo Diocesano de Salamanca, los Libros de Parroquias Defunciones-, especialmente la de San Pedro de Alba de Tormes, a la que ha pertenecido el Monasterio desde su establecimiento en intramuros y la búsqueda ha sido infructuosa; con lo cual, nos quedamos con el conocimiento de la 
existencia de ésta Monja música ponderada y admirada por sus compañeras y que fue en su momento, el " Alma de las Alabanzas divinas" como la llaman en el Libro de Crónicas.

\section{ISIDRA SANTOS Y SANTOS}

En la primera treintena del siglo XIX, se nos presenta otra monja música, natural de la localidad de Terradillos, Provincia y Diócesis de Salamanca. Doña Isidra Santos y Santos quien había nacido el 5 de marzo de 1814 y fue bautizada el 9 del mismo mes y año en la Parroquia de Terradillos - Salamanca; hija legítima de Don Timoteo Santos y Doña María Manuela Santos con abuelos paternos J uan Santos y Felícima Macarro y maternos Bernardo Santos y María Serrano, todos naturales del mismo Terradillos.

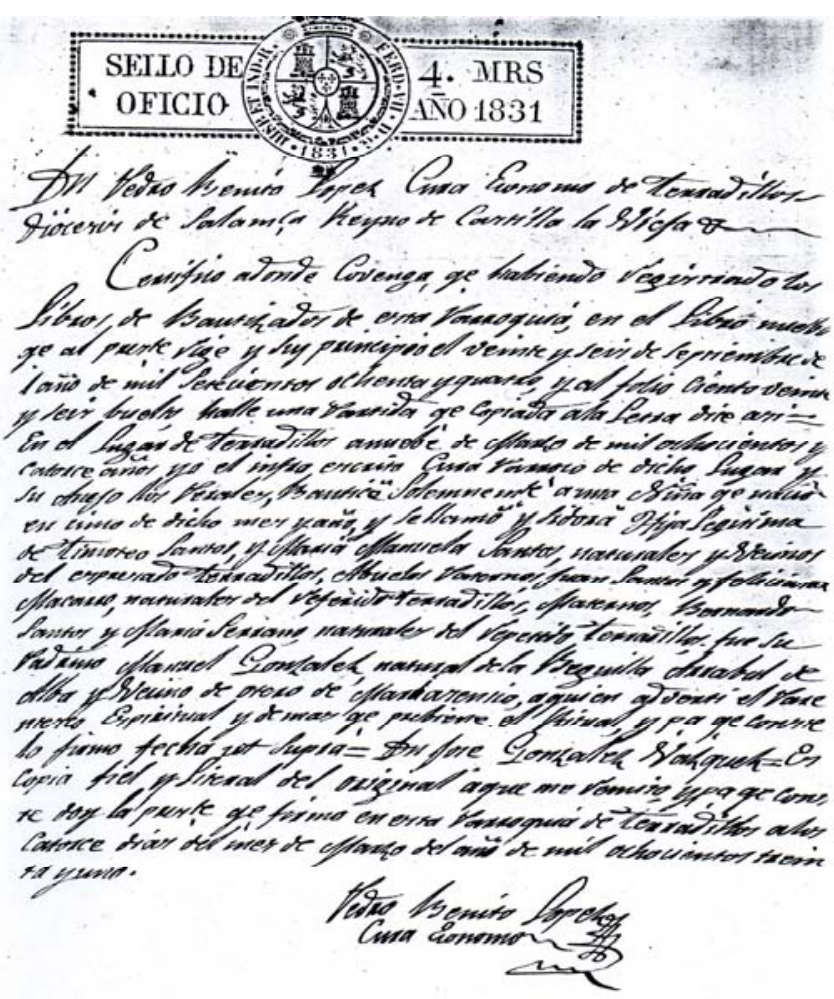

16. ASMD. Certificado sobre la existencia de la Fe de Bautismo, de Dña. Isidra

Santos y Santos, expedido por el Cura Pedro Benito López, Cura ecónomo de Terradillos - Salamanca. Del 14 de Marzo de 1831.

Era común en estas épocas y especialmente en los pueblos, que se diera el parentesco entre familias, de ahí los dobles apellidos encontrados en las personas. ¿Qué podemos saber de los orígenes de la pequeña villa de Terradillos, contigua a Alba de Tormes y situada en las cercanías de Salamanca - capital, pueblo de Doña Isidra Santos? Las primeras noticias que aparecen sobre la existencia de población 
en lo que hoy es el municipio de Terradillos vienen proporcionadas por un dolmen situado a 900 metros al SW del pueblo, en una zona elevada. Se trata del dolmen conocido como las Piedras Hitas, nombre dado por el padre Cesar Moran arqueólogo e investigador -, ubicado en la partida conocida con el Topónimo de "la torrecilla". No hay noticia de la existencia de poblamineto en época posterior, si bien la existencia de la cercana calzada, considerada como romana, puede hacer presumir que el poblamiento se mantuvo a lo largo de esta época. Dicha calzada responde a un ramal de la vía de la Plata, que unía a Salamanca con Alba de Tormes. Según los historiadores, parece ser así.

Evolución histórica: El Nombre de Terradillos (Terradielos en el siglo XIII aparece en 1224 en un documento del rey Alfonso IX y es solo a partir del siglo XVI cuando comienzan a aparecer datos de población que nos proporcionan una información directa de Terradillos, empiezan aparecer los primeros censos. La Batalla de Arapiles es el mayor momento histórico. Las tropas francesas se asentaban en las actuales urbanizaciones de El Encinar y Los Cisnes, Calvarrasa de Arriba y El Arapil Grande. Los ingleses se situaban entre Calvarrasa de Abajo y el Arapil Chico. Muy cerca de El Encinar, junto al camino que va de Arapiles a Calvarrasa de Arriba, hay una zona conocida como Cementerio de los franceses, donde presuntamente yacen enterrados los muertos del ejercito galo. Por la Constitución de 1812, Terradillos pasa a ser municipio independiente y se elige por primera vez un Ayuntamiento Constitucional.

Siglo XX. Hasta los años 70, Terradillos sufre un declive en su población causada por la emigración y a partir de los años 80 , la construcción de las urbanizaciones del Encinar y de Los Cisnes trajo consigo nuevamente el aumento de población.

Retomando la vida de Doña Isidra Santos y Santos, nos enteramos por el Libro de Dotes, que el día 9 de febrero de 1831 ingresó al Monasterio - con 16 años de edad -, como cantora y organista y el día 13 del mismo mes del año 1832, profesó definitivamente para iniciar su vida conventual y su magisterio musical, llegando a ser Abadesa durante nueve años.

Aquellos períodos de su desempeño como Abadesa, están relacionados en el Libro de Visitas y Elecciones, así: 
- Primer período : 26 de junio de 1865 (Primera elección)

- $\quad$ Segundo Período: El 10 de agosto de 1868 (Segunda elección)

- $\quad$ Tercer período : 2 dejulio de 1861 (Tercera elección)

Una particularidad muy especial, es la encontrada en su Epistolario, en la que llegados los veintiocho años de magisterio musical, ella solicita al Prelado de Salamanca la baja de sus competencias como cantora y organista y llega a un acuerdo con la Comunidad para dar una dote de cinco mil reales - pues en aquel entonces, cobraba una peseta diaria del Estado -, para cubrir las necesidades por el resto de sus días en el Monasterio. Este y el de la monja Dña. Escolástica Campo Martín, son los únicos casos que encontramos en que se da la situación de baja del cargo, pero condicionado al pago de una dote para continuar en el Monasterio y terminar sus días en él.

Veintiocho años desempeñó su cargo frente a la música desde su ingreso en 1832 y pasó a ser de dote el 3 de marzo de 1859, por cuanto las dos plazas de sus oficios que ya desde muchos años atrás existían, estaban cubiertas por compensación del Estado.

El epistolario que ella sostiene con el Sr. Obispo de Salamanca nos lo ilustra esta situación, así:

“Excelentísimo Señor, y mi venerado Padre, y Prelado: después de saludar a vuestra Ilustrísima con aquel amor y respeto que se merece; su humilde súbdita, Isidra Santos monja de esta su Comunidad de Santa María de las Dueñas, Orden de Benedictinas de la villa de Alba de Tormes, molesta su atención a fin de exponer a vuestra Ilustrísima con el más profundo reconocimiento como; llevando veinte y ocho años, en el desempeño, de cantora y organista; últimamente , con el ejercicio continuado de ambos oficios, el pecho y la garganta se han resentido y en virtud de estar provistas las plazas, cantora y organista señaladas por (...) ordenes pretendo relevarme de esta carga, por si otro día me inutilizo, pagando el dote mi familia a la Comunidad, con arreglo a los últimos que se dieron a mi entrada en la Religión en el año 32 - que fueron de cinco mil a seis mil reales v., en cuya cantidad han convenido las Sras. Del Consejo, en atención a estar pensionada poir el Gobierno y no tener que sustituir de ello (...) como no puede verificarse esto sin la 
correspondiente Licencia de mi Prelado $=$ A vuestra Señoría Ilustrísima pido y suplico, que en alivio de mi triste situación, cansada por el continuo trabajo, se sirva concederme, esta Licencia, admitiendo en ello especial favor al que viviré reconocida.

Isidra Santos"171

Don Anastasio Rodrigo Yusto, Obispo de Salamanca durante el período comprendido entre 1857 a 1867, le otorga su Licencia, respondiéndole en estos términos:

“Salamanca Febrero 19 de 1859

En atención a lo expuesto por la suplicante y la conformidad de la Revda. Madre Abadesa y Sras. del Consejo del Monasterio de Benedictinas de la Villa de Alba de Tormes y a que existen en él, las dos plazas de oficios desempeñadas por otras religiosas concedemos nuestra Licencia para que mediante la cantidad convenida de 5.000 reales Sor Isidra Santos sea dada de baja en los oficios de cantora y organista que venía desempeñando y pase a clase de monja con dote previniéndose que la entrega de dicha cantidad se verifique a las cuatro Sras. del Consejo y a presencia del Sr. Arcipreste y Capellán de la Comunidad quienes firmarán el Acta que de entrada en el Libro de Dotes. Se acordó S.S.I. el Obispo mi Sr. De que certifico ="172

\section{- $\quad$ SU PERSONALIDAD}

Pocos documentos nos revelan su personalidad y su desempeño musical, aunque el período de tiempo al frente de la música (28 años) ameritaría más información. El Libro de Dotes y especialmente las anotaciones de su defunción, nos ofrecen una mínima relación de cualidades personales diciendo:

"sobresaliendo en todas las virtudes especialmente en la observancia monástica y fue muy amante de la Comunidad por la que toda la vida se sacrificó siendo Abadesa durante tres trienios"173

Cuando contaba con tan solo 49 años y a partir del año 1859 fecha en que se le concede la Licencia de baja al cargo de cantora y organista, Dña. Isidra Santos,

171 ADS. Monasterio de Santa María de las Dueñas. Expedientes de monjas Benedictinas. Caja № 1, Años 1853 - 1942)

172 Ibídem.

173 ASMD. Libro de Dotes, p. 33 
continúa en el Monasterio hasta el año 1891, cuando fallece a la edad de 77 años; dieciocho años sobrevive después de retirarse de las actividades musicales.

PAGOS REALIZADOS A Dña. Isidra Santos y Santos por su magisterio musical:

En los Libros de cuentas el del año 1833 - 34, encontramos una nota que a letra dice:

“1468 rls. dados a las religiosas más 8 ducados a Dña. Isidra Santos por su trabajo de organista"174

- FALLECIMIENTO

Las notas sobre su fallecimiento, nos hablan sobre sus virtudes y que murió el día 11 de agosto del año 1891 a la edad de 77 años.

\section{- ANTONIA MARTÍNEZ GUTIERREZ}

Dña. ANTONIA MARTÍNEZ GUTIERRZ, ingresó en el Monasterio de Santa María de las Dueñas de Alba de Tormes en el cargo de Cantora en el año 1853; fue natural de Santa María de Tajadura, un pequeño pueblo del municipio de Quintanillas en Burgos. Había nacido en el año de 1827 alcanzando a vivir tan solo 53 años. Nació el 11 de junio de 1824, hija de Agustín Martínez y de Justa Gutiérrez, naturales y vecinos del lugar de Tajadura y ella natural de Pedrosa Reino de Teruel, con abuelos paternos Fernando Martínez y Josefa Del Barrio y maternos, Félix Gutierrz y Antonia Santos. Su padre fue muy respetado por su cargo de Alcalde por varias décadas del pueblo de Tajadura y por otros cargos públicos.

Llegó al Monasterio siendo muy joven - a la edad de 26 años -; este, posiblemente sea uno de aquellos casos en que aparte de que ella misma expresaba su vocación y su deseo de tomar la vida religiosa, los documentos de su expediente nos dan a entender que su familia deseaba "apartarla de personas sospechosas y de malas compañías", considerando que estaba expuesta a muchos peligros, - según

174 ASMD. Libro de Cuentas. Años 1833- 1834, p. 56. 
palabras de los testigos que declararon sobre sus hábitos y costumbres de vida -. 175

En documento firmado, ella misma solicita al Obispo de Salamanca, su ingreso en el Monasterio de Santa María de las Dueñas de Alba de Tormes y concretamente la Plaza de "Cantora".

"Excelentísimo e Ilustrísimo Sr. Obispo de Salamanca

Antonia Martínez natural del pueblo de Santa María Tajadura Diócesis de Burgos: con el debido respeto y veneración a S.E.I. hace presente que hallándose desde su tierna edad con vocación al estado de religiosa y deseando ingresar en uno de sus conventos de religiosas Benedictinas de Alba de Tormes, con la plaza de cantora para cuyo cargo se considera ya instruida, como en caso necesario podrá remitirse a las personas inteligentes en la facultad. En este estado A S.E.I. suplica humildemente se digne agraciarla con la dicha Plaza, en lo que recibirá especial agradecimiento. Santa María de Tajadura y mayo diez y ocho de 1853. Antonia Martínez"176

La respuesta a esta solicitud, llegó de manos del Sr. Secretario del Obispo, en estos términos:

"Salamanca mayo 24 de 1853

Nuestro Arcipreste de Alba se constituirá en el Convento de Religiosas Benedictinas asistido del Capellán del mismo y en la forma acostumbrada y por votos secretos hará que la Comunidad manifieste si admite a cantora a la suplicante extendiendo acta del resultado con expresión del número de Religiosas cuántas toman parte en la votación y los votos en pro y en contra que resulten del escrutinio - Evacuada este diligencia nos informará con reserva y exactitud acerca de la vacante de cantora y de las circunstancias de la familia de la suplicante, de las suyas personales, motivos que probablemente la inducen a entrar en el Claustro y señales que haya dado para calificar la vocación, tras todo lo cual le encargamos la Conciencia - lo acordó el Ilustrísimo Obispo mi Sr. De que certifico $=$ Dr. Secretario Ávila."177

175 ASMD. Documento de Averiguaciones a testigos, firmado por el Arcipreste Don Luís Francisco García. Informaciones de Dña. Isabel García Quintana. Caja 1. Documento sin numeración. 176 ASMD. Expediente de Dña. Antonia Martínez.

177 Ibídem. 
El acta levantada el 20 de junio de 1853, recoge varios puntos de considerable importancia para la decisión de aceptación, especialmente para ingresar a la vida religiosa: primeramente, la cuantía de votos a favor y en contra de los cuales salieron 20 votos a favor y uno en contra, quedando admitida por mayoría de votos. En segundo término, y de acuerdo a lo dicho por los testigos, se analiza la limpieza de sangre de sus padres y abuelos paternos y maternos, se dice que son cristianos puros, que no han cometido delito alguno infame, y por el contrario siempre su padre ha recibido los honores del pueblo en su calidad de Alcalde y en otras ocasiones por ser Regidor y haber ejercido la Mayordomía de la Iglesia. En tercer término, hacen referencia a las inclinaciones personales de la pretendienta y a los motivos que la inducen a tomar la vida religiosa; dicha vocación fundada en su adhesión al culto religioso, a sus muchas virtudes y desde otro punto de vista, se analizan las palabras de los testigos Don Diego Carrillo y Don Matías de la Iglesia, vecinos del lugar, quienes hablan que ha sido apartada de personas sospechosas y de "malas compañías".

Don Felipe García, Cura párroco beneficiado del dicho lugar de Tajadura (Burgos), el día 26 de abril de mil ochocientos cincuenta y tres, hace comparecer ante sí a los testigos, los Señores Don Diego Carrillo y Don Matías de la Iglesia, los dos naturales del lugar de Tajadura, los cuales fueron interrogados y respondieron así a las preguntas formuladas:

A la primera pregunta, si conocían a la joven Antonia Martínez y a sus padres y abuelos, si eran de buena raza y si habían ejercido oficios viles, ellos contestaron:

" respondieron en primer lugar, que Antonia es hija de legítimo Matrimonio de Agustín Martínez y Justa Gutiérrez por saber estar legítimamente casados y velados, que durante el matrimonio tuvieron a la dicha Antonia, que es cristiana y limpia de toda raza, por cuanto saben y les consta que sus padres, abuelos paternos y maternos estuvieron siempre en buena reputación, y que lejos de haber tenido los padres y abuela de la pretendienta, así paternos como maternos oficio vil y bajo, al contrario han ejercido y obtenido varias veces todos los más honoríficos de este pueblo como al presente ejerce y obtiene el padre dela pretendienta el 
oficio honorífico de Alcalde y en otra ocasión el de Regidor y Fabriquero de la Iglesia; es lo que responden a la primera pregunta."178

A la segunda pregunta, encaminada a escudriñar sobre la Limpieza de sus actuaciones, ellos respondieron:

" que no ha llegado a su noticia que la Antonia Martínez pretendienta, ni sus padres hayan cometido delito alguno por el que hayan podido incurrir en la nota de infamia pública, antes saben que así la pretendienta como sus padres han vivido honrada y pacíficamente en este pueblo de donde son y han sido y que por el conocimiento y trato que tienen y Han tenido de todas las personas expresadas, parece a los testigos que no se les podía ocultar si hubieran cometido semejantes delitos y la justicia en este caso les hubiera puesto las correspondientes penas; en cuyo supuesto verdadero, no pueden decir otra cosa, sino que la dicha pretendienta es moza alenta, bien criada, apartada de malas compañías e inclinada a obras de virtud; como es público y notorio a cuantos la han tratado."179

A la tercera y última pregunta orientada a saber sobre la salud física de la pretendienta, los testigos dijeron:

"que tienen a dicha pretendienta por robusta y sana del cuerpo sin enfermedad contagiosa, por cuanto la han conocido desde niña y vistola siempre ágil, expedita en todos sus miembros"180

Como se observa que la naturaleza de las preguntas se conserva, aunque reducida, puesto que se permite que los testigos firmen a la vez su declaración en una comparecencia conjunta.

Con las anteriores averiguaciones y teniendo más claridad en cuanto a los orígenes de la pretendienta, de sus padre y abuelos, se continúa con las debidas diligencias; así que tratado el caso de Dña. Antonia Martín al interior del Monasterio y condicionado su ingreso al examen de un facultativo de la música, el Secretario del Sr. Obispo, Dr. Ávila, le concede un mes de plazo para que se presente a practicar las diligencias oportunas en la forma que se prescriba.

178 ASMD. Expediente de Dña. Antonia Martínez. Carpeta de Informaciones. Documento sin numeración. 


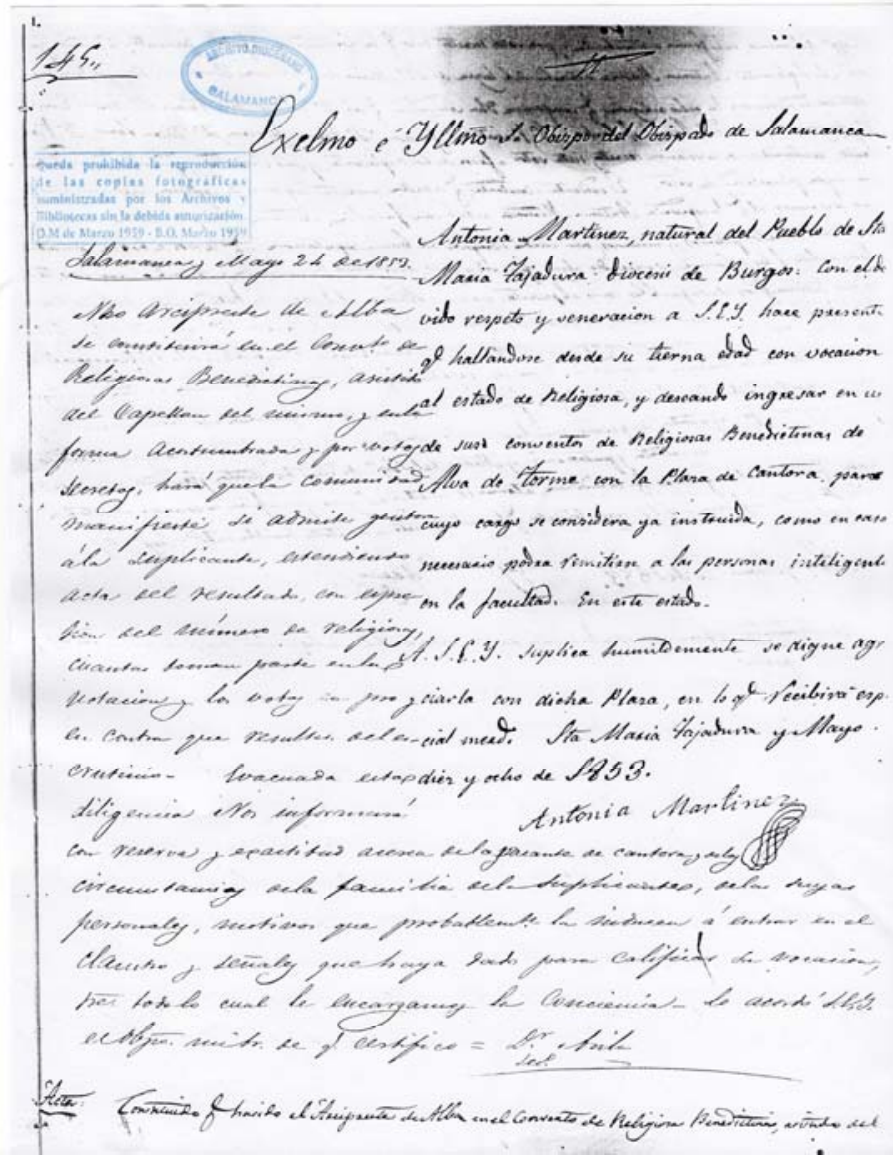

17. ASMS. Solicitud de ingreso a la plaza de "cantora" de Dña. Antonia Martínez Expediente - Carpeta de Informaciones.

En vista de la necesidad que el Monasterio tenía de incorporar a una cantora, el siguiente paso para Dña. Antonia, fue el de superar la prueba de canto y este examen fue efectuado por el Sr. Don Agapito López profesor de Música de la Villa de Alba de Tormes, que examinando a Dña. Antonia Martínez la halló muy útil tanto en el canto llano, como en el canto figurado y con bastante disposición y actitud por sus buenos conocimientos en la materia y la forma de dirigir el Coro y todo esto en presencia del Arcipreste y otras personas que conformaron un tribunal.

El Arcipreste envía al Sr. Obispo la comunicación sobre los resultados del examen con la conformidad de las Religiosas del Monasterio e Santa María de las Dueñas de Alba de Tormes. 


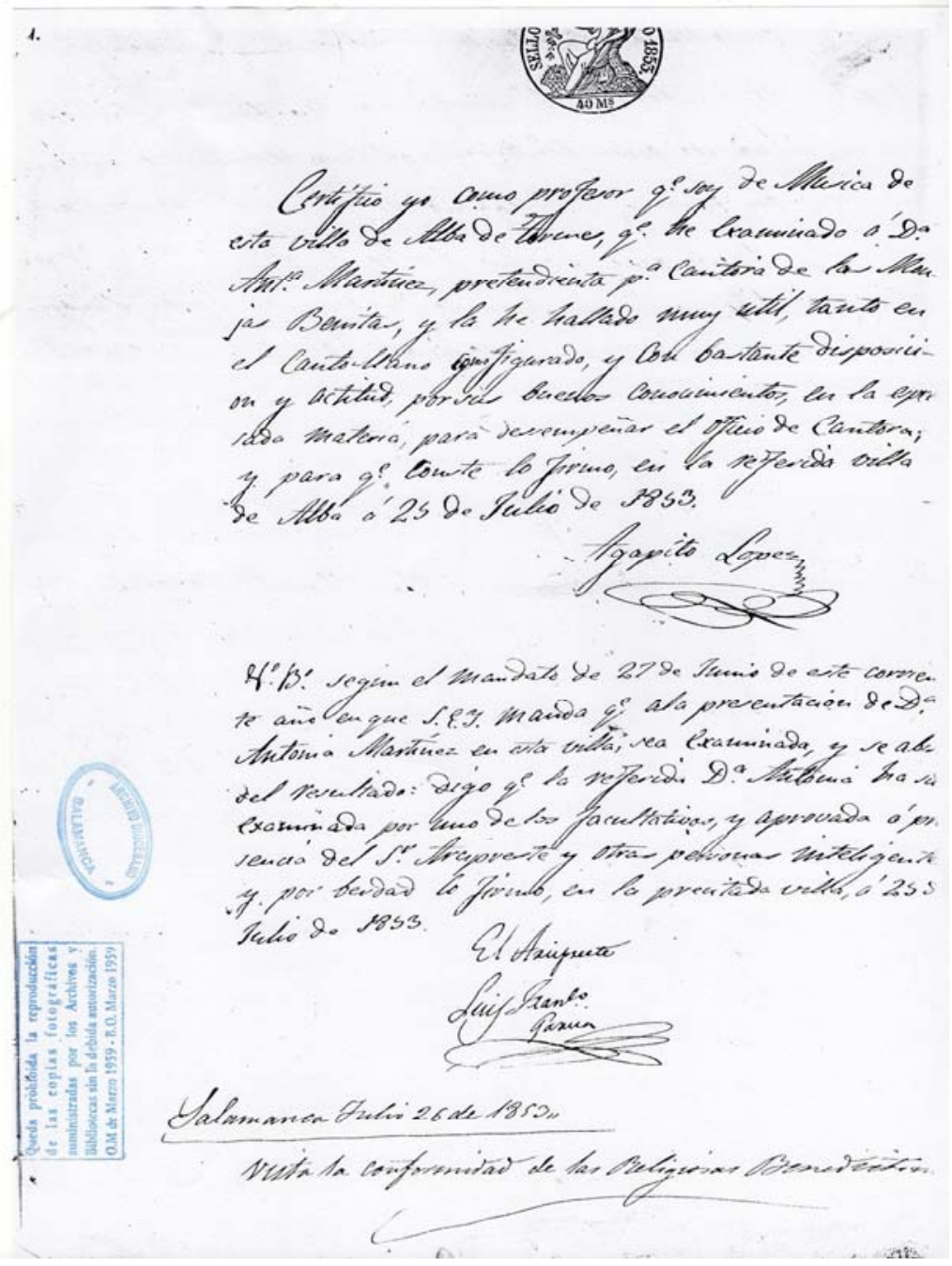

18. ASMD. Acta de examen de Dña. Antonia Martínez. Carpeta de Informaciones.

Conocido el concepto del Maestro de música, Don Luís Francisco García, Arcipreste de esta Villa, es comisionado para que le el hábito a Doña Antonia Martínez con arreglo a lo presentado en el ritual de la Orden. En el documento que encarga esta comisión, se hace énfasis a la forma de cantar y la actitud con que dirige el Coro. Dicho documento está firmado por Don J osé de Colsa, Gobernador electo de la Villa por mandato de su Ilustrísima.

De esta forma y cumplimentadas todas las debidas diligencias, ingresó al Monasterio. 
Una vez ingresó como Novicia, un año de prueba tuvo Dña. Antonia Martínez, para afianzarse en la fe, en las costumbres y sobre todo en la observancia a la Regla de San Benito, al cabo del cual, fue sacada del noviciado para llevar a cabo la Diligencia de Exploración correspondiente ordenada por el Sr. Obispo, siendo interrogada sobre su libertad de actuar, sobre los impedimentos civiles y canónicos que tuviese, y para ser puesto en su conocimiento las cargas de la Comunidad y sus responsabilidades de cara al cargo de su ejercicio musical, a lo que ella contestó con claridad sobre estos asuntos, diciendo que conocía las cargas de la Comunidad y que no tenía enfermedad ninguna que le impidiera su trabajo.

El dos de agosto de Mil Ochocientos cincuenta y cuatro, con toda la solemnidad que precisa un acontecimiento de esta naturaleza, Dña. Antonia Martínez hace su profesión como religiosa de "velo completo" - Véase el documento de su Profesión -, e inicia de esta manera su vida religiosa con todas las obligaciones de su profesión de "Cantora".

Los cargos desempeñados y relacionados con su Profesión, fueron el de Cantora primera y Vicaria de Coro.

El Libro de Crónicas nos la describe como una mujer de paciencia admirable y que desempeñó su oficio de Cantora con mucho celo y responsabilidad. El día 17 de abril, después de padecer una penosa enfermedad durante diez meses, murió a la edad de 53 años.

\section{- ESCOLÁSTICA CAMPO MARTÍN}

ESCOLÁSTICA CAMPO MARTÍN - Organista -, la que en el siglo fuese bautizada con el nombre de Dorotea, había nacido en Villalón de Queja, (Villalonquejar) Provincia y Diócesis de Burgos, el 28 de marzo de 1841 siendo hija legítima de Raimundo Campo y de Emeteria Martín vecinos de la ciudad de Burgos, con abuelos paternos Dn. Francisco del Campo y Dña. Francisca Marcos y maternos Dn. Salustiano Martín y Dña. María González. Recibió el Sacramento de la Confirmación el 11 de julio de 1844 en la Parroquia de San Lorenzo de la ciudad de 
Burgos. A los 15 años de edad solicitó el ingreso en la plaza de Organista y a los 16 ingresó en el Monasterio de Santa María de las Dueñas de Alba de Tormes Salamanca, ya con el cargo ganado y a su retiro de la actividad musical, al cumplir los 20 años de Magisterio Musical, pagó una dote de 2.500 pesetas. Desconocemos los motivos de su prematuro retiro del ejercicio musical, pero podemos entender que las obligaciones de Abadesa que desempeñó por muchos años, le obligaron a desligarse de la obligación contraída inicialmente. En esta primera parte de nuestro relato, vamos a llamarla por su nombre de Pila - Dorotea- y una vez haya tomado los votos definitivos la llamaremos por su nombre de Religión Escolástica -.

Ubiquémonos en Villalonquejar, un pequeño pueblo a cinco Kms. de Burgos. Revisando las carpetas de Informaciones del Archivo de Santa María de las Dueñas, es preciso decir que de la Provincia de Burgos, se encuentran relacionadas muchas jóvenes que vinieron a ingresar en la vida religiosa al Monasterio de Santa María de las Dueñas de Alba de Tormes. En este mismo plano, podemos ubicar el pueblo de Santa María de Tajadura, de donde fue Doña Antonia Martínez Gutierrez, cantora del Monasterio, referida anteriormente.

Burgos, ampliamente conocida, tan rica en acontecimientos que llenan la historia de España con las leyendas del legendario Cid Campeador, con Santo Domingo de Silos, Las Huelgas, la Cartuja de Miraflores y protagonista en la Ruta obligada al Camino de Santiago, definitivamente ha sido y desde siempre, una maravilla de espacio y conjunto monumental e histórico que merece ser apreciado en toda su dimensión.

Para conocer sobre la situación política y social en que se encontraba la ciudad de Burgos en los límites cronológicos en que se encuentran relacionadas nuestras monjas músicas oriundas de esta región, lo más conveniente es repasar un poco los acontecimientos que llenaron el siglo XIX, en esta Provincia. El siglo XIX trae dos acontecimientos: Uno político y otro institucional de vital importancia: La Guerra Napoleónica y las Cortes de Cádiz. Burgos resiste desde su entrada en 
España y en la Ciudad, a los franceses y soporta durante cuatro años la presencia en su recinto de tropas extranjeras.

En segundo término, Burgos se convierte en capital de provincia, con el Real Decreto de 30 de noviembre de 1834; finalmente el ejército y la Iglesia se contagian del espíritu centralista y burocrático de la época.

“El Seños Don Hilario María Iglesias Presbítero Canónigo de esta Santa Iglesia Catedral y Vicesecretario de Cámara y Gobierno de esta Dignidad Episcopal $=$

Certifico: que del Libro registro de las Comunidades Religiosas que se hallan en esta Diócesis y que obra en esta Santa Catedral, aparece vacante la plaza de Organista en el de San Benito de la Villa de Alba de Tormes, y para los efectos correspondientes doy la presente de orden de S.E.I. del Obispo mi Señor, en Salamanca a veinte y tres de febrero de mil ochocientos cincuenta y siete. Don Hilario María Iglesias Vice - Secretario.”181

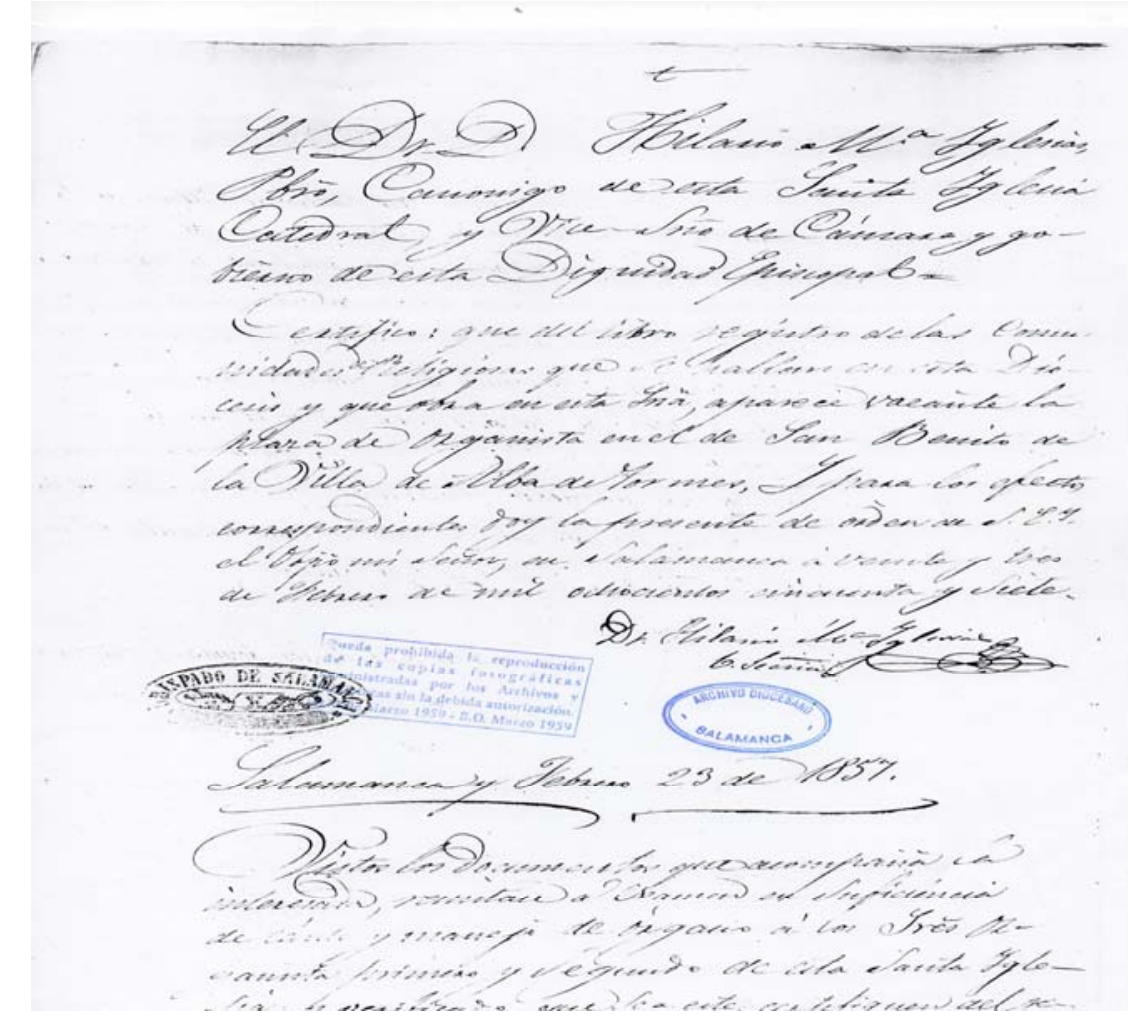

19 ADS. Plaza de Organista. Expediente de Dña. Escolástica Campo Martín. Caja 1 (Años 1853 - 1942)

181ADS. Caja 1(años 1853 - 1942) Expediente de Dña. Escolástica Campo - Organista. 
Comentamos anteriormente, que estas plazas de música eran apetecidas por los padres para sus hijas, buscando en muchas ocasiones el acomodo para su futuro, una seguridad económica y para que tuvieran una vida digna y para ello, se las hacía instruir musicalmente con Maestros de Música de las Catedrales o de las Parroquias, haciendo en cierta forma una inversión para la vida posterior de sus hijas.

A los 15 años Dña. Dorotea, solicitó su ingreso al Monasterio para la plaza de Organista y el derecho a pensión que por tal concepto y por vía de subsistencia les estaba señalada por el estado a las que desempeñan el precitado oficio en las Comunidades religiosas por aquel entonces; "y con la instrucción de su maestro, suficiente para el bien desempeño del expresado cargo de organista."182

Su deseo expreso de ingresar a la vida religiosa siendo tan joven, queda plasmada en la siguiente carta dirigida al Sr. Obispo de Salamanca, en los siguientes términos:

\begin{abstract}
“Dorotea Campo natural del pueblo de Villalon en la Diócesis de Burgos, de edad de 15 años, hija legítima de Raimundo Campo y de Emeteria Martín vecinos actualmente de esta ciudad de Burgos a V.E.I. con la mayor veneración expone : que llamada por la Bondad divina a abrazar el estado religioso pretendió vestir la santa Cogulla de San Benito, de clase de Organista en el Monasterio de Religiosas Benedictinas de la Villa de Alba de Tormes de esa vuestra Diócesis cuenta ya con el voto unánime de las religiosas del referido Monasterio y con la instrucción al parecer de su Maestro, suficiente para el buen desempeño del expresado cargo de organista en cuya atención suplico A V.E.I. que en vista de los Documentos que tiene la honra de acompañar a este memorial, se sirva otorgarle la Licencia necesaria para su ingreso y toma de hábito en el referido Monasterio de Benedictinas de Alba de Tormes con el dicho cargo de Organista y derecho a la pensión que por tan concepto y por vía de subsistencia les está señalada por el Estado a las que desempeñan el
\end{abstract}

182 ASMD. Documento de solicitud de ingreso y toma de hábito. Carpeta de informaciones. Expediente de Dña. Dorotea Campo Martín. 
precitado oficio en las Comunidades de religiosas Dios guíe la importante vida de V.E.I. para el bien de la Diócesis Burgos 11 de febrero de 1857."183

Estando sin firma el presente documento, se percibe que este planteamiento lo hace al Obispado, la Sra. Abadesa y en nombre de la pretendienta.

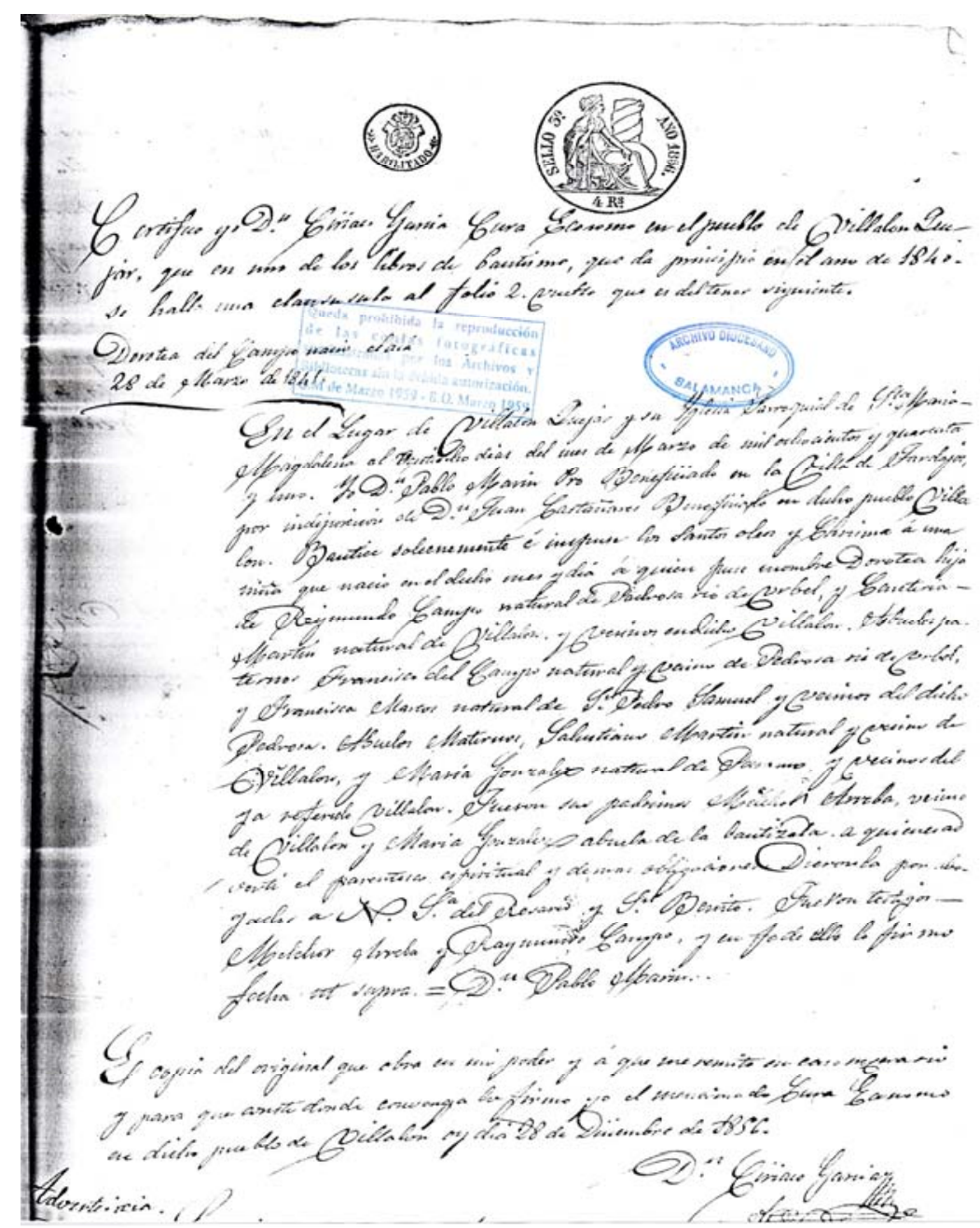

20. ADS. Escolástica Campo M. Fe de Bautismo - Caja. 1 (años 1853 - 1942)

Al solicitar el ingreso al Monasterio en calidad de Organista, a la par con las averiguaciones de rutina, como los testimonios de testigos y las informaciones de buena conducta y costumbres, la pretendienta debía acreditar su solvencia en el 
manejo del órgano y de la lectura del canto llano y el solfeo; el Organista Don Antonio López de la Iglesia Parroquial de San Esteban de la ciudad de Burgos, da certificación de aquella capacidad que Dña. Dorotea Campo M. posee para el ejercicio de Organista, así:

“Certifica Don Antonio López Organista de la Iglesia Parroquial de San Esteban de esta ciudad de Burgos; que Dorotea Campo natural de Villalón de este Arzobispado, hija de Raimundo y Emeteria Martín está suficientemente instruida en el ejercicio de Organista.

Y para que conste y surta los efectos que haya lugar, doy la presente que firmo en esta ciudad de

Burgos a 12 de febrero de 1857.Antonio López"184

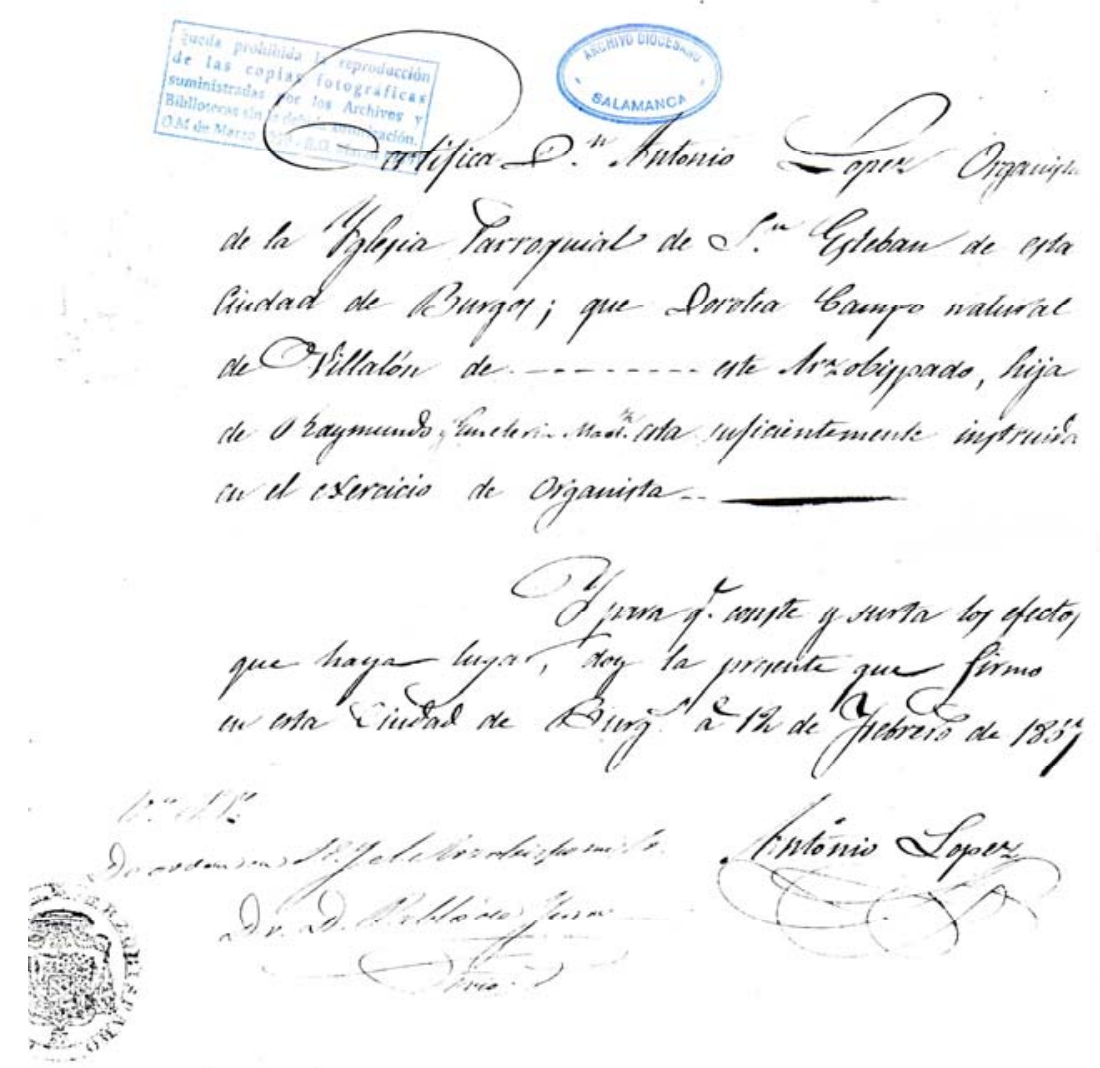

21. ADS. Certificado de idoneidad musical de Dña. Dorotea Campo, firmado por su tutor musical Dn. Antonio López.

Expediente - Caja № 1 (años 1853 - 1942)

184 ADS. Caja 1(años 1853 - 1942) Expediente de Dña. Escolástica Campo - Organista. 
Los epistolarios cruzados entre la Señora Abadesa del Monasterio, el Sr. Obispo de Salamanca, el Sr. cura Párroco de la localidad de Tajadura - Burgos, el Sr. Don Antonio López, Profesor de Música instructor de Dña. Dorotea Campo Martín, incluyendo los testigos, forman un corpus de fuentes importante que nos permite conocer el procedimiento y los pasos llevados a cabo para su ingreso.

“Dña. Gregoria Paramas, Abadesa en el Convento de Religiosas Benedictinas, de Alba de Tormes, Provincia y Obispado de Salamanca, en virtud de la facultad delegada por el Excelentísimo e Ilustrísimo Sr. Don Fernando de la Puente y Rivera, Obispo de Salamanca, autorizo por la presente a Don Felipe García , cura Beneficiado en la Iglesia Parroquial de el lugar de Tajadura, Provincia y Arzobispado de Burgos, para que haga las informaciones de vida y costumbres de Dña. Dorotea Campo, pretendienta al Santo hábito de San Benito , y de sus padres conforme al tenor de las Constituciones de nuestra orden; En virtud de la cual doy la presente firmada de mi nombre en el sobre dicho convento de Alba de Tormes a veinte y siete de febrero de mil ochocientos cincuenta y siete.

Gregoria Paramas - Abadesa."185

En el mismo documento, y a continuación de la anterior solicitud, Don Felipe García cura Párroco de la Iglesia de la Inmaculada de la localidad de Tajadura Burgos, contesta:

“Aceptación= Yo Don Felipe García cura Párroco en la Parroquia de la Inmaculada Concepción de el lugar de Tajadura Provincia y Arzobispado de Burgos, acepto desde luego la comisión dada por la Sra. Dña. Gregoria Parama Abadesa del Convento de Religiosas Benedictinas de Alba de Tormes Provincia y Obispado de Salamanca, para hacer las informaciones de Dña. Dorotea Campo, natural de Villalón, Provincia y Arzobispado de Burgos, pretendienta al Santo hábito de San Benito, y de la buena opinión y fama de sus padres, residentes al presente en la ciudad de Burgos, desde un año a esta parte, $y$ prometo cumplir fiel y exactamente los deberes que me son inherentes, en la fe de lo cual firmo en el lugar de Tajadura a cinco de marzo de mil ochocientos cincuenta y siete $=$

Don Felipe García"186

185ADS. Caja 1(años 1853 - 1942) Expediente de Dña. Escolástica Campo - Organista 186 Ibídem 
El citado cura Párroco Don Felipe García inicia las averiguaciones y hace comparecer ante si a Don Balentín González de sesenta años de edad y a Pablo Páramo de sesenta y cuatro años de edad vecinos de Villalon quienes prometieron decir la verdad a toda pregunta que se les formulara.

Tres preguntas encerraban las averiguaciones necesarias que permitirían a nuestra monja música, su ingreso en la vida de Religión; recordemos aquí, que para el ingreso de Dña. Isabel García Quintana, las preguntas fueron cuatro y estas a su vez encerraban varios cuestionamientos. A la fecha en que nos encontramos, el año 1857, dichas preguntas algo se han simplificado y por ende las respuestas de los testigos. Por lo demás en el presente caso, los testigos son solo dos personas, a diferencia de los casos de las anteriores religiosas, los testigos eran cuatro. Observemos como, con el pasar del tiempo, todo cometido o acción se comprime, se reduce a sus mínimas expresiones, por diferentes motivos, que se pueden analizar como un ahorro de tiempo, un ahorro en la gestión, falta de personal que gestione con rapidez los asuntos, falta de papel, se consideraría muy largo y tedioso el procedimiento anterior, en fin, variadas razones pudieron motivar los paulatinos cambios que vamos encontrando al respecto.

¿Cuál era la naturaleza de las preguntas en el caso de Doña Escolástica Campo Martín, - otrora Dorotea?

\footnotetext{
“1̄ Conocen Vs. A los Padres de Dña. Dorotea Campo por una buena opinión y fama, o si han sido castigados por pena infamante?

2 ${ }^{\text {a }}$ Saben Vs. Si Dña. Dorotea es de buena conducta, si ha frecuentado los Stos. Sacramentos y otros actos de piedad, o si padece alguna enfermedad contagiosa e incurable?
}

3a Saben Vs. Si hay algún otro motivo que pueda ser impedimento para su admisión en la Religión?"187

Conozcamos cómo fueron las respuestas de los dos testigos que a la par, firman el documento:

187 Ibídem. 
“Respuestas.

1a A la primera pregunta declararon que conocían bien a los Padres de Dña. Dorotea desde que nacieron, que son y ha sido tenidos siempre por gente honrada, que no ha ejercido jamás oficio vil, o infamante, antes bien ha ejercido el oficio honroso de Secretario del Ayuntamiento por espacio de una docena de años, hasta hace poco más de un año que pasó a la ciudad de Burgos, en donde nos consta también una conducta inreprensible ="

2a Manifestaron a la segunda pregunta que Dña Dorotea es de buenas y edificantes costumbres, que ha frecuentado los Santos Sacramentos muy particularmente de tres años a esta parte en que manifestó tener vocación al estado de Religiosa; y que su robustez y agilidad en el andar manifiesta no tener enfermedad alguna $=$

3a - Dijeron a la tercera pregunta que no conocían hubiese motivo alguno que la impidiese poder entrar en la Religión y que su resolución en tomar el Santo hábito, creen que será con el fin de servir a Dios con más perfección y trabajar en el negocio de su salvación.

Todo lo cual habiéndolo leído de vervo ad vervum, se ratificaron en ello, y en testimonio de la verdad lo firmaron en referido lugar de Tajadura a cinco de Marzo de mil ochocientos cincuenta y siete.

\section{Balentín González}

I

A estas interrogaciones presentadas con la mayor diligencia a favor de Dña. Dorotea, se dio fin a estas informaciones asegurando además ser conocidos los testigos como hombres de probidad, y no tener yo noticia alguna al contrario de sus declaraciones, y para que así conste, lo firmo en el precitado lugar de Tajadura dicho día, mes y año ut supra $=$

Don Felipe García"188

Aparte de los testigos interrogados, otras varias personas se presentaron a declarar sobre la buena conducta y las buenas costumbres de Dña. Dorotea; es el caso de Don Andrés Sainz, Una vez realizadas las anteriores diligencias, encontramos a

188 Ibídem. 
Dña. Dorotea en el momento de demostrar su talento y sus habilidades, para alcanzar la aprobación en los exámenes que se le practicarán. Vistos los documentos que conforman el expediente de Dña. Dorotea, el Sr. Don Hilario María Iglesias Vice - Secretario de Cámara, por disposición del Sr. Obispo, ordena que la pretendienta sea remitida a los examinadores para dar la prueba de Suficiencia de canto y manejo de órgano, señores Organista Primero y Segundo de la Santa Iglesia Catedral de Salamanca y que verifique que se haga el examen y que los Srs. Organistas certifiquen del resultado y lo firmen. De tal manera, que el examen se hace el 23 de febrero de 1857 y los Señores Organistas Don Manuel Hernández y J uan J osé de Siles, certifican el resultado, con estas palabras:

“Los infra firmantes organistas de esta Santa Basílica Catedral cumpliendo las ordenes de S.E.I. hemos examinado a Dña. Dorotea Campo que hoy ha presentado a este oficio; y la hemos hallado en el manejo del órgano o mismo que en las necesarias nociones de Canto llano, en estado de bastante instrucción y soltura suficiente ara el desempeño de cualquier plaza que requiera conocimientos tales. $Y$ en virtud de ello certificamos. Salamanca y febrero 23 de 1857

Manuel Hernández

J uan J osé de Siles"189

Habiendo superado la pretendienta, la prueba musical con éxito, la Sra. Abadesa Dña. Gregoria Paramos, envía el expediente al Obispado y en carta anexa, fechada a 11 de marzo de 1857, le informa al Sr. Obispo de Salamanca, sobre la votación realizada al interior del Monasterio y su aprobación por unanimidad, para poner hábito a Dña. Dorotea, a la par que le solicita se sirva designar a la persona que él crea conveniente o sea de su agrado, para dar el Santo hábito a la nueva novicia.

Aún queda la indagación a la aspirante y para ello es designado el Arcipreste para que proceda a hacer el exploro de la aspirante; interrogatorio que va encaminado a conocer especialmente su voluntad para entrar en la vida religiosa, su vocación y reiterarle el conocimiento de las obligaciones que contrae con su plaza y la

189 Ibídem. 
enseñanza y si está dispuesta a aceptarlas. Entre otras preguntas, se desea conocer si tiene o no algún impedimento civil o canónico; este interrogatorio se lleva a cabo el 12 de marzo de 1857 y el 13 del mismo mes y año, se da comisión al Arcipreste para que pueda vestir el hábito de San Benito a Dorotea Campo, conforme a las Constituciones y Regla de la Comunidad de Religiosas Benedictinas de la Villa de Alba de Tormes; había solicitado mudar el nombre de Dorotea por el de Escolástica como lo deseaba.

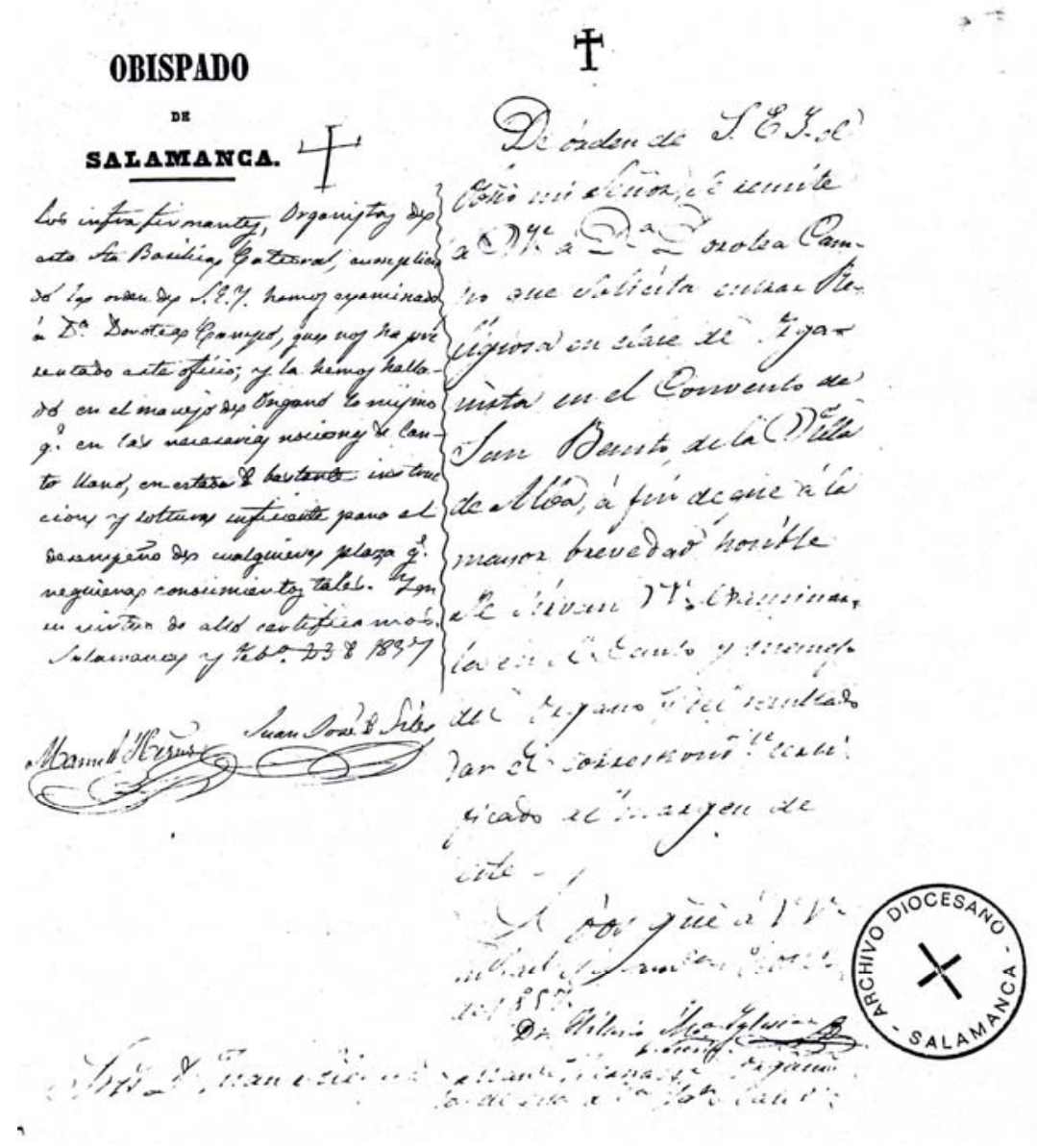

22. ADS. Acta de examen firmada por los Organistas de la Catedral de Salamanca, Don Manuel Hernández y DonJ uan J osé de Siles. Año 1857. Caja № 1 - Expediente de Doña Dorotea Campo.

Por las Crónicas del Monasterio nos enteramos de algunos detalles particulares de su infancia y su llegada al Monasterio; de muy pequeña pasó a vivir a la ciudad de Burgos, - Ya supimos por testimonios de los testigos que su padre que fue secretario del Ayuntamiento de Villalón de Quejar, pasó a Burgos -, y vivía la niña 
con su familia y un tío suyo, quien se interesó por su educación, especialmente por lo musical, pues tan niña, daba sus primeras señales de vocación y de su talento musical; así las cosas, la puso a estudiar música con un organista, el párroco ya mencionado Dn. Antonio López, mostrando grandes progresos desde las primeras lecciones y muy pronto estuvo en condiciones de poder acompañar con el órgano en la Parroquia a la que pertenecía.

Llegado el momento tomó rumbo a Salamanca y Alba de Tormes, con sus deseos a punto de verlos convertidos en realidad y con su madre que la acompañó en un penoso viaje que duró ocho días - por la falta de medios de comunicación de la época - dio su examen y el día 15 de marzo de 1857, fue el día señalado para que la jovencita pretendienta vistiera el hábito de Benedictinas y de esta forma da principio a su noviciado, llegando a ser Prelada, venerable y ejemplar para la Comunidad. Pasó el año de noviciado y el 22 de marzo de 1858 hizo la Santa Profesión. En los Libros de Visitas y Elecciones, se la encuentra relacionada con varios cargos a la vez, esto debido al reducido el número de Religiosas, por ende, se veían en la obligación de desempeñarse en diversas funciones.

\section{GASTOS OCASIONADOS POR SU INGRESO Y PROFESIÓN}

Fecha:

Concepto : Hechura del hábito 20 rls.

: Sacristán.................................. 11 rls.

: Demandadera 10 rls.

Total : 131 rls.

\section{SU PERSONALIDAD}

Dotada de grandes virtudes que cultivó desde su ingreso en el Monasterio, llegó a ser Abadesa por cinco trienios, se sabe que poseía un gran corazón y un temple de hierro; Esta mujer es el prototipo vivo de la "mujer gestora innata", única y brillante en los asuntos económicos que para sacar a la Comunidad adelante cuando vivieron tantos apuros económicos, especialmente en su primer período como Abadesa, iniciando el año 1880, cada noche robándole horas al descanso, escribía cartas y mantenía estos epistolarios con personas pudientes Duques, 
Condes, Marqueses, Prelados, que le pudieran brindar el apoyo financiero para cubrir las necesidades de sus "hijas" como llamaba afectuosamente a las religiosas, logrando suficientes ayudas para la Comunidad, incluso de la Universidad de Salamanca. Veamos algunas de esas importantes ayudas que consiguió de personas prestantes:

- $\quad$ EN SU PRIMER PERÍODO COMO ABADESA - 1884 (1ª Elección)

- Del Capellán. 100 rls.

- Del Arzobispo de Cuba 100 rls.

- Del Duque de Useda 100 rls.

- Del Capellán 100 rls.

- De Don Alejandro Cifuntes. 100 rls.

- De Don Juan Sánchez. 100 rls.

- De la Marquesa de Uceda. 100 rls.

- Del Patriarca de los Judíos................................. 100 rls.

- $\quad$ Del Duque de Uceda.......................................... 100 rls.

- Del Conde de Plasencia.......................................200 rls.

- $\quad$ De la Duquesa de Alba..................................... 400 rls.

• De la Palmas y Canrias...................................... 2940 rls.

- $\quad$ EN SU TERCER Y ÚLTIMO PERÍODO COMO ABADESA 1896 (3a Elección)

- $\quad$ Del Duque de Useda ........................................... 100 rls.

- Dela Viscondesa de Bahía Honda ......................... 100 rls.

- $\quad$ Del Conde de Plasencia ........................................ 200 rls.

- $\quad$ Del Conde de Francos .........................................200 rls.

- Del Obispo de Salamanca (20 de Enero de 1892) ...... 1000 rls

- De la Marquesa de Castellanos............................. 100 rls.

- De Dña. Dolores Clavijo........................................ 100 rls.

- De Dña. Concepción Aguillon................................ 600 rls. 
- $\quad$ Del Rector de la Universidad................................ 100 rls.

- De la Condesa de Moriana .................................... 200 rls.

- $\quad$ Del Obispo de Salamanca (30 de Agosto de 1892)...... 400 rls.

Las ayudas económicas mencionadas se encuentran relacionadas entre otras muchas, en los Libros de cuentas del Monasterio de los años 18841885 y 1891 1892. Con fecha del 27 de octubre de 1891, sin número de páginas.

Veamos a qué Rector de la Universidad de Salamanca, le correspondió conceder tan bienvenidas ayudas económicas al Monasterio de Santa María de Las Dueñas de Alba de Tormes. Por los años relacionados en los documentos conventuales (Libros de cuentas de los años 1884 - 1885 y 1891 - 1892) y conociendo los nombres y la trayectoria de los Rectores de la Universidad de Salamanca a través del tiempo, se puede saber que el Sr. Don MAMÉS ESPERAVÉ LOZANO, Catedrático, que fue nombrado Rector de la Universidad de Salamanca, el 4 de octubre de 1869, se le puede relacionar con esta noble acción, por cuanto fue nombrado Rector en 4 de octubre de 1869, permaneciendo en el cargo por 31 años y cesando en 1900 por jubilación obligatoria al cumplir los setenta años. A éste ilustre Señor Rector, le sucedió, Don Miguel de Unamuno.

Como rector trabajó para restaurar y conservar el patrimonio de la Universidad, tanto en los edificios como en los documentos, también potenció las becas y ayudas para los estudiantes y las pensiones. Se le conoció como hombre cabal y de buen corazón, que buscaba el mejoramiento de todos y se le conoció como un hombre comprometido socialmente. De ahí, se puede deducir su interés con las causas sociales representado en la ayuda brindada al Monasterio de Santa María de las Dueñas de Alba de Tormes. Al terminar su rectorado, la Universidad ya había recuperado su nombre y su prestigio. 190

190 LAMBAS MONTAÑÉS, Javier, HERNÁNDEZ VICENTE, Severiano. Mamés Esperabé Lozano (1830-1906): Un Ejeano al frente de la Universidad de Salamanca. Zaragoza: Centro de Estudios de las Cinco Villas, 1997, pp. 84-119. 


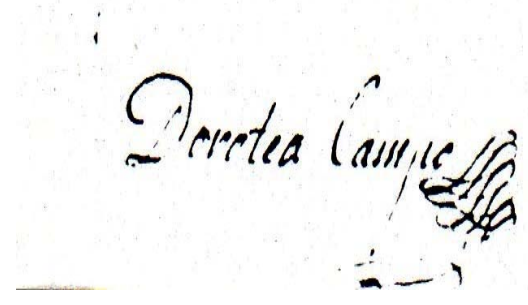

23. Firma de la monja música Doña Dorotea Campo. Después en Religión conocida cono Escolástica Campo.

El Libro de Visitas y Elecciones, nos permite conocer los años en que salió elegida Abadesa, que fueron: el 1880, más tarde en el 1896, para ser reelegida en el 1899 hasta el día de su fallecimiento acaecido en el 1909.

Humilde, pero enérgica y con un gran corazón, llegaba al punto de privarse ella misma de todo para dárselo a los demás. El Libro de Crónicas nos habla sobre la existencia de una nota de su puño y letra que se conserva con gran cariño filial en el Monasterio, la cual refleja que en su noble alma vivían juntas la humildad y la caridad; la nota dice al pie de la letra:

"Seré verdaderamente humilde si reconozco el mérito de mi prójimo, aún cuando fuese mi mayor enemigo"191

El amor fraternal y espiritual que rebosaba y trasmitía, hacía que alentara a sus "hijas" a cultivar cualidades y virtudes hasta llevarlas a la perfección. Dotada de una inteligencia excepcional y de un entusiasmo desbordante en todo lo que emprendía, durante sus años de Abadesa, logró grandes progresos en el sentido musical y material. Resplandecieron en ella las virtudes de la discreción y la prudencia. En una palabra fue "modelo de perfección" para la Comunidad, trasmitiendo todo lo bueno y noble que tenía en sí misma.

Si alguna religiosa se enfermaba, ella misma pasaba las horas a su cabecera para ayudarla y prodigarle todos los cuidados necesarios; por estos gestos se le reconocía el amor que sentía por cada una de sus religiosas, considerándosele una “Madre". Ajustó siempre su vida, como hija amante de la Orden, con las

191 ASMD. Libro de Crónicas, p. 186. 
obligaciones contraídas, dejando una honda huella de madre "cariñosa y santa". El Libro de Crónicas en su página 189, relata la memoria de su ingreso y la elogia, contandonos cómo el día 22 de Marzo de 1858 hizo su Profesión y cómo a partir de esta fecha, la joven profesa solo pensó en adornar su alma de las más sólidas virtudes monásticas; aún, siendo la Comunidad de entonces muy reducida en número, le proporcionaba medios abundantes para ello. La Madre Escolástica desempeñó s su vez varios cargos y dicen las crónicas que lo hacía a fuerza de abnegarse y sacrificarse.

Aparte de sus obligaciones como Organista, varios cargos desempeñó a lo largo de su vida; El Libro de Visitas y Elecciones arrojan los siguientes datos:

- $\quad 1868$ - 10 de Agosto Sacristana

- 1871 - 10 de Agosto Portera

- $\quad 1874-10$ de Agosto Sacristana

- $\quad 1877-29$ de Sept. Portera y Provisora

- $\quad 1881-2$ de Junio Maestra de Novicias y Depositaria

- $\quad 1884-5$ deJunio $\quad$ Abadesa (1a Elección)

- 1887- 16 Oct. Maestra de Novicias

- $\quad 1890$ - 25 de Oct. $\quad$ Abadesa (2a Elección)

- $\quad 1893-26$ de Oct. Maestra de Novicias

- $\quad 1896-1$ de Dic. $\quad$ Abadesa (3a Elección)

- $\quad 1899$ - 1 de Dic. Continúa en el cargo

- 1903 - 14 de Marzo $\quad$ Maestra de Novicias y Depositaria

- $\quad 1909$ - 15 de Marzo $\quad$ Abadesa

\section{- SU DESEMPEÑO MUSICAL}

Llegando con 15 años al Monasterio y con un alto grado de instrucción musical, es de suponer la calidad de la actividad que desarrolló a lo largo de 20 años de ejercicio musical. Perfeccionista al máximo, buscando siempre el esplendor que ella deseaba en lo tocante a la música y así mismo en todos los asuntos 
relacionados con el culto divino y con las generalidades del Monasterio, logró elevar el nivel de la vida musical y el nivel de la vida conventual, en general.

Desarrolló una amplia actividad de magisterio musical, como pedagoga de las niñas que por aquel entonces, se educaban en el Convento y a falta de monjas, con la ayuda de las educandas y con el acompañamiento del órgano, lograba que la música tomara otras dimensiónes, que las festividades y el culto divino en general fueran más suntuosos. Se la considero un alma selecta y grande. Siempre buscando el refinamiento tanto en la música como en las costumbres y hábitos diarios, pues era entusiasta del culto divino, dando muestras de ello desde muy jovencita.

En pos de este objetivo, se preocupó por atraer a la Comunidad a personas idóneas en la música como el Revdo. Padre llamado Carlos Azcárate, monje del Real Monasterio de Santo Domingo de Silos, que por aquel entonces estaba impartiendo clases de Gregoriano en el Seminario de Salamanca, según el modelo propio de Pio X, para que diera instrucción a las monjas, durante la primavera del 1906. Las cantoras especialmente, las que eran instruidas en la música, se aplicaron, aprovecharon y se destacaron al recibir las enseñanzas del Monje Benedictino; no obstante, la Sra. Abadesa quiso que todas sus religiosas, incluso las legas, aprendieran a cantar bien el canto llano y es así como el 22 de junio, toda la Comunidad participó en el Canto, interpretando una misa en Gregoriano puro, a satisfacción de su Maestro. La Abadesa Dña. Escolástica, no perdonó sacrificio para que todo el evento tuviera la altura que se merecía.

“Con las buenas instrucciones del inteligente Padre Carlos, quedó la Comunidad y muy particularmente el grupo de cantoras, bastante impuestas en el canto a pesar de no haber recibido sus lecciones más que un mes poco más o menos, pero la celosa Prelada Rma. Madre Escolástica quiso que quedara implantad con la mayor perfección posible, para lo cual volvió otra temporada nuestro Padre Carlos. Loado sea Dios Nuestro Señor que desde el día 22 de J unio de 1906 que se cantó la primera Misa en Canto Gregoriano, no han dejado de resonar en nuestro coro estas suaves melodías verdadero canto 
de la Santa Iglesia, hasta la fecha que esto se escribe, hoy día 18 del mes de septiembre de 1933."192

Este mencionado monje Benedictino de Silos, volvió al Monasterio en otras temporadas para continuar reforzando la instrucción y de esta manera se conservó la tradición de cantar en gregoriano, durante muchos años en el Monasterio.

\section{- SUS BODAS DE ORO}

Celebró sus “Bodas de Oro" el 15 de marzo de 1907, llegando a cumplir cincuenta y dos años en la Comunidad y a dos años de su fallecimiento. Cincuenta años muy bien empleados en el servicio a Dios y del Monasterio. Dicho acontecimiento fue celebrado con gran entusiasmo por la Comunidad. La Abadesa no quería que se le hicieran aquellos honores que ella consideraba no merecidos, pero las religiosas se empeñaron en agasajarla por lo alto. Sin hacer mucha ostentación, se hizo una verdadera celebración con la presencia de las personas más allegadas, se la obsequió con varios detalles, como cuadros y trabajos hechos por las religiosas y se hizo la renovación de los sagrados votos con la plática de Don Martín Monzón, Párroco de la Villa de Alba.

\section{- SU FALLECIMIENTO}

Una larga y penosa enfermedad que resistió y aceptó con resignación y asombrosa paciencia hasta su último suspiro, fue ejemplo de templanza y fuerza de espíritu, para su Comunidad; nos relatan las Crónicas, que ya nada le tomaba por sorpresa “(...) vivía por encima de las cosas de este mundo y se notaba palpablemente en ella, que su unión con Dios era cada día más íntima."193

Sabias palabras leemos en el manuscrito de su fallecimiento que encontramos en los anexos de su vida, que dice:

“(...)su vida merece todo elogio; desplegó durantelos 15 años de Prelacía el más delicado celo e interés por la prosperidad temporal y espiritualde la Comunidad, no perdonando trabajo fatigas $y$ develos para conservar $\mathbf{y}$ hermosear el edificio, todo con el santo fin de atraer nuevas esposas que 
habitasen en la casa de Dios, su vida ejemplarísima y su muerte preciosa y envidiable, el Señor había remunerado las heróicas virtudes de la que fue modelo de Preladas norma y dechado de monjas Benedictinas; amante del sacrificio del deber perseverando hasta el fin."194

Nos develan el gran aprecio que la Comunidad tuvo por su Prelada, a quien respetaron y consideraron "modelo" en todas las acciones que emprendió a favor de su Monasterio, ya fuese en los asuntos materiales, como en los espirituales y muy especialmente, los musicales. Todos los esfuerzos por ella realizados para mejorar la vida conventual, se vieron recompensados en la respuesta de sus religiosas y en la de las personas a quienes acudió en momentos difíciles.

Inmediatamente a su muerte acaecida el 18 de enero del 1909, la Comunidad hizo la Elección de la nueva Prelada y esta responsabilidad recayó en la monja Dña. Dolores Quintana.

Habiendo sufrido varias dolencias a lo largo de su vida, esta última fue muy penosa puesto que se trataba de una pulmonía doble, para la que se emplearon curas muy dolorosas, a punta de sangrías, se le puso el pecho y la espalda en carne viva, los médicos que la atendían pusieron todo los medios a su alcance para salvarle la vida, infructuosamente; “(... ) la ciencia médica agotó todos los recursos para salvar tan preciosa vida, pero todo fue en vano." 195

Sabios consejos dio a las religiosas en su lecho de muerte, haciéndoles hincapié en el amor que se debían unas a otras, haciendo claridad en los recursos económicos necesarios que dejaba para cubrir las necesidades del monasterio, una economía saneada y en la lectura constante del "Kempis" - la imitación de Cristo. Nos describen las Crónicas que su aliento se fue extinguiendo hasta entregar su espíritu a Dios. Honda huella dejó Dña. Escolástica Campo Martín, en la Comunidad, por su entrega a los demás, por su desempeño musical, por su tesón para conseguir en ocasiones hasta lo imposible para el bienestar de "sus hijas", por el alto grado nivel de vida que alcanzó el Monasterio bajo su mandato y porque

194 ASMD. Libro de Dotes (se relacionan también los fallecimientos) Dña. Escolástica Campo Martín, p.37

195 ASMD. Libro de Crónicas, p. 184. 
fue modelo de virtudes y prototipo de mujer con un temple excepcional, aún para la época en que vivió.

\section{- Dña. JOSEFA MARTÍN Y MARTÍN - (Cantora)}

La última monja música del Monasterio de Santa María de las Dueñas, que se relacionará en este Capítulo, es Dña. J osefa Martín y Martín, natural de la localidad de Fuentes de Nava en la Provincia de Palencia. Había nacido el 19 de marzo de 1845 y fue hija legítima de Don Santiago Marín y Dña. Petra Martín ambos naturales de la citada Villa.

Miremos dónde queda Fuentes de Nava y cuál es su historia:

Bella localidad palentina, situada en el corazón de la Comarca Natural de Tierra de Campos, una de las comarcas naturales más grandes de Europa. Situada en un paisaje pleno de luz y transparencia, se nos muestran las considerables estepas cerealistas salpicadas de casetas y palomares de adobe que conforman este paisaje castellano de Tierra de Campos.

Sus signos de identidad son: La esbelta torre de S. Pedro, conocida como la "Estrella de Campos", la Laguna de la Nava y el Canal de Castilla. ¿Y de su historia qué se puede decir?

La cercanía de la Nava hizo, al mismo tiempo, que tomara tal sobrenombre en multitud de documentos, habiéndose generalizado hasta nuestros días. El primer documento en el que se cita la villa, es en el Códice donde se encuentra el Índice de Dueñas, fechado en el año 974. Pero en este documento se la denomina: "Fuentes de Don Bermudo". ¿Quién fue o pudo ser este D. Bermudo que dio nombre al pueblo?. Pudo ser un señor de la nobleza leonesa, que como tantos otros en aquellos años, llevaron a cabo repoblaciones dejando su nombre en las mismas. Pero dado el espacio geográfico que ocupa Fuentes, este noble fundador pudiera tener dos orígenes bien distintos: En el primero, la historia nos cuenta como a la muerte del Rey leones Ordoño III, ocurrida en el año 956, su hijo el Infante Bermudo, no pudo ser coronado rey por ser niño todavía. Cuando diez años más 
tarde muere el Rey Sancho el Craso, su hermana la monja Doña Elvira se encargaría de salvaguardar la corona para su sobrino Ramiro, hijo del Rey. Hecho que impidió nuevamente que Don Bermudo fuera coronado, y pudo motivar que emigrara hacia estas tierras de campos. La segunda hipótesis nos remite a la documentación de Santo Toribio de Liébana del año 924. Dicha documentación nos habla de ciertos magnates lebaniegos, que serán primero Condes de Saldaña y después, de Carrión. Estos magnates son el matrimonio formado por Alfonso y J usta, cuyos hijos fueron: Munio, Bermudo y Pepi Adefonsi. Cuando los Condes de Carrión fundan el Monasterio de San Zoilo, se encontrará entre los pueblos que se citan vinculados a sus rentas, a Fuentes de Don Bermudo, dado que su parroquia de San Román pertenece a tal Monasterio y por la que se cobra uno de los tercios que se dividía el diezmo de sus iglesias. A la hora de optar por uno u otro, cabe añadir un dato: Fuentes era según el Libro de las Behetrías de 1350, conservado en Simancas, un lugar de Behetría de señor natural y pagaba sus impuestos además de al rey, a sus señores naturales: La casa de los Lara, los Girorens, los Tellos y la Casa de Vizcaya, quienes eran considerados descendientes de su fundador.196

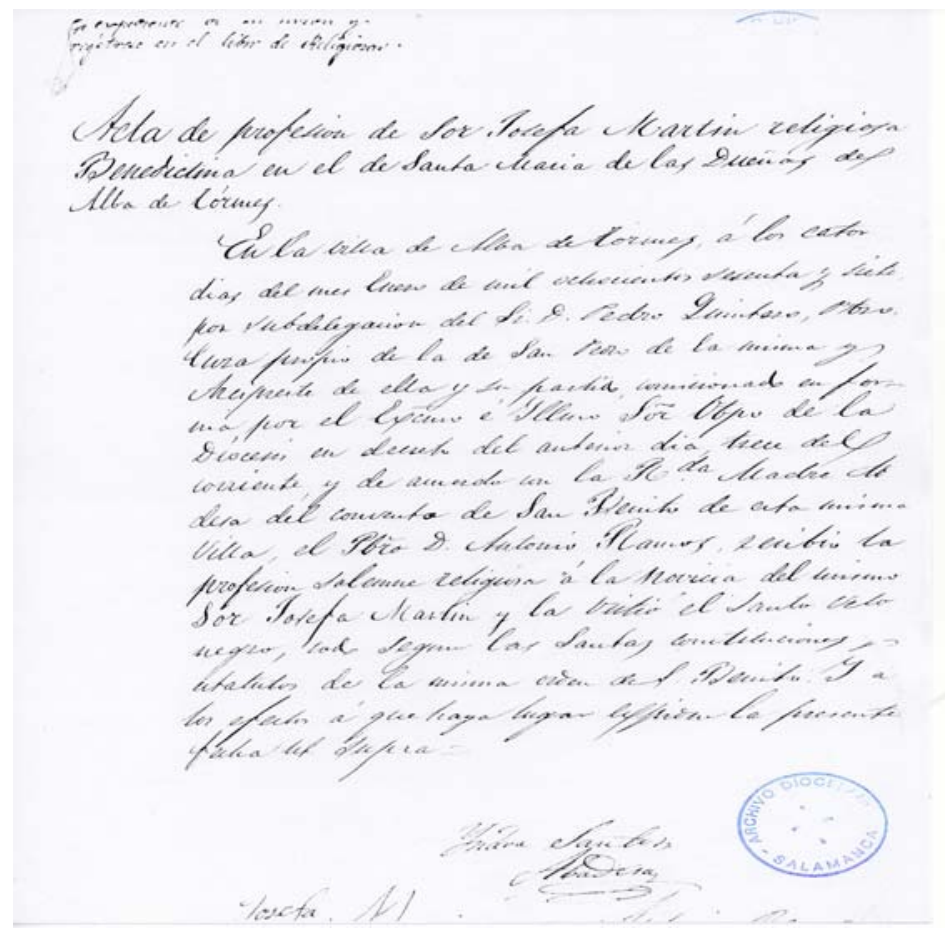

24. Acta de Profesión de J osefa Martín y Martín

196 Información tomada de<www.fuentesdenava.com> (consultado el 26 de junio de 2006). 
J osefa Martín expresa a su padre Don Santiago, su deseo de abrazar la vida religiosa y servir como monja música en el Monasterio de Santa María de las Dueñas de Alba de Tormes, de quien obtiene el consentimiento expreso. En Documento firmado por Dña. Isidra Santos - ya conocida por la crónica hecha sobre su vida como monja música, ahora la encontramos en sus funciones de Abadesa -, ella presenta al Ilustrísimo Sr, Obispo de Salamanca, los Documentos acreditativos de la pretendienta y solicita Licencia para el ingreso de Novicia con el Oficio de Cantora - Organista, en este Monasterio de Santa María de las Dueñas de Alba de Tormes. El Obispo de Salamanca, a 29 de noviembre de 1865, mediante carta dirigida a la Sra. Abadesa, permite poner en votos secretos a la postulante, pero no da Licencia para la toma de hábito, hasta que le conste estar reunidas todas las cantidades ofrecidas para la Dote de dicha interesada.

En el desarrollo del procedimiento normal, el 14 de noviembre de 1865, se presentaron los testigos, Don Miguel Sevilla Rodriguez, Don Ignacio Monje Martín y Don Juan García Fernández, ante Don Tomás Cano Calvo y Don Mateo Martín, funcionarios del Ayuntamiento de esta Villa de Fuentes de Nava, diciendo que conocen a J osefa Martín, a sus padres y certifican que son personas de sanas costumbres, cristianos y que no han oído comentarios que difamen su buena reputación.197

La negativa recibida de boca del Sr. Obispo de Salamanca, no desalentó a la Sra. Abadesa ni a sus religiosas, que se pusieron manos a la obra para conseguir el dinero de la dote, para cubrir lo referente a la Plaza que era una exigencia del Señor Obispo, para garantizar el Pago a una nueva cantora y organista, ya que las otras plazas estaban ocupadas y pagadas por el Gobierno- dinero que se tomó de los ahorros que tenía la Comunidad y que fueron por una cantidad de cuatro mil pesetas -, completando la dote, con lo aportado por el Sr. De Santisteban y por Don Teodoro González, hasta completar las cinco mil pesetas ajustadas. Dicha plaza de cantora y organista fue solicitada por encontrarse muy delicadas de salud las religiosas que las tenían a su haber. De tal manera que en carta enviada al Sr. 
Obispo la Sra. Abadesa le explica la situación referida haciéndole énfasis en el monto de la dote conseguido para dar pronta solución al problema.

Ya sabemos que en este punto cronológico en que nos encontramos, los pagos a las monjas cantoras u organistas eran abonados por el Estado. El 3 de diciembre de Mil ochocientos sesenta y cinco, la Sra. Abadesa escribe a su amigo Don Anastacio Leal, para que ponga en conocimiento al Prelado sobre las cantidades reunidas para la Dote, las cuales ya reposan en las arcas de la Comunidad para que supla a la Organista actual y explica detalladamente, la situación en que se encuentran, por las enfermedades de las religiosas músicas del momento y por el fallecimiento de otras y que solicita al Sr. Leal, que hable con el Obispo para la Licencia de poner el hábito de la pretendienta J osefa Martín. De tal manera y vista la realidad del momento, el 20 de diciembre de 1865, el Sr. Obispo Don Anastacio Rodrigo Busto, - Senador del Reino, Caballero Gran Cruz de la Real Orden Americana de Isabel la Católica, Comendador de la Distinguida de Carlos III - Prelado Doméstico de Salamanca -, impone el hábito a la pretendienta, con la "condición precisa de suplir en el oficio de organista en defecto de la que desempeña este cargo."198

Con este permiso, Don Pedro Quintero, Párroco de esta Villa y Arcipreste de la misma, imponen el hábito de Benedictinas a Dña. J osefa Martín y Martín y reitera en el documento de imposición, la condición de suplir a la Organista de oficio. Y lo firman: El Sr. Arcipreste de la Villa de Alba de Tormes, la Sra. Abadesa, Doña Isidra Santos y la pretendienta y consagrada, Dña. J oséfa Martín y Martín. Inicia su vida conventual y por ende su magisterio musical. Fue Abadesa del 1893 a 1896. De ella, se desconocen gran parte de datos importantes, como: su formación musical, los pagos hechos por el Estado y su desempeño musical a través de tantos años de vida religiosa.

198 ADS. Caja 1 (años 1853 - 1942) Expediente de Dña. J osefa Martín y Martín - Cantora y organista. 


\section{- SU FALLECIMIENTO}

El 30 de agosto de 1901, tras una larga enfermedad, fallece Dña. J osefa Martín y Martín, a la edad de 56 años y 36 que pasó en el Monasterio.

\section{- J ULIANA DEL CORAZÓN DE J ESÚS}

En J aén, en la madrugada del 19 de junio de 1853, fue hallada a la puerta de la casa de Don Benito Gonzales, una niña recién nacida, la cual fue recogida y ese mismo día, en la Villa de Poscuna, fue bautizada simplemente con el nombre de J uliana del Corazón de J esús, sin más identificación que su nombre - sin apellidos, como aparece en todos los documentos -. Su madrina fue una mujer de J aén llamada Doña Ana de San Pedro, quien el Sr. Cura párroco advirtió su parentesco espiritual y las obligaciones contraídas con la niña y con su conciencia.

La niña, pese a tener una madrina, fue llevada a vivir al Hospicio de mujeres de la Ciudad de J aén. Le fue dado el Sacramento de la Confirmación a los quince años de edad, el 29 de abril de 1868 y en los Libros de Confirmaciones aparece con el número ciento veinte y seis y con el simple nombre de J uliana Expósita. En cierta forma un término algo desdeñoso.

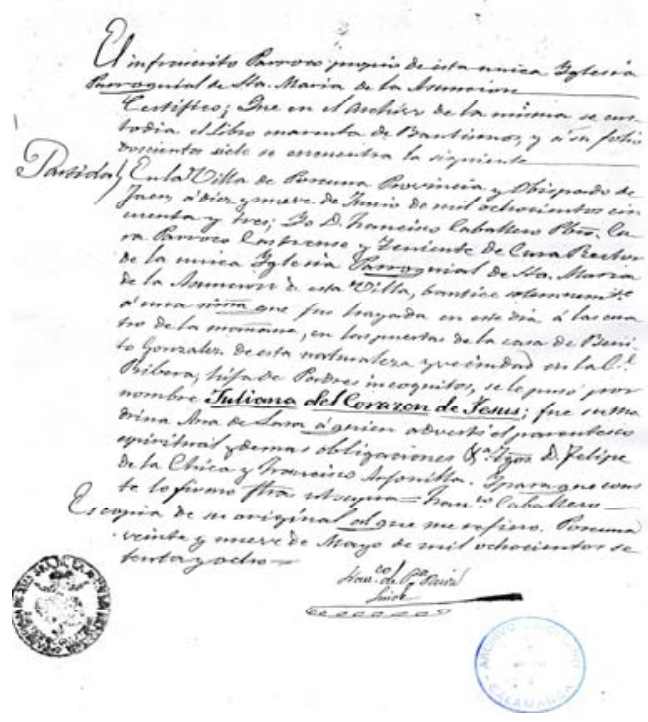

25. ADS. Acta de nacimiento. Caja 1 (años 1853 - 1942) Expediente de Dña. J uliana del Corazón de J esús - Cantora y organista. 
El Palacio de Villardonpardo de J aén ocupa una manzana y fue edificado en el año 1592 por Don Fernando de Torres y Portugal, Virrey del Perú. Bajo este importante edificio se encuentran unos Baños Árabes utilizados en alguna época como bodegas de vino. Desde 1751 albergo al Hospicio de mujeres de J aén hasta 1970; acogió también la Sala cuna y la Maternidad. Su cierre definitivo se produjo en 1970, para ser convertido en sede del Museo de Artes y Costumbres populares y Museo internacional de Arte de Niaf "Manuel Moral”.

Conocer J aén, puede resultar interesante, con el objeto de ubicarnos en el contexto social y cultural de la época:

Mirando hacia atrás en la historia de J aén, podemos conocer que los visigodos se asentarían definitivamente en el primer tercio del siglo VI. Jaén quedaría al margen de sus asentamientos y seguiría siendo un territorio en el que predominaba la población hispanorromana, con algunas guarniciones militares, como Mentesa, en las que se concentraba la población germánica. Durante todo este siglo, la presencia visigoda por tanto es débil y son frecuentes las rebeliones de la aristocracia romana. La presencia visigoda supuso un momento de decadencia para la ciudad, en favor a Mentesa, La Guardia, hasta donde llegaba el limes bizantino.

Del J aén Islámico, se puede saber que durante cinco siglos estuvieron los árabes asentados en Jaén. La consideraron como una gran ciudad. Le dieron importancia, levantaron mezquitas, construyeron fortificaciones y palacios.

Conquistada Jaén por Abdelazib, en el siglo X sería la capital del reino moro llamado Dijaryan. Los almorávides la incorporarían a su imperio en 1091 y los almohades la ganarían en 1148. Con los árabes J aén, la cora de Yayyan, es una excelente tierra regada por abundante agua que fluye en forma de ríos y fuentes, poseedora de gran cantidad de cultivos y abundante cereal, bosques frondosos, así como de una famosa industria de tapices y utensilios domésticos de madera que se exportaban por todo Al-Andalus y el Magreb.

La victoria de los cristianos en la Batalla de las Navas de Tolosa (1212) supuso la apertura del valle del Guadalquivir para los ejércitos cristianos. De esta forma, con 
el nombre de Iahen, que daría lugar al topónimo actual, en 1246 la ciudad fue reconquistada por el Reino de Castilla bajo el reinado de Fernando III el Santo a través de un pacto de vasallaje con el rey nazarí de Arjona, Muhammad I "Alhamar" (nacido en Arjona y quien ordenó levantar en su exilio la Alhambra de Granada), en el año 1246. Los nazaríes la atacaron en 1300, pero no consiguieron hacerse con la plaza debido a la ayuda prestada a J aén por los Caballeros de Baeza. Se fortifica el castillo y la ciudad, que pasa a ocupar un lugar estratégico por su cercanía con el reino moro de Granada, lo que le vale reconocimientos y privilegios reales.

Trasportándonos a la época en que vivió nuestra monja música, nos ubicamos en el Jaén de principios del siglo XIX, en que la ciudad se hallaba en franca decadencia. Al principio de la guerra de Independencia (1808-1813) la ciudad es tomada y saqueada brutalmente. J aén se unió al sistema de Juntas de gobierno para hacer frente al vacío de poder y a la ocupación francesa. Después de la batalla de Bailén y la posterior reconquista francesa de 1809, el rey J osé I emprende la conquista de Andalucía. El 23 de enero de 1810 el general francés Sebastiani toma la ciudad. Una vez pacificada, el rey J osé I la visitara el 15 de marzo de 1810. Se siguieron sucediendo los episodios sangrientos y los franceses establecieron una guarnición en el castillo, que volarían a su marcha.

Durante el reinado de Fernando VII, en el Trienio Liberal, la ciudad será escenario de la batalla entre las tropas absolutistas y las liberales, dirigidas estas por Rafael Riego. La ciudad no fue nombrada capital de provincia hasta 1833, lo que vendría a suponer un respiro en su proceso de decadencia. Sin embargo, esta tendencia no se rompería hasta 1960, cuando J aén recobraría impulso e iniciaría una nueva fase de crecimiento. Ya bajo Isabel II, la ciudad se mantuvo leal a la reina frente a los partidarios carlistas. En 1862 la reina Isabel realizo una gira por Andalucía, donde visito J aén. En 1873 se proclamó cantón independiente.

El Acta de exploración de nuestra monja música de Jaén, nos revela datos desconocidos hasta el momento; en el interrogatorio, la pretendienta, hace referencia al nombre que desea llevar a la toma de hábito; ella pide que de ahora en adelante se le llame Trinidad del Corazón de J esús. En este momento dice que 
cuenta con 26 años de edad y de estado civil, soltera; dice ser hija de Don Pablo Cruz y Dña. Antonia Gómez - difunta -. Es de suponer que fueron padres adoptivos, aunque ningún documento de su expediente nos lo revela, por cuanto sabemos y podemos apreciar por su acta de Bautismo que aparece como nacida de padres incógnitos.

En carta enviada al Señor Obispo de Salamanca, a 1 de julio de 1878, la pretendienta dice que habiendo llegado a sus oídos la información de que la plaza de Organista está vacante en este Monasterio de Benedictinas, por el fallecimiento de Doña María Manuela Huete y ella sintiéndose "instruida" para el desempeño de la plaza como organista, solicita y suplica se le conceda el cargo.

Don Antonio Manjón Soria, Presbítero y Capellán del Hospicio de mujeres de J aén, certifica sobre ella, con estas palabras:

“Certifico: que mi asilada Juliana del Corazón de Jesús está dedicada a la profesión de Organista y se le ve muy inclinada a ser monja profesa, dando las mejores pruebas de ser cristiana, es mi confesada frecuentando los Santos Sacramentos de la Confesión y Sagrada Comunión, que es buena vida y costumbres tanto moral, como religiosas. $Y$ para los efectos que haya lugar sello y firmo este en J aén a 4 de junio de $1878=$ Pbro. Antonio Manjón Soria”.199

Con la citada recomendación, con la revisión de su expediente y especialmente movido el Monasterio por la necesidad urgente de una "organista", fue aprobada en votación secreta - según la costumbre y como lo ordenan las Constituciones se dio lugar a su ingreso. Es de anotar y con especial significancia que este es el segundo caso encontrado de que una pretendienta de padres desconocidos, recogida y educada en un Hospicio, pudo llegar a ser religiosa y especialmente música. Ya conocimos en el Capítulo III, el caso de la Monja francesa María Rosalía Delpy, también abandonada por su madre y de padre desconocido, se educó en un Hospicio de la localidad de Montalván en Francia e ingresó como monja y con la profesión en el siglo, de bondadora. Y conocemos las exigencias o procedimientos del Sistema para el ingreso a los Monasterios de cualquier joven, 
desde siglos atrás; las postulantes debía ser hijas de matrimonio legítimo, de padres conocidos y en lo posible, apreciadas por la sociedad, cristianos y de buenas costumbres así fueran de humilde condición. Los referidos casos pueden ser excepcionales, ya que las jóvenes aspirantes aunque no cumplieran con lo anteriormente dicho, venían recomendadas por personas o clérigos de reconocida trayectoria.

El 11 de julio de 1878, previa Licencia del su Ilustrísima el Obispo de Salamanca, se llevó a cabo la imposición del Santo hábito a Dña. Juliana del Corazón de Jesús, desde ahora llamada “Trinidad del Corazón de J esús” y lo recibió con la obligación de prestar en dicho Monasterio el oficio de "Organista" cumpliendo en todo con lo prescrito en dicha Regla. Próxima a cumplir el año de noviciado, se efectuó el procedimiento de la Exploración y el 24 de junio de 1879, a las 10:00 de la mañana, haciéndola salir de la Clausura, se la trasladó a una habitación independiente, donde ella contestó al Arcipreste del la Villa de Alba de Tormes, Don Pedro Quintero Bonilla - quien estuvo acompañado por el Notario de la Audiencia Territorial de Valladolid y Notario Eclesiástico -, libre y espontáneamente las preguntas formuladas conforme a lo establecido en las Constituciones de la Orden y disposiciones canónicas.

A la primera pregunta formulada sobre el deseo expreso de cambiar su nombre, se ratificó sobre ello. A la segunda interrogación, sobre el tiempo que llevaba como novicia dijo estar ahí desde el "año próximo pasado", a la tercera y cuarta interpelación que hacía referencia a la libertad de tomar la vida religiosa, se confirmó con alegría sobre su libre deseo de ingresar definitivamente en la Orden, a la quinta pregunta sobre las obligaciones contraídas con el cargo de la música, dice que las cargas que tiene en el Convento que las que tenía en el siglo y que quiere profesar en la religión como monja de Coro o velo negro. Declarando sobre juramento como la verdad absoluta de lo dicho.200 
Superada la prueba de exploración, Doña Plácida Santos - Abadesa, en carta enviada con fecha 9 de julio de 1879 a su Ilustrísima Obispo de Salamanca, comunica que la dote para cubrir la asignación de pago anual de "organista", para la novicia Juliana del Corazón de Jesús, reposa en poder de la Comunidad representada en títulos nominales de la deuda pública de España.

Trinidad del Corazón de J esús, tomó al hábito de San Benito, el 11 de julio de 1878 y profesó el 13 del mismo mes y año a la edad de 26 años con el cargo de "organista", falleció a los 36 años de edad demostrando siempre y hasta el último momento de su vida, un sentimiento de gratitud con la Comunidad Benedictina, por haberla recibido y haberle permitido vivir en esta Casa, según nos lo relata El Libro de Crónicas en su página 53. 201

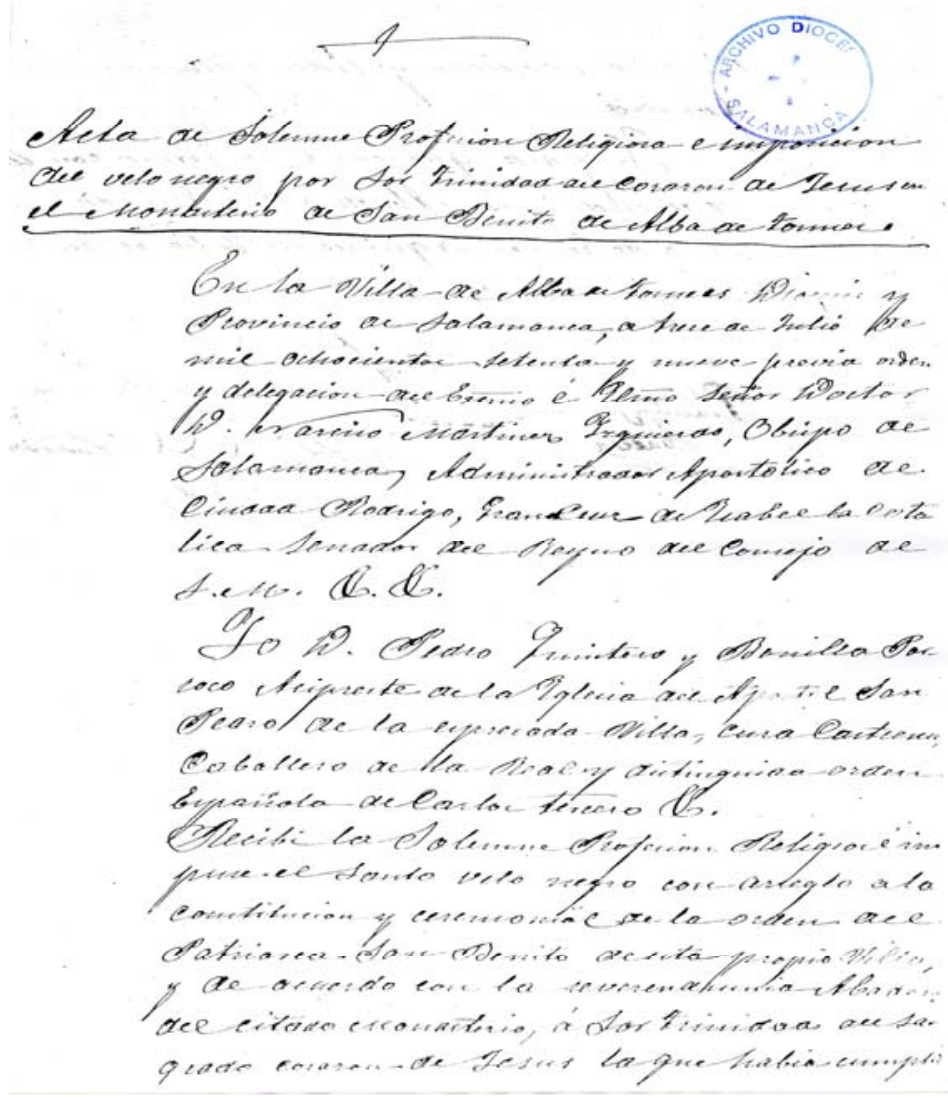

26. ADS. Acta de Profesión de Dña. Trinidad del Corazón de J esús.

Caja 1(años 1853 - 1942) Expediente de organista.

201 Confrontar el Libro de Dotes del Monasterio de Santa María de las Dueñas de Alba de Tormes, en el que se encuentran las referencias dedicadas a los fallecimientos de cada religiosa. 


\section{- MARÍA DOLORES QUINTANA Y SÁNCHEZ (Cantora)}

La última monja música del Monasterio Benedictino de Santa María de las Dueñas de Alba de Tormes (Salamanca) de la que haremos su relato de vida conventual y musical, es Doña María Dolores Quintana Sánchez, la que había nacido en la Ciudad de Burgos - capital -, el 7 de abril de 1866; María Dolores fue bautizada al día siguiente de su nacimiento en la Iglesia de San Cosme y Damián, como consta en el Libro 19 de Bautizados - folio 28 - de la citada Parroquia; fue hija legítima de Don Manuel Quintana - escribiente de profesión y Dña. Inés Sánchez, naturales, el de la villa de Berzosa de Bureba, Burgos y ella su madre, natural de Quintanilla del Agua - Burgos -, así como sus abuelos paternos fueron Don Miguel Quintana y Dña. Rafaela Galbarros y maternos, Don Domingo Sánchez y Dña. Bonifacia Marcos. Muy pequeña recibió el Sacramento de la Confirmación - según reza en los documentos -, el día 12 de mayo de 1868 de manos del Sr, Obispo de la Catedral de Burgos, Don Anastasio Rodrigo.

Cumplidos los 15 años y medio, el 18 de enero de 1882, la joven aspirante escribe al Prelado de Salamanca, solicitando su ingreso al estado religioso y expone en su carta, que especialmente por la imposibilidad de conseguir una dote para ingresar a la vida religiosa, se ha dedicado desde hace varios años, al estudio de la música, con el objeto de llenar algún día los deseos de su vocación y que instruida como se siente ya en la interpretación del Canto llano y figurado, se ha dirigido a la Señora Abadesa de este Monasterio Benedictino, pretendiendo la plaza de "Cantora" y que vista la documentación y certificación de sus maestros de Música, el tenor y el Sochantre de la Iglesia Metropolitana de Burgos, Señores Don Sebastián de Mendieta y Don J uan de Gorachurreta, respectivamente, con el visto bueno del Presbítero Don Manuel Rivas, esta ha manifestado hallarse conforme en que la aspirante ingrese como "Cantora" en el Monasterio. 

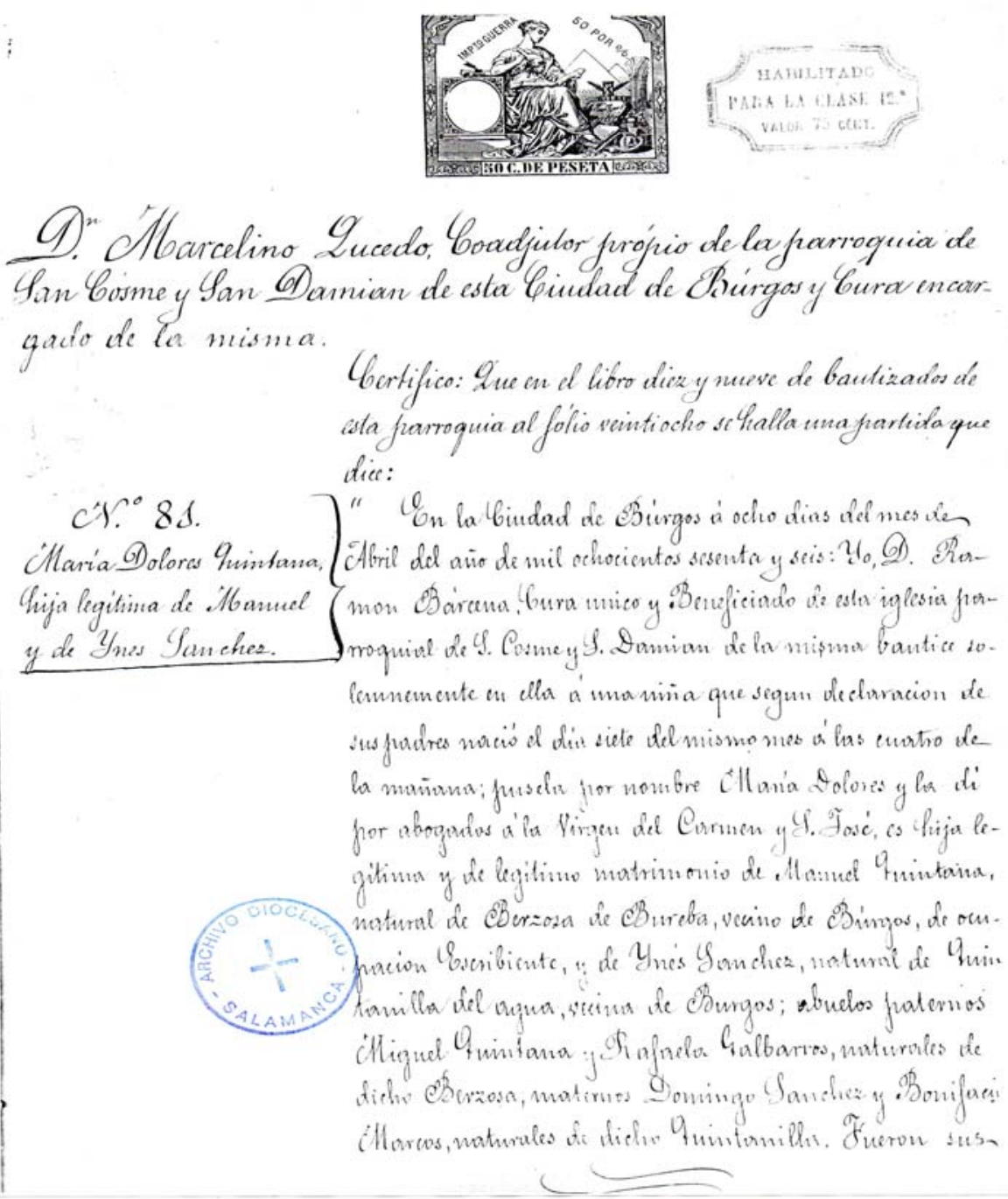

27. ADS. Certificación del Bautismo de Doña María Dolores Quintana y Sánchez Monja música del Monasterio de Santa María de las Dueñas - Alba de Tormes Salamanca

\section{Caja 1(años 1853 - 1942) Expediente de cantora}

El 21 de enero del mismo año, el Prelado da contestación a su carta, autorizando poner en votos secretos de la Comunidad a la aspirante, con la condición de remitir los resultados, vale decir tenerla en observación y enviar periódicamente a su despacho, un informe sobre su vocación, su desempeño y sus cualidades. Este procedimiento de tener a las aspirantes en observación, se presenta en los casos en que las novicias eran demasiado jóvenes; las que entraban con catorce, quince y 
hasta diez y seis años, eran más observadas, lo que se puede considerar enteramente lógico.

Su expediente, ofrece gran cantidad de documentos que permiten hacer un seguimiento al proceso de su ingreso. Don Ramón María de Laviano, Cura Párroco de la Parroquia de Santiago en la Iglesia Metropolitana de Burgos, certifica que Dolores Quintana en de sanas costumbres, feligresa de esta Iglesia, de cristiana conducta; el documento termina con estas palabras:

“(...) y por contarme así firmo y sello la presente certificación en papel de oficio por ser pobre la interesada. Burgos, 16 de enero de 1882. Ramón María de Laviano."202

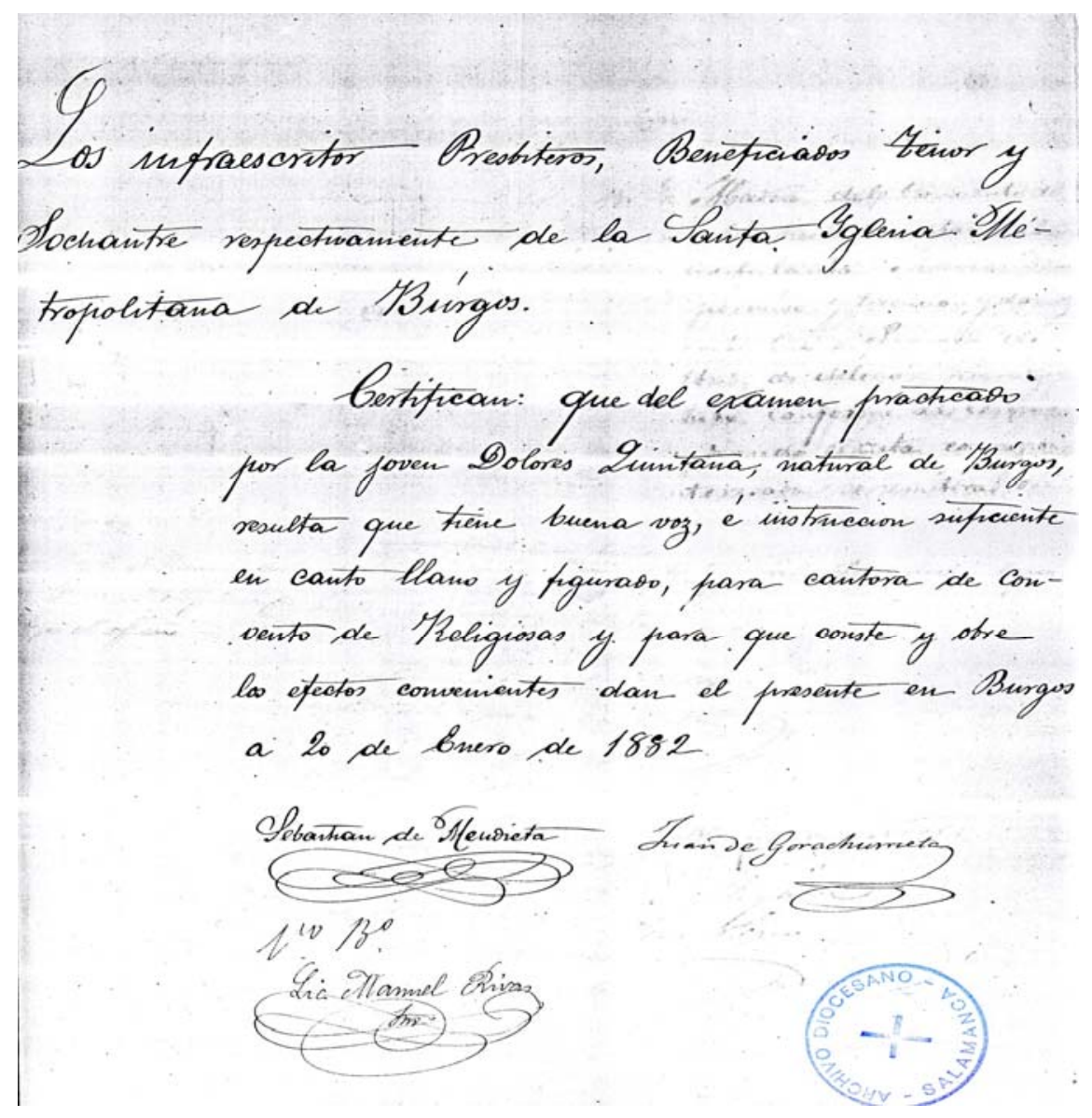

28. Acta del examen de Música practicado a Dña. DOLORES QUINTANA, por el Sochantre y tenor de la Iglesia Metropolitana de Burgos.

ADS. Caja 1(años 1853 - 1942) Expediente de cantora.

202 ADS. Caja 1(años 1853 - 1942) Expediente de cantora. 
Su madre Doña Inés Sánchez (viuda) da su consentimiento con estas palabras:

“Inés Sancho, viuda, natural de Quintanilla del Agua vecina de esta ciudad de Burgos respetando la voluntad de Dios nuestro Señor y deseando el mayor bien espiritual de mi hija, María Dolores Quintana, quien me ha manifestado sentirse con vocación al estado religioso, la otorgo del mejor grado, mi venia y consentimiento, para que libre y espontáneamente, pueda abrazar y vestir el Santo hábito en el Monasterio de Religiosas Benedictinas de Alba de Tormes, Diócesis de Salamanca.

Burgos 19 de enero de 1882.

Inés Sánchez."203

El consentimiento de los padres era documento primordial, para el ingreso de una aspirante a la vida religiosa. Ya tenemos claridad de los innumerables casos que se dieron en estas épocas en las que muchas ingresaron contra su voluntad, pero en la crónica que se ha hecho de nuestras monjas músicas hemos observado que todas llegaron a la vida religiosa y a ejercer su magisterio musical con toda su voluntad y entusiasmo.

El prelado de Salamanca, solicita a la Señora Abadesa Dña. Isidra Santos, que garantice la dote que el Monasterio debe tener a su haber para cumplir con la obligación anual de esta nueva plaza. Ya que la que tenía la religiosa que se encontraba enferma, era plaza fija y pagada por el gobierno y ella estaba relacionada en nómina y no se podía disponer de aquella asignación del Estado, mientras ella aún viviera, ya sabemos que estos pagos eran vitalicios y el Monasterio en concordancia con el Obispado había creado otra plaza para reemplazar a la monja música quebrantada por la salud. De tal manera que lo que pretendía el Obispado, era asegurar el bienestar económico de la nueva cantora. La Señora Abadesa da contestación al Prelado, comunicándole que la dote convenida de seis mil reales la tenía en sus arcas.

Aclarados estos asuntos pecuniarios, el 30 de enero de 1882, el Señor Obispo de Salamanca, da su consentimiento para que procedan a imponerle el Santo hábito

203 ADS. Caja 1(años 1853 - 1942) Expediente de cantora y en ASMD. Carpeta de informaciones. 
conforme al ceremonial y Constituciones de la Orden, extendiendo el acta correspondiente y enviando el original a su Ayudante de Cámara.

Transcurridos los diez meses de noviciado reglamentario, se solicita la Licencia para que la a joven novicia le sean practicados el interrogatorio pertinente que aclarará sus sentimientos respecto a la vida conventual y a la profesión definitiva y el 3 de enero de 1883, se da Comisión a Don Pedro Quintero, Parroco de la Iglesia de San Pedro y Arcipreste de Alba de Tormes para que acompañado del Notario realice a la novicia el interrogatorio.

Llegando el día convenido, 14 de enero de 1883, se reunieron el Sr. Arcipreste de la Villa y el Sr. Notario de la Audiencia Territorial de Valladolid en el partido judicial de la villa de Alba de Tormes, con la Señora Abadesa y haciendo salir del Noviciado a la novicia la trasladaron a la Sacristía.

A la primera pregunta encaminada a saber sus datos personales, ella contestó su nombre completo, su procedencia, fecha y sitio de su Bautismo, el nombre de sus padres y habló sobre su estado civil.

A la segunda interrogación, contestó la fecha de ingreso al Noviciado y los meses que en él se ha encontrado. A La tercera interpelación del Arcipreste, que se encuentra a gusto en el sitio de la Sacristía donde están. Una de las preguntas que más interesan es saber si la novicia está ahí, por su propia voluntad, a lo que ella contesta que se encuentra vistiendo el Hábito y haciendo esta declaración con entera libertad. De igual manera dice que se encuentra a gusto desempeñando las cargas que tiene en su vida conventual, las cuales considera más llevaderas que las del siglo, vale decir fuera del Monasterio. Finalmente solicita Licencia al Señor Obispo para profesar definitivamente. Todo lo anterior, dice que lo ha declarado bajo juramento y con entera libertad.204

En el Acta de Profesión Solemne con fecha del 4 de febrero de 1883, queda consignado el procedimiento de la imposición del velo negro con todo lo que expresan dichas Constituciones.

204 ADS. Caja 1(años 1853 - 1942) Expediente de cantora. ASMD. Leer Expediente de Dña. Dolores Quintana y Sánchez, monja música - cantora. 


\section{- SU VIDA MUSICAL Y SU FALLECIMIENTO}

De su desempeño musical, poco y nada nos brindan los documentos del Monasterio, solo podemos saber por el Libro de Crónicas, que ingresó en el Monasterio con 16 años de edad y con el cargo de cantora, el cual desempeñó por espacio de 8 años y en el año 1890, pagó su dote quedando exenta de dicha obligación.

Su fallecimiento, como nos lo describe el Libro de Crónicas:

“Al finalizar el año santo de 1950, el 31 de diciembre a las 11 de la noche falleció la Rvda. Madre Doña Dolores Quintana Sancho a los 84 años de edad y 68 de religión siendo Priora en la actualidad: también ejerció 34 años, alternando con otras - el cargo de Abadesa trabajando incansable por el bien espiritual y temporal de la Comunidad, amaba la observancia y aunque por su delicada salud, materialmente no podía llevarla la vivía en espíritu dándonos ejemplo de paciencia y virtudes monásticas, distinguiéndose en el silencio, prudencia en su gobierno y Caridad sobretodo con las enfermas a las que siendo prelada, no dejaba de visitar dos o tres veces todos los días, procurando con solicitud maternal que nada les faltare para su asistencia. Los último meses de su vida no pudiendo asistir a ningún acto de la Comunidad, por sentirse ya agotada de fuerzas, los pasó completamente retirada en su celda, según ella nos decía, pensando en cosas santas, preparándose para la muerte que esperaba tranquila y plácidamente. Así terminó sus días esta benemérita madre y creemos que el Señor con quien estaba unidad, le habría dado el premio merecido por los trabajitos de su larga vida."205

Antes de hacer una breve conclusión al presente capítulo, es preciso recordar y hacer claridad acerca de aquel proceso de desamortización que llevó al clero y a las comunidades monásticas a perder gran parte de su patrimonio tangible, lo que supuso un cambio radical en muchos aspectos de la vida conventual y eclesiástica y por ende a los pagos a las monjas músicas de los monasterios españoles - tema que nos atañe - , pagos que como es conocido, siempre fueron efectuados por los mismos monasterios - gracias a la provisión de dotes y por rentas -, para el desenvolvimiento de la liturgia y la vida musical.

205 ASMD. Libro de Crónicas del Monasterio. p. 58. 
Con cada una de las monjas músicas investigadas, los Libros de Cuentas y los Libros de Dotes, han permitido conocer aquellos procedimientos de desembolsos realizados por los Monasterios a través de los años; al producirse la Desamortización - por la ley del 29 de julio de 1837 -, esta situación cambia definitivamente; de tal manera que aproximadamente a partir del 1840, los pagos aparecen ejecutados por el Estado y es así como a partir de la monja música Doña Isidra Santos y Santos, vemos que tiene la asignación de una (1) peseta diaria del Estado.

Para concluir este capítulo de nuestras monjas - músicas, es menester hacer una breve relación cronológica de los hechos acaecidos en referencia a aquel proceso de Desamortización, anotando inicialmente las diferentes desamortización que se produjeron:

“Existen varias desamortizaciones:

I. En 1768 se produce la llamada Reforma de Olavide, dotada sobre todo de un sentido social, por la que el Estado vende tierras de su propiedad (parte de ellas obtenida tras la confiscación de los bienes de los jesuitas que habían sido expulsados de España) a:

I.1. Labradores ricos que pudieran poner en exlotación esas tierras sin necesidad de subvenciones.

I.2.Propietarios que deberían arrendar obligatoriamente las tierras a braceros.

I.3.Campesinos relativamente pobres que pudieran explotar un pequeño terreno por sí mismos.

Estas ventas se hacían con la condición de que la posesión de las tierras nunca pudiera volver a manos muertas. De esta ley sólo se cumplieron los puntos 1 y 2 dado que era necesario conceder préstamos y subvenciones para que el punto 3 pudiera salir también adelante.

a) Antes de la Guerra de la Independencia tiene lugar la desamortización de Godoy (bienes pertenecientes a hospitales, hospicios, casas de misericordia, cofradías). 
b) Entre 1808 y 1823 se aplican las desamortizaciones decretadas, por un lado por José Bonaparte y por otro, por las Cortes de Cádiz (bienes de la Inquisición y reducción a un tercio del número de monasterios y conventos).

c) En la desamortización de Mendizábal 1834 -1854 se procede a la venta del patrimonio del clero regular (monjes, frailes) y de parte del secular, lo que implicó la desaparición de monasterios y conventos y que el Estado se comprometiera a proteger al clero por medio de subvenciones y pago de salarios.

d) La Ley General de 1 de mayo de 1855 o Ley Pascual Madoz es la más importante, dado que es la de mayor duración y completa la enajenación de los bienes del clero tanto regular como secular.

El conjunto de todas estas desamortizaciones tuvo como resultado la venta de una extensión de tierras equivalente al $25 \%$ del territorio español y el saneamiento parcial de la economía en momentos puntuales en que las guerras o las crisis económicas hacían más necesaria la disposición de dinero por parte del Estado. Sus beneficiarios fueron sobre todo los miembros de la burguesía tanto urbana como rural, y en mucha menor medida los campesinos, por lo que se puede decir que no tuvo efectos determinantes en el aspecto social." 206

Desarrollando lo anterior, miremos con detenimiento cada punto, para tener un mejor entendimiento de la situación:

\section{La pérdida del patrimonio por la "desamortización"}

Como resultado de todo este proceso, la propiedad aparece "amortizada", es decir, sustraída a libre circulación porque su venta estaba prohibida o restringida. Como reacción a esta situación y durante el siglo XIX la propiedad eclesiástica sufrió un proceso de "desamortización" que abarca dos fases: nacionalización y privatización. 1ํ․ La incautación por el Estado de los bienes eclesiásticos que se convierten en bien nacional; $2^{\underline{o}}$. La enajenación de esos bienes nacionales que generalmente se realizó mediante venta a particulares en pública subasta.

¿A quién o a qué perjudicaba, supuestamente, que el clero y las órdenes monacales tuvieran tanto a su haber? Entre las causas para promover la desamortización se aducía que la propiedad en manos muertas era perjudicial a la agricultura, 
impedía la creación de propietarios libres y creaba grandes obstáculos al progreso económico del país.

Los liberales acometieron la desamortización eclesiástica sin permiso del Papa. Durante las Cortes de Cádiz apenas se llevó a efecto. En cambio, durante el trienio constitucional (1820-1823), se realizaron ventas importantes de muchos conventos suprimidos. El gran momento desamortizador tuvo lugar por iniciativa de Mendizábal. Afectó, primero, a los bienes del clero regular. Las exclaustraciones o supresiones de conventos de los años 1835, 1836 y 1837 incluían la incautación de sus bienes, a la que siguió la venta progresiva a partir de 1836.

La desamortización de bienes del clero secular se realizó por la Ley de 29 de julio de 1837. En virtud de ella, «Se suprimen la contribución del diezmo y primicias y todas las prestaciones emanadas de las mismas» (art.1) y «todas las propiedades del clero secular en cualquiera clase de predios, derechos y acciones que consisten...se adjudican a la Nación, convirtiéndose en bienes nacionales» (art.3).

La venta de esos bienes del clero secular no se hizo de inmediato. Se programó a partir de 1840 en sextas partes. De hecho comenzó en 1841y se interrumpió en 1844 bajo el gobierno moderado, que preparaba el Concordato con la Iglesia. Posteriormente, empero, la Ley Pascual Madoz (1 de mayo de 1855) impulsó de nuevo la desamortización eclesiástica, vendiendo los bienes que habían sido devueltos a la Iglesia por el Concordato.

La resultante de la desamortización será, por un lado, la pérdida de la autonomía económica de la Iglesia, al quitársele los bienes propios, y, por otro, la consiguiente dependencia de una Iglesia desposeída respecto del Estado.

\section{Del sustento con medios propios a la dotación de la Iglesia}

El mantenimiento del Catolicismo como religión oficial, obligaba a los gobernantes a mantener el culto y clero. Por ello, los gobernantes establecieron, como justa compensación por parte del Estado que nacionaliza y vende bienes, la 
correspondiente dotación, que se introduce en la Constitución de 1837: «La Nación española se obliga a mantener el culto y los ministros de la Religión católica que profesan los españoles» (artículo 11).

Ese Artículo 11 se repetirá con ligeras variantes en las Constituciones de 1845, artículo 11; de 1856, artículo 14 (aun cuando no llegara a promulgarse); de 1869, artículo 21, y de 1876, artículo 11.

El sentido de compensación se refleja y consolida, de forma definitiva y pactada en el Concordato de 1851. La Iglesia renuncia a la devolución de los bienes vendidos que a tenor de las disposiciones civiles a la sazón vigentes se hubieran adquirido legítimamente, así como a otra serie de anteriores ingresos, a cambio de que se le asegure (tal como se tenía previsto en la Ley de 17 de abril de 1849 de dotación del culto y clero) una dotación fija, segura eindependiente.

Para tratar de conseguir la así denominada "dotación de culto y clero", se destinaron una serie de fondos que, según el art. 38 del Concordato, eran los siguientes:

- El producto de los bienes devueltos al clero por la Ley de 3 de abril de 1845.

- El producto de las limosnas de la Santa Cruzada.

- Los productos de las Encomiendas y Maestrazgos de las cuatro Órdenes militares vacantes y que cesaren.

- Una imposición sobre las propiedades rústicas y urbanas y riqueza pecuaria, en la cuota que sea necesaria para completar la dotación, tomando en cuenta los productos expresados en los párrafos 1.ㅇ, 2. ․ㅡ y 3.ำ y demás rentas que en lo sucesivo, y de acuerdo con la Santa Sede, se asignen a este objeto.

El clero recaudará esta imposición, percibiéndola en frutos, en especie o en dinero, previo concierto que podrá celebrar con las provincias, con los pueblos, con las parroquias o con los particulares, y en los casos necesarios será auxiliado por las autoridades públicas en la cobranza de esta imposición aplicando al efecto los medios establecidos para el cobro de las contribuciones. 
Tras unos años de paz sobrevino el bienio progresista (1854-56) que a través de la mencionada Ley de 1 de mayo de 1855, aunque reconocía la parte del concepto de desamortización, encontró el procedimiento para quedarse con los bienes sin necesidad de tener que dar títulos a cambio.

\section{Supresión y restauración de la dotación estatal}

Con el advenimiento de la II República se hace tabla rasa del Concordato de 1851. Por la Constitución de 1831 (de 9 de diciembre) se pasa a una nueva desamortización: por una parte, quedan disueltas las Órdenes religiosas que estatutariamente impongan un voto especial de obediencia a autoridad distinta de la legítima del Estado y sus bienes nacionalizados (art.26) - que se reflejará en la Compañía de J esús- y, por la otra, se preveía la supresión completa de la dotación de culto y clero en el plazo de dos años.

Al finalizar la guerra civil, por el gobierno del General Franco se restablece la dotación (por Ley de 9 de noviembre de 1939) y se recoge en los Presupuestos de 1940 la partida asignada en 1930, último año de la Monarquía con la cantidad de 66.899.000 como capítulo de «obligaciones eclesiásticas» (dentro del presupuesto general de gastos que ascendía a 5.960 millones de pesetas).

Finalmente y de forma pactada con el Estado mediante el Concordato de 1953 (artículo 19, n.2), "se asignará anualmente una adecuada dotación", recogiéndose de manera expresa el «título de indemnización por las pasadas desamortizaciones de bienes eclesiásticos», si bien se le añade un segundo fundamento, el de «contribución a la obra de la Iglesia en favor de la Nación».

Para concluir, y haciendo una valoración de lo investigado y lo narrado, en primer lugar, podemos apreciar la variedad de jóvenes profesas que llegaron a los Monasterios, desde distintos puntos de la geografía española y de otras latitudes cada una con su idiosincrasia propia, con sus costumbres, su formación musical, su talante y sus formas de pensar y desde otro punto de vista, no se puede poner en duda el papel desempeñado por la mujer en los ámbitos monásticos, con momentos de bonanza, con momentos de penuria, a base de trabajo, de esfuerzo, 
sacrificio y en ocasiones hasta con grandes privaciones - porque tuvieron sus momentos difíciles -, donde alcanzaron grandes metas; es importante que se aprecie la dimensión del trabajo realizado por la mujer desde el interior de estos recintos de oración y vida conventual y específicamente por la mujer música en estas épocas, la cual formó parte importante de la vida monacal y fue protagonista de la auténtica historia musical de los Monasterios. Hablando específicamente de la monja música llamada Sor Escolástica Campo considerada "El alma del culto divino", significó mucho para el Monasterio en sus períodos de Abadesa, al que llevó a un estado de refinamiento en todo lo que ahí se hacía y se decía; las que fueron Abadesas, fueron mujeres ilustradas, talentosas e instruidas, con gran espíritu de trabajo, de abnegación y ante todo fueron grandes gestoras, administradoras de capitales y con grandes responsabilidades, capaces de hablar y gestionar ante Obispos, Príncipes, Duques, Condes, Rectores de Universidades o con quien fuera necesario para alcanzar las metas de los Proyectos de vida para el Monasterio. Este ejemplo y este espíritu de trabajo se han mantenido en el Monasterios femeninos de Alba de Tormes, a lo largo de los siglos, fieles a un mensaje, a Dios, a sus fundadores y fieles con ellas mismas.

Ya desde la vida familiar, ya desde la vida monacal, ya desde la vida laboral fuera del núcleo familiar, la mujer ha movido al mundo y seguirá empujando e influyendo sobre él, llevando hacia adelante la existencia del mismo. Valorar y respetar su figura y apreciar el rol desempeñado desde tiempos inmemoriales, debe ser compromiso de todos. 


\section{CAPÍTULO IV}

LA VIDA CONVENTUAL EN ÉPOCAS VIRREINALES EN LA NUEVA GRANADA (ACTUAL TERRITORIO DE COLOMBIA)

IV.1. BOSQUEJ O HISTÓRICO DE SANTA FE DE BOGOTÁ

IV.2.FUNDACIONES CONVENTUALES FEMENINAS

IV.3. DESCRIPCIÓN DE LA VIDA CONVENTUAL EN SANTA FE DE BOGOTÁ EN ÉPOCA VIRREINAL Convento de Santa Clara

Monasterio de Santa Inés (Dominicas)

IV.4. ANÁLISIS COMPARATIVO DE LA VIDA MUSICAL EN LOS CONVENTOS FEMENINOS DE ALBA DE TORMES Y SANTA FE DE BOGOTÁ (Colombia)

IV. 5. EL MAESTRO J UÁN DE HERRERA Maestro de Música de las monjas Inesitas 


\section{CAPÍTULO IV \\ LA VIDA CONVENTUAL EN ÉPOCAS VIRREINALES EN LA NUEVA GRANADA (ACTUAL TERRITORIO DE COLOMBIA)}

\section{IV.1. BOSQUEJ O HISTÓRICO DE SANTA FE DE BOGOTÁ}

Santa Fe de Bogotá, capital del Nuevo Reino de Granada y actual territorio de Colombia, desde su fundación se convirtió en el centro político, social, cultural y como los cronistas nos lo describen, aunque no existe un acta de fundación de la ciudad, se ha aceptado como fecha de fundación el 6 de agosto de 1538. Según la tradición, aquel día el sacerdote fray Domingo de las Casas ofició la primera misa en una iglesia pajiza, levantada cerca de la actual catedral o del actual Parque de Santander. Se dice que ese día la región recibió el nombre de Nuevo Reino de Granada y el poblado se llamó Santa Fe.

“Bogotá antes de la llegada de Gonzalo Jiménez de Quesada, su fundador, estaba habitada por las culturas Chibcha y Muisca que se extendían por lo que es hoy Bogotá, Tunja, Iracá, Tundama y Guanetá, la zona estaba organizada bajo el mando de dos jefes: el Zipa y el Zaque.

Gonzalo J iménez de Quesada, general español encargado de buscar el mítico El Dorado, llega a América por el norte en 1537 en compañía de 750 hombres. Una vez en Bacatá somete, asesina y maltrata en compañía de su tropa a indígenas por las ansias de oro y esmeraldas.

Después de la muerte del Zipa de Bogotá, Quesada decidió fundar una villa para establecerse en el terreno conquistado, y por la consigna de los conquistadores de "fundar y poblar" para establecer un gobierno estable y una vivencia ordenada para los indios. La villa fue erigida en Thybzaca (hoy Teusaquillo) por su abundancia de aguas, la cercanía de recursos como madera, piedra, tierras, y la protección del viento que les daban los cerros Monserrate y Guadalupe.

Comenzaron con 12 bohíos y una modesta capilla construida por los indígenas y se escogió el día de la "Transfiguración del Señor", 6 de agosto, para la celebración por la edificación la villa y por el terreno tomado que nombró Santa Fe de Bacatá en honor a Santa Fe de Granada, lugar de origen 
de Jiménez de Quesada. La fundación de Bogotá coincide con la llegada de otros dos exploradores europeos, Sebastián de Belalcázar (que fundaría posteriormente la ciudad de Cali) y el alemán Nicolás de Federman.

Aunque no existe acta de fundación de la ciudad, se aceptó como fecha de fundación el 6 de agosto de 1538, pues según cuenta la historia, aquel día el sacerdote Fray Domingo de las Casas ofició la primera misa en la capilla erigida en el centro de la villa. Ese día también se nombró a la región Nuevo Reino de Granada. El poblado luego se llamó Nuestra Señora de la Esperanza, después se llamo Bogotá y finalmente se bautizó con el de Santa Fe de Bogotá Distrito Capital en 1991.”207

Después de la dominación indígena, comenzó la conquista de las almas por parte de la Iglesia con la ayuda de las órdenes religiosas que se establecieron desde el siglo XVI en todo el territorio de la actual Colombia. Se construyeron iglesias y conventos a cargo de las comunidades Franciscana, Dominica, Agustina y más tarde, en 1604, de los Jesuitas, los Capuchinos y las monjas Clarisas (1628), Dominicas y Carmelitas Descalzas. Estas comunidades marcaron el espíritu y las costumbres de los santafereños, pues ejercieron un dominio ideológico, político y cultural que apenas se vio un tanto opacado cuando, en 1767, Carlos III ordenó la expulsión de los jesuitas de las colonias de España en América, mediante Real Decreto de 27 de febrero, y Pragmática-Sanción de 2 de abril de este año. Madrid: Imprenta Real de la Gazeta, 1767, pp. 1-46.

\footnotetext{
“Atractivo sin par, definitiva influencia desplegó la música de Iglesia en la labor civilizadora y misionera que los doctrineros llevaron a cabo para atraer neófitos a la fe católica. Enseñaron a los indios intérpretes algo de canto eclesiástico para dar más solemnidad al culto, y como estos iban asimilándolo, al cabo de poco tiempo, ya sabían algunos extractos del Kyrial y jaculatorias cantadas. Donde quiera que iban a predicar el evangelio inculcaban a la par a los indios que el mejor medio de alabar a Dios era la oración cantada, el canto gregoriano, acordes con el aforismo medioeval de que bis orat qui cantat , el que canta ora doblemente."
}

207 Tomado de Colombia Aprende, portal educativo del Ministerio de Educación Nacional, $<w w w . c o l o m b i a a p r e n d e . e d u . c o / h t m>$ (consultado el 3 de junio 2008). 
"Felipe II en sus Ordenanzas aconseja que donde la doctrina cristiana se enseñe, los sacerdotes en ayuda de su misión "podrán usar la música de cantores y de ministriles altos y bajos".208

Con esta perspectiva socio - cultural y religiosa, Santa Fe de Bogotá y sus alrededores, tuvieron desde sus orígenes considerable actividad musical, gracias a la fundación de colegios en los que se enseñó a leer, a escribir y a leer e interpretar el canto llano, así como tañer instrumentos musicales como el órgano, la flauta, el arpa, entre otros.

Como en el resto de la América hispana, las órdenes religiosas fueron fundamentales en el campo de la educación, que por orden de la Corona se impartía en iglesias y conventos. Las dos primeras cátedras universitarias se deben a los frailes dominicos (1563 y 1573). En 1592 se fundó el Colegio Seminario de San Bartolomé para impartir educación superior a los hijos de españoles; los jesuitas dirigieron este colegio en 1605 y fundaron el Colegio Máximo que estaba situado en una de las esquinas de la Plaza Mayor.

En 1580 los dominicos fundaron la Pontificia Universidad de Santo Tomás de Aquino para Artes y Filosofía, y en 1621 los jesuitas iniciaron los cursos en la Universidad de San Francisco Javier (o Javeriana). En 1653 fray Cristóbal de Torres fundó el Colegio Mayor de Nuestra Señora del Rosario. En 1783 se inició la primera comunidad educativa y la primera escuela para la educación de la mujer en la Nueva Granada: el colegio de La Enseñanza, de la comunidad de María. Desde ese momento, se iniciaron las lecciones escolares para las mujeres, derecho que hasta entonces estaba reservado a los varones.

208 PERDOMO ESCOBAR, José Ignacio. Historia de la música en Colombia. Plaza y Janes Editorial Colombia. Bogotá. 1980. p. 18. 


\section{IV.2. FUNDACIONES CONVENTUALES EN SANTA FE DE BOGOTÁ EN ÉPOCA VIRREINAL}

\section{CONVENTO DE SANTA CLARA}

Santa Fe de Bogotá - Colombia

En pos de la evangelización, llegaron a América muchas órdenes religiosas, que se establecieron y realizaron una extensa labor a lo largo de los siglos hasta nuestros días. En Santa Fe de Bogotá, capital del Nuevo Reino de Granada de aquel entonces, se instauraron los Monasterios de Dominicos, de Jesuitas, de Franciscanos, Agustinos calzados y recoletos y las órdenes femeninas que se crearon fueron: con insignia de Santo Domingo, las Dominicas con el Convento de Santa Inés, con el emblema de Santa Clara, las Clarisas y las Concepcionistas.

El Convento de Santa Clara fue uno de los Monasterios con más trascendencia por la importancia de su fundación y por el la jerarquía de los personajes que en ella estaban involucrados.

Conozcamos a cerca de este proceso fundacional en el Nuevo Mundo:

"Durante el arzobispado de Hernando Arias de Ugarte y con su apoyo se logra que el rey Felipe III otorgue licencia para su fundación y en 1629 se inaugura con una procesión que parte desde la iglesia del Carmen. "Promovido el señor Arias al Arzobispado de Charcas, antes de terminarse la obra de la iglesia y del convento, dejó encargo de concluirla a su hermano Diego Arias Forero. En 1628 se hizo la fundación de acuerdo con Bula del Pontífice Gregorio XV, con tres monjas, una de las cuales era hermana del Arzobispo Arias de Ugarte y las otras dos sus sobrinas, que cambiaron el hábito del Carmen por el de Santa Clara. Otra sobrina del Arzobispo, doña María Arias de Ugarte, "empleó su hacienda en continuar la fábrica de la iglesia y adornos de ella". Costó el edificio más de \$ 60,000 y sirvió de convento hasta 1863.

La iglesia fue consagrada en 1645 como oratorio para las monjas Clarisas. La particularidad del templo, concebido de acuerdo a la moda de su tiempo, 
es la que los muros se cubrían totalmente con adornos de madera y cuadros. Los muros exteriores son de piedra y calicanto."209

Muchos fueron los intereses creados alrededor de esta fundación conventual; las cláusulas estipulaban la sucesión del patronazgo del convento en el linaje de los Árias Ugarte. La designación de una primera Abadesa fue para una Árias Ugarte, así como las religiosas fundadoras fueron de la misma familia. Corría el año de 1634 cuando se concluyó la construcción de la fuente de piedra del claustro; para esto, la antigua carmelita Damiana de San Francisco, hermana del Arzobispo y priora en el Convento del Señor San J osé de esta ciudad y de la Orden de Nuestra Señora del Carmen, vendió la celda de su convento, a la hija de Fernández de Valenzuela, puesto que a petición de sus hermanas J uana de J esús e Isabel de la Trinidad y por su experiencia como monja antigua, fundadora y priora en el dicho convento, logró el cargo de primera Abadesa del Convento de Santa Clara.

Desde el punto de vista anecdótico, inusitadas leyendas se dieron en torno a la vida conventual, las cuales a lo largo de la historia, nos han ilustrado sobre los intereses, amores, desamores, raptos, encierros, enredos y tramas familiares y políticas susitados en las clases sociales de todos los tiempos. La que se relata a continuación, es una hitoria con connotaciones amorosas: La noche del 21 de marzo de 1669, fue raptada del convento de Santa Clara, la religiosa María Orgaz, amante desesperada del oidor Bernardino Angel de Yunza. Para tamaño lance halló el dicho Bernardino, la complicidad de su colega en la Audiencia, Domingo Rocha Ferrer, a quien no sorprendió la aventura, ya que su esposa la bella señora Labarces había volado a sus brazos del propio convento de Santa Clara, en Cartagena.

209 Leer en Crónicas de Bogotá, a IBÁÑEZ, Pedro María. Crónicas de Bogotá, Imprenta Nacional, Bogotá, 1913.T.1 y a POSADA, Eduardo. Narraciones. Capitulos para una historia de Colombia. $2^{\text {a }}$ ed. Villegas Editores. Bogotá 1988. 


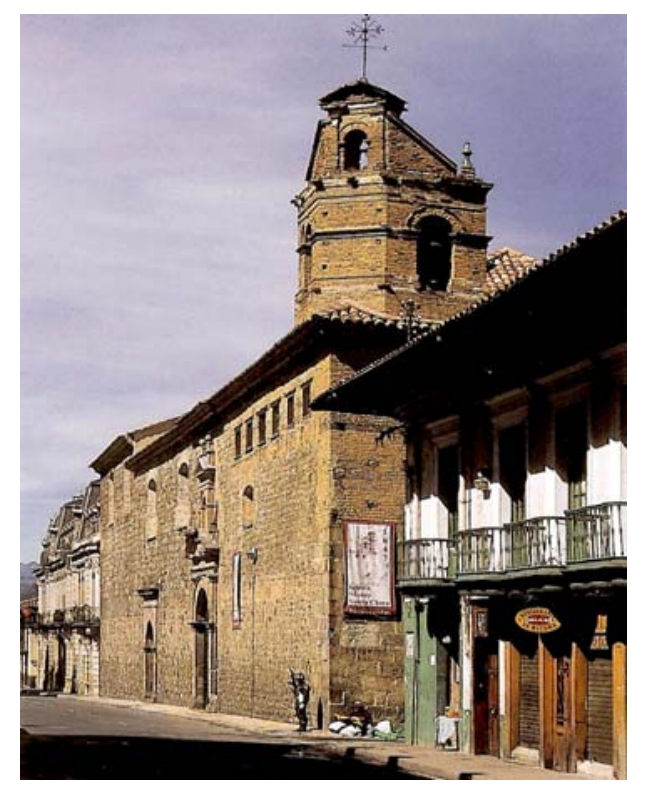

28. Iglesia de Santa Clara - Bogotá - Colombia

El arquitecto español Matías de Santiago terminó de construir la iglesia convento de Santa Clara, de Bogotá, en 1647. Allí habitaron las hermanas clarisas hasta 1862, fecha cuando se dio el proceso de desamortización en Colombia ordenado por el presidente General Tomás Cipriano de Mosquera, en su segundo período presidencial (1861-1863), emitió una serie de decretos que tenían por objetivo controlar el poder de la Iglesia Católica, entre los que sobresalen el de desamortización de bienes de manos muertas, por el cual se expropiaron las tierras que poseía esta entidad, para luego ser rematadas en pública subasta; así mismo decretó la expulsión de los jesuitas del territorio nacional.

Realizada su fundación, el Monasterio de las monjas Clarisas, pasó a ser el tercero de la ciudad, junto con el de La Concepción y El Carmen. En 1625, se destinó a Arias de Ugarte al arzobispado de Lima y como ya lo vimos, fue su hermano Diego Arias quien concluyó la obra, un año después que el Papa Urbano VIII aprobara definitivamente la fundación del convento. En 1855 una explosión de pólvora en una casa vecina afectó la iglesia, que perdió su techumbre, y en febrero de 1863, las monjas fueron expulsadas del convento por el general Tomás Cipriano de Mosquera. Como testimonio de la vida conventual de las Clarisas en épocas virreinales, queda su iglesia y de la cual se tiene éste relato: 
"La iglesia es de una nave y el muro lateral ubicado sobre la carrera 8a conserva las dos puertas de acceso propias de una iglesia perteneciente a un convento de monjas. Conserva el coro con una celosía mudéjar, el arco toral, que divide la nave del presbiterio, y junto a este, la sacristía. El espacio interior está rematado con una falsa bóveda de cañón con lunetos, y cuenta con una sorprendente decoración compuesta por flores pintadas alternadas con rosetones lobulados o pentafolias de madera recubierta con laminilla de oro. Según Santiago Sebastián es el interior mejor logrado dentro de las iglesias de Bogotá, y uno de los más expresivos del arte neogranadino del siglo XVII. La fachada de la iglesia fue despojada del pañete que la cubrió, dejando a la vista una silletería casuística. El acceso principal está resaltado por una portada de piedra y ladrillo, con pilastras lisas que sostienen un arco de medio punto. Sobre este se apoya un frontón partido flanqueado por pináculos, en cuyo centro una hornacina protegía la imagen de Santa Clara, ya desaparecida. En la esquina de la edificación se mantiene la espadaña de tres cuerpos con sus respectivas campanas." 210

Remitiéndonos hacia épocas más recientes, en 1969, el claustro fue demolido para construir la Facultad de Derecho y Ciencias Políticas de la Universidad Nacional y la iglesia fue adquirida por el Instituto Colombiano de Cultura que la restauró entre 1975 y 1983 y la adecuó como museo, en este último año. Allí se exponen 117 pinturas, una de ellas de escuela europea, y 40 esculturas, la mayoría de talleres santafereños de los siglos XVII y XVIII. Entre las obras destacadas están "La Piedad” y "La misa de San Gregorio" de Baltasar de Figueroa (siglo XVII) y "El sueño del bachiller Cotrina" de Gregorio Vásquez de Arce y Ceballos. Actualmente se le hace una nueva restauración a este museo, que pertenece al Ministerio de Cultura.

$210<\mathrm{http}$ // www.skyscrapercity.com> (consultado el 4 de agosto de 2008). 


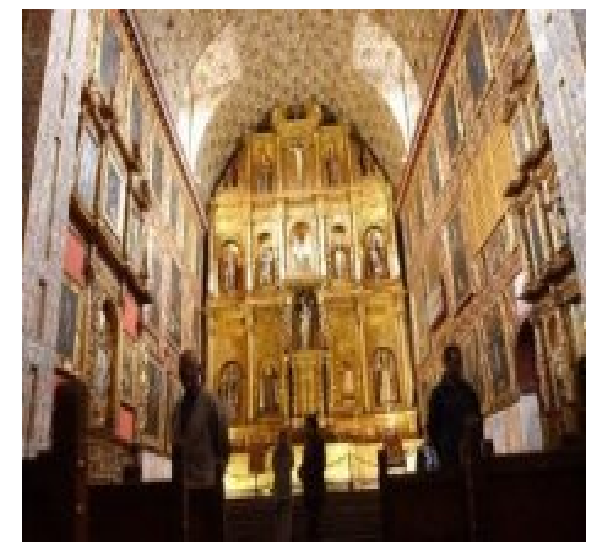

29. Museo Iglesia de Santa Clara (Bogotá)

\section{FERNANDO ARIAS DE UGARTE}

Por razones históricas y por estar al tanto de la personalidad de este personaje, quíen fuese el fundador del tercer convento más importante de Nueva Granada de entonces, es preciso conocer las motivaciones que le llevaron a emprender una la fundación de tal importancia para los tiempos que corrían en aquella época. El principal objetivo o motivo por el cual Árias de Ugarte realizó esta fundación, fue por razones de sangre relacionadas con la preservación del honor y la memoria de su linaje, asegurando un decente sostenimiento económico a las mujeres de su familia. Nacido en territorio de la Nueva Granada, de ascendencia extremeña por parte de madre y vasca por padre, fue enviado a España a la edad de 15 años, para estudiar en la Universidad de Salamanca; ejerció varios cargos en la administración real y en el gobierno eclesiástico, para ver cumplido más adelante, su deseo de ser Arzobispo de Santa Fe de Bogotá, donde regresó en Enero de 1618, cuando contaba con 57 años. 


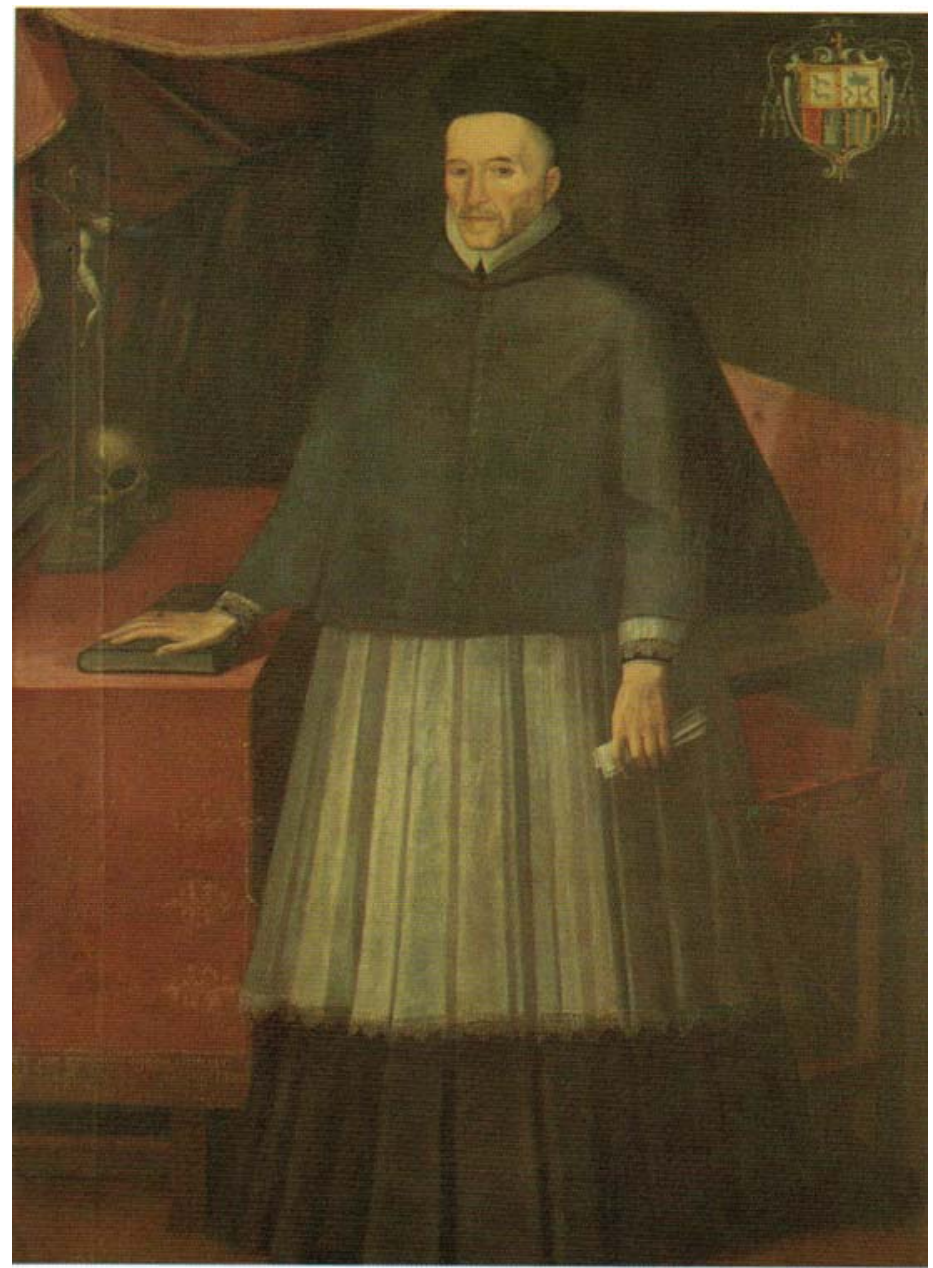

1rzobispo Fernando Arias de Ugarte. Atribuido a Gaspar de Figueroa, óleo obre tela, siglo xvir. Colección Museo Iglesia Santa Clara.

31. Arzobispo Arias de Ugarte Forero - Fundador del Convento de Santa Clara Santa Fe de Bogotá - Colombia. Tomado de la obra A falta de oro, linaje, crédito y salvación. La historia del Real Convento de Santa Clara de Santa Fe de Bogotá. Siglos XVII y XVIII.

\section{“ÉL ARZOBISPO DON FERNANDO ARIAS DE UGARTE}

(Historia Eclesiástica, Capitulo XIV).

Vacante la silla episcopal metropolitana de Santa Fe, por fallecimiento del señor Ordóñez, vino a ocuparla el doctor don Fernando Arias de Ugarte, hijo ilustre de esta ciudad; nacido en ella el día 9 de septiembre de 1561, hijo legítimo del contador don Hernando Arias Torero, regidor del cabildo de Santa Fe, y de doña Juana Pérez de Ugarte, ambos de los nobles de Cáceres de Extremadura y Vizcaya. Sus abuelos maternos fueron de los pobladores de Santa Fe, en que tuvieron empleos honoríficos y los repartimientos de indios de Engativa y Tegua. Fue su padrino de bautismo el adelantado don Gonzalo J iménez de Quesada. La ciudad de Santa Fe debe gloriarse de haber tenido por 
el hijo al señor Arias de Ugarte que seguramente ha sido uno de los prelados más grandes que hayan ocupado la silla metropolitana de Santa Fe.

Mostró desde la niñez su inclinación a la virtud y a las letras. Su padre lo puso a estudiar gramática en el colegio de los padres dominicanos, donde empezó a manifestar una gran capacidad y aplicación; pero como en aquellos tiempos no era posible esperar que en el país pudiera formarse un hombre tal como su padre quería, lo mandó a España para que hiciese sus estudios en la Universidad de Salamanca, adonde llegó siendo de edad de diez y seis años. Bien pronto se hizo notable en aquella Universidad por sus grandes talentos y virtudes, y llegado el tiempo se graduó de bachiller; y después de doctor en ambos derechos en la Universidad de Lérida. Concluidos sus estudios, se propuso viajar y visitó gran parte de Italia y España, llevando un diario de observaciones sobre el natural, usos y costumbres de los pueblos que visitaba. Volvió a la corte de edad de veinticinco años, donde fue recibido de abogado de los reales consejos, $y$, experimentando su gran juicio y capacidad en algunas comisiones que se le encargaron, fue nombrado auditor general del ejército que pasó al reino de Aragón. En este destino se acabó de conocer su importancia, y vuelto a Madrid se le destinó a tres corregimientos, que no aceptó. Hízole el rey oidor de Panamá y al poco tiempo fue promovido a la audiencia de Charcas. El virrey don Luis de Velazco le nombró por corregidor de Potosí, con el título de su lugarteniente, capitán general de aquellas provincias y visitador de la casa de moneda y cajas reales. Ascendió luego a oidor y alcalde de corte de la audiencia de Lima; y su virrey, el conde de Monterrey, le nornbró visitador de las minas de Huancaelica, en cuya comisión estuvo tres años."211

El Libro de Crónicas de Bogotá, relata noticias en torno a la figura de Árias de Ugarte y la fundación del convento de Santa Clara. El libro nos cuenta que en el Concilio que dirigió el señor Arias de Ugarte se votó por protector contra los temblores de tierra a San Francisco de Borja, que acababa de ser beatificado canonizado más adelante el 1671 - . Al voto asistieron el Presidente don J uan de Borja, nieto del Santo, un hijo de don J uan, Tesorero de la iglesia Catedral, un Obispo, los Prelados de las religiones y los Cabildos civil y eclesiástico. Firmó el acta del voto el cronista bogotano Alonso Garzón de Tahuste (...) obtuvo el señor Árias de Ugarte permiso del rey, el año de 1619, para fundar en esta ciudad monasterio de monjas de Santa Clara, en casas que compró con tal

211 Cfr. Capitulo XIV. Historia Eclesiástica. Biblioteca Luís Ángel Arango. Santa Fe de Bogotá. 
objeto y dotó de rentas suficientes a veinticuatro monjas, doce de ellas de su raza, y las otras descendientes de conquistadores.212

Respecto a la Bula Papal, se conoce que pasados nueve años de la expedición de la Cédula Real, el 1 de diciembre de 1628, junto a la Catedral de Santa María la Mayor en Roma, Urbano VIII firmó el Breve Apostólico por medio del cual concedió la Licencia Fundacional del Convento al Arzobispo Árias de Ugarte. Pasados dos años, el 22 de marzo de 1630, el notario y Auditor de la Cámara Apostólica, hacía público y oficial el Breve Papal. Leer a Toquica, Constanza quien en su obra "A falta de oro: linaje, crédito y salvación, cita a Marcus de Vances.213

Para el Papa Urbano VIII, el destino que justificó la Fundación de este Monasterio, era el carácter social y de protección a la mujer en estas épocas, en tierras del Nuevo Reino de Granada. Inicialmente se erigió para recibir en él a doncellas de escasos recursos económicos, vale decir fue creado con la concepción de una Obra Pía. Esto, significaba desembolsar considerables cantidades de dinero para mantener en buena forma el Monasterio que solo podría albergar las cantidades de pretendientas que el mismo pudiera sostener sin problemas económicos. Desde otro punto de vista, se creía que la Clausura, protegía a la mujer de la prostitución, de las mezclas raciales indeseadas, de las malas compañías, de las influencias religiosas de mujeres indígenas y negras esclavizadas. Pero como se sabe, en él ingresaron mujeres de la sociedad, hijas, sobrinas y parientas de las personas más destacadas de la sociedad del momento, las que aportaron grandes cantidades dinerarias por dote. A la par tomaron los hábitos, mujeres de humilde cuna, amparada en las dotes creadas por el Arzobispo Arias de Ugarte, para este fin.

212 Crónicas de Bogotá Pedro M. Ibañez. Biblioteca Luis Ángel Arango. Banco de la República de Colombia. 213 TOQUICA, Constanza. A falta de oro, linaje, crédito y salvación. Siglos XVII y XVIII. Bogotá: Universidad Nacional de Colombia, 2008, p. 61. 


\section{FUNDACIÓN DEL MONASTERIO DE “SANTA INÉS”}

\section{Monjas Contemplativas}

\section{Santa Fe de Bogotá - Colombia}

Con el signo de las Religiosas Dominicas, fue el convento femenino el de Santa Inés en Santa Fe de Bogotá, el que se fundó en 1645. El Padre Zamora en su libro sobre la provincia de San Antonio, nos describe el venturoso día así: “'Hábitos blancos y palmas en las manos", el día 19 de julio de 1645, en ceremonia solemne a las 7 de la mañana.

Sus fundadores, los hermanos Chaves Antolínez, tras largos años de espera, lograron la fundación mediante la Real Cédula de su Majestad el Rey, Don Felipe IV.214

Las religiosas fundadoras, fueron las monjas Beatriz de la Concepción, Francisca Eufrasia de J esucristo y Paula de la Trinidad, rinden obediencia al ordinario. Otras monjas recibieron el hábito al día siguiente de su fundación, mientras que las demás prometen guardar y enseñar a las que entrasen después, las Constituciones del Padre Santo Domingo, que profesan las religiosas. Eran por aquellos tiempos, Provincial, fray Francisco Farfán y Obispo, el Dominico Fray Cristóbal de Torres; este último, nombró como profesor de las monjas, a Fray Francisco de Aschuri.

Las Dominicas de Santa Fe de Bogotá, establecidas desde 1645, realizaron una ardua labor de evangelización y aunque su estado de vida era el contemplativo, fundaron un colegio para dar educación a las jóvenes. El decreto de extinción de todos los conventos, durante el gobierno dictatorial de Tomás Cipriano de Mosquera, fue causa de la expulsión y dispersión en 1861 y de la supresión definitiva en 1863. Después de la muerte del General Mosquera, acaecida en el 1878, el Monasterio fue reorganizado. Tres fundaciones más, de Dominicas se registran en Colombia en el siglo XX: En Ocaña (Norte de Santander), en Duitama (Boyacá) y en Sogamoso (Boyacá). Para la fundación de Duitama, apoyada por el

214 Tomado de <http:// www.opcolombia.org/ familia dominica/monjas.html> (consultado el 10 de agosto de 2008). 
entonces Obispo de esa Diócesis, José J oaquín Flores, enviaron desde Bogotá, ocho monjas de Coro, capacitadas musicalmente para el desarrollo de la Liturgia.

Veamos con más detalle el proceso fundacional:

Hernando de Caicedo, nacido en la ciudad de Santafé de Bogotá, persona acaudalada, de nobleza y riquezas, soltero aún, que con la ayuda de Tomás Velázquez, escribano de Cámara de la Real Chancillería de la misma ciudad, y de Alonso López de Mayorga, todos parientes, intentó fundar un convento de religiosas dominicanas, informando de sus intenciones al Presidente Gobernador don J uan de Borja, caballero del orden de Santiago, que a su vez éste, informó al Rey sobre estas personas y de la piedad de la obra; EL Rey Felipe III, despachó su Cédula en 24 de diciembre del año de 1615. Sin embrago, solo en el año 1645 se llevó a cabo la fundación definitiva del Monasterio.

Al poco tiempo de esto, se casó Don Hernando de Caicedo; el principal inconveniente para lograr la licencia, fue por habérsele concedido ya una, al Arzobispo don Fernando Arias de Ugarte para el de Santa Clara. Muere Hernando de Caicedo y los albaceas Francisco Beltrán Caicedo, su hermano, y su cuñado Francisco de Berrío, aplicaron la hacienda a otras Obras Pías, por no haberse logrado el asentimiento póstumo, y a dos capellanías de a mil pesos de renta anual para descendientes; y no lo habiendo, cuatro capellanías de a cuatrocientos y doscientos a cada patrón. En Crónicas de Bogotá de Pedro M. Ibañez, encontramos el relato de la fundación de este Monasterio. Continuando el propósito Tomás Velásquez y Alonso de Mayorga insistieron en la solicitud de licencia para la fundación de convento, ofreciendo siete mil patacones y Francisco Beltrán de Caicedo diez mil de su hacienda, y de la de su hermano Hernando de Caicedo diecinueve mil que habían quedado sin distribuir y los capellanes, que todo se reputaba por cuarenta mil; y en esta conformidad informó al Rey la Real Audiencia en 30 de junio de 1622 y no hubo resultado alguno; la conversación de detuvo hasta que habiendo sido nombrado por Gobernador de la Provincia de Antioquia, en interinidad, Juan Clemente de Chaves, Alférez Mayor de la ciudad de Santafé, hombre bien entendido, culto y cortés, fue ayudando su hermana doña Antonia de Chaves, viuda de López de Céspedes, primer Alférez Real 
propietario de esta ciudad, encomendera de los indios de Ubaque, Cáqueza y sus anexos, que condescendió en la disposición, dedicando las casas de ambos hermanos y otras contiguas de una prima con haciendas de campo y otras cosas, representándolo en la Real Chancillería, pidiendo su informe para impetrar licencia de Su Majestad, como le dio en 7 de julio de 1630 en fundamento de lo ofrecido, que era diez y ocho mil patacones en dinero y cuarenta estancias de ganado mayor y menor, pobladas con ganados en la sabana de Bogotá, y otras seis en tierra caliente, de trapiche con negros y cañaverales para miel y azúcar, las dos. partes de casas en la ciudad y mil patacones cada año de los de su vida en la renta de la encomienda, estimado todo en cincuenta mil patacones para el sustento de cincuenta religiosas, que asignó diez sin dote a su elección, y las demás con el de dos mil patacones sujetas al ordinario, consiguiendo juntamente informes propicios del Arzobispo doctor don J ulián de Cortázar y del Deán y Cabildo de 6 y 14 del mismo mes y año; y por haberse librado Cédula Real para que volviesen a informar la Audiencia y Arzobispo, informaron en 25 y 26 de octubre de 1632.

Hizo doña Antonia de Chaves sus despachos a la Corte y escribió recomendándolos a la memorable doña Marina de Escobar, para que, como parienta, fomentase la licencia, que le respondió lo haría no obstante que para ello se hallaba con poca introducción y alimento, y que se asegurase la conseguiría y la fundación de convento había de ser de grande importancia y muy del agrado de Dios, aunque se padecerían dificultades, pleitos y trabajos; y se alcanzó despacho una respuesta así:

\section{“EL REY}

Por cuanto por parte de vos doña Antonia de Chaves, viuda de Lope de Céspedes, vecina de la ciudad de Santafé del Nuevo Reino de Granada y encomendera, que decis ser del repartimiento de Ubaque y sus sujetos, me ha sido hecha relación que sois hija de los primeros conquistadores del dicho Nuevo Reino, y que por hallaros con cantidad de hacienda que heredastes de Juan Clemente de Chaves, vuestro hermano, Gobernador que fue de la Provincia de Antioquia, y deseáis emplearla en servicio de Dios Nuestro Señor y utilidad seais emplearla en servicio de Dios Nuestro Señor y utilidad del dicho Reino, fundando un convento de monjas de la Órden de Santo Domingo en la dicha ciudad de Santafé, con advocación de Santa Inés de Monte Policiano, sujeto al ordinario, para entraros en él en religión y que hagan lo mismo algunas mujeres principales descendientes de conquistadores, que por hallarse con necesidad no tienen que tomar otro estado, para lo cual tenéis dispuesto hasta sesenta mil pesos que valen vuestras haciendas en oro, estancias, ganados y otras cosas, con que había cantidad suficiente para la 
dicha fundación y sustento de las monjas que entraren en el dicho convento; y para que esto se haga como conviene, podrían ser las fundadoras juntamente con vos, Beatriz de la Concepción y Ana de San J erónimo, vuestras hermanas, y Francisca Eufrasia de Cristo, sobrina vuestra, monjas profesas en el monasterio de La Concepción de la dicha ciudad y de toda virtud y perfecta vida, que por haber tenido los oficios más preeminentes del dicho monasterio son de la experiencia necesaria para el gobierno del que pretendéis fundar; suplicándome, atento a ello y para que semejante obra tuviese efecto, os mandase dar licencia para la dicha fundación, con las condiciones que parecieren más convenientes para su perpetuidad, conforme lo que se acordare con el prelado en razón de la seguridad de lo que ofrecéis para la dicha fundación y forma que habéis de tener en el gobierno del dicho convento $y$ nombramiento de patrones perpetuos $y$ prioras fundadoras. $Y$ visto por los de mi Consejo de las Indias y las relaciones y pareceres que en razón dello enviaron por mi mandado el Presidente y Oidores de mi Audiencia Real de la dicha ciudad y el Arzobispo de ella, he tenido por bien de dar la presente, por la cual os doy licencia y facultad a vos la dicha doña Antonia de Chaves para que fundéis el dicho convento de monjas de la orden de Santo Domingo, con la advocación de Santa Inés, en la dicha ciudad de Santafé, en la forma y manera que queda referida, con calidad, que si salieren las dichas Beatriz de la Concepción y Ana de San Jerónimo, vuestras hermanas, y Francisca de Eufrasia de Cristo, sobrina vuestra, del dicho convento de La Concepción de esta ciudad para la dicha fundación, se hayan de quedar y queden para él los dotes, rentas y demás hacienda que llevaron cuando recibieron su hábito, y que lo mismo se entienda con las demás monjas que salieren del dicho convento para el dicho efecto que eran novicias, cuando propusisteis las condiciones de la dicha fundación, que así es mi voluntad.

Fecha en Madrid, a dos de noviembre de 1638 años.

Yo el Rey

Por mandado del Rey nuestro señor, | don Fernando Ruiz de Contreras”215

Durante el reinado de Felipe IV, se dio la fundación de este importante Monasterio en Santa Fe de Bogotá; primeramente, vale destacar, que los grandes patrimonios adquiridos por los primeros españoles llegados a las Indias y asegurados por sus descendientes afincados en el territorio, permitieron entonces, acometer grandes empresas de distinta índole. La profunda religiosidad existente en el momento y el sentido de piedad arraigado en las conciencias humanas, llevaron a muchas personas a invertir sus grandes capitales en Obras Pías; sin embargo y analizando la naturaleza de las personas que por lo general conformaron el grupo de 
beneficiarios en dichas fundaciones, podemos ver que en su mayoría fueron miembros de una misma familia, entre ellas, tías, sobrinas, hijas, o viudas, que en cierta forma aseguraron de por vida su situación económica, pero con un objetivo o un sentido de servicio a los demás, lo que les garantizaba una tranquilidad espiritual.

“Obedecióla mandando se guardase y cumpliese en 31 de diciembre de 1644 don Martín de Saavedra y Guzmán, caballero del orden de Calatrava, Presidente, Gobernador y Capitán General del Nuevo Reino de Granada, y doña Antonia de Chaves, que fue singular en lo activo, oficioso y en gobierno en el interin de la negociación de licencia dispuso las cercas y oficinas del convento en las casas de su asignación, iglesia, porteña, ornamentos y todo lo demás que requiere el Ministerio. Y teniéndolo en buena forma en 18 de julio de 1645 el Provisor doctor don Alonso de la Cadena y Sandoval, reconoció judicialmente la nueva iglesia, altares, sacristía, convento, coros, rejas, puerta reglar, torno, dormitorio, refectorio, enfermería, vivienda, oficinas y cercas, y para el culto divino cálices, ornamentos y lo demás que le pertenece, declarando por suficiente para la colocación del Santísimo Sacramento en su iglesia, y para poderse celebrar en ella entrar y estar en clausura las monjas, y que se podía ejecutar, y concedió licencia a la abadesa de La Concepción para dejar salir las madres fundadoras; $y$ al siguiente 19 bendijo los ornamentos y iglesia, y pasó a la portería del otro convento, y revestido con capa de coro y prevención de cruz alta sacó de la clausura las religiosas fundadoras que le dieron obediencia besándole la mano en señal, y las llevó en procesión y concurso de eclesiásticos y seglares, a las siete de la mañana, yendo la madre Beatriz de la Concepción en medio del maestro don Cristóbal de Villa y Arellano y bachiller Pedro Ortiz Maldonado Mano-salvas, Maestrescuela y Canónigo en esta ciudad, que la llevaban de mano, y a la madre Francisca Eufrasia de Cristo el doctor don J uan Baptista Pardo de San Nicolás, Canónigo, y don Diego Osorio Nieto de. Paz, patrón; y a la madre Paula de la Trinidad (que sustituyó por Ana de San J erónimo, que era muerta) el bachiller don Bartolomé del Río y Portillo, racionero, y el Capitán Juan Ortiz Maldonado Manosalvas, persona anciana, y con repique de campanas y música de ministriles pasaron a la nueva iglesia, donde hicieron oración, y volvieron a dar la obediencia al Ordinario, y de allí a su portería, en que repitieron la acción de obediencia tercera vez, y entraron por la puerta reglar que cerró por dentro la madre Beatriz de la Concepción, con lo cual el Provisor declaró estar hecha la fundación de convento de religiosas y quedar en clausura; y fue en 19 de julio de 1645 . Volviose a abrir la puerta reglar y el 
Provisor creó y nombró por priora y fundadora a la misma madre, y por superiora y vicaria a Francisca Eufrasia de Cristo, y por portera a Paula de la Trinidad, obrando en todo sustituyendo al Arzobispo con su comisión especial por estar enfermo; y volviéndose a la iglesia nueva cantó misa solemne y colocó en el Sagrario del altar mayor el Santísimo Sacramento y entregó la llave al Capellán, maestro don Gregorio Osorio Nieto de Paz, la iglesia y ornamentos, poniéndolo por auto y testimonio. Inmediatamente fueron entrando otros sujetos, nuevas plantas de tan precioso vergel; y en 25 de junio de 1638 había hecho la patrona fundadora constituciones que aprobó el Arzobispo; y en 15 de junio de 1645 las reformó con la misma aprobación arzobispal, limitadas en algo, según se dirá, y revocando lo que a las segundas se oponían las primeras, que son como se siguen:

\section{Constituciones}

la Que dotaba al monasterio en sesenta mil pesos de a ocho reales de principal, con mil de renta en cada un año de los de su vida, situados en las encomiendas de Ubaque.

2a Que mientras viviese como patrona, y los patronos que nombrase, gocen de las preeminencias y honores que les pertenecen por tal título, concedidas por derecho y por cédulas reales, como son la de 25 de mayo de 1591 y septiembre de 1595.

3a Que hubiese cincuenta monjas de velo negro y no más, con sus dotes de a dos mil patacones $\mathrm{y}$ propinas $\mathrm{y}$ ajuar, $\mathrm{y}$ más cien patacones para alimentos del año de noviciado, pagándolo todo antes de la profesión. El número de cincuenta se reformó por las segundas, a treinta y tres, con las de nombramiento patronal, sin que excediese, y en la aprobación del Arzobispo quedaron en treinta y cuatro.

4a Que hubiese doce monjas legas con dote de a cuatrocientos pesos de a ocho reales y ajuar de dos hábitos, su cama y ropa blanca a disposición de la priora, excluyendo mulatitas.

5a Que las de velo negro sean de legítimo matrimonio, nobles de sangre, virtuosas y por lo menos limpias de toda mala raza, sin excluir la hija natural, concurriendo las otras calidades.

6a Que en el número señalado se incluyesen diez de velo negro, sin dote, a nombramiento de la fundadora, por una vez, de las partes referidas; y si su 
sobrino don Diego Osorio Nieto de Paz, sucesor del patronato, tuviese de matrimonio una o dos hijas, pudiesen entrar en las primeras dos vacantes de las diez sin dote, por ser de su sangre; y teniendo más, entren con mitad de dote, sin que esto se extienda a otro patrón que no sea de su sangre, sino solamente con los hijos, nietos y descendientes de don Diego Osorio que representase siempre la persona de la fundadora con todo el derecho de patrón fundador, y sus hijas o nietas obtengan el título de fundadoras, pues para este privilegio se despojaba en vida de lo que compone la dotación en que cabía superabundantemente. En las segundas limitó que después de las diez del primer nombramiento no le hubiese de patronos, sino sólo de cuatro nombradas perpetuamente en lugar de las que murieren.

7a Que demás del primer decenio de monjas a nombramiento, sin dote, entrasen por fundadoras Beatriz de la Concepción, su hermana, religiosa de La Concepción que había sido abadesa; Francisca Eufrasia, su prima, y más con título de fundadoras dos inclusas en las diez, Francisca María de la Cruz y Beatriz de Santa Inés, novicias en La Concepción, por ser personas de calidad y virtud que había criado. Murió antes la segunda y enfermó la primera, y casádose.

8a Que atendiendo al buen gobierno, experiencia y buenas calidades que concurrieron en Beatriz de la Concepción y Francisca Eufrasia de Cristo, fundadoras, fuesen prioras, una después de otra, por sus turnos, mientras no hubiese suficiencia entre las demás religiosas.

9a Que cuando se haya de imponer algún censo a favor del convento, redimirle o tomarle por necesidad, sea con parecer y consulta de la fundadora, priora y madres de consejo, impetrando licencia del Arzobispo, sin que el mayordomo ni priora puedan por sí hacerlo.

10. Que, en cuanto a lo temporal, no puedan la priora y monjas disponer nada sin voto y parecer de la fundadora por la inteligencia y manejo de las haciendas, y después de su vida haya de tener voto sólo consultivo el patrón que fuere por el celo y aumento de la fundación.

11. Que haya de haber tres capellanes a nombramiento del fundador y patrones.

12. Que para capellanes prefieran los hijos y descendientes más propicios de don Diego y don Gregorio Osorio, sus sobrinos, y los mismos, siendo clérigos. 
13. Que las religiosas tengan obligación de oficiar la misa y responso que el Capellán celebrare por la fundadora los lunes de cada semana, con doble de campanas al responso, y los miércoles y sábados del año digan las religiosas salve cantada delante del Santísimo Sacramento a devoción de la fundadora, y oficien todas las misas de su disposición.

14. Que no entren niñas a criarse entre las monjas particulares; y si por algún caso entrare alguna, sea con maestra nombrada por la priora y madres de consejo. Y lo reforzó por las segundas con prohibición de entrar seglar en depósito ni en otra ninguna manera, sino para religiosa, lo cual amplió el Arzobispo que pueda entrar persona de prendas tan relevantes que a voto de las tres partes del monasterio padecería detrimento de no la recibir.

15. Que las monjas no tengan más de una criada, y si fuere esclava, sea haciendo donación al convento para después de sus días.

Recordemos aquí, la costumbre - y esto fue una práctica permisiva muy habitual que se puede observar en la historia de los monasterios españoles -, de algunas mujeres de noble cuna, que ingresaron a la vida monacal, llevando consigo a otras mujeres de bajo rango, para su servicio; en la anterior cláusula, de las Constituciones de este Monasterio Santafereño, se entiende que al morir la religiosa, su criada debía continuar en el convento y en calidad de lega, por su condición servil.

17. Que el monasterio y religiosas estén sujetas a los Arzobispos de la ciudad de Santafé para que, como prelados, ejerzan jurisdicción en las cosas y casos que por derecho les pertenecen." 216

\section{RELIGIOSAS PERTENECIENTES AL MONASTERIO DE SANTA INÉS}

1. J erónima de San Antonio, hija legítima de don Francisco Osorio Nieto de Paz y de doña Margarita de Colmenares.

2. Bárbara de la Trinidad, hija legítima del Regidor J uan Bautista Cortés y de doña Beatriz de Olalla Vasconcelos; Vicaria.

3. J uana de la Concepción, hija legítima de don Pedro Arias Maldonado.

216 Ibídem. 
4. María de San Miguel, hija legítima de Hernando de Herrera Calderón y de doña Micaela de Acosta.

5. Felipa de J esús María, nacida en Chiquinquirá.

6. María de San J osé, hija legítima de Juan de Poveda y de Micaela de la Plaza; había sido casada con J ulián Chacón, con hijos, y en mayor edad vino a la religión desde la ciudad de Cartagena.

7. La Madre Beatriz de San Vicente entró el año de 1648 con otras tres hermanas, Mariana, la mayor, y menores Teresa y Brígida, criollas de Cartagena, hijas legítimas del Alférez Arez Núñez de Villadun Anides y de Mariana de la Bandera y Presno, de quienes así mismo es hijo el maestro fray Francisco Núñez, dominicano. La doña Brígida murió niña, sin entrar en noviciado, y en él la Mariana, con sobrenombre de Santo Domingo, y la otra se pondrá en su lugar.

8. Clara de San Bruno, hija legítima de Pedro Fernández Valenzuela, médico, y de doña J uana Vásquez de Solís.

9. Catalina de J esús, hija legítima de Francisco de Santillana y de doña María de Céspedes.

10. Madre Isabel de San Esteban, hija legítima de Juan García Pedroso y de María de la Oliva.

11. Ana María de San J osé, hija legítima de Sebastián Trujillo y de María de la Oliva.

12. Elvira de la Trinidad, hija legítima del Capitán don Gonzalo de León Venero y de doña Ana de Guzmán.

13. Teresa deJ esús, ya nombrada, con sus tres hermanas.

Catalina de la Encarnación, hija de los referidos Capitán don Gonzalo .de León Venero y doña Ana de Guzmán, su mujer.

15. J osefa de Cristo, hija legítima de Juan de Obregón y de Antonia Romero. 
16. Inés del Niño J esús, hija legítima de Miguel Gutiérrez.

17. Anastasia de San J osé, hija del primer matrimonio de Francisca de la Barrera, mujer de Pedro González Piedrahita.

18. Antonina de la Cruz, hija legítima de Isidro López Madero y de Juana Vásquez.

19. J erónima de San Miguel, hija legítima de J erónimo de Cifuentes y de María Vásquez.

20. Francisca de San J osé, hija legítima de J uan Fernández de Posadas y de María de Pedraza.

21. Antonia de Santo Domingo, hija da Juan de Obregón y de Antonia Romero, su mujer.

22. Marina de J esús, hija legítima de J uan García de Ordaz de Figueroa y de doña Agustina Antolinez de Burgos, hija de Agustín de Burgos Antolinez, vecino de la ciudad de Los Remedios.

23. María de San Lorenzo, hija legítima de don Luis de Berrío Mendoza y de doña María de Berrío.

24. Inés de Cristo, hija del patrón don Diego Osorio Nieto de Paz y de doña Catalina de Salazar Falcón, su mujer, con preeminencia de fundadora por la Constitución sexta y despacho del Arzobispo de 19 de septiembre de 1665.

25. J erónima de San J uan, hija legítima de Diego de Salas Soto, Regidor de Muzo, y de doña J erónima de Meneses.

26. María de San Carlos, hija legítima de Pedro Fernández de Ribera y de doña Inés de Santibáñez, vecinos de la ciudad de La Palma.

27. María de Cristo, hija legítima de Domingo Alvarez de la Bandera y de su primera mujer.

28. J uana de J esús, de los mismos padres. 
29. Elvira de San J uan, hermana de las anteriores.

30. Leonor de San Francisco, hija del Maese de Campo don J acinto Ramírez Florián y de doña María J uana Cortés, su segunda mujer.

31. Manuela de J esús, hija legítima del Oidor don Diego López de la Puerta y de doña Isabel de Padilla y Mendoza, que profesó en 26 de abril de 1670.

32. María Manuela de San J uan, hija legítima de don Diego Ochoa Abechuco y de J uana de Párraga.

33. Gabriela de Jesús, hija legítima de Pedro Fernández y de Lorenzana de Miranda.

34. Isabel de San Pedro, hija de Pedro González Barroso y de Florentina de Medina, su mujer, vecinos de la villa de Honda.

35. Lucía de San Vicente, hija legítima del Oidor don Diego López de la Puerta.

36. Catalina de San Antonio, hija legítima de don Antonio de Chaguren y Murga y de doña María Romero Ochoa.

37. J uana de Santa Rosa, natural de la ciudad de La Palma.

38. Elena de Santo Domingo, hija de Domingo Alvarez de la Bandera y de su primera mujer.

La primera madre prelada del Monasterio fue Dña. Beatriz de la Concepción, la que nació en Santafé el año de 1577; La familia Chaves, fundadora y benefactora de esta Obra Pía, estaba conformada por Dn. Francisco de Chaves, que murió temprano y el Gobernador J uan Clemente Chaves nacido en el 1582; y en el 1584 nace doña Antonia de Chaves, todos estos hermanos, hijos legítimos del Capitán Juan de Chaves y de doña Eufrasia de Santiago, cuya noble ascendencia es reconocida en su árbol genealógico. Murió doña Antonia de Chaves en 18 de octubre de 1660 y por enero del propio año había muerto la Priora Beatriz de la Concepción; y el 27 del mismo mes fue nombrada en su lugar por Priora, con la 
anuencia del Deán y Cabildo, la madre Francisca Eufrasia de Cristo, que había sido Vicaria y por sub priora a Jerónima de San Antonio y portera J erónima de San Miguel.

Alrededor del 1660, se originó un escandaloso pleito contra el monasterio y sus rentas, pleito que fue sentenciado a favor de los demandantes. Cuando las monjas iban a abandonar el convento, intervino a su favor el Arzobispo fray Juan de Arginao, quien pagó a los acreedores las sumas debidas. Este Arzobispo reedificó el templo y el convento, pues ambos edificios se habían mandado demoler por sentencia de la Real Audiencia. "Tuvo el gusto, dice un cronista, de ver acabada la iglesia, de bendecirla.217 El Arzobispo protector Arguinao, fallece en Santa Fe de Bogotá el 5 de octubre de 1678 de edad de noventa años y medio. Su entierro se celebró con gran pompa en la iglesia del convento de Santa Inés, que él había construido, y su cadáver según nos lo describe las crónicas de Bogotá, se le sepulto debajo del altar mayor. El señor de Arguinao gobernó la Arquidiócesis del Nuevo Reino de Granada, durante diez y siete años. El hecho de haber edificado el monasterio y templo de Santa Inés, donde se conserva su retrato, le granjeó el cariño y simpatías entre sus feligreses de Santafé. Otro retrato suyo que se conserva en la galería de Prelados de la Catedral, de los mejores desde el punto de vista artístico, tiene esta leyenda:

El Illmo y R.mo S.r Mr. ${ }^{\circ}$ D. Fr. Juan de Arguinao, Cathedrático de la Rl Universidad de los Reyes, Obispo de S.ta Cruz de la Sierra y desimo Arzobispo de este Reyno. Entró en esta ciu.d de S.ta Fee a 17 de junio año de 1661 C. S. Falleció a 5 de octubre de 1,67. Leer a Pedro M. Ibañez en Crónicas de Bogotá. Pedro M. Ibáñez. Capítulo IV.

La filosofía, la intencionalidad y los procedimientos para llevar a cabo una fundación conventual, eran similares tanto en España, como en el Nuevo mundo; por lo general, las personas acaudaladas y de noble cuna, fueron las gestoras y promotoras de tantas fundaciones femeninas que acogieron en sus espacios a mujeres de diversas condiciones sociales.

217 CALVO DE LA RIVA, Pedro. Vida dela venerable Sor María de Santa Inés. p. 36 y sig. GROOT. lib. cit., vol. I, pp. 336 y 356. 
Habiendo dado un mirada a estos relatos sobre los procesos de fundación de los Monasterios femeninos, de Santa Clara y de Santa Inés de Santa Fe de Bogotá en Colombia, podemos afirmar en general, que cada fundación conventual conserva el sello personal de sus fundadores, conserva el espíritu de sus santos patronos y todos con un objetivo claro sobre la concepción de la vida espiritual y contemplativa, la oración, el culto divino y el trabajo, este ya fuese a puertas cerradas o en su labor evangelizadora y formativa con la juventud y/ o la niñez.

En los Monasterios femeninos, de todo el mundo, la economía, la espiritualidad, la sociedad y el poder político, caminaron de la mano en torno la figura de la mujer, la cual fue tenida por la iglesia en un segundo plano, pero considerada sustentadora de la columna del mundo; en ellos, tuvo una forma de vida y un espacio de desarrollo personal.

\section{3. DESCRIPCIÓN DE LA VIDA CONVENTUAL EN SANTA FE DE BOGOTÁ EN ÉPOCA VIRREINAL}

\section{CONVENTO DE SANTA CLARA}

Santa fe de Bogotá - Colombia

Respecto a nacimiento del Monasterio de Santa Clara de Santa Fe de Bogotá en Colombia, ya conocimos el proceso de su fundación; ahora desarrollemos algunos aspectos relevantes de la vida monacal que en él, se desarrollaron en épocas coloniales. Primeramente, es preciso tener presente los dos componentes que rigieron el orden social, religioso y político en la vida de la Nueva Granda del siglo XVII al XIX; la religión y el idioma, son dos importantes estructuras de larga permanencia en América, que se ha transformado paulatinamente. Los aspectos étnicos, lo pluricultural, las herencias sociales, de pensamiento y de riqueza artística, permitieron el nacimiento de una nueva cultura que ha identificado por mucho tiempo a los pueblos americanos. Aquel convivir de personas de distinto tipo social y aquellas relaciones creadas o nacidas de fuerza, establecieron obligadamente las clases sociales. Durante todo el siglo XVII y el XVIII, se 
formaron los gremios de mineros, artesanos, terratenientes, burócratas y se marcó la diferencia entre el hombre de campo y el de ciudad.

Analizando el proceso de la vida conventual del Monasterio de Santa Clara, se puede ver que este se fundó con los criterios de una "Obra Pía", como lo dice la escritura de su fundación, sin embargo, hagamos referencia a los tipos de mujeres que en él ingresaron, como fueron: Las descendientes de encomenderos, las hijas de aquellos personajes que ostentaban algún cargo público de relevancia, como los presidentes de la Real Audiencia, oidores, gobernadores, regidores, capitanes y las viudas ricas; de igual manera, tomaron los hábitos, las criadas que acompañaban a las monjas de velo negro, las niñas de las familias de las religiosas, las doncellas pobres de velo blanco, y las indeseadas mujeres separadas, cuyo lugar en las nacientes ciudades, atentaba contra el orden social que se estaba conformando.218.

Como se puede apreciar no solo las nobles y adineradas llegaron al Claustro. Hubo mujeres de escasos recursos, las indeseadas, como lo concibió el Arzobispo Arias de Ugarte Forero, en la visión y misión de su fundación. Las pertenecientes a las familias más acaudaladas del Reino, - como lo concibió su fundador: doce doncellas de las mejores familias y doce doncellas de humilde cuna -, las que aportaron los recursos para dar sostenimiento, fueron las llamadas monjas de velo negro y fueron las que en primer lugar, llegaron a ejercer los cargos más importantes dentro del Monasterio, como abadesas, vicarias y maestras de novicias y en segundo término, tenían total poder para decidir y poseían el derecho a votar en las elecciones conventuales y ocupar los oficios de mando mencionados.

La música fue altamente valorada, por cuanto la práctica de la liturgia requería de la misma y análogamente con lo que se estilaba en lo conventos españoles, la monja música María Bonifacia, 1686, pagó dote, pero en este caso, tan solo la mitad de su capital, por sus habilidades y talento musical como corista. Como ya hemos visto en capítulos anteriores, en los conventos femeninos de España a 
diferencia de los erigidos en el Nuevo Mundo, la monja música no pagaba dote y es muy posible pensar que en aquellas épocas, en tierras americanas cuando escaseaba el dinero, no se permitían la posibilidad de entrar sin dote alguna.

Fuertes diferencias sociales se reafirmaron al interior del Convento de Santa Clara, por cuanto la vida social santafereña, así estaba organizada; la diferencia de clases sociales fue impuesta por el colonizador, dueño de grandes extensiones de tierra, de minas y de ganado, por ende, con gran poder económico, quien ejerció supremacía y dominación sobre la población indígena, incluso sobre los llamados chapetones - vale decir, hijos de españoles nacidos en el territorio americano y de escasos recursos económicos-. La vida conventual de las Clarisas fue ajustada de acuerdo con la Regla que para ellas escribió el Arzobispo fundador Arias de Ugarte. Existía un rango de cargos cuyas condiciones principalmente fueron de orden moral, las cuales normaban desde el ejercicio cotidiano de la Abadesa hasta el de la hortelana más humilde. El Convento transcribía de esta manera, dentro de la clausura, las divisiones sociales del mundo colonial, ya que los altos cargos, solo podían ser desempeñados por las religiosas de velo negro, las monjas consideradas de "limpia sangre", mientras los cargos menores eran desempeñados por las religiosas de velo blanco provenientes de familias de blancos pobres.

Estando marcadas las clases sociales, tanto en América como en Europa, este Monasterio, no fue la excepción; Las dotes de las monjas pertenecientes a los estratos sociales altos, como: las sobrinas del fundador, las hijas, o parientas de los encomenderos, de los funcionarios reales o de personajes de la nobleza, aparte de sellar el compromiso de la unión mística de la pretendienta, sellaba las redes de las alianzas de poderes entre los diferentes miembros de la élite santafereña. Para la institución, las fortunas que aportaban, constituían la base de su cuestión financiera. Los créditos fueron una solución para las familias de pocos recursos económicos o que se vieran afectadas por las crisis, y que deseaban ingresar a sus hijas en el Monasterio.

Árias de Ugarte Forero - su fundador -, nació en Santa Fe de Bogotá, se educó en España en la Universidad de Salamanca (1578 - 1582) y en la Universidad de 
Lérida. Desempeñó altos cargos en la administración real y más adelante, en el gobierno eclesiástico. A sus 57 años, vio cumplido su sueño de estar al frente de la Arquidiócesis de Santa Fe de Bogotá.

Detrás de tan relevante dato en torno a la historia del fundador del Convento de Santa Clara y con gran expectativa inicié la búsqueda de los documentos en la Biblioteca antigua, teniendo en cuenta las fechas pertinentes, evidencias que podían ilustrar su paso por esta, nuestra Universidad. Labor minuciosa, pero el deseo de encontrar los documentos originales de su matrícula como estudiante para Bachiller, me mantuvieron ilusionada en el tema y firme en mi escudriñamiento. Encontrando - después de varios días de leer detalladamente Libro a libro y folio a folio -, en el Libro de matrículas del año 1577, en su página 85, lo siguiente:

“Fernando Árias Forero nacido en la ciudad de Santa Fe del Nuevo Reino de Granada en Indias a 6 de septiembre de 1578"219

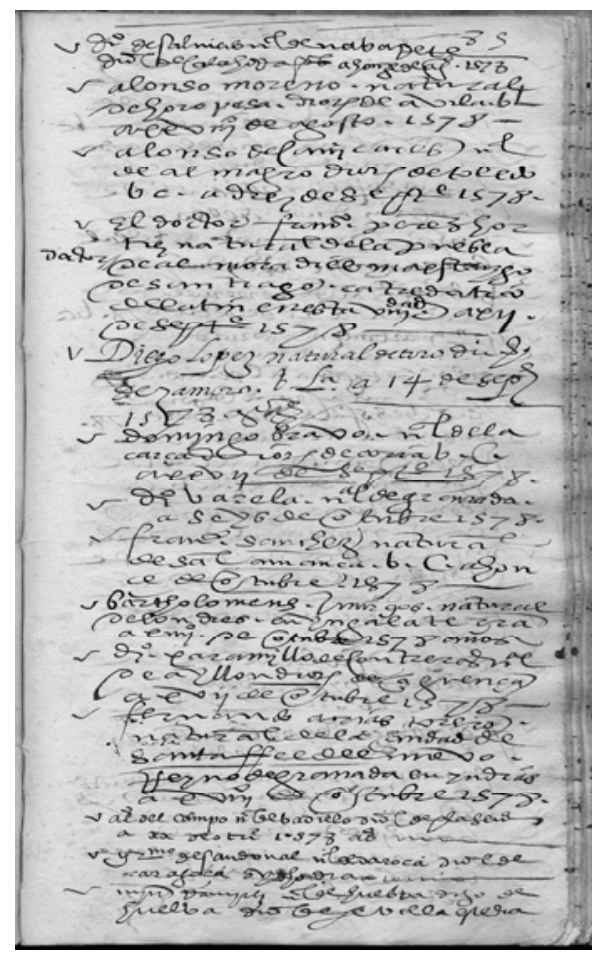

32. Matrícula de Don Fernando Arias Forero como estudiante De la Universidad de Salamanca. Tomado del Libro de matrículas ABAUSAL. . Año 1577.

219 Tomado del Libro de matrículas. ABAUSAL. Año 1577, p. 85. 
“El amor a la virtud de la castidad le inspiró el pensamiento de fundar un convento de vírgenes, como lo verificó, fundando en Santa Fe el de las monjas de Santa Clara para lo cual compro las casas en que se levantó el edificio con su iglesia, y después de promovido a Charlas continuó enviando fondos hasta concluirlo bajo la inspección de su hermano don Diego Arias Torero. Conseguida la licencia del rey en 8 de marzo de 1619, y la bula pontificia en diciembre de 1628, se hizo la fundación en 7 de enero siguiente llevando en procesión desde el convento del Carmen a las fundadoras, que lo fueron Damiana de San Francisco, J uana de J esús e Isabel de la Trinidad sobrina del fundador, el cual impuso además una renta para dotes de veinticuatro doncellas doce de las que fueran de su sangre y otras doce de pobres virtuosas, descendientes de conquistadores, y que en continua sucesión se nombrasen por los fundadores.”220

Desde otro punto de vista, examinemos la vida conventual de este Monasterio tan importante - en su momento -, en Santa Fe de Bogotá, capital del Nuevo Reino de Granada, territorio de la actual República de Colombia. Lo económico, lo social y lo musical, son los tres pilares en su momento.

\section{- LA ECONOMÍA}

Como sabemos, el Monasterio fue fundado en el año 1628 y desde entonces inició sus actividades "crediticias", dentro de la llamada economía espiritual. Apoyado en la religión y por supuesto por la Iglesia, el convento se nutrió de las dotes, como cualquier institución monacal europea del momento, pero a la par, se constituyó en una entidad crediticia, que a mediados del siglo XVII y durante el XVIII, hacía circular activamente sus capitales y prestaba dinero a las familias de las aspirantes que deseaban entrar y no tenían la dote necesaria para el ingreso. Los movimientos de esta economía se iniciaban desde el momento de la profesión de la novicia, con el pago de una enorme suma de dote, sellando así, un compromiso místico y al mismo tiempo que abría un camino de salvación económica para las familias, mediante el acceso al crédito. Los dineros se utilizaban de la siguiente

220 Crónicas de Bogotá Pedro M. Ibañez. Biblioteca Luis Ángel Arango. Banco de la República de Colombia. 
manera: una parte al sostenimiento de las religiosas y otra parte se prestaba a censo. Los movimientos de los dineros fueron llevado meticulosamente en cuentas anuales de "cargo y data" por las diferentes administraciones del convento: Abadesas o Mayordomos síndicos. Los aspectos económicos se fundamentaros sobre tres ejes:

- La estructura de los ingresos

- La estructura de los egresos

- Los bienes materiales

Los documentos que dan cuenta de los ingresos, permiten conocer los grupos sociales con los que interactuó el Monasterio y el contorno geográfico sobre el que intervino. Tiempos de crisis llegaron durante parte de los siglos XVII y XVIII improductividad en la economía colonial, descenso de la explotación de la minería del oro, - y esto obligó a los dueños, a buscar puestos burocráticos y la opulencia económica de las personas se vio reducida, lo cual trajo consigo la escasez de buenos partidos para firmar alianzas matrimoniales y a su vez, falta de dinero impedía pagar una buena dote matrimonial. Con lo cual, el único recurso para asegurar el futuro de una hija, fue pensar en el ingreso al convento, cuya suma de dote de todas maneras era menor, que para contraer una alianza matrimonial. ¿Qué era una alianza matrimonial? Era una contribución que hacia la familia de la prometida a fin de ayudar a afrontar los gastos en que se incurriera durante el matrimonio. También una especie de garantía financiera que tenía el fin de resguardar el bienestar de la mujer en caso enviudase.

Variadas formas de dotes existieron: dote estimada, la cual debía ser devuelta por el marido o sus herederos, la dote inestimada, la cual retornaba al poder de la mujer, en caso de muerte del cónyuge o divorcio. También existió la dote necesaria que debía entregarse por parte del padre, abuelo o bisabuelo y la voluntaria, que entregaba la madre u otro pariente.

Otro bien que le pertenecía a la mujer fueron, las arras, regalo que el novio le hacía con motivo de la boda; este bien, no debía exceder la décima parte de su fortuna, lo cual equivalía, en la mayor parte de familias de la elite a bienes entre 
6000 y 10000 patacones, un tipo de moneda de plata que pesa una onza y que se usó en éstas épocas. Todos los bienes de la mujer figuraban por lo general en algún documento notarial, donde se detallaban los recibos o cartas dotales firmados por los padres ante testigos. El esposo recibía el derecho de administrarlos de forma eficaz. Las dotes santafereñas comprendieron, alhajas y mobiliarios como ropas, bienes inmuebles, como casas o quintas como también esclavos.

El tema de la dote, llama la atención de manera especial, y la entendamos como lo máximo que los padres debían entregar por sus hijas, ya que la propia hija no valía lo suficiente y este era el medio por el cual los padres aseguraban económicamente a sus hijas.

Las religiosas de velo negro, pagaban 2000 patacones y las de velo blanco, entre 300 y 1000 patacones.

Las distintas entidades eclesiásticas (la Iglesia, los Conventos, los Seminarios, etc.) recibían de los feligreses, dinero, tierras, propiedades urbanas, animales. Con todo esto se sostenía: el culto divino, las monjas, los clérigos. Con estos bienes se pagaban las dotes, obras pías, capellanías, cuotas de cofradías y de hermandades, de tal manera que los bienes eclesiásticos se acrecentaban considerablemente, mientras las herencias familiares se dividían y se esfumaban.

\section{- $\quad$ LAS DOTES}

En torno a las Dotes, se conoce que estas eran pagadas por los padres de las profesas. Las monjas que iniciaron la fundación del convento, se beneficiaron con la obra pía del Arzobispo de Ugarte, de igual manera las doncellas que ocuparon sus lugares a la muerte de estas. Merece en este momento hacer una comparación con la "dote perpetua" encontrada en el Monasterio de Santa María de las Dueñas de Alba de Tormes (Salamanca), fundada por Doña María de los Dolores Fernández Cantero, oriunda de Salamanca, quien deseaba que varias doncellas de escasos recursos económicos, se beneficiaran de dicha dote e ingresaran al Monasterio siempre relevando después de su fallecimiento a quien la tuviera y con la condición de tomar su nombre y adorar al Santísimo Sacramento. Las dotes en Santa clara admitían ser pagadas de diferentes maneras: limosnas, Obras pías, un bien censado, una capellanía, una herencia, o simplemente dinero contante y 
sonante, todo era posible. Por ejemplo como cosas curiosas: una monja lega de velo blanco, fue pagada con un órgano para el convento. Otra monja de velo negro, fue pagada por su padre dejando en depósito dos "esclavos negros" para el servicio del Convento. Aquí, podemos ver cómo en este convento todo era posible; las condiciones de ingreso, eran manipuladas desde un punto de vista comercial y trasformadas para facilitar el ingreso de las aspirantes, beneficiándose por supuesto de aquellos elementos ya fuesen materiales o humanos - apartándose naturalmente de la concepción primera con que fue fundado el convento; Ahora, veamos cómo era valorada la aportación hecha por una monja de velo blando frente con lo que contribuía una de velo negro. Un instrumento musical, que es de carácter temporal, era aceptado para el ingreso de una hermana lega, quien a lo largo de su vida desempeñaba los oficios más humildes, mientras que el aportar a dos personas para el servicio del convento, era una contribución importante que solo las que tenían una desahogada posición económica podían darse ese lujo; por lo citado anteriormente y que como vimos, se daba de igual manera en el Monasterio de Santa Inés, dicho "esclavo", "sirviente" o como se los quiera designar, eran individuos que quedaban de por vida para el servicio conventual. En 1644, se autoriza disponer de una cuantiosa suma de dotes, (4000 patacones) para la construcción de una iglesia Barroca, como una necesidad imperiosa para compartir la devoción.

A diferencia de lo que es usual encontrar en los Monasterios españoles de la época, las doncellas que eran instruidas o talentosas en la Música, en Santa Fe de Bogotá, si debían pagar por lo menos la mitad de la dote, para ingresar al Monasterio.

Con el fin de dar organización a una estructura económica, se observaron los distintos documentos del Convento y se clasificaron en tres grandes apartados o ejes, como son: ingresos, egresos y la composición de los bienes. Los libros de cuentas muestran una enorme actividad económica, basada en las redes de crédito y la movilidad de bienes rurales y urbanos que se movían a través de tales redes, indicando la habilidad financiera de esta institución.

Las distintas instituciones eclesiásticas recibieron de los devotos, bienes, dinero, propiedades urbanas, tierras y ganado, reservados al sostenimiento del culto, de 
los clérigos y de las monjas. Con estos bienes, se pagaban dotes, capellanías, cuotas de cofradías y hermandades. Los ingresos provenientes de los réditos o intereses por el dinero otorgado a censo, los cuales crecieron ostensiblemente en el siglo XVIII; de tal manera que, hablando en términos generales, los conventos masculinos o femeninos y la Iglesia, eran dueños de cerca de la mitad de la sabana de Bogotá.

Las dotes de las monjas de velo blanco oscilaban entre los 300 y los 600 patacones, también admitían ser pagadas con obras pías, limosnas y tenían que ver con la utilidad que la doncella pudiera prestar al convento, como tocar un instrumento musical, saber de botica u otros menesteres de provecho. Si bien estas dotes aunque de menor cuantía que las de las religiosas de velo negro, conformaban unos ingresos nada despreciables, pero lo más importante era la cuestión social que manejaba el monasterio como lugar de refugio no solo para las mujeres pertenecientes a la élite Santafereña, como para las doncellas con menor estatus económico y social. Obras pías, herencias y donaciones, capellanías censadas, limosnas, fueron las figuras materiales que el Convento Clariano, emulando a lo que se estilaba en Europa, mantenía viva la fe y la vida económica de los Monasterios.

\section{- CENSOS Y J UROS}

Las cuestiones económicas estuvieron condicionadas al rendimiento de la producción; la demanda de préstamos siempre fue permanente. Hubo varias clases de censos:

- Censo préstamo consignativo - prestar en efectivo.

- Censo gravamen pecuniario perpetuo - financiar la adquisición de bienes raíces; inmuebles gravados por censo.

- Censo gravamen pecuniario perpetuo por dote - pagar la dote con un bien.

Estos censos fueron un costumbre que de mucho tiempo atrás estaba establecida, pero fue cortada de tajo con las leyes promulgadas por el General Tomás Cipriano de Mosquera en el año 1863. 


\section{- DONACIONES Y LIMOSNAS}

Las herencias y donaciones retratan tanto las inmensas y variadas posesiones del convento, como la actividad de sus donantes. Juan de Obando fue uno de los benefactores del convento de Santa Clara quien con su diversidad de legados y relaciones con figuras de la vida económica colonial, como censos y capellanías, establece un modelo único de la complicada red financiera que se desprendía de un miembro de la élite santafereña, a partir de sus relaciones familiares, sociales y económicas. Leer a Toquica, Constanza. A falta de oro: Linaje, crédito y salvación. Bogotá. 2008. p. 140. Las limosnas se concebían desde dos puntos de vista: internamente, dentro del monasterio; me explico: Las limosnas otorgadas por el Monasterio, fueron dejadas por las religiosas al morir, para beneficio de sus compañeras de escasos recursos y durante mucho tiempo, esta práctica de repartir limosnas, se hacía los sábados entre las monjas enfermas y necesitadas y externamente, algunos benefactores con sus limosnas, beneficiaron a varias religiosas. Muchas otras doncellas se favorecieron con las dotes dejadas, en relevo a la muerte de alguna religiosa protegida por el fundador.

\section{- GASTOS POR FIESTAS RELIGIOSAS: Música y funerales.}

Las festividades relacionadas directamente con el Anuario litúrgico, como la Natividad, la Semana Santa y la Pascua, la fiesta de Santa Clara, el Corpus Christe, la conmemoración de San J osé, la Concepción y San Antonio de Padua, fueron los perfiles que enmarcaron las actividades y que fueron motivo de alegría - excepto la conmemoración de la pasión y muerte de Cristo -, para las Clarisas. Cuerdas y castañuelas, flautas y arpas fueron los elementos e instrumentos que se estilaban en este monasterio., A las monjas cantoras, se remuneraba con 40 patacones anuales. Existieron las seglares cantoras pagadas a 12 patacones al año. Mujeres que sin ser religiosas colaboraban en las festividades especiales del Convento.221 Gastos por Cuaresma, comprendían: Alimento de religiosas, fiesta de San J osé, pago a la sacristana para acicalar el monumento. Los fallecimientos tanto de religiosas como de los miembros de las Hermandades, relacionadas con el convento, generaban una serie de gastos especiales. Entre los años 1682 - 1684 se

221 AGN (Bogotá) Conventos 67 p. 259 r - 273 v; conventos 58, p. 939 r- 954v. 
gastaron 950 patacones en el entierro de siete religiosas y entre 1719 y 1720, se gastaron 550 patacones. Costaba más el funeral de una monja de velo negro que el de una monja de velo blanco o de un criado. 144 patacones costaba el entierro de una monja de velo negro, incluyendo las honras fúnebres, y el novenario de misas. Cuatro entierros de monjas de velo blanco y una de velo negro, costaron 350 patacones. El entierro de una monja de velo negro, un criado de sacristía y una criada, costó alrededor de 1656 patacones. Desglosando, se puede clasificar los gastos de funerales, por rangos, así aproximadamente: Entierro de monja de velo negro, 150 patacones, monjas de velo blanco, 50 patacones y criado o criada, 6 patacones. Como vemos, el juego de las clases sociales, estaba presente en el Convento de Santa Clara.

\section{- FUNCIÓN SOCIAL DEL CONVENTO DE SANTA CLARA}

Durante el período colonial, se generaron conflictos y negociaciones entre los componentes de esta mezcla multiétnica y pluricultural que identifica a los pueblos americanos. En todo este mestizaje, coexisten estructuras mentales, políticas, económicas, sociales, religiosas y artísticas, que descienden de ellos. El idioma y la religión son estructuras de larga duración y el rol femenino y la figura de la mujer, abnegada, sumisa y honesta tiene su origen en las corrientes del pensamiento postridentino, que la iglesia propagó como estereotipo, entre la sociedad en Europa y por ende en el Nuevo Mundo.

La vida social Neogranadina, estaba delimitada por estratos muy marcados, diferenciados por la hegemonía étnica, con cuatro grupos, así: los indígenas muiscas, los españoles y sus descendientes criollos, los africanos y los mestizos.

Para hacer una breve relación de las múltiples funciones sociales que manejó este Monasterio, en primer lugar, miremos las redes que tejió el convento con la sociedad santafereña; es preciso conocer este grupo hegemónico conformado por la élite. ¿Quienes pertenecían a éste estrato social? Obispos, y arzobispos, Tesoreros de la Real Caja, Gobernadores, Regidores. Imperaba la "limpieza de sangre” y el ingreso al Convento, al igual que a las Universidades, los Colegios Mayores y el Seminario fue discriminado por razones de linaje. 
Las monjas de velo negro pertenecían a las más altas jerarquías; de este selecto grupo, salían las abadesas, las Vicarias de Coro, las Maestras de novicias, todas hijas legítimas de las familias más acaudaladas y con ellas se inician las redes de circulación de las grandes sumas dinerarias y los créditos.

Como sabemos, también las viudas, las huérfanas, las separadas y las hijas naturales, tuvieron cabida en estos centros espirituales., máxime que este Monasterio desarrolló una enorme actividad social.

\section{LA VIUDA GERÓNIMA MALDONADO DE MENDOZA: DESTACADA MONJ A DE VELO NEGRO}

Jerónima Maldonado de Mendoza, matrona de la Casa de los Maldonado afincados en Santa Fe de Bogotá en épocas coloniales, brinda un claro ejemplo de las influencias ejercidas a través de las religiosas de velo negro. Su árbol genealógico elaborado por Juan Flores de Ocaríz (1612 - 1692) historiador de la Real Capilla de su Majestad - 1674 -, en su Libro I de las genealogías del Nuevo Reino de Granada, muestra que esta familia descendiente de Álvarez Maldonado, señor de la Casa de cal de Calderos de Salamanca, tuvo varias monjas Clarisas, numerosos censos otorgados a diversos miembros de la familia y el préstamo de dinero a censo más grande efectuado por el convento sobre propiedad alguna: 9.311 patacones asignados sobre el mayorazgo de la dehesa de Bogotá, cuyas 45.000 hectáreas , según Germán Colmenares, conforman una de las propiedades más notables de todo el Nuevo Reino.222

\section{GENEALOGÍA DE LA FAMILIA MALDONADO Pertenecientes a la Familia salmantina}

J erónima de Maldonado, viuda ingresó en el Monasterio como clarisa de velo negro y al parecer fue una monja muy influyente en los asuntos de préstamos para

222 Fuente tomada del Museo de Arte Colonial de Bogotá.

Libro I de la Genealogías del Nuevo Reino de Granada. (2 tomos), Real Capilla de su Majestad. Madrid. 1674. 
dotes de otras doncellas y demás préstamos otorgados por el convento a sus hijos, sumas equivalentes a la media fortuna de una familia acomodada en estas épocas. Las encumbradas posiciones de las religiosas de las familias Santafereñas de élite, dentro de la jerarquía conventual, facilitaban el control de la distribución crediticia, por cuanto bajo su influencia, se decidía a quién se prestaba o se auxiliaba económicamente. La clausura conventual, se constituyó en una forma de perpetuar la honra, el poder económico, el poder político y religioso. El porqué de cada uno: La honra, porque el ingreso en el Convento, era garantía de una vida conforme a la moral imperante, en lo económico, por cuanto el tener y mantener un poder adquisitivo tan escaso en estas épocas - por las crisis económicas sufridas - era señal de prosperidad, en lo político, porque solo los adinerados, accedían fácilmente a los cargos públicos y a las posiciones de más prestigio y en lo religioso, la Iglesia y con ella todos sus estamentos se consolidaban fuertes y se hacían creíbles y respetados ante el pueblo.

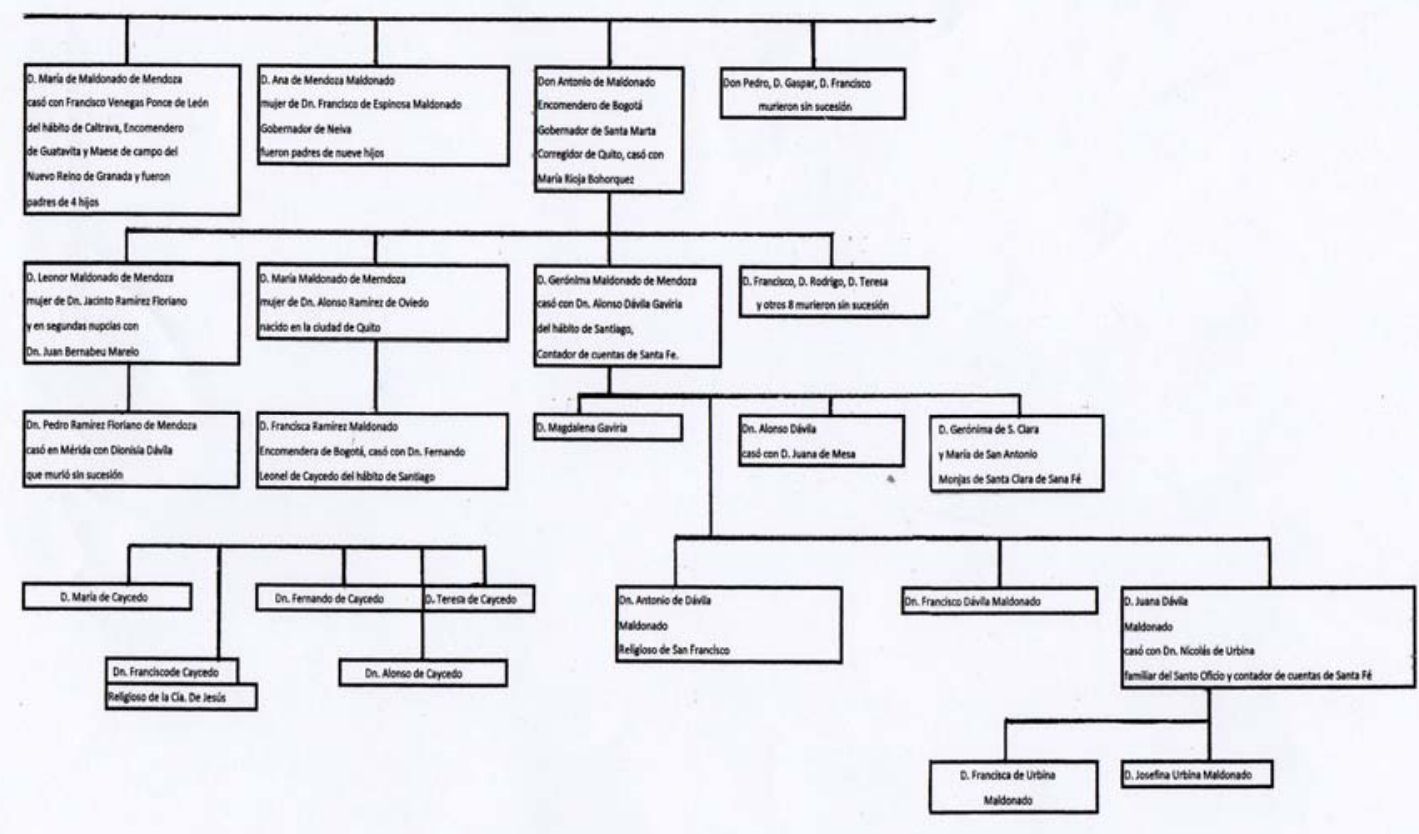

33. J uan Flores de Ocaríz. Libro primero de Genealogías del Nuevo Reino de Granada. J oseph Fernández de Buendía, impresor de la Real Capilla de su Majestad. 1674. 
Las monjas de velo blanco, pertenecientes a las familias más humildes, se ocupaban de los oficios domésticos y de atender la botica. Cantar en el Coro o tocar algún instrumento fue privilegio de las monjas de velo negro. Este último aspecto, a diferencia de lo investigado y conocido del sistema en España, es que al interior de este convento Neogranadino, aunque el saber música era muy valorado, como ocurría en los Monasterios de España, las aspirantes a tomar los hábitos como monjas de "velo blanco", sí debían pagar la mitad de la dote y no se lee en las fuentes consultadas, ninguna referencia que dé a conocer que allí, las monjas músicas recibieran pagos por su desempeño o magisterio musical. Su media dote alcanzaba la suma de 600 patacones, pero no todas podían pagar ese importe.

Mujeres de todas las condiciones sociales llegaron a este Monasterio. Niñas que desde muy temprana edad, se criaron con las fundadoras; este aspecto lo encontramos exactamente igual en el Monasterio de Santa María de las Dueñas de Alba de Tormes. Recordemos aquí a Beatriz de Ahumada, sobrina de Santa Teresa de J esús, quien ingresó al Monasterio de Santa María de las Dueñas a la edad de cinco años, en calidad de educanda. Las mujeres de élite que se convirtieron en un problema social por sus devaneos amorosos, para las cuales el convento fue tomado por cárcel, incomunicándolas por un buen tiempo, huérfanas, hijas naturales, divorciadas, etc. De esta manera se puede pensar que el Convento de Santa Clara fue una institución plurifuncional, bajo un manejo significativo de las cuestiones religiosas, económicas y sociales.

Muchas referencias existen en torno a la clase de mujeres que habitaron y convivieron en el Monasterio. Una de ellas, doña María Lugarda de Ospina, mal llamada “La Marichuela”, por haber sido amante del Virrey Don J osé Solís; los dos tomaron los hábitos después de su intrincada vida; él renunció a su cargo de Virrey y tomó, los hábitos franciscanos y ella fue encerrada contra su voluntad en el Convento de Santa Clara, solicitando al cabo del tiempo, al Virrey de La Cerda, le dejara en libertad y en castigo, fue retirada a la localidad de Usme; con los años, llegó a ser una gran matrona dueña de una excelente hacienda con muchas cabezas de ganado. 


\section{- LA FUNCIÓN POLÍTICA DE LA INVERSIÓN RELIGIOSA}

Se le puede llamar "inversión religiosa" a aquella práctica que se dio en la colonización, en que el Imperio español de entonces y la Iglesia se unieron para afianzarse mutuamente y entraron fuertemente unidas en los nuevos territorios; Dicha práctica religiosa, unida a las cuestiones del honor, a la política, a lo social y a lo económico, conformaba el panorama de las ciudades españolas desde el siglo XVII hasta las postrimerías del XIX; y Santa Fe de Bogotá, capital del Nuevo Reino de Granada por aquel entonces, no fue la excepción. Se puede deducir que en estos tiempos, tener una hija en un convento, tener un hijo sacerdote, pagar una Capellanía, pertenecer a una hermandad, administrar una imagen de Semana Santa - incluso hoy día -, conferían distinción y poder a quienes lo hacían.

La corona y la Iglesia se afianzaron para la colonización del Nuevo Mundo. La simbolización de la tradicional alianza entre la Iglesia y el poder político, económico y social era perfecto. Esta como institución extendía su influencia sobre todos los estamentos y en el pasado, logró este control, gracias a los tratados, leyes y alianzas de familia, dentro de las élites y mantener esto tenía un precio enorme.

En lo que se puede apreciar en cuanto a las relaciones Iglesia - convento, economía y política, en la colonia, este movimiento de relaciones interactúan en beneficio de todos y cada uno y lo hacen desde las esferas más altas. Ya leímos, qué clase de mujeres ingresaron y cuáles eran las condiciones de cada esfera social.

En principio se crearon 24 dotes donadas por sus fundadores, repartidas en doce para las doncellas de la familia del Arzobispo Árias de Ugarte y algunas otras, oriundas de ciudades cercanas, legítimas, de clase, sin mezcla de indios, mulatos ni negros. A la muerte de alguna de ellas, se recibiría en su lugar otra en quien concurrieran las partes y calidades referidas, prefiriendo siempre a las parientas de los fundadores. Las otras doce dotes, se instauraron para doncellas hijas de españoles de escasos recursos económicos en calidad de Legas. En este detalle se puede tener claridad de lo elitista del asunto. 


\section{- VOTOS: Obediencia, Pobreza y Castidad}

Ligados directamente a la Regla o Constituciones, la obediencia, la castidad y la pobreza, constituían los preceptos que se debía cumplir. La obediencia en primer lugar, era el instrumento que facilitaba el control sobre la comunidad femenina; era una dura prueba de voluntad y el confesor y la Abadesa, eran los pilares del cumplimiento de la observancia. El confesor, decidía sobre la vida espiritual de las monjas, reforzaba la ortodoxia si era necesario y tenía poder para denunciarla ante las autoridades. La Abadesa o la Priora, premiar a las obedientes y castigara a las díscolas. Las Visitas de los eclesiásticos se producían anualmente, sin embargo siempre que lo quisieran, las jerarquías podían vigorizar su papel y hacer cambios drásticos en el Claustro, que afectaban directamente a los miembros de la Comunidad.

“[CAPÍTULO I] [¡En el nombre del Señor! Comienza la forma de vida de las Hermanas Pobres]

La forma de vida de la Orden de las Hermanas Pobres, forma que el bienaventurado Francisco instituyó, es ésta: guardar el santo Evangelio de nuestro Señor J esucristo, viviendo en obediencia, sin propio y en castidad. Clara, indigna sierva de Cristo y plantita del muy bienaventurado padre Francisco, promete obediencia y reverencia al señor papa Inocencio y a sus sucesores canónicamente elegidos y a la Iglesia Romana. $Y$ así como al principio de su conversión, junto con sus hermanas, prometió obediencia al bienaventurado Francisco, así promete guardar inviolablemente esa misma obediencia a sus sucesores. Y las otras hermanas estén obligadas a obedecer siempre a los sucesores del bienaventurado Francisco y a la hermana Clara y a las demás abadesas canónicamente elegidas que la sucedan."223

Al igual que lo que encontramos en los Monasterios Albenses, en éste Convento de Clarisas de Santa Fe de Bogotá, los Mandatos que se imponían en las Visitas, advertían y precisaban normas de comportamiento; por ejemplo: se prohibían las diversiones profanas, se prohibían los bailes, los disfraces y vestirse de hombres y 
matachines. Mandaban que en los tornos y porterías, no se hablara sino lo necesario y evitar de esta manera la pérdida de tiempo.

Respecto a la pobreza, veamos la Regla de Santa Clara, que nos dice:

“[CAPÍTULO VI] [Que no se han de tener posesiones]

Después que el altísimo Padre celestial se dignó iluminar con su gracia mi corazón para que, siguiendo el ejemplo y la enseñanza de nuestro muy bienaventurado padre san Francisco, yo hiciera penitencia, poco después de su conversión, junto con mis hermanas le prometí voluntariamente obediencia.

Y el bienaventurado Padre, considerando que no teníamos miedo a ninguna pobreza, trabajo, tribulación, menosprecio y desprecio del siglo, antes al contrario, que los teníamos por grandes delicias, movido a piedad, escribió para nosotras una forma de vida en estos términos: «Ya que por divina inspiración os habéis hecho hijas y siervas del altísimo y sumo Rey, el Padre celestial, y os habéis desposado con el Espíritu Santo, eligiendo vivir según la perfección del santo Evangelio, quiero y prometo tener siempre, por mí mismo y por mis hermanos, un cuidado amoroso y una solicitud especial de vosotras como de ellos.» Lo que cumplió diligentemente mientras vivió, y quiso que fuera siempre cumplido por los hermanos.

Y para que jamás nos apartásemos de la santísima pobreza que habíamos abrazado, ni tampoco lo hicieran las que tenían que venir después de nosotras, poco antes de su muerte de nuevo nos escribió su última voluntad diciendo: «Yo, el hermano Francisco, pequeñuelo, quiero seguir la vida y la pobreza del altísimo Señor nuestro J esucristo y de su santísima Madre, y perseverar en ella hasta el fin; $y$ os ruego, mis señoras, y os doy el consejo de que siempre viváis en esta santísima vida y pobreza. $Y$ protegeos mucho, para que de ninguna manera os apartéis jamás de ella por la enseñanza o consejo de alguien.»"224

De Santa Clara y San Francisco de Asís, conocemos que eran hijos de familias nobles, linajudas y una de las razones que más les motivo a cambiar sus vidas, fue el profundo dolor que les causaba el sufrimiento de los pobres, mientras sus familias vivían en la opulencia y miraban con indiferencia a los desvalidos. 
Santa Clara fue una de las primeras mujeres en escribir una Regla para su Comunidad y los tres puntos que ella consideraba inevitables en la vida de sus seguidoras fueron: la fidelidad a San Francisco, la pobreza y la unión fraterna.

La forma de vida del Monasterio de Santa Clara se había alejado de su forma primitiva, al igual que muchos conventos hispanoamericanos y de Europa. El Confesor, como ya se comentó, tenía absoluta involucración en los asuntos personales de las monjas. Él podía conocer de las Clarisas, sus objetos personales, sus rentas y sus legados. Les alentaba que la pobreza se podía tener a nivel personal, mas no en comunidad, de acuerdo a la voluntad política y económica amparada por la Iglesia desde el siglo XIII con el Papa Urbano y ratificada en el siglo XVI, durante el Concilio de Trento, por medio de la cual - dejando en libertad a las que quisieran seguir la primitiva Regla de Santa Clara -, se dispensó el voto estrecho de pobreza concediéndolas tener rentas en común.

Santa Clara establece a principios del s.XIII la comunidad de San Damián y su idea sobre la pobreza es similar a la de San Francisco, vale decir, aplica la renuncia tanto a los bienes individuales de las monjas como a los bienes comunitarios del convento. Esta imposición es ratificada ya en 1216 por Inocencio III en un célebre documento, cuyo original no ha llegado hasta nosotros, y que se conoce como Privilegium Paupertatis, es decir, el privilegio de optar por la pobreza absoluta. En este curioso documento, el Papa se compromete a proteger la decisión adoptada por las Clarisas de vivir en la pobreza, de forma que nadie pueda obligarlas a recibir ningún tipo de bienes.

Numerosas personas quisieron favorecerlas con cuantiosas donaciones, a las que rechazaron, por las condiciones de su condición y pensamiento. Santa Clara insistió siempre en la necesidad de mantener la más absoluta pobreza cuando, ya próxima su muerte, redacte la regla de 1253.

Los deseos de la fundadora chocarán continuamente con las jerarquías de la Iglesia, las cuales consideran que para asegurar la clausura indefinida de una comunidad es necesario que ésta acumule un patrimonio mínimo que le permita la autosuficiencia económica. Esta convicción, y la cada vez mayor participación de los nobles y grupos acomodados urbanos en la fundación de nuevas comunidades 
de clarisas, hará que las reglas de 1247 y, sobre todo, la de Urbano IV de 1263 reconozcan de forma definitiva la propiedad comunitaria en los monasterios de la Orden de Santa Clara. Tanto es así, que se instituirá incluso la figura de un procurador externo, es decir, una persona que no habite en el convento, que controle los bienes de éste y rinda cuentas a la abadesa.

Aun conociendo la Regla y las disposiciones del Concilio de Trento, los réditos anuales que las religiosas de Santa Clara, percibían el dinero legado por sus padres, lo administraban ellas a su gusto, utilizándolos en los mejores hábitos, en adquisición de muebles curiosos, en cosas superfluas. Esta referencia citada por Toquica y tomada de "Diálogo entre un confesor y una religiosa profesa" ACSC (Bogotá) f. 12 v. nos explica el declive o la relajación de la observancia, pese a las advertencias de su confesor, quién les señala que esta forma de vida "era un engaño con ellas mismas y con Dios".225

Su fundador bien pensó en todo. Que los dineros que llegaran al Monasterio por rentas, dotes, legado, herencias, limosnas y otros, fueran recibidos por la Abadesa y se debían escribir en un libro que ha de cuidar la monja notaria del convento y deberá ser custodiado en un arca de tres llaves distintas. Una, la tendría la Abadesa, otra, la secretaria y una tercera, una de las monjas discretas, la más antigua. Al sacar dinero, se debería anotar cuidadosamente en el libro y se anotarían los dineros entregados a la provisora del convento. Para evitar los casos de estafa, el fundador dispuso que no se debiera dar "cédula" al mayordomo, ni a otro cobrador del convento. Los arriendos del hato y casas del convento, no se pueden hacer sin las diligencias de derecho necesarias.

La vida en castidad, formaba parte de la devoción y esto les hacía cerrar las puertas a todos los placeres corporales. La castidad posibilitaba la pureza espiritual necesaria para el compromiso de unión con Cristo y con su Iglesia y a su vez confería a la Iglesia un gran poder económico, por cuanto era ella la receptora, de las herencias de familias sin descendencia o si las religiosas querían legar lo

225 TOQUICA, Constanza. A falta de oro, linaje, crédito y salvación. La historia del Real Convento de Santa Clara de Santa Fe de Bogotá. Siglos XVII y XVIII. Bogotá: Universidad Nacional de Colombia, p. 295. 
propio. Cualquier flaqueza en este aspecto de la castidad, entre otros, era motivo de ayunos, penitencias y flagelaciones, que fortalecían la resistencia a las tentaciones. Este aspecto puntual, lo encontramos en varias lecturas sobre la castidad en las monjas en los Monasterios en general. Lo simbólico del desposorio con Cristo, inundaba la mente de las profesas, quienes consolidaban la idea de concentración en el cumplimiento de los deberes con Dios.

\section{- LA VIDA MUSICAL}

Como hemos anotado a lo largo de este trabajo y generalizando, la liturgia fue en una de las principales actividades para lo que las monjas tuvieron que estar bien preparadas en el ejercicio musical; con lo cual, infinidad de referencias se encuentran relacionadas en la vida personal de las religiosas y en los Libros de Crónicas de los monasterios. Las clarisas a su turno, tuvieron como maestro de música, al clérigo santafereño Don Martín Palacio Galán Figueroa Arias, rosarista y sochantre. En el convento se conserva un buen retrato con la pauta en las manos y con ésta leyenda: "Fue maestro de las monjas de Santa Clara, les enseño música y arregló el coro y sirvió de capellán. Después pasó a Tunja."226

Las actividades musicales estaban altamente valoradas, dentro del ámbito conventual. Varias referencias encontramos relacionadas con la música y más concretamente, sobre la cuantía de la dote, de las monjas músicas, puesto que en cierta forma, el saber música, no las excusaba de pagar la dote, simplemente aliviaba la carga a la mitad.

La vida musical del Monasterio se reflejaba en las celebraciones y actos litúrgicos, intensa actividad para la que no se escatimaban recursos económicos. Los repertorios musicales para las diferentes celebraciones estaban compuestos por Misas, Villancicos, Obras para el día de profesión, obras Marianas, obras a Santa Clara, obras al Santísimo Sacramento, complementando auditivamente el montaje escénico de la Iglesia Barroca.

226 PERDOMO ESCOBAR, José Ignacio. Historia de la Música en Colombia. Bogotá: Plaza y J anés, 1980, p. 47. 


\section{MONJ AS DESTACADAS}

Por los distintos períodos de la historia del convento pasaron monjas que destacaron por su personalidad y por formación musical; entre ellas podemos citar a TOMASA DE CRISTO, quien ingresó al convento con excelente formación musical y fue interprete del arpa y cantora a su vez.

MARÍA PAREDES y MARÍA GERTRUDIS, cantoras

De ANTONIA MANUELA DEL SACRAMENTO, se sabe que fue útil tocando el banjo en 1688.

De MARÍA GERTRÚDIS DE ORJ UELA, en 1728, conocimos que fue útil en la música, sin especificar su cargo. 227

Entre los cargos de importancia, estaba el de la Vicaria de Coro, responsable de que las actuaciones musicales, tuvieran la mejor interpretación posible, por ende, su oficio fue el de cuidar que las cantoras tuvieran las lecciones bien aprendidas, las calendas en sus fechas correctas y estudiaba cuidadosamente el ceremonial de Semana Santa y de todo el año, para hacerlo cumplir.

Dentro de esta mística y sus relaciones de unión con Cristo, leamos los siguientes versos de canciones, que se guardan celosamente en el Archivo conventual de Santa Clara en Bogotá:

“Villancico al Santísimo

Ay Dios del amor

Que vendado y que ciego

Con nievey con llamas

Amas

Ay amor que me flechas

Ay amor que me flechas

Ay amor que me arrojas

Que me

Ay, ay, ay

Que me arrojas flechas al alma

Flechas al alma, al alma

Hecho un blanco de tu amor

Ay Dios del amor

227 Leer a TOQUICA, Constanza. A falta de oro, linaje, crédito y salvación. La historia del Real Convento de Santa Clara de Santa Fe de Bogotá. Siglos XVII y XVIII. Bogotá: Universidad Nacional de Colombia, p. 122. 
Ay Dios del amor

Del amor...

El espíritu católico universal de la Contrarreforma, que combatía las ideas luteranas, queda reflejado en los siguientes versos en defensa de la figura de la Virgen María, con acompañamiento de arpa y tiple:

“Alarma y guerra”228.

Al arma y guerra y

Guerra y, y

Al arma , guerra y

Defended jerarquías a vuestra Reina

Defended a vuestra Reina

Viva, viva, viva

La culpa muera defended

Alarma guerra

Alarma guerra

Alarma guerra alarma

Alarma guerra guerra

A vuestra Reina

Alarma guerra

Defended jerarquías a vuestra Reina

Alarma guerra

Viva, viva la niña

La culpa muera.......229

De esta comunidad Clarisa en Colombia y aunque vivió en la colonial ciudad de Tunja, es preciso mencionar a la monja ascética Sor Francisca J osefa del Castillo y Guevara, escritora, y música quien tocaba con destreza el órgano. Las comunidades religiosas asentadas en el Nuevo Mundo, como los Dominicos,

228 Sobre la tipología de los villancicos a batalla, me remito a los interesantes artículos del profesor Carmelo Caballero con sus análisis melódico-textuales de este repertorio específico en: CABALLERO FERNÁNDEZ-RUFETE, Carmelo. "Atención a la trova. Bailes dramáticos y villancicos barrocos en la catedral de Valladolid". Calderón: Innovación y Legado: Actas selectas del IX Congreso de la Asociación Internacional de Teatro Español y Novohispánico de los Siglos de Oro. Madrid: Peter Lang, 2001, pp. 53-86.

CABALLERO FERNÁNDEZ-RUFETE, Carmelo "La trova de los humano a lo divino: las óperas de Calderón de la Barca y los villancicos de Miguel Gómez Camargo". La Ópera en España e Hispanoamérica: Una creación propia, v. I. Madrid: ICCMU-SGAE, 2001, pp. 95-116.

229 Leer a TOQUICA, Constanza, y RESTREPO, Luís Fernando. "Las canciones del Coro alto del Archivo del Convento de Santa Clara de Santa Fe de Bogotá". Cuadernos de Literatura. Pontificia Universidad J averiana de Colombia VI (2000-2001), pp. 90-117. 
Franciscanos, Agustinos calzados y recoletos y de las Órdenes femeninas, Concepcionistas, Clarisas, y especialmente las de Santa Inés, tuvieron grandes obras corales, como nos lo narra el mismo Perdomo Escobar y dice sobre los Maestros de Capilla de la Catedral: ¿Qué decir del Juan de Herrera, profeta, capellán de las Inesitas y su maestro de música?”230

"La madre Francisca Josefa del Castillo (1671-1742) ingresó a los diecinueve años de edad al Convento de Santa Clara, en Tunja. Había sido criada con gran recato y cuidado dentro del may or encierro posible, como era lo acostumbrado entonces; y en el claustro encontró un ambiente en el que, al igual que en el resto de la sociedad, reinaba el prejuicio contra la instrucción femenina, hasta tal punto, que en el capítulo general de su comunidad se le acusó de haber enseñado a una novicia a escribir. Por eso, tal vez, leyó poco y sólo escritos anteriores a Luis de Gongora (15611627). Además de sus versos, J osefa del Castillo escribió su autobiografia en prosa, titulada Mi vida, gracias a la sugerencia de su confesor; y otra obra en prosa, Afectos, en la cual consignó sus sentimientos. Por otra parte, las referencias de sus escritos son todas místicas, no se ocupan para nada del entorno; pues, como lo señaló Rocio Velez de Piedrahita en un ensayo sobre esta escritora, para Francisca, Babilonia está en la esquina de enfrente; Nueva Granada no existe y, a pesar de que la obra sobre su vida fue publicada por la Imprenta de la Compañía de J esús en 1740, que es la primera publicación que se conoce del Nuevo Reino de Granada, entre sus contemporáneos ésta fue bastante desconocida; Mi vida no fue reeditada hasta 1817 , setenta y cinco años después de la muerte de su autora, $y$ los Afectos apenas se publicaron en 1843."231

En conclusión, la vida en comunidad en este Monasterio Neogranadino, estuvo marcada por la regla que marcó en su momento, las jerarquías y las competencias conventuales, los cuales de una u otra forma reproducían al interior del Monasterio, las marcadas divisiones sociales existentes en la sociedad. Los dispositivos de seguridad para el convento, instituidos por su fundador el Arzobispo Arias de Ugarte, se convertían en un mecanismo de vigilancia de cada

230 PERDOMO ESCOBAR, J osé Ignacio. Historia de la Música en Colombia. Plaza y Janes, Editores. Colombia. 1980. p. 41.

231 LONDOÑO VEGA, Patricia. "Educación de la mujer en época colonial”. Boletín Cultural y Bibliográfico XXXI (1994), en http:// es.catholic.net/460/423/articulo.php?=7364 (consultado el 26 dejunio de 2006). 
una en particular y de sus semejantes. A semejanza de los monasterios españoles, las medidas de vigilancia o control, estaban en concordancia.

En Santa Clara, para seguir el control de la vida monacal, su fundador, ordenó que en el monasterio, solamente existiese una puerta, sin postigo, ni ventana para entrar en el claustro, y salir de él, cuando fuere necesario, y ordenó, que esto fuese conforme a la ley de la entrada y salida puesta en esta Regla, con lo cual, las posibilidades de salida fácil, eran relativamente pocas.232

La vida económica y en general la conventual, tuvo sus altibajos; Con la exclaustración y desamortización de bienes de "manos muertas", - ya comentada , impuestas en Colombia, las monjas, tuvieron que volver a vivir estrictamente, con su voto de pobreza franciscana.

\section{MONASTERIO DE SANTA INÉS \\ Santa Fe de Bogotá - Colombia VIDA CONVENTUAL}

El Monasterio de Santa Inés al igual que el de Santa Clara tuvo su protector en todos los aspectos de la vida cotidiana del Convento. El Arzobispo Juan de Arguinao gobernó la Iglesia del Nuevo Reino durante diez y siete años. Dado el ambiente religioso y musical reinante en la colonia, en el Nuevo Reino de Granada, el arzobispo Juan de Arguinao, puso a las monjas de Santa Inés, un maestro de música, para que las instruyera en canto gregoriano y salmodias y dotara a la Iglesia del Monasterio, de un órgano y libros corales, con el objeto a enaltecer las funciones del culto. Pero alrededor de la vida conventual, surgieron historias inusitadas, como la que relataré a continuación:

Allá por el año de 1789, ingresó como novicia al convento de Santa Inés de Bogotá la señorita doña María J osefa Camero, de diez y seis años de edad, huérfana de padre y madre, de relevante hermosura y bien dotada de bienes, puesto que era una de las más ricas herederas de la Sabana y según todas las apariencias, con muy poca o ninguna vocación para la vida del claustro. En la misma época servía al

232 Biblioteca Luis Ángel Arango. Crónicas de Bogotá. 
Virrey Ezpeleta, un apuesto Capitán de guardias, don Antonio de Aguirre, joven español que gozaba de mucho valimiento cerca del Virrey, y que era, entre las tímidas doncellas de Santafé, objeto de viva curiosidad y causa de perpetuas inquietudes.

Antes de entrar al convento la joven Camero, nuestros protagonistas se habían conocido en un velada y joven Aguirre había quedado prendado de la belleza de moza o tal vez, de su cuantiosa fortuna. A ésta la había impresionado agradablemente la elegancia, la galantería y el vistoso uniforme verde del Capitán que le sentaba muy bien! Pero el tutor de la joven, no miraba con buenos ojos a don Aguirre, pues creía, siguiendo las ideas de su tiempo, que lo que más convenía era asegurar la felicidad eterna de su pupila, conservándole su gran fortuna, pero sacrificando su efímera dicha terrenal. Para lograr esto había proyectado hacerla profesar, dando al convento una nueva monja y una gran fortuna, la de la señorita Camero. El tutor tuvo como auxiliar, para llevar a cabo sus piadosos planes, el apoyo del poder eclesiástico, a cuyas poderosas sugestiones no pudo resistir la joven, aun cuando presentía que al entrar al convento, contrariando sus inclinaciones, se abrían para ella las puertas de un infierno anticipado. Pero esa era la época y como joven principal, de buena familia y bien educada debía sacrificarse en aras de las preocupaciones reinantes. Ya podremos imaginarnos el invencible desagrado que la novicia demostraría por el convento y la melancolía que de ella se apoderaría desde el momento en que, pasados los umbrales del claustro, las puertas del mundo se cerraron tras ella, ocultándole, tal vez para siempre, al Capitán Aguirre. Pero para hombre enamorado, no había obstáculos invencibles, y ni así, las mismas grandes puertas de un convento del siglo XVIII, con todas sus preeminencias, eran capaces de hacerlo retroceder. Antes, quizás, las fuertes rejas de Santa Inés estimularon su capricho, y ganándose a una mandadera del convento, logró entablar con la novicia, amorosa y clandestina correspondencia. Las cartas del Capitán, con sus protestas de amor, con sus ardientes palabras y con sus esperanzas para un futuro en común, agravaron la lamentable situación de la novicia. Sólo Dios pudo saber las terribles luchas que agitaron el espíritu de aquella desdichada niña, encerrada en las frías paredes de una celda, y a todas horas asediada por las monjas, que de ninguna manera querían que se les fuera de entre las manos la gran fortuna que ella les traía. Tal 
estado no podía menos que alterar profundamente la salud de la novicia, que día por día enfermaba más y más. Conocedor de esta situación el Capitán Aguirre, puso todo su empeño con el Virrey para que éste reclamara del poder eclesiástico a la señorita Camero. Pero el Gobernador del Arzobispado no accedió a nada, y sólo después de muchas notas cruzadas con el Virrey consintió en que la novicia, dado el mal estado de su salud, saliera del convento por unos días, pero con orden terminante de que en la casa adonde se llevara no debía recibir, fuera de las del médico, otras visitas que las de su tutor y las de su padre espiritual; que debía ajustarse a la disciplina del convento, y que el hábito de novicia no debía quitárselo ni aun para dormir, como para que tuviera presente a todas horas que su destino estaba inexorablemente trazado, que su única aspiración debía ser el crucifijo y su universo una estrecha celda. Pero hasta ese retiro, y a pesar de todas las precauciones de vigilancia que se habían tomado, el Capitán, por medio de la aguadora de la casa, consiguió hacer llegar a manos de la infeliz novicia nuevas esquelas amorosas, que fortalecían su ya decaído ánimo.

Los dos años del noviciado pasaban muy de prisa, y, vuelta la novicia al convento, se acercaba ya la fecha fijada para la profesión, sin que hasta entonces hubieran dado resultado alguno las constantes reclamaciones del Virrey y de la autoridad civil. El Gobernador del Arzobispado, a la cabeza de todo el elemento religioso, quería que la heredera profesara, y, necesariamente, tenía que profesar.

Era ceremonial obligado en ese tiempo, que cuando alguna joven principal tomaba el hábito, los tres días anteriores a la profesión abandonaba el convento y era festejada por su familia y sus amigos con alegres fiestas, continuas reuniones y diversiones constantes, con el objeto de despedirla de esta vida mundana. Eso era lo que, en el lenguaje de la época, se llamaba los requerimientos - especie de duelo final que el ascetismo de la presunta monja libraba contra los halagos del mundo y sustentaciones - , y no pocas veces el resultado de tan dura prueba era el que debía ser: el cambio del rudo sayal por el alegre traje de la desposada. Aun cuando la suerte de nuestra novicia parecía de antemano fatalmente trazada, no se podía prescindir de los requerimientos, dadas su posición, su edad y su fortuna; pero como no tenía familia, era huérfana con gran fortuna, la Virreina, quizás de acuerdo con el Capitán Aguirre, se presentó en persona en el convento a por la 
señorita Camero, y los requerimientos tuvieron lugar en Palacio, celebrándose con magníficos banquetes, fiestas y toda clase de celebraciones, presididas por la misma Virreina. Allí, entre la lo más granado de la juventud de Santafé, descollaba Aguirre, luciendo, como de costumbre, su brillante uniforme verde de Capitán de Guardias españolas, más enamorado que nunca, y, cosa inexplicable, apareciendo el último día de los requerimientos alegre y satisfecho como el más feliz de los mortales.

Terminados los regocijos, la joven Camero se despidió de la Virreina y de sus amigas; por unos pocos momentos, y demostrando la más viva zozobra, habló en voz baja con Aguirre, y, abandonando los ricos vestidos que tanto la habían embellecido por tres días, volvió a vestir el modesto hábito de la novicia y fue de nuevo conducida al convento. La comunidad, formada en el claustro principal, la recibió con vivas demostraciones de regocijo, festejándola con un abundante refresco como se estilaba en la epoca. Una vez instalada en su antigua celda, debía recibir los saludos de toda la comunidad. Después de la Priora, una a una y en riguroso orden jerárquico entraron todas las monjas, todas las sirvientas y todas las mandaderas a saludarla y a felicitarla por la insigne victoria que había alcanzado sobre el mundo y sus vanidades. La batalla se había librado, y el convento, según todas las apariencias, quedaba vencedor, con monja nueva y con gran fortuna. Sin embargo, algo extraño se intuía. El siguiente día sería el de la profesión; el semblante de la novicia, era distinto y comenzó a susurrarse entre la gente de servicio del convento que la Hermana Camero no profesaría. Pasados los regozijos del primer momento, la comunidad volvió de nuevo a su monótona y ordinaria tranquilidad de siempre.

Al otro día en las horas de la tarde, estaban las monjas reunidas en el coro, entregadas a sus devociones de regla, cuando fueron interrumpidas por extraño tumulto de gentes. En la contigua calle se oía tropel de gente armada, toques de clarines y de tambores, y voces de mando y terribles golpes sonaban en las puertas del convento. Al mismo tiempo los tranquilos habitantes de Santafé, para quienes era éste un extraordinario acontecimiento, veían asombrados que la Compañía de Guardias del Virrey, mandada por el Capitán Aguirre, quien llevaba su siempre vistoso uniforme verde, rodeaba el monasterio de Santa Inés y se preparaba como 
para un formal ataque contra las indefensas monjas. A los golpes dados en la puerta principal del convento por el Capitán en persona, acudió la Hermana portera, quien oyó con estupefacción la orden del Virrey para que fuera inmediatamente entregada, de grado o por fuerza, la novicia María J osefa Camero. La portera subió volando al coro a comunicar a la Priora lo que ocurría, y ésta, después de reflexionar un momento, y viendo que toda tentativa de resistencia era inútil, ordenó que se introdujera al coro, pero por la puerta de la iglesia, al mensajero de tan extraña orden. A los pocos instantes se abrieron las puertas de la iglesia, y subiendo al coro, se presentó en medio de la consternada comunidad el Capitán Aguirre, con espada desnuda, sombrero a la cabeza, espolines y su gran uniforme verde, que impresionó profundamente a las asombradas monjas, y dirigiéndose a la Priora, en términos altaneros le comunicó la orden del Virrey. La desolada superiora, con voz severa y entrecortada por los sollozos, llamó a la Hermana Camero y, tomándola de la mano, la entregó al atrevido Capitán, repitiendo la orden de que la novicia saliera a la calle por la puerta de la iglesia, para que no se profanaran con tan grande atentado los umbrales de la sagrada casa. Las monjas, que no podían creer que esta profanación fuera obra humana, vieron en el Capitán vestido de verde al mismo demonio, y desde entonces el verde fue sinónimo de diablo, principalmente entre monjas, mandaderas y demás gentes allegadizas a los conventos de esta ciudad, sobre todo para designar un diablo inquieto, atrevido y perturbador de la santa tranquilidad de la vida monástica.

Pocos días después de lo ocurrido, don Antonio de Aguirre y doña María J osefa Camero contrajeron matrimonio, y como el escándalo dado hacía imposible su permanencia en la piadosa Santafé, partieron para Puerto Rico, adonde el Capitán había logrado ser promovido, no sin antes haberse hecho con las valiosas propiedades de su esposa, entre ellas una importante hacienda llamada "La Ramada", en la vecindad de Puentegrande. Muchos años transcurrieron sin que de ella se volviera a tener noticia en Santafé de Bogotá, y ya en el convento no se hablaba de la Hermana Camero, cuando un correo de los que de tarde en tarde traían la correspondencia de España, trajo para la Priora carta de la antigua novicia, que causó profunda impresión en la comunidad. La esposa de Aguirre relataba toda una vida de amargura y de dolor, y terminaba reconociendo su enorme falta y pidiendo humilde perdón a la superiora y a la comunidad entera. 
Instalados en Puerto Rico, Aguirre había malbaratado la fortuna de su esposa, trocándose para ella en desapiadado verdugo, sumiéndola en terrible miseria, y, arrancándole los dos hijos que habían tenido, la había arrojado del hogar, abandonándola por completo. Desde entonces, cada vez que a Santafé llegaba correspondencia de las Antillas, no faltaron las desoladas cartas de la Hermana Camero, como todavía era llamada en el convento, cartas que leía la Priora ante la comunidad, para edificación y ejemplo de monjas y mandaderas, quienes veían la mano de Dios pesando sobre la desdichada que había profanado el monasterio huyendo de él en pos de "El Verde" como despectivamente lo llamaron. Por último, dejaron de venir las acostumbradas cartas, y nada más se volvió a saber sobre la infeliz suerte de la antigua novicia."233

Como sabemos, Antonia Chaves estableció en 1645 este monasterio para las monjas de la orden dominicana siguiendo la voluntad de su hermano Juan Clemente de Chaves, quien había obtenido en 1638 la licencia para fundarlo. Las monjas permanecieron en él hasta el año de 1863, cuando fueron expulsadas como consecuencia de la expedición del decreto de extinción de las comunidades religiosas en 1861 durante la administración del general Tomás Cipriano de Mosquera.

Habiendo conocido los detalles de su Fundación y los pocos detalles sobre la vida de este Monasterio, por cuanto es sabido que el decreto de extinción de los Conventos durante el gobierno dictatorial del General Tomás Cipriano de Mosquera fue causa de su expulsión y dispersión en 1861 y de la supresión definitiva en 1863, para ser fundado de nuevo y con las mismas directrices del anterior, en la ciudad de Duitama (Boyacá) en el año 1960. Su vida musical al parecer fue muy rica, por cuanto se sabe que tuvieron durante muchos años como maestro de Música a Don J uan de Herrera; de estos tiempos del Monasterio, nos dice Perdomo Escobar:

"El profesor fue don J uan de Herrera que era al mismo tiempo capellán de las monjas. El cronista Calvo de la Riva, en su biografía de Sor María de Santa Inés, al hablar del aprendizaje de las monjas, se expresa en estos términos, que nos recuerdan el estilo guasón que campea en "El carnero".Y músico

233 Leer en Crónicas de Bogotá. Tomo II. Por Pedro M. Ibañez. 
soberano les enseña los puntos y las notas por la mano. Seis son las notas del canto llano: Ut, re, mi fa, sol, la. Y con estas comunes notas les enseñó el sabio maestro un canto nuevo y elevada música en la cítara sonora de su rueda;.." 234
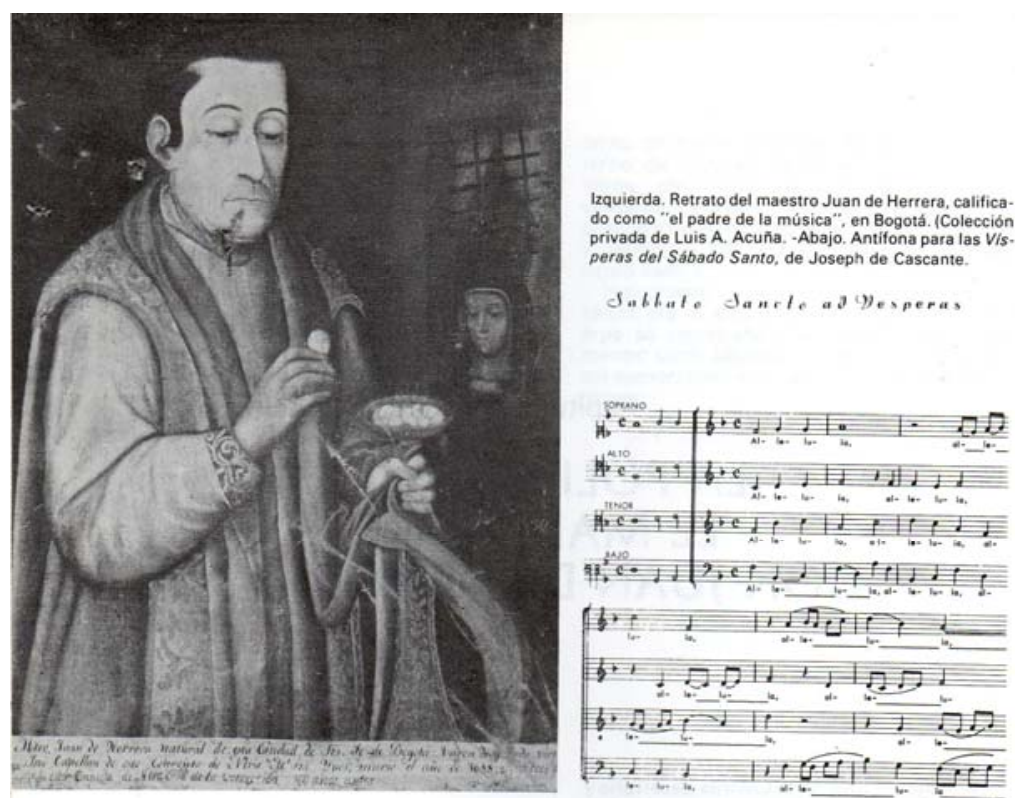

34. Retrato de Juan de Herrera, maestro de música de las monjas del Convento de Santa Inés de Santa Fe de Bogotá. Tomado de la obra "Historia de la música en Colombia” de J osé Ignacio Perdomo Escobar. p. 40.

La cita anterior es muy significativa, para hacernos una idea del quehacer musical del Monasterio y de la labor desarrollada por el Maestro de música.

\section{IV.4. ANÁliSIS COMPARATIVO DE LA VIDA MUSICAL EN LOS CONVENTOS FEMENINOS DE ALBA DE TORMES (Salamanca) $Y$ SANTA FE DE BOGOTÁ (Colombia)}

A manera de introducción, si damos una mirada a lo que fue la vida conventual en América y más concretamente en la ciudad de Santa Fe de Bogotá, entonces capital del Reino de la Nueva Granada, hoy territorio de Colombia, varias Órdenes religiosas tanto masculinas como femeninas, llegaron a América, procedentes de España, se establecieron, e iniciaron su labor evangelizadora y educativa en el

234 PERDOMO ESCOBAR, J osé Ignacio. Historia de la Música en Colombia. Plaza y Janes, Editores. Colombia. 1980. p. 47 
territorio, algunas hasta nuestros días; entre ellas, Franciscanos, Franciscanas, Clarisas, J esuitas, Dominicos y Dominicas, Agustinos Recoletos entre otros. Las Fundaciones de estas Ordenes en Santa Fe de Bogotá, se dieron al igual que en España, gracias al apoyo de personas con fortuna y poder, gentes de noble cuna, Prelados de la Iglesia, con la anuencia de la Corte de Madrid y con el consentimiento de Roma, como una continuación de la misión evangelizadora de la Iglesia en el Nuevo Mundo. Habiendo tratado el tema de las Fundaciones conventuales de los Monasterios de Santa Clara (Clarisas) y de Santa Inés (Dominicas) en el Capítulo correspondiente, si es preciso recordar algunos aspectos de la historia Fundacional y la vida conventual de estos Conventos erigidos en Santa Fe de Bogotá en los años 1629 y 1645 respectivamente -, con el objeto de hacer una comparación con los temas relacionados y desarrollados por los investigadores mencionados al inicio del capítulo presente.

El Rey Felipe III otorga licencia para la fundación de este convento y en 1628 se hizo la fundación de acuerdo con Bula del Pontífice Gregorio XV, con tres monjas, una de las cuales era hermana del Arzobispo Arias de Ugarte y las otras dos sus sobrinas, que cambiaron el hábito del Carmen por el de Santa Clara. En 1629 selleva a cabo la inauguración con una procesión que parte desde la iglesia del Carmen. Promovido el señor Arias al Arzobispado de Charcas, antes de terminarse la obra de la iglesia y del convento, queda a cargo su hermano Diego Arias Forero. Otra sobrina del Arzobispo, doña María Arias de Ugarte, empleó su hacienda en continuar la fábrica de la iglesia y adornos de ella. La iglesia fue consagrada en 1645 como oratorio para las monjas Clarisas. La particularidad del templo, concebido de acuerdo a la moda de su tiempo, es la que los muros se cubrían totalmente con adornos de madera y cuadros. Los muros exteriores son de piedra y calicanto. 235

“En el Concilio que presidió el señor Arias de Ugarte se votó por abogado contra los temblores de tierra a San Francisco de Borja, que acababa de ser beatificado. Al voto asistieron el Presidente don Juan de Borja, nieto del

235 Leer en Crónicas de Bogotá, a Ibáñez, Pedro María. Crónicas de Bogotá, Imprenta Nacional, Bogotá, 1913.T.1. y a Eduardo Posada. Narraciones. capitulos para una historia de Colombia. 2ª ed. Villegas Editores. Bogotá 1988, o en <www.lablaa.org> (consultada El 26 de junio de 2006) 
Santo, un hijo de don J uan, Tesorero de la iglesia Catedral, un Obispo, los Prelados de las religiones y los Cabildos civil y eclesiástico. Firmó el acta del voto el cronista bogotano Alonso Garzón de Tahuste.

Obtuvo el señor Arias de Ugarte permiso del Rey, el año de 1619, para fundar en esta ciudad monasterio de monjas de Santa Clara, en casas que compró con tal objeto y dotó de rentas suficientes a veinticuatro monjas, doce de ellas de su raza, y las otras descendientes de conquistadores.236.

Al igual que sucedió en España, el convento femenino colonial se convirtió en el único espacio donde las mujeres criollas de élite pudieron vivir libre del yugo doméstico, impuesto por su condición de esposas y madres en una sociedad enteramente patriarcal. El Convento fue fundado como una institución social que permitió al grupo de españoles y a sus descendientes a proteger a sus doncellas de los peligros de mezclas indeseadas. Vemos con esto, la existencia desde los inicios de la vida en común de las gentes en el Nuevo Reino de Granada ya una clara discriminación en estratos sociales muy marcados, sellada por las condiciones económicas, de razas y credo; vale decir, la limpieza de sangre y las cuestiones monetarias. El Monasterio fue una importante institución religiosa, pieza clave del funcionamiento de la Iglesia Católica postridentina en Hispanoamérica, la cual cumplió una función religiosa central, de cara a la sociedad.

Pero los aspectos sobre la forma de vida conventual, la clausura, la función religiosa y social del Monasterio de Santa Clara, se pueden analizar desde la perspectiva "económico - religiosa". En el 1628 año de fundación del Convento y desde entonces empezó a ejercer funciones crediticias. Apoyado en la religión, en las cuantiosas dotes recibidas, el Monasterio creó un mecanismo de préstamo fortaleciéndose como una entidad financiera. Los movimientos de esta economía, se iniciaban desde el día de la profesión de las novicias con la entrega de las considerables dotes con las que se sellaba el compromiso místico de la profesa y aseguraba de esta manera el camino de la salvación económica de su familia y de otras mediante el acceso al crédito. Las diferentes Instituciones Eclesiásticas recibían de los fieles, propiedades urbanas, tierras, ganado, todo destinado al sostenimiento del culto, de de los clérigos y de las monjas, Tanto así, que hasta las 
postrimerías del siglo XVIII, la iglesia y los conventos femeninos y masculinos era dueños de la mitad de las fecundas tierras de la sabana de Santa Fe de Bogotá.

Las condiciones a priori en la elección de la vida Clariana de quienes podían ingresar en este Monasterio, como monjas de velo negro eran de carácter social y estaban determinadas radicalmente por el linaje y por el ascendiente racial, por la "limpieza de sangre", antes que por lo económico, ya dicho. Las primeras dotes fueron donadas por sus fundadores, dotes que correspondieron a las hermanas y sobrinas del Arzobispo Arias de Ugarte. A las condiciones de orden social, seguían las exigencias económicas. De acuerdo a lo estipulado en la escritura fundacional y en la Bula de Clemente VIII, solo 24 monjas podían entrar al erigirse el Monasterio.

La vida comunitaria se desarrolló de acuerdo a la normativa impuesta por su fundador Arias de Ugarte; Existía una jerarquía de cargos cuyas condiciones especialmente de orden moral normaban el desempeño cotidiano de cada una de las religiosa y sus cargos, desde la Abadesa hasta la hortelana más humilde. De esta manera el Monasterio en su interior, reproducía las divisiones sociales del mundo colonial.

Cada parámetro, es motivo de análisis, por cuanto la cultura, el pensamiento, las formas de religiosidad y todas las manifestaciones ya fueran de carácter artístico musicales -, social y/o político, se trasladaron y se acomodaron a las circunstancias y a la vida colonial del momento.

Entrando en el ámbito comparativo, en primer lugar, se apreciarán los aspectos musicales desde las directrices económicas y religiosas de los Monasterios investigados, unificando en ello especialmente el aspecto litúrgico. Cada uno desde su configuración presenta semblantes relevantes. Para la Iglesia, en términos generales, la música representó un medio o cauce para llegar a Dios; de tal manera, los monasterios fueron los centros espirituales donde la música se cultivó y se desarrolló específicamente por motivos espirituales. El factor económico fue muy importante para el desarrollo de las capillas musicales y para 
el enlucimiento de la actividad litúrgica. En los Monasterios femeninos españoles de Alba de Tormes, la música fue respaldada económicamente desde dos puntos de vista: Primero, la asignación de los dineros para la compra, arreglo y mantenimiento de instrumentos musicales, para la obtención de libros de música, compra de manuales de enseñanza - métodos de Teoría musical -, y en segundo término, el establecimiento de los pagos anuales a las mujeres instruidas en la música, pagos que se hacían por lo general de forma vitalicia o se mantenían hasta que la monja - música pudiera cumplir con sus obligaciones laborales; Consultamos que cuando una monja decidía por motivos de salud u otro cualesquiera que fuera, retirarse de la actividad musical, pagaba su dote normal, para continuar su vida monacal sin cargas obligatorias musicales. No sucedía esto en Monasterio de Santa Clara de Bogotá; en él, las mujeres formadas musicalmente, pagaban la mitad de la dote, incluso, ésta en algunos casos, solo se aminoraba en un pequeño porcentaje. Se puede pensar que las condiciones económicas en el Nuevo Mundo no serían las mismas que se manejaban en la península, por ello y aunque las actividades musicales estaban altamente apreciadas al interior de los Monasterios femeninos, las monjas músicas no estaban exentas del pago total de este compromiso, a pesar de lo que pasaba en esta misma época en España.

Respecto a la formación musical de las monjas, recibida de manos de Maestros de Capilla, en los Monasterios de Santa Fe de Bogotá, se tiene amplio conocimiento, por las investigaciones realizadas por el Maestro J osé Ignacio Perdomo Escobar, y por el cronista de Bogotá Don Pedro Ibáñez, que las monjas del Monasterio de Santa Inés tuvieron por espacio de cuarenta años como Capellán y su Maestro de Música a Don J uan de Herrera, Maestro de Capilla de la Catedral de Bogotá, y las monjas de Santa Clara tuvieron como Maestro de música al clérigo santafereño Don Martín Palacio Galán. Sochantre de la Catedral. De nuestras monjas músicas en los Monasterios de Alba de Tormes, se destaca la monjas Dorotea Campo, en religión Escolástica Campo, quien tuvo como profesor de música al organista Don Antonio López de la Iglesia Parroquial de San Esteban de la ciudad de Burgos, quien da certificación de aquella capacidad que Dña. Dorotea Campo posee para el ejercicio de organista. En nuestros monasterios femeninos Albenses, se 
desconocen los datos sobre quiénes impartieron la instrucción musical a la mayoría de las monjas investigadas. Generalmente se encuentra las actas de los exámenes practicados, pero no se encuentra referencia alguna sobre quién las instruyó musicalmente.

Acerca de la actividad coral en el Monasterio de Santa Clara, la comunidad no escatimaba recursos para que las celebraciones tuvieran el esplendor que merecían las ocasiones especiales, cantos que complementaban auditivamente las representaciones escénicas de la Iglesia barroca. No encontramos en los monasterios Albenses esas representaciones teatrales. De los instrumentos musicales utilizados, en los monasterios del Nuevo Reino de Granada, especialmente en el Monasterio de las Clarisas, se tiene conocimiento que se utilizaban los que estaban en su apogeo en España: el órgano, el violín, el arpa, además, se encuentran referencias sobre la utilización del "tiple", instrumento musical muy típico de Colombia con la apariencia de guitarra pero de pocas dimensiones y de sonidos agudos.

Por primera vez, alrededor del año 1746, se encuentra mención en el territorio colombiano la palabra tiple para designar un instrumento de cuerda. Ese año, con ocasión del paseo de la jura para la coronación del rey Fernando VI de Borbón, se hicieron varios festejos en Popayán, capital del Cauca grande: desfiles, comedias, veladas, actos religiosos y un sinnúmero de actividades conmemorativas. La relación de estas celebraciones se encuentra en un expediente que reposa en el Archivo Central del Cauca, en esa ciudad, - actual Archivo histórico - , con la signatura No. 9648, Colonia, CIII, 21, distrital, según catalogación efectuada por el Dr. J osé María Arboleda Llorente. Allí se cuenta que "hubo mascaradas de indios, con instrumentos músicos proporcionados a sus estaturas de guitarras, tiples, flautas, y otros varios". 237

Algunos entendidos en la materia, relacionan el tiple colombiano con el "timple" canario, pero dicen que los inmigrantes de origen canario, que pasaron al Nuevo Mundo, fueron escasísimos y que no se puede tener la seguridad de que el 
instrumento canario hubiera arraigado en la Nueva Granada, a diferencia de la guitarra que sí entró con fuerza en el Continente americano y ha perdurado hasta nuestros días. Revisando el catálogo de informaciones de "Pasajeros a Indias" de Luís Rubio y Moreno, desde 1492 hasta 1592, entre los ancestros de las familias españolas que pasaron al continente americano en el primer siglo de colonización, se destacan los andaluces quienes fueron la gran mayoría de esa migración. Otro tanto fue de las provincias de Cáceres, Badajoz y Salamanca. Luego, en orden de importancia numérica, Valladolid, Burgos, Toledo, Córdoba, Cádiz, J aén, Vizcaya, Ávila, Segovia, Madrid, Palencia, Zamora, Santander, Ciudad Real, Guadalajara, Guipuzcoa, Soria, León, Álava, Asturias, Galicia, Navarra, Aragón, Cataluña, Valencia, Baleares, Murcia y en un pequeñísimo porcentaje, de Canaria.238 Con lo cual, aquel instrumento llamado el "tiple" tan representativo de la música en Colombia, tiene una significancia o afinidad con la voz tiple, con la voz aguda de cuatro y cinco ordenes y en la actualidad de 12 ordenes, el cual servía para acompañamiento; hoy día, el tiple tiene un rango de instrumento solista de concierto.

El órgano fue el instrumento por excelencia en la Iglesia y en los monasterios femeninos; el mantenimiento de una monja organista era primordial para el enlucimiento de la Liturgia. Este instrumento y otros de tecla, como el clavicémbalo, siguen teniendo en aquella época, una importancia transcendental dado el carácter religioso del pueblo español. Como vimos en capítulos anteriores, muchas referencias nos muestran sobre la existencia de mujeres organistas y/o por cierto, muy profesionales, al frente de la Capilla musical en los monasterios Albenses. Esta práctica del aprendizaje e interpretación del órgano, se trasladó a America y es así como se conoce en el Nuevo Reino de Granada, de la monjas ascética clarisa, escritora y música Sor Francisca J osefa del Castillo y Guevara quien desde muy temprana edad tocaba el órgano y al ingresar al convento continuaba su arte musical en el mismo.

La vida Litúrgica, las festividades y conmemoraciones, seguramente, estuvieron colmadas de repertorios musicales, tanto a capella, como con acompañamiento 
instrumental, que cada Monasterio manejó de acuerdo a sus necesidades y posibilidades. Muchos debieron ser los Repertorios que se interpretaban, pero como veremos en el siguiente capítulo, hubo factores que influenciaron en la pérdida de valiosas partituras de música, el monasterio de Santa María de las Dueñas de Alba de Tormes, escasos repertorios del siglo XIX, se encuentran en sus archivos; música que y en la actualidad no se interpreta, igual situación en el Monasterio de "La Anunciación”.

\section{IV.5. El Maestro de música de las monjas de Santa Inés - Dominicas de Santa Fe de Bogotá J UAN DE HERRERA} *Santa Fe de Bogotá c. 1665 +Santa Fe de Bogotá, 18 de marzo de 1738

Pero conozcamos en pocas palabras quien fue J uan de Herrera. En mi trabajo de investigación en años anteriores en Colombia, en torno al tema, varios datos adquiridos, pueden ilustrar la vida de este músico colonial santafereño.

J uan de Herrera fue uno de los compositores oriundos de Santa Fe de Bogotá, más talentosos y fecundos de la época colonial. Nació en Santa Fe de Bogotá alrededor de 1670,donde Herrera aparentemente vivió toda su vida y donde por treinta y cinco años tuvo el cargo musical más importante de la ciudad: Maestro de Capilla de la Catedral.

Por su testamento, se sabe que Herrera era hijo del alférez real Fernando de Herrera y Aguilar, quien financió sus estudios y ordenación con la capellanía de una calera - vale decir una mina -, localizada tras del cerro de Monserrate, que le había costado 5000 pesos y de Francisca Larrarte.

Ahora, Herrera, según los cronistas, debió tener un título universitario además de haber recibido las órdenes sacerdotales, ya que es el único maestro de capilla colonial a quien se le designa como "bachiller presbítero". Este título fue posiblemente en teología, sin embargo, hasta ahora no se tiene conocimiento de si Herrera cursó estudios sacerdotales y universitarios en el Colegio de San Bartolomé y Universidad J averiana, regentados por padres jesuitas; o en el Colegio 
Mayor de Nuestra Señora del Rosario y Universidad Tomística, regentados por padres dominicos, los dos únicos seminarios y universidades en la ciudad. Parece ser posible, que Herrera hubiese trabajado en el plantel musical de la Catedral antes de su nombramiento como maestro de capilla, bajo el mando de su antecesor J osé de Cascante, sacerdote - 1620 - 170 -, y que haya recibido alguna instrucción musical allí.

El primer trabajo musical de Herrera del cual se tiene noticia, fue el de profesor de música y capellán del Convento de Santa Inés, monjas dominicas. No se sabe la fecha exacta en que Herrera inició este trabajo, pero debió ser hacia finales de la década de 1690, ya que éste dice en su testamento fechado en 1738, que ha servido a las monjas de Santa Inés durante cuarenta años. Al parecer, Herrera le tuvo un cariño especial al Convento, ya que en su testamento expresa el deseo de que su funeral se celebre en su capilla y de que sus restos sean sepultados en el altar de Jesús Nazareno y parece ser que así se cumplió su voluntad, pero cuando dicha iglesia fue demolida el 16 de febrero de 1957, sus restos fueron trasladados al antiguo osario de la Catedral.

Se desconoce el desempeño de Herrera durante sus cuarenta años de servicio en Santa Inés, ya que se han perdido los documentos que contenían información acerca del funcionamiento del Convento durante la Colonia. Pero es conocido que tuvo alumnas aventajadas, ya que una de ellas, María Gertrudis Teresa de Santa Inés (1668-1730), era famosa en toda la ciudad por tener una bella voz y mucha gente asistía a la misa del Convento con la finalidad de oírla cantar.

De su repertorio musical, existen obras con los nombres de monjas, al igual que se dá en la producción musical de algunos compositores españoles. La inscripción "24 abríl 1733 soy de Maria Magdalena" aparece en la soprano 2 de la misa In cordis et para voces y organo y los nombres de varias monjas aparecen en las distintas partes de la obra para once voces Laetatus sum-Nisi Dominus Lauda J erusalem, entre ellos el de la ya mencionada María Gertrudis en la parte de Alto 2. Esto parece indicar que Herrera componía obras que pudieran ser interpretadas tanto en el Convento como en la Catedral. 
Herrera empezó a trabajar como maestro de capilla de la catedral en enero de 1703, tras la muerte de su antecesor, el clérigo J osé de Cascante, mencionado anteriormente. Su confirmación dice que ha demostrado "idoneidad y habilidad" como músico y que por esa razón se le contrata como maestro de capilla y compositor. Su salario se fijó en doscientos cincuenta pesos y se conservó así hasta su muerte treinta y cinco años más tarde.

El testamento del músico, está firmado el 2 de febrero de 1738. Allí aparece como un hombre caritativo con muy pocos bienes materiales. Sus posesiones consistían en muy pocos objetos, tales como un crucifijo hecho por el estatuario santafereño Salvador Lugo y una imagen de la Virgen, y varios libros sobre temas espirituales, entre ellos las obras completas de Luis de Blois y de Eusebio Nieremberg. Sus deudas ascendían a 560 pesos, una cantidad considerable para alguien que recibía 250 pesos al año. Las monjas de Santa Inés le condonaron la deuda de 200 pesos que tenía con ellas, y saldó con libros la de 360 pesos que tenía con las monjas del convento de Nuestra Señora. La heredera de sus bienes restantes fue una tal J uana de Acuña, quien lo cuidó durante su última enfermedad. El documento está firmado por un notario, ya que Herrera estaba demasiado enfermo para hacerlo él mismo.

Herrera murió a principios de marzo de 1738 y, cumpliendo con sus últimos deseos, fue enterrado en el altar de J esús Nazareno de la Capilla de Santa Inés. Como era Cuaresma, el capitulo catedralicio se vio obligado a buscarle reemplazo lo más rápidamente posible, y por esta razón se nombró al clérigo Francisco de Paula Amaya como maestro de música interino. 239

Respecto a su formación y trabajo musical, se dice que probablemente fue discípulo de J osé Cascante hijo -Maestro de Capilla de la Catedral de Bogotá hasta 1702- ya que Herrera continuó con los cánones musicales establecidos por éste y por J osé Cascante padre según se infiere de sus composiciones de música religiosa litúrgica en latín (responsorios, invitatorios, salmos, lamentaciones y misas) y de música religiosa no litúrgica en castellano (villancicos, romances y jácaras). 
Posiblemente también fue discípulo de Fray Manuel Blasco, compositor español que residió en Santa Fe de Bogotá, entre 1680 y 1682.

Desempeñándose como titular, su función estuvo orientada a la composición de música para la liturgia, la dirección e instrucción musical de los cantores del coro alto o capilla de música (quienes se encargaban de la ejecución de música polifónica) y de los instrumentistas o ministriles (que se encargaban del doblaje de las voces para dar apoyo a éstas como también de la ejecución de música exclusivamente instrumental). El canto llano estaba a cargo del coro bajo integrado únicamente por los miembros del cabildo eclesiástico y en éste el maestro de capilla no tenía injerencia alguna.

Las Crónicas de Santa Fe de Bogotá en su capítulo XVI, nos ilustra sobre una reflexión hecha por el Maestro Herrera en torno al incierto futuro de la vida a manera de testamento.

"A mediados del siglo XVII floreció el músico Juan de Herrera y Chumacero, presbítero, natural de Bogotá, maestro de capilla de la Catedral, artista distinguido y de gran talento, quien hizo composiciones clásicas en música sagrada y cuyo nombre es el primero en el orden cronológico de los compositores nacionales, Recuérdase también al maestro Herrera por una profecía, que muchos han visto cumplida en la edificación del templo gótico que se levanta en Chapinero, o en la construcción de la capilla que levantó don Ignacio Forero en aquel barrio, como veremos después, consignada en el siguiente testamento, que de su original copiamos en el archivo de la Curia, como curioso documento:

En el nombre de Dios Padre todo poderoso. Amén. En la ciudad de Santa Fé, á diez días del mes de agosto de 1668. Yo el maestro Juan de Herrera presbítero domiciliario de este Arzobispado y hijo legítimo de D. Mateo Herrera y de D.' Fran.ca Larrarte y hallandome agora no solamente en mi entero juicio si no sano del cuerpo he venido en hacer este mi testamento cerrado, no para disponer de bienes temporales pues por la bondad de Dios N.o S.r y su misericordia no los tengo; sino por hacer ver á la posteridad los males que vendran sobre este infeliz lugar y para ello imploro la protecion divina, y creyendo como creo, en todo lo que confiesa y cree N. Madre S.ta Yglesia. Tengo entendido que llegará tiempo en que rodeados y aflijidos de guerras buscaran asilos adonde refujiarse, y tan apagado el vínculo de la caridad que se arruinarán los unos con los otros malamente por el espíritu de partido. Los temblores y terremotos los atemorisarán y las tinieblas se 
esparcerán para acabar con todo. Las divisiones seran hostiles y sus conflictos insuperables; pero si en este tiempo se levantare una capilla extramuros de la ciudad dedicada al misterio de la Concepcion de María, entonces no sufrirá este lugar su total ruina pero si no se levantare se arruinará del todo y levantada que llegue a ser se formara una congregacion de Clerigos con el título de encadenados, los que solos se destinarán á dar ejercicios y conducir el evanjelio a la ciudad. Este mi testamento no será abierto hasta el año 1796 por ser esta mi voluntad y fines que me propongo como queda advertido en la carátula del sobre-escrito y depositado hasta dicho año en la Curia Metropolitana con la autenticidad del Escribano y Testigos que sean necesarios.

Maestro J uan de Herrera."240

Su testamento fue abierto en 1796 por el Arzobispo don Baltasar Jaime Martínez Compañón. Un siglo después, en 1896, se colocó en el templo gótico de Chapinero una pintura, al óleo, retrato del presbítero J uan de Herrera, que tiene al pie una inscripción, que dice:

“El maestro Juan de Herrera natural de esta ciudad de Sta. Fe de Bogotá varón de grande virtud, fue Capellán de este convento de Ntra. M Sta. Inés, murió el año de 1688. Profetizó la fundación de esta Capilla de Ntra. Sra. de la Concepción, 100 años antes”.241

Las obras de Herrera que se encuentran en el archivo de Santa Fe de Bogotá lo señalan como uno de los compositores más prolíficos de la Hispanoamérica Colonial, en la misma categoría de maestros como Manuel de Zumaya (c. 16781739), maestro de capilla de la Catedral de Ciudad de México, Esteban Salas y Castro (1725-1803), músico de la Catedral de Santiago de Cuba; J osé Angel Lamas (1775-1814), bajonista de la Catedral de Caracas; y J osé de Orejón y Aparicio (1705-1765), maestro de capilla de la Catedral de Lima.

Aunque el número de obras que se conservan de Herrera es excepcional tratándose de un músico colonial, es muy posible que su producción haya sido aún más numerosa. Como era costumbre en la Catedral, la música de este compositor

240 Ibídem.

241 De mi conocimiento, aquella inscripción aún se puede observar el la Capilla de Chapinero de la ciudad de Bogotá en Colombia. 
se guardaba en cuadernillos y hojas sueltas de papel manuscrito que se han ido perdiendo con el paso de los años. Por esta razón algunas de sus obras han desaparecido, mientras otras han quedado incompletas.

Herrera compuso su música para el uso específico de la Catedral, y por este motivo sus obras ilustran el tipo de música predilecta allí. Todas son vocales, con excepción de una para órgano con dos bajones. Sus obras en español consisten en villancicos religiosos, la mayoría en honor a Santos o devociones populares en la Santa Fe de Bogotá colonial; y las de latín consisten en seis misas, tres de ellas para difuntos y numerosas obras para los oficios divinos.

El Maestro Perdomo Escobar nos dice:

“El bachiller Herrera fue prolífico e inspirado compositor. Su música es uniformemente elevada. De los autores criollos es de quien conserva un mayor número de composiciones el Archivo de Bogotá. Se ha logrado integrar alrededor de cincuenta. En latín para la Liturgia solemne, su obra es preferentemente policoral. Debió usarse y cantarse con inusitada frecuencia, por lo gastados que se hallan los fascículos, así, como los de los maestros españoles renacentistas. Esto demuestra cómo se mantuvo a un alto nivel el cultivo de la polifonía religiosa en Santa Fe a todo lo largo del siglo XVIII.

Sus obras de mayor importancia son sus seis misas, una de Requiem, un Oficio de Difuntos, tres colecciones de Lamentaciones y siete colecciones de Salmos Vesperales.

Escribió también Villancicos y Jácaras. Para estos prefería el trío o el dúo vocal.

Del Recitativo Un bachiller soy que vengo, que trascribe el Dr. Stvenson como ejemplo 5⿳亠丷厂 en un valioso ensayo, quienes lo redactamos tuvimos la fortuna de encontrar más partes e integrar el conjunto. El Coro le exige todos los requerimientos para un examen de grado colonial y le pide que haga el examen en esdrújulos." 242

242 PERDOMO ESCOBAR, José Ignacio. El Archivo musical de la Catedral de Bogotá. Publicaciones del Instituto Caro y Cuervo XXXVII. Bogotá. 1976. p. 37. 


\section{IV.5.1. Su producción musical}

\section{Obras compuestas para el Monasterio de Santa Inés}

\section{A. VILLANCICOS}

1. De la alta providencia s/ f Soprano y A San Cayetano - acompa. De organo

2. De misterio es la fiesta soprano 1, alto, a nuestra señora del rosario acompañamiento

3. Ea, la Maldonado toca las sonajas coro 1: soprano 1, soprano 2. coro 2: soprano 1, soprano 2

4. La tierra ayuda a tu celo - Al nacimiento de nuestro señor soprano, alto 1

5. Las gitanas que los montes hacen coro 1: solo, Al nacimiento de nuestro señor

6. Casa de placer (a 6) soprano 2 coro 2: soprano 2 arpa

7. Ligeros cazadores soprano 1, soprano2, soprano 3, soprano 4, alto 1, alto2, alto 3, bajo

8. Morenas gitanas soprano 1, soprano 2 y arpa

9.Nevado jazmín soprano, alto

\section{b. Obras en latín}

1. Misa in cordis soprano 1, soprano 2, - acompa. de organo

2. Misa de difuntos

1. coro 1: soprano 1, soprano 2, alto 1. coro 2: alto 2, alto 3 coro 3: soprano 3, soprano 4

d. Maitines, oficio de difunto

1. Lauda anima mea dominum - para órgano

2. Regem cui omnia vivunt - parce mihi coro 1: soprano 1, soprano 2, alto 1 coro 2: soprano 3, soprano 4, alto acompa. 
e. Maitines, Semana Santa

1. de lamentatio jeremiae prophetae

coro 1: soprano 1, soprano 2, alto 1, alto 2 coro 2: soprano 2 - acompa.

2. Incipit jeremiae prophetae

soprano 2, soprano 3, - acompa.

3. Domine ad adjuvandum - dixit dominus domino - confitebor tibi domine beatus vir qui timet -laudate pueri dominum -laudate dominus omnes gentes magniflcat (a 7)

soprano 1, soprano 2,órgano, alto 1, alto 2,

4. Domine ad adjuvandum - dixit dominus domino - dixit dominus domino laudate pueri dominum- laetatus sum in his -nisi dominus aedifica verit donum magnificat (a 8)

coro 1: soprano 2 coro 2: soprano 2 coro 2: soprano 2

laetatus sum in his - nisi dominus aedificaverit donum -lauda

laudate pueri dominum 243

El bachiller y presbítero J uan de Herrera, fue uno de los músicos más destacados y prolíficos entre los nacidos en la Nueva Granada durante el periodo colonial. Ocupó el cargo de Maestro de Capilla de la Catedral de Santa Fe de Bogotá desde 1703 hasta su muerte y además, por cerca de cuarenta años, fue maestro de música y capellán de la Iglesia del Convento de Santa Inés. Por obligaciones de su oficio, su producción musical, se constituye uno de los legados musicales más extensos y valiosos que se conservan de los compositores criollos de la América Hispánica.

\section{Revisando su cronología:}

1665 Nació en Santa Fe de Bogotá. Fue hijo legítimo del Alférez real Don Fernando de Herrera y Aguilar y de Dña. Francisca Larrarte.

1689 De esta fecha, data su obra Laudate Dominum omnes gentes, la primera de sus obras más conocidas.

1703 Fue nombrado Maestro de Capilla de la Catedral de Santa Fe de Bogotá, tras la muerte de Don J osé Cascante (hijo) 
1711 Presentó la renuncia temporal al cargo por desavenencias con el superintendente Francisco de Ospina y Maldonado, Canónigo Magistral del Cabildo.

1738 Murió Don J uan de Herrera el 18 de marzo en Santa Fe de Bogotá.

\section{IV.5.2. Análisis de la obra musical de J uan de Herrera}

La obra de Juan de Herrera se divide en dos grupos: el litúrgico (salmos, responsorios, invitatorios, lamentaciones, misas) y el paralitúrgico (villancicos y jácaras). El primero de ellos está conformado en su mayoría por salmos compuestos para ser ejecutados no en la misa, ya que en ésta predominaba el canto llano, sino en los oficios de vísperas y completas (seis de la tarde y nueve de la noche respectivamente).

Los salmos y las misas son las piezas mejor logradas de Herrera. Son obras a seis (coro y dos solistas), a 8 (doble coro), y 12 voces (triple coro). En las que predomina la textura homofónica, no estando exenta de ciertos gestos contrapuntísticos.

Herrera se destaca por ser uno de los pocos compositores de las colonias latinoamericanas que escribió misas de difuntos, sin duda algo inusual para ser el maestro de capilla de una catedral de limitada importancia.

Christus factus est, escrita en 1713, representa un claro ejemplo de cómo Herrera hacia uso de la homofonía. Se trata de un breve gradual -canto tras la lectura de la epístola- en modo menor para coro a cuatro voces. Su escritura rítmica es sencilla y homogénea salvo por leves gestos de ornamentación melódica expresados en algunas notas de paso y bordaduras.

En lo que concierne a la música religiosa no litúrgica, Herrera escribió villancicos, jácaras y romances. Eran piezas vocales - instrumentales en lengua vernácula, las cuales tenían cabida en los oficios nocturnos, especialmente en los maitines de navidad. En la escritura de este tipo de piezas, suele predominar la textura homofónica o de melodía acompañada y la textura de bajo continuo, es decir, una o dos voces melódicas yuxtapuestas a un bajo firme, en contraposición a unas voces intermedias menos destacadas. 
Conociendo las características del género musical "la ensalada", en la que se conjugan variedad de aspectos tanto musicales como literarios, la Ensalada de navidad Los grados es el ejemplo más atractivo de los escritos por Herrera en este género. Se divide en dos partes: en la primera aparece un prolongado recitativo en el que un estudiante proclama con poca modestia sus intenciones de hacerse bachiller. A esto responde un coro a manera de jurado interpolando preguntas acerca de su origen y sus conocimientos. El coro advierte al bachiller sobre los costos del examen de grado: "pues amigo, la propina "in primis" para el examen... diez pesos para el bedel... mil pesos de chirimías... quinientos pesos de vino... trescientos de bizcochuelo, mil pesos de chocolate"

Pese a lo costoso del examen el estudiante accede al precio y el jurado le exige responder en esdrújulos todas las preguntas. En la segunda parte de la pieza aparecen tres series de coplas separadas entre si por cadencias conclusivas (perfectas auténticas) escritas con textura homofónica. Cada serie de coplas consta de doce preguntas y respuestas:

- ¿dónde es tu patria?

- En Sáchica.

- ¿Con qué nos pagas?

- Con rábanos.

- ¿Y la propina?

- De cáscaras".

En esta serie de preguntas y respuestas se hace la única referencia, por cierto muy somera, al supuesto carácter religioso de la pieza: “¿Cómo es el Niño? - Altísimo”.

Haciendo una analogía de la vida de Herrera con algún Maestro de Capilla español, he escogido a Tomás Micieces el menor nacido en Toledo, el 4 de diciembre de 1655, fallecido en Salamanca, 16 de mayo de 1718; también se le conoce como Tomás Micieces II, quien fuera Maestro de capilla de la Catedral de Salamanca. A su padre Tomás Micieces se le ha llamado El Mayor, y la afinidad de sus nombres ha dado para confusiones en algunas ocasiones. Como es de suponer, Tomás Micieces - el menor -, pasó su niñez y juventud en catedrales e iglesias, primero en la de Toledo, luego en las Descalzas de Madrid y finalmente en la de Pamplona. En 1679 residía en Madrid y desde ahí, consigue un puesto en Castellar 
(J aén). De mayo de 1684 a 1692 trabaja en El Burgo de Osma. De esta época se conservan algunos villancicos en el Pilar. De El Burgo pasará a ocupar el magisterio de la capilla de la Seó de Zaragoza entre 1692 y 1694. Este último año ganó la oposición al magisterio musical de la catedral de Salamanca, cargo en el que permaneció hasta su muerte. En 1699, tras la muerte de Diego Verdugo, obtuvo la cátedra de música de la Universidad.

En el Catálogo de Música del Archivo de la Catedral de Salamanca, se encuentran relacionadas muchas de sus obras de diferente género:

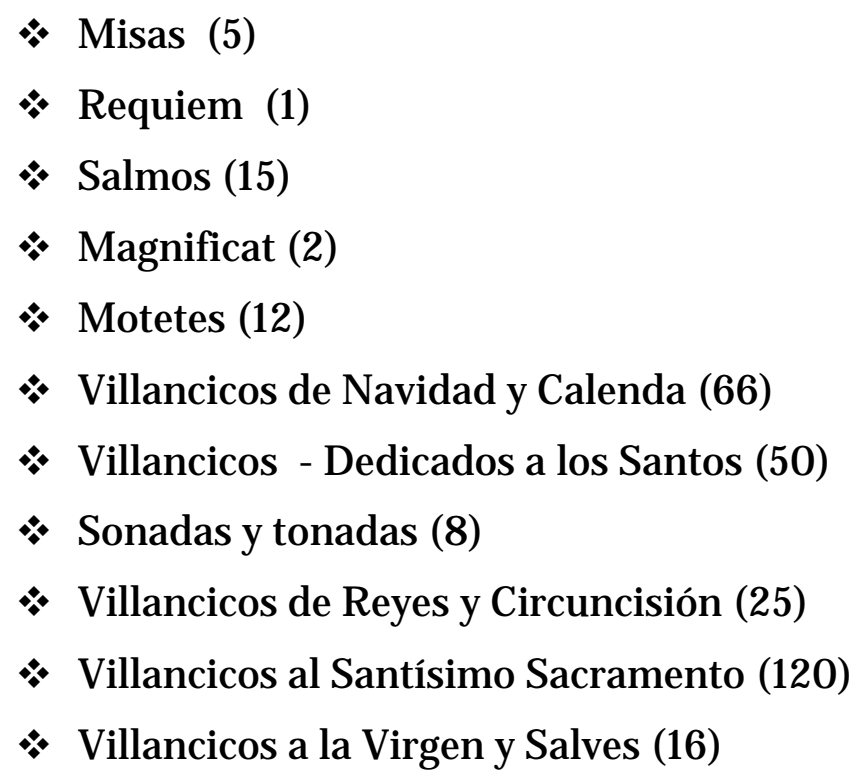

La mayor parte de sus obras se conservan inéditas en el archivo de la Catedral de Salamanca; he tomando como ejemplo, una de sus obras: el Villancico Al nacimiento de Nuestro Señor J esucristo244, nos sirve de parangón con la obra de Herrera.

\author{
A la fiesta señores, a la fiesta señores, señores \\ Paz celebrada, corran, lleguen, vengan \\ Vayan tore ri, tore ri toreri, los de fama \\ Toreritos, toreri, toreritos los de fama \\ Que hoy la suerte es del hombre
}




\author{
Pues se publican, publican \\ Pues se declaran, pues se declaran \\ Con el Rey entre el infante y el hombre \\ Las paces sagradas \\ A la fiesta Señores, a la fiesta Señores \\ Señores, señores, Paz celebrada \\ Corran, lleguen, vengan, vaian, \\ Tore ri , toreri, tpreri \\ Toreritos de fama, vengan, vengan \\ Toreritos de fama \\ A la fiesta señores, a la fiesta señores \\ Señores, a la fiesta señores, Paz celebrada.
}

\title{
ESTRUCTURA
}

INTRODUCCIÓN - COPLAS (I - II) - SOLO - INTRODUCCIÓN - COPLA

Bajón

Canto con letra Violón

Bajón

Canto con

letra

Los mismos géneros musicales y formas compositivas que se estilaban en la época en España, pasaron al Nuevo Mundo, donde sus compositores se empaparon de los estilos prevalecientes y se dejaron cautivar de las influencias musicales de los grandes en Europa, adaptando dichas formas y maneras de hacer música a la naciente forma de vida, producto de la unión de las culturas que ahí confluyeron.

En conclusión, la traslación de la cultura llevo consigo el establecimiento de tan variadas formas de vida, costumbres, procedimientos, situaciones y hechos históricos, sociales y culturales relevantes, que hicieron posible en su tiempo, que la vida en común de las gentes en el Nuevo Mundo, se vieran inmersas en la 
necesidad de adaptarse a lo nuevo, creando paulatinamente cambios que permitieron el nacimiento de una identidad propia. La vida comunitaria de las órdenes religiosas tanto masculinas como femeninas, se consolidaron; algunas perduraron, otras por diversos motivos y especialmente por las disposiciones reales o gubernamentales desaparecieron; pero hablando en términos de género, la figura femenina, vista en la mujer - música, o en la figura de la mujer escritora o poeta, incluso las mujeres que tuvieron a su cargo la administración de un Claustro y la responsabilidad espiritual del mismo, tuvo una significancia especial, ya que los Monasterios, fueron un espacio importante para el ejercicio de su magisterio musical y desarrollo intelectual. 


\section{CAPÍTULO V}




\section{CAPÍTULO V \\ V. REPERTORIOS LITÚRGICOS CONSERVADOS EN LAS CAPILLAS MUSICALES DE ALBA DE TORMES}

\section{V.1. OBRAS MUSICALES}

Introducción y consideraciones acerca de los Repertorios Musicales de algunos Monasterios Femeninos de España

\section{V.2. CATALOGACIÓN DE OBRAS}

V.3. FICHA TÉCNICA POR OBRA

V.4. ANÁLISIS MUSICAL 


\section{CAPÍTULO V}

\section{REPERTORIOS LITÚRGICOS CONSERVADOS EN LAS CAPILLAS MUSICALES DE ALBA DE TORMES}

\section{V.1. OBRAS MUSICALES}

\section{V.1.1.Introducción y consideraciones acerca de los Repertorios Musicales de algunos Monasterios Femeninos de España}

Dado que los repertorios encontrados en el monasterio de Santa María de las Dueñas de Alba de Tormes pertenecen específicamente al siglo XIX, considero importante hacer una breve alusión a la problemática de periodización de este siglo, que afecta a la producción musical. Los primeros años, deben ser considerados con claros nexos de unión con el siglo anterior; paulatinamente, comenzaron a fraguarse determinados acontecimientos que marcaron la transición de la edad moderna a la edad contemporánea y la nueva filosofía de la Ilustración, trajo profundas convulsiones en todos los ámbitos. Los reyes y sus ministros introdujeron importantes mejoras en la cultura y las artes, aunque se mantuvo la situación social del antiguo régimen. Se vivieron las consecuencias de la guerra de independencia y se produjeron los decretos desamortizadores, hechos que repercutieron directamente en las cuestiones organizativas y económicas que afectaban directamente a la producción y vida musical de la Iglesia española. La Monarquía española de Carlos IV había firmado la alianza con Francia en 1796; en 1809 J osé I suprimió en todos los territorios ocupados por los franceses, las Órdenes religiosas masculinas, con lo cual, los monjes regresaron a sus lugares de origen a reforzar las Capillas musicales, casi siempre de forma desinteresada. Muchas son las Capillas catedralicias que trataron de mantener su alto nivel de calidad y el número de sus componentes, pero la marcha de tantas personas al exilio y a los frentes de batalla, debilitó gradualmente este esplendor del culto, aunque los Cabildos hicieron lo posible por mantenerlo, reservando las plazas a sus músicos, admitiendo transitoriamente a clérigos y religiosos ajenos a la 
Capilla. El Santo Oficio se suprimió por Decreto imperial de Napoleón en 1808 y sus bienes se incorporaron a la Corona.

Para poder contextualizar la producción musical de los conventos que nos ocupan, hagamos una breve pausa en el panorama general de la composición en España. Estilísticamente, las formas compositivas de los inicios del siglo XIX, nos dan una muestra de entrelazamiento de rasgos, que convivieron en ocasiones, en la producción musical de los compositores de esta época. Los repertorios muestran un claro predominio melódico, con acompañamiento especialmente de piano u órgano, con pasajes solistas; otros presentan elementos de estilo culto, con la influencia de Viena y otras ya proyectan el carácter romántico, en las que aún pervive el empleo de lo contrapuntístico y el lenguaje polifónico clásico renacentista. Estos rasgos apenas difieren de los que caracterizan los repertorios instrumentales, incluso teatrales de la España del momento. Desde el punto de vista de la influencia que ejercieron los acontecimientos históricos en el acontecer de las Capillas musicales, se puede decir que existen contrastes en proporción a la situación reflejada en la transición del siglo anterior. En los inicios del siglo XIX, la plantilla musical de una Catedral de influencia podía tener una plantilla con los siguientes músicos, aproximadamente: 2 violines, 1 viola, dos oboes, 2 trompas, 1 bajón, 1 violón, 1 contrabajo, y acompañamiento. Gradualmente, los bajos fueron sustituidos por fagotes, se incorporaron los clarines. Como ejemplo, alrededor de 1815, la Capilla Real estaba constituida por: un Maestro de Capilla, un Capellán de altar, Sochantres, salmistas, 4 tiples, 4 contraltos, 4 tenores, 3 bajos, 4 organistas, 2 trompas, 2 fagotes, 10 violines, 2 violas, 3 violones, 4 oboes/flautas, 2 clarines, 2 clarinetes, 3 contrabajos. Con esta plantilla trabajaron compositores como: J osé Lidón (1814-1827), Francesco Federici (1827-1830), F. Andrerí (18301836) y Rodríguez de Ledesma. Las disposiciones de los gobiernos liberales afectaron a las Capillas musicales, ya que se vieron ostensiblemente diezmadas en la conservación de sus plantillas de músicos. El número de actos o fiestas solemnes disminuyó y se empezaron a contratar músicos solo para las ocasiones especiales. 
En relación con la citada plantilla de la Capilla Real musical, en el siguiente cuadro, se puede observar que durante el Reinado de la Reina Isabel II, -la "Reina de los tristes destinos", como también ha sido llamada, desde su exilió en Francia en 1868, tras el triunfo de la revolución conocida como "La Gloriosa"-, la plantilla de músicos de la Capilla Real, bajó notoriamente alrededor de 1848, quedando conformada, así:

\begin{tabular}{|c|c|c|c|c|c|}
\hline & & & & & \\
\hline & & \multicolumn{3}{|c|}{ CAPILLA REAL DE MÚSICA } & \\
\hline & & \multicolumn{3}{|c|}{ REINADO DE ISABEL II } & \\
\hline & & & \multicolumn{2}{|c|}{$1833-1868$} & \\
\hline & \multirow{2}{*}{\multicolumn{5}{|c|}{ Maestro de Capilla : HILARIÓN ESLAVA }} \\
\hline & & & & & \\
\hline & & & & & \\
\hline & & & & PIANTULIANST & \\
\hline & \multicolumn{2}{|c|}{ PLANTILLA VOCAL } & & \multicolumn{2}{|c|}{ PLANTILLA INSTRUMENTAL } \\
\hline & \begin{tabular}{|l} 
Contralto (1 y2) \\
\end{tabular} & & & Violines (4) & \\
\hline & Tenor (1 y 2) & & & Viola (1) & \\
\hline & Baritono (1) & & & Violonchello (1) & \\
\hline & Bajo ( 1 y 2) & & & Contrabajo (1) & \\
\hline & Tiple (1 y 2) & & & Oboe (1) & \\
\hline & \multicolumn{2}{|c|}{\begin{tabular}{|l|} 
Tenor supernumerario \\
\end{tabular}} & & Clarinete (2) & \\
\hline & Organista & & & Flauta (1) & \\
\hline & \multicolumn{2}{|c|}{ Ayudante de organista } & & Fagot (1) & \\
\hline & & & & Trompa (2) & \\
\hline & & & & Clarín (1) & \\
\hline & & & & Organero afinador & \\
\hline & & & & Archivero copista & \\
\hline & & & & & \\
\hline & \multicolumn{4}{|c|}{ MÚSICOS SUPERNUMENRARIOS } & \\
\hline & & & & & \\
\hline & Contralto & & & & \\
\hline & Tenor & & & & \\
\hline & Bajo & & & & \\
\hline & Organista 2o & & & & \\
\hline & Oboe (1) & & & & \\
\hline & Clarinete (2) & & & & \\
\hline & Flauta (1) & & & & \\
\hline & Fagot (1) & & & & \\
\hline & \begin{tabular}{|l|} 
Violoncello (1) \\
\end{tabular} & & & & \\
\hline & Contrabajo & & & & \\
\hline & Violín & & & & \\
\hline & & & & & \\
\hline
\end{tabular}

De Evaristo Ciria, (tenor $2^{\circ}$ ), músico y compositor de la citada plantilla de Música, se encontró en el Monasterio de Santa María de las Dueñas de Alba de Tormes un villancico titulado "Los pastores al Niño Dios" para voz con acompañamiento de órgano. 
J esús Ignacio Pérez Perazzo, hace una relación de acontecimientos importantes en cuanto a los repertorios musicales del siglo XIX:

\begin{abstract}
“A raíz de los desastres militares, Napoleón se vio obligado a permitirle al Papa su regreso a Roma, en donde entró triunfalmente el 24 de mayo de 1814. Ese período de dificultades sirvió a la Iglesia para fortalecerla. La iglesia de la Restauración se propuso recristianizar las masas populares cuya práctica religiosa había quedado resquebrajada por los años de la Revolución. La Compañía de Jesús es rehabilitada como orden de jurisdicción universal, y surgen nuevas congregaciones de hombres y mujeres en varias naciones, todo lo cual influyó en la recuperación y renovación del catolicismo, el cual apareció remozado e intensificado. De inmediato se inician importantes trabajos en la dirección de fortificarlo y desarrollarlo.
\end{abstract}

En Alemania, por su parte, y desde sus comienzos, el Romanticismo acusaba una tendencia religiosa. Así florece un renovado Arte A Capella, con maestros como Eduard Grell (1800-86) y Heindrich Bellermann (1852-1903), que vuelven su mirada al pasado e intentan actualizar las técnicas de los grandes maestros de la polifonía del pasado.

En tal sentido, uno de los acontecimientos más importantes, fue el renacimiento del interés por la música Gregoriana (del siglo VI) y el reconocimiento de su condición de la Palabra de Dios cantada. Las autoridades de varios centros y monasterios del siglo XIX, como por ejemplo, en la famosa y conocida Abadía de Solesmes, con Dom Prosper Guéranger (1805-1875), Dom Joseph Pothier (1835-1923); además del discípulo y continuador de la tarea de sus predecesores, Dom André Mocquereau (18491930); y en Beuron, con M.y PI. Wolter, abordaron con empeño y magníficos resultados, esta encomiosa tarea.

En la Abadía de Solesmes, Francia, la Congregación Benedictina, bajo las directrices del abad Dom Guéranguer el año 1833 se inició un importante proceso de rescate, análisis, estudio y Restauración del Canto Gregoriano más genuino; luego de profundos estudios y conclusiones, se impuso la correcta interpretación y respeto de la pronunciación, acentuación y fraseo de los cantos; se trabajó en comparación de los distintos manuscritos antiguos de toda Europa y se creó el Taller de Paleografía Musical para el serio y minucioso estudio y análisis de los documentos musicales de las edades antigua y media. Se trató de un proceso cultural y espiritual complejo, de amplísimos alcances.

A través de la obra de Dom Prosper Guéranguer, difundida en sus varios escritos, tales como $L^{\prime}$ anée liturgique e Institutions liturgiques, y con su permanente batalla contra la liturgia neogalicana y a favor de la liturgia romana, el movimiento litúrgico se basa en las intenciones más profundas que habían sido planteadas por Pío $\mathrm{V}$ acerca de la liturgia.

A finales del siglo XIX, el Papa Pío IX (Giovanni Maria Mastai Ferreti, cuyo pontificado tuvo lugar entre 1846 y 1878), proclamó el dogma de la Inmaculada Concepción de María (1854), el de la Infalibilidad Pontificia (1870) y en 1868, renovó la Schola Cantorum. Durante este tiempo en Milán, Roma y Venecia, el Patriarca Sarto (quien más tarde, entre 1903 y 1914 ocuparía el solio pontificio con el nombre de Pío $X$ y en 1954, fuera canonizado como San Pío X), hizo pública una Carta Pastoral que venía a anunciar lo que luego, en 1903, convertiría en Encíclica. 
El arranque del verdadero movimiento litúrgico de nuestros tiempos se inicia en el primer decenio del siglo XX. Su fundamento fueron sin duda las palabras programáticas de la mencionada Carta Pastoral Tra le sollecitudini del cardenal Sarto, quien expresaba: ...Siendo un vivísimo deseo nuestro que florezca nuevamente de todas las maneras posibles el verdadero espíritu cristiano..., es necesario antes que nada atender a la santidad y dignidad del templo, donde se reúnen precisamente los fieles para beber ese espíritu de su primera e indispensable fuente, que es la participación activa en los sacrosantos misterios y en la oración pública y solemne de la iglesia...

Se profundizan entonces, los intentos de Renovación de la música sagrada, aparecen muchísimas composiciones dentro del nuevo espíritu litúrgico de compositores como Laurent de Rillé y Louis Lambillotte S.J. (1796-1855), autor además, de un tratado intitulado Esthétique, théorie et pratique du chant grégorien. Esta renovación se hace patente sobre todo, en el marco del Movimiento Ceciliano (La Sociedad Ceciliana había tenido entre sus fundadores en Francfort 1818, al cantante, maestro y director alemán Johann Nepomuk Schelble, 1789-1837) con el Congreso de Arezzo (1882), donde se formularon con serios argumentos, las finalidades, propósitos y condiciones para el estudio del canto litúrgico, cuyas conclusiones se concretaron en la fundación de una asociación internacional para el perfeccionamiento de la música del culto.

Dos años más tarde en 1884, el Papa León XIII (Gioacchino Pecci, Papa de 1878 a 1903), restringía el uso de instrumentos musicales y del órgano.

El Concilio Vaticano I (1870) estimula la renovación y profundización de la vida eclesial bajo la guía del Papado y el florecimiento de una renovada teología (de la escuela romana y de la escuela de Tübingen); a ellos se sumarán los esfuerzos continuos del cardenal Giuseppe Melchiorre Sarto (más tarde Pío X), en tal sentido, quien insistía en la fundación de instituciones para el estudio y enseñanza de la Música y el Canto litúrgico. Ya como Papa, Pío X, hace público su Motu Proprio del 22 de noviembre de 1903 sobre la Restauración de la música sagrada.

En los 29 puntos de este documento se redefinía a la Música como un auxiliar de la religión. Sin embargo, la Encíclica asumió con prudencia el no prohibir la formidable literatura musical producida después de Palestrina. Se otorgaban algunas concesiones a los Cecilianos; se restablecía el uso del Canto Gregoriano el cual se complementaba con el Estilo palestriniano; se combatía el estilo teatral, el uso de otros Instrumentos en la iglesia salvo aquellos de viento cuyo sonido se consideraba semejante al órgano; las voces de mujeres se sustituyeron, una vez más, por voces de niños; y se asignó al Órgano un papel muy modesto en el acompañamiento de la liturgia y el Officium."245

Paralelamente en el desarrollo de este apartado, es preciso comentar sobre las fuentes musicales existentes, que nos develan la existencia de los repertorios musicales y la actividad musical desarrollada en diversos Monasterios femeninos españoles desde el siglo XVII al XIX. Códices, cantorales, epistolarios, relacionados con la producción musical de Maestros de Capilla, entre otras, son las fuentes primarias que permiten hacer una valoración de la actividad musical

245 PÉREZ PERAZZO, Jesús Ignacio. El repertorio litúrgico en los inicios del siglo XX. $<$ www.histomusica.com> (consultada el 14 de enero del 2008). 
desarrollada al interior de los Monasterios femeninos. Son varios los autores que han investigado al respecto, entre los que podemos citar a Soterraña Aguirre Rincón, Alfonso de Vicente, Collen R. Baade, Matilde Olarte Martínez, Miguel Querol, y Carmelo Caballero, entre otros.

Continuando con el orden en que se han citado los investigadores del tema, hago referencia al trabajo investigativo publicado por Soterrraña Aguirre Rincón246; este estudio brinda en primera instancia, una reflexión sobre el tema, considerándolo como la obra de una cultura muy particular, apropiado para ser examinado y rescatado y en segundo término, es prototipo de la tarea realizada por las personas creadoras, emisoras del códice y las receptoras, fomentándose de ésta manera, una formas de comunicación entre las mismas. Otra consideración, es la relacionada con los aspectos religiosos y culturales del convento, como por ejemplo, el ceñimiento de sus actividades musicales a un calendario litúrgico y el compromiso religioso asumido por las monjas en estas actividades, en concreto: “El Repertorio está formado por un grupo de composiciones litúrgicas que como el propio copista señala en la portada, cubrían "todo lo necesario para el oficio divino de misas y vísperas"247

Asimismo, en las pp. 187-90, la autora hace una descripción del Libro de música dedicado a Sor Luisa -nieta del célebre Antonio de Cabezón-, el cual aparte de las composiciones para Vísperas o a la liturgia de la Misa, posee otro tipo de composiciones. Este valioso repertorio musical está representado en Salmos, himnos para Domingos de prima, Misas de Gloria, una Misa de difuntos, Lamentaciones y una Pasión según San Mateo y cantos para Completas; con su devoción Mariana, el Convento conserva dentro de su repertorio Salves Regina y Magnificats.

Aparte de lo anteriormente descrito, la autora nos ilustra sobre la existencia de otro corpus musical, como son: Breviarios, Manuales y Misales seráficos de la época; los diferentes cantorales monódicos en un total de diez y seis (16), algunos de ellos llegaron procedentes del antiguo Convento de Santa Isabel, pero al menos

246 AGUIRRE RINCÓN, Soterraña. "El manuscrito polifónico de Santa Clara de Carrión de los Condes - más que un repertorio musical - (Libro de música dedicado a Sor Luisa)". Revista de Musicología XX (1997), pp. 185-98.

247 Ibídem, p. 187. 
cuatro, nos dice la autora, pertenecían al de Santa Clara en la época que se realizó la investigación248. Entre sus obras se pueden citar:

Salmos (9)

* Dixit Dominus

* Beatus Vir

* Laudate Pueri

* Laudate Dominum

* Laetatus sum

* Credidi

* Nisi Dominus

* Lauda J erusalem

* Beati Omnes

Himnos (17) Algunos son:

* Pange Lingua

* Sacre Solemniis

* Verbum supernum

* Pange Lingua

* O gloriosa Domina

* Ave Maris Stella

* Hostis Herodes

* Exsultet coelum

Antífonas:

* Veni Sponsa Christi

* Tota Pulcra est

El interesante artículo de Alfonso de Vicente titulado "La actividad musical en los Monasterios de monjas en Ávila durante la edad moderna"249, ofrece variadas posibilidades metodológicas para enfrentar un trabajo investigativo sobre el tema de la música en los monasterios de las monjas, aplicable a cualquier época. En su artículo nos dice: 
"De los cuatro monasterios femeninos abulenses de los que se tiene documentación relacionada con su actividad musical, solo del de Santa Ana se conoce un archivo de partituras relevante, la may or parte de ellas compuestas y copiadas para las monjas e interpretadas por ellas. De ahí el enorme interés que tiene el estudio de esas obras y del funcionamiento de la actividad litúrgico - musical”250.

Entre las obras significativas que el autor nos muestra y que conforman este repertorio musical conservado, se encuentran obras de Tomás Luis de Victoria, Cristóbal Galán, D. Scarlatti, Mozart, Gaspar Smith, Sonatas y versos para órgano (Libro 49). Las obras más relevantes conservadas en este Monasterio de Santa Ana, son:

* La Misa L'homme armé de Francisco Guerrero, conservada en el Libro 2 de este Monasterio.

* Los Motecta de Tomás Luís de Vistoria

* Arded, corazón, arded -Villancico al Santísimo- de Cristóbal Galán (Cuatro coplas)

* Sonata en Re M de Doménico Scarlatti (Libro 50)

* El "Vals favorito” de W. A. Mozart (Manuscrito de 1790)

* El autor De Vicente cita a Margarita Soto Viso, quien ha trascrito, revisado y publicado la Suite de danzas para tecla, obra atribuida a Gaspar Smith, Maestro de Capilla de la Catedral de Tuy.

* Sonatas y versos para órgano (Libro 49) Tres libros de finales del siglo XVIII que pertenecieron a la monja María Teresa Verdugo, que contiene especialmente obras para órgano, clave y pianoforte.

De Vicente, nos dice nombrando a Miguel Querol y a Carmelo Caballero, que las cartas de las Carmelitas de la Encarnación de Ávila, ya dejan ver el interés de las monjas por conseguir obras que se les acomoden a sus posibilidades.

Miguel Gómez Camargo en el siglo XVII, recibe una misiva de la monja del convento de La Encarnación, Isabel Pinel: “Recibí los dos Villancicos y el Salmo que Ud. me hizo(...)”251. 
De la investigadora americana Collen R. Baade queremos destacar su estudio "La música sutil - del monasterio de la madre de Dios de Constantinopla: aportaciones para la historia de la música en los monasterios"252. Brinda en este artículo una detallada descripción de la fundación del Monasterio de Nuestra Señora de la Salutación, conocido más comúnmente como Madre de Dios de Constantinopla, así como detalles de los libros de fábrica del convento, con los que fácilmente se puede hacer un seguimiento de la actividad musical y la puesta al día en cuanto a las prácticas musicales y se puede tener una visión llamativa de lo que era la música en los coros y capillas de las monjas músicas españolas, así como las memorias de toma de hábito y profesiones y en los que destaca la presencia en el monasterio, de monjas destacadas en el canto. La colección de poemas de Miguel de Toledano, nos dice el autor, reúne unos 194 Villancicos, sonetos y romances, repartidos así:

* 36 poesías dedicadas a la Natividad

* 64 Romances y Villancicos dedicados al Santísimo Sacramento

\section{"Lamentablemente, no se ha conservado ninguna música de los villancicos que se cantaron en el Monasterio de Constantinopla y no ha sobrevivido tampoco ningún libro de cuentas de los años 1604 a 1624 que pudiera arrojar más luz sobre el asunto”253}

La Dra. Matilde Olarte Martínez, investigadora musical, quien entre otras muchas interesantes temáticas ha trabajado especialmente los estudios de género, nos brinda una serie de publicaciones sobre el tema de los repertorios musicales en cuestión, como: “Las monjas músicas en los Conventos españoles del Barroco Una aproximación etnohistórica”254, o “Difusión de la música barroca española a través de los Maestros de Capilla y músicos de los Monasterios" y en su libro “Miguel de Irízar y Domenzain (1635 - 1684?): Biografía. Epistolario y estudio de sus lamentaciones", publicado por la Universidad de Valladolid, nos enseñan

\footnotetext{
252 BAADEN, COLLEEN R. "La música sutil del monasterio de la Madre de Dios de Constantinopla: aportaciones para la historia de la música en los monasterios femeninos de Madrid a mediados del siglo XVI - siglo XVII". Revista de Musicología XX (1997), pp. 221ss. 253 Ibídem, p. 228.

254 OLARTE MARTÍNEZ, Matilde. “Las monjas músicas en los Conventos españoles del Barroco . Una aproximación etnohistórica”. Revista de Folklore CXLVI (1993), pp. 56-63.
} 
cómo Don Miguel de Irízar y Domenzain, maestro de capilla de la catedral de Segovia, recibía varias peticiones de Monasterios femeninos, para remitirles obras para las solemnes festividades religiosas.

Por tanto, siendo los Monasterios de Alba de Tormes (Benedictinas y Carmelitas descalzas) Centros menores, comparados con otros Centros representativos de gran envergadura, como la Catedral de Salamanca o la de Sevilla o la de Toledo, en el desarrollo de la investigación, los documentos analizados, permiten conocer la actividad musical que se desarrolló en su interior y son muchas las memorias que nos dan a entender que se desplegaba una serie de actividades litúrgicas y ceremoniales, en las que la música era imprescindible. Una de las ocasiones grandes en que se tuvo una amplia actividad musical, - nos lo relatan las Crónicas del Monasterio de Santa María de las Dueñas -, fue con motivo del traslado de la Comunidad de extramuros a la nueva casa en la que habitarían hasta la fecha, intramuros. Cuatro días de celebraciones, misas solemnes diarias y el traslado de las Fiestas del Corpus para estas fechas - julio de 1775 -, fueron motivo suficientemente grande para desplegar un movimiento musical significativo, así como la profesión de las novicias lo cual se constituía en uno de los acontecimientos más relevantes y significativos para la Comunidad, así como las fiestas de la Natividad y Semana Santa, las Bodas de Oro de alguna Abadesa, el fallecimiento de alguna religiosa - si era la Abadesa- con mayor significancia, la fecha conmemorativa del Santo Patrono de la Comunidad - San Benito-.

\section{V.1.2. OBRAS MUSICALES CONSERVADAS EN EL MONASTERIO DE SANTA MARÍA DE LAS DUEÑAS DE ALBA DE TORMES}

- Obras para voz y órgano

- Misas a dos y tres voces con acompañamiento de órgano o piano

- Villancicos

- Salves

- Un Método para el aprendizaje del Canto Gregoriano. 
Santa María de las Dueñas, de Alba de Tormes, es uno de los Monasterios que según su trayectoria como Orden Benedictina y conforme a los documentos que en él reposan, - los cuales hablan ampliamente sobre la existencia y sobre la actividad musical de sus monjas músicas -, da a entender que en el interior de sus muros, se desarrolló una gran actividad musical. Siguiendo paso a paso el camino recorrido por este Monasterio Albense, desde sus inciertos orígenes hasta nuestros días, se puede precisar sobre las diversas dificultades por las que pasó y los momentos de impulso que vivió a lo largo de los siglos. Periodos de traslados, períodos de guerras, incendios y las dificultades económicas, así como momentos de esmero y perfección en las maneras de ser y hacer y especialmente en lo concerniente a la música, condicionaron la conservación de los repertorios musicales. Explorando y clasificando dichos repertorios musicales, las obras de más antigüedad, pertenecen a los inicios del siglo XIX.

Dando una mirada este siglo, vemos como este estilo artístico nace en el seno de una nueva sociedad burguesa. La música busca ser un arte total, susceptible de representar subjetivamente cualquier contenido y aliarse con otras manifestaciones artísticas como: la poesía, las artes decorativas, la danza, etc.. La música fue concebida como la expresión de los sentimientos; sin crear formas nuevas, aplicó un espíritu diferente a las heredadas del clasicismo. Formas musicales, tanto gigantescas como menores o íntimas caracterizaron los repertorios de este período.

Conforme a las formas musicales que se desplegaron a lo largo del romanticismo, vemos como los compositores hicieron del piano su vital medio para plasmar su inspiración y desarrollar un amplio repertorio ya fuese para el instrumento como solista o para que fuese acompañante del Lied o canción, principal forma musical de entonces. Las pequeñas formas musicales como: los valses, las romanzas, las gavotas, las arias y los preludios, - entre otras -, que se estilaron, conformaron el corpus creativo de los compositores románticos; por ende, parte de los repertorios musicales de éste Monasterio, guardan o presentan el estilo Lied, en los que la presencia del acompañamiento del piano - o el órgano -, es primordial. 
En torno a la música religiosa, es preciso recordar algunos sucesos, que condicionaron los drásticos cambios sufridos por los músicos del momento. El 17 de Octubre de 1851, se firmó el Concordato entre España y la Santa Sede, concluyendo con ello, las negociaciones iniciadas desde 1843, cuya principal problemática radicaba en la enajenación de los bienes del clero, que tuvo lugar en 1836, declarándoseles, bienes nacionales. Si el Concordato supuso la base para la estabilidad del clero, no todo fueron consecuencias positivas para la música, ya que una de las disposiciones influyó negativamente; los músicos deberían ser obligatoriamente clérigos. Se redujo el número de componentes de las Capillas Musicales, quedando establecido: Un Maestro de Capilla, un organista, un contralto, un tenor y un Schosantre.

El sentimiento religioso aún arraigado con fuerza en esta época y de hecho, el creciente número de actos de religiosidad popular, sentimiento extensivo a los albores del siglo XX, hicieron que muchos compositores dedicaran su creación a la composición de obras de estilo religioso y dedicadas a las formas Marianas, Himnos, Misas, Villancicos, Cantos a los Santos Patronos, Motetes Eucarísticos, etc.

En parte, de los repertorios encontrados en el Monasterio de Santa María de las Dueñas, se desconoce la identidad de algunos compositores de las obras pertenecientes a los géneros enunciados; Generalmente, en los monasterios se encuentran composiciones hechas por personas que siendo sacerdotes o monjes de otras congregaciones crearon para las necesidades del culto divino o de las festividades religiosas y su música se difundió por monasterios, parroquias y congregaciones. Algunas partituras llevan expreso en su encabezamiento el nombre de su compositor, agregando alguna indicación específica, por ejemplo, dice: "monje Benedictino" o "sacerdote Jesuita" o "Pbro". Tal vez fueron compositores casi anónimos, que no alcanzaron notoriedad ni reconocimiento, pero que contribuyeron en cierta forma, al enlucimiento de la liturgia y las fiestas importantes de la Iglesia en monasterios y parroquias normales. 


\section{* OBRAS PARA VOZ Y ÓRGANO}

Entre las obras representativas de éste estilo musical, varias Salves, o Canciones Marianas, presentan la forma de Lied, sugiriendo el acompañamiento del piano o del órgano. Tuvo el Órgano su época dorada, sus momentos de apogeo en el barroco, tanto para compositores como intérpretes. Después de la época barroca y de la muerte de los grandes compositores, el instrumento entró en decadencia en el papel de la música de concierto, donde la indiferencia de los grandes compositores, hizo que quedara relegado exclusivamente en su papel de acompañante para la música religiosa. En el romanticismo, salvo contadas excepciones, sigue igual de relegado y marginado entre los grandes de la música. Algunas obras musicales del Monasterio, presentan la plantilla: A dúo con acompañamiento de piano / órgano. En referencia a los textos, se desconocen los autores, por cuanto ninguna obra especifica el autor o autores de la poesía.

Entre las obras musicales que presentan la plantilla, voz con acompañamiento de piano y/u órgano, se eligió Pensando en ti, un vals, para canto y piano sobre texto de Carmen Perafane.

\section{MISAS}

La Misa como forma musical, se concibió desde el siglo XV, como un todo musicalmente unificado, en la que los compositores encontraron coherencia y complejidad formal mayor. Las hay con funcionalidad litúrgica y con funcionalidad de Concierto. En el romanticismo, la Misa adquirió dimensiones líricas, con acompañamiento orquestal, con reducción de voces, como los solos a una voz o a dúo.

De los Compositores Luiguie Bordese PEQUEÑA MISA SOLEMNE a dos voces con acompañamiento de piano/ órgano, Ignacio Bastida Chic, MISA a tres voces, solista y coro), A. Dierrex MISA a dos voces iguales, se escogieron las Misas representativas a dos voces, con acompañamiento de piano u órgano. 
Cada Misa contiene sus partes enteras, como son:

$>$ Kyrie

> Gloria

$>$ Credo

$>$ Sanctus

$>$ Benedictus

$>$ Agnus Dei

\section{* VILLANCICOS}

La popularidad alcanzada por esta forma musical, ha ido en aumento paulatinamente. No hemos de olvidar que en su origen, el villancico fue un género musical exclusivamente español y que tuvo muy diversos usos a lo largo de la historia. A pesar del paso del tiempo, en los villancicos del siglo XIX, perviven algunas características del antiguo villancico como es la estructura del estribillo y de las coplas.

Algunos villancicos atractivos por su melodía y texto, fueron seleccionados de la clasificación realizada de los Repertorios musicales del Archivo del Monasterio de Santa María de la Dueñas:

> Albricias pastores (anónimo)

> Villancico - Al nacimiento de Nuestro Señor J esucristo de S. Rosado

> Los pastores - Villancico al Niño J esús de Evaristo Ciria.

> Solo Dios llora - Villancico de Alfonso Ugarte Leturia

\section{* SALVES Y CANTOS MARIANOS}

Dedicadas especialmente a la alabanza de la Virgen María y conocidas desde la antigüedad - ya que Las Cantigas de Alfonso X “El Sabio”, se constituyen en la mayor colección de canción monódica medieval y figura como el fondo Mariano más rico y variado de cuantos nos han llegado - , se encuentran en la forma Lied o canción para voz soprano con acompañamiento de piano, sobre textos castellanos y latinos. Entre las obras Marianas, clasificadas, se escogieron:

> Una Salve Monserratina, para voz y armonio u órgano, del compositor Martinus Moncada. 
> Salve - anónimo -, la cual que incluye una estrofa para ser interpretada por coro de niños.

> Salve Regina, A dos voces con acompañamiento de armonio u órgano, alternada con el canto gregoriano a coro, del compositor H. Ribera y Palaou, Pbro.

> Toda hermosa de autor desconocido, incluye un solo de niños.

De los repertorios sobre cantos populares, en forma Lied, fue escogida la canción Pensando en ti, para vozy piano, en ritmo de vals.

\section{* MÉTODO DE CANTO GREGORIANO}

En cuanto al Canto Gregoriano, - como se ilustró anteriormente -, esta actividad tomó relevancia después de la visita del Rvdo. Padre Carlos Azcárate, monje del Real Monasterio de Santo Domingo de Silos, que en los inicios del siglo XX, más concretamente alrededor de 1909, estaba impartiendo clases de Gregoriano en el Seminario de Salamanca, según el modelo propio de Pio X. De este quehacer, quedan en el Monasterio, los Libros de instrucción - manuscritos -, sobre el aprendizaje, lectura y análisis del Canto Gregoriano; Manuales que aún hoy día son consultados por las monjas músicas de éste Monasterio Benedictino.

En conclusión, la clasificación de los repertorios musicales del Monasterio de Santa María de las Dueñas de Alba de Tormes, nos llevan a entender que sí hubo una gran actividad musical en torno a la Liturgia diaria y en torno a las fiestas religiosas importantes que marcaron épocas en el Monasterio, así como las de estilo profano o popular, pero que a la vez se detecta una falta irreparable en cuanto a la previsión para salvaguardar repertorios que tal vez fueron la fuente de la actividad musical en tiempos más remotos. A continuación, una página manuscrita del Manual de instrucción sobre Canto Gregoriano, que reposa en el Archivo conventual. 


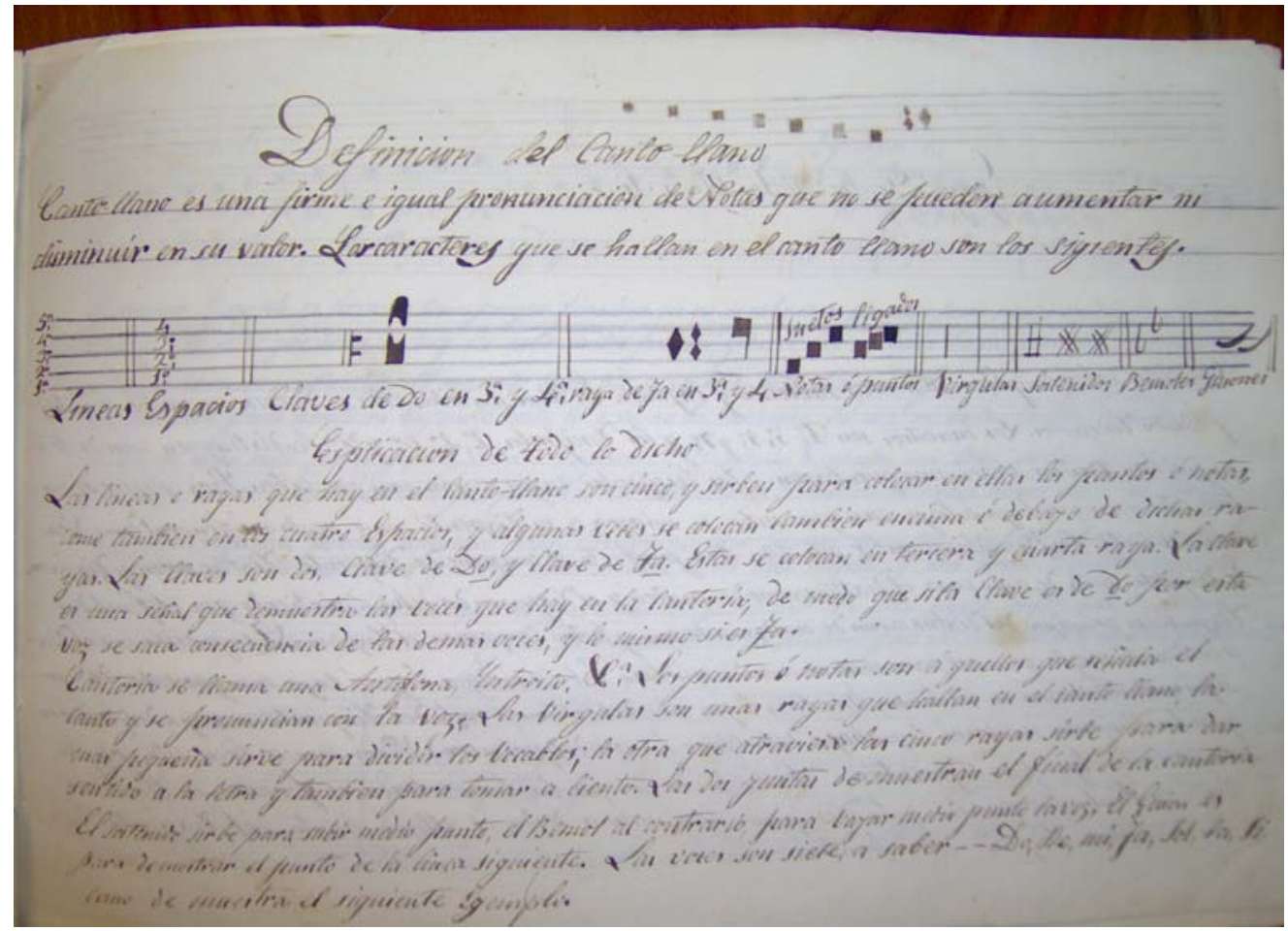

35. Manuscrito del Libro de instrucción básica sobre interpretación y análisis del Canto Gregoriano. ASMD.

\section{V.2. CATALOGACIÓN DE OBRAS MUSICALES}

\section{V.2.1.CRITERIOS PARA LA CATALOGACIÓN DE OBRAS MUSICALES}

¿Cómo abordar un trabajo de catalogación?, ¿Qué aspectos deben ser objeto de catalogación? Tomar como base la normativa del RIMS para catalogación de obras, nos ha parecido lo más adecuado; la elaboración y aplicación de una ficha nos permitirá tener claridad sobre la descripción del contenido interno, - en este caso el contenido musical -, de la obra, y desde un segundo plano, la descripción externa del soporte físico, vale decir, describir corporalmente el documento para situarlo en un ámbito histórico determinado.

Los criterios de selección están relacionados básicamente con la identificación de las obras musicales, la selección y el ordenamiento en base a los siguientes parámetros: 
Por orden cronológico

- Género

- Estilo

- Especie (manuscrito o impreso)

Revisando los datos que proyectan las fuentes, se ha elaborado una ficha de catalogación para obras musicales, basada y adaptada a la que hoy, exige la normativa internacional RISM; ello ha permitido, estructurar una forma para el adecuado manejo de la información. Ciñendo esta catalogación a un orden cronológico, tendríamos en primera instancia: Misas, Villancicos, Himnos y cantos Marianos, incluyendo en ellos, las Salves, pertenecientes al siglo XIX. En segundo término, se pueden catalogar las Antífonas, aunque no son manuscritos de antiguas épocas, ya que fueron copiadas en torno a los inicios de siglo XX, posiblemente cuando se llevó a cabo la implantación del Canto Gregoriano en el Monasterio en el año 1933, como lo relata el Libro de Crónicas del Monasterio; su contenido es puramente de Canto Gregoriano.

Haciendo un análisis cualitativo en torno a los Repertorios musicales, según el historial del Monasterio de Santa María de las Dueñas, debieron ser en algunos de sus períodos, muy ricos, por cuanto la Liturgia estaba establecida en toda regla y las Crónicas nos cuentan sobre las grandes celebraciones que el él se llevaba a cabo en fechas espaciales. Pero como ya se dijo, muchos aspectos influirían en su momento para la pérdida de los repertorios musicales. Desde otro punto de vista, otra reflexión, puede hacerse: Según las posibilidades económicas del Monasterio, este se podían enriquecer o no, con la adquisición de Repertorios musicales o de Literatura y/o encargar a determinado compositor la composición de obras para las solemnidades del Monasterio. Pero al respecto, nada ha sido posible encontrar. 


\section{V.3.FICHA TÉCNICA POR OBRA}




\section{V.3. FICHA TÉCNICA POR OBRA}

\section{V.3.1. MISAS}

Ficha No 1

Título: PEQUEÑA MISA SOLEMNE a dos voces con acompañamiento de órgano - Luigi Bordese.

LUIGI BORDESE: Compositor italiano, nacido en Nápoles en 1815; se dedicó a la composición de canciones y especialmente a la Música religiosa. Compuso una ópera sin mucho éxito, llamada "I promessi sposi”. Murió en 1886. Varias Misas están reconocidas dentro de su producción musical; entre ellas la célebre Pequeña Misa solemne a dos voces con acompañamiento de órgano o armonio y otros géneros especialmente religiosos, como su famoso Tantum Ergo.

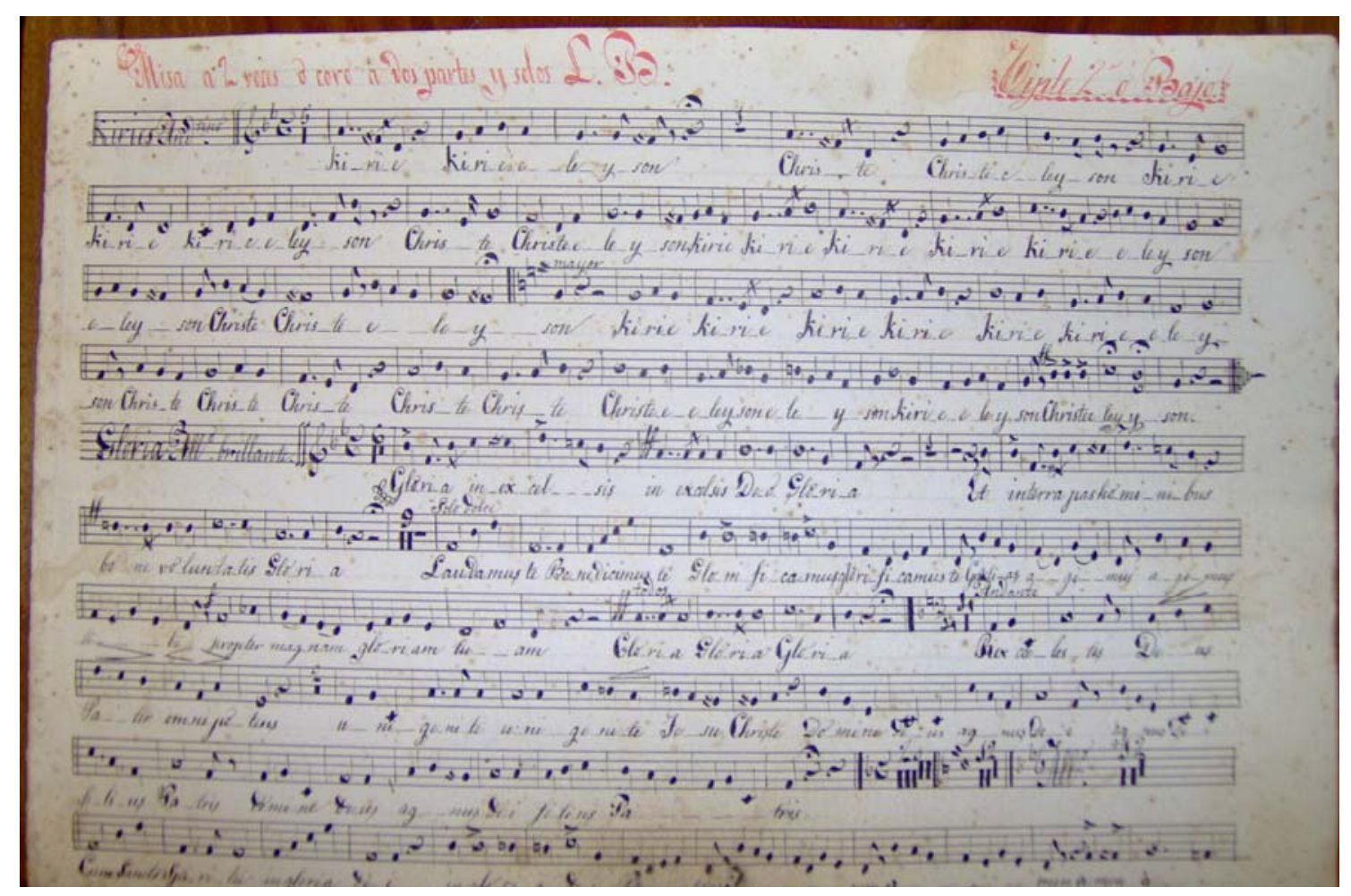

ASMD. Pequeña Misa Solemne. Kyrie. Luigi Bordese 
PEQUEÑA MISA SOLEMNE

A dos voces con acompañamiento de órgano

Luigi Bordese - Manuscrito del ASMD

\begin{tabular}{|c|c|c|c|c|}
\hline & $\begin{array}{l}\text { FICHA DE CATALOGACIÓN } \\
\text { DE OBRAS MUSICALES }\end{array}$ & & & \\
\hline BLOQUE I & & & & \\
\hline $\begin{array}{l}\text { Comp. } \\
\text { Norm. }\end{array}$ & BORDESE, Luigi*1815 - +1886 & & & $\begin{array}{l}\text { Fechas: } \\
\text { *1815 - } \\
+1886\end{array}$ \\
\hline $\begin{array}{l}\text { Tit. } \\
\text { Uniforme }\end{array}$ & PEQUEÑA MISA SOLEMNE & & & \\
\hline $\begin{array}{l}\text { Comp. } \\
\text { Norm. } \\
\text { Arch. }\end{array}$ & BORDESE, Luís & & & \\
\hline $\begin{array}{l}\text { Título } \\
\text { propio }\end{array}$ & $\begin{array}{l}\text { PEQUEÑA MISA SOLEMNE } \\
\text { A dos voces con } \\
\text { acompañamiento de órgano o } \\
\text { armonio y/o (piano) } \\
\end{array}$ & & $\begin{array}{l}\text { Plantilla: } \\
\text { Tiple 1, } \\
\text { Tiple 2 y } \\
\text { órgano }\end{array}$ & \\
\hline $\begin{array}{l}\text { Forma mus. } \\
\text { Dipl. }\end{array}$ & MISA & $\begin{array}{l}\text { № de } \\
\text { Partes: } 5\end{array}$ & & $\begin{array}{l}\text { Forma mus. } \\
\text { Normal: } \\
\text { Misa a } 5 \text { partes }\end{array}$ \\
\hline № opus & $\ldots$ & $\begin{array}{l}\text { Ton/des la } \\
\text { las partes de } \\
\text { la obra. } \\
\text { Kyrie: sol m } \\
\text { Gloria: si b } \\
\text { Credo:Do M }\end{array}$ & & $\ldots$ \\
\hline
\end{tabular}




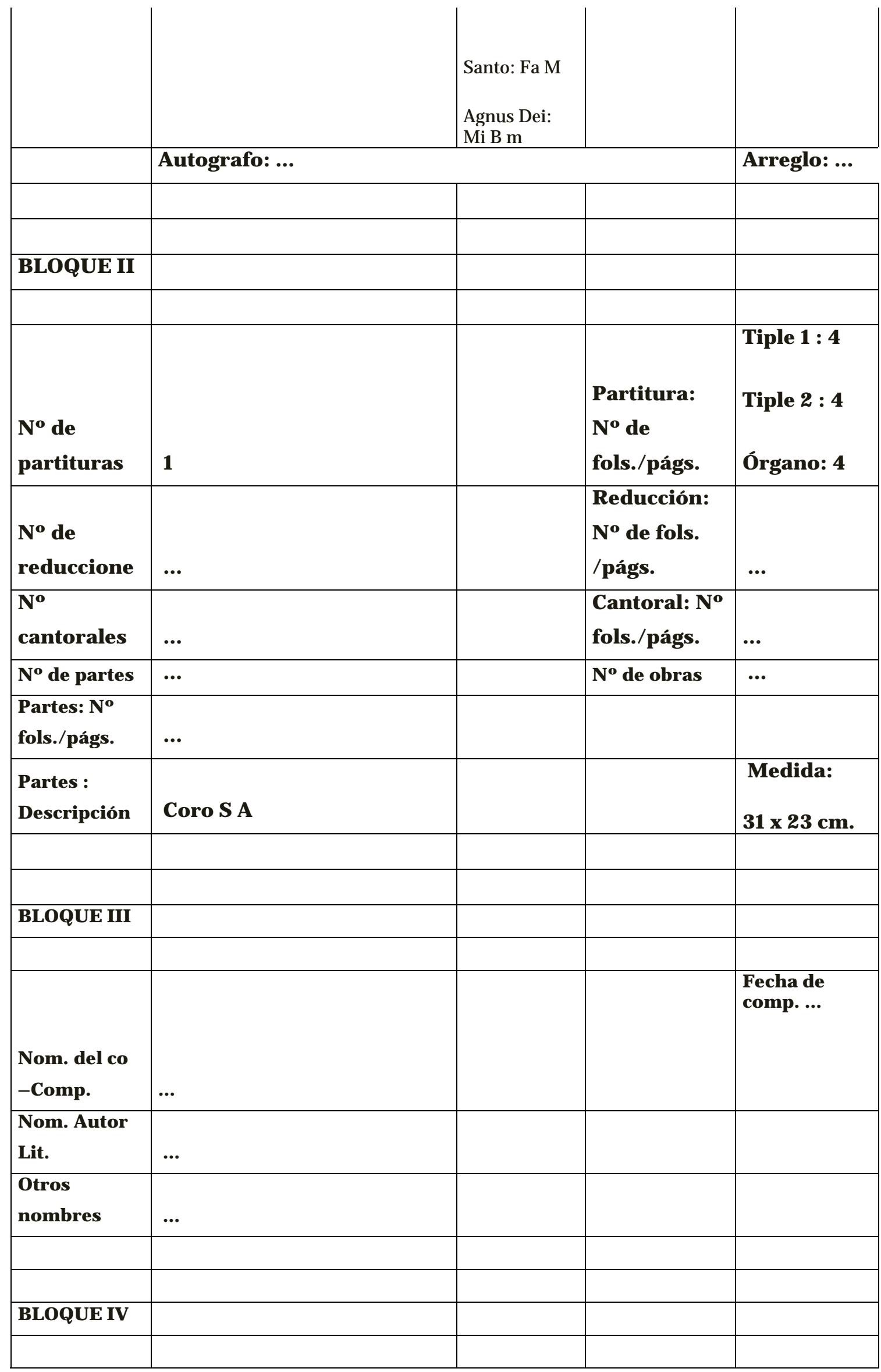




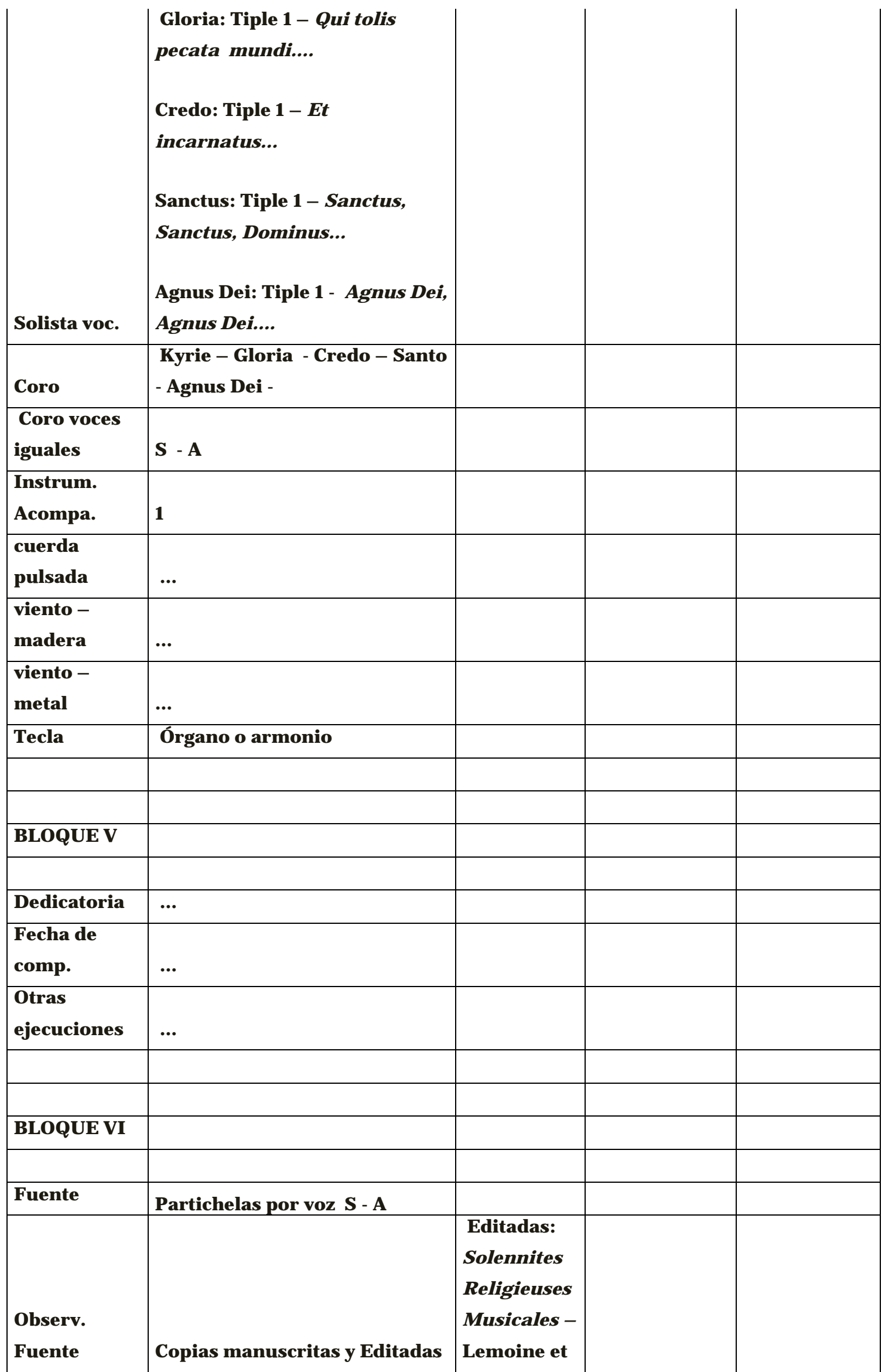




\begin{tabular}{|c|c|c|c|}
\hline & & flis - París. & \\
\hline $\begin{array}{l}\text { Procedenc. } \\
\text { Fuente }\end{array}$ & ASMD. Alba de Tormes & & \\
\hline $\begin{array}{l}\text { Biblioteca o } \\
\text { Arch. }\end{array}$ & ASMD. Alba de Tormes & & \\
\hline BLOQUE VII & & & \\
\hline $\begin{array}{l}\text { Incipit: } \\
\text { Orden } \\
\text { numér. }\end{array}$ & V.3/1 & & $\begin{array}{l}\text { Incipit - } \\
\text { Voz/Instrum. }\end{array}$ \\
\hline $\begin{array}{l}\text { Incipit: } \\
\text { personaje }\end{array}$ & $\ldots$ & & $\begin{array}{l}\text { Incipit - } \\
\text { Epígrafe: ... }\end{array}$ \\
\hline $\begin{array}{l}\text { Incipit: } \\
\text { tempo }\end{array}$ & Andantino & & Incipit: clave \\
\hline $\begin{array}{l}\text { Incipit: } \\
\text { Tonalidad }\end{array}$ & 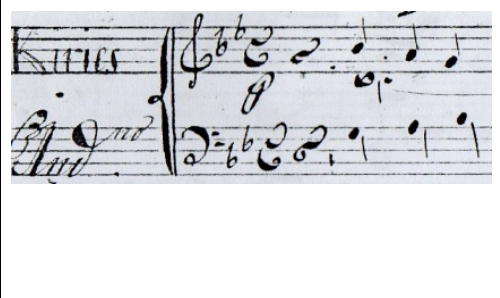 & & $\begin{array}{l}\text { Incipit: } \\
\text { Compás: } 4 / 4\end{array}$ \\
\hline $\begin{array}{l}\text { Incipit } \\
\text { musical }\end{array}$ & 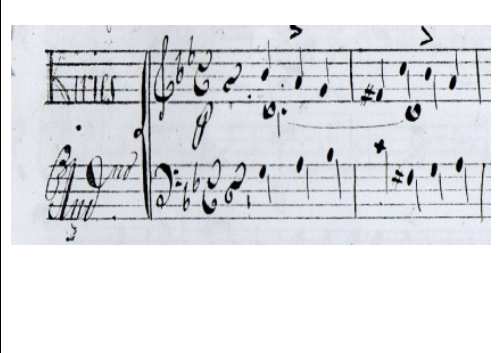 & & \\
\hline
\end{tabular}

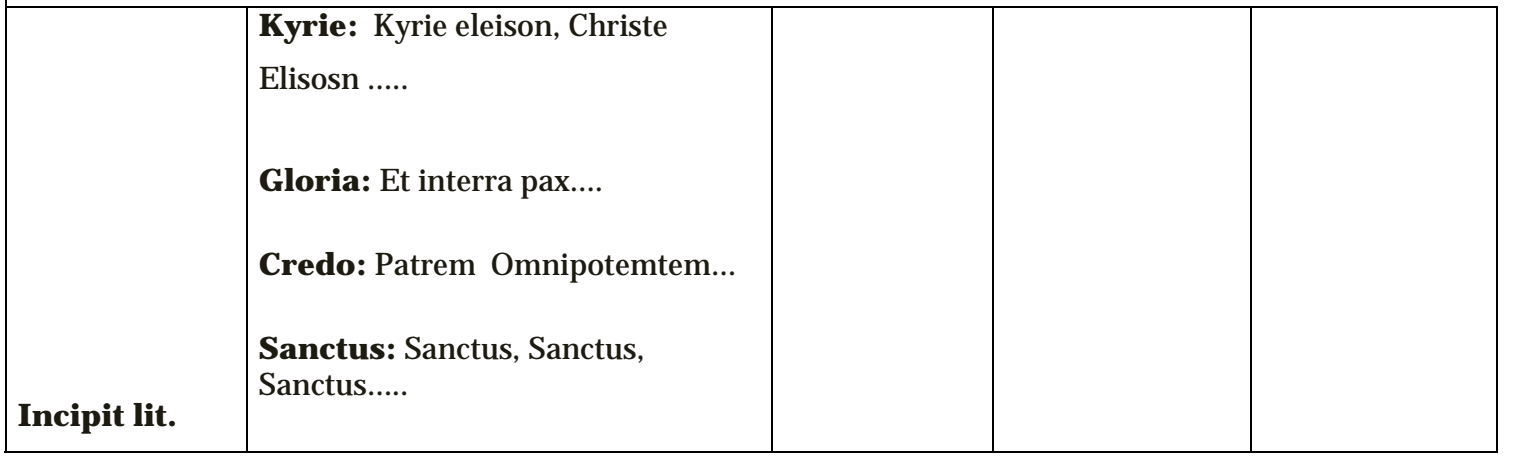




\begin{tabular}{|l|l|l|l|l|}
\hline & $\begin{array}{l}\text { Benedictus: Benedictus qui } \\
\text { venit... } \\
\text { Agnus Dei: Agnus Dei qui tolis... }\end{array}$ & & & \\
& & & & \\
\hline $\begin{array}{l}\text { Incipit sacro. } \\
\text { Lat. }\end{array}$ & $\ldots$ & & & \\
\hline & & & & \\
\hline
\end{tabular}

\section{V.3.1. MISAS}

\section{F ICHA № 2}

\section{MISA (a tres voces solistas y coro) IGNACIO BASTIDA CHIC}

Perteneció a una familia de renombrados músicos, compuesta por Antonio, su padre, y sus hermanos Antonio y Luciano. El 27 de febrero de 1856, Antonio (hijo), organista de la Catedral de Salamanca, solicita al Cabildo, que se nombre a su hermano Ignacio como "segundo organista"; el Cabildo accede a ello, pero sin determinar el sueldo, vista las circunstancias económicas difíciles, de despojo de todos los bienes en que se vio sumida la Iglesia en su momento, por parte del Gobierno. Más adelante, solicitando el músico "dos o tres reales diarios" el Cabildo le nombra en el cargo, pagándole solo "dos reales y medio", para desempeñar varias funciones, entre ellas:

- Desempeñar el contralto en las obras que fuese necesario

- Regir o llevar la batuta en las Misas

- Dirigir la Escuela de Música poniendo a toda brevedad, en disposición de cantar a los que manifiesten voz y a los que no la tengan o la pierdan, dar instrucción de violín, violonchello y trompa

- Y en concepto de segundo organista suplir al primero en ausencias y enfermedades.

- Entre sus obras están: Caminemos a Belén (Vill. 4v y órg.), Letanías a la Virgen (3v y órg.), Misa (3v, fl.bajo, órg.), Misa (3v, cl, crn, bd, cb) 
Ignacio Bastida Chic, pasó de organista a la ciudad de Coria; desde ahí envió a su hermano Antonio, el villancico que se describe entre sus obras y que está fechado en 1878255.

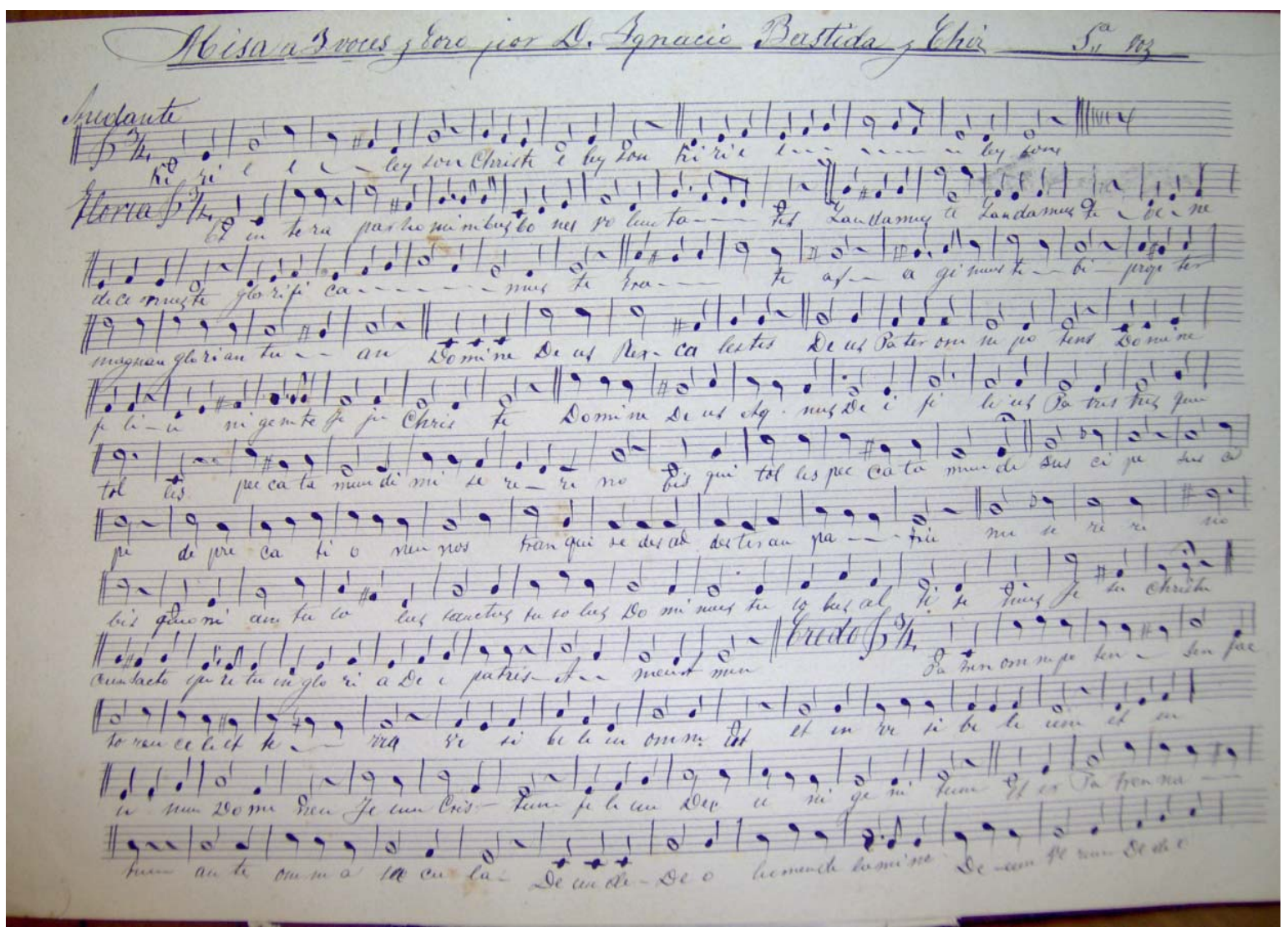

ASMD. Manuscrito de la primera página de la Misa de Ignacio Bastida Ch.

255 Estos datos fueron recogidos de CASARES RODICIO, Emilio. Diccionario de la música española e hispanoamericana, v. II. Madrid: SGAE/ ICCMU, 1999, pp. 284-85. 


\section{MISA}

A tres voces femeninas

IGNACIO BASTIDAS CHIC

\begin{tabular}{|c|c|c|c|c|}
\hline & $\begin{array}{l}\text { FICHA DE CATALOGACIÓN DE } \\
\text { OBRAS MUSICALES }\end{array}$ & & & \\
\hline \multicolumn{5}{|l|}{ BLOQUE I } \\
\hline Comp. Norm. & BASTIDA CHIC, Ignacio & & & \\
\hline Tit. Uniforme & MISA & & & \\
\hline $\begin{array}{l}\text { Comp. Norm. } \\
\text { Arch. }\end{array}$ & BASTIDA Y CHIC, Ignacio & & & \\
\hline & & & & Fechas: \\
\hline Título propio & MISA A TRES VOCES Y CORO & & & $\cdots$ \\
\hline $\begin{array}{l}\text { Forma mus. } \\
\text { Dipl. }\end{array}$ & $\ldots$ & & & $\begin{array}{l}\text { Forma mus. } \\
\text { Normal } \\
\text { MISA (5 partes) }\end{array}$ \\
\hline № opus & $\ldots$ & $\begin{array}{l}\text { Tonalidad } \\
\text { de la obra: } \\
\text { DO M }\end{array}$ & DO M & \\
\hline & Autografo: ... & & & Arreglo: ... \\
\hline BLOQUE II & & & & \\
\hline $\begin{array}{l}\text { No de } \\
\text { partituras }\end{array}$ & 1 & & $\begin{array}{l}\text { Partitura: № de } \\
\text { fols./págs. }\end{array}$ & 7 \\
\hline $\begin{array}{l}\text { № de } \\
\text { reducciones }\end{array}$ & 3 & & $\begin{array}{l}\text { Reducción: № de } \\
\text { fols. / págs. }\end{array}$ & $\begin{array}{l}1 \mathrm{a} \text { voz }=3 \text { fols. } \\
2^{\mathrm{a}} \text { voz }=2 \\
\text { fols. } \\
3^{\mathrm{a}} \text { voz }=2 \text { fols. }\end{array}$ \\
\hline № cantorales & $\ldots$ & & $\begin{array}{l}\text { Cantoral: № } \\
\text { fols./págs. }\end{array}$ & $\ldots$ \\
\hline
\end{tabular}




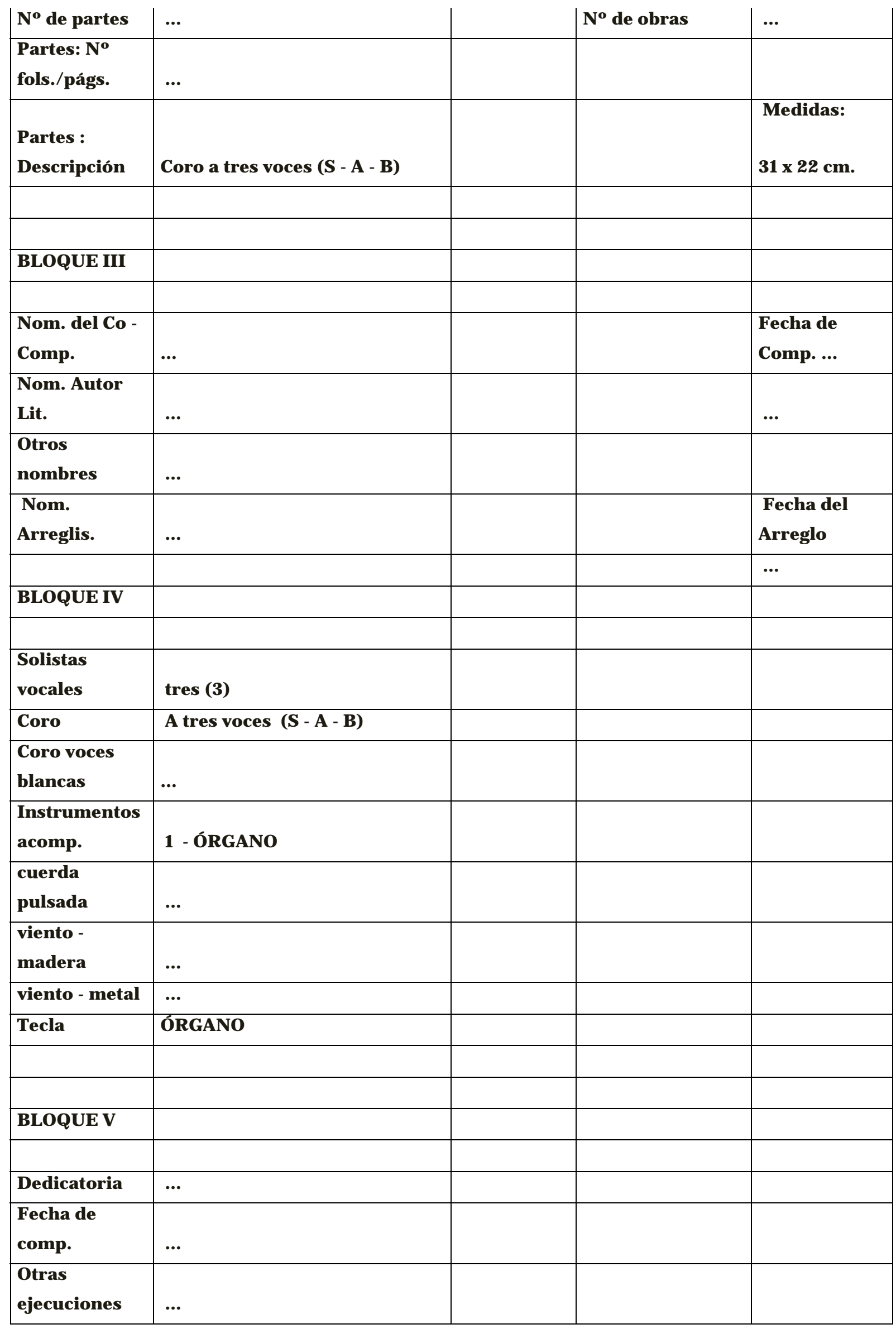




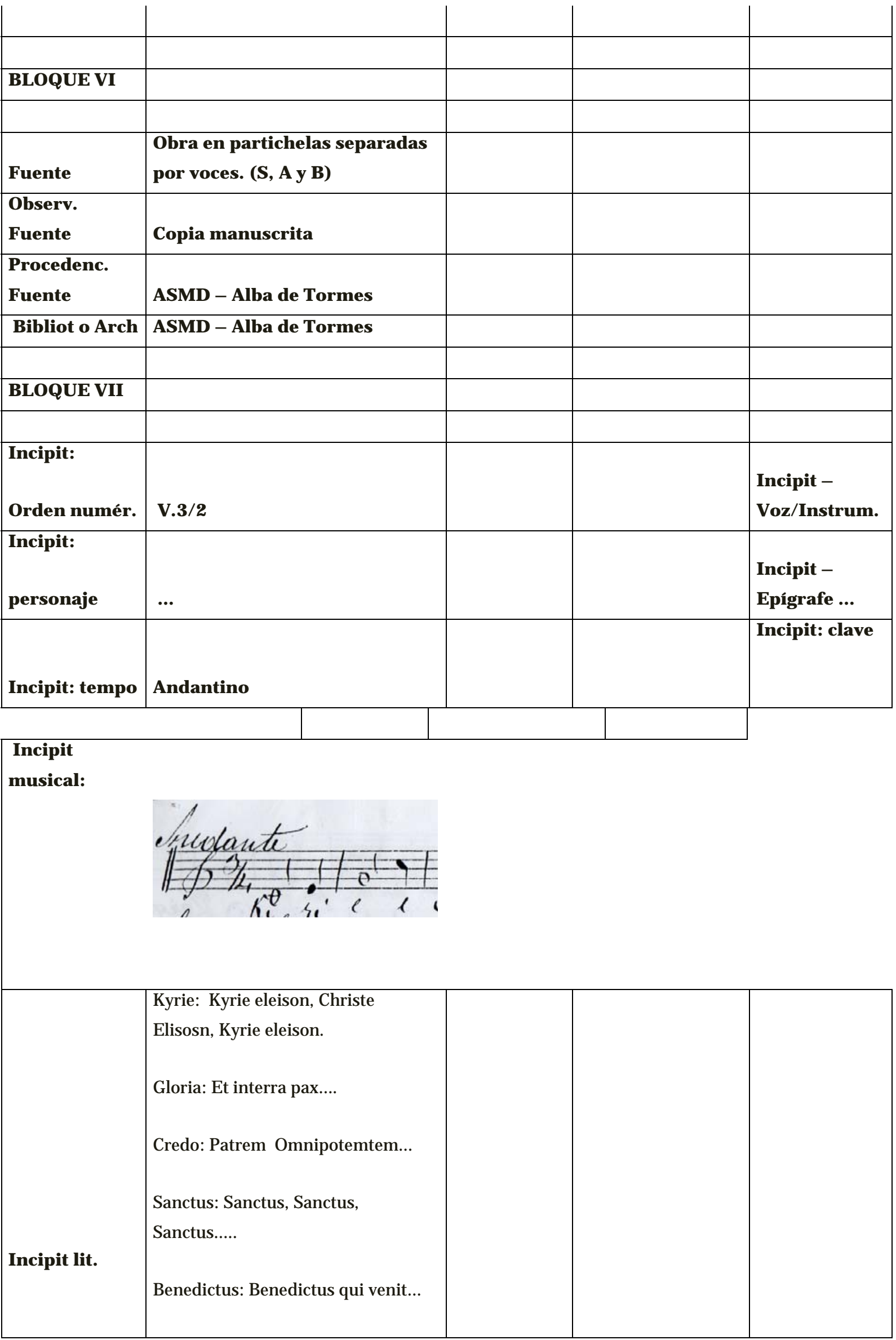




\begin{tabular}{|l|l|l|l|l|}
\hline & Agnus Dei: Agnus Dei qui tolis... & & & \\
\hline $\begin{array}{l}\text { Incipit sacro. } \\
\text { Lat. }\end{array}$ & $\ldots$ & & & \\
\hline & & & & \\
\hline
\end{tabular}

FICHA № 3

MISA A DOS VOCES IGUALES

Por: A. DIERREX

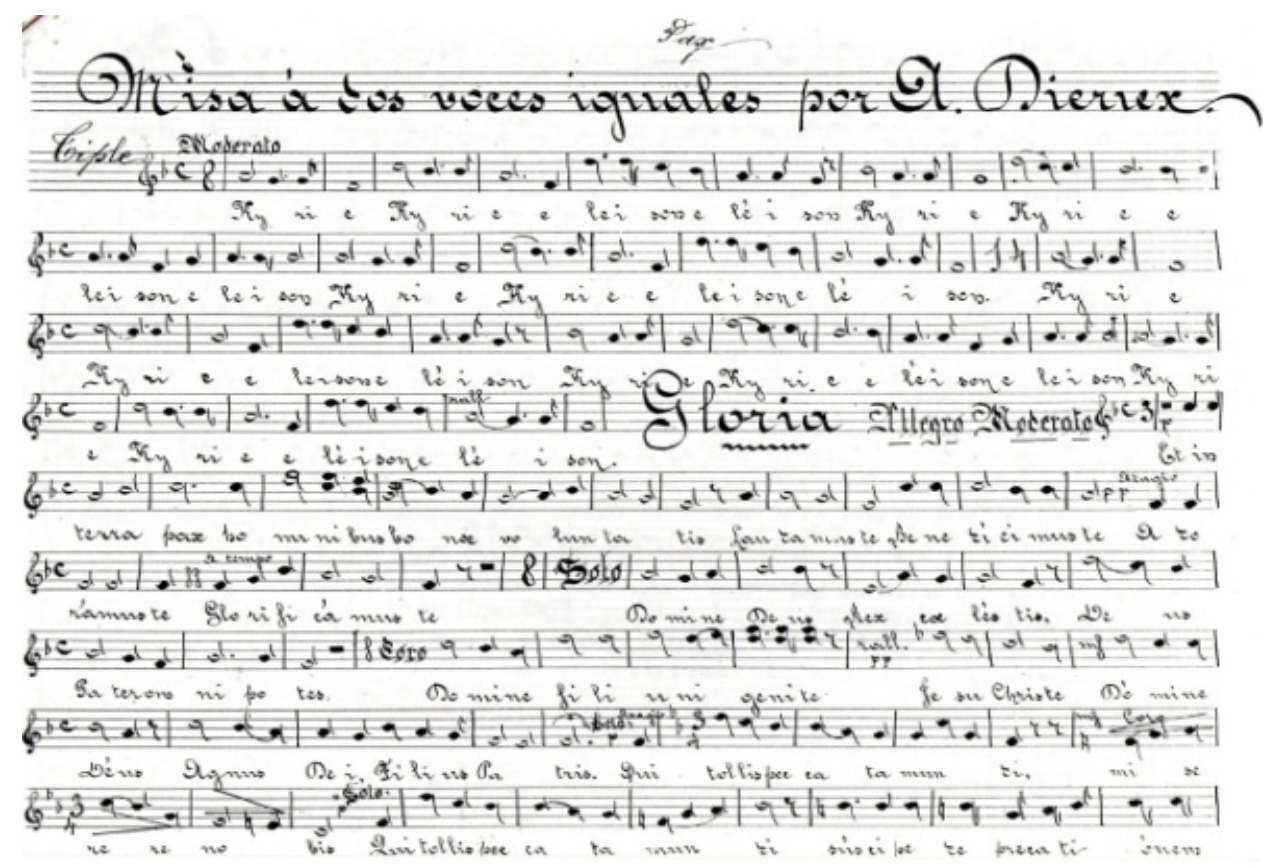

ASMD. Misa a dos voces por A. Dierrex 
MISA

A dos voces iguales

A. DIERREX

\begin{tabular}{|c|c|c|c|c|}
\hline & $\begin{array}{l}\text { FICHA DE CATALOGACIÓN DE } \\
\text { OBRAS MUSICALES }\end{array}$ & & & \\
\hline \multicolumn{5}{|l|}{ BLOQUE I } \\
\hline \begin{tabular}{|l|} 
Comp. \\
Norm.
\end{tabular} & DIERREX, A. & & & \\
\hline \begin{tabular}{|l|} 
Tit. \\
Uniforme
\end{tabular} & MISA a dos voces iguales & & & \\
\hline \begin{tabular}{|l|} 
Comp. \\
Norm. Arch.
\end{tabular} & DIERREX, A. & & & \\
\hline $\begin{array}{l}\text { Título } \\
\text { propio }\end{array}$ & MISA a dos voces iguales & & & Fechas: ... \\
\hline $\begin{array}{l}\text { Forma mus. } \\
\text { Dipl. }\end{array}$ & Misa (5 partes) & & & $\begin{array}{l}\text { Forma mus. } \\
\text { Normal: } \\
\text { Misa }\end{array}$ \\
\hline \multirow[t]{3}{*}{ № opus } & ... & $\begin{array}{l}\text { Tonalidad } \\
\text { de la obra }\end{array}$ & FA M & \\
\hline & \multicolumn{3}{|l|}{ Autografo: ... } & Arreglo: ... \\
\hline & & & Datación: & $\ldots$ \\
\hline BLOQUE II & & & & \\
\hline \begin{tabular}{|l|} 
No de \\
partituras
\end{tabular} & $\mathbf{1}$ & & $\begin{array}{l}\text { Partitura: № } \\
\text { de fols./págs. }\end{array}$ & 4 \\
\hline \begin{tabular}{|l|} 
No de \\
reducciones
\end{tabular} & $\mathbf{1}$ & & $\begin{array}{l}\text { Reducción: № } \\
\text { de fols. / págs. }\end{array}$ & 4 \\
\hline \begin{tabular}{|l|} 
No \\
cantorales
\end{tabular} & $\ldots$ & & $\begin{array}{l}\text { Cantoral: № } \\
\text { fols./págs. }\end{array}$ & $\ldots$ \\
\hline \begin{tabular}{|l|} 
№ de partes \\
\end{tabular} & 5 & & № de obras & $\ldots$ \\
\hline \begin{tabular}{|l} 
Partes: № \\
fols./págs.
\end{tabular} & 4 & & & \\
\hline
\end{tabular}




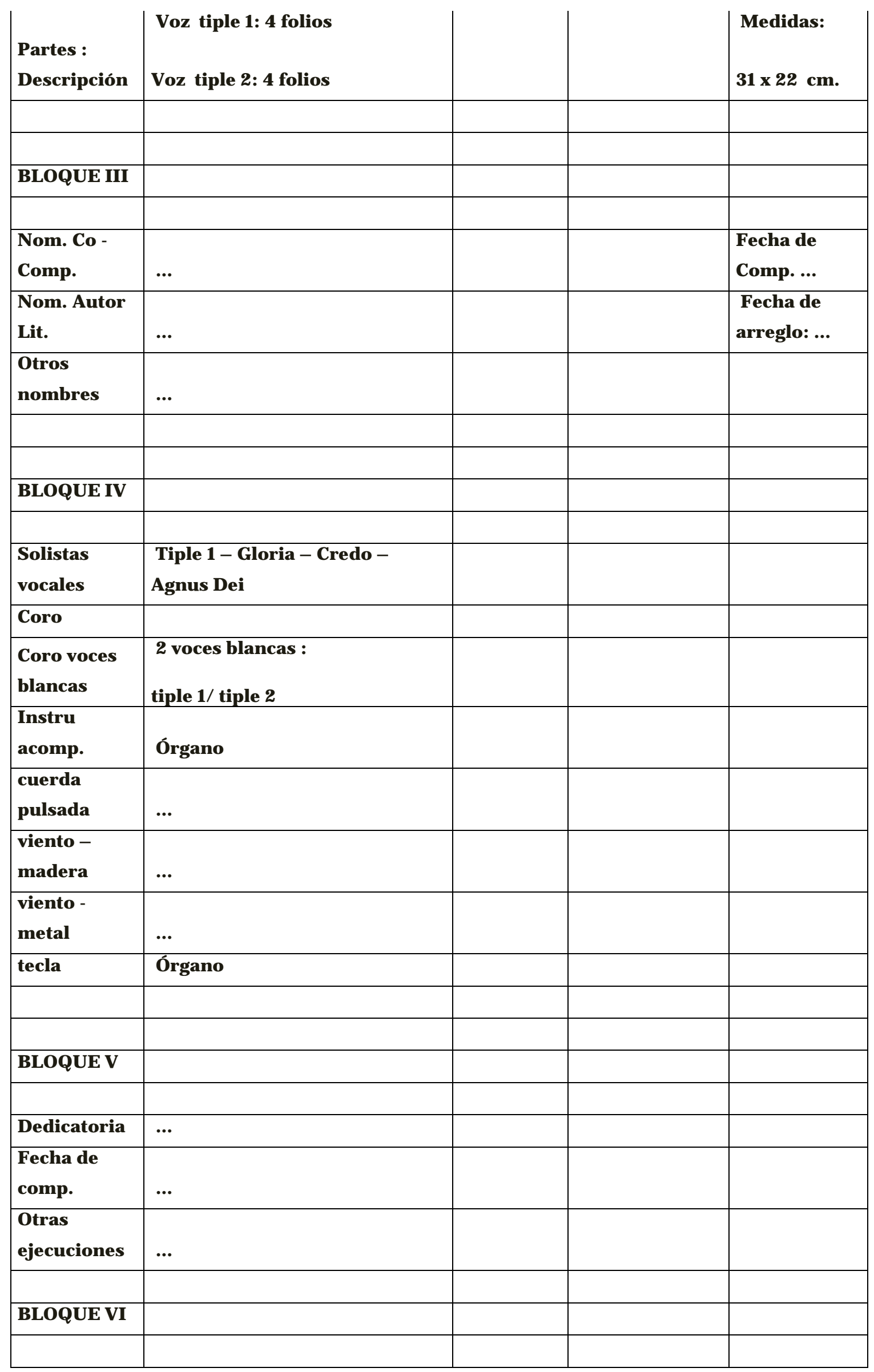




\begin{tabular}{|c|c|c|c|}
\hline Fuente & Partitura & & \\
\hline $\begin{array}{l}\text { Observ. } \\
\text { Fuente }\end{array}$ & Copia Manuscrita & & \\
\hline $\begin{array}{l}\text { Procedenc. } \\
\text { Fuente }\end{array}$ & ASMD Alba de Tormes & & \\
\hline $\begin{array}{l}\text { Biblioteca o } \\
\text { Arch. }\end{array}$ & ASMD. Alba de Tormes & & \\
\hline BLOQUE VI] & & & \\
\hline $\begin{array}{l}\text { Incipit: } \\
\text { Orden } \\
\text { numér. }\end{array}$ & V.3/3 & & $\begin{array}{l}\text { Incipit - } \\
\text { Voz/Instrum. }\end{array}$ \\
\hline $\begin{array}{l}\text { Incipit: } \\
\text { personaje }\end{array}$ & & & $\begin{array}{l}\text { Incipit - } \\
\text { Epígrafe }\end{array}$ \\
\hline $\begin{array}{l}\text { Incipit: } \\
\text { tempo }\end{array}$ & Moderato & & Incipit: clave \\
\hline $\begin{array}{l}\text { Incipit: } \\
\text { Tonalidad }\end{array}$ & 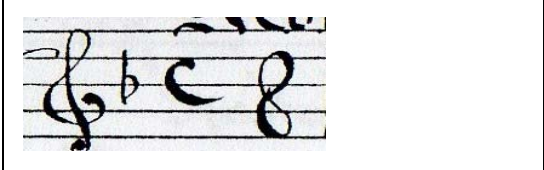 & FA MAYOR & $\begin{array}{l}\text { Incipit - } \\
\text { compás: 4/4 }\end{array}$ \\
\hline $\begin{array}{l}\text { Incipit } \\
\text { Musical: }\end{array}$ & 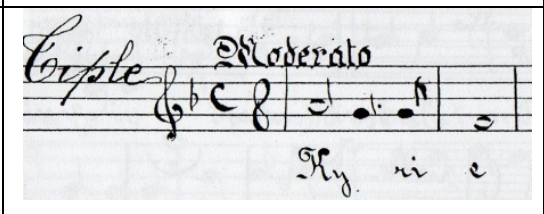 & & \\
\hline Incipit Lit: & $\begin{array}{l}\text { Kyrie: Kyrie eleison, Christe } \\
\text { Elisosn, Kyrie eleison. } \\
\text { Gloria: Et interra pax.... } \\
\text { Credo: Patrem Omnipotemtem... } \\
\text { Sanctus: Sanctus, Sanctus, } \\
\text { Sanctus.... } \\
\text { Benedictus: Benedictus qui venit... } \\
\text { Agnus Dei: Agnus Dei qui toli }\end{array}$ & & \\
\hline $\begin{array}{l}\text { Incipit } \\
\text { sacro. Lat. }\end{array}$ & ... & & \\
\hline
\end{tabular}




\section{V.3.2 VILLANCICOS}

¿Cómo se concibió el Villancico durante los siglos XVIII y XIX? En primer lugar, esta es la época del triunfo definitivo del estilo operístico italiano, el cual se adueña de todos los países europeos. En España sucede lo mismo, y no sólo en el terreno de la ópera y de la zarzuela, sino también en otros géneros, como es el caso del villancico. Frente a la estructura uniforme de coplas y estribillo existente durante los siglos anteriores, los villancicos del siglo XVIII pueden llegar a tener una complejidad tal de secciones que en muchos casos no serán sino una alternancia de recitativos y arias da capo, al estilo de la ópera seria italiana.

\section{FICHA № 4}

\section{ALBRICIAS PASTORES}

De autor desconocido, este es un Villancico a dos voces con acompañamiento de órgano o piano, con un solo para voz tiple.

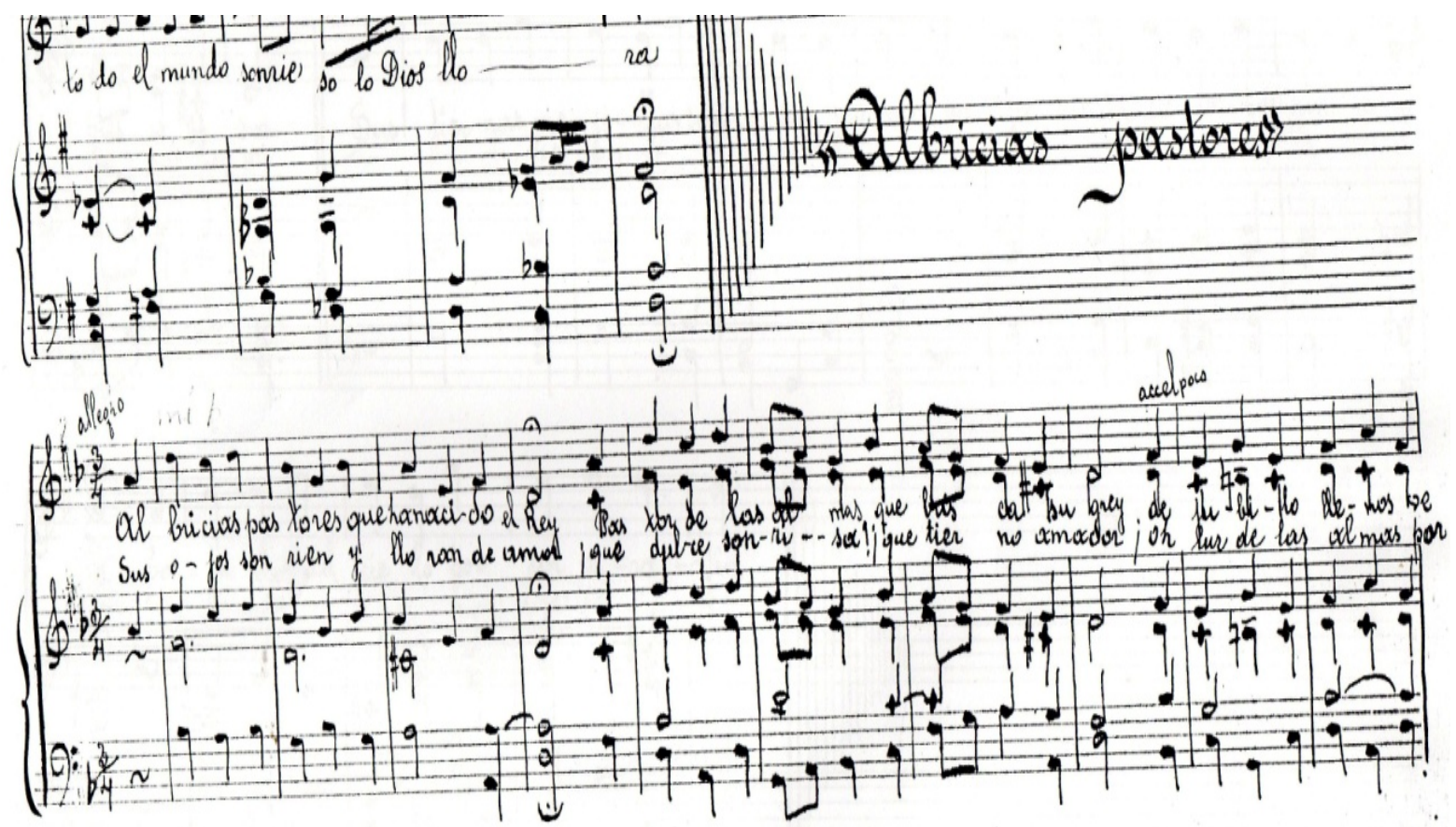

ASMD. Villancico “Albricias pastores" - autor desconocido - folio 1 

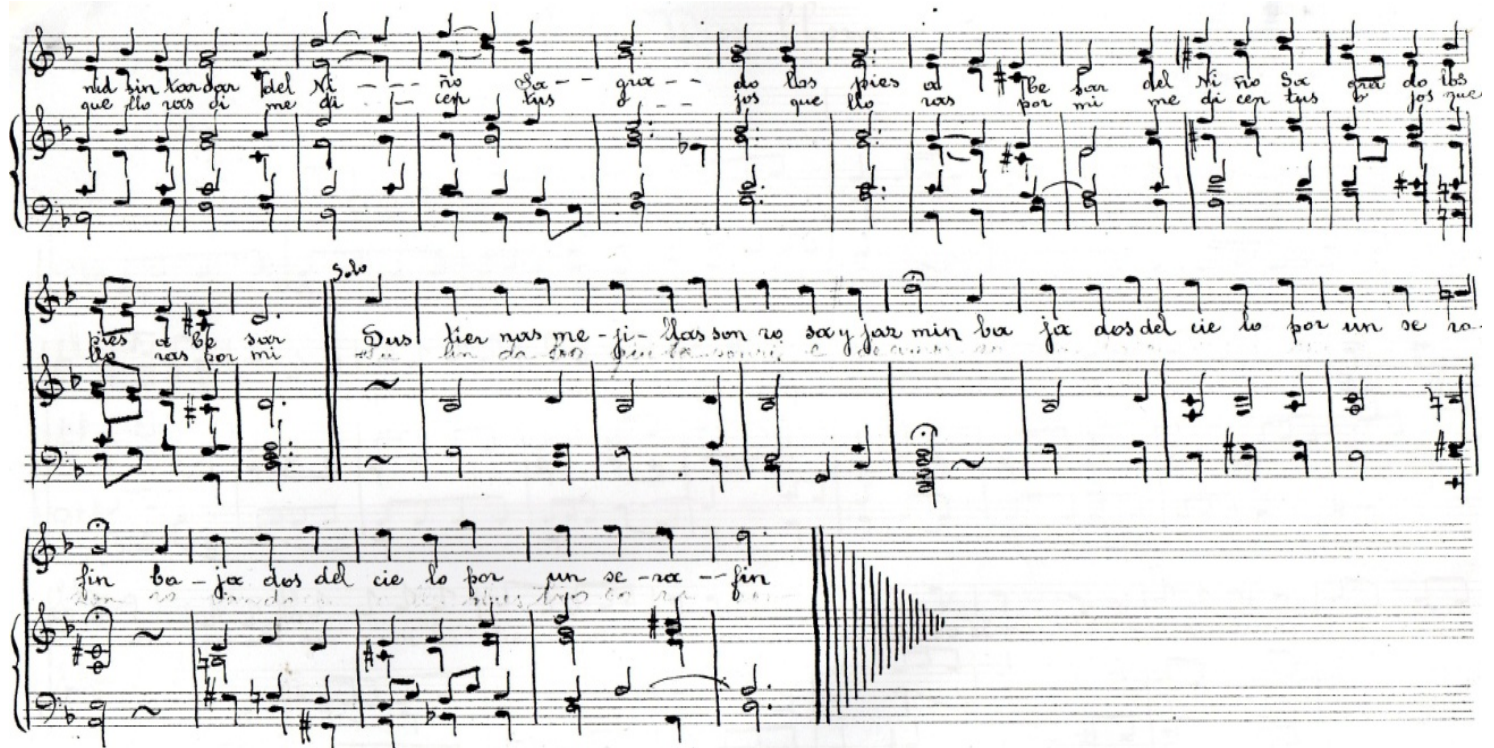

Ibidem - Folio 2

\section{ALBRICIAS PASTORES}

Estrofa

Albricias pastores que ha nacido el Rey

Pastor de las almas que busca su grey

De J úbilo llenos venid sin tardar

Del niño sagrado los pies a besar

Del niño sagrado los pies a besar

Solo:

Sus tiernas mejillas son rosa y jazmín

Bajados del cielo por un serafín

Estrofa

Sus ojos sonríen y lloran de amor

que dulce sonrisa, que tierno amador

Oh! Luz de las almas por qué lloras, dime

dicen tus ojos, que lloras por mí, me dicen tus ojos,

tus ojos que lloras por mí. 
ALBRICIA PASTORES

Villancico - anónimo

\begin{tabular}{|c|c|c|c|c|}
\hline & $\begin{array}{l}\text { FICHA DE CATALOGACIÓN DE } \\
\text { OBRAS MUSICALES }\end{array}$ & & & \\
\hline \multicolumn{5}{|l|}{ BLOQUE I } \\
\hline Comp. Norm. & Autor desconocido & & & \\
\hline Tit. Uniforme & ALBRICIAS PASTORES & & & \\
\hline \multirow[t]{2}{*}{$\begin{array}{l}\text { Comp. Norm. } \\
\text { Arch. }\end{array}$} & Autor desconocido & & & \\
\hline & & & & Fechas: \\
\hline Título propio & $\begin{array}{l}\text { ALBRICIAS PASTORES a dos voces } \\
\text { con acompañamiento de piano y } \\
\text { solos }\end{array}$ & & & $\ldots$ \\
\hline $\begin{array}{l}\text { Forma mus. } \\
\text { Dipl. }\end{array}$ & Tono: menor & & & $\begin{array}{l}\text { Forma mus. } \\
\text { Normal: } \\
\text { Villancico - } \\
\text { Estrofa I- } \\
\text { Solo - Estrofa } \\
\text { II }\end{array}$ \\
\hline \multirow[t]{2}{*}{ № opus } & $\ldots$ & $\begin{array}{l}\text { Tonalidad } \\
\text { de la obra }\end{array}$ & Re menor & \\
\hline & \multicolumn{3}{|l|}{ Autografo: ... } & Arreglo:... \\
\hline BLOQUE II & & & & \\
\hline $\begin{array}{l}\text { No de } \\
\text { partituras }\end{array}$ & 1 & & $\begin{array}{l}\text { Partitura: No de } \\
\text { fols./págs. }\end{array}$ & 2 \\
\hline $\begin{array}{l}\text { No de } \\
\text { reducciones }\end{array}$ & $\ldots$ & & $\begin{array}{l}\text { Reducción: № } \\
\text { de fols. / págs. }\end{array}$ & $\ldots$ \\
\hline № cantorales & $\ldots$ & & $\begin{array}{l}\text { Cantoral: № } \\
\text { fols./págs. }\end{array}$ & $\ldots$ \\
\hline
\end{tabular}




\begin{tabular}{|c|c|c|c|c|}
\hline № de partes & 2 & & | № de obras & ... \\
\hline $\begin{array}{l}\text { Partes: № } \\
\text { fols./págs. }\end{array}$ & 2 & & & \\
\hline $\begin{array}{l}\text { Partes : } \\
\text { Descripción }\end{array}$ & Dos folios & 1-2 & & $\begin{array}{l}\text { Medidas: } \\
31 x 22 \mathrm{~cm} .\end{array}$ \\
\hline \multicolumn{5}{|l|}{ BLOQUE III } \\
\hline $\begin{array}{l}\text { Nom. del co - } \\
\text { Comp. }\end{array}$ & $\ldots$ & & & $\begin{array}{l}\text { Fecha de } \\
\text { Comp... }\end{array}$ \\
\hline $\begin{array}{l}\text { Nom. Autor } \\
\text { Lit. }\end{array}$ & $\ldots$ & & & \\
\hline $\begin{array}{l}\text { Otros } \\
\text { nombres }\end{array}$ & $\ldots$ & & & \\
\hline \multicolumn{5}{|l|}{ BLOQUE IV } \\
\hline $\begin{array}{l}\text { Solistas } \\
\text { vocales }\end{array}$ & Soprano & & & \\
\hline \multicolumn{5}{|l|}{ Coro } \\
\hline $\begin{array}{l}\text { Coro voces } \\
\text { iguales }\end{array}$ & Coro a dos voces Tiple 1-2 & & & \\
\hline $\begin{array}{l}\text { Instrumentos } \\
\text { acomp. }\end{array}$ & $\mathbf{1}$ & & & \\
\hline $\begin{array}{l}\text { cuerda } \\
\text { pulsada }\end{array}$ & $\ldots$ & & & \\
\hline $\begin{array}{l}\text { viento - } \\
\text { madera }\end{array}$ & $\ldots$ & & & \\
\hline viento - metal & $\ldots$ & & & \\
\hline tecla & Piano & & & \\
\hline BLOQUE V & & & & \\
\hline Dedicatoria & $\ldots$ & & & \\
\hline Fecha de & $\ldots$ & & & \\
\hline
\end{tabular}




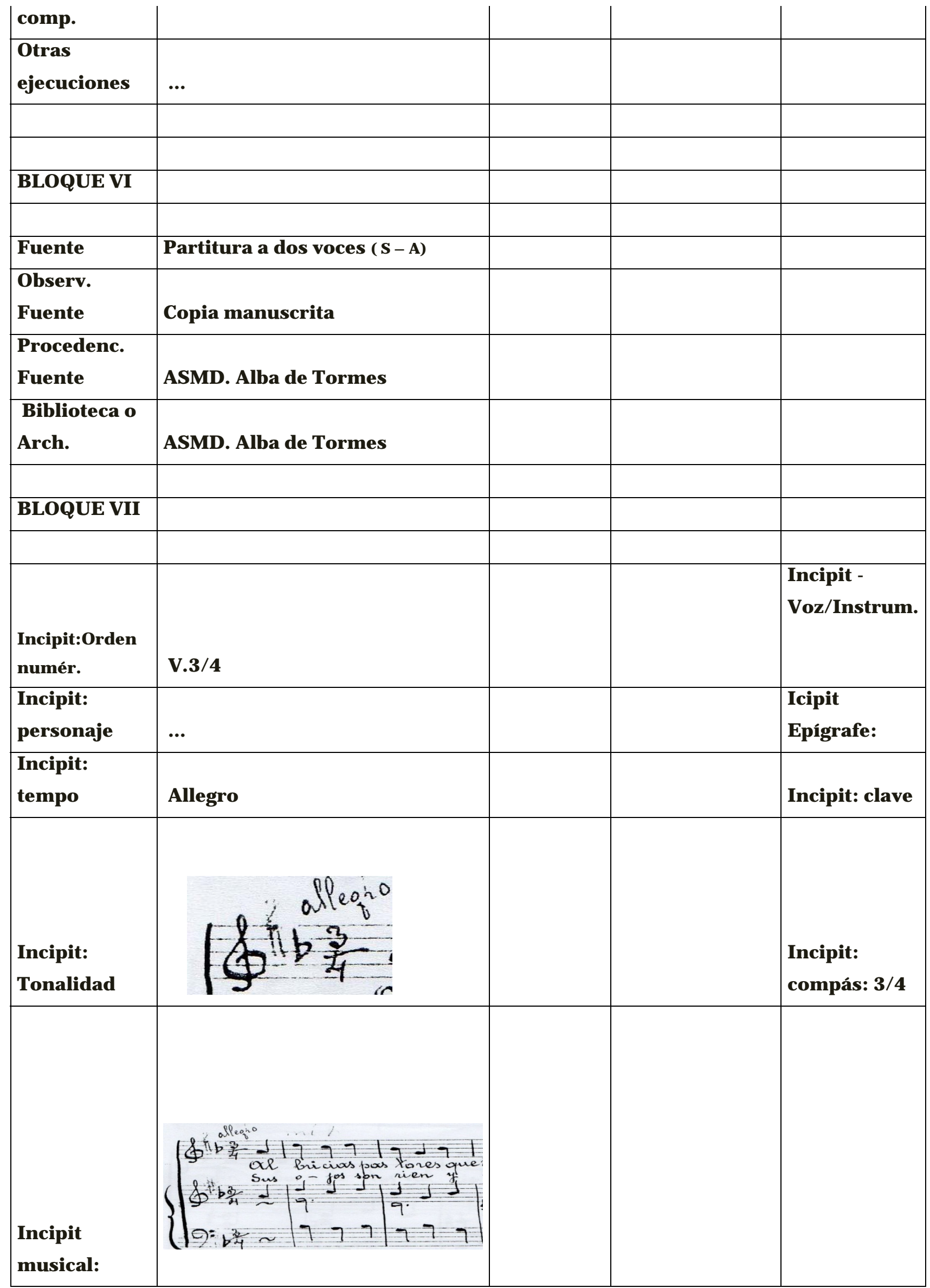




\begin{tabular}{|l|l|l|l|l|} 
& & & \\
\hline Incipit liter & $\begin{array}{l}\text { Albricias pastores que ha nacido } \\
\text { el Rey...... }\end{array}$ & & & \\
\hline Incipit & & & & \\
sacro. Lat. & $\ldots$ & & & \\
\hline & & & & \\
\hline
\end{tabular}

\section{FICHA № 5}

\section{VILLANCICO - AL NACIMIENTO DE NUESTRO SEÑOR J ESUCRISTO}

\section{A dos o tres voces con acompañamiento de piano u órgano por $\mathrm{S}$. Rosado.}

Rosado Santos Luís Gonzaga, natural de Ávila, nacido el 1 de noviembre de 1814 En 1822, su padre solicitó al Cabildo, se lo admitiese como mozo del Coro, pero no le fue concedida su petición, por la mala situación económica. Pero fue admitido el 7 de enero de 1824, una vez que fueron devueltas a la Catedral sus posesiones, tras la desamortización. Tras el cambio de voz en 1831, continuó su vinculación con la Catedral, como tenor. En 1833 fue nombrado salmista. Sucesivamente, aparece como: Capellán, salmista y bajo del Coro. Termina su vinculación con la Catedral de Ávila y más adelante, con el envío de una Misa al Cabildo, aparece como MC de la Encarnación de Madrid, uno de los más altos y estimados puestos de toda España. Entre sus obras se destacan:

- Alavado T1 - T- ÓRG. O P

- Gozos al Patriarca San J osé VV, órg o p

- Himno (para cuando toman el hábito las religiosas)

- Motete al Santísimo VV y p

- Villancico al nacimiento de Nuestro Señor J esucristo $3 \mathrm{v}$ - órg o p

- Ofertorio a la Natividad de Nuestro Señor J esucristo VV fl. Cl. Cb. Órg

- Trisagio a la Sma. Virgen María 2v y órg

- Misa de Difuntos 4v, arm. Imp.

- OH admirable 6 v, vnsfl. Cls. Tps. Fg. Vl.cb. 
Estos datos fueron recogidos del Diccionario de la música española e hispanoamericana. CASARES RODICIO, Emilio. Sociedad general de autores y editores. Madrid. 1999. Tomo IX, p. 418.

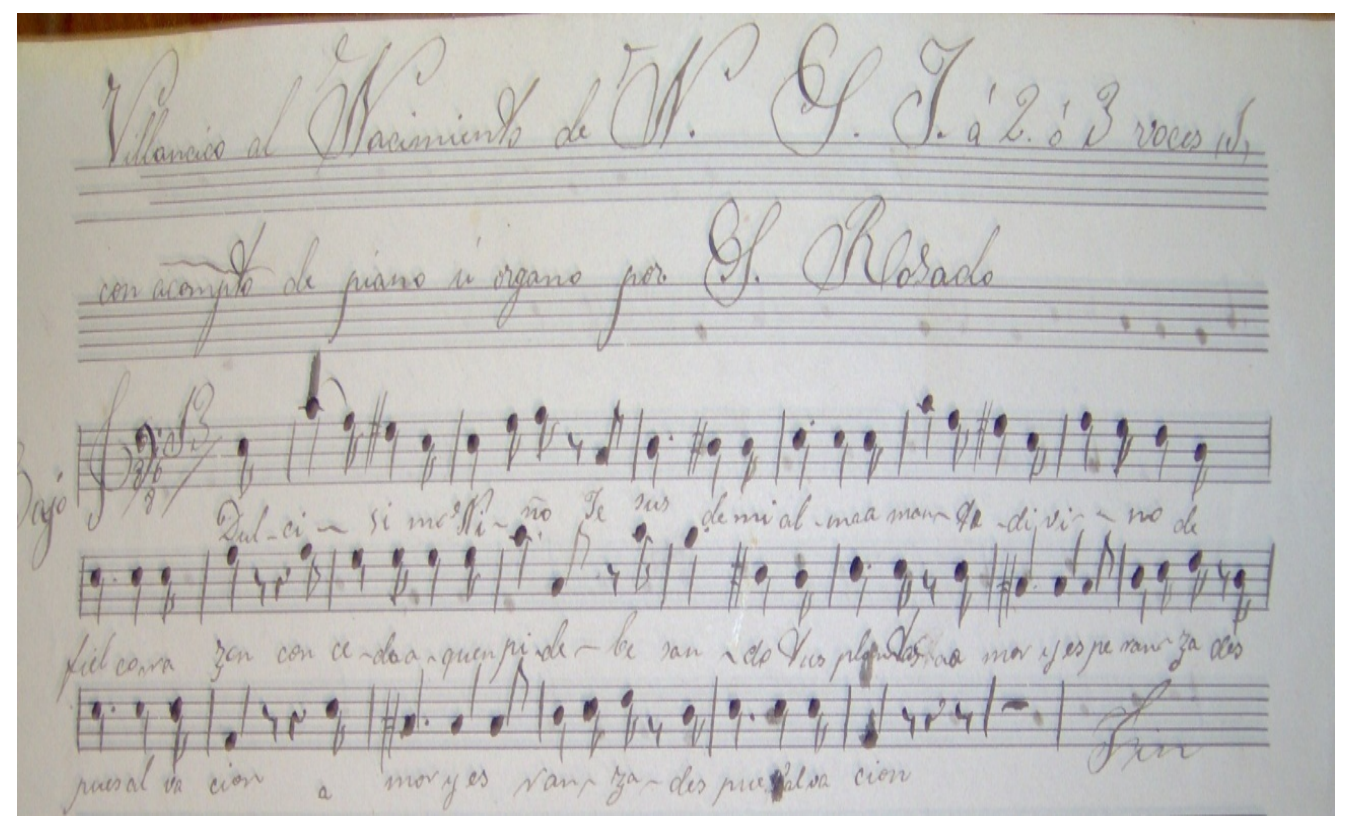

ASMD. “Al Nacimiento de Nuestro Señor J esucristo” de S. Rosado.

\section{AL NACIMIENTO DE NUESTRO SEÑOR J ESUCRISTO}

\section{Dulcísimo Niño J esús}

de mi alma amor divino

de fiel corazón concede al que pide

besando tus plantas, amor y esperanza, después salvación amor y esperanza, después salvación 
AL NACIMIENTO DE NUESTRO SEÑOR J ESUCRISTO

Villancico por S. ROSADO

\begin{tabular}{|c|c|c|c|c|}
\hline & $\begin{array}{l}\text { FICHA DE CATALOGACIÓN DE } \\
\text { OBRAS MUSICALES }\end{array}$ & & & \\
\hline & & & & \\
\hline \multirow{2}{*}{\multicolumn{5}{|c|}{ BLOQUE I }} \\
\hline & & & & \\
\hline Comp. Norm. & S. ROSADO & & & \\
\hline Tit. Uniforme & $\begin{array}{l}\text { Al nacimiento de Nuestro Señor } \\
\text { J esucristo }\end{array}$ & & & \\
\hline \multicolumn{5}{|l|}{$\begin{array}{l}\text { Comp. } \\
\text { Norm. Arch. }\end{array}$} \\
\hline & & & & $\begin{array}{l}\text { Fechas: * } 1814 \\
\text { Aún en } 1887 \text { se } \\
\text { tiene noticia de } \\
\text { su existencia, } \\
\text { por una Misa } \\
\text { enviada al } \\
\text { Cabildo. Se } \\
\text { desconoce la } \\
\text { fecha de su } \\
\text { fallecimiento. }\end{array}$ \\
\hline Título propio & $\begin{array}{l}\text { Al nacimiento de Nuestro Señor } \\
\text { J esucristo a } 2 \text { o } 3 \text { voces con } \\
\text { acomp. de piano u órgano de S. } \\
\text { ROSADO. }\end{array}$ & & & \\
\hline $\begin{array}{l}\text { Forma mus. } \\
\text { Dipl. }\end{array}$ & Tono: menor & & & $\begin{array}{l}\text { Forma } \\
\text { mus.Normal }\end{array}$ \\
\hline \multirow[t]{3}{*}{ № opus } & $\ldots$ & $\begin{array}{l}\text { Tonalidad } \\
\text { de la obra }\end{array}$ & La menor & Villancico \\
\hline & \multicolumn{3}{|l|}{ Autografo: ... } & Arreglo... \\
\hline & & & & \\
\hline \multicolumn{5}{|l|}{ BLOQUE II } \\
\hline $\begin{array}{l}\text { No de } \\
\text { partituras }\end{array}$ & 1 & & $\begin{array}{l}\text { Partitura: № de } \\
\text { fols./págs. }\end{array}$ & 3 \\
\hline $\begin{array}{l}\text { No de } \\
\text { reducciones }\end{array}$ & 3 & & $\begin{array}{l}\text { Reducción: № de } \\
\text { fols. / págs. }\end{array}$ & 3 \\
\hline № cantorales & $\ldots$ & & $\begin{array}{l}\text { Cantoral: No } \\
\text { fols./págs. }\end{array}$ & $\ldots$ \\
\hline № de partes & $\ldots$ & & № de obras & $\ldots$ \\
\hline
\end{tabular}




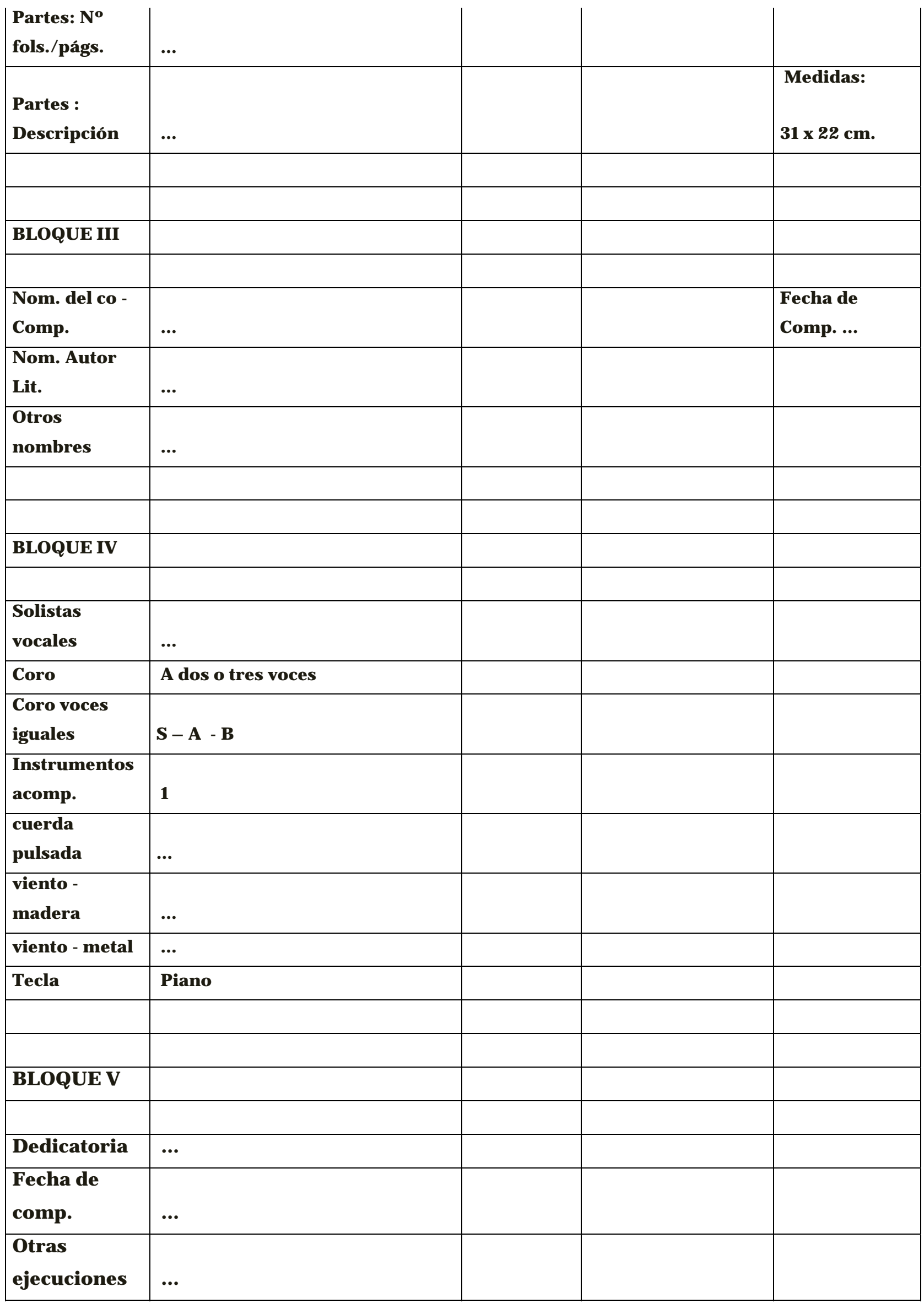




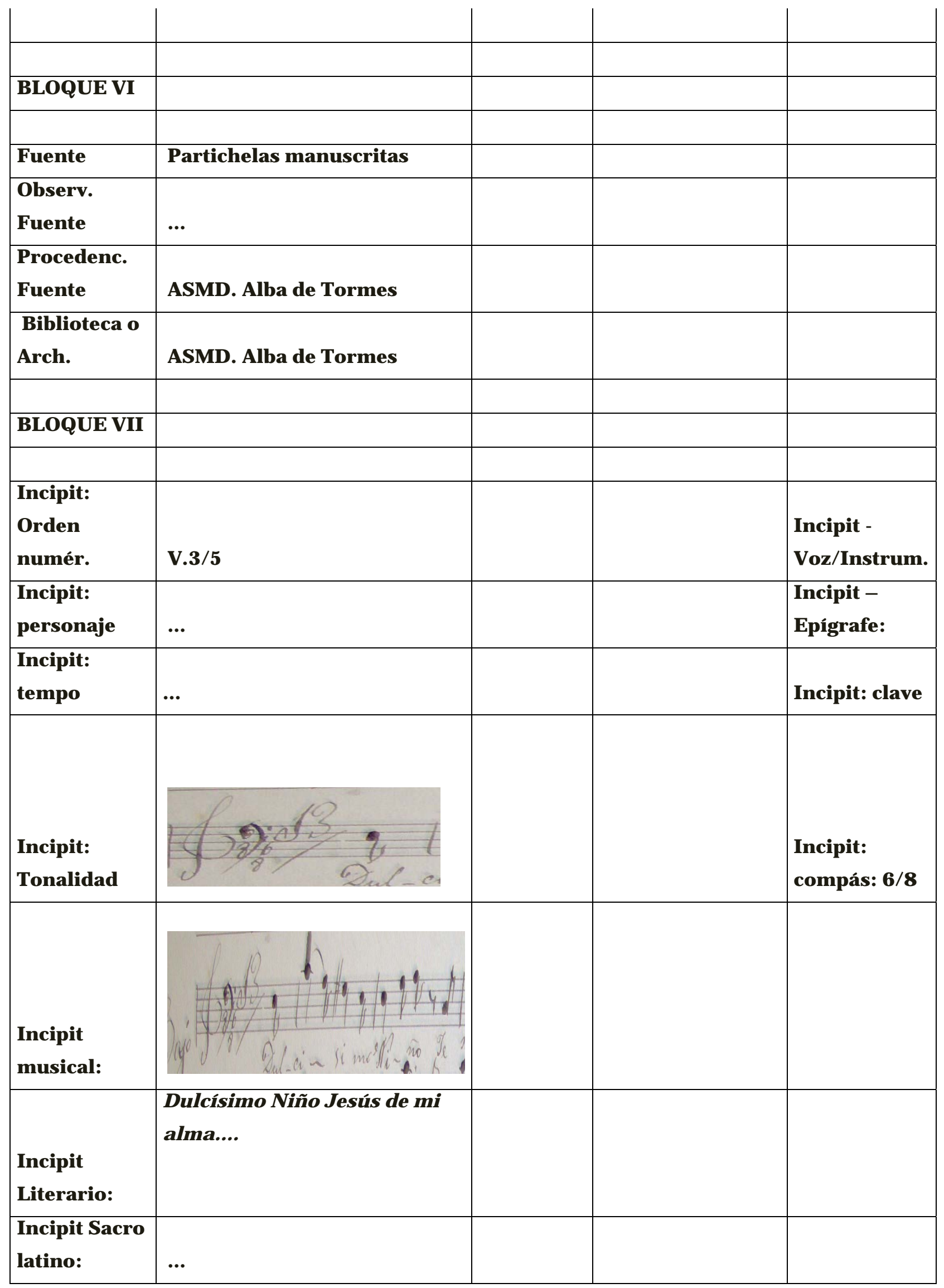




\section{FICHA № 6}

\section{LOS PASTORES - VILLANCICO AL NIÑO J ESÚS por Evaristo Ciria Sanz, Profesor de la Real Capilla de su Majestad.}

EVARISTO CIRIA: Músico de la Corte. Nació en Calatayud (Zaragoza), el 26 de octubre de 1802 y murió el 20 de junio de 1875; cantante, compositor y profesor. Inició sus estudios con el Maestro de la Colegiata de Santa María, Antonio Bastida, a la edad de catorce años. Al cabo de cuatro años fue nombrado contralto de la capilla de Santa María de Calatayud. Cursó estudios de Teología y se ordenó Presbítero en 1827. En 1828, se presentó a la oposición de una plaza de contralto para la Real Capilla de la Reina Isabel II, siendo Maestro de Capilla Hilarión Eslava. Ciria ejercía la voz de Contralto 2oㅡ, sin llegar a ganar la oposición de contralto 1ํ, como nos lo demuestra el Documento de la Guía de la Real Casa y Patrimonio del año 1848.256 El mismo día que recibió el fallo, la Priora del Monasterio de la Encarnaciónde Madrid, le concedió una plaza de contralto, la cual aceptó y ahí permaneció hasta que la Encarnación fue suprimida. Se dedicó entonces a la docencia, siendo profesor de solfeo y canto del Colegio de Nuestra Señora de Loreto. Algunas de sus obras, quedaron en el archivo del citado colegio. Una Misa en pastorela, un Stabat Mater, una Plegaria a la Virgen, -compuesta para sus alumnas; Su línea de composición fue el género sacro, entre los que destacan: Misas, Salmos, Oficios, Villancicos, Misas de Difuntos. Es de explicar cómo funcionó todo un sistema de redes entre Monasterios, Catedrales y Colegios religiosos, redes con las que se logró la difusión de importantes repertorios en la época. Algunas composiciones han sido encontradas por otros investigadores, en diferentes monasterios de España. El Archivo de música de la Catedral de J aén conserva cuatro de los Villancicos para una voz con acompañamiento de órgano - 8 folios en partituras impresas.257 También dedicó tiempo a la construcción de

256 Guía de la Casa Real y Patrimonio. Año 1848. Madrid. Imprenta de Aguado. Universidad Complutense. b1752943 X. R 1968 - 21969. p. 121.

257 ACJ . Catálogo de música del Archivo de la Catedral de J aén. № 1225. B Eslava. 70/ 25 
instrumentos musicales. Finalmente, el día 3 de diciembre de 1843, la Reina lo nombra oficialmente contralto de su Real Capilla.

Algunas de sus obras en los distintos géneros, son:

Coro y acompañamiento:

- Domare Cordis.Ps. 4v. e: Mp;

- El asedio de Tetuán. H.ar. p(SR)

- Himno a SantaIsabel. 4V. E: Mp

- Himno guerrero español H.ar. o p (SR)

Voz y acompañamiento

- Canto del Ángel. V p u órg.

- Cuenta, cuenta pastorcito V p. u órg.

- La gitanilla Vill. Vy p.

- La súplica Vill. Vy p.

- Lamentación Vp. u órg.

- Las dos zagalas VV. Y p. u órg.

- Los pastores Vill. Al Niño J esús.

Estos datos fueron recogidos del Diccionario de la música española e hispanoamericana. CASARES RODICIO, Emilio. Sociedad general de autores y editores. Madrid. 1999. Tomo III, p. 717. 


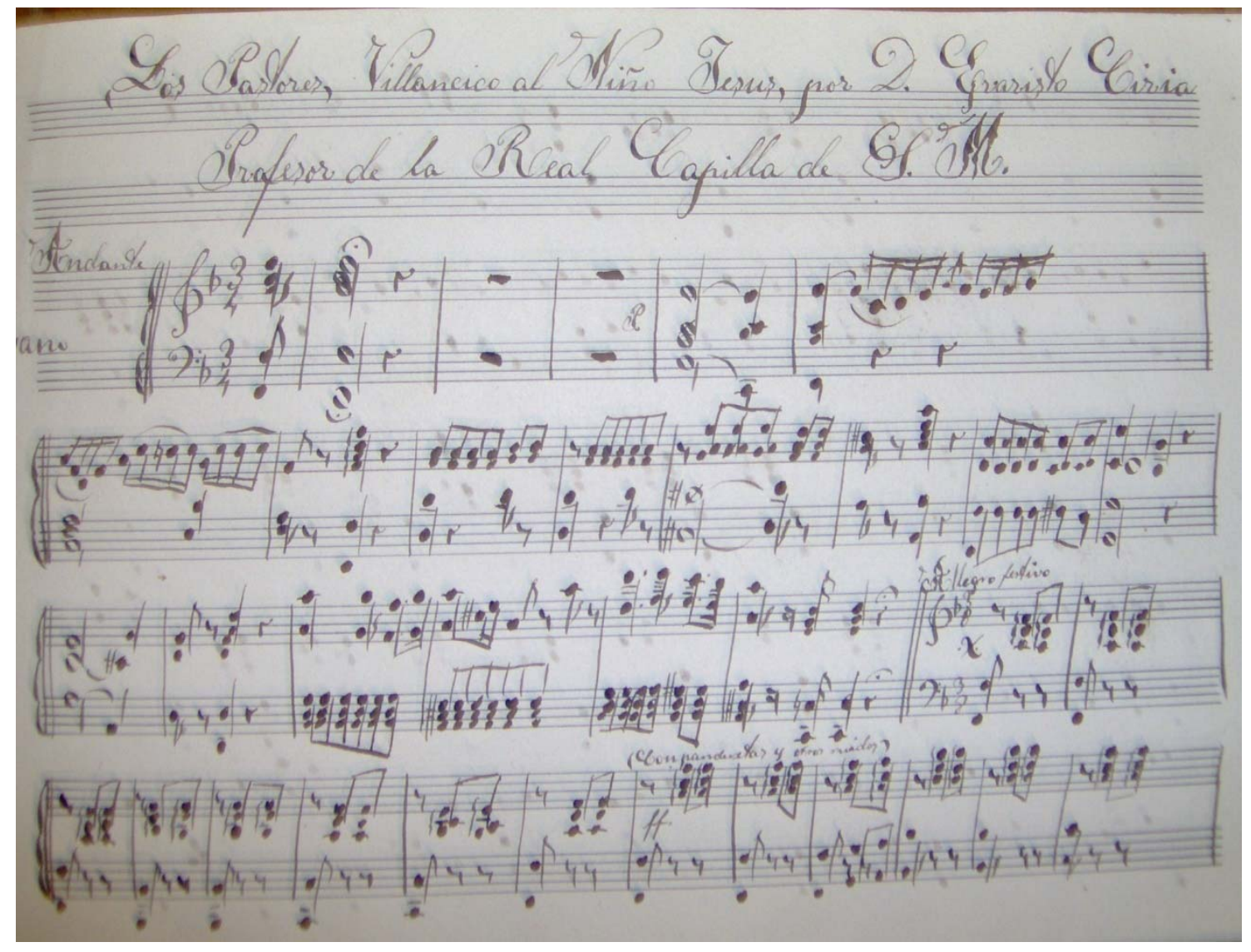

ASMD. Partitura manuscrita del Villancico Los Pastores, Villancico al Niño Jesús por Evaristo Ciria. Parte para órgano. 


\section{LOS PASTORES}

Villancico al Niño J esús

Por Evaristo Ciria

\begin{tabular}{|c|c|c|c|c|}
\hline & $\begin{array}{l}\text { FICHA DE CATALOGACIÓN DE } \\
\text { OBRAS MUSICALES }\end{array}$ & & & \\
\hline BLOQUE I & & & & \\
\hline Comp. Norm. & Ciria, Evaristo & & & \\
\hline Tit. Uniforme & $\begin{array}{l}\text { Los pastores - Villancico al } \\
\text { Niño J esús }\end{array}$ & & & \\
\hline $\begin{array}{l}\text { Comp. Norm. } \\
\text { Arch. }\end{array}$ & $\begin{array}{l}\text { Los Pastores - Villancico al } \\
\text { Niño J esús }\end{array}$ & & & \\
\hline & & & & $\begin{array}{l}\text { Fechas: } 1802 \\
-1875\end{array}$ \\
\hline Título propio & $\begin{array}{l}\text { Los pastores - Villancico al } \\
\text { Niño J esús }\end{array}$ & & & $\ldots$ \\
\hline $\begin{array}{l}\text { Forma mus. } \\
\text { Dipl. }\end{array}$ & 要 & & & 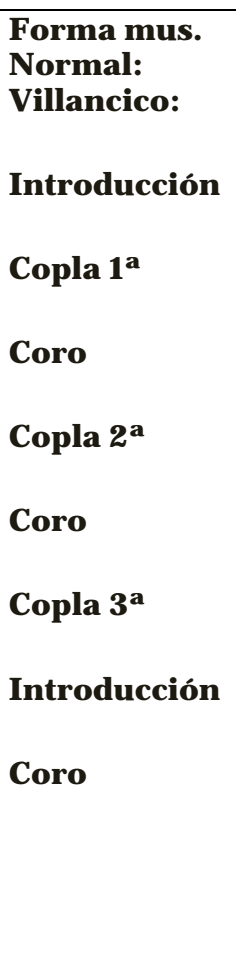 \\
\hline № opus & & Tonalidad de & FA MAYOR & Villancico \\
\hline
\end{tabular}




\begin{tabular}{|c|c|c|c|c|}
\hline & & la obra & & \\
\hline & Autografo: ... & & & Arreglo:... \\
\hline & & & & \\
\hline BLOQUE II & & & & \\
\hline & & & & \\
\hline $\begin{array}{l}\text { № de } \\
\text { partituras }\end{array}$ & 1 & $\begin{array}{l}\text { Instrumental } \\
\text { Piano }\end{array}$ & $\begin{array}{l}\text { Partitura: № de } \\
\text { fols./págs. }\end{array}$ & 5 \\
\hline $\begin{array}{l}\text { № de } \\
\text { reducciones }\end{array}$ & $\ldots$ & & $\begin{array}{l}\text { Reducción: № de } \\
\text { fols. / págs. }\end{array}$ & $\cdots$ \\
\hline № cantorales & $\cdots$ & & $\begin{array}{l}\text { Cantoral: No } \\
\text { fols./págs. }\end{array}$ & $\cdots$ \\
\hline № de partes & & & № de obras & \\
\hline $\begin{array}{l}\text { Partes: № } \\
\text { fols./págs. }\end{array}$ & $\cdots$ & & & \\
\hline $\begin{array}{l}\text { Partes : } \\
\text { Descripción }\end{array}$ & Vocales e intrumental(piano) & & & \begin{tabular}{|l} 
Medidas: \\
$31 x 22 \mathrm{~cm}$.
\end{tabular} \\
\hline BLOQUE III & & & & \\
\hline $\begin{array}{l}\text { Nom. del co - } \\
\text { Comp. }\end{array}$ & $\cdots$ & & & $\begin{array}{l}\text { Fecha de } \\
\text { composición: } \\
\ldots\end{array}$ \\
\hline $\begin{array}{l}\text { Nom. } \\
\text { Autor Lit. }\end{array}$ & $\ldots$ & & & \\
\hline $\begin{array}{l}\text { Otros } \\
\text { nombres }\end{array}$ & $\cdots$ & & & \\
\hline BLOQUE IV & & & & \\
\hline $\begin{array}{l}\text { Solistas } \\
\text { vocales }\end{array}$ & $\begin{array}{l}\text { 1- Copla - S } \\
2^{\text {a Copla - B }} \\
\text { 3" Copla a Dúo }\end{array}$ & & & \\
\hline Coro & $\mathbf{S}-\mathbf{A}-\mathbf{B}$ & & & \\
\hline $\begin{array}{l}\text { Coro voces } \\
\text { blancas }\end{array}$ & $\cdots$ & & & \\
\hline
\end{tabular}




\begin{tabular}{|c|c|c|c|}
\hline $\begin{array}{l}\text { Instrumentos } \\
\text { acomp. }\end{array}$ & $\mathbf{1}$ & & \\
\hline $\begin{array}{l}\text { cuerda } \\
\text { pulsada }\end{array}$ & $\ldots$ & & \\
\hline $\begin{array}{l}\text { viento - } \\
\text { madera }\end{array}$ & $\ldots$ & & \\
\hline viento - metal & $\ldots$ & & \\
\hline tecla & Piano u órgano & & \\
\hline BLOQUE V & & & \\
\hline Dedicatoria & $\ldots$ & & \\
\hline $\begin{array}{l}\text { Fecha de } \\
\text { comp. }\end{array}$ & $\cdots$ & & \\
\hline $\begin{array}{l}\text { Otras } \\
\text { ejecuciones }\end{array}$ & $\ldots$ & & \\
\hline BLOQUE VI & & & \\
\hline Fuente & Copia manuscrita & & \\
\hline $\begin{array}{l}\text { Observ. } \\
\text { Fuente }\end{array}$ & Partichelas por voces & & \\
\hline $\begin{array}{l}\text { Procedenc. } \\
\text { Fuente }\end{array}$ & ASMD. Alba de Tormes & & \\
\hline $\begin{array}{l}\text { Biblioteca } \\
\text { y/o Archivo: }\end{array}$ & ASMD. Alba de Tormes & & \\
\hline BLOQUE VII & & & \\
\hline $\begin{array}{l}\text { Incipit: } \\
\text { Orden } \\
\text { numér. }\end{array}$ & V.3/6 & & $\begin{array}{l}\text { Incipit - } \\
\text { Voz/Instrum. }\end{array}$ \\
\hline $\begin{array}{l}\text { Incipit: } \\
\text { personaje }\end{array}$ & ... & & $\begin{array}{l}\text { Incipit - } \\
\text { Epígrafe }\end{array}$ \\
\hline $\begin{array}{l}\text { Incipit: } \\
\text { tempo }\end{array}$ & Andante & & Incipit: clave \\
\hline $\begin{array}{l}\text { Incipit: } \\
\text { Tonalidad }\end{array}$ & $\left|\begin{array}{ccc}p & 2 & q \\
5: b 3 & f\end{array}\right|$ & FA M & $\begin{array}{l}\text { Incipit: } \\
\text { compás } 3 / 4\end{array}$ \\
\hline
\end{tabular}




\begin{tabular}{|l|l|l|l|l|} 
Incipit & & & & \\
musical & $\begin{array}{l}\text { En Belén a media noche una } \\
\text { Virgen parirá, Una Virgen } \\
\text { parirá, alegraos pastorcitos, } \\
\text { el que nace Dios será.... }\end{array}$ & & & \\
\hline Incipit Liter: & $\begin{array}{l}\text { Incipit sacro. } \\
\text { Lat. }\end{array}$ & $\ldots$ & & \\
\hline & & & & \\
\hline
\end{tabular}

\section{FICHA № 7}

\section{VILLANCICO SOLO DIOS LLORA de Alfonso Ugarte Leturia.}

Nació el 2 de agosto de 1879 en Anzuola (Guipúzcoa) y murió el 31 de mayo de 1937 en Estella (Navarra).Compositor, organista y Docente. Estudió armonía y composición con Pedro Fernández de Retana, de quien fue discípulo predilecto. En 1900, ganó por oposición, la plaza de organista de la Parroquia de San Pedro de Estella; solo en 1902, tomo posesión de la plaza ganada. A la par con su desempeño como organista de la citada parroquia ejerció como profesor de música del Colegio de los Escolapios y en el de los Capuchinos.

\section{PRODUCCIÓN MUSICAL}

Entre sus obras con sello de perfección Escolástica, destacan entre otras:

\section{Misas:}

Missa in honorem Sacratissimi Cordis Jesu 3v ac., Misa sobre tonos gregorianos $3 \mathrm{v}$ ac.

Obras religiosas en latín: Adoremus in aeternum V ac., Ave María V ac., J esus Dulcis memoria V ac., Regina mundi V ac., Salve Regina V ac., Stabat Mater 3v ac., Tantum Ergo 4 v ac. 
Música Religiosa en Castellano: A fray Diego de la Estella H 3 v ac., A San Francisco de Asís H 3v ac., A Santa Cecilia H 4v ac., Gozos a San Antonio de Padua V ac., Colección de Cantos al Sagrado Corazón V ac., Dulces himnos de gloria V ac., Salve Oh! Reino 3 v ac., Toda hermosa, eres María 3 v ac.

Música Escénica: El roscón de San Francisco. Zarzuela en 1 Acto, Juguete infantil. Zarzuela en 1 Acto

Música de Cámara: Cruz de flores qnt., Las blusas blancas qut., Melodía vn. P., Obertura qnt.

Órgano: Andantereligioso, Adagio, Entretenimiento, Marcha religiosa

Piano: Consuelo, Cruz de flores - vals, Humoreske, Los confetis, Vals Boston, Vals capricho, Zortzico, La perla del Océano.

Estos datos fueron recogidos del Diccionario de la música española e hispanoamericana. CASARES RODICIO, Emilio. Sociedad general de autores y editores. Madrid. 1999. Tomo X, pp. 551-52.

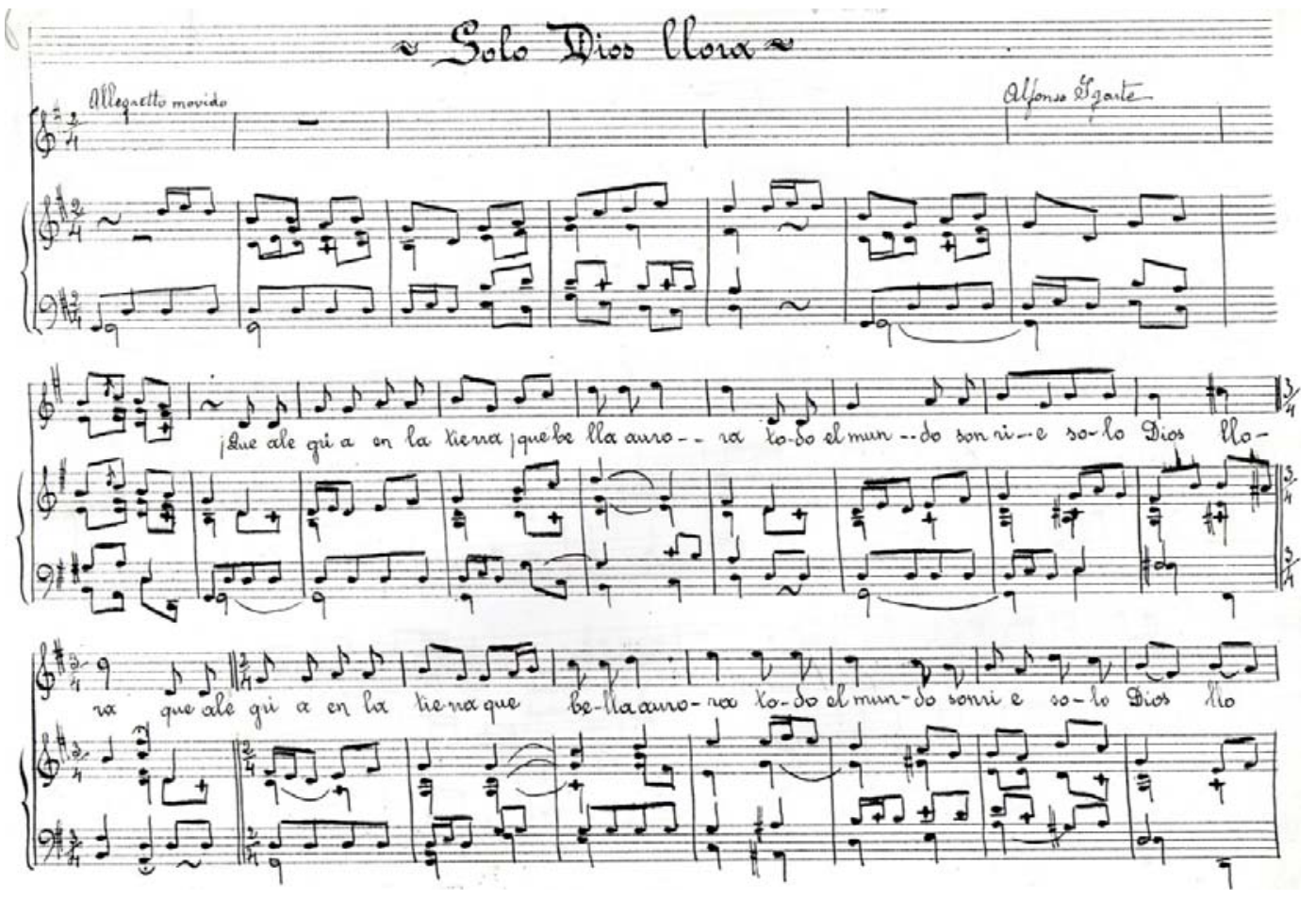

ASMD. Villancico “Solo Dios llora" - de Alfonso Ugarte Leturia 


\section{SOLO DIOS LLORA}

Qué alegría en la tierra, que bella aurora

Todo el mundo sonríe, Solo Dios llora

Qué alegría en la tierra, que bella aurora

Todo el mundo sonríe, solo Dios llora.

Angelitos del cielo, pastor del valle

Alegremos al niño para que calle

Angelitos del cielo, pastor del valle

Alegremos al niño para que calle

J esusito del alma prenda querida

Dúerme que yo te canto calla enseguida.

J esusito del alma prenda querida

Duerme que yo te canto calla enseguida.

J esusito del alma oye mi canto

Duerme prenda querida cese tu llanto 


\section{SOLO DIOS LLORA}

Villancico

De Alfonso Ugarte Leturia

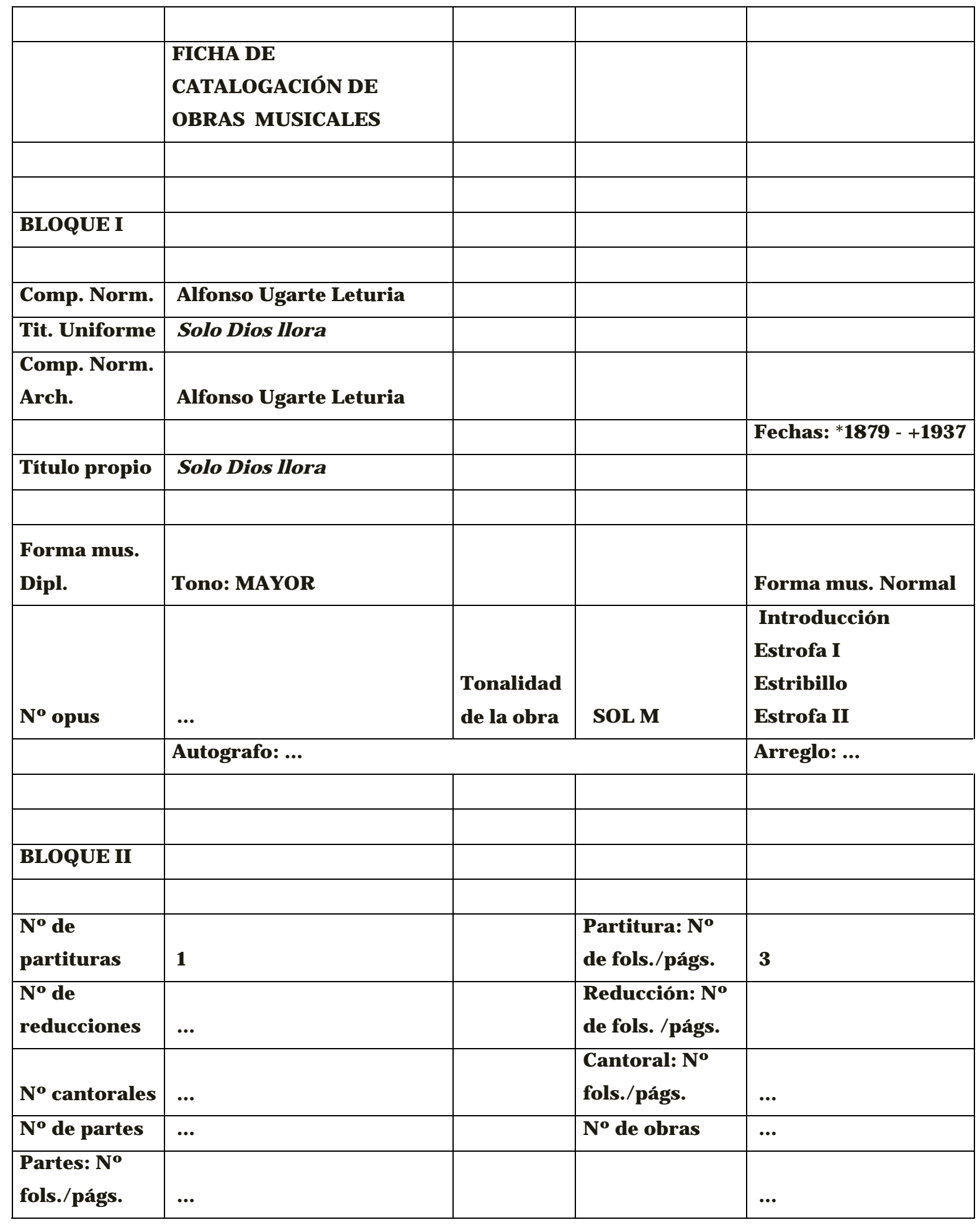




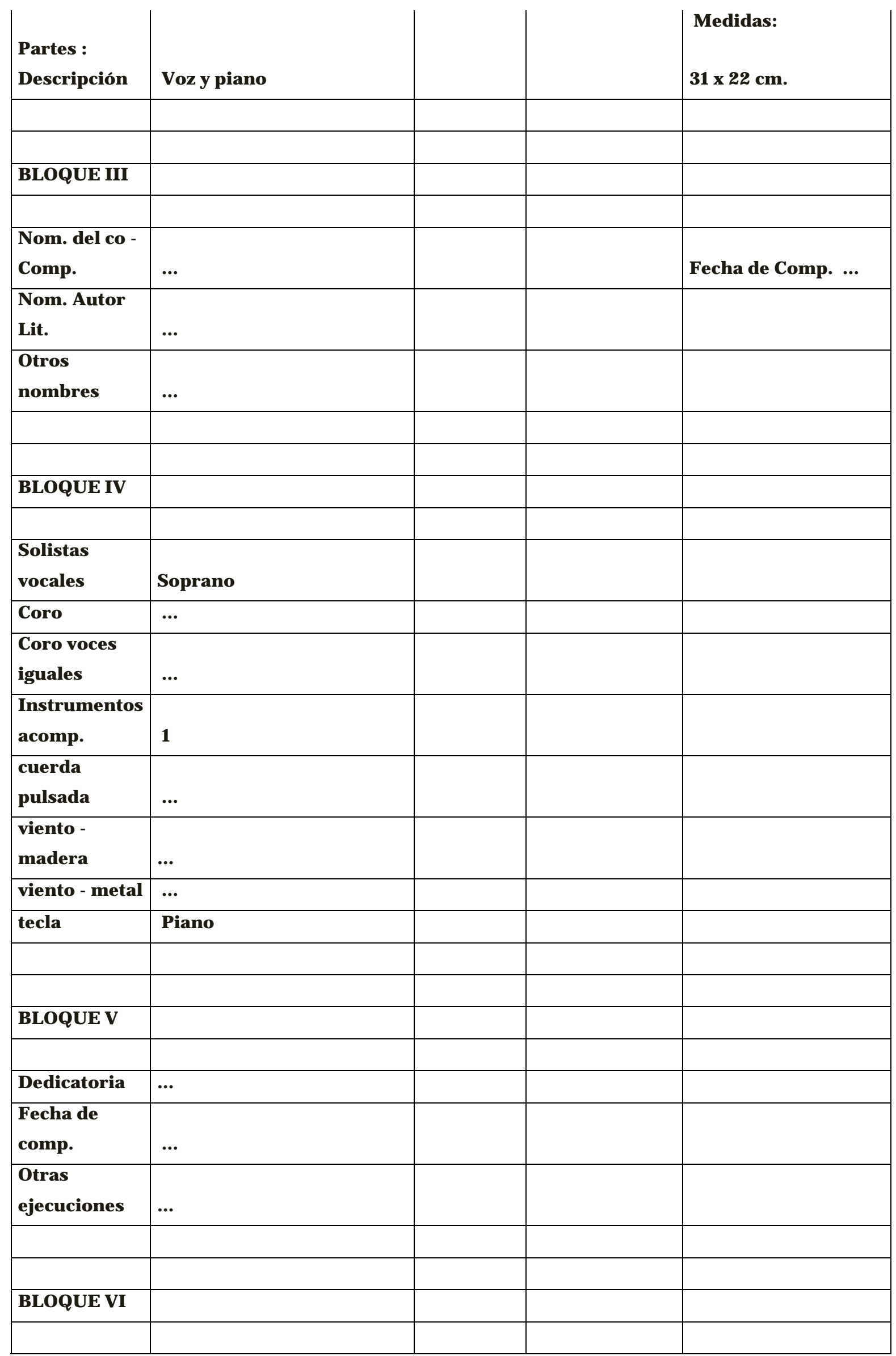


LA VIDA MUSICAL EN LOS CONVENTOS FEMENINOS DE ALBA DE TORMES (Salamanca) MATILDE DEL TRÁNSITO CHAVES DE TOBAR

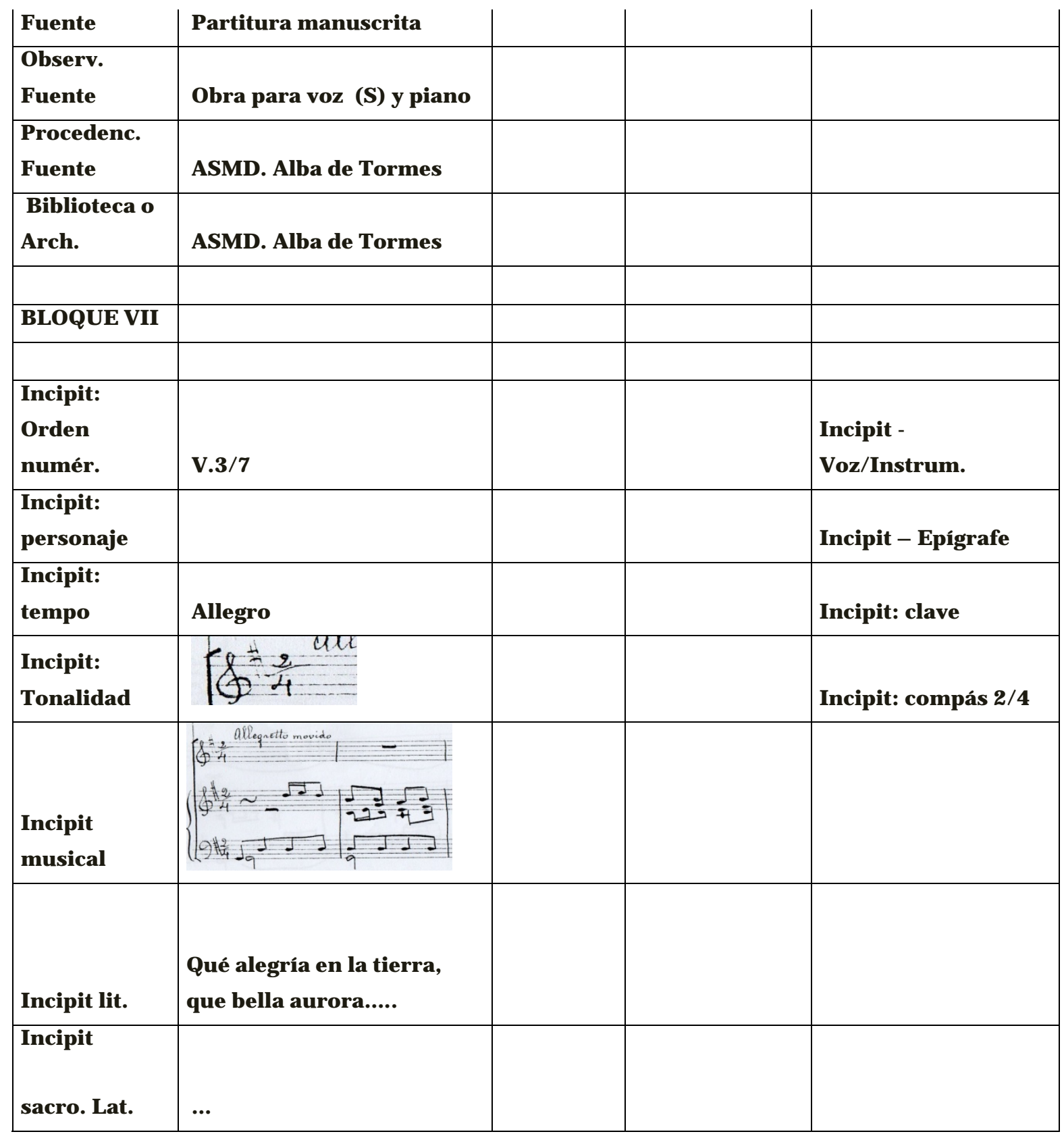




\section{V.3.3. CANTOS MARIANOS}

Continuando ahora con las obras representativas de este género musical, dedicadas a la veneración Mariana y situándonos con este tipo de repertorio en el siglo XIX, examinemos las que nos ofrecen información acerca del estilo compositivo de la época; Ya sabemos acerca de las formas musicales que siendo herencia de siglos pasados, en este momento se enriquecieron y se transformaron. La canción, será una de las formas preferidas por los compositores del siglo XIX, para la que escribieron antiguas y nuevas formas, ligadas en general a la literatura, ya a través de la palabra o bien mediante elementos poéticos. Todos estos medios se prestaban al lucimiento virtuoso de los intérpretes, especialmente en la música íntima y en los conciertos. La forma canción - ya fuera de tipo popular o religioso -, acompañada al órgano o más concretamente al piano, que fue el instrumento por excelencia en la época, se llevó a su máxima expresión. Al servicio de la música religiosa también podemos ver como esta forma musical tuvo su desempeño.

Pertenecientes al Repertorio musical del Monasterio de Santa María de las Dueñas, encontramos variadas canciones religiosas con acompañamiento de piano - entre villancicos, cantos marianos, cantos espirituales y algunas canciones populares; éste último género, nos da a entender que por entretenimiento o por cultura, las monjas también interpretaban este tipo de repertorio popular. De compositores anónimos y de algunos conocidos como: Alfonso Igarte, Hermenegildo Rivera y Palou o Martinus Monacada, relacionamos las siguientes obras: Solo Dios llora, relacionada como villancico con acompañamiento de piano u órgano, Salve Regina, Salve Monserratina, Salve. 


\section{FICHA № 8}

SALVE MONSERRATINA - Para vozy piano

De Martinus Moncada, recogida en el Salterio Sacro -hispánico (Publicación continúa de Música Religiosa antigua y moderna, fundada y dirigida por el Maestro Felipe Pedrell y que concluyó en 1860, publicada entre 1892 y en 1905.) Obras relacionadas con esta publicación: La salve y el Filia J erusalem. Aparte de sus obras, Pedrell recogió en su Salterio Sacro- Hispano - editado entre 1892 y 1905 obras de otros compositores, los cuales encontramos entre los repertorios musicales del Monasterio de Santa María de las Dueñas. Es preciso anotar, que la forma compositiva de Pedrell - referente en cierta forma a lo que se interpretaba en el momento -, dio un cambio con el descubrimiento y la importancia que dio Pedrell a la música antigua. El Salterio Sacro - Hispano, junto con la Revista notas musicales y literarias y la Revista de ilustración musical, dan fe de esta nueva huella musicológica. Salve Montserratina es una obra musical para Voy y órgano en tiempo lento, dividida en versos señalizados por numeración romana. Conserva el archivo del Monasterio una versión de edición perteneciente a Ildefonso Alier. Editor. Madrid.

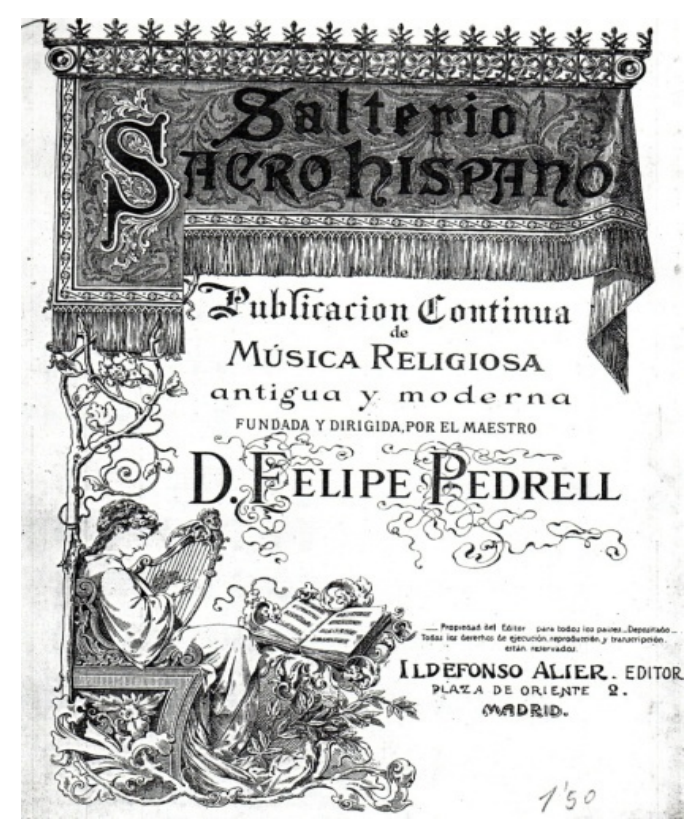

ASMD. Carátula del Salterio Sacro- Hispano de Felipe Pedrell 
SALVE MONSERRATINA

Para voz y piano de Martinus Moncada

\begin{tabular}{|c|c|c|c|c|}
\hline & $\begin{array}{l}\text { FICHA DE } \\
\text { CATALOGACIÓN DE } \\
\text { OBRAS MUSICALES }\end{array}$ & & & \\
\hline & & & & \\
\hline \multicolumn{5}{|l|}{\begin{tabular}{|l} 
BLOQUE I \\
\end{tabular}} \\
\hline \begin{tabular}{|l} 
Comp. Norm. \\
\end{tabular} & MONCADA, Martinus & & & \\
\hline Tit. Uniforme & Salve Monserratina & & & \\
\hline $\begin{array}{l}\text { Comp. Norm. } \\
\text { Arch. }\end{array}$ & MONCADA, Martinus & & & \\
\hline & & & & Fechas: \\
\hline Título propio & $\begin{array}{l}\text { Voz/órgan- Salve } \\
\text { Monaserratina/ } \\
\text { MONCADA, Martinus }\end{array}$ & & & \\
\hline $\begin{array}{l}\text { Forma mus. } \\
\text { Dipl. }\end{array}$ & Tono: menor & & & $\begin{array}{l}\begin{array}{l}\text { Forma } \\
\text { mus.Normal }\end{array} \\
\text { Canción }\end{array}$ \\
\hline № opus & $\ldots$ & $\begin{array}{l}\text { Tonalidad } \\
\text { de la obra: } \\
\text { Re m }\end{array}$ & & 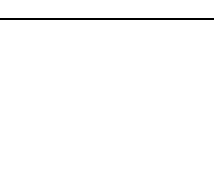 \\
\hline & \multicolumn{3}{|l|}{ Autografo: ... } & Arreglo: ... \\
\hline BLOQUE II & & & & \\
\hline \begin{tabular}{|l|} 
No de \\
partituras
\end{tabular} & 1 & & $\begin{array}{l}\text { Partitura: № de } \\
\text { fols./págs. }\end{array}$ & 2 \\
\hline \begin{tabular}{|l|} 
No de \\
reducciones
\end{tabular} & $\cdots$ & & $\begin{array}{l}\text { Reducción: № de } \\
\text { fols. / págs. }\end{array}$ & $\cdots$ \\
\hline № cantorales & $\ldots$ & & $\begin{array}{l}\text { Cantoral: № } \\
\text { fols./págs. }\end{array}$ & $\ldots$ \\
\hline № de partes & $\ldots$ & & № de obras & $\ldots$ \\
\hline
\end{tabular}




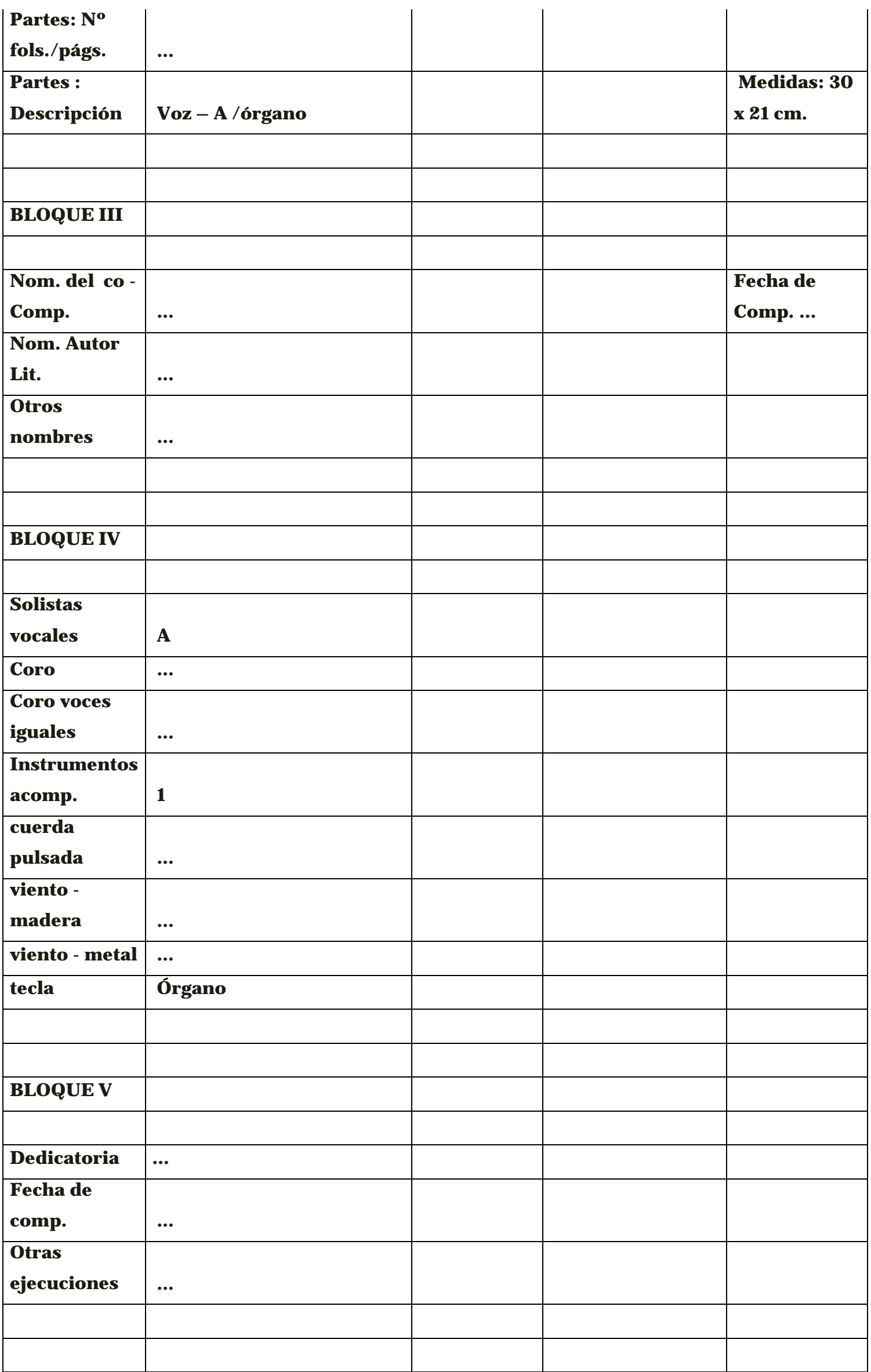




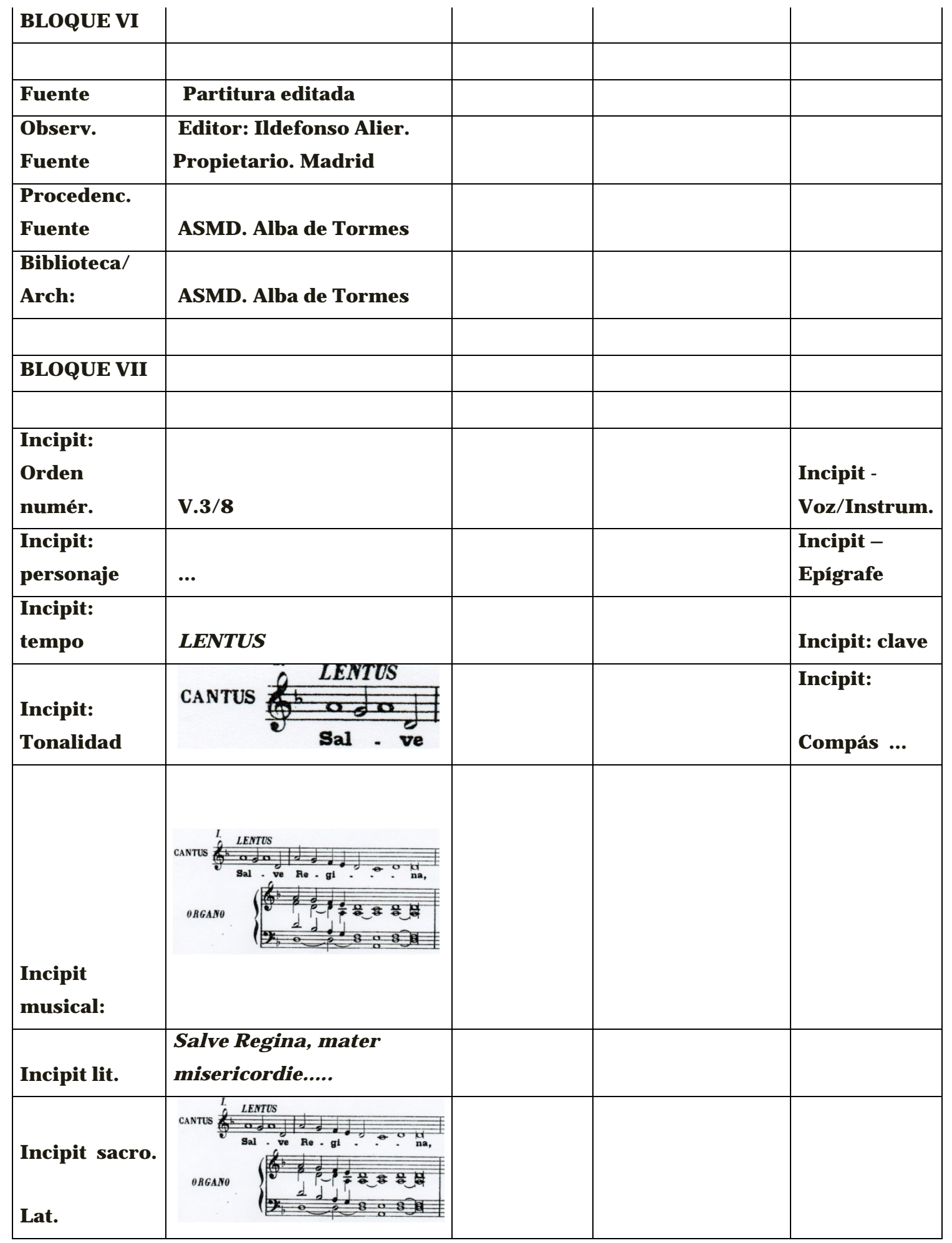




\section{Ficha No 9}

\section{SALVE en Coro para voces infantiles.}

Esta obra de compositor anónimo, está compuesta para voz de contralto con acompañamiento de piano, alternando las partes de la solista con un Coro de niños. La copista, ha insertado en el primer folio de la partitura, una dedicatoria que dice: "Para mis inolvidables Madres Carmelitas". Por su escritura musical se deduce que es una copia manuscrita de los albores el siglo XX.

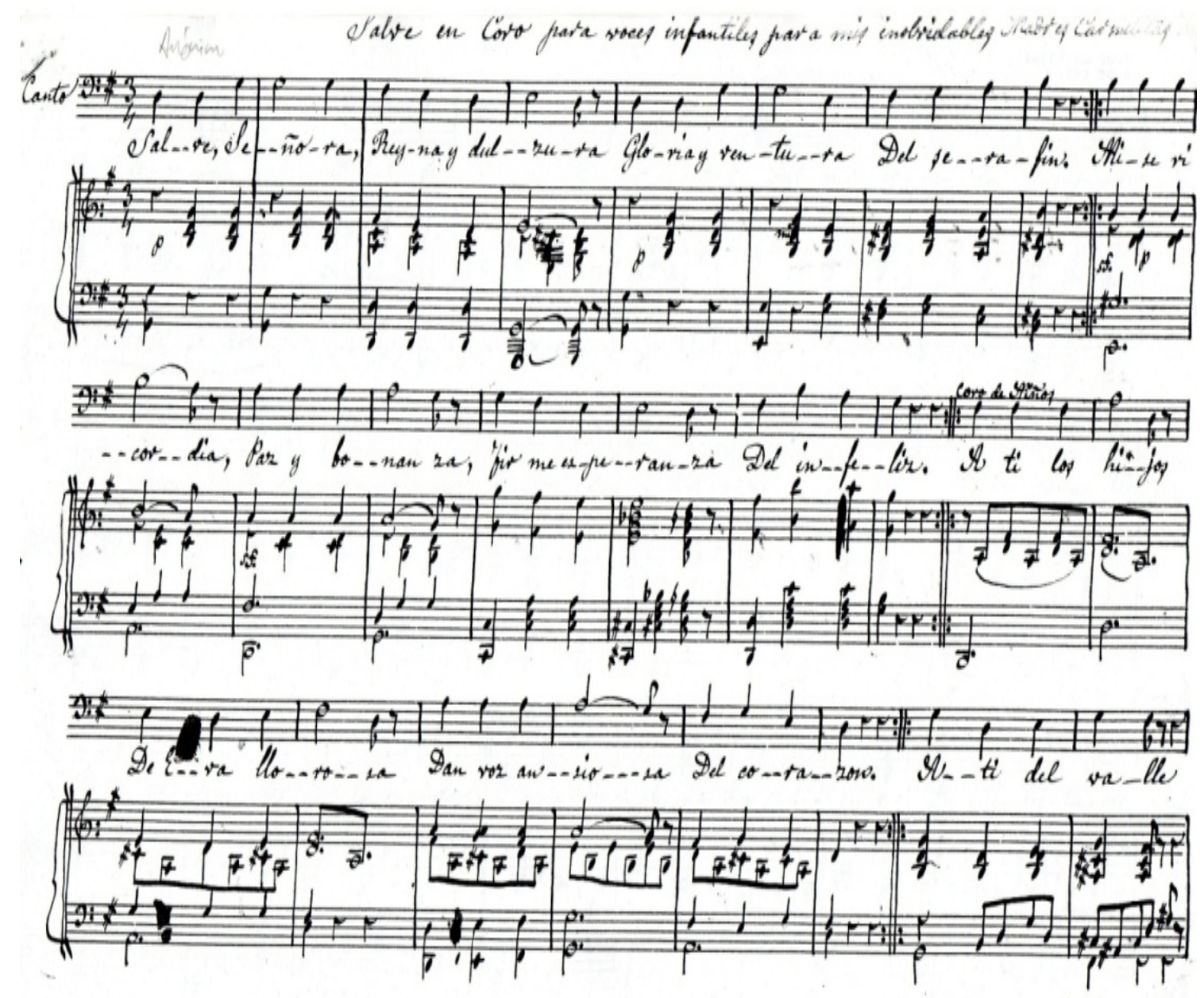

ASMD. "Salve" en Coro para voces infantiles. 


\section{SALVE}

A Coro para voces infantiles

"Para mis inolvidables Madres Carmelitas"

Salve Señora, Reina y dulzura

Gloria y ventura de Serafín.

Misericordia, paz y bonanza

firme esperanza del infeliz.

A ti los hijos de Eva llorosa

Dan voz ansiosa del corazón.

A ti del valle donde gemimos,

A ti decimos nuestro dolor.

Dulce abogada, suspiros damos,

de ti esperamos gracia y solaz.

Vuelve a nosotros esos fulgentes

Ojos clementes de tu piedad.

Y cuando el alma rompa el encierro

De este destierro tan opresor.

Al rico fruto de tu amoroso

Vientre dichoso, preséntanos.

¡O cara Madre del Rey, del Santo

Eleva en tanto plegaria y luz

Que sus promesas por ti queremos

y alcanzaremos gloria sin fin. 


\section{SALVE}

\section{Anónimo}

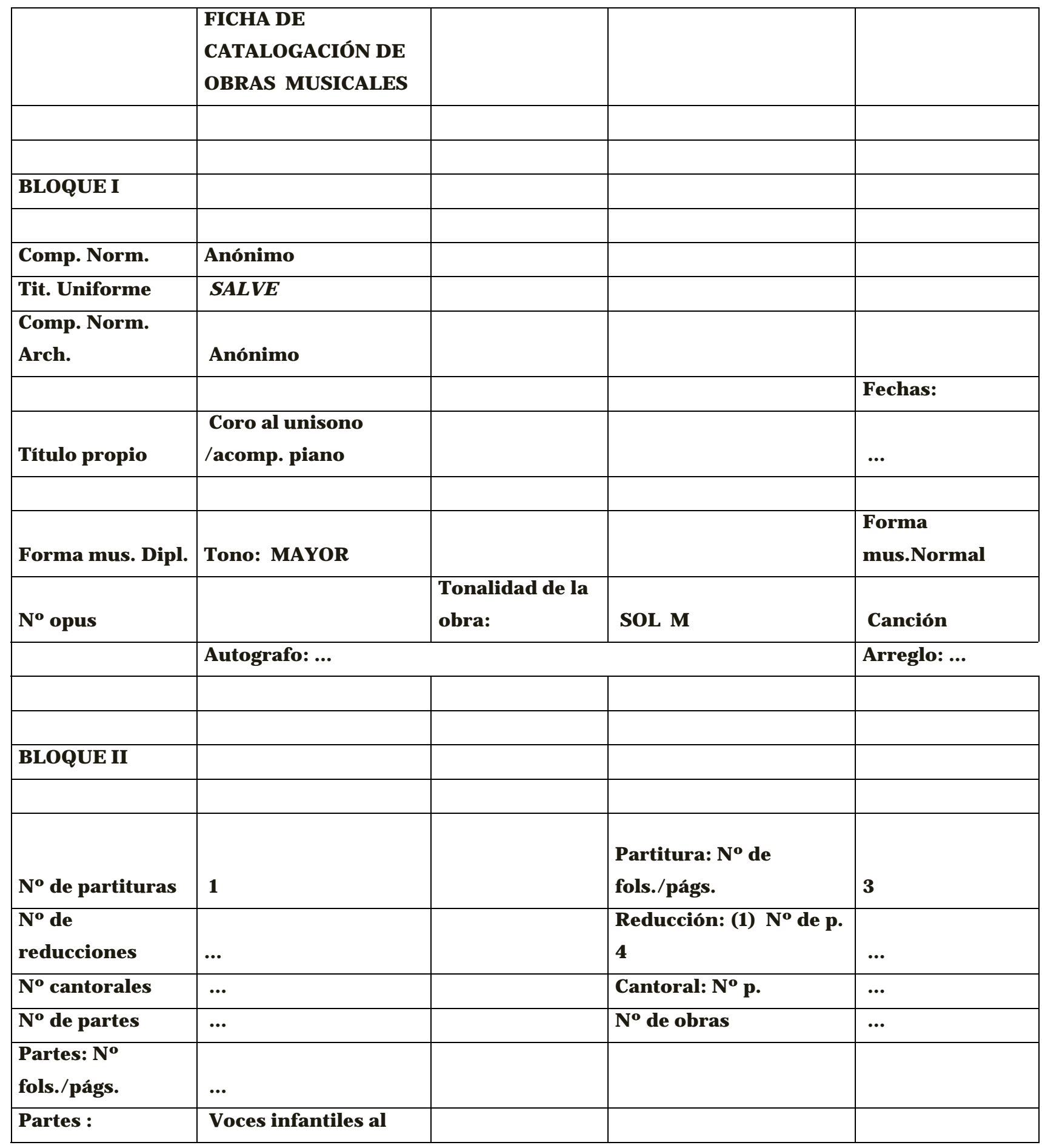




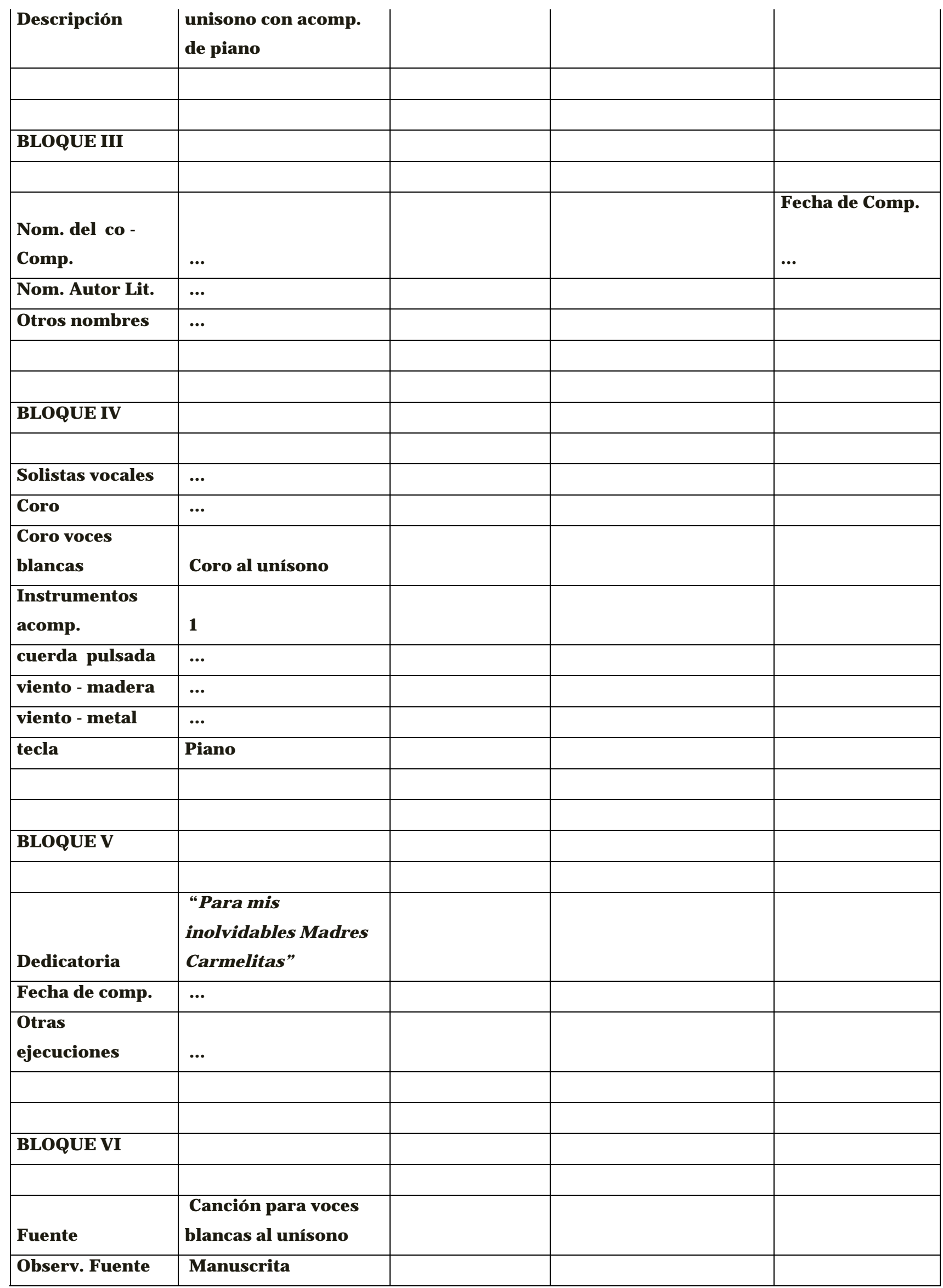


LA VIDA MUSICAL EN LOS CONVENTOS FEMENINOS DE ALBA DE TORMES (Salamanca) MATILDE DEL TRÁNSITO CHAVES DE TOBAR

\begin{tabular}{|l|l|l|l|l|}
$\begin{array}{l}\text { Procedenc. } \\
\text { Fuente }\end{array}$ & $\begin{array}{l}\text { ASMD. Alba de } \\
\text { Tormes }\end{array}$ & & & \\
\hline Biblioteca/Arch. & $\begin{array}{l}\text { ASMD. Alba de } \\
\text { Tormes }\end{array}$ & & & \\
\hline & & & & \\
\hline BLOQUE VII & & & & Incipit - \\
\hline $\begin{array}{l}\text { Incipit: Orden } \\
\text { numér. }\end{array}$ & V.3/9 & & Voz/Instrum. \\
\hline $\begin{array}{l}\text { Incipit: } \\
\text { personaje }\end{array}$ & $\ldots$ & & Incipit - Epígrafe \\
\hline Incipit: tempo & $\ldots$ & & Incipit: clave \\
\hline $\begin{array}{l}\text { Incipit: } \\
\text { Tonalidad }\end{array}$ & $\begin{array}{l}\text { Canto } \\
\text { Incipit: compás }\end{array}$ \\
\hline $\begin{array}{l}\text { Incipit sacro. } \\
\text { Lat... }\end{array}$ & $\begin{array}{l}\text { Salve Señora, Reina y } \\
\text { dulzura... }\end{array}$ & & & 3/4 \\
\hline & $\ldots$ & & & \\
\hline
\end{tabular}




\section{FICHA № 10}

\section{TODA HERMOSA}

Es un canto Mariano, al parecer anónimo, puesto que carece de cualquier indicación que nos dé a entender la autoría de algún compositor; en escritura manuscrita. Por su ámbito melódico, se ve claramente que está hecho para ser cantada por voces messo - sopranos incluso contraltos, alternando las voces blancas con una solista y el Coro. No se encuentran partes de acompañamiento instrumental, ni partes para una segunda o tercera voz, en lo que respecta al Coro.

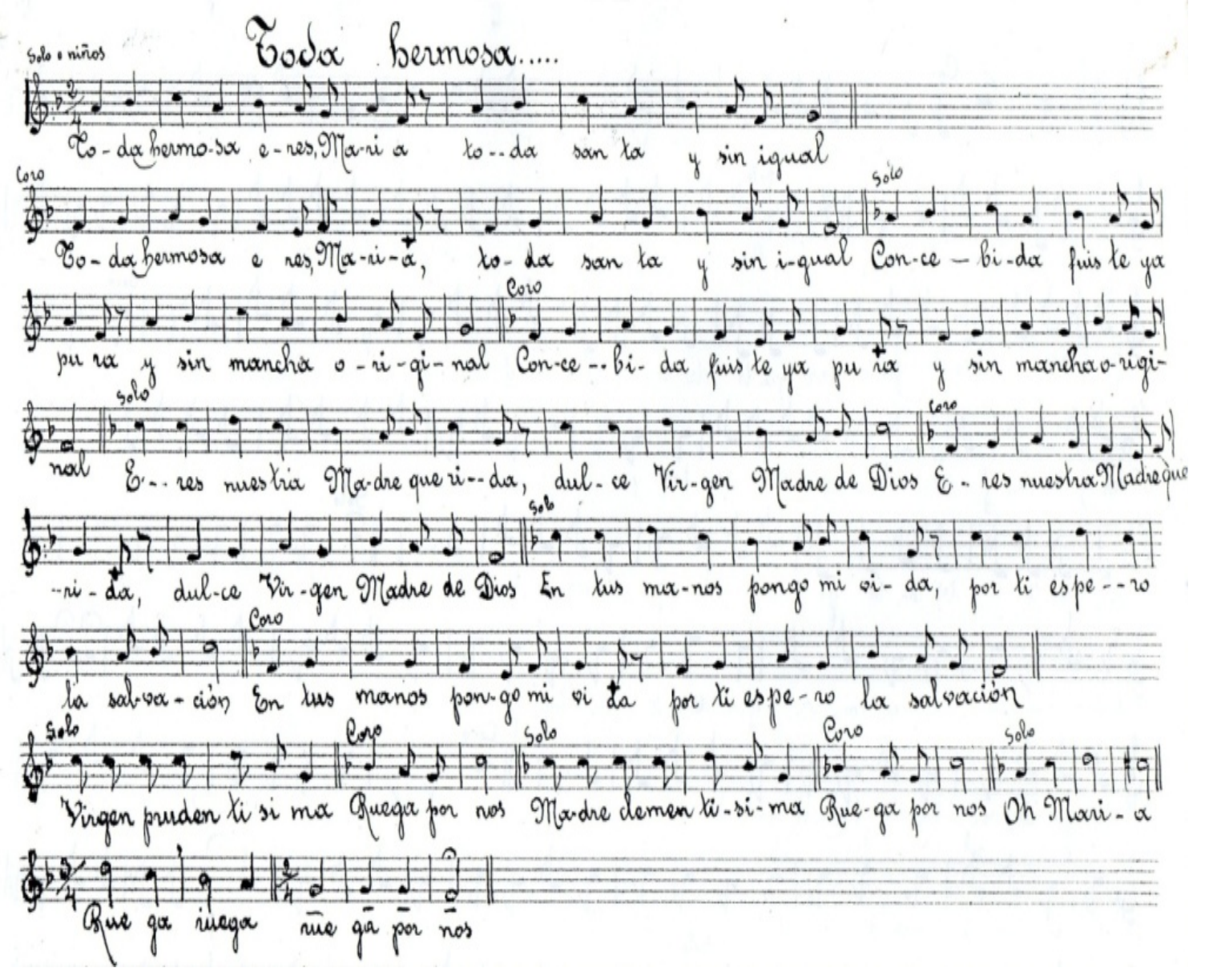

ASMD. Toda hermosa - anónima 


\section{TODA HERMOSA}

TODA HERMOSA ES MARÍA

TODA SANTA Y SINIGUAL

TODA HERMOSA ES MARÍA

TODA SANTA Y SINIGUAL.

CONCEBIDA FUISTE YÁ,

PURA Y SIN MANCHA ORIGINAL

CONCEBIDA FUISTE YÁ,

PURA Y SIN MANCHA ORIGINAL

ERES NUESTRA MADRE QUERIDA

DULCE VIRGEN MADRE DE DIOS

EN TUS MANOS PONGO MI VIDA

POR TI ESPERO LA SALVACIÓN

EN TUS MANOS PONGO MI VIDA

POR TI ESPERO LA SALVACIÓN.

Virgen prudentísima, ruega por nos

Madre clementísima, ruega por nos

Oh ! María, ruega, ruega, ruega por nos. 


\section{TODA HERMOSA}

\section{Anónimo}

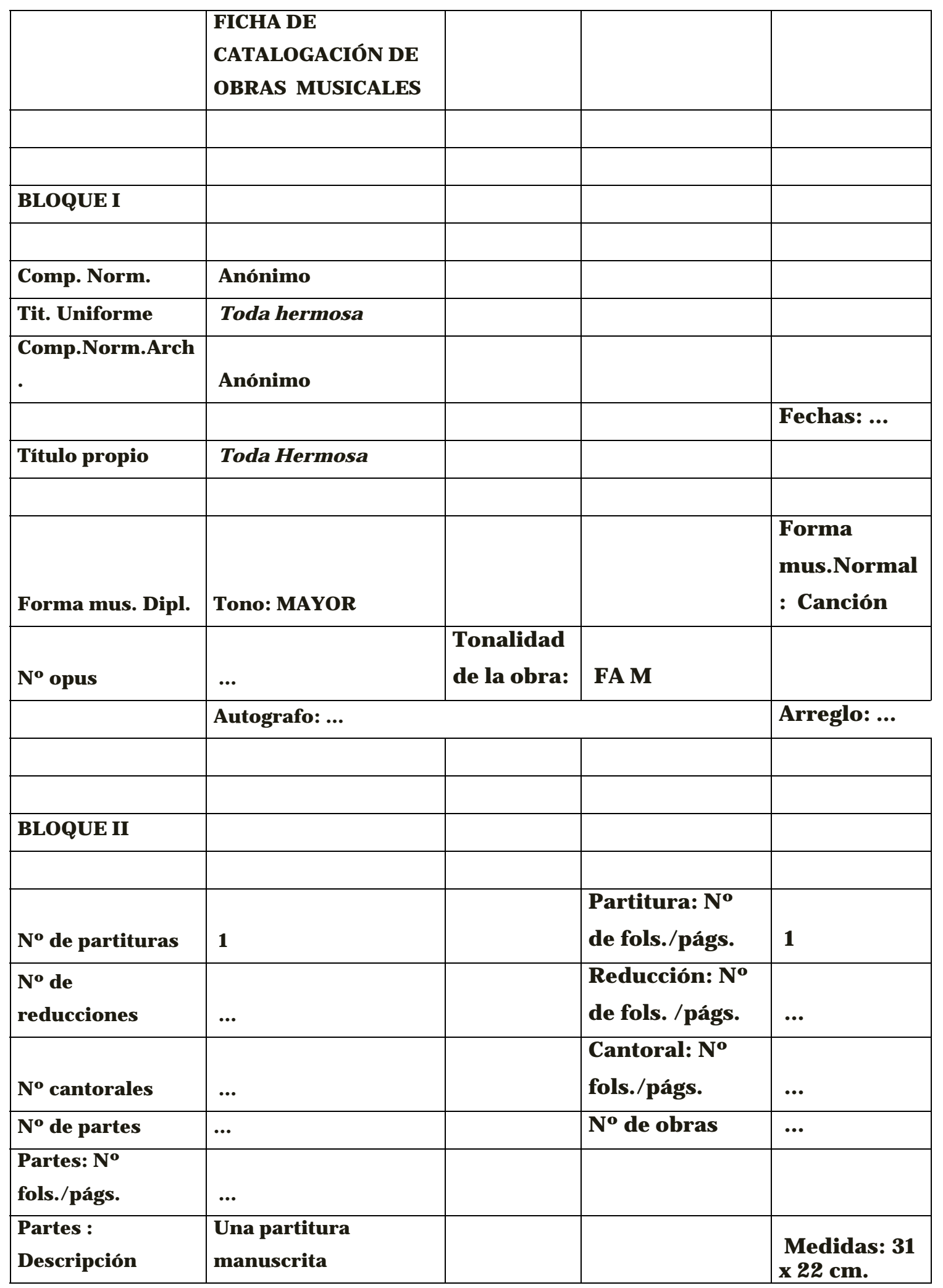




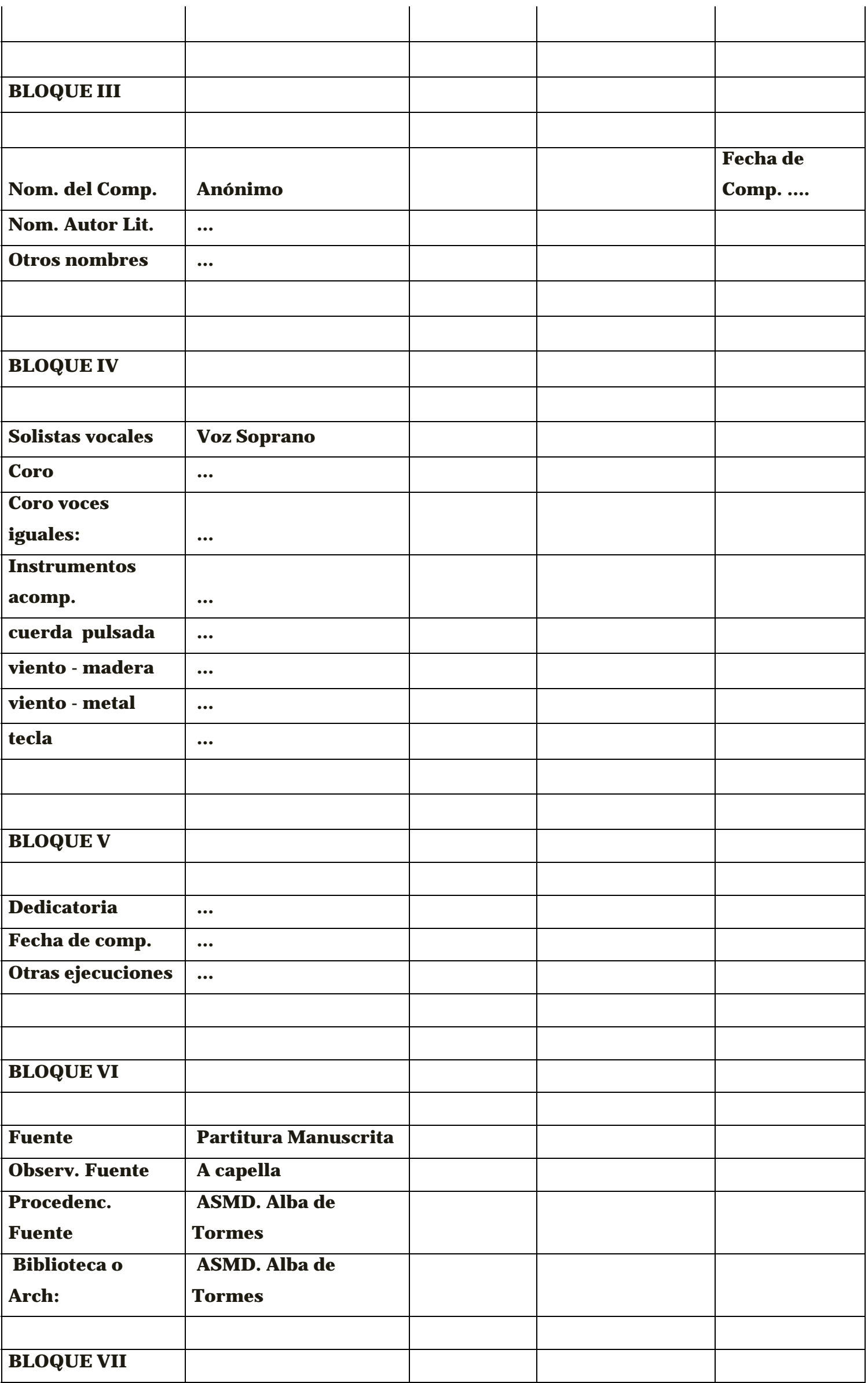


LA VIDA MUSICAL EN LOS CONVENTOS FEMENINOS DE ALBA DE TORMES (Salamanca) MATILDE DEL TRÁNSITO CHAVES DE TOBAR

\begin{tabular}{|c|c|c|}
\hline $\begin{array}{l}\text { Incipit: Orden } \\
\text { numér. }\end{array}$ & V.3/11 & $\begin{array}{l}\text { Incipit - } \\
\text { Voz/Instrum. }\end{array}$ \\
\hline $\begin{array}{l}\text { Incipit: } \\
\text { personaje }\end{array}$ & $\ldots$ & $\begin{array}{l}\text { Incipit - } \\
\text { Epígrafe }\end{array}$ \\
\hline Incipit: tempo & & Incipit: clave \\
\hline $\begin{array}{l}\text { Incipit: } \\
\text { Tonalidad }\end{array}$ & 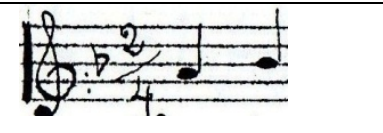 & $\begin{array}{l}\text { Incipit: } \\
\text { compás 2/4 }\end{array}$ \\
\hline Incipit musical: & 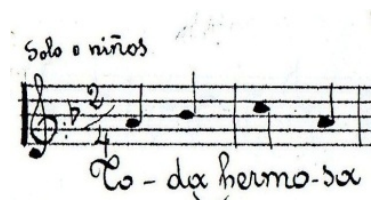 & \\
\hline Incipit lit. & $\begin{array}{l}\text { Toda hermosa es } \\
\text { María..... }\end{array}$ & \\
\hline $\begin{array}{l}\text { Incipit sacro. } \\
\text { Lat. }\end{array}$ & $\ldots$ & \\
\hline
\end{tabular}




\title{
V.3.3.1. OBRAS PARA VOZ Y PIANO
}

\section{Ficha № 11}

PENSANDO EN TI - compositor anónimo, sobre texto de Carmen Perafane.

Ésta composición en ritmo de vals con acompañamiento de piano, para voz soprano y cuya estructura está organizada sobre: una introducción, un Tema A y un Tema B, con repeticiones.

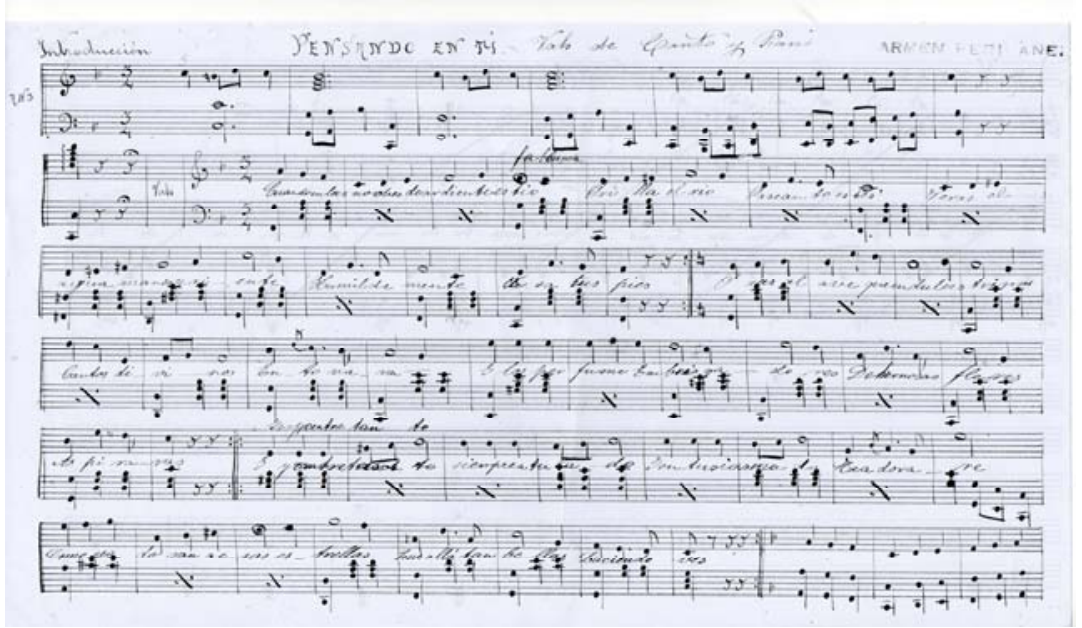

ASMD. Pensando en ti

\author{
Pensando en ti \\ Anónimo, sobre textos de Carmen Perafane
}

Cuando las noches de ardiente estío

Brila el río, paseando estés,

Verás que el agua mansa y riente,

Humildemente besa tus piés.

Oirás al ave que en mansos trinos

Cantos divinos entonará,

Y los perfumes embriagadores

De hermosas flores tu tomarás

Y hambriento siempre

Atu lado, entusiasmado te adoraré

Como se adoran a esas estrellas

Que allá tan bellas luciendo ves. 


\section{PENSANDO EN TI}

\section{Anónimo}

\begin{tabular}{|c|c|c|c|c|}
\hline & \begin{tabular}{|l} 
FICHA DE \\
CATALOGACIÓN DE \\
OBRAS MUSICALES
\end{tabular} & & & \\
\hline \multicolumn{5}{|l|}{ BLOQUE I } \\
\hline Comp. Norm. & Anónimo & & & \\
\hline Tit. Uniforme & Pensando en ti & & & \\
\hline \multirow[t]{2}{*}{$\begin{array}{l}\text { Comp.Norm.Arc } \\
\text { h. }\end{array}$} & Anónimo & & & \\
\hline & & & & Fechas: ... \\
\hline Título propio & Pensando en ti & & & \\
\hline Forma mus. Dipl. & Tono: MAYOR & & & $\begin{array}{l}\text { Forma } \\
\text { mus.Normal: } \\
\text { Canción }\end{array}$ \\
\hline \multirow[t]{2}{*}{ № opus } & $\ldots$ & $\begin{array}{l}\text { Tonalidad } \\
\text { de la } \\
\text { obra: }\end{array}$ & FA M & $\begin{array}{l}\text { Modulante a } \\
\text { Do M, La M y } \\
\text { Mi M }\end{array}$ \\
\hline & \multicolumn{3}{|l|}{ Autografo: ... } & Arreglo: ... \\
\hline BLOQUE II & & & & \\
\hline № de partituras & 1 & & $\begin{array}{l}\text { Partitura: № } \\
\text { de fols./págs. }\end{array}$ & $1-2$ \\
\hline $\begin{array}{l}\text { № de } \\
\text { reducciones }\end{array}$ & $\ldots$ & & $\begin{array}{l}\text { Reducción: № } \\
\text { de fols. / págs. }\end{array}$ & $\ldots$ \\
\hline № cantorales & $\ldots$ & & $\begin{array}{l}\text { Cantoral: № } \\
\text { fols./págs. }\end{array}$ & $\cdots$ \\
\hline № de partes & $\cdots$ & & № de obras & ... \\
\hline $\begin{array}{l}\text { Partes: № } \\
\text { fols./págs. }\end{array}$ & $\ldots$ & & & \\
\hline
\end{tabular}




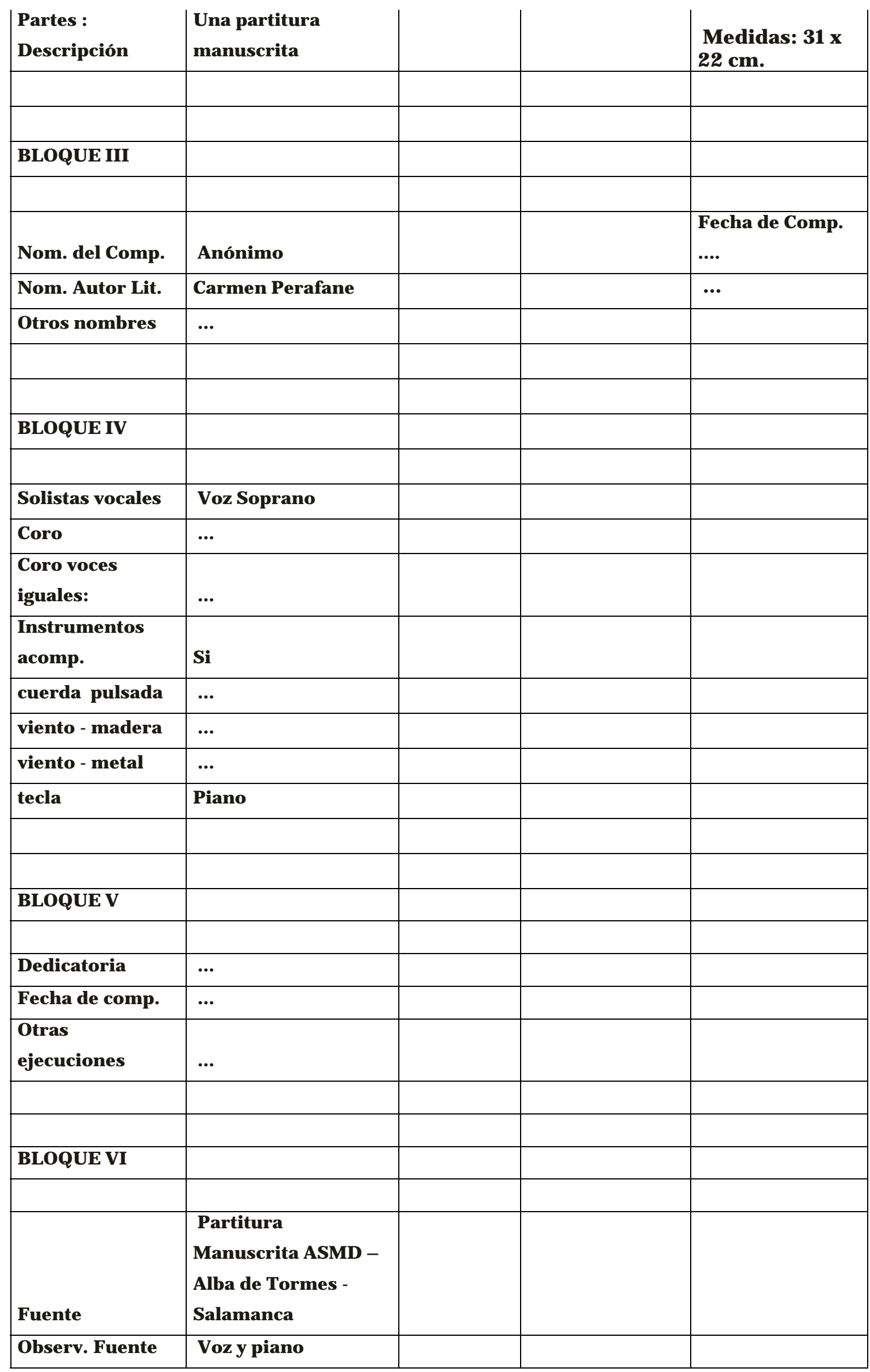




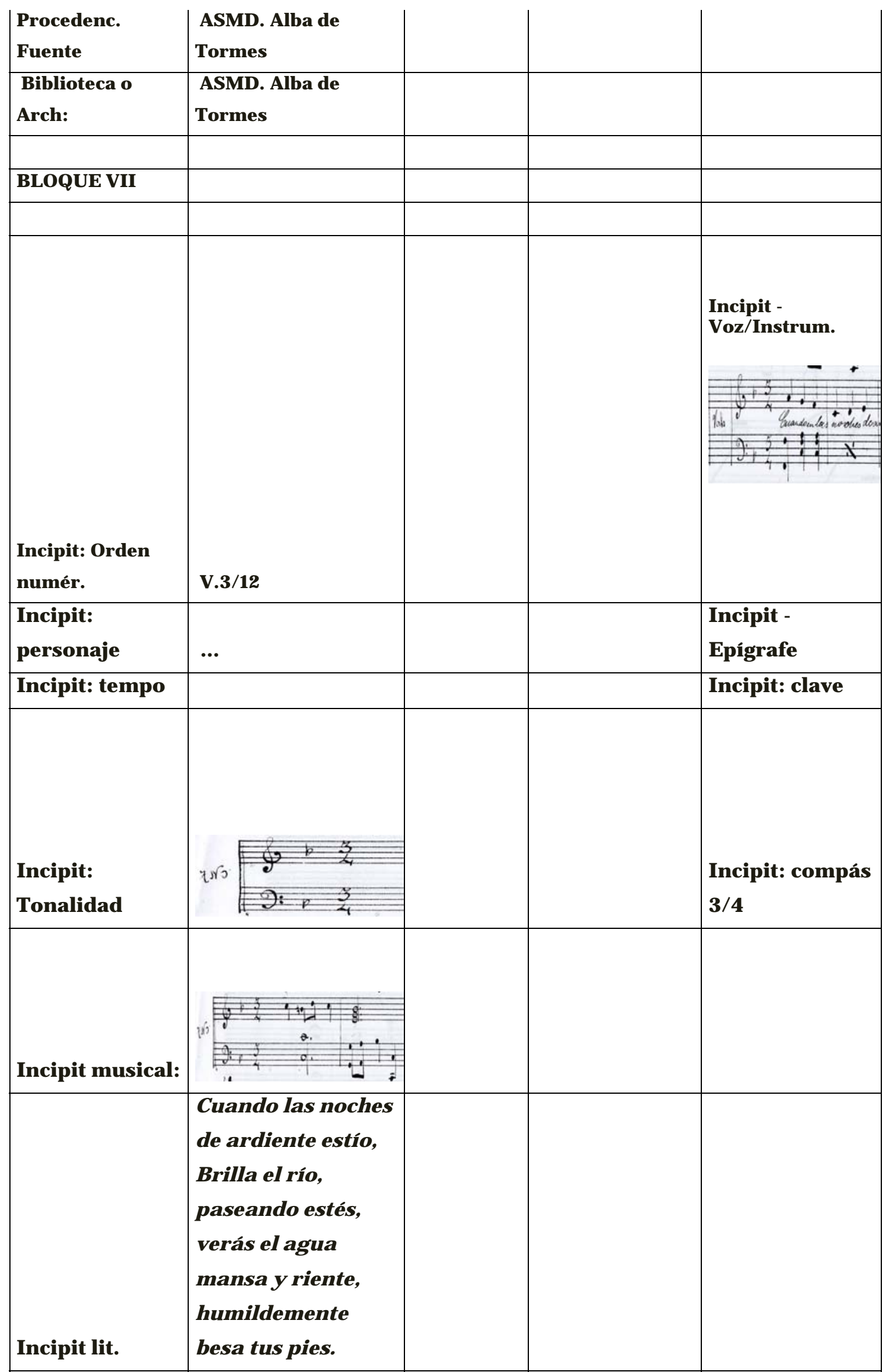


Incipit sacro.

Lat.

$\cdots$

\section{V.4. ANÁLISIS MUSICAL DE LOS REPERTORIOS MUSICALES}

\section{Introducción}

Con el devenir del tiempo, tantos altibajos - épocas de bonanza, épocas de escases, épocas entre guerras -, por los que han pasado muchos Monasterios de España entre los siglos XVII y XIX, investigados, éste de Santa María de las Dueñas, no ha sido la excepción. Muchos son los motivos que podemos apuntar, en torno al escaso repertorio conservado en él, como pudo ser la falta de previsión para guardar la música manuscrita o impresa, un posible incendio que sufrió el Monasterio extramuros en el siglo XVII - sin fecha determinada -, el estallido de la guerra de independencia española - conflicto armado que entre 1808 y 1814 convulsionó a España como consecuencia de la entrada de las tropas napoleónicas en la Península Ibérica con la excusa de invadir Portugal -, y el momento en que los españoles perdieron la batalla a orillas del Tormes y entraron los franceses victoriosos en la villa, la comunidad se vio despojada de sus claustros y privada de sus bienes comunes -, la guerra civil, cuando durante el bombardeo del 3 de julio de 1937, varias bombas cayeron sobre el Monasterio, destrozando parte del Claustro, la época de la desamortización y la penuria de la vida que era grande en muchos aspectos, pudieron ser la causa de que en asuntos de repertorios musicales no se haya tenido la suerte de encontrar más de lo que se pensó en un primer momento. El repertorio encontrado, está conformado por una serie de Misas a dos voces con solos y acompañamiento de órgano, Cantos Marianos con solos para voces infantiles, - que podrían perfectamente haber sido compuestas para ser cantados por niñas educandas del Monasterio -, varias Salves, entre las que se encuentra una "Salve Montserratina" para voz y órgano y en lo concerniente al Canto gregoriano, varios libros didácticos para el aprendizaje del solfeo de Canto llano y de la teoría musical, Villancicos, Canciones espirituales y una serie de cantos 
populares, entre los que se ha seleccionado el titulado: Pensando en ti, anónimo sobre un texto de Carmen Perafane.

La Liturgia Romana fue reformada sin que esto constituyera una obligación, para ser cumplida por las Órdenes religiosas católicas; de tal manera que cada una se decantó por tener sus propios rituales, conservando las reglas básicas de sus Constituciones, lo que trajo consigo reformas en la forma de interpretar.

El Concilio Vaticano II, (1962 - 1965), en épocas más recientes, pretendió que fuera una "puesta al día de la Iglesia", renovando los elementos que más necesidad tuvieran de ello, revisando el fondo y la forma de todas sus actividades. Con ello, se pretendió proporcionar una apertura dialogante con el mundo moderno, actualizando la vida de la Iglesia sin definir ningún dogma, incluso se habló con nuevo lenguaje conciliatorio frente a problemas actuales y antiguos.

\section{V.4.1. Obras musicales y didácticas}

\section{* Misas}

* Villancicos

* Voz y órgano

* Cantos Marianos

* Cuadernos manuscritos de metodología gregoriana

Este repertorio debió ser interpretado por las monjas en sus fechas importantes y/ o en sus prácticas devocionales, como la toma de Profesión, Navidades, Fiestas Marianas, Semana Santa y Fiestas al Santo Patrono y ello evoca su actividad coral y musical en general. Las Misas con las partes correspondientes al común de la Misa, están escritas en un ámbito sonoro para voces femeninas messo - sopranos y Altos, con solos incluidos generalmente en los Benedictus, el Gloria y el Credo.

Con este pequeño corpus de repertorio musical, se pretende desarrollar el presente capítulo, teniendo en cuenta la siguiente metodología y los parámetros correspondientes para su desarrollo. 


\section{V.4.2.Metodología de trabajo}

Seguidamente y en el trascurso del presente apartado, se expone paso a paso, el procedimiento metodológico desde la recopilación de las fuentes musicales, pasando por su clasificación, hasta llegar a su análisis musical.

\section{V.4.2.1. Recopilación de las fuentes musicales}

Aproximándonos al tema y al tratar de centrarlo, se han establecido limitaciones, puesto que el corpus de repertorio que se encontró en el Monasterio de Santa María de las Dueñas, en primer lugar es escaso y en segundo término este repertorio musical pertenece al siglo XIX, por lo tanto, no está centrado en la variedad de formas musicales que se deseaba encontrar.

Aquellas limitaciones obligaron a delimitar:

1. Un espacio cronológico

2. Dos géneros musicales y por ende los tipos de formas que se repiten.

\section{V.4.3.Modelo de análisis general}

El marco conceptual y la metodología que se emplean quedan claramente expuestos en la introducción general del trabajo.

Se utilizan las técnicas musicológicas para estudiar integralmente las obras musicales. Analizando los siguientes aspectos:

- géneros,

- rasgos musicales,

- función

- permanencias

* $\quad$ Atiende a la tradición como marco regulador de la práctica, por lo que propone estudiar la recepción de repertorios musicales y la existencia de una red de comunicación entre los monasterios, para su divulgación y utilización de los mismos. 


\section{Los géneros:}

- Las obras vocales representadas en misas a dos voces, cantos marianos y villancicos

- Las obras instrumentales, para órgano.

\section{Los rasgos musicales:}

- Las características estéticas y compositivas en materia musical del siglo XIX, están reflejadas en el repertorio musical que se analizará; vale decir: el predominio de la voz con acompañamiento instrumental que impera en la época, ya fuese con un acompañamiento al piano o al órgano.

\section{* La función:}

- La funcionalidad de la música se advierte en la medida que cada una de las obras musicales en cuestión, se utilizaron para determinado momento de la liturgia o de la vida espiritual. Villancicos y Cantos Marianos pudieron ser interpretados en los ciclos oportunos o para ensalzar una determinada festividad.

Permanencias: Las vigencias musicales en éste tipo de repertorios musicales religiosas, han traspasado el siglo XIX; en la actualidad, aún se sigue componiendo música religiosa de éste género para voz con acompañamiento instrumental. El hecho de que estos mismos repertorios puedan ser encontrados en otros monasterios, significa que existió en su momento un interés por adquirir las obras para el despliegue de la Liturgis y las festividades especiales.

\section{V.4.4.Ficha técnica}

La elaboración de una ficha técnica, permite concentrar los datos identificativos de la obra musical, como: título, opus, fecha de composición, compositor, editor - si es impresa -, época, género musical, forma, dedicatoria, marcas de agua.

En referencia al análisis musical de cada obra, este se constituye en el soporte para conocer a fondo las particularidades de la organización de las ideas musicales y de la estructura formal como: forma, melodía, ritmo, armonía, - modos y/o 
tonalidades - expresión, relaciones texto música -, el estilo, la época y la estética - ; conociendo de antemano los parámetros formales constituidos en determinada época para definir la organización coherente de una "forma musical", se podrá utilizar como una herramienta auxiliar que permitiría comprender el posible valor que estas obras musicales contienen. Tener claridad en la época a que corresponde por su forma de composición, modo, su escritura musical y el tipo de acompañamiento, servirá para definir el estilo y la estética. No se puede desligar cualquier análisis de una obra musical, de la historia de la música, de los géneros y de los estilos que caracterizaron cada período.

Limitada a tres géneros musicales. El género coral, el género instrumental (órgano o piano) y el género de obras para voz y piano. Cada obra musical tiene para su catalogación, una ficha técnica en la que se detalla la descripción física de la misma, su género y seguidamente los elementos de ámbito histórico, de estilo y elementos musicales que la conforman.

\section{V.4.5. Criterios para el análisis musical}

- El análisis será reflexivo y sistemático, para evitar que se convierta en un ensayo literario

- No debe parecer un simple inventario de hechos evidentes

- Al hablar de análisis musical se tratarán inicialmente los elementos morfológicos para posteriormente tratar los sintácticos, que en combinación con las características estilísticas de la época, nos permitirá determinar la forma musical.

- Analizar los elementos morfológicos (idea o motivo), es lo básico; los cuales bajo distintas maneras de la construcción son capaces de generar diferentes tipologías sintácticas.

- EL análisis de la forma se mirará desde la construcción sintáctica de los motivos y los tipos estructurales tradicionales de la música del XIX.

- Los elementos melódicos, rítmicos, armónicos y las cuestiones interpretativas se analizarán teniendo en cuenta los principios básicos de composición de cada obra y la forma (vocal o instrumental). 


\section{V.4.6. Procedimiento analítico}

Recabar la mayor cantidad y variedad de información a partir de la partitura, es el primer quehacer. Gran parte de esta información la encontramos en la partitura, pero algunos datos se tienen que buscar en libros, en Enciclopedias, incluso en soporte internet, para describir especialmente lo referente a los autores y su obra en general.

Los datos recogidos se van anotando, para posteriormente ser ordenados; de tal manera que nos permitan llegar a conclusiones claras.

Todo el material básico (células o motivos melódicos, células rítmicas, escalas, acordes, elementos temáticos significativos etc.) figuran a modo de relación de forma explícita.

Lo armónico (cifrados, progresiones, modulaciones), se va comprobando de forma clara.

Para plasmar la estructura de la forma se ha recurrido a un diagrama, con el fin de que sea lo más gráfico posible.

\section{V.4.7. Sistematización del análisis}

- Antecedentes y referencias históricas:

- Del autor

- Desu obra

- De la que se está analizando

- Descriptivas:

- Título

- Época

- Autor literario

- Plantilla vocal o instrumental

- Partes substanciales determinantes de un análisis musical:

- Forma

- La interválica : De inicio: Reveladora de la forma del arranque 
- La interválica de curso de frase: El flujo melódico que discurre con naturalidad moviéndose en las diferentes distancias de los intervalos que conforman la melodía.

- Conducción melódica: El movimiento natural de la melodía con intervalos cortos y con frecuencia conjuntos, dando la sensación de suavidad y discurso tranquilo.

- Tipo de escala

- Semifrase, frases y períodos

- Esquemas rítmicos (células rítmicas, tipo de compás, pulso rítmico, figuraciones rítmicas)

- Síncopas

- Arranques

- Terminaciones

- El análisis armónico que es capital nos permitirá conocer:

- Tipos de armonía: Tonal, modal...

- Clases de intervalos armónicos predominantes

- consonancias, perfectas e imperfectas y disonancias

- El encadenamiento de acordes y por ende, los tipos de semicadencia y cadencias.

- Modulaciones

- Cifrados

- Otros aspectos que se analizan, son los aspectos interpretativos:

- La textura

- La tesitura de las voces

- El ámbito melódico

- Las relaciones texto música

- La Dinámica y la agónica.

Para presentar el análisis musical se ha elaborado una ficha, con el objeto de anotar en ella, los datos técnicos y los datos analíticos de cada obra. 
LA VIDA MUSICAL EN LOS CONVENTOS FEMENINOS DE ALBA DE TORMES (Salamanca) MATILDE DEL TRÁNSITO CHAVES DE TOBAR

\begin{tabular}{|l|l|l|l|l|l|l|l|}
\hline & & & & & & & \\
\hline & & & & & & & \\
\hline & & & & & & \\
\end{tabular}




\section{V.5.PLANTILLAS DE ANÁLISIS MUSICAL DE LAS OBRAS}




\section{V.5. PLANTILLAS DE OBRAS}

V.5.1. Solo Dios llora - Alfonso Ugarte (Partitura)

V.5.2. Pequeña Misa Solemne a dos voces - Luigie Bordese (partitura)

V.5.2.1. Kyrie

V.5.2.2. Sanctus

V.5.2.3. Agnus Dei

V.5.3. Albricia pastores - Anónimo (partitura)

V.5.4. Salve - Anónimo (partitura)

V.5.5. Los pastores Evaristo Ciria (partitura) 


\section{V.5.1. Solo Dios llora - Alfonso Ugarte Leturia}

Son varios miles los villancicos que guardan los Archivos Catedralicios, Colegiatas y Capillas musicales, muchos de ellos de notables proporciones, con variedad de instrumentos, voces y extensión. El villancico polifónico se introdujo de forma definitiva como parte integrante del Oficio solemne de Maitines de la Noche de Navidad y del Corpus Christi, extendiendose en algunas ocaciones a otras festividades importantes (Ascención, Patronos del lugar...). Se cantaban con acompañamiento de órgano e instrumentos en sustitución de los responsorios del día. La práctica fue común durante los siglos XVII y XVIII. Se les puede encontrar con la denominación similar que la de los responsorios: "Villancico Primero del Segundo Nocturno".

Aparte de los ocho villancicos que se interpretaban durante el Oficio de la Noche de Navidad o en los Maitines en la Víspera del Corpus Christe, prolongando la celebración durante varias horas, hasta muy entrada la madrugada o la noche respectivamente, era ya tradicional el "Villancico de Calenda o Kalenda", que se interpretaba el 24 de Diciembre al término del Oficio de Prima. La interpretación de los villancicos gozó de tal popularidad, pese a la prohibición decretada por el Rey Felipe II, que los Maestros de Capillase proveían de los textos y los hacían imprimir para que el pueblo los siguiera con atención. Esta tradición del villancico, como integrante popular de la Liturgia, al modo de la Cantata Litúrgica protestante, ha supervivido hasta bien entrado el siglo XIX.

En el repertorio musical del Archivo de Santa María de las Dueñas, se encontraron varios villancicos, que presentan la forma de villancico "Cantata", con estructuras como:

\footnotetext{
* Introducción instrumental

* Estribillo

* Coplas a solo y a dúo

- Estribllo
} 
Vuelta a la introducción

El villancico Solo Dios llora de Alfonso Ugarte, presenta una pequeña introducción al piano como instrumento acompañante y tres estrofas para voz (S), con tres temas definidos en cuanto a su conformación rítmico - melódica.

Su estructura:

\section{Introducción A - puente I: B :I - C}

El pequeño puente configurado en cuatro compases, enlaza el tema A con el tema $\mathrm{B}$, para terminar con el tema $\mathrm{C}$.

Los posibles esquemas son: A-B-A

A-B-C

A-B-C-A 

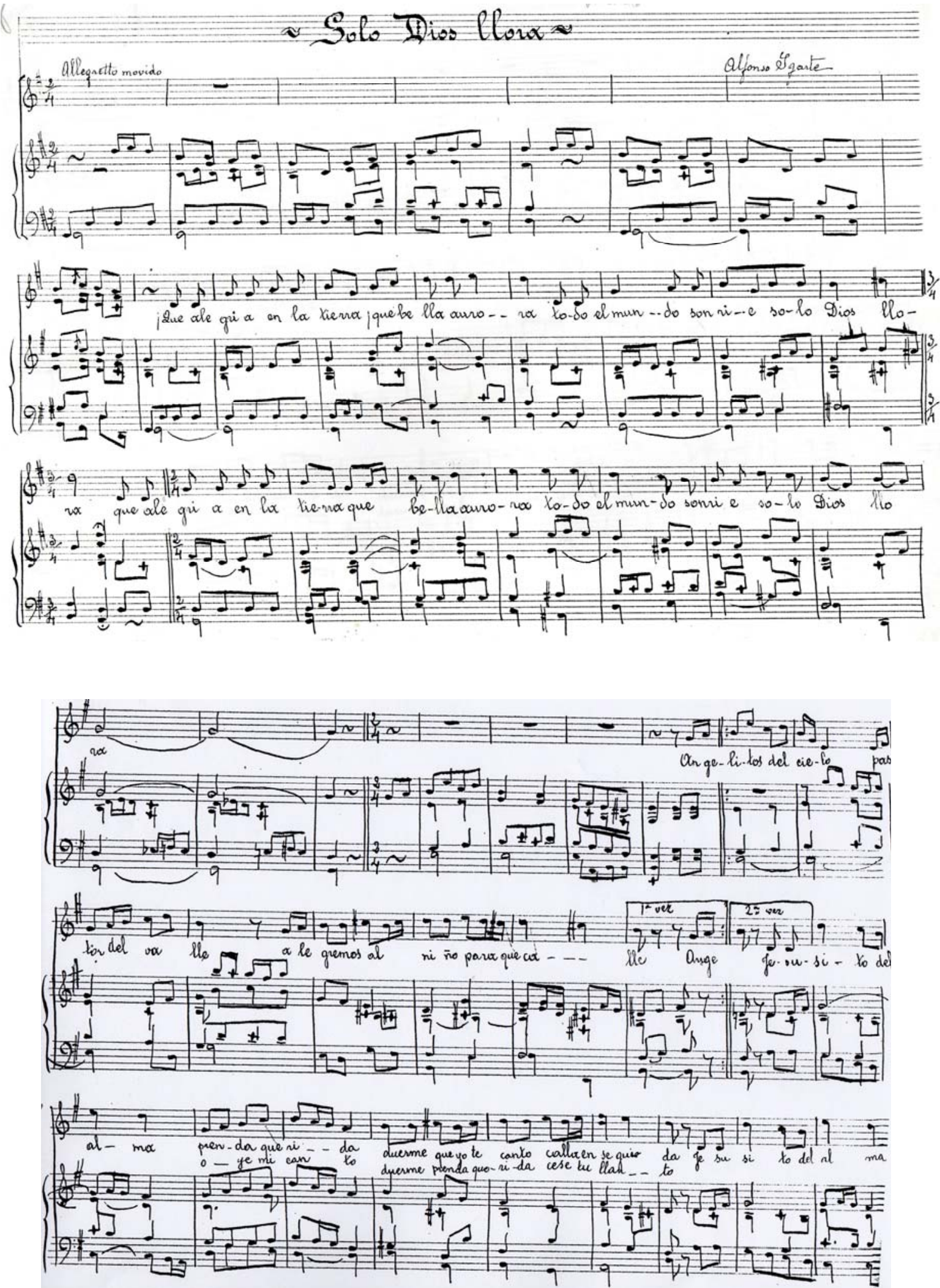

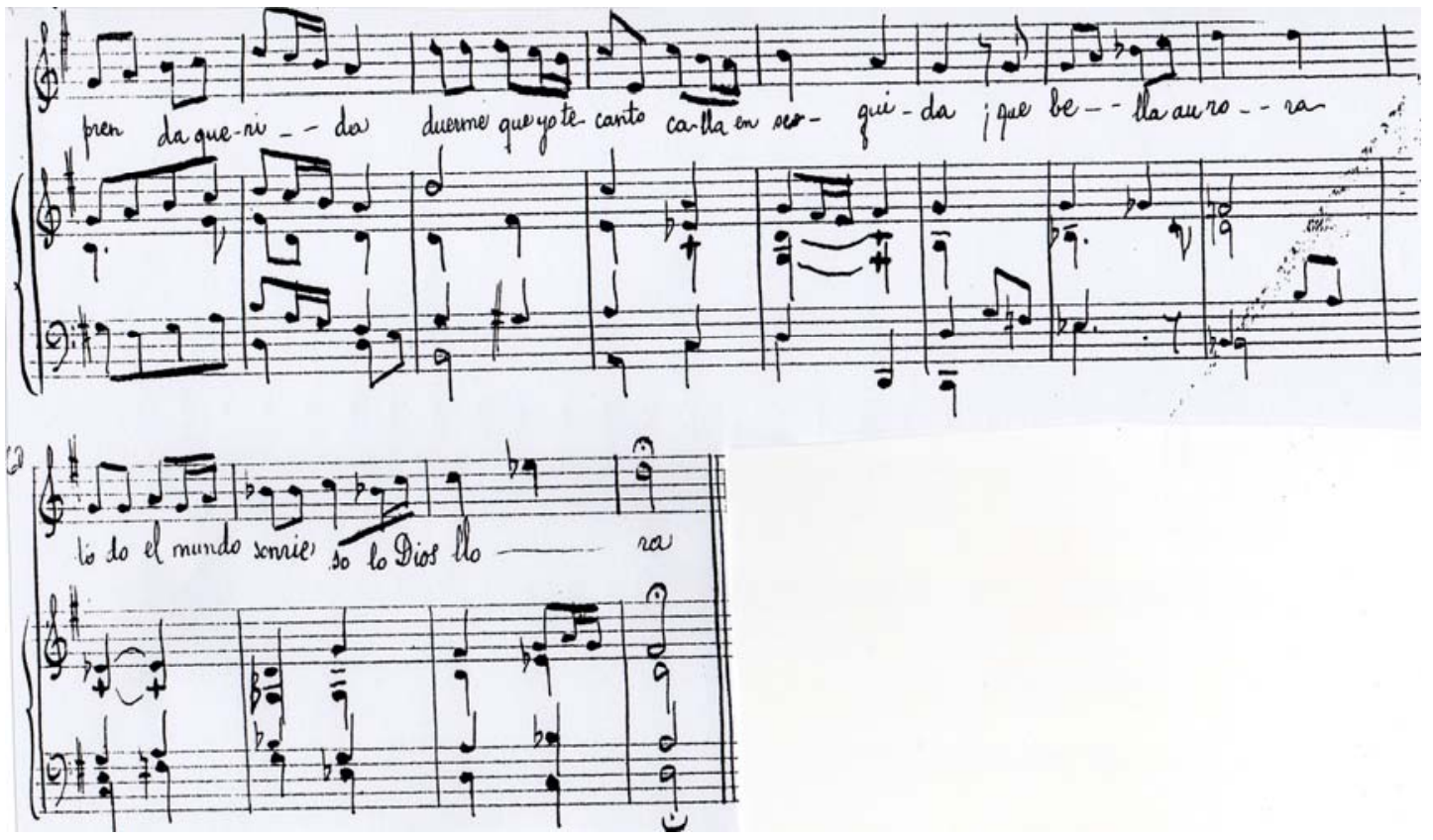

\section{V.5.2. Pequeña Misa Solemne}

A dos voces con acompañamiento de órgano o piano

Luigi Bordese

A manera de recordación, las Misas las encontramos con funcionalidad litúrgica y las hay de concierto. Las primeras someten el texto litúrgico, el lenguaje musical y la estructura formal a una cierta concreción y unidad exigidas por el rito sacro. Las misas de concierto, dentro de una intencionalidad religiosa, abren horizontes expresivos, medios técnicos, rítmicos, armónicos y formales acercandolas a la forma oratorio por sus largos desarrollos, repeticiones de texto, como las obras monumentales de Bach y Beethoven. Hadyn, Mozart, Schubert, Bruckner, hicieron hermosas misas solemnis. Los grandes Maestros de Capilla españoles conocieron el oficio de componer Misas solemnes, dejando en los archivos catedralicios un enorme y valioso legado como por ejemplo, la Misa hecha para la colocación del altar Mayor de la Catedral de Segovia que data de 1775 de Juan Montón y Mallen escrita a doble coro y con orquesta.258

258 Las edades del hombre. Música en la Iglesia de Castilla y León. Misa de Juán Montón y Mallen. Orquesta Sinfónica de Castila y Leó. Coro Universitario de León. Dir. Max Bragado Darman. 
Otras Misas Solemnes importantes, son las de: Antonio Ripa, Francisco García Fager, Pedro Arañáz y Vides, Antonio Soler y Francisco Teixidor.

De la Pequeña Misa Solemne a dos voces con acompañamiento de órgano o piano, de Luigi Bordese - compositor italiano -, se encuentra en el Archivo de Santa María de las Dueñas, una copia manuscrita de esta obra, aún siendo conocidas las ediciones que se han hecho de la misma, como la de Gérard Billaudot. El manuscrito encontrado, consta de las cinco partes - Kyrie, Gloria, Credo, Sanctus y Agnus Dei - y el acompañamiento de órgano en partichelas separadas para cada voz e instrumento acompañante. En su estructura, es una Misa de pequeñas dimensiones, práctica y funcional, sin grandes desarrollos.

\section{V.5.2.1. KYRIE}

(Dela Pequeña Misa Solemne)

Luigi Bordese

1a voz

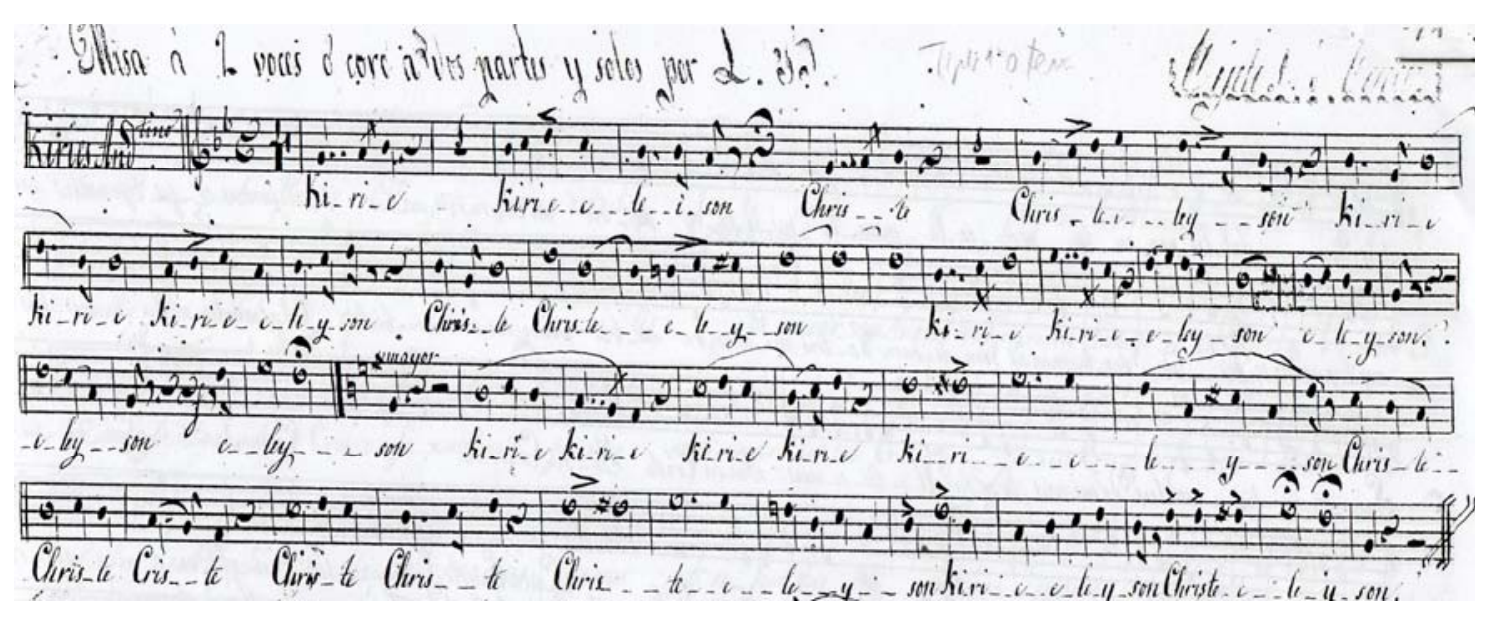


$2^{\mathrm{a}} \mathrm{VOZ}$

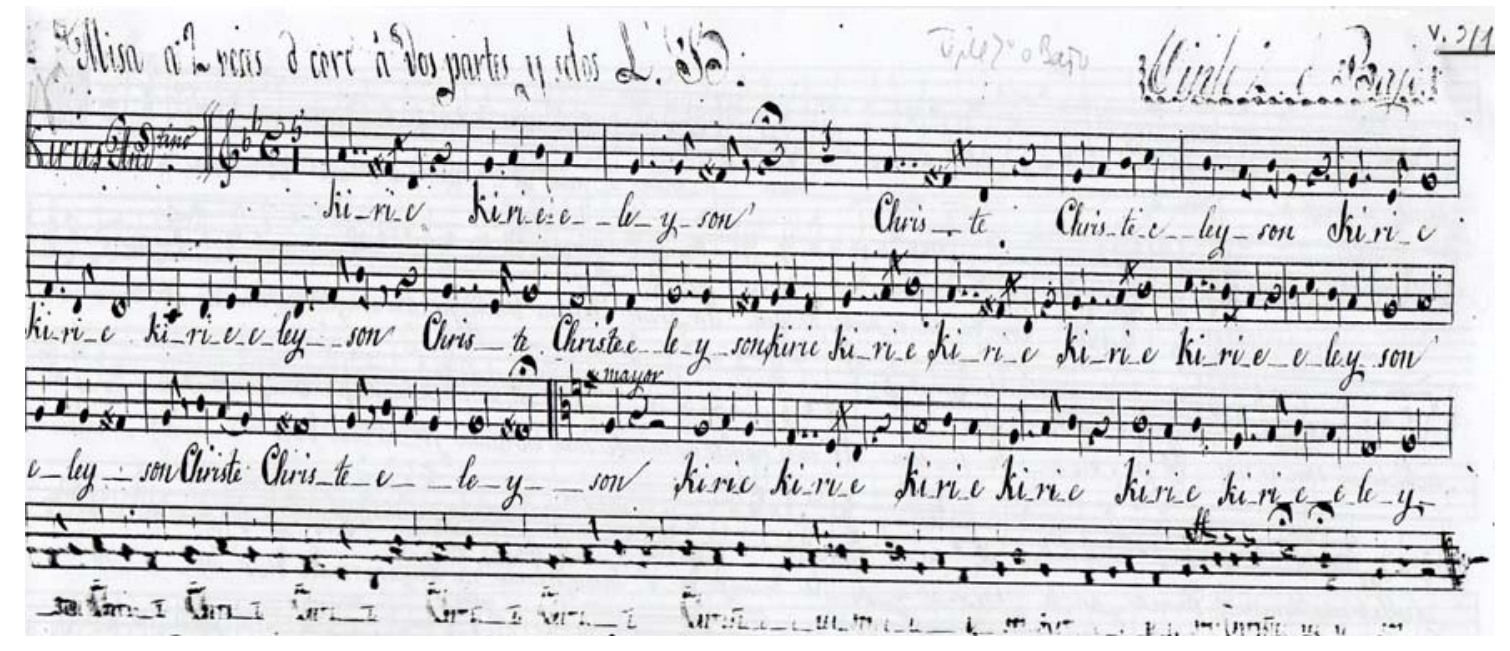




\section{Kyrie}

Acompañamiento del órgano

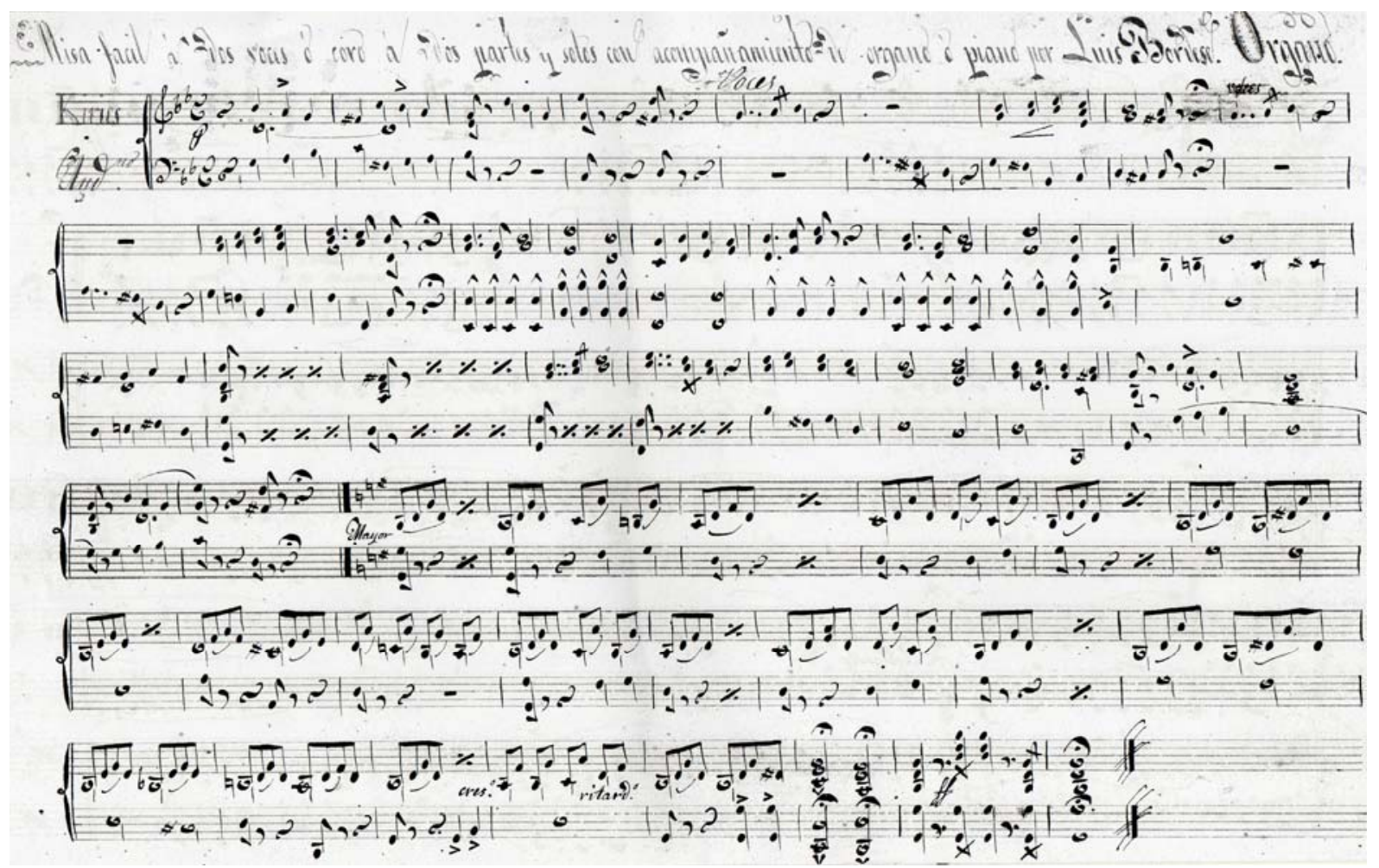




\section{V.5.2.2. SANCTUS}

(De la Pequeña Misa Solemne)

Luigi Bordese
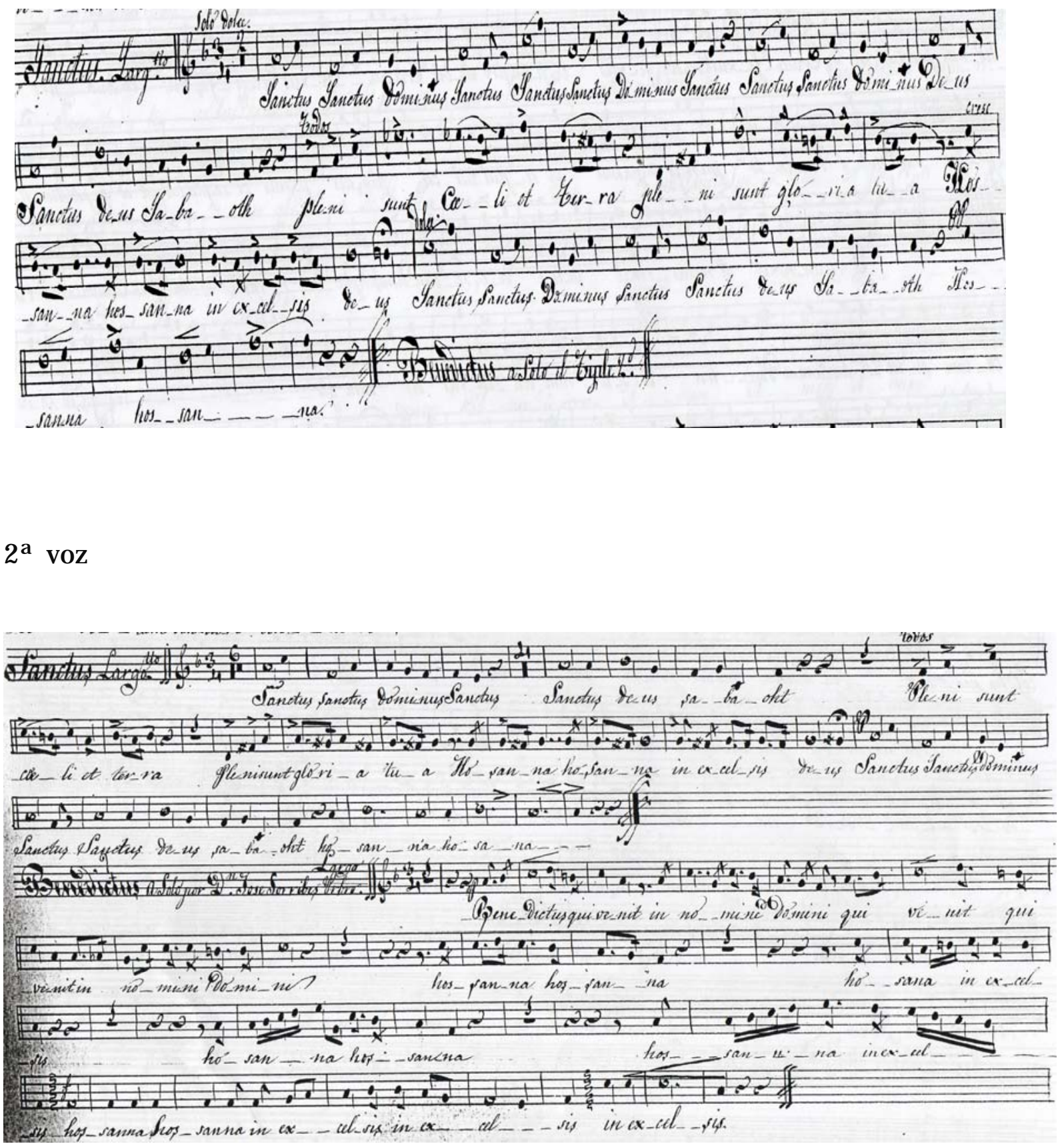


\section{SANCTUS}

Acompañamiento de órgano

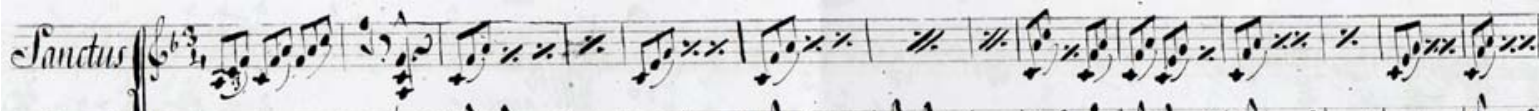

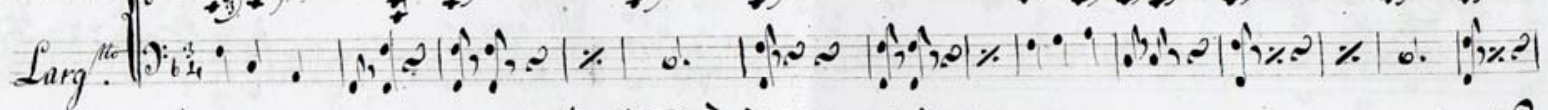
$\mid \because \div \%$.

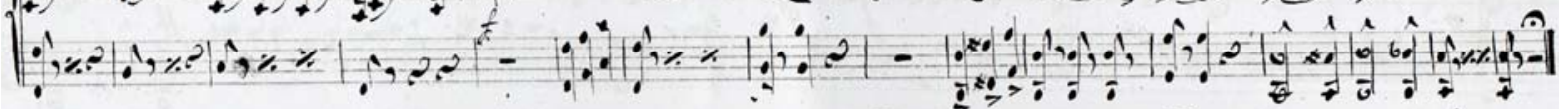

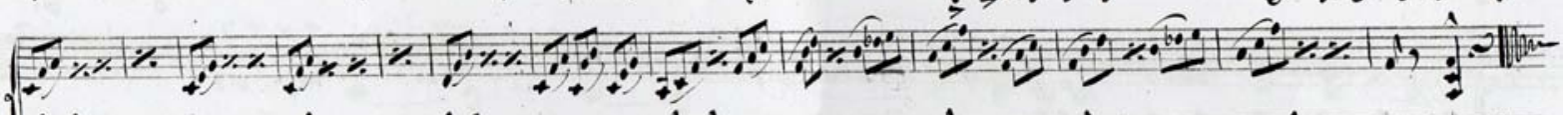

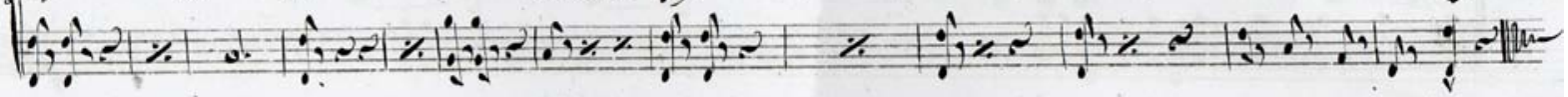

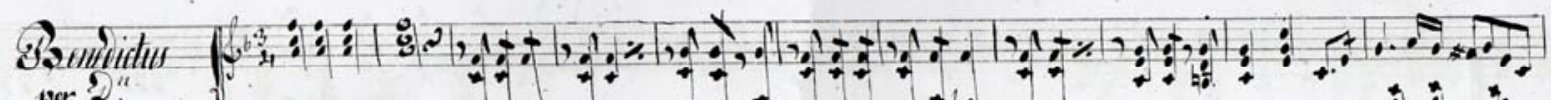

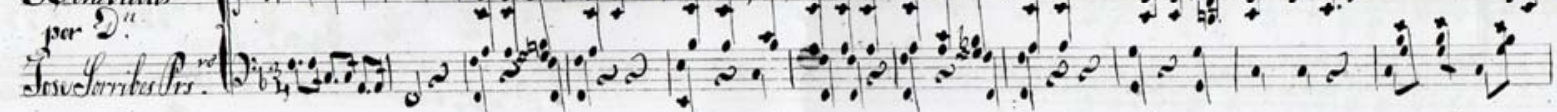

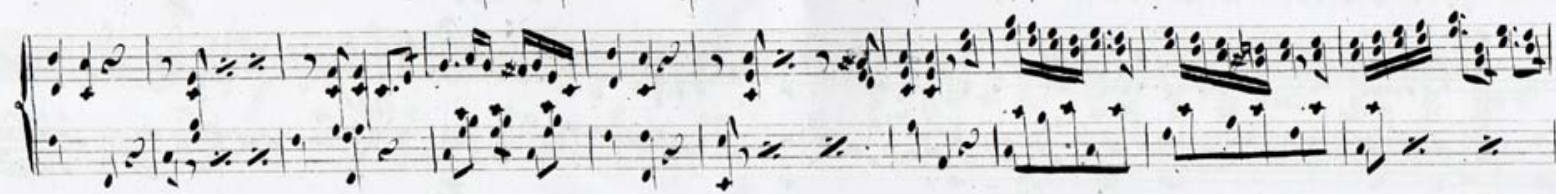

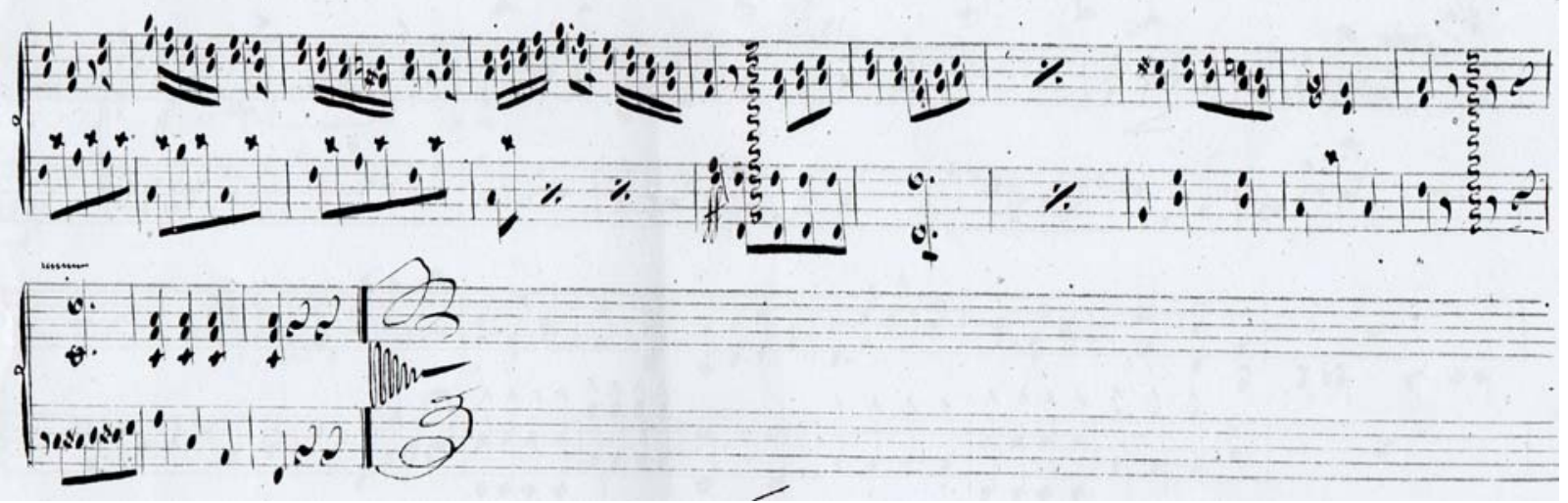




\section{V.5.2.3. AGNUS DEI}

(De la Pequeña Misa Solemne)

Luigi Bordese

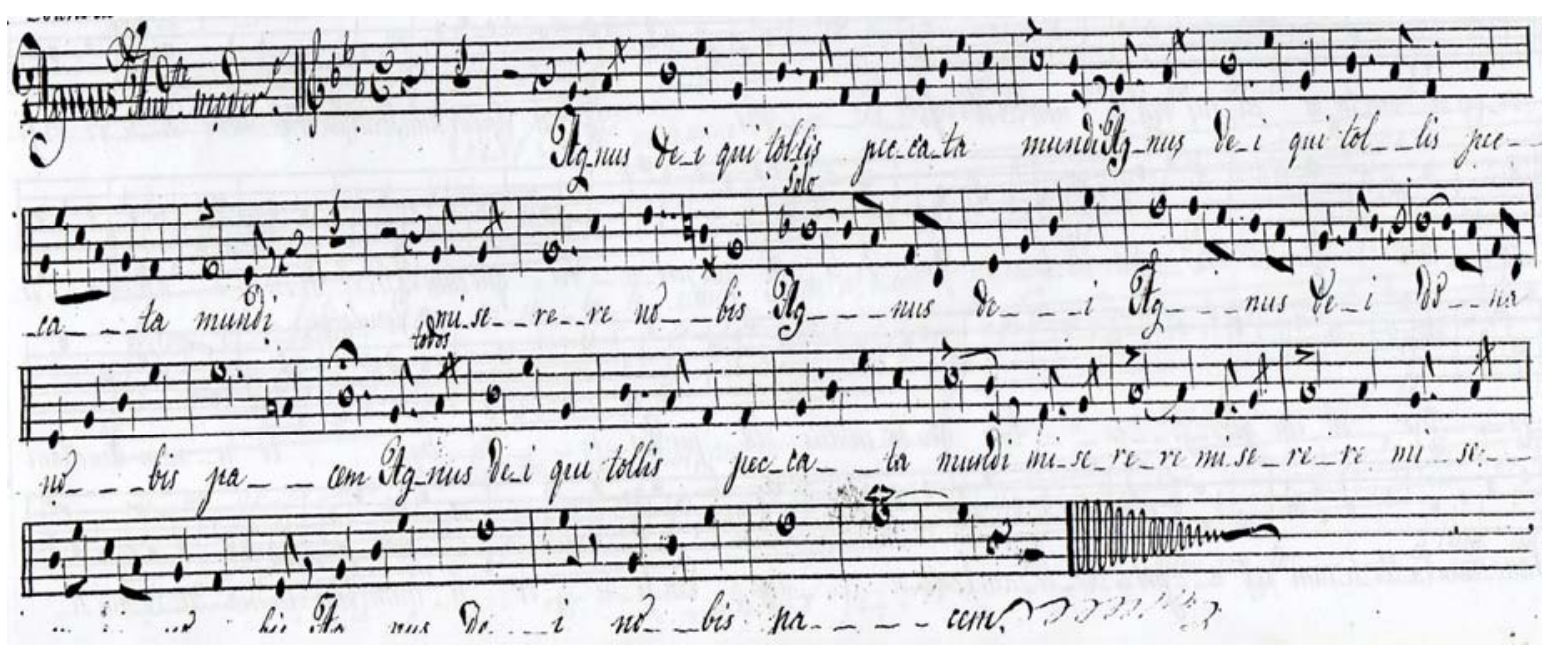

$2^{\mathrm{a}}$ VOZ

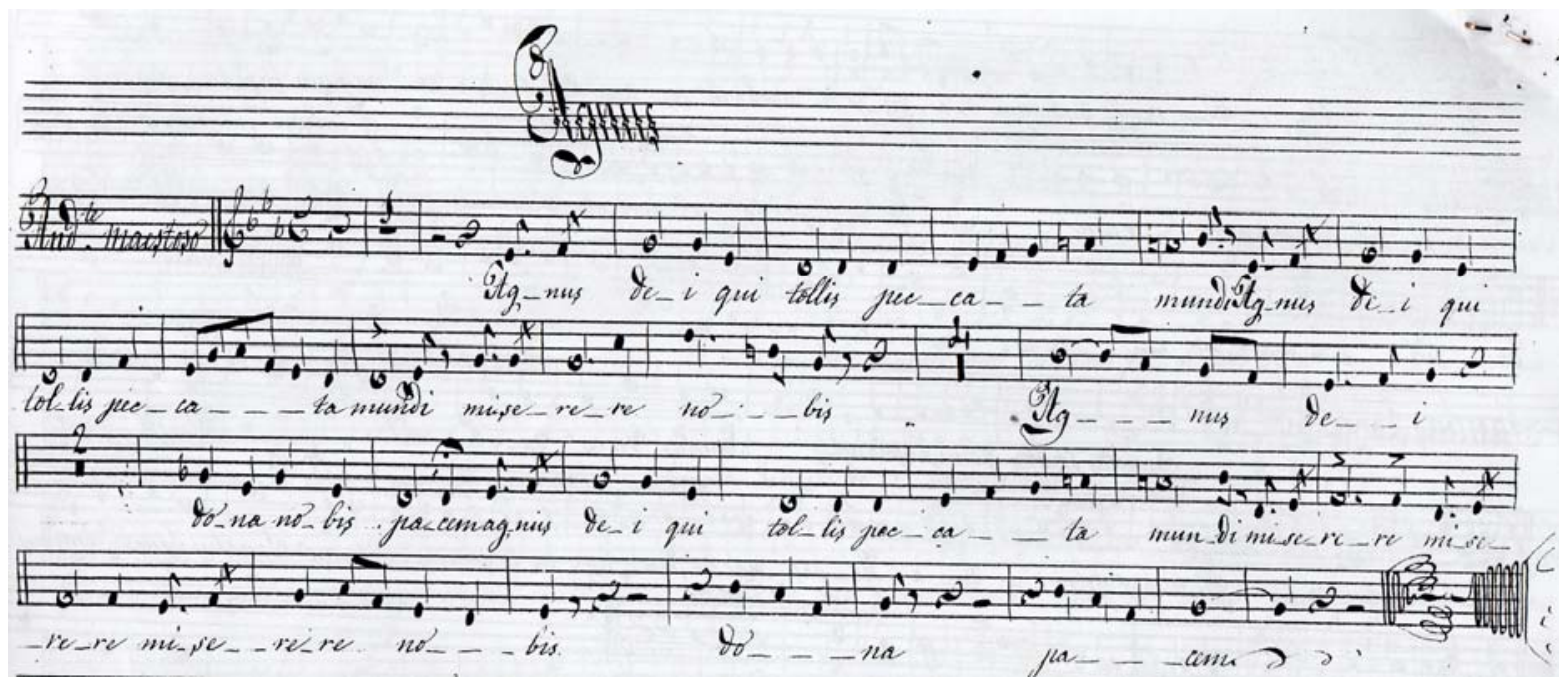




\section{AGNUS DEI}

Acompañamiento de órgano

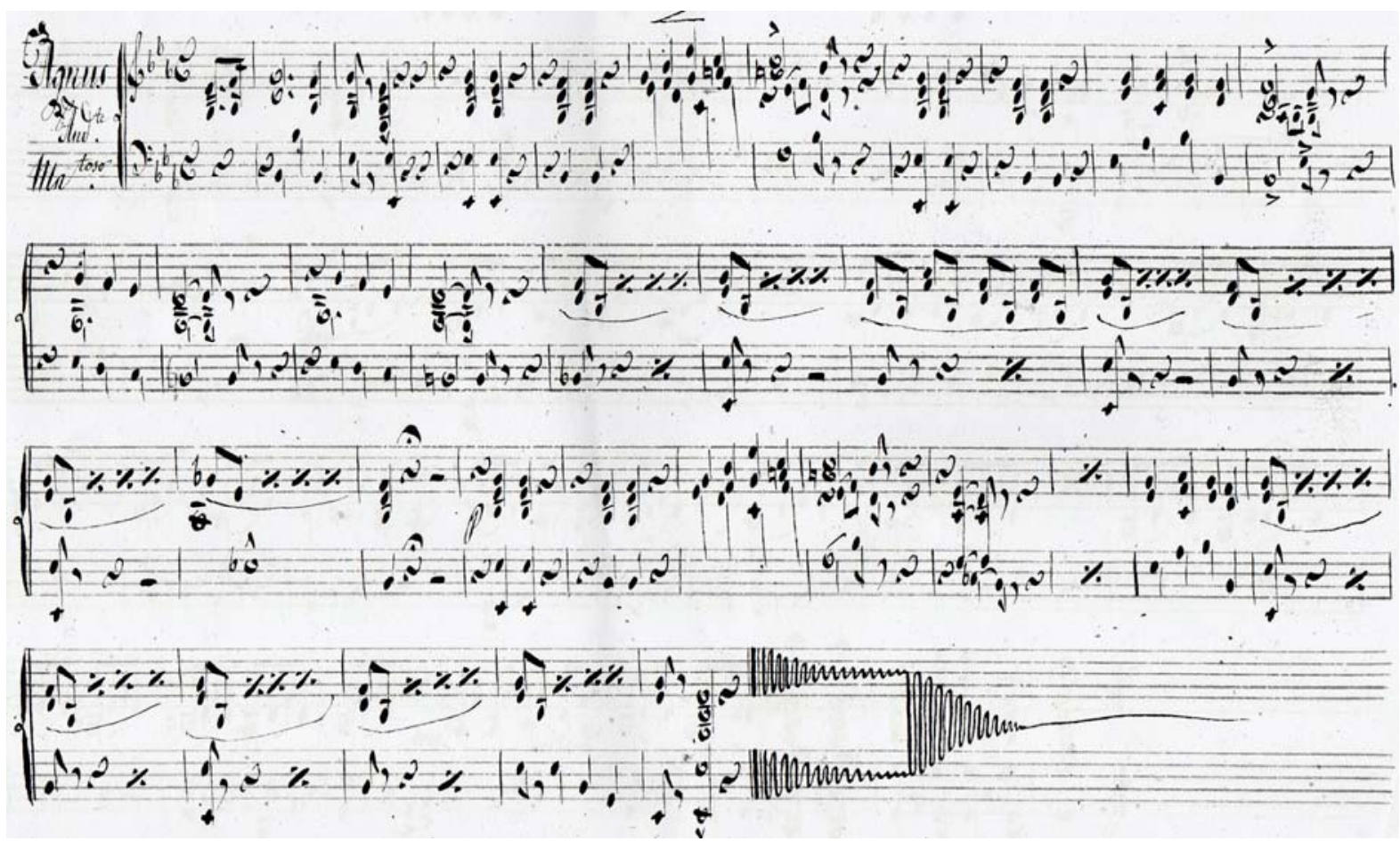




\section{V.5.3. ALBRICIA PASTORES}

\section{Anónimo}

Dentro del género villancico, perteneciente al Ciclo de Navidad, encontramos, esta agraciada pieza musical de alegría de Natal, manuscrita y conformada por dos estrofas a dúo y partes a solo con acompañamiento de piano. Pensada para dos voces femeninas, inicia presentando el tema, al unisono - cuatro compases -, para continuar a dos voces y luego con el solo de la voz tiple en el intermedio, para concluir con la segunda estrofa.
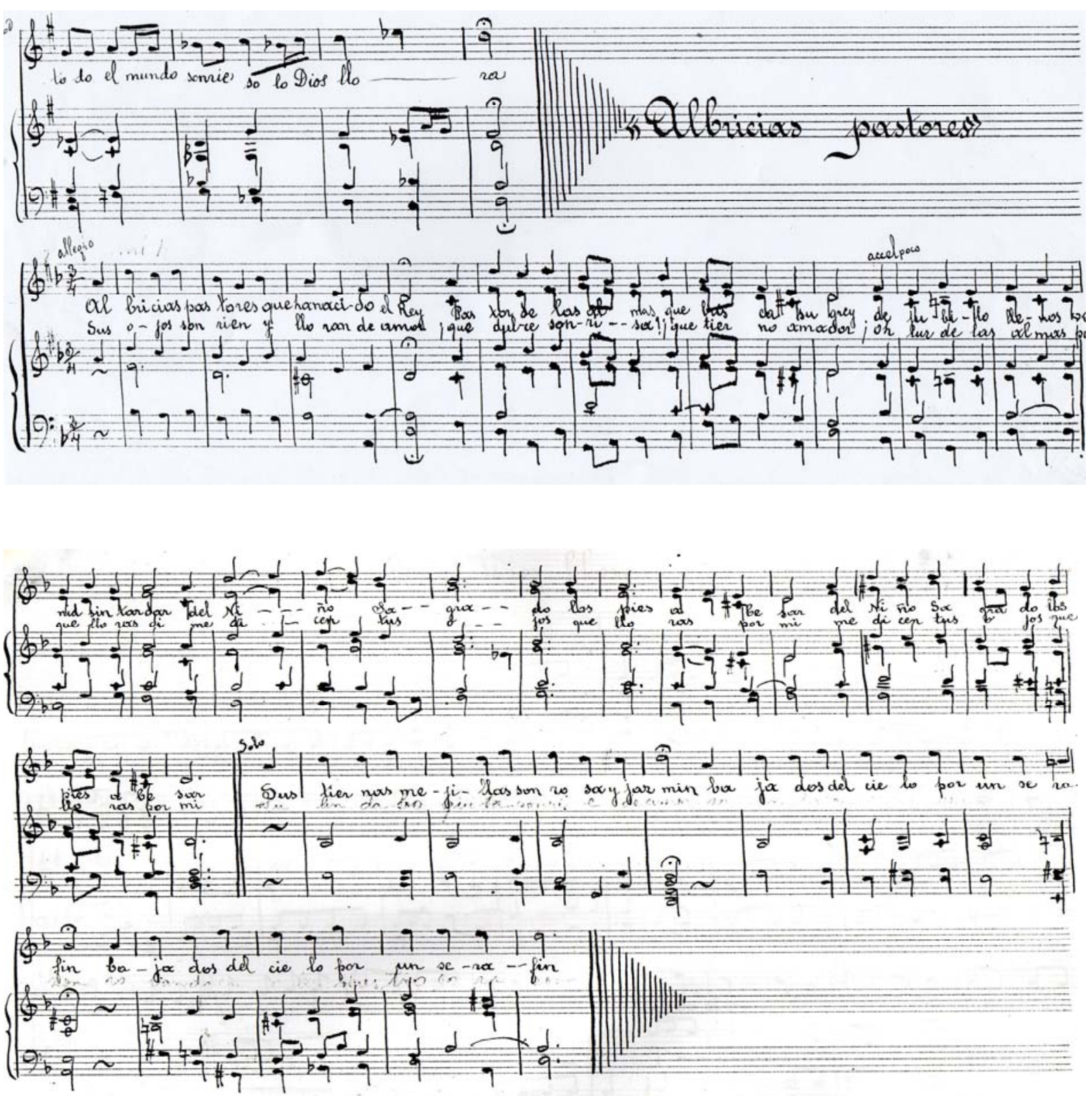


\section{V.5.4. SALVE - anónima}

La devoción Mariana, ha sido para los compositores de todas las épocas de nuestra era cristiana, el impulso o inspiración para la creación de infinidad de obras musicales, las cuales se han escrito bajo la advocación de la Virgen María, así como hermosos poémas y escritos en prosa; los grandes pintores y escultores la han representado en sus colosales obras artísticas y el pueblo la ha venerado desde tiempos inmemoriales, como una figura representativa de mujer, esencialmente como madre amantísima.

Un buen número de piezas musicales entre Salves, Magníficat, Ave María y canciones con diferentes títulos alusivos a la Virgen María, se conservan en los Monasterios investigados.

La salve, es una forma musical dentro de las canciones Marianas, que al la par que tiene un carácter de "saludo", en su texto, los hombres piden clemencia, misericordia y protección para su vida y ha sido adoptada por diferentes colectivos; por citar un ejemplo: la Armada Española canta la Salve Marinera, himno a la Virgen del Carmen, su Patrona:

\section{SALVE MARINERA}

¡Salve! Estrella de los mares, delos mares Iris de eterna ventura;

¡Salve! Fénix de hermosura

Madre del Divino Amor.

De tu pueblo a los pesares

Tu clemencia dé consuelo.

Fervoroso llegue al cielo

Y hasta Tí, y hasta Tí nuestro clamor... 
Salve - anónima

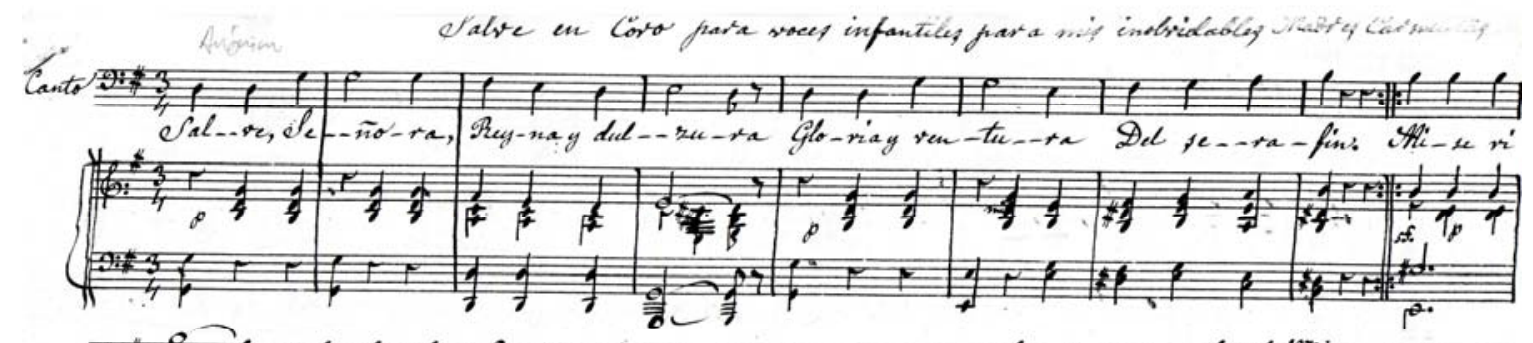

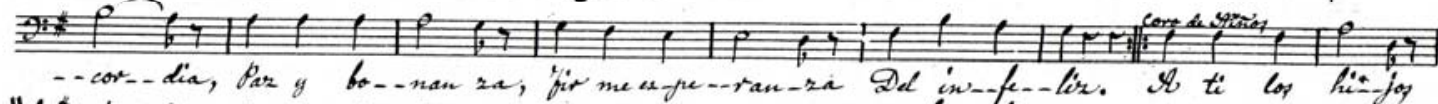

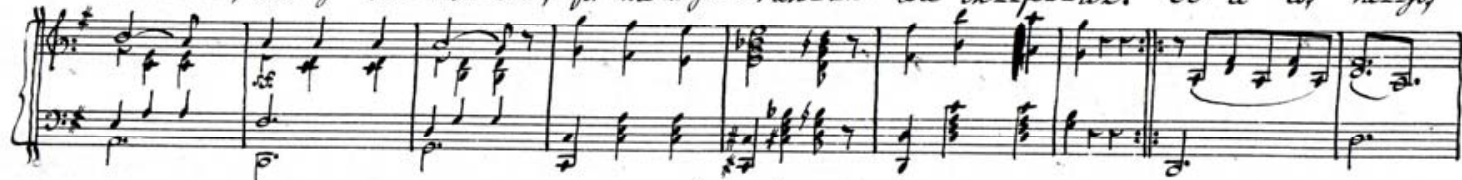

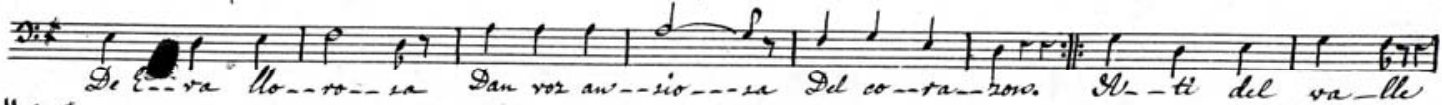

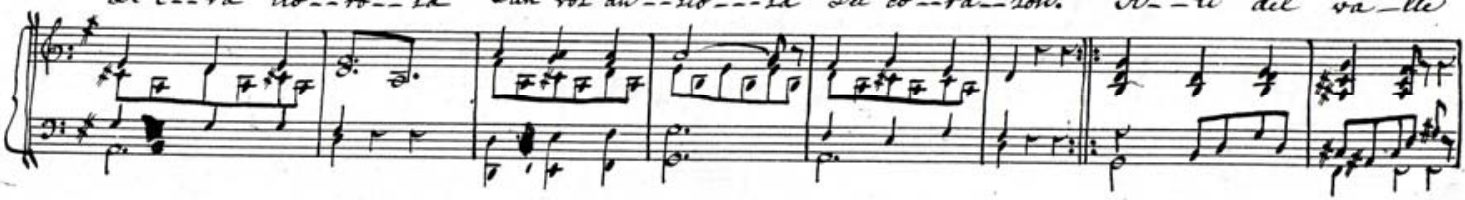

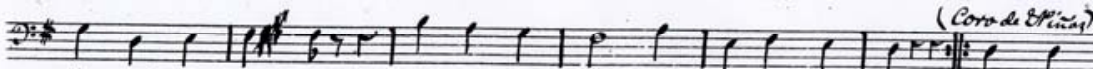

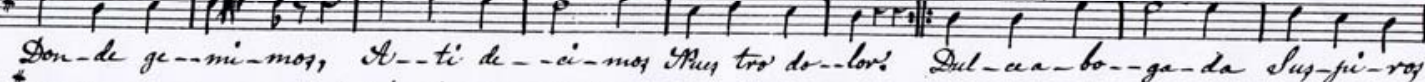

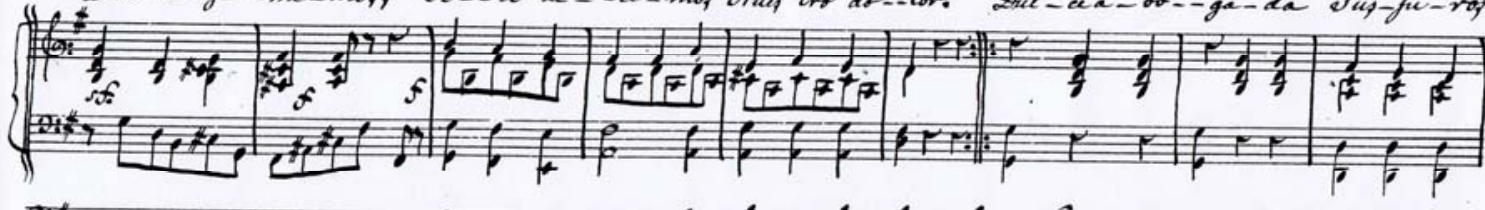

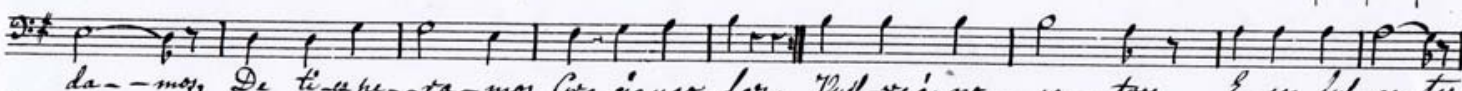

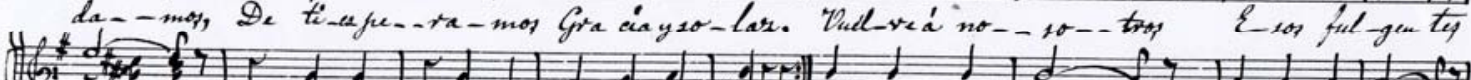

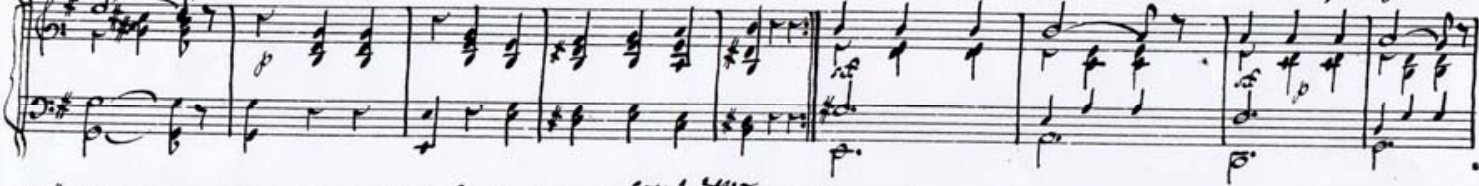

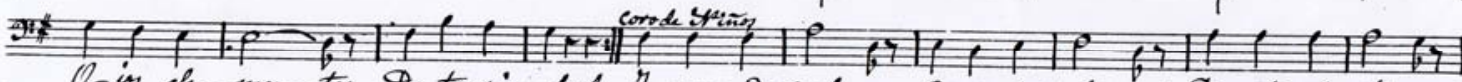

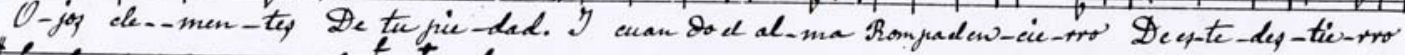

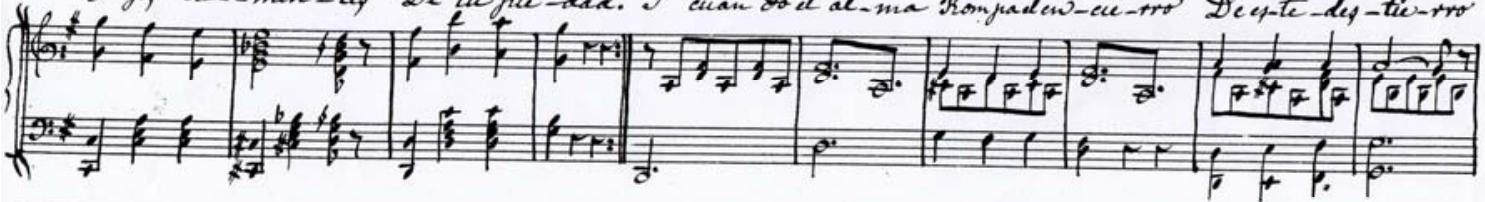




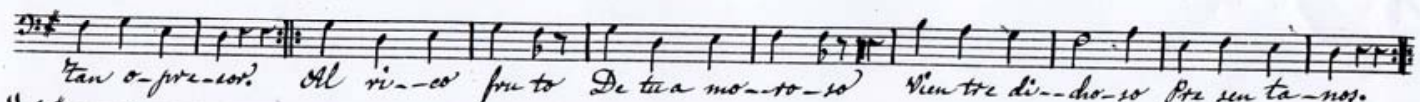
|

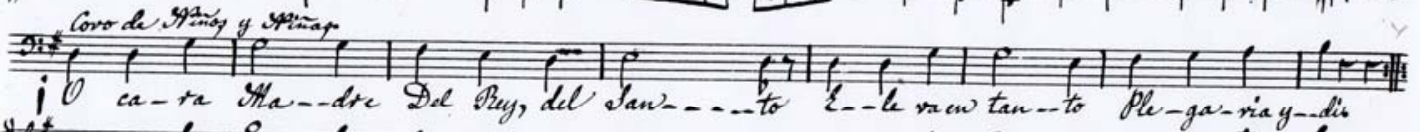

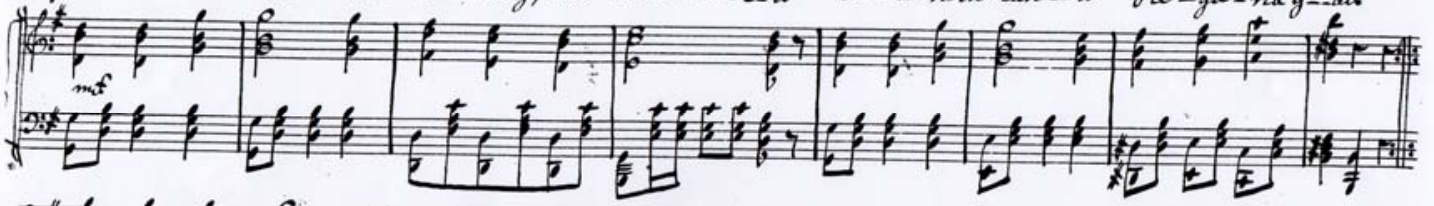

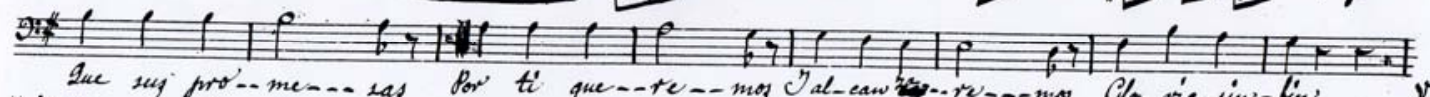

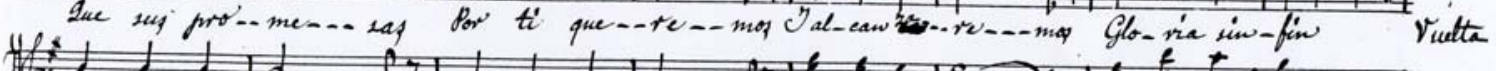
(20)

\footnotetext{
0
}

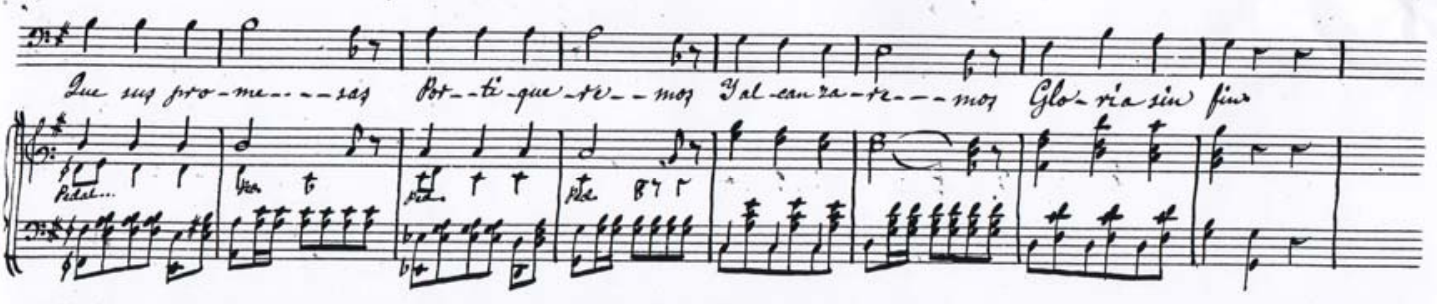
$\frac{\text { Gloria sin fin }}{\text { Glom }}$

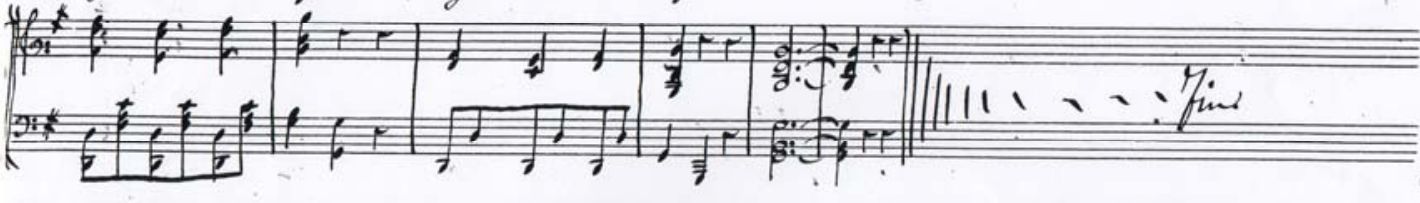

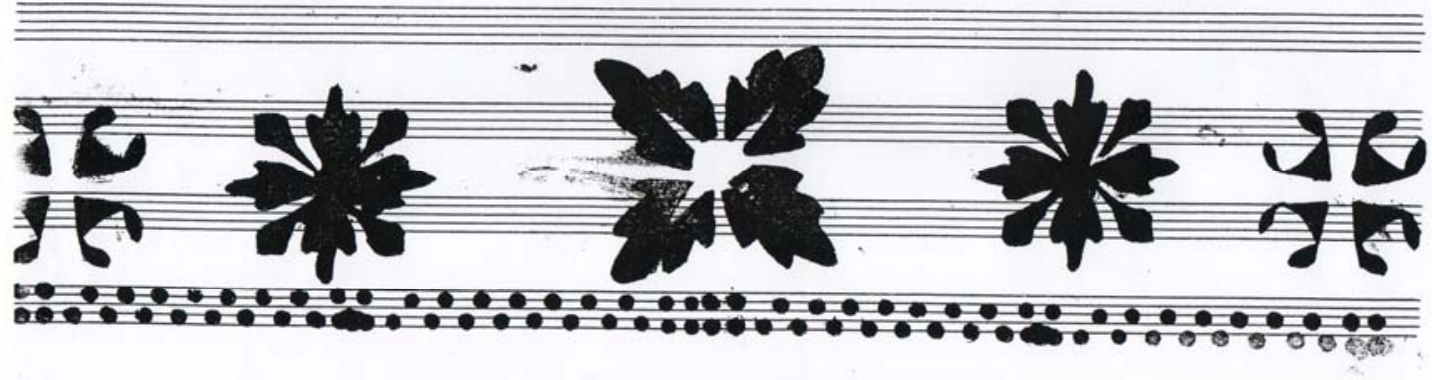




\section{CONCLUSIONES}

Las conclusiones del presente trabajo de investigación, se estructuran en cinco ejes principales. El primero en lo concerniente al problema central: La vida musical de los conventos femeninos de Alba de Tormes; la metodología, el contexto social y religioso desde el siglo XVII y las fuentes de la investigación (Introducción y capítulo I); los tres siguientes ejes, relacionados entre sí, son: los aspectos de la vida conventual, los procesos fundacionales y las características esenciales de la vida cotidiana, de los conventos femeninos en Alba de Tormes (capítulo II), y la actividad musical, la evolución del papel de la monja música desde el siglo XVII hasta la actualidad y las monjas destacadas en Alba de Tormes (capítulo III), el cuarto eje concerniente a la traslación de la cultura religiosa de la península a tierras del Nuevo mundo en épocas coloniales: Vida conventual en épocas virreinales en la nueva Granada, actual territorio de Colombia, analizando comparativamente, las analogías y las diferencias de la vida conventual (capítulo IV) y por último el relativo a los repertorios litúrgicos conservados en las Capillas musicales de Alba de Tormes (capítulo V).

A lo largo del trabajo, se ha intentado cumplir con el objetivo específico propuesto, como es sacar a la luz la documentación inédita en gran parte, de dos archivos conventuales Albenses y a través de ella estudiar y conocer la vida fundacional, la vida cotidiana y la actividad musical que en ellos se desarrolló desde el siglo XVII al XIX.

Desde otro punto de vista, interesaba ocuparse de temas poco estudiados sobre la vida de clausura femenina y acercarse al mundo de la mujer como sector marginado que fuera en aquellas épocas y la vida de aquellas mujeres músicas que demostraron su talento artístico y que se convirtieron en gestoras de capitales y alma de la Liturgia al interior de los mismos. 


\section{- El problema central y la metodología}

El estudio de los conventos femeninos de Alba de Tormes, permitió confirmar la hipótesis de su función religiosa, social y musical, unido a lo económico. La religión fue código de referencia constante, por lo que aquella mentalidad religiosa favoreció la actividad musical destinada al culto litúrgico y aunque los monasterios estaban regidos o controlados por la Iglesia, cada uno desde su concepción, ha mantenido su sello indeleble. El estudio comparativo de los monasterios Albenses, con el monasterio de Santa Clara (Clarisas) y de Santa Inés (Dominicas) de Santa Fe de Bogotá en épocas virreinales, nos permitieron llegar a conocer las diferencias fundacionales y de funcionalidad de cada uno (en lo social y en lo económico) y las diferencias en cuanto a la vida conventual femenina dentro de la clausura. Consultados los documentos de los archivos conventuales, que son el principal conjunto de fuentes primarias tan valiosas - por cuanto ofrecen la vida monacal en todos sus aspectos -, de primera mano, se seleccionaron con el objeto de darle organización a la investigación y por orden de importancia y prioridad. La problemática se presentó en el momento en que nos encontramos con lagunas documentales, por años. De tal manera, si en un principio el tema se quiso centrar exclusivamente en el siglo XVII, la misma documentación nos encaminó a la ampliación de los límites cronológicos, que a la larga fueron de gran beneficio por la interesante composición de legajos originales, relacionados con el tema central del trabajo: La vida de las monjas músicas.

\section{- Novedad en las fuentes empleadas}

Primeramente, lo aportado en este trabajo, es el estudio y transmisión de la documentación de archivos inéditos en su mayoría, hasta ahora. No hay referencias en la historiografía Albense sobre la vida musical y sobre las monjas músicas de sus monasterios femeninos, excepto aspectos relacionados con el arte, con la vida de Santa Teresa y la fundación del Monasterio de "La Anunciación”, peregrinaciones y sus fiestas conmemorativas. El monasterio de Santa María de las Dueñas, guarda valiosa documentación sobre el tema, que merece ser 
conocido. El hecho de tratarse de archivos que se encuentran en zonas de clausura que no son instituciones públicas, complica la investigación por cuanto no es fácil llegar a ellos. Por el contrario, el Archivo Catedralicio de Salamanca, el Diocesano y el de la Biblioteca antigua de la Universidad de Salamanca, aportaron importantes fuentes manuscritas inéditas sobre temas relacionados con las fundaciones conventuales, tanto en Alba de Tormes como en Santa Fe de Bogotá y sobre la vida personal y musical de las monjas del Monasterio de Santa María de las Dueñas.

Al hacer inicialmente el análisis de los documentos que reposan en estos Monasterios, se pudo ver la riqueza y variedad documental que poseen; se deja de esta forma el campo abierto para que los interesados en temas conventuales puedan continuar la investigación en muchos aspectos. Se ha intentado dar certeras conclusiones a cada capítulo, por lo tanto lo que se ofrece a continuación son algunas reflexiones personales, que la investigación realizada permite repasar y puntualizar sobre el conventualismo femenino colectivo en general y en el ámbito de la comarca de Alba de Tormes, primordialmente.

\section{- Las Fundaciones conventuales y vida conventual como punto de partida}

De entrada, el contexto religioso, social, económico y político de una época nos sitúa en el tiempo y en el escenario de la investigación; por lo tanto la primera reflexión que nace, es la proporcionada por ese propio contexto de la época. Se tiene claridad que las fundaciones conventuales fueron la lógica solución al clima social y religioso del momento, marcado por la Reforma y la Contrarreforma, por las disposiciones del Concilio de Trento y las nuevas formas de espiritualidad. Partiendo del análisis de quienes conformaron estas instituciones monacales y de cómo se establecieron estas fundaciones, se llega a la conclusión de que el modelo conventual es la consecuencia inmediata de las condiciones en que se establece cada fundación; sin embargo, sobre las cuestiones religiosas se ha comprobado que existen bastantes analogías. 
Las Constituciones de ambas Órdenes femeninas - Benedictinas y Carmelitas-, con espiritualidades diferentes en su origen, aunque en la vida conventual y en la aplicación de la práctica religiosa tienen muchas similitudes, nos presentan el funcionamiento de los monasterios en cuanto a la vida cotidiana, la espiritualidad, la liturgia, la música, la economía, la disciplina, vida en comunidad. El contexto religioso influía sobre la personalidad de las monjas que habitaban los conventos y sobre su vida religiosa. Dada las manifestaciones del momento, como milagrerías, visiones y estigmas, no se encuentra en el Monasterio de Santa María de las Dueñas, ningún relato al respecto, salvo, algunos apuntes sobre la práctica del ayuno, que se imponían las monjas a manera de mortificación para agradar a Dios; no se menciona que fuese a manera de castigo para enmendar las culpas.

En la vida de las mujeres enclaustradas y al servicio de la religión, se observa que algunos elementos de las primeras cristianas romanas, se conservan, como la virginidad, la viudez y la capacidad de servicio a la comunidad, aspectos que fueron retomados como nuevos designios o propósitos por la modernidad pos tridentina dentro de una nueva formalidad de las prácticas religiosas. La noble procedencia de algunas monjas, fueron un componente presente en los monasterios Albenses y ello se puede considerar como la herencia de la espiritualidad monástica medieval. El Concilio de Trento dio las pautas a seguir en cuanto a espiritualidad y perfeccionamiento personal; por ello, encontramos las Directoras espirituales, que controlaban el cumplimiento de la Regla y a su vez vigilaban, la lucha librada por las mujeres en su vida conventual. Las visitas periódicas de los Prelados a los monasterios, se constituían en un mecanismo de control sobre la espiritualidad y sobre la vida cotidiana de las monjas, metiendo en cintura lo que no estaba en concordancia con lo establecido. La importancia de Cristo como figura central de religiosidad, se dejó sentir en la vida de las enclaustradas como una acción simbólica de unión matrimonial con él y con Dios (con la Iglesia). La espiritualidad de los laicos y en ocasiones el sentido social, favoreció notablemente a los monasterios, personas aportaron lo necesario para erigir las fundaciones y contribuir a su mantenimiento, con donaciones, herencias, limosnas, dotes perpetuas, etc., todo a cambio de la salvación de sus almas. Habiendo hecho una comparación entre los Monasterios Albenses y los 
Monasterios del Nuevo Reino de Granada de entonces, se llega a la conclusión de que el carácter social que cada monasterio se manejaba en función de su espiritualidad, su economía o su política. Como lo económico y lo material estaban fuertemente unidos al mundo de la salvación del alma, por las creencias de la sociedad y por la administración que de ellas hacía la Iglesia, no existía esa división actual entre bienes materiales y espirituales.

Los monasterios estudiados, así como la generalidad de los conventos femeninos españoles de estas épocas fueron habitados por conjuntos de mujeres de distintas condiciones humanas y sociales, sometidas a un duro régimen de vida, aunque en cierta forma bastante más instruidas que la generalidad de las mujeres que vivían en el exterior, pero que necesitaron a veces del control, de las normas de la Regla o Constituciones. La vida en comunidad estuvo marcada por la Regla que señalaba las jerarquías y los oficios conventuales, los cuales de una u otra forma reproducían al interior de los monasterios las divisiones existentes en la sociedad.

\section{- Respecto a la vida musical}

Sin ser grandes Capillas musicales, los monasterios de Alba de Tormes, presentan haber desarrollado una actividad musical; los documentos económicos encontrados con relevantes referencias respecto a la música, son un testimonio de aquel despliegue musical que se llevó a cabo durante años y que aún hoy en día se sigue conservando pero con más sencillez.

Desde otro punto de vista, la música dominaba el panorama de las actividades Litúrgicas y las fechas relevantes en los monasterios. Muchas son las referencias que se encontraron en los documentos, en las que se hace alusión a lo interpretado tanto en la celebración diaria, como en las festividades especiales de los Santos Patronos, Natividad, Semana Santa, Corpus Christe, toma de votos y en el fallecimiento de alguna religiosa; y con más boato, si la religiosa era la Abadesa. Esto, permitió hacerse un juicio sobre la importancia de la música en los monasterios y sobre la actividad musical desarrollada. 
Ya que los repertorios musicales encontrados pertenecen al siglo XIX, estos revelan el estilo y por ende, las formas y los géneros musicales que imperaban en el momento: la ópera y el lied o canción. Íntegramente decae la música religiosa, en estas épocas siglo romántico; sin embargo, los compositores continúan haciendo música religiosa (misas, villancicos, cantos marianos, etc.) en menor escala, pero ceñidos a las formas musicales del período. La mayoría de las obras musicales se clasifican en lo que se conoce como Lied o canción, con acompañamiento de piano $\mathrm{u}$ órgano en algunos casos. Las misas a dos voces con acompañamiento de piano u órgano y los villancicos para voz y piano, son la generalidad del repertorio musical encontrado. Los análisis musicales realizados, se han incluído a manera de complementación al trabajo de investigación.

Es cierto que los datos estudiados en este trabajo de investigación conciernen a conventos determinados en una localidad determinada; pero aunque se constatan contrastes y también similitudes en algunos aspectos con los estudios antes realizados y referidos en el estado de la cuestión, la base social sobre la que se trabaja es la misma: la población religiosa femenina, las condiciones en que se desarrolla la vida conventual, la mentalidad religiosa de estas épocas. Lo novedoso en esta investigación, es el estudio realizado a profundidad sobre la vida de las monjas músicas, la temática de género y los repertorios musicales de los monasterios Albenses. Todo lo anterior se enmarca dentro del estudio de interés de esta investigación, aportando fundamentos y referencias importantes a la vida musical de Alba de Tormes.

Con este trabajo se ha pretendido motivar a las personas interesadas para la continuación de esta línea de investigación y se aporta una perspectiva más para la realización de investigaciones musicológicas de este tipo. 


\section{BIBLIOGRAFÍA}




\section{BIBLIOGRAFÍA}

\section{ACTIVIDADES MUSICALES EN CONVENTOS FEMENINOS}

AGUIRRE RINCON, Soterreña. "El manuscrito polifónico de Santa Clara de Carrión de los Condes: Más que un repertorio musical". Revista de Musicología XX (1997), pp. 185-98.

ARENAL, Electa y SABAT RIVERS, Georgina (eds). Sor Marcela de S. Félix. Obras completas. Barcelona, PPU, 1988.

ASENSIO PALACIOS, J uan Carlos; LORENZO ARRIBAS, J osemi. El Códice de las Huelgas. Madrid: Fundación Caja Madrid, 2004.

BAADE, Colleen R. "La 'música sutil' del Monasterio de la Madre de Dios de Constantinopla: aportaciones para la historia de la música en los monasterios femeninos de Madrid a mediados del siglo XVI-siglo XVII". Revista de Musicología XX (1997), pp. 221-30.

CAPDEPÓN VERDÚ, Paulino. "La capilla de música del monasterio de las Descalzas Reales de Madrid”. Anuario del Instituto de Estudios Madrileños XXXVII (1997), pp. 215-26.

CAPDEPÓN VERDÚ, Paulino. "Maestros de capilla del monasterio de la Encarnación”. Anuario del Instituto de Estudios Madrileños XXXVI (1996), pp. 455-86.

CAPDEPÓN VERDÚ, Paulino. "Maestros de capilla del Monasterio de las

Descalzas Reales de Madrid en el siglo XVIII (I)". Anuario del Instituto de Estudios Madrileños XLVII (2007), pp. 293-320.

CAPDEPÓN VERDÚ, Paulino. "Maestros de capilla del Monasterio de las

Descalzas Reales de Madrid en el siglo XVIII (II)". Anuario del Instituto de Estudios Madrileños XLXIX (2009)

CAPDEPÓN VERDÚ, Paulino. La música en el Monasterio de la Encarnación (Siglo XVIII). Madrid: Fundación Caja Madrid, 1997.

CAPDEPÓN VERDÚ, Paulino. La música en el Monasterio de las Descalzas Reales (Siglo XVIII). Madrid: Fundación Caja Madrid, 1999. 
GARCÍA DE LA CONCHA, Víctor y ALVAREZ PELLITERO, Ana. Libro de romances y coplas del Carmelo de Valladolid. Salamanca: Consejo General de Castilla y León, 1982.

GLIXON, Beth L. "Scenes from the life of Silvia Galiarti Manni, a seventeenthcentury virtuosa". Early Music History XV(1996), pp. 97-146.

GOMEZ MUNTANÉ, M. Carmen. "El manuscrito 1bis del Monasterio de Santa María de Vallbona". Recerca Musicològica IX-X (1989-90), pp. 59-72.

IBARZ, Mํㅡㄹ Trinidad. "El canto de las mujeres en el Templo durante el reinado de Alfonso XII. Reflexiones sobre el IV Congreso Nacional de Música Sacra". Nasarre IX (1993), pp. 221-79.

LORENZO ARRIBAS, Josemi. ¿Una atribución a una compositora castellana de principios del siglo XIV?. Nuevas interpretaciones para una polémica en torno al "Códice de Las Huelgas". Revista de musicología XXVIII (2005), pp. 86-101.

LORENZO ARRIBAS, Josemi. "Madres sabias, musas y monjas cantoras: transmisión musical y magisterio femenino en la Edad Media". Arenal: Revista de Historia de Mujeres VI (1999), p. 5-29.

LORENZO ARRIBAS, Josemi. Hildegarda de Bingen (1098-1179). Madrid: Ediciones del Orto, 1996.

LORENZO ARRIBAS, J osemi. Una relación disonante: las mujeres y la música en la edad media hispana, siglos IV-XVI. Alcalá de Henares : Ayuntamiento de Alcalá de Henares, Centro Asesor de la Mujer, 1998.

MACEY, Patrick. "Galeazzo Maria Sforza and musical patronage in Milan: Compére, Weerbeke and J osquin". Early Music History XV (1996), pp. 147212.

MARTINEZ SOLAESA, Adalberto. "La música sacra en el monasterio de Santa Clara". Celtiberia LXXI-LXXII (1986), pp. 87-97.s

OLARTE MARTÍNEZ, Matilde. "La mujer española y la enseñanza musical en nuestro siglo". La mujer ante el Tercer Milenio. Salamanca: Plaza Universitaria Ediciones, 1997, pp. 161-78.

OLARTE MARTÍNEZ, Matilde. "Las 'Monjas Músicas' en los conventos españoles del Barroco. Una aproximación etnohistórica". Revista de Folklore CXLVI (1993), pp. 56-63. 
OLARTE MARTÍNEZ, Matilde. "Retribución económica de la enseñanza musical de la mujer en los conventos femeninos de clausura". La Mujer, creadora y transmisora de culturas en el área mediterránea: el Mediterráneo como ágora de encuentro, Valencia, 1992, pp. 275-87.

OLARTE MARTÍNEZ, Matilde. "Músicas, cantoras y ministriles en el convento de Loreto de Peñaranda de Bracamonte". Estudios multidisciplinares de Género I (2004), pp. 287-99.

OSUNA LUCENA Maㅡ Isabel. "La música en el monasterio de Santa Inés: D. Buenaventura Iñíguez". Laboratorio de Arte V (1993), pp. 177-218.

RAMOS LOPEZ, Pilar. "Los estudios de género y la música ibérica del siglo XVII". Revista de Musicología XX (1997), pp. 231-44.

REARDON, Colleen. Holy Concord Within Sacred Walls: Nuns and Music in Siena, 1575-1700. Oxford: Oxford University Press, 2001.

RUIZ DE ELVIRA SERRA, Isabel. "Introducción". Catálogo de villancicos de la Biblioteca Nacional. Siglo XVII. Madrid, Biblioteca Nacional, 1992, pp. XIXVIII.

SÁNCHEZ SISCART, Montserrat. "Evolución formal del villancico y el oratorio dieciochescos en las catedrales zaragozanas". Recerca Musicologica IX-X (1989-90), pp. 327-340.

SUBIRA, J osé. "La música en la Capilla y Monasterio de las Descalzas Reales de Madrid". Anuario Musical XII (1957), pp. 147-66.

TOQUICA, Constanza, y RESTREPO, Luís Fernando. “Las canciones del Coro alto del Archivo del Convento de Santa Clara de Santa Fe de Bogotá". Cuadernos de Literatura. Pontificia Universidad J averiana de Colombia VI (2000-2001), pp. 90-117.

VEGA CERNUDA, Daniel. "Retórica y música en los plactus del Códice de Las Huelgas: un aporte metodológico". Revista de musicología XXIII (1990), pp. 421-50.

VEGA GARCÍA-FERRER, Ma J ulieta. La música en los conventos femeninos de clausura en Granada. Granada: Universidad de Granada/Junta de Andalucía, 2005.

VICENTE DELGADO, Alfonso de. La música en el Monasterio de Santa Ana de Avila. Madrid, SEdM, 1989. 
VICENTE DELGADO, Alfonso de. “Diez años de investigación musical en torno al Monasterio de Santa Ana de Ávila. Revista de Musicología XXIII (2000), pp. 509-62.

VIRGILI BLANQUET, Ma Antonia. "La música en la guerra de la independencia". Revista de Musicología XIV (1991), pp. 51-61.

WEAVER, Elissa B. Convent Theatre in Early Modern Italy: Spiritual Fun and Learning for Women. Cambridge: Cambridge University Press, 2002.

WOODCOCK, Edith. "Women's Participation in Music During the Early Christian Period". Bulletin of the American Musicological Society 11 (1948), 46-47.

YARDLEY, Anne Bagnall. Performing Piety: Musical Culture in Medieval English Nunneries. New York: Palgrave MacMillan, col. The New Middle Ages, 2006.

\section{ASPECTOS HISTÓRICOS CONVENTUALES CONSULTADOS}

CARO BAROJA, Julio. Las formas complejas de la vida religiosa, siglos XVI y XVII. Barcelona: Galaxia. Gutenberg, 1995.

COLOMBAS GARCÍA, María. El monacato primitivo. Madrid: Editorial Católica, 1974.

FORTES GARCÍA, Ana y SÁNCHEZ HERMIDA, J acobo. Salamanca, Conventos y Monasterios. Tres Diócesis y una Provincia. Salamanca: Grupo Promotor Salmantino. 1995.

FRANCO SALAMANCA, Germán. Templo de Santa Clara Bogotá. Bogotá: Colcultura.1987.

GARCÍA GONZÁLEZ, J . J . Vida económica de los Monasterios Benedictinos en el siglo XIV. Valladolid. Universidad de Valladolid. 1972.

GARCÍA, Gloria; PRADO, Mari Luz de. Mujer y memoria en la Salamanca del Siglo XVI. Salamanca: Universidad Pontificia, 2006.

GÓMEZ HOYOS, Rafael. La iglesia de América en las leyes de Indias. Madrid: Instituto Gonzalo Fernández de Oviedo e Instituto de Cultura Hispánica de Bogotá.,1961.

GONZÁLEZ, Nicolás. El Monasterio de la Encarnación de Ávila. Ávila: Ed. Caja de Ahorros, 1976. 
IMIRIZALDU, J esús. Monjas y beatas embaucadoras. Madrid: Editora Nacional, 1978.

LORENZO PINAR, Francisco J avier. Conventos femeninos y vida religiosa en la ciudad de Zamora (1666- 1650). Zamora: Editorial SEMURET, 2004.

LORENZO PINAR, Francisco J avier. "Vida conventual femenina en la Zamora del siglo XVIII". Mentalidad e Ideología del Antiguo Régimen, vol. II. Murcia: Universidad de Murcia, 1992, pp. 305- 317.

MOELLER, Charles. Mentalidad Moderna y Evangelización. Barcelona: Editorial Herder, 1964.

NEUSS, Wilhem. La iglesia en la Edad Moderna y en la actualidad. Madrid: Rialp, 1962.

PANIAGUA PÉREZ, J esús; María Isabel Viforcos Marinas (coords). Claustros leoneses olvidados; aportaciones al monacato femenino. León:Universidad de León, Secretariado de publicaciones, 1996.

SÁNCHEZ HERNÁNDEZ, María Leticia y GARCÍA SANZA, Ana. Conventos de las Descalzas Reales y de la Encarnación: Dos Clausuras de Madrid. Madrid: Editorial Patrimonio Nacional, 1999.

SÁNCHEZ HERNÁNDEZ, María Leticia. El monasterio de la Encarnación de Madrid: Un modelo de vida religiosa en el siglo XVII. Madrid. Ediciones Escurialenses, 1997.

SÁNCHEZ HERNÁNDEZ, María Leticia. "Un manuscrito de Santa Teresa en el Monasterio de la Encarnación de Madrid". Reales Sitios: Revista del PatrimonioNacional CI (1989), pp. 63-68.

SÁNCHEZ LORA, J osé L. Mujeres, conventos y formas de religiosidad Barroca. Madrid: Ed. Fundación Universitaria española, 1998.

SAVATER MARCH, J oaquín. Las Comunidades religiosas en el Derecho español. Barcelona: Herder, 1955.

TOQUICA, Constanza. A falta de oro: linaje, crédito y salvación. Una historia delReal Convento de Santa Clara de Santa Fé de Bogotá, siglos XVII y XVIII. Bogotá: Universidad Nacional de Colombia. Ministerio de Cultura: Instituto Colombiano de Antropología e Historia, 2008. 
TORRES SÁNCHEZ, Concepción; DÍAZ MEDINA, Ana. La clausura femenina en Salamanca en el siglo XVII: Dominicas y Carmelitas Descalzas. Salamanca: Ediciones de la Universidad de Salamanca, 1991.

VEGA GARCÍA-FERRER, María J ulietta. La música en los Conventosfemeninos de Granada. Granada: Universidad de Granada, 2005.

VIFORCOS, María Isabel; CAMPOS SÁNCHEZ-BORDONA, María Dolores (eds.). Fundadores, fundaciones y espacios de vida conventual: Nuevas aportaciones al Monacato femenino. León: Universidad de León, Secretariado de Publicaciones, 2005.

VIGIL, Mariló. La vida de las mujeres en los siglos XVI y XVII. Madrid: Siglo XXI de España, 1986.

\section{SOBRE HISTORIA DE ESPAÑA Y COLOMBIA UTILIZADOS}

BERMÚDEZ, Egberto. "Música: la tradición indígena y el aporte colonial". Gran Enciclopedia de Colombia, vol 6, Arte. Bogotá: Círculo de Lectores, 1993, pp. 205-216.

BERMÚDEZ, Egberto. Antología de música religiosa. Siglos XVI a XVIII. Archivo Capitular. Catedral de Bogotá. Bogotá: Presidencia de la República, 1988.

BERMÚDEZ, Egberto. Historia de la música en Santa Fe y Bogotá. Bogotá: Fundación de Música, 2000.

CARDOSO, Ciro; PÉREZ BRIGNOLI, Héctor. Los métodos de la historia. Barcelona: Ed. Crítica, 1976.

COLMENARES, Germán. "Censos y Capellanías: formas de crédito en la economía agrícola”. Cuadernos Colombianos II (1974), pp. 125-43.

CORREDERA MARTÍN, J esús María. Alba de Teresa. Salamanca: Diputación de Salamanca, 1990.

DOMINGUEZ ORTÍZ, A. Las clases privilegiadas en la España del antiguo régimen. Madrid: Istmo, 1973.

FURLONG CARDIFF, Guillermo. La Cultura femenina en la época colonial. Buenos Aires: Kapelusz, 1951.

GARCÍA GARCÍA, J esús María. Alba de Tormes: Páginas sueltas de su historia. Salamanca: Diputación de Salamanca, 1991. 
JARAMILLO URIBE, Jaime. Ensayos sobre la historia social colombiana. Bogotá: Universidad Nacional de Colombia, 1968.

MARTÍNEZ, Carlos. Santa Fe capital del Nuevo Reino de Granada. Bogotá: Editorial Presencia, 1988.

MONSALVO ANTÓN, José María. Documentación histórica del Archivo Municipal de Alba de Tormes (siglo XV). Salamanca: Ediciones de la Diputación de Salamanca, 1988.

MURIEL, J osefina. Las mujeres de Hispanoamérica Época colonial. Madrid: Editorial MAPFRE, 1992.

PARDO TOVAR, Andrés. La cultura musical en Colombia. Bogotá. Ediciones Lerner, 1966.

PERDOMO ESCOBAR, José Ignacio. El Archivo musical de la Catedral de Bogotá. Bogotá: Publicaciones del Instituto Caro y Cuervo, 1976.

PERDOMO ESCOBAR, J osé Ignacio. Historia de la música en Colombia. Bogotá: Plaza y J anés, 1980.

PEREZ GONZÁLEZ, Juliana. "Génesis sobre los estudios de música colonial hispanoamericana: esbozo historiográfico". Revista Frontera de la Historia IX (2004), pp. 281-321.

RESTREPO, Margarita. Tres misas de difuntos de Juan de Herrera. Caracas: Consejo Nacional de Cultura (CONAC), Fundación Vicente Emilio Sojo, 1996.

RODRÍGUEZ CRUZ, Águeda. "Proyección en América: Una perspectiva española" Historia de la Universidad de Salamanca, vol. 3, tomo II. Salamanca: Universidad de Salamanca, 2004, pp. 1229-1326.

RODRÍGUEZ CRUZ, Águeda. “La Escuela de Salamanca y el sistema de educación universitario en Iberoamérica". Cuadernos Salmantinos de Filosofía XXX (2003), pp. 407-16.

RODRÍGUEZ CRUZ, Águeda. "El modelo universitario salmantino y su reconversión en Hispanoamérica”. Miscelánea Alfonso IX 2002 (2002), pp. 151-65.

RODRÍGUEZ CRUZ, Águeda. "Profesores salmantinos en América”. Estudios de historia social y económica de América XVI-XVII (1998) , pp. 355ss. 
RODRÍGUEZ CRUZ, Águeda. “La Universidad de Salamanca, hilo conductor y de relación en la historia de las Universidades hispanoamericanas". Revista Ciencias de la Educación 155 (1993), pp. 363-72

RUBIO Y MORENO, Luís. Pasajeros a Indias. Compañía Americana de Publicaciones, S.A. Madrid, 1917.

SANTA TERESA, Silverio de. Historia del Carmen Descalzo en España, Portugal y América, vols. Vy XIV. Burgos: Ed. Monte Carmelo, 1945

SCHÄFER, Ernesto. Índice de la colección de documentos inéditos de Indias, 2 vol. Madrid: C.S.I.C., 1946-1947.

STEVENSON, Robert. La música colonial en Colombia. Cali: Publicaciones del Instituto Popular de Cultura de Cali, Departamento de Investigaciones Folklóricas, 1964.

VILAR, Pierre. Oro y moneda en la Historia (1450 - 1920). Barcelona: Ariel, 1972.

\section{SOBRE METODOLOGÍA Y ANÁLISIS}

BLAXTER, Lorraine, HUGHES, Christina, TIGHT, Malcolm. Cómo se hace una investigación. Barcelona: Gedisa, 2001.

ECO, Umberto. Como se hace una tesis. Barcelona: Gedisa, 1994.

FERNÁNDEZ, Stella Maris. Técnicas de trabajo intelectual. Buenos Aires, Paidós, 2004

FRANCH, J osé. Aprender a investigar. Métodos de trabajo para la redacción de tesis doctorales. Humanidades y Ciencias Sociales. Madrid: Compañía Literaria, 1994.

GARCÍA LABORDA, J osé Ma. "Algunas consideraciones en torno a la musicología sistemática”. Revista de Musicología XII (1989), pp. 11-21.

GARCÍA ROLDÁN, José Luís. Cómo elaborar un proyecto de investigación. Alicante: Publicaciones de la Universidad de Alicante, 1995.

GONZÁLEZ, Ma J José. Metodología de la investigación social. Técnicas de recoleccion de datos. Madrid: Editorial Aguaclara España, 1997.

HERNÁNDEZ SAMPIERI Roberto; FERNÁNDEZ COLLADO, Carlos; BAPTISTA, Lucio Pila. Metodología de la investigación. México DF: McGraw Hill México, 1998. 
HERRERA, Enric. Teoría Musical y Armonía Moderna, vol. I y II. Barcelona: Editorial Antonio Bosch, 1987.

HINDEMITH, Paul. Adiestramiento elemental para Músicos. Buenos Aires: Editorial Ricordi, 1949.

HODEIR, André. Les formes de la Musique. Paris: PUF, 1978

J URAFSKY, A. Manual de Armonía. Buenos Aires: Ricordi Americana, 1946.

LUNA CASTILLO, Antonio. Metodología de la tesis. México: Trill, 1996.

LLACER PLA, Francisco. Guía Analítica de Formas Musicales para Estudiantes. Madrid: Real Musical, 1987.

MERCADO, Salvador. ¿Cómo hacer una tesis?, tesinas, informes, memorias, seminarios de investigación y monografías. México: Limusa, 1998

MUNETA MARTÍNEZ DE MORETÍN, Jesús María. Análisis musical y fundamentos de composición (Formas musicales). Teruel: Instituto Musical Turolense, 1997.

ROBLES SASTRE, Esperanza. Metodología de la investigación. Contenido y formas. Madrid: Universidad CamiloJ osé Cela, 2001.

SERAFINI, María Teresa. Cómo se estudia. La organización de un trabajo intelectual. Barcelona: Paidós, 1991.

SIERRA BRAVO, R.: Tesis doctorales y trabajos de investigación científica: Metodología general de su elaboración y documentación. Madrid: Paraninfo, 1996.

\section{REPERTORIOS, CATÁLOGOS Y DICCIONARIOS}

CASARES RODICIO, Emilio (dir. y coord.); FERNÁNDEZ de la CUESTA, Ismael; LÓPEZ CALO, José (eds.). Diccionario de la Música Española e Hispanoamericana , 10 vols. Madrid: SGAE/ ICCMU, 1999-2002.

Catálogo Biblioteca Complutense: http:// www.ucm.es/BUCM

New Grove On Line: http:/ / www.grovemusic.com

RIDI(Répertorie International d'Iconographie Musicale):

http:// web.gc.cuny.edu/rcmi

RISM: http://rism.stub.uni-frankfurt.de/index__e.htm

RIPM: http:// www.ripm.org

E. RECURSOS DE INTERNET: Bibliotecas Virtuales para Descargas: 
www.cervantesvirtual.com

www.virtualibro.com

www.todoebook.com

www.libronauta.com

www.librosparadescargar.com

www.libros-online.com 


\section{RELACIÓN DE ILUSTRACIONES}

1. Mapa de los Monasterios Benedictinos en España 259

2. Privilegio del Rey Alfonso XI - "El Emplazado" 260

3. ASMD. Informaciones: "Autos y demás diligencias sobre la libertad y profesión de Dña Manuela Álvarez de Reiero - Año de 1753" - Monja música

4. Solicitud de la Monja Florentina Infanzón para la toma de Hábito de su sobrina Rosa Infanzón.261

5. Acta del examen de órgano y canto llano aplicado a la monja - música Dña. Escolástica Campo Martín, del Monasterio de Santa María de las Dueñas de Alba de Tormes - Salamanca.

6. Distribución de los Dineros de una dote. ASMD.

7. “Dote perpetua” fundado por Dña. María de los Dolores Fernández Cantero ASMD. Libro de Dotes, Testamentos y Defunciones 1900

8. Testamento de Doña María de Rosales, benefactora del Monasterio. ASMD. ASMD. Caja de Dotes y testamentos

9. Manuscrito de la compra de un órgano para el Monasterio de Santa María de las Dueñas de Alba de Tormes - Salamanca. En el año de 1766. ASMD.

10. ASMD - Manuscrito del Libro de cuentas de los años 1750 - 1773 pág. 43 Pago a la monja música Dña. Ángela Collantes Abarca.

11. Rúbrica de Dña. Ángela Collantes Abarca - Monja música del Monasterio de Santa María de las Dueñas. ASMD. Tomado del Libro de Dotes 1766 - 1863. Pág. 17

12. ADZ. Partida de Bautismo de Dña. Catalina Gato Rosete Libro de Bautismos 227-1 Libro 3. Parroquia de San J ulián - Toro (I -1-3) pág. $109 \mathrm{v}$.

13. ASMD. Gastos con la Señora Cantora Dña. Catalina Gato.

259 Tomado de la Revista Monjas Benedictinas.

260 Documento que reposa en el Archivo del Monasterio de Santa María de las Dueñas, Alba de Tormes

261 Libro de Dotes, pág. 46. Carpeta de Informaciones № 1. Años 1724 - 1868 - Religiosas. Florentina Infanzón 9 de Sep. de 1866 y la respuesta del Obispo a 11 de Septiembre del mismo año. 
Libro de cuentas 1750 - 1773. pág. 175 v.

14. Relación de pagos a Dña. Catalina Gato Rosete. ASMD. Datos tomados del Libro de Cuentas 1774 - 1794

15. ACHDT. Fe de Bautismo de Dña. Isabel García Quintana Verdugo

Parroquia del Sagrario - Catedral de Tuy. Libro XV. Bautizados. Folio 92 v.

16. ASMD. Certificado sobre la existencia de la Fe de Bautismo, de Dña. Isidra Santos y Santos, expedido por el Cura Pedro Benito López, Cura ecónomo de Terradillos - Salamanca. Del 14 de Marzo de 1831.

17. ASMS. Solicitud de ingreso a la plaza de "cantora” de Dña. Antonia Martínez Expediente - Carpeta de Informaciones.

18. ASMD. Acta de examen de Dña. Antonia Martínez. Carpeta de Informaciones. 19. ADS. Plaza de Organista. Expediente de Dña. Escolástica Campo Martín. Caja 1 años 1853 - 1942)

20. ADS. Escolástica Campo M. Fe de Bautismo - Caja. 1 (años 1853 - 1942)

21. ADS. Certificado de idoneidad musical de Dña. Dorotea Campo, firmado por su tutor musical Dn. Antonio López. Expediente - Caja № 1(1853 - 1942)

22. ADS. Acta de examen firmada por los Organistas de la Catedral de Salamanca, Don Manuel Hernández y DonJuan José de Siles. Año 1857. Caja № 1 Expediente de Doña Dorotea Campo

23. Firma de la monja música Doña Dorotea Campo. Después en Religión conocida como Escolástica Campo.

24. Acta de Profesión de J osefa Martín y Martín

25. ADS. Acta de nacimiento. Caja 1(años 1853 - 1942) Expediente de

Dña. J uliana del Corazón de J esús - Cantora y organista.

26. ADS. Acta de Profesión de Dña. Trinidad del Corazón de J esús.

Caja 1(años 1853 - 1942) Expediente de organista.

27. ADS. Certificación del Bautismo de Doña María Dolores Quintana y Sánchez Monja música del Monasterio de Santa María de las Dueñas - Alba de Tormes Salamanca. Caja 1(años 1853 - 1942) Expediente de cantora

28. Acta del examen de Música practicado a Dña. Dolores Quintana, por el Sochantre y tenor de la Iglesia Metropolitana de Burgos. ADS. Caja 1(años 1853 - 1942) Expediente de cantora29.

29.Iglesia de Santa Clara - Bogotá - Colombia 
30. Museo Iglesia de Santa Clara (Bogotá - Col.)

31. Arzobispo Arias de Ugarte Forero - Fundador del Convento de Santa Clara

Santa Fe de Bogotá - Colombia. Tomado de la obra A falta de oro, linaje, crédito y salvación. La historia del Real Convento de Santa Clara de Santa Fe de Bogotá. Siglos XVII y XVIII.

32. Matrícula de Don Fernando Arias Forero como estudiante

De la Universidad de Salamanca. Tomado del Libro de matrículas ABAUSAL. . Año 1577.

33. Juan Flores de Ocaríz. Libro primero de Genealogías del Nuevo Reino de Granada. Joseph Fernández de Buendía, impresor de la Real Capilla de su Majestad. 1674.

34. Retrato de Juan de Herrera, maestro de música de las monjas del Convento de Santa Inés de Santa Fe de Bogotá. Tomado de la obra "Historia de la música en Colombia” de J osé Ignacio Perdomo Escobar. Pág. 40.

35. Manuscrito del Libro de instrucción básica sobre interpretación y análisis del Canto Gregoriano. ASMD. 


\section{ANEXOS}




\section{I.DOCUMENTOS HISTÓRICOS}

I.1. Convento de La Anunciación

1.1. Fundacionales: - Documento de Fundación

- Licencia del Obispo Don Pero González, para la Fundación del Convento

- Advocación de la Casa, a la Virgen del Carmen

- Documento de Consagración de Santa Teresa

Como Patrona de España, por el Rey 1627)

- Movimiento milagroso de la lámpara

- Capellanía

- Dote de Dña. María de la Asunción - monja

Carmelita desclaza - Año de 1604.

I.2.Monasterio de Santa María de las Dueñas

2.1. Privilegios regios: Privilegio otorgado por el Rey Alfonso XI

Fechado en Ávila el 6 de Septiembre de 1319

2.2. Carta de amparo al Monasterio por el Infante Don Sancho de 1279

I.3.Testamentos y Capellanías

3.1. Testamento de Doña María de Rosales

3.2. Fundación de Capellanías 


\section{ANEXOS}




\section{ANEXO I}

\section{DOCUMENTOS HISTÓRICOS}

I.1. Convento de la Anunciación - Madres Carmelitas

I.1.1. Fundacionales: - Documento de Fundación

- Licencia del Obispo Don Pero González para la Fundación del Convento

- Advocación de la Casa a la Virgen del Carmen

- Documento de Consagración de Santa Teresa como Patrona de España

- Capellanía

- Dote de Dña. María de la Asunción - monja Carmelita Descalza (año 1604)

I. 2. Monasterio de Santa María de las Dueñas

I.2.1. Privilegios Regios:

- Privilegio otorgado por el Rey Dn. Alfonso XI, fechado en Ávila el 6 de septiembre de 1619

- Carta de Amparo al Monasterio por el Infante Dn. Sancho en el año 1279

I.2.2. Testamentos y Capellanías

I.2.2.1. Testamento de Dña. María de Rosales

I.2.2.2. Fundación de Capellanías 


\section{I.1. Convento de la Anunciación - Madres Carmelitas (3 folios)}

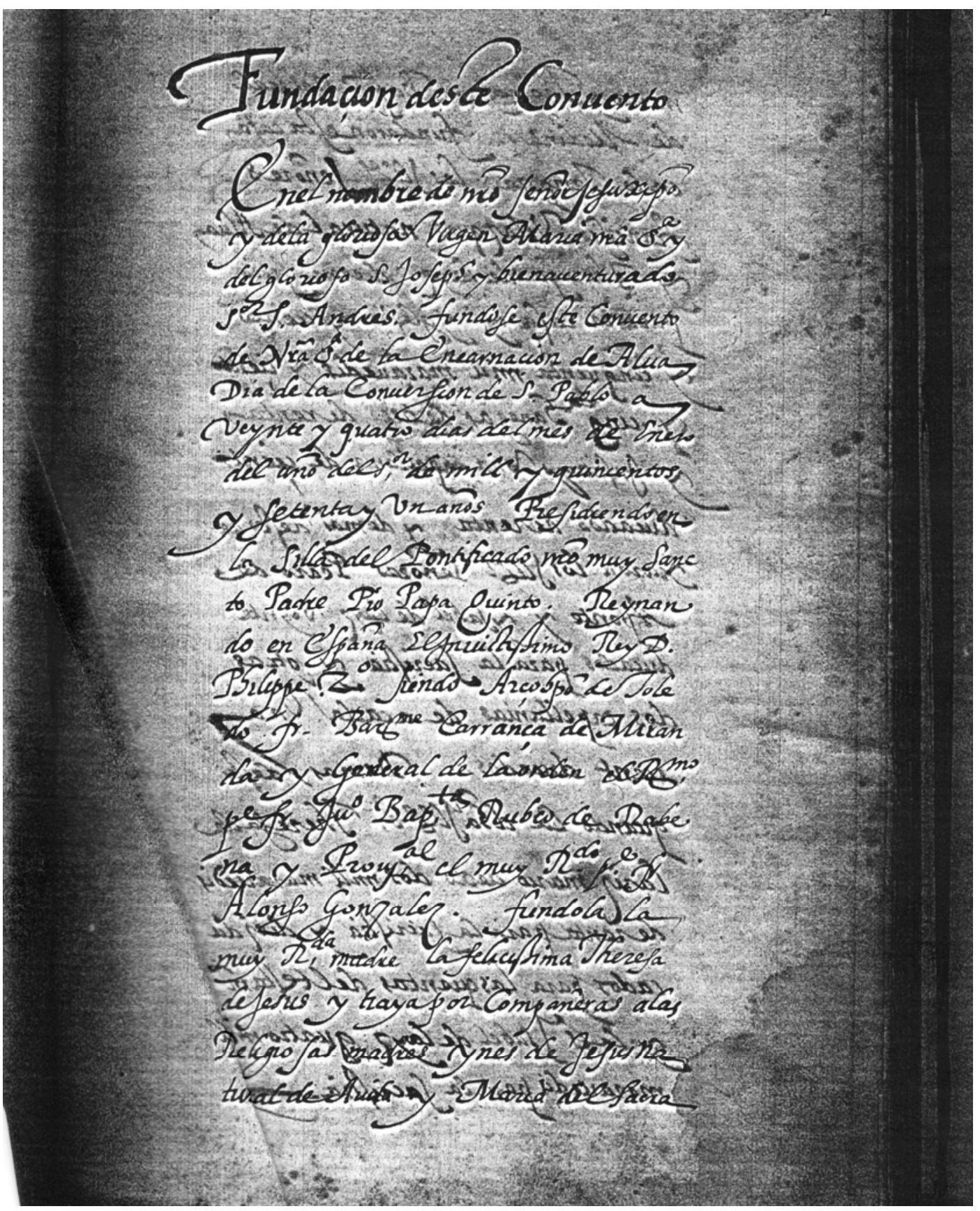

ACA. Documento de Fundación (Folio 1) 


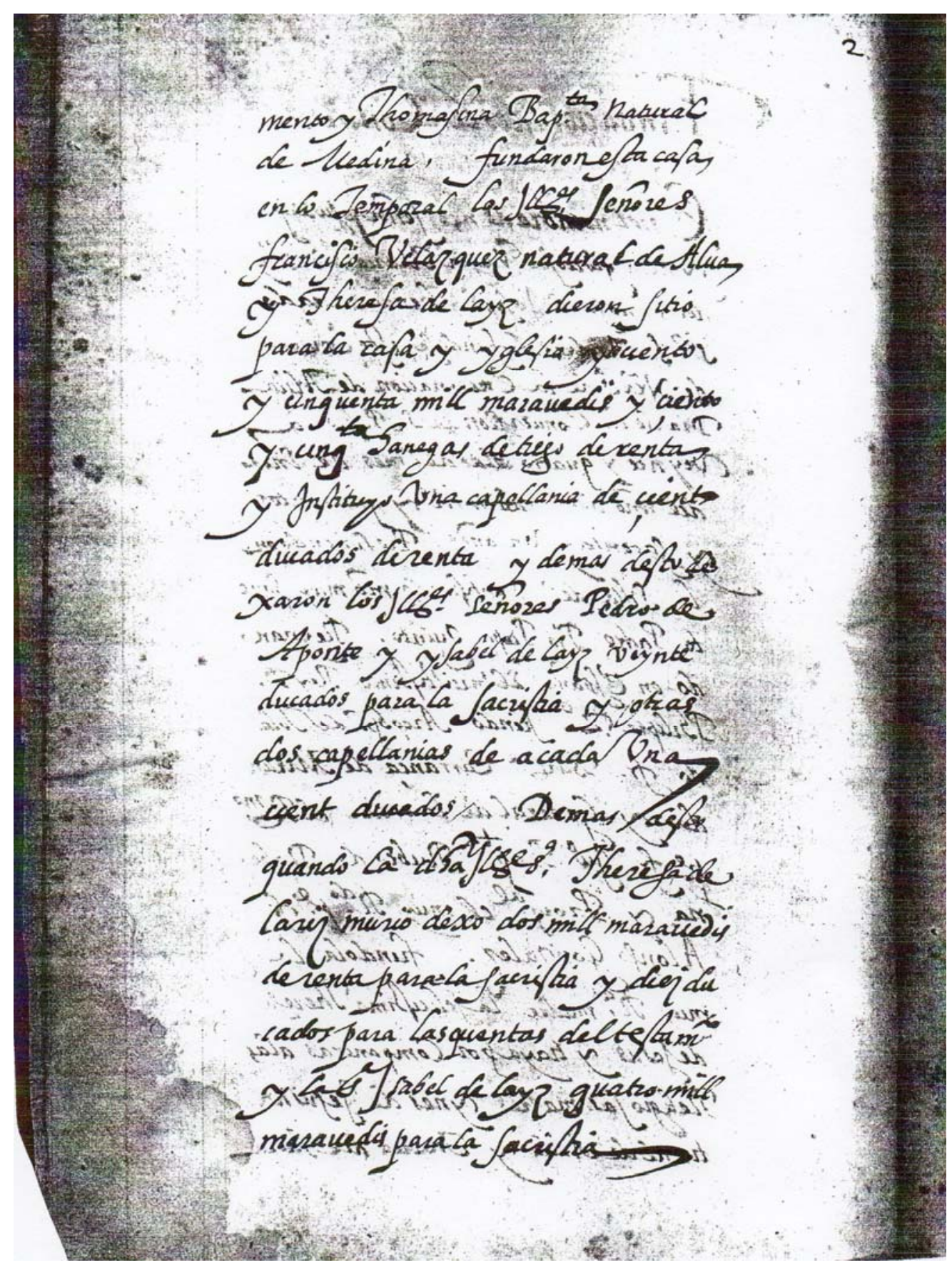

(Folio 2) 


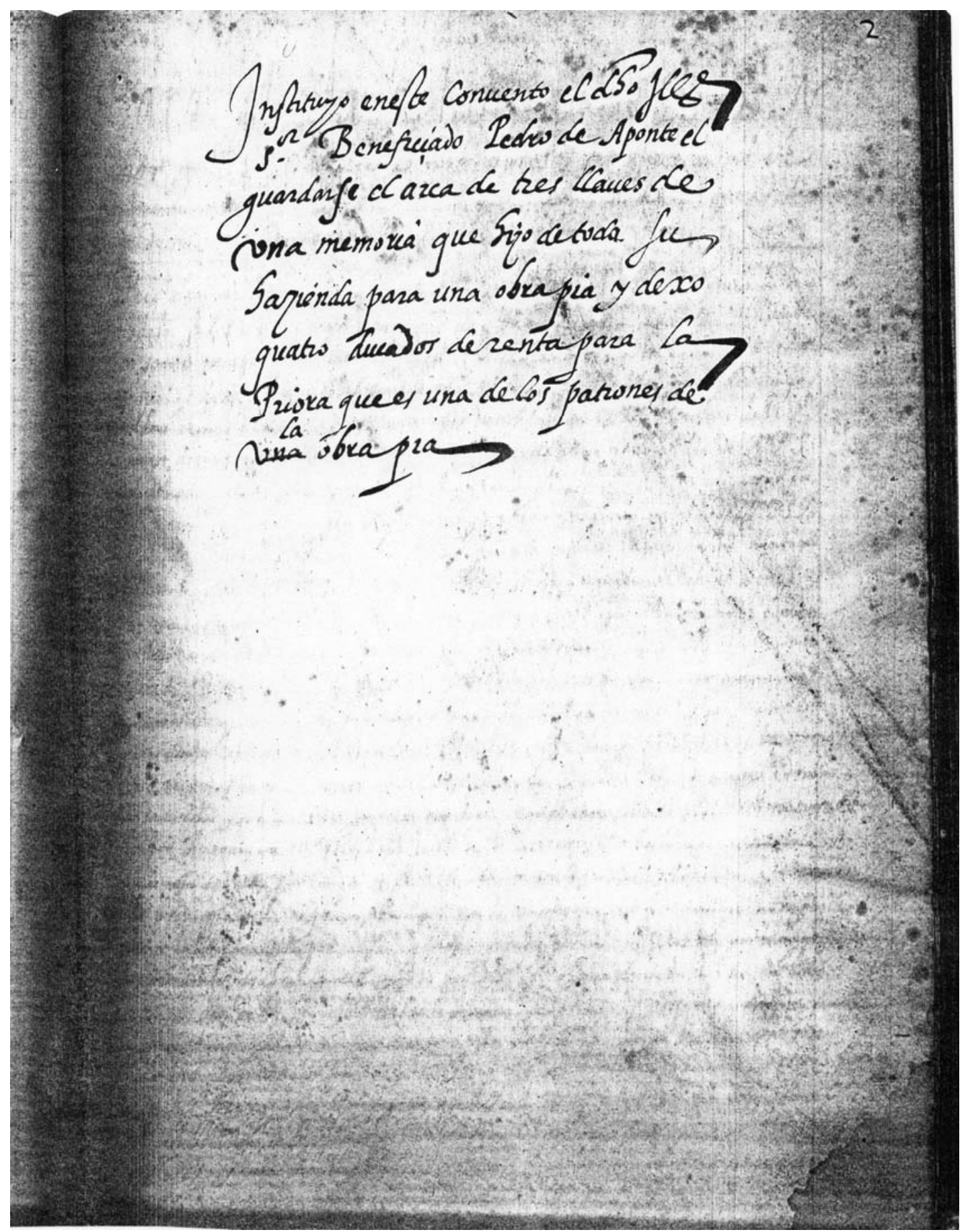

(Folio 3) 


\section{Licencia de Fundación del Obispo Dn. J osephe González}

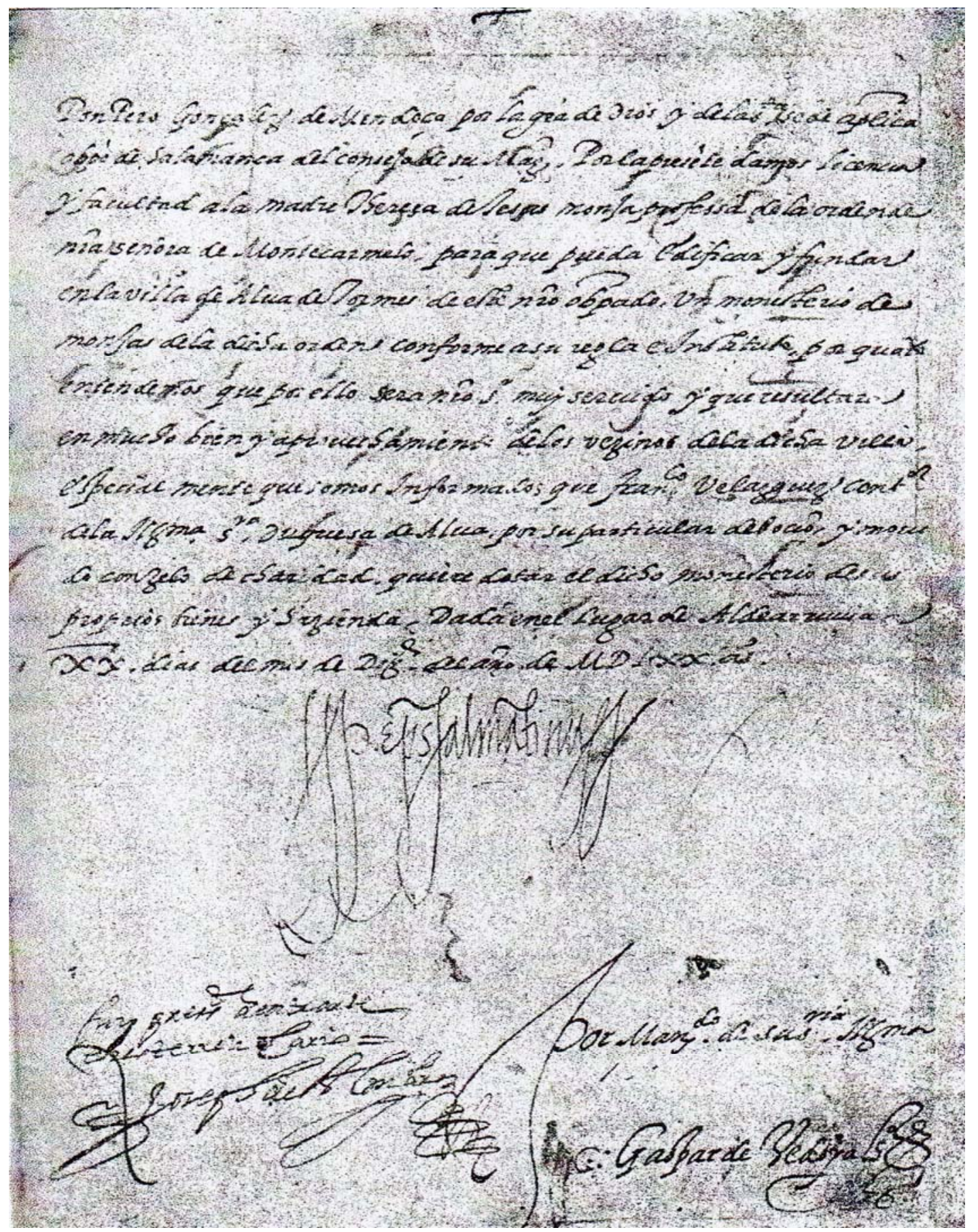




\section{Advocación del Monasterio, a la Virgen del Carmen (3 Folios)}

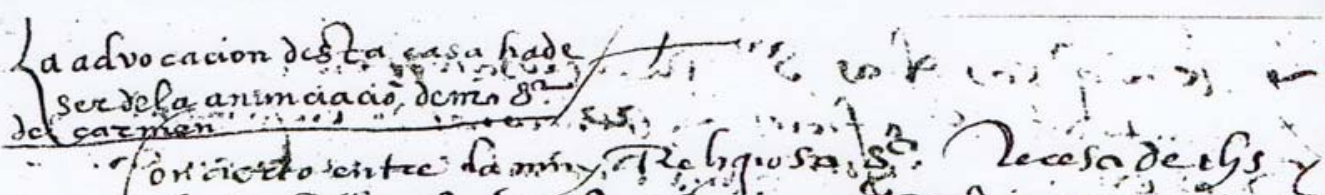

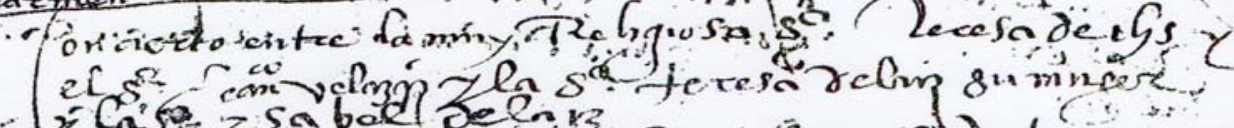

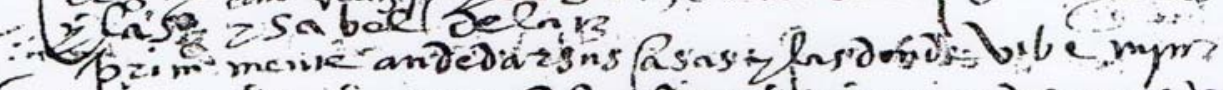

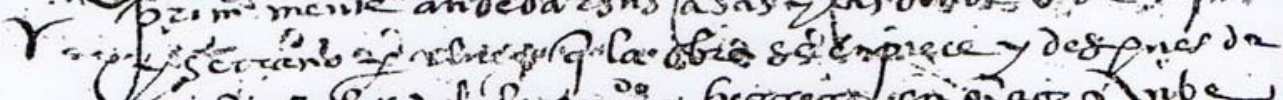

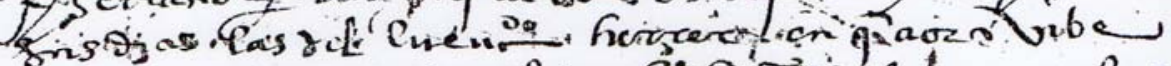

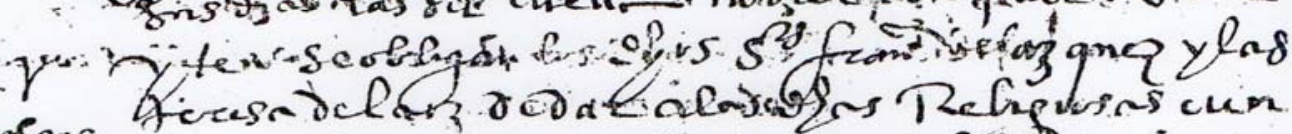

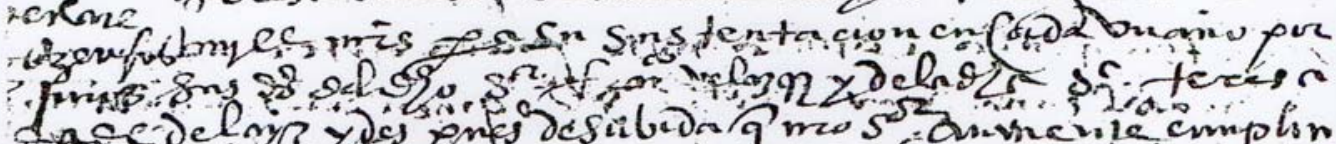

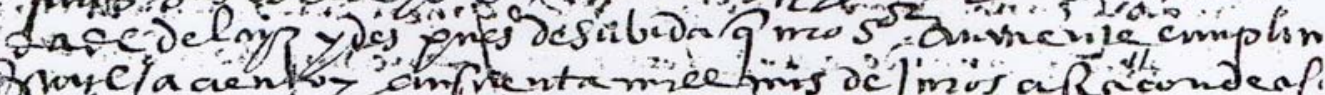

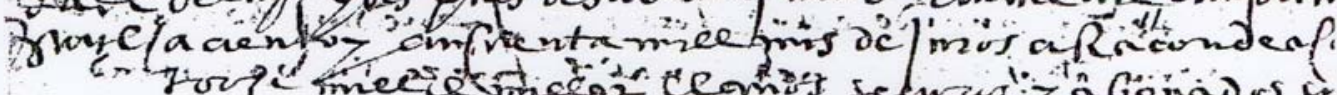

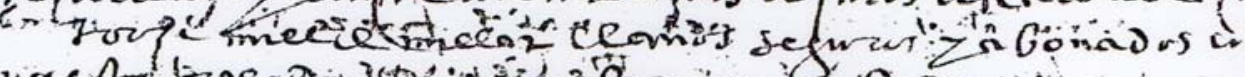

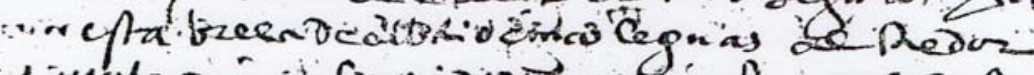

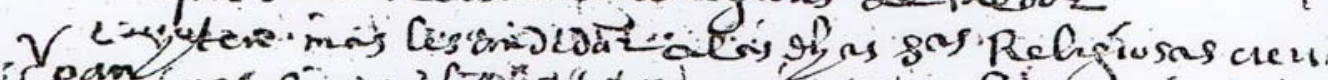

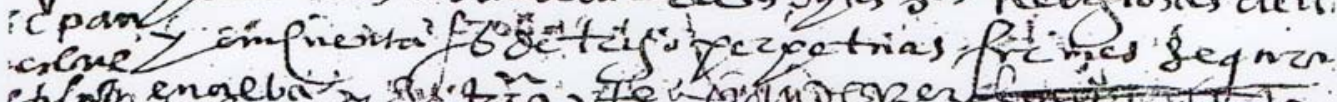

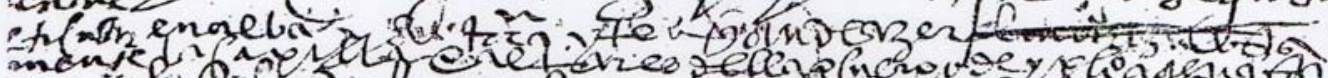
I.

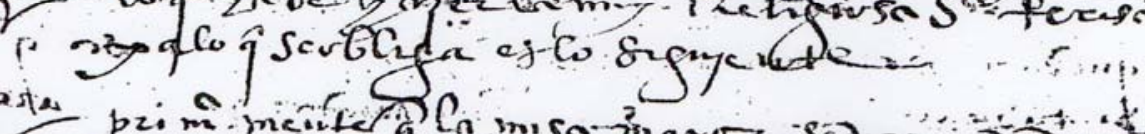

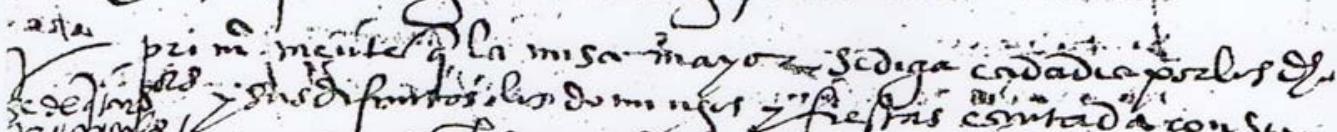

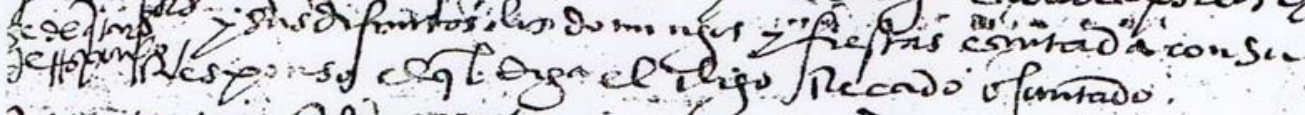

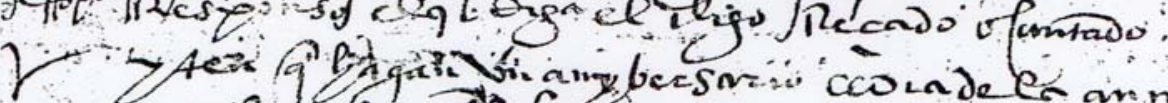

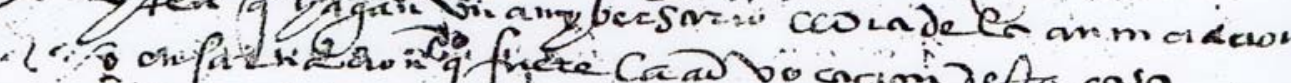

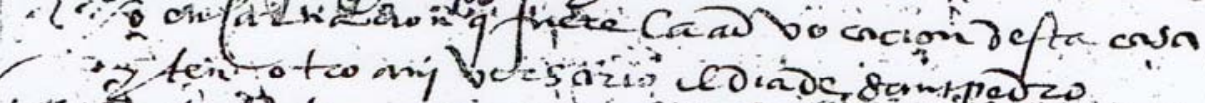

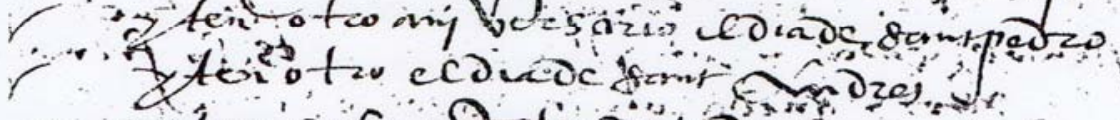

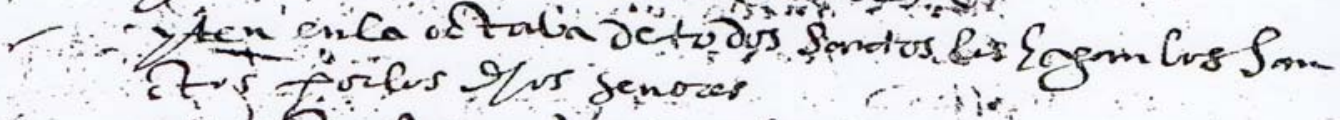

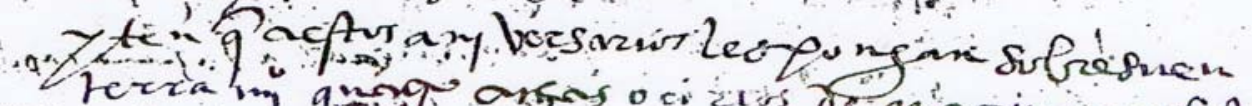

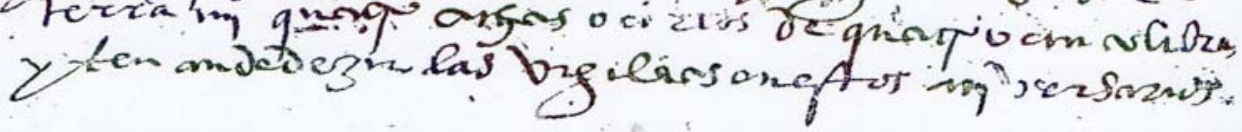

(Folio 1) 


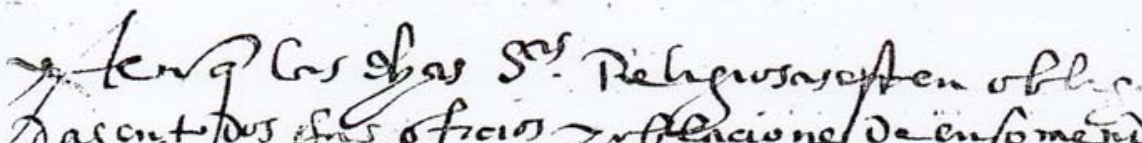

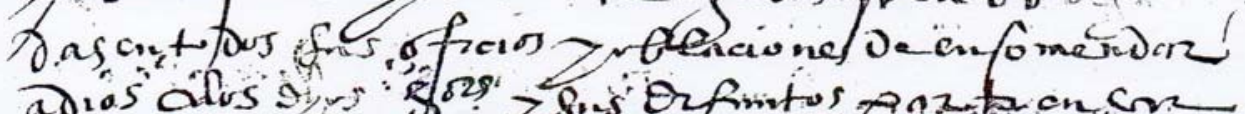

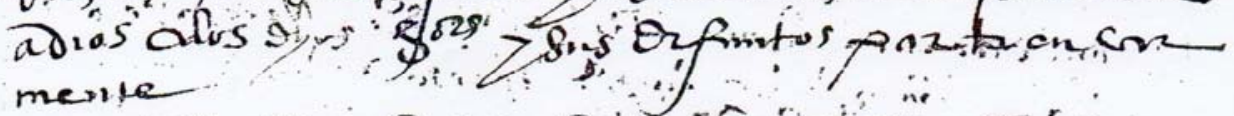

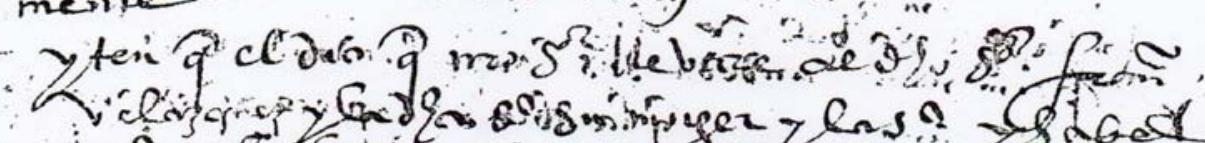

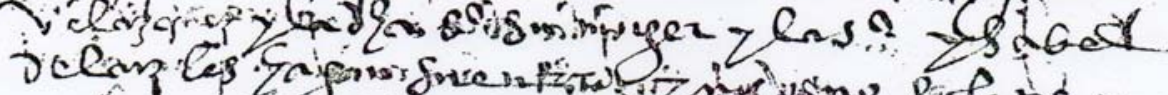

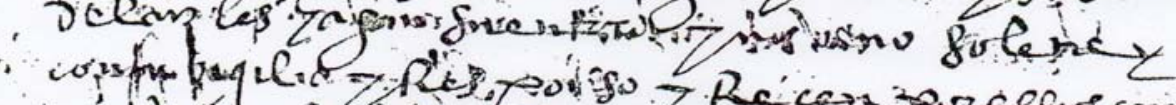

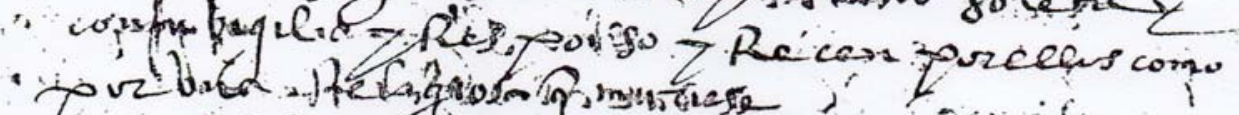

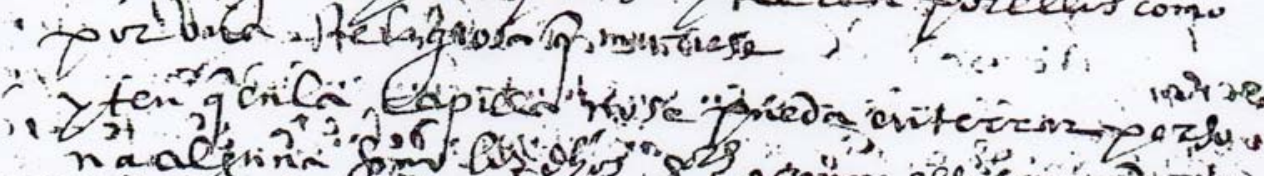

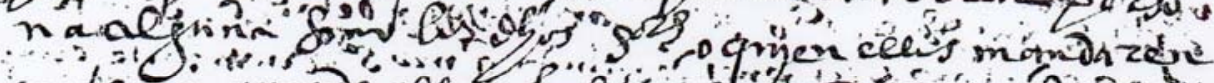

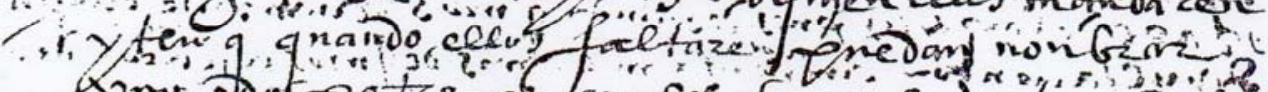

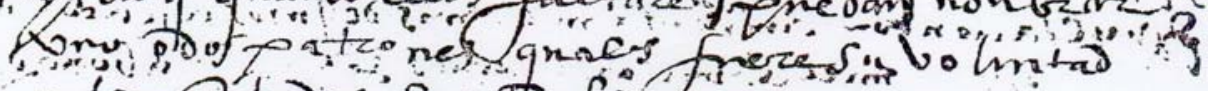

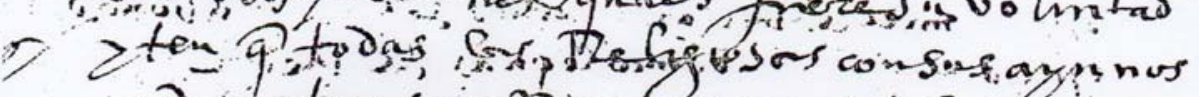

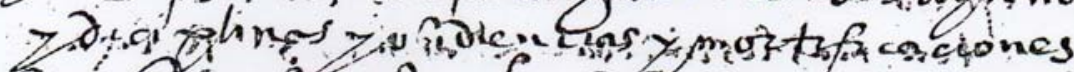

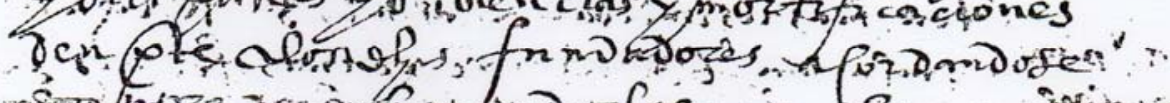

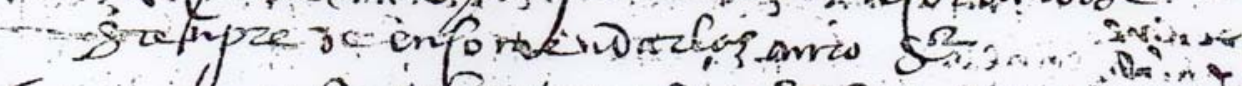

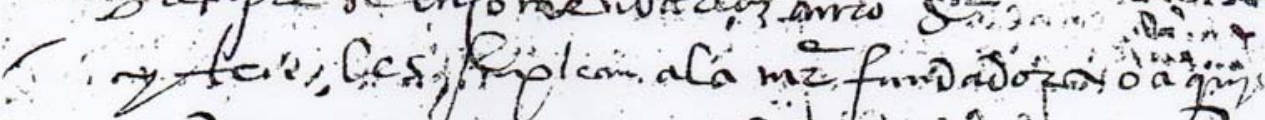

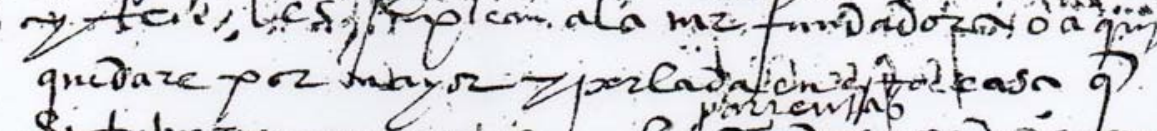

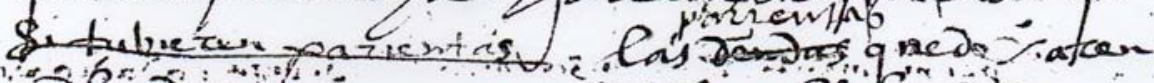

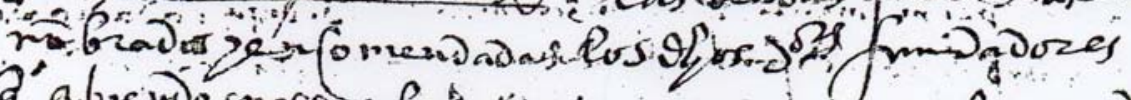

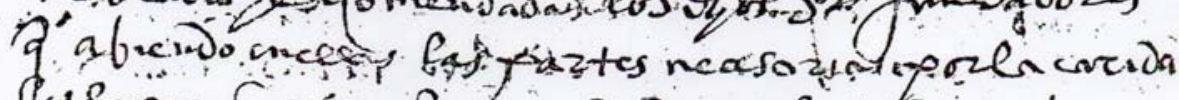

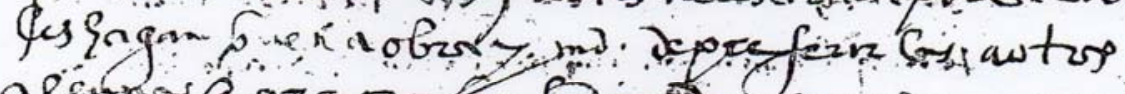

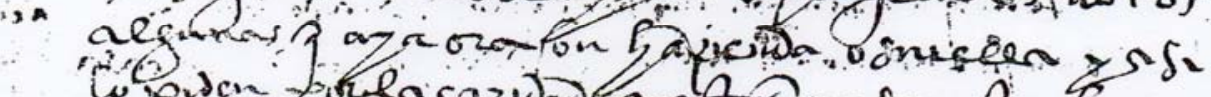

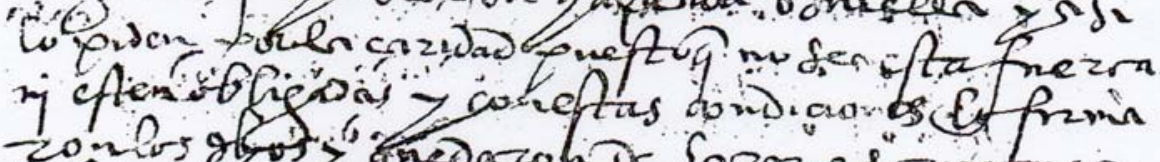

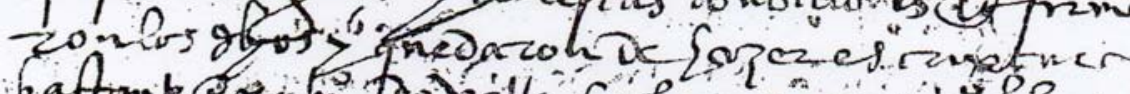

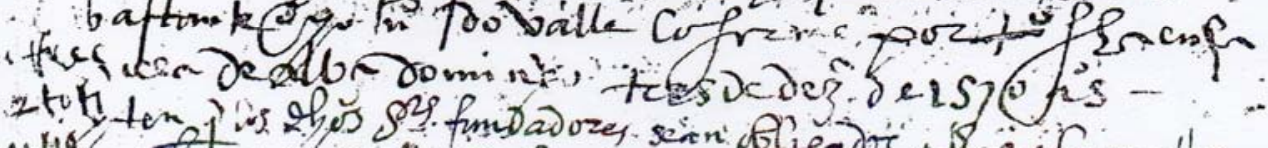

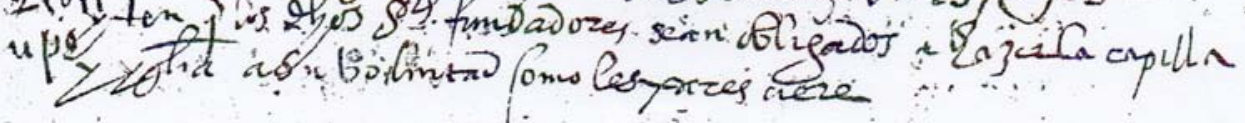

(Folio 2) 


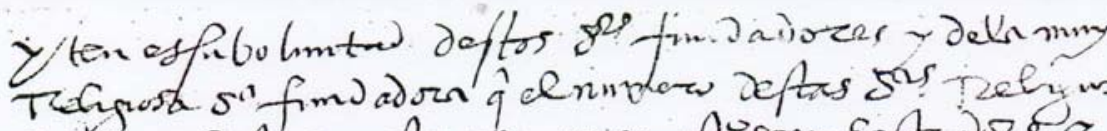

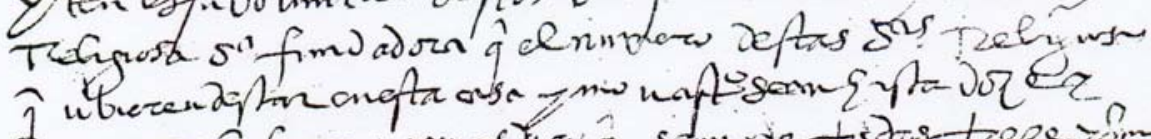

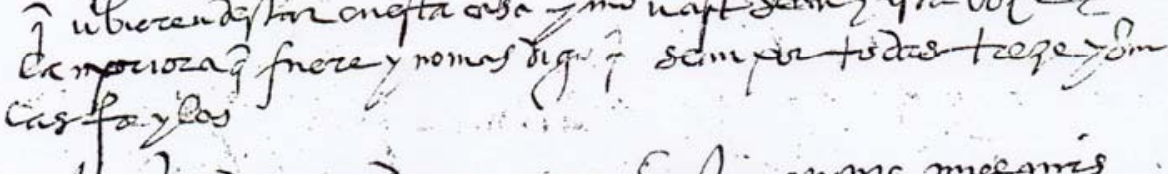

yteng anagquano que aya Enfa quppe meemis

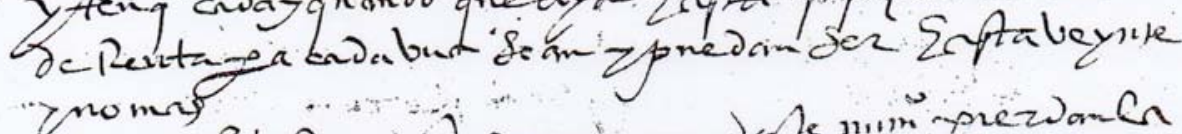

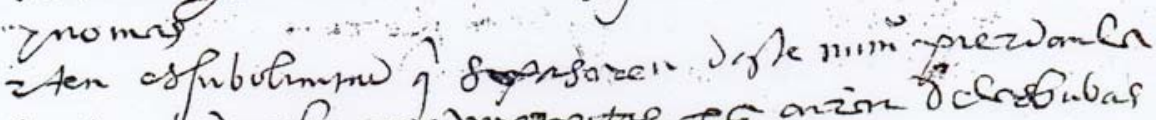

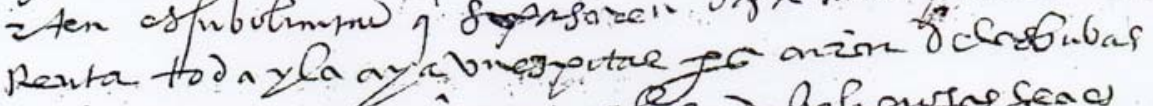

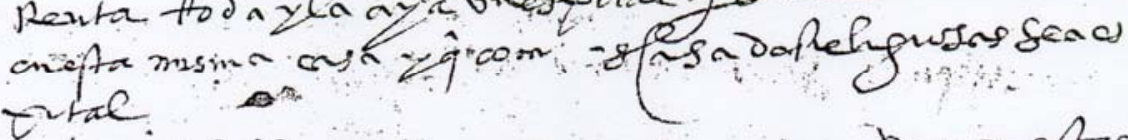

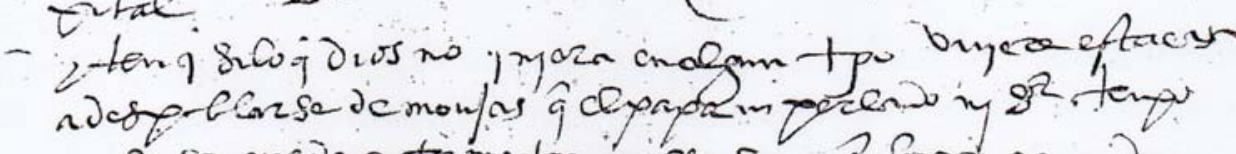

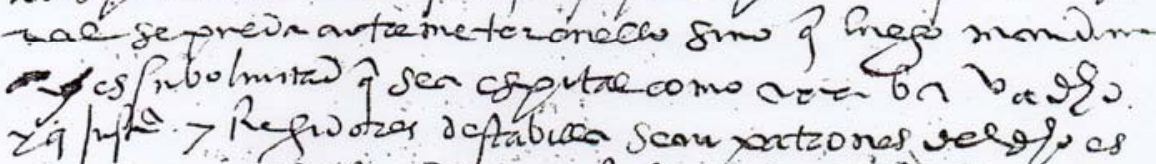

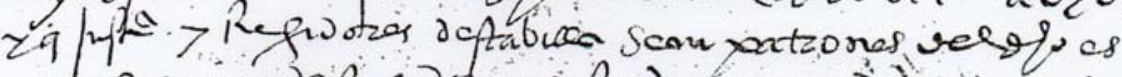

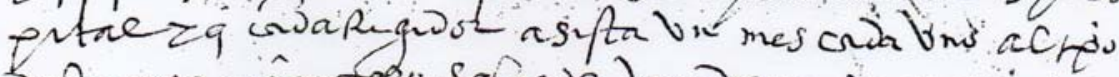

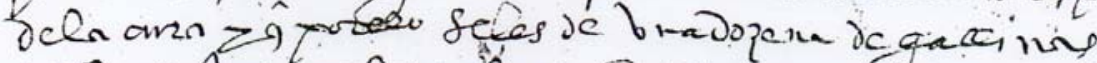

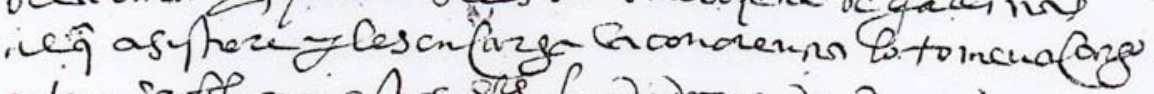

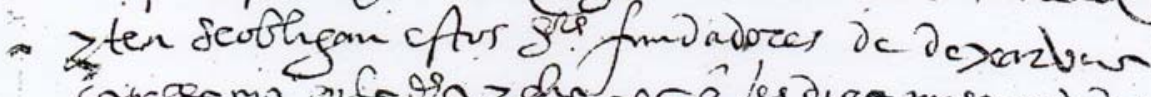

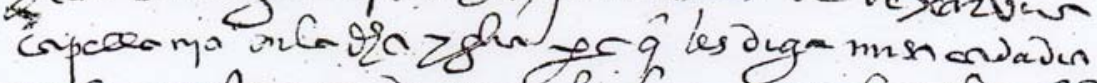

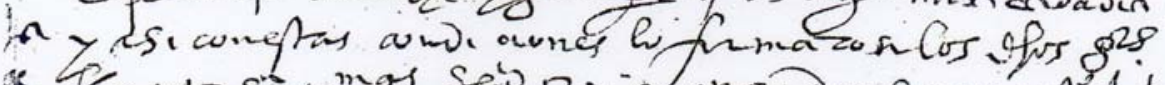

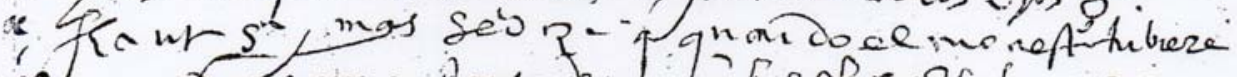

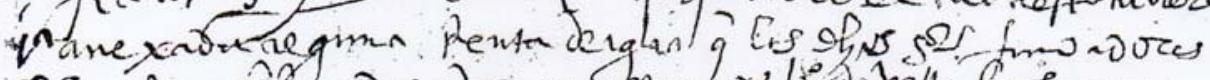

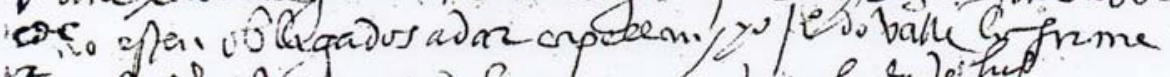

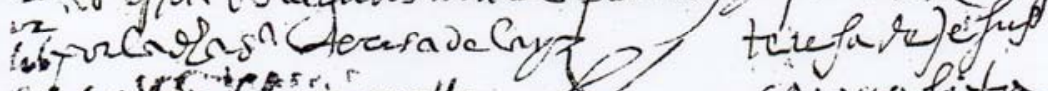
ch 1 o

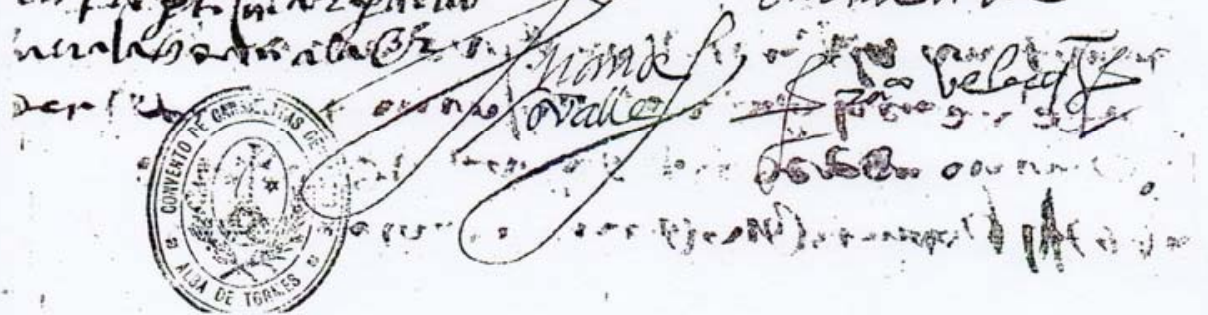

(Folio 3) 


\section{Consagración de Santa Teresa de J esús como Patrona de España Por el Rey - Año 1627}
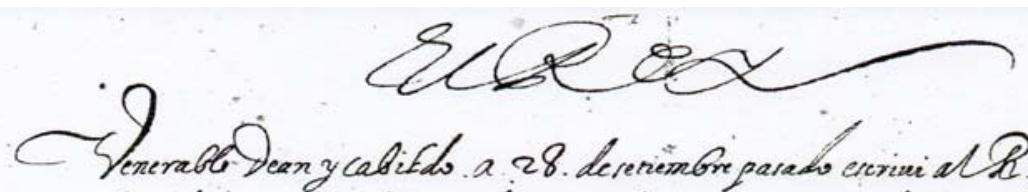

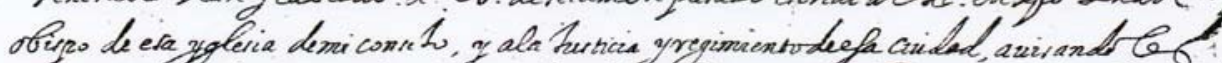

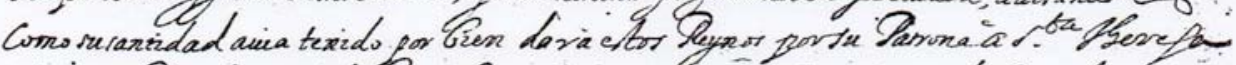
de lesur, forquales anter de baore la avian necivido portal; paraquediefen ordan que

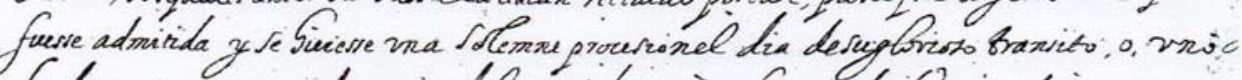

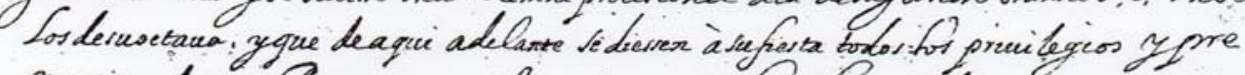

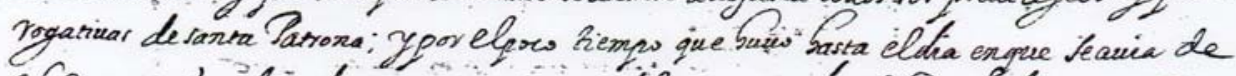

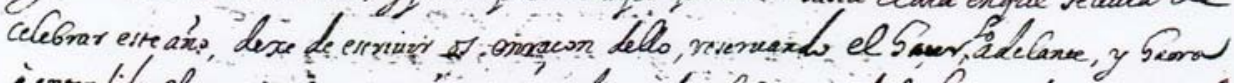

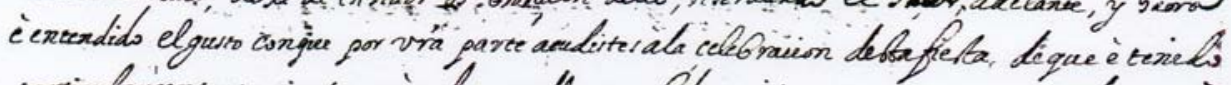

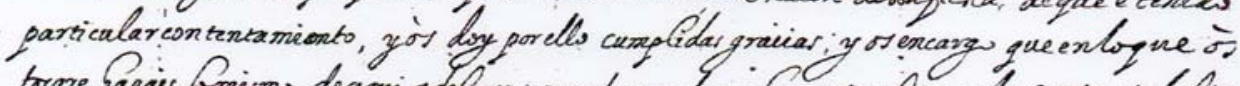
trare bagais Domisms deaqui adelante; que demas de explearre tambien en la santa, todala

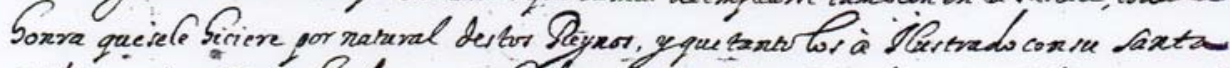

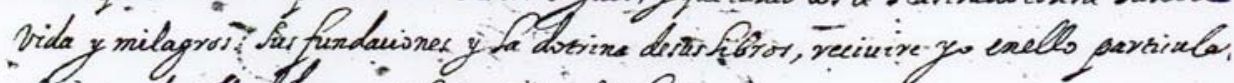

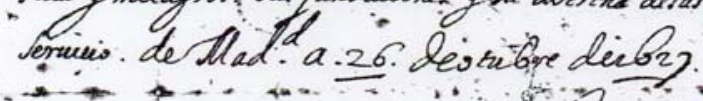

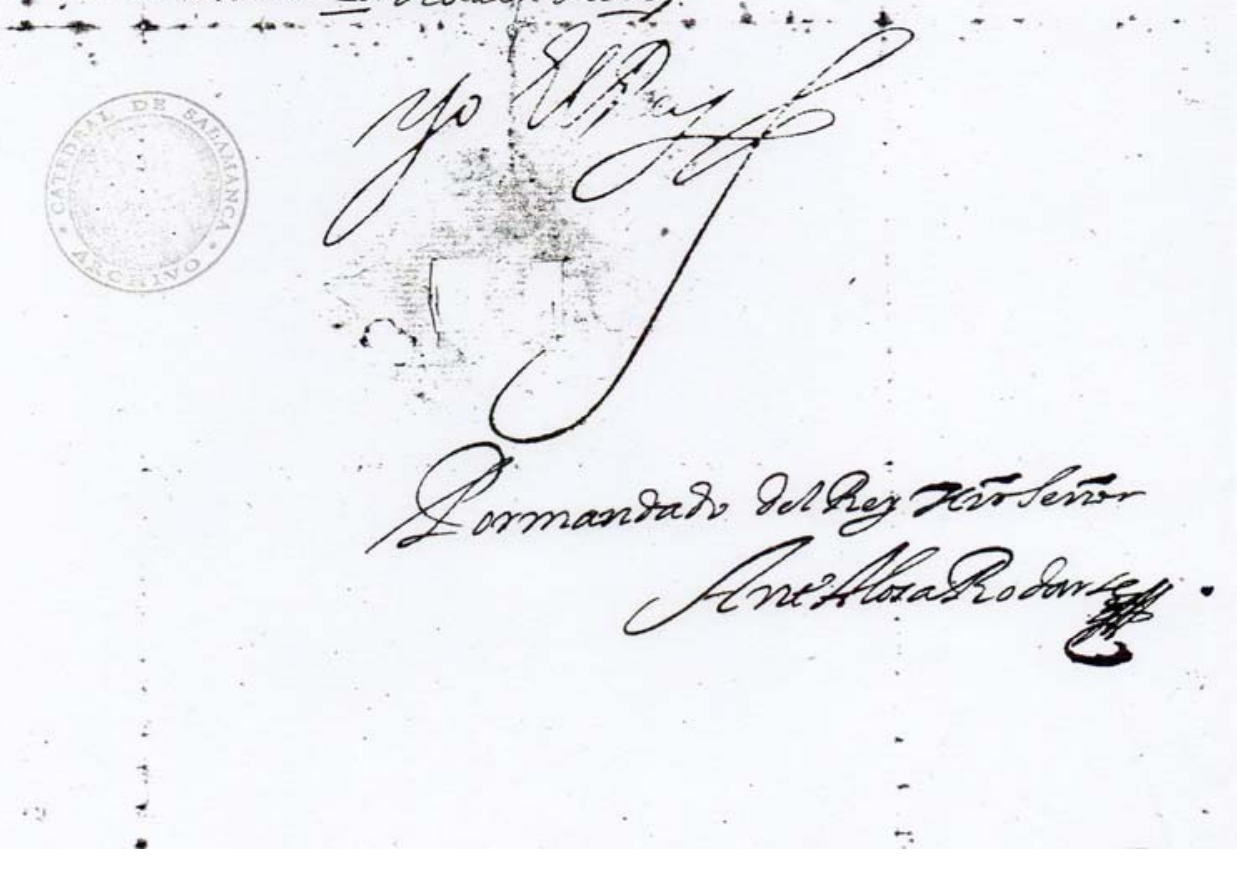




\section{Fundación de Capellanía, por Francisco Velásquez y Teresa Laíz}

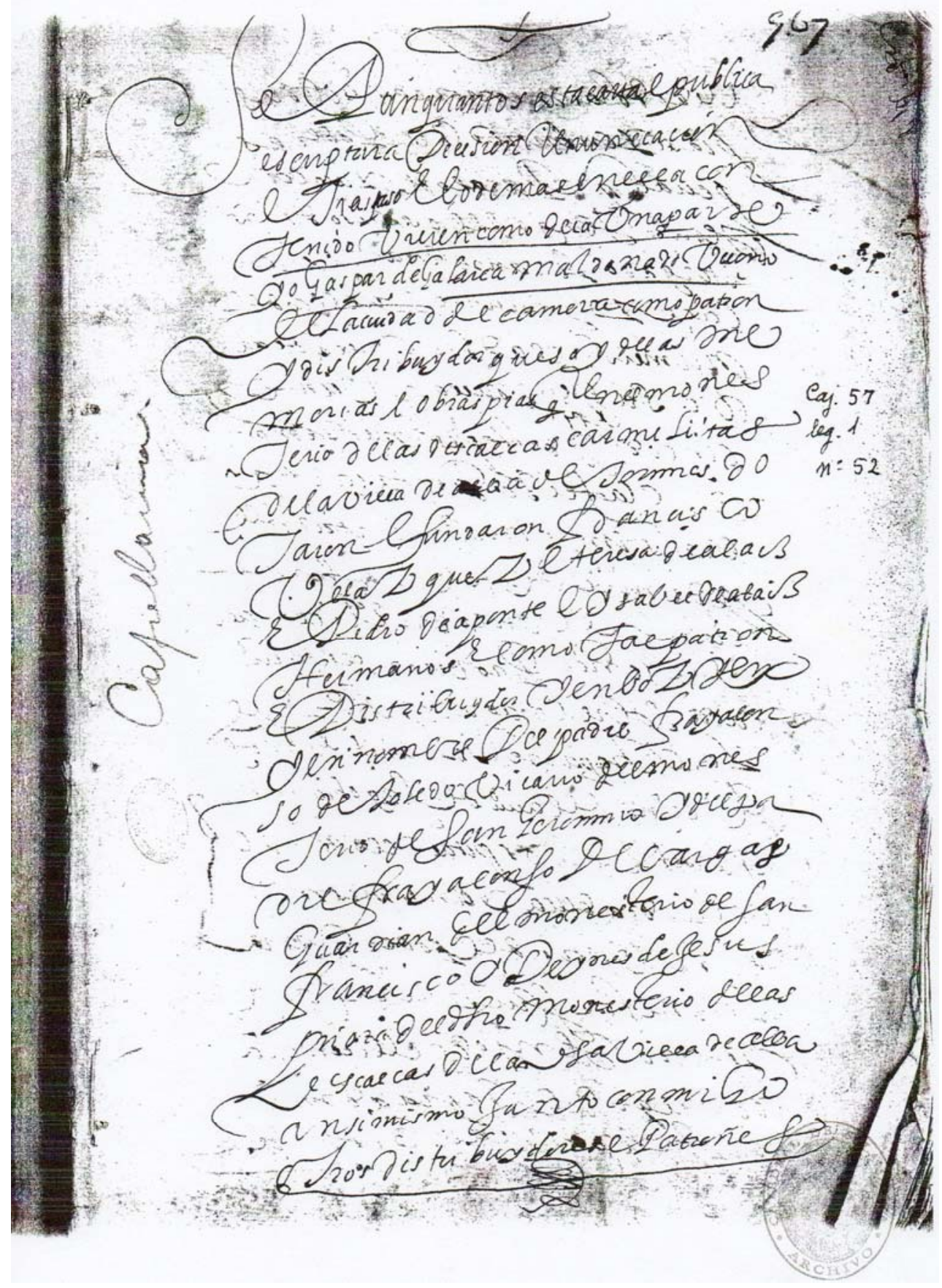


Dote de Dña. María de la Asunción, monja Carmelita Descalza Año 1604.

Cajon. 52.

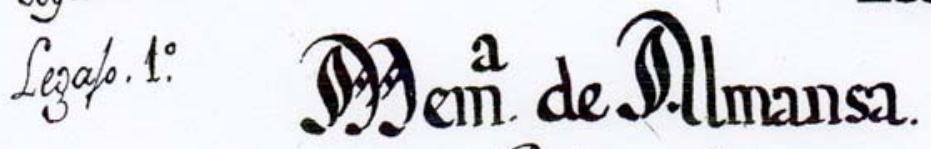

Caxtar depago de ochocientos ducados

1lum. 21 . cíadote de Ataxia deta Assumpcion Aionja Caxmel'ita Dercalza Ontav. Cefliva, g quatrocientor tie mas Qla almentor delaño deldorrias q. a favo del O.'O, Intonio flimansa Herm. Detadha Stania dela anum7.1 li 1 pcion, otrugaton la Mbadera of trongas Cetho Conv to \& Carmelizas Dercalras ollav. oeftuva ante Alonso Sanchen

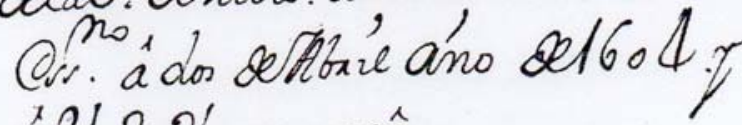
àlL. de Ono mesy año. 


\section{I.2. Monasterio De Santa María de las Dueñas}

Privilegio Regio otorgado por el Rey Alfonso XI, fechado en Ávila el 6 de septiembre de 1319

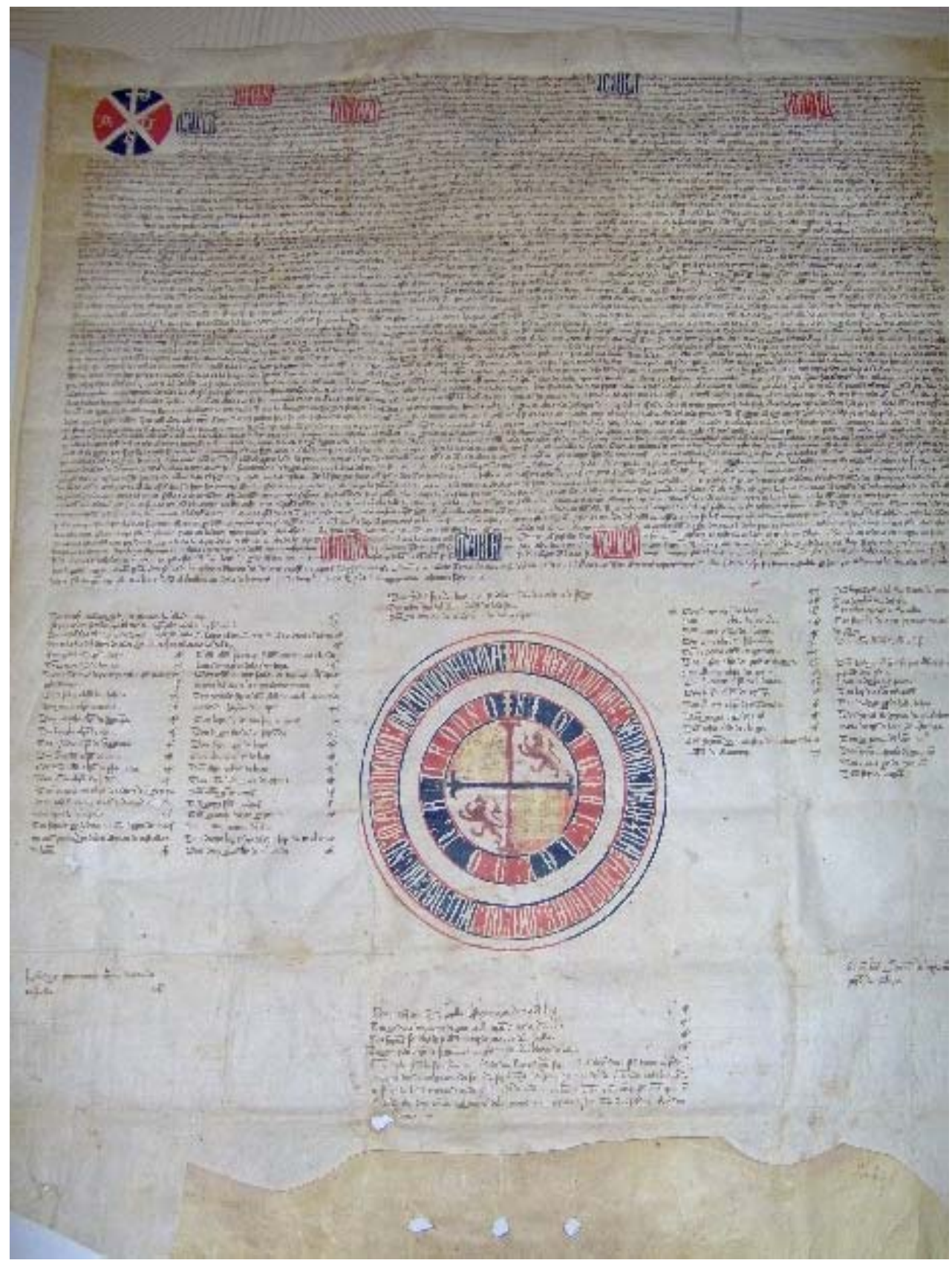




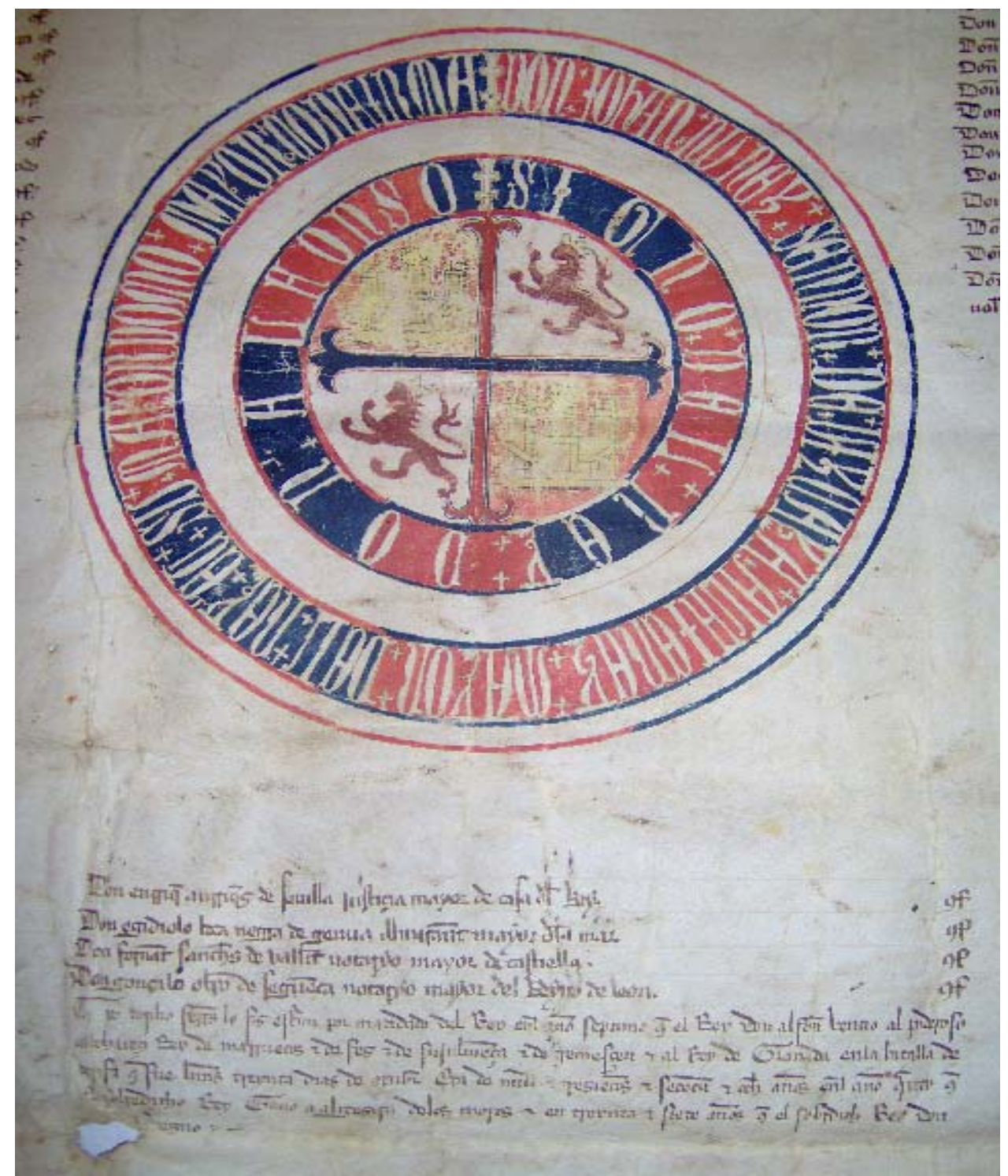

Privilegio Regio - Detalle 
Carta de Amparo por el Infante Dn. Sancho - Año 1279

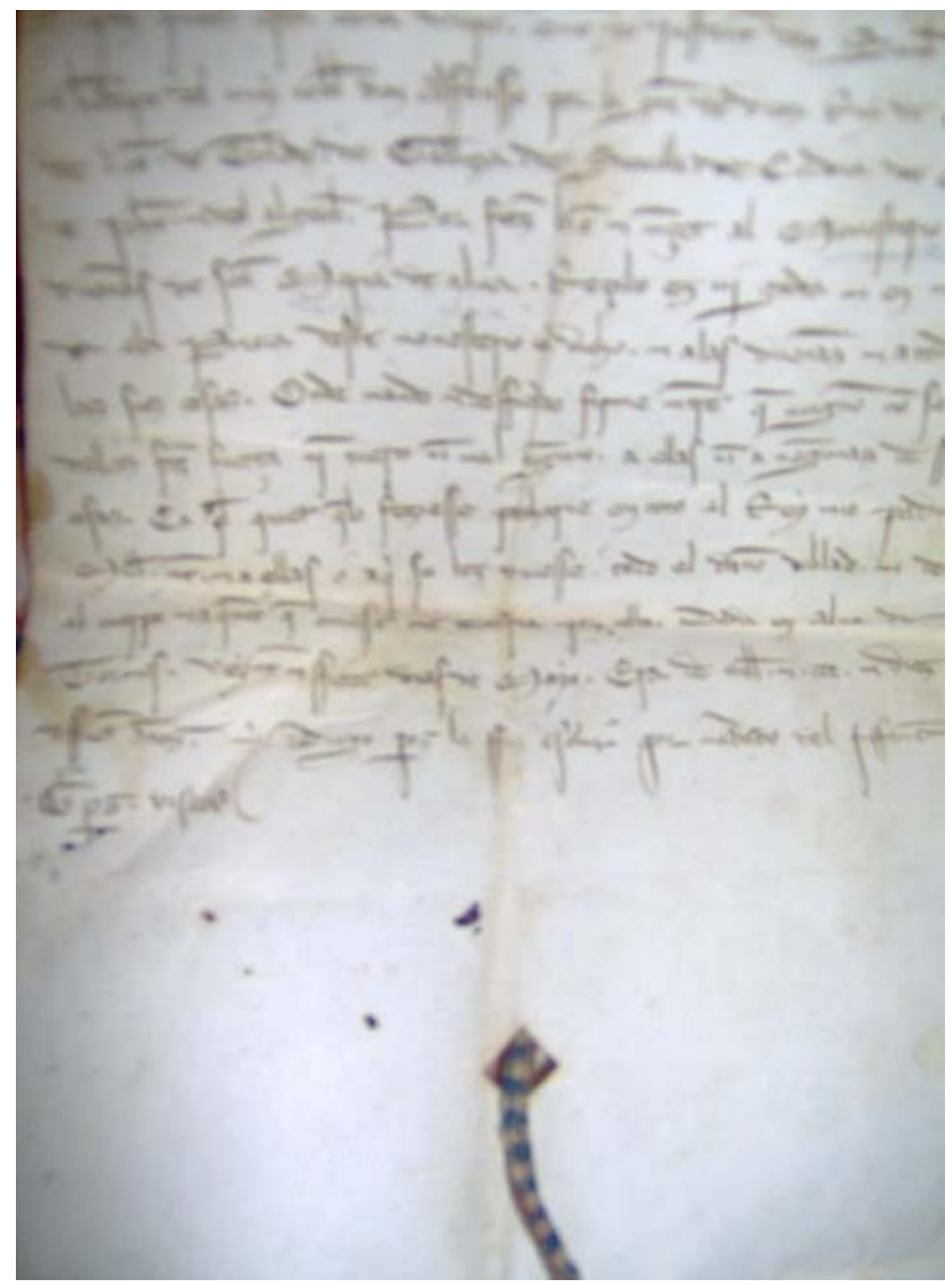


Testamento de Dña. María de Rosales

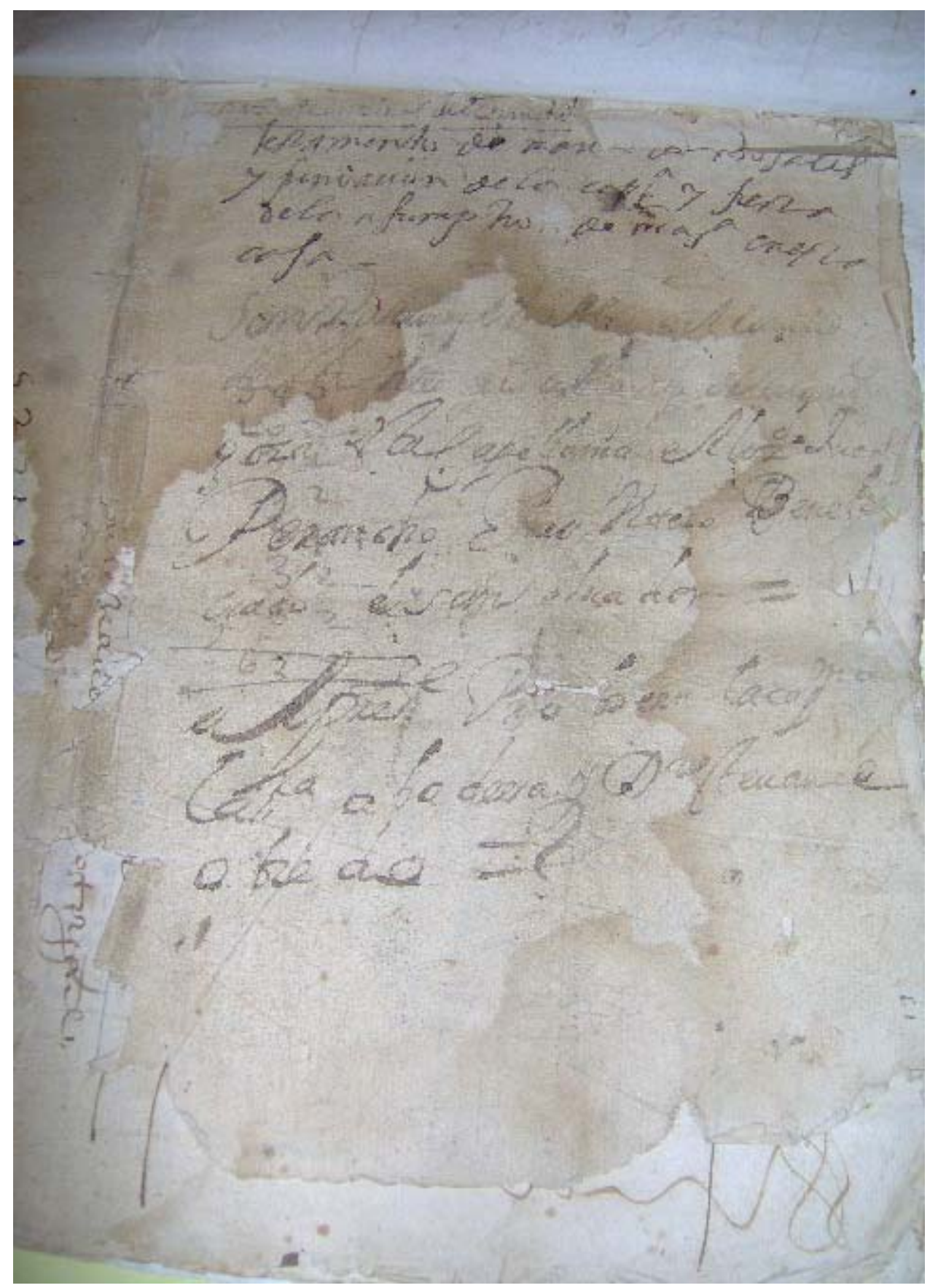

(Folio 1) 


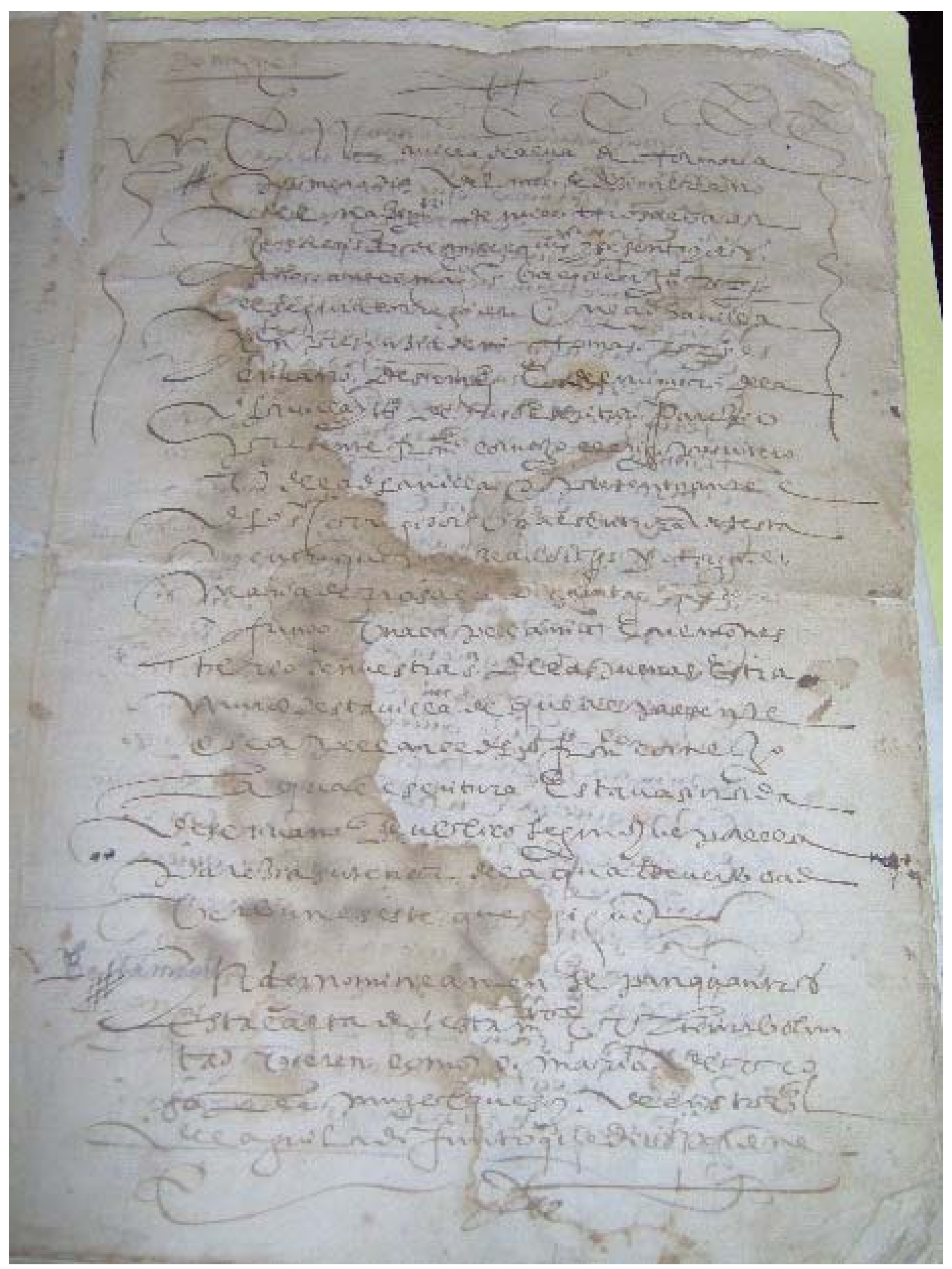

(Folio 2) 


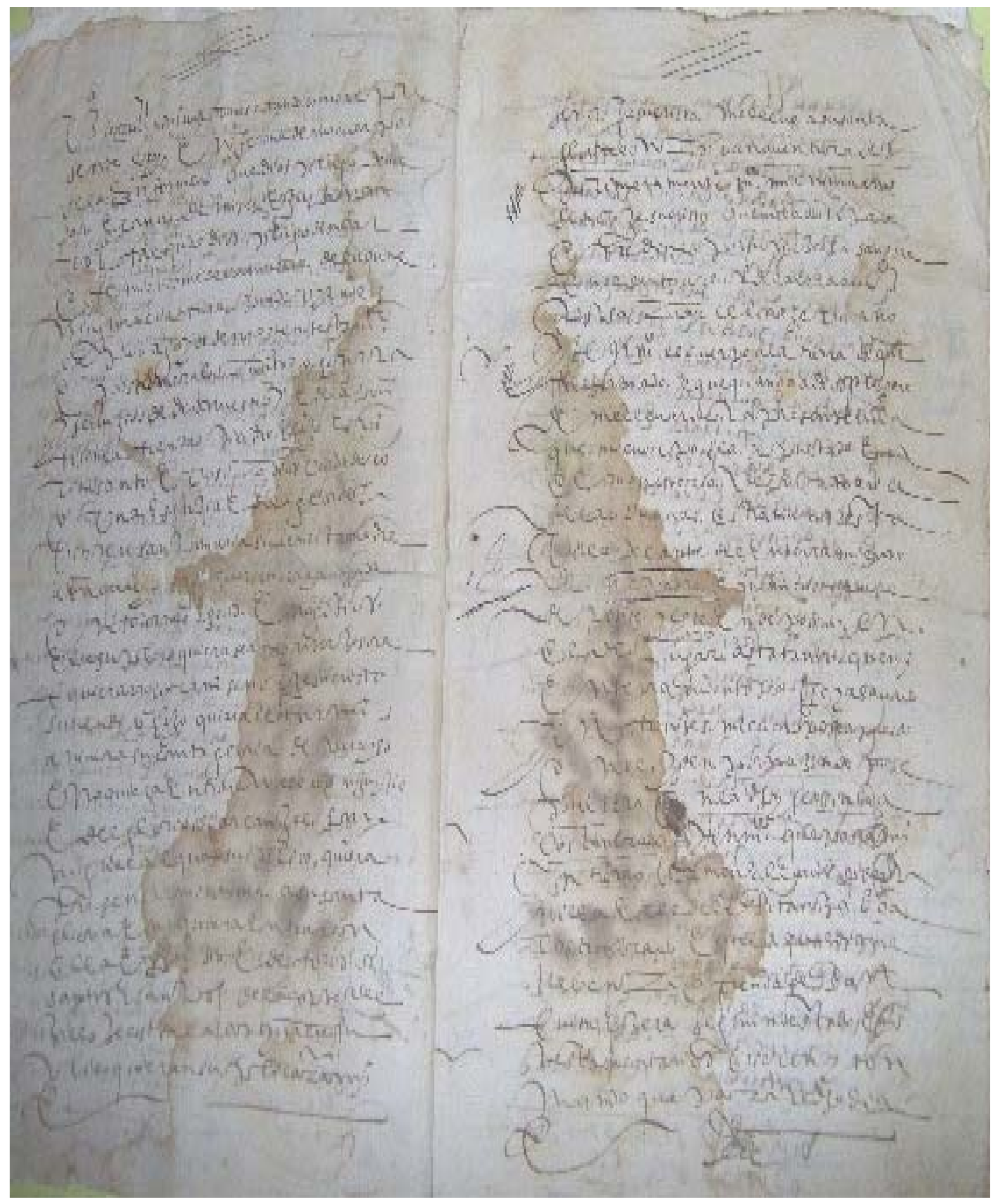

(Folio 3) 


\section{Fundación de Capellanías ASMD.}

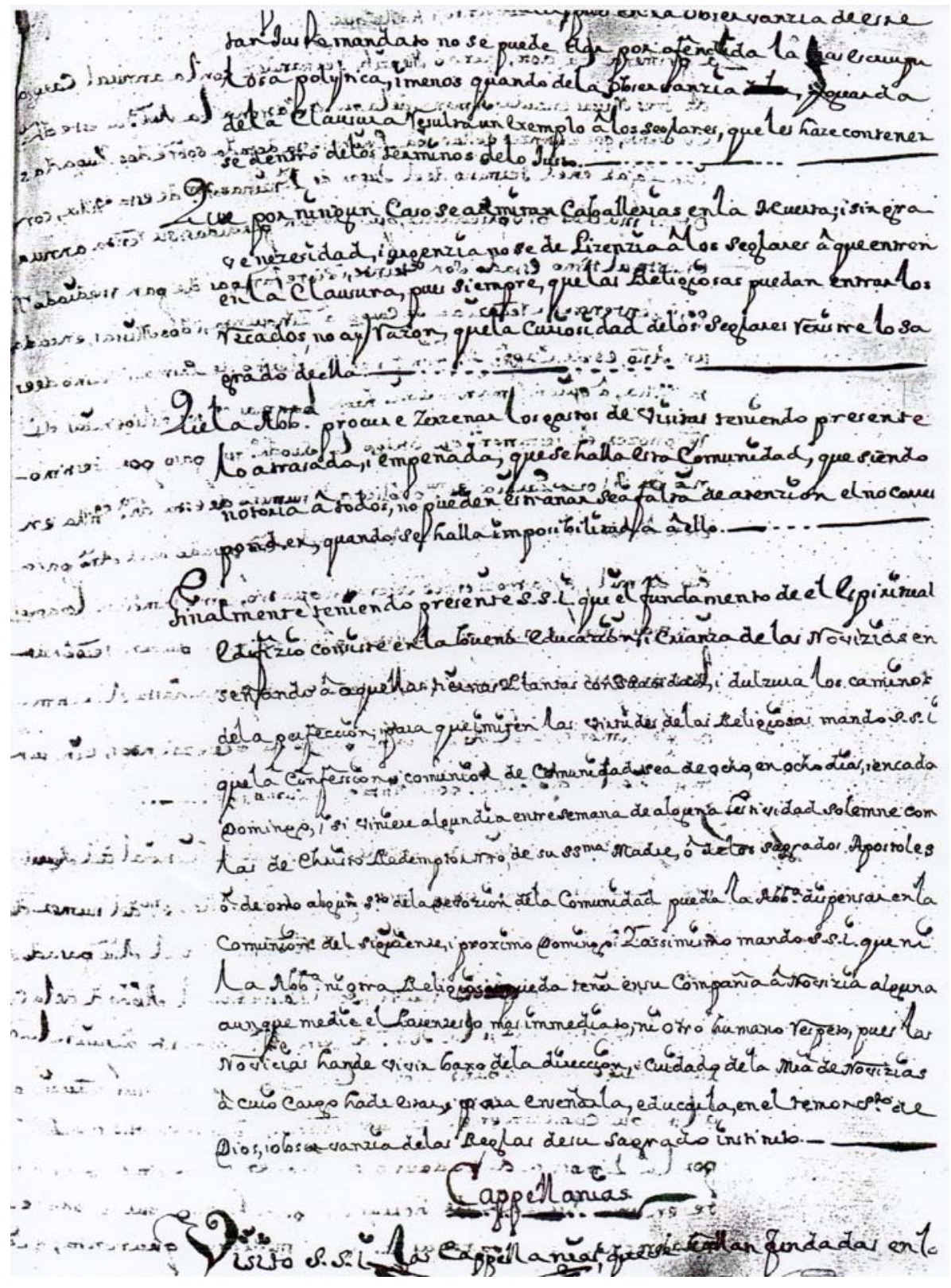

(Folio 1) 


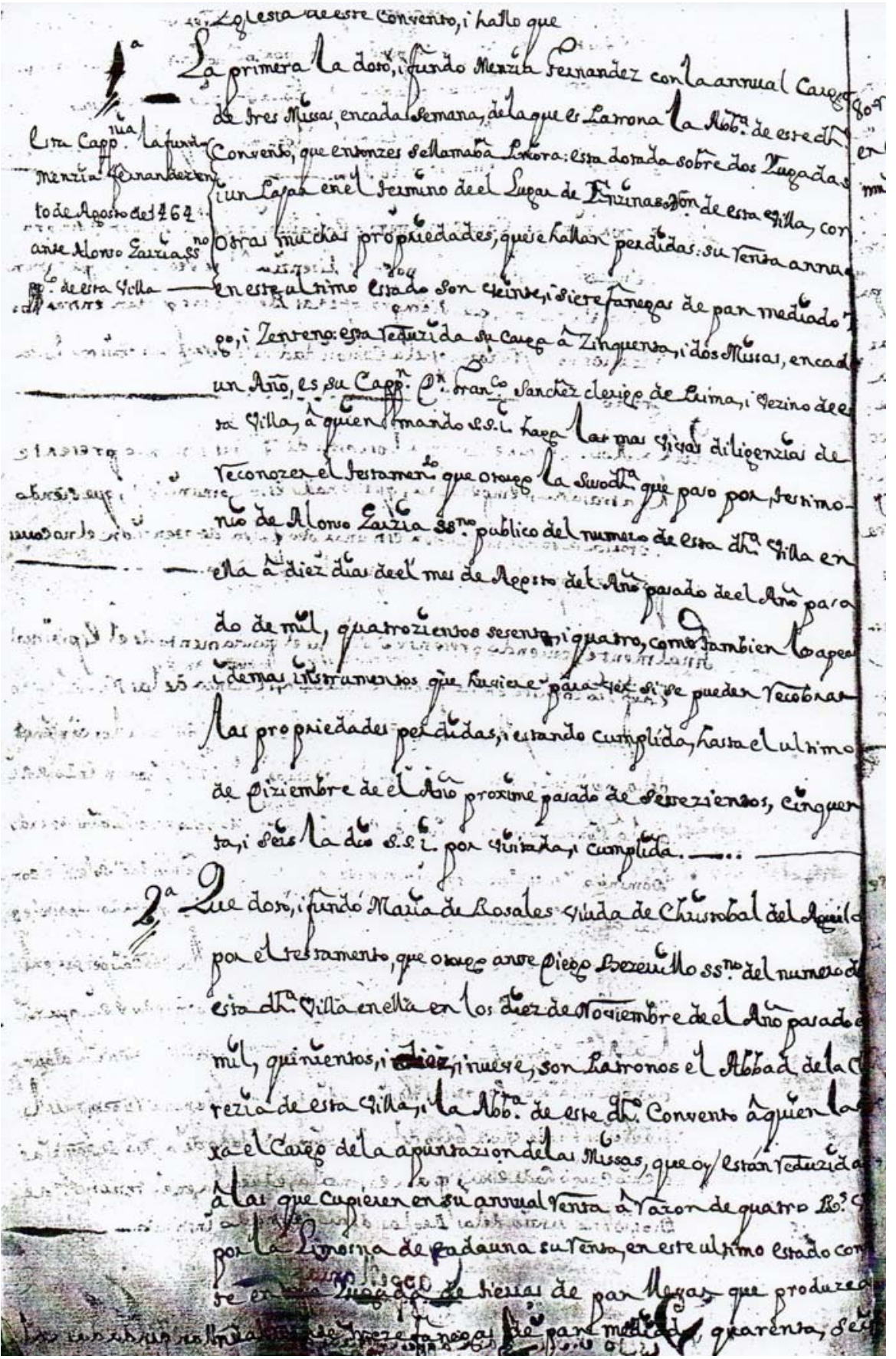

(Folio 2) 
Kyrie de la Misa de Sor Hildegard von Bingen

$N^{\circ} 19$

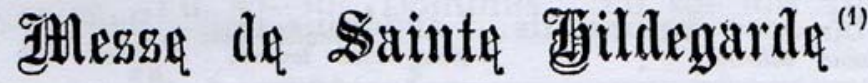
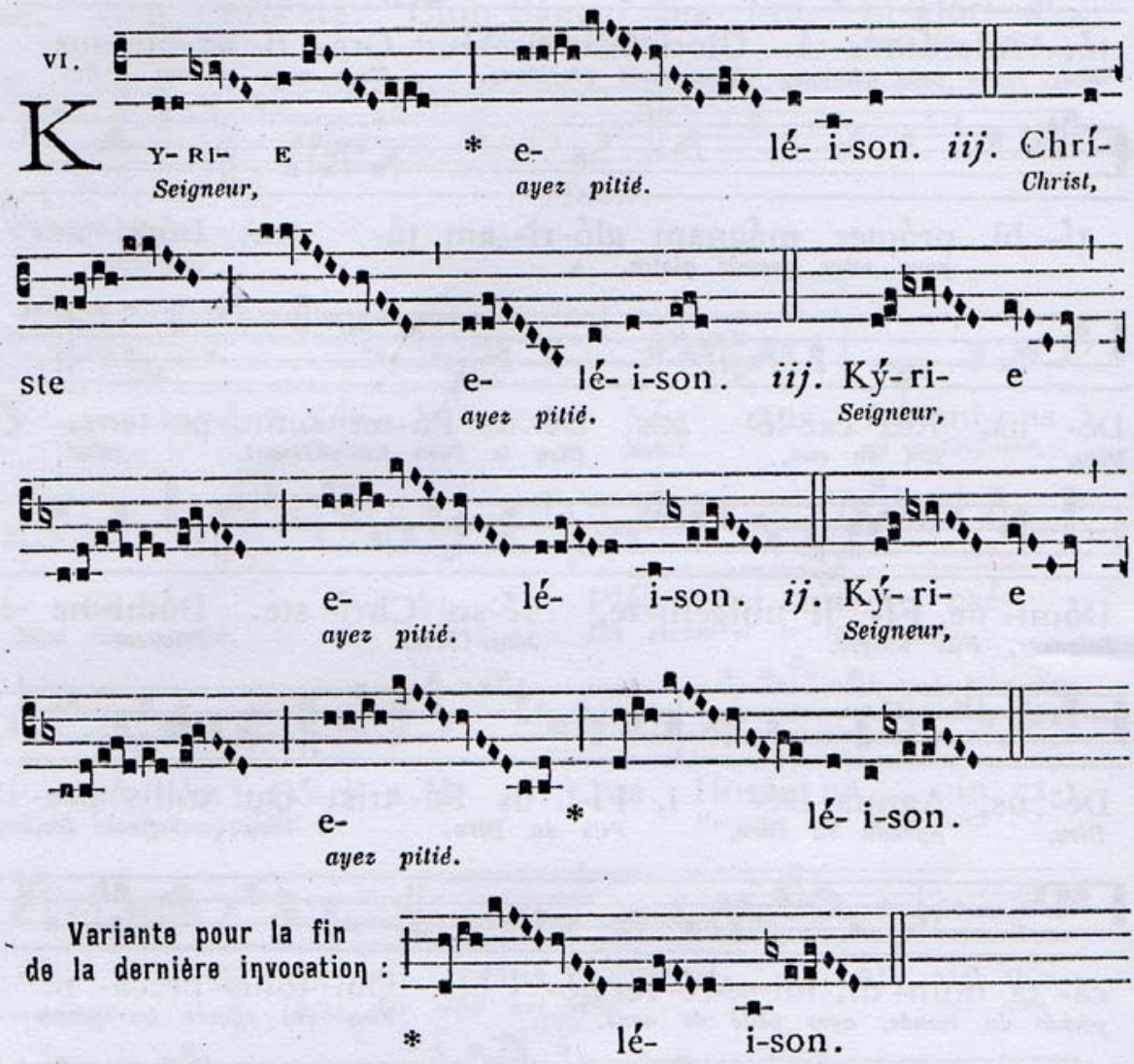

(1) Le Kyrie est composé par Ste Hildegarde; le reste est composé par D. J. Pothier d'après les mélodies de la Sainte : le Gloria est construit sur lo $\mathrm{n}$. O magne Deus; le Sanctus sur le $\mathrm{k}$. Ave Mavia; l'Agnus sur le k. O

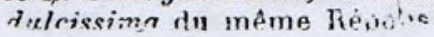


Kyrie de la Misa de Sor Hildegard von Bingen - versión manuscrita del Monasterio de Santa María de las Dueñas

$$
\frac{\text { Misa Se Jta Hildegardis. Harmanizacion. }}{\text { R.P. Casiano Kojo. S.S.R. Silos. }}
$$

$$
\begin{aligned}
& \text { Kyvie compuesto por tha. Heldegardio. }
\end{aligned}
$$

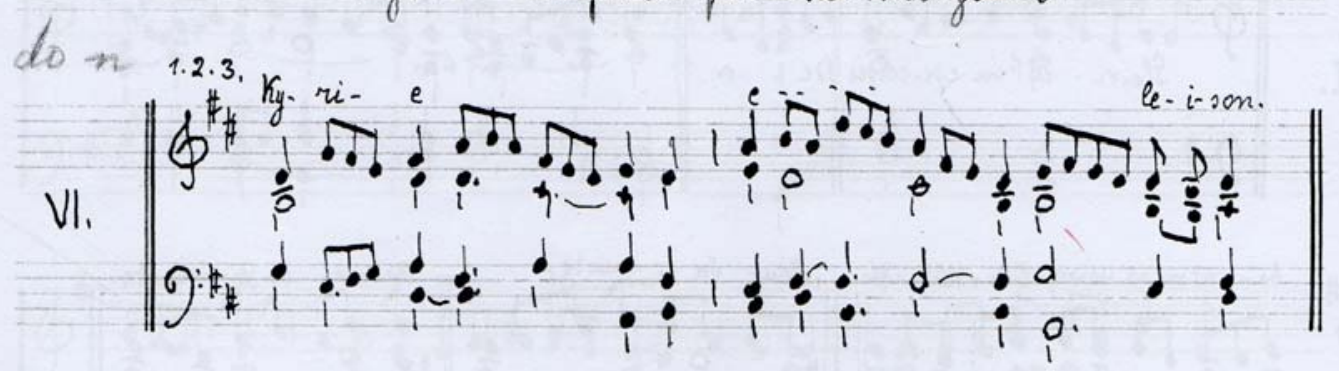

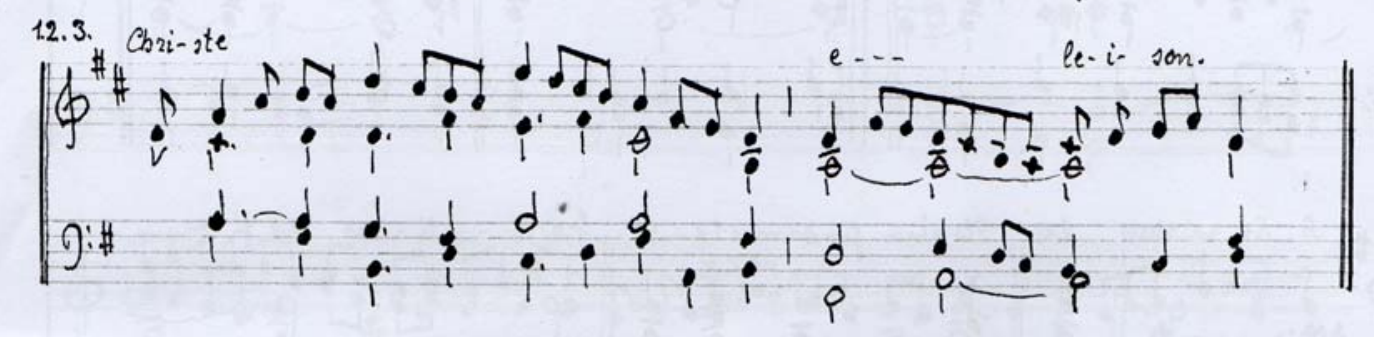

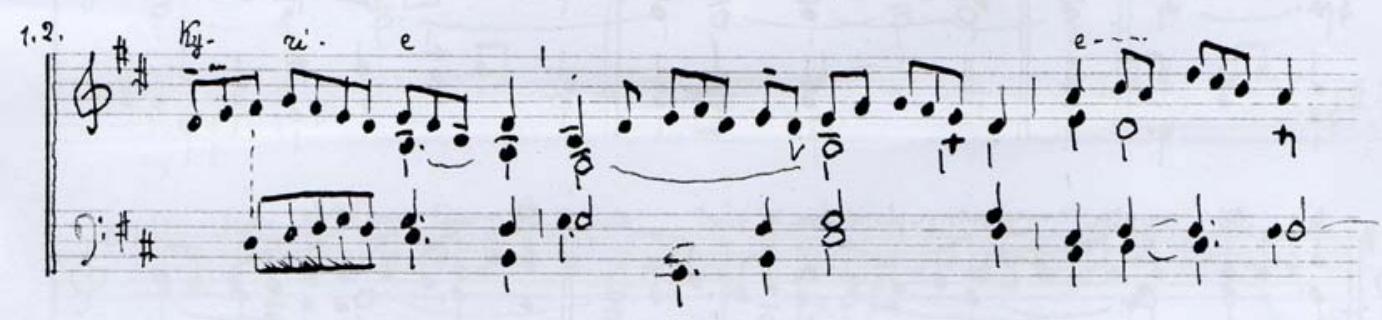

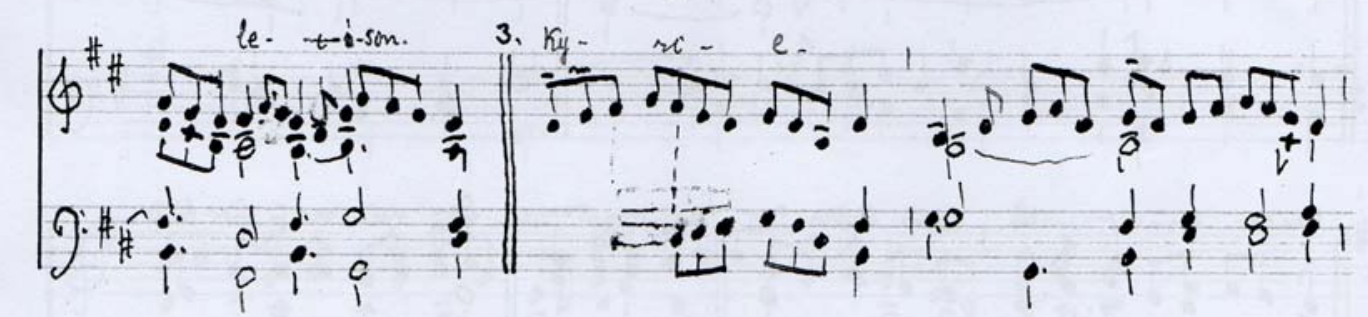

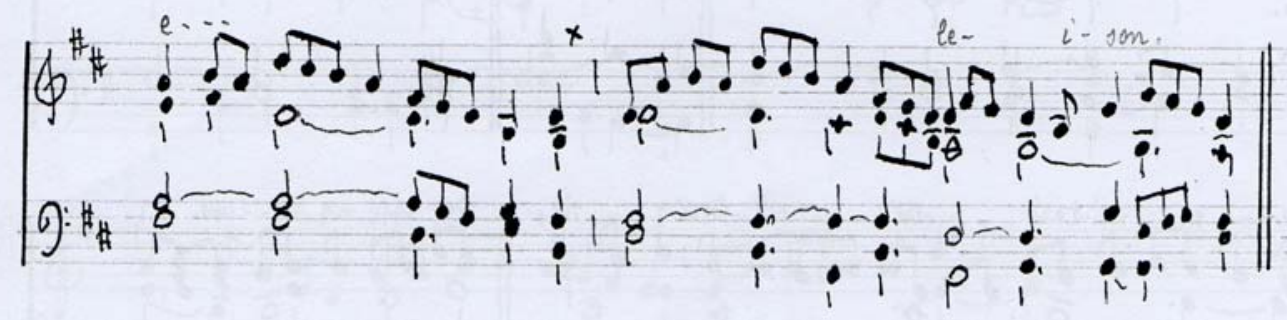


